\title{
AMERICAN PRIMTIME
}

MUSIC

FREDERICK·R-BURTON 
$x \cdot \ldots .$.

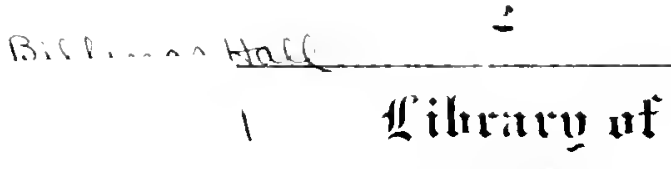

211 llitill)

Hurchasod from

एhe

N! 8122.7 
Date Due

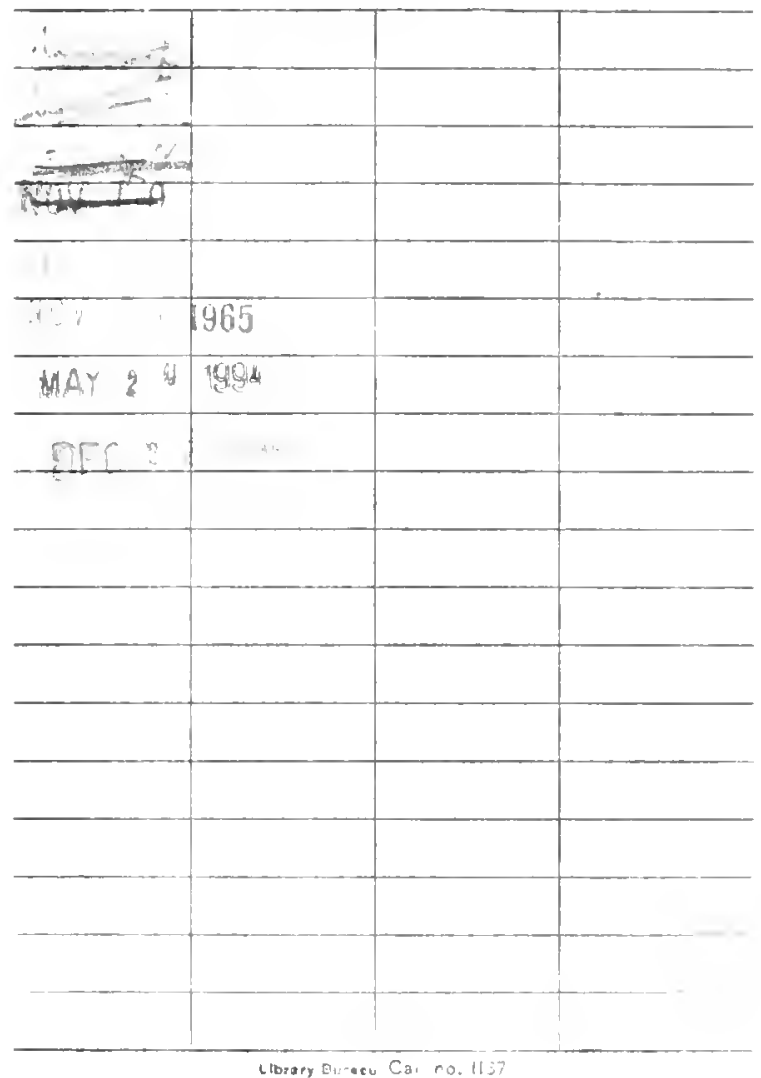



AMERICAN PRIMITIVE MUSIC 


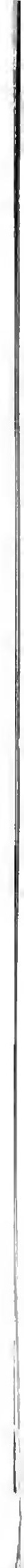





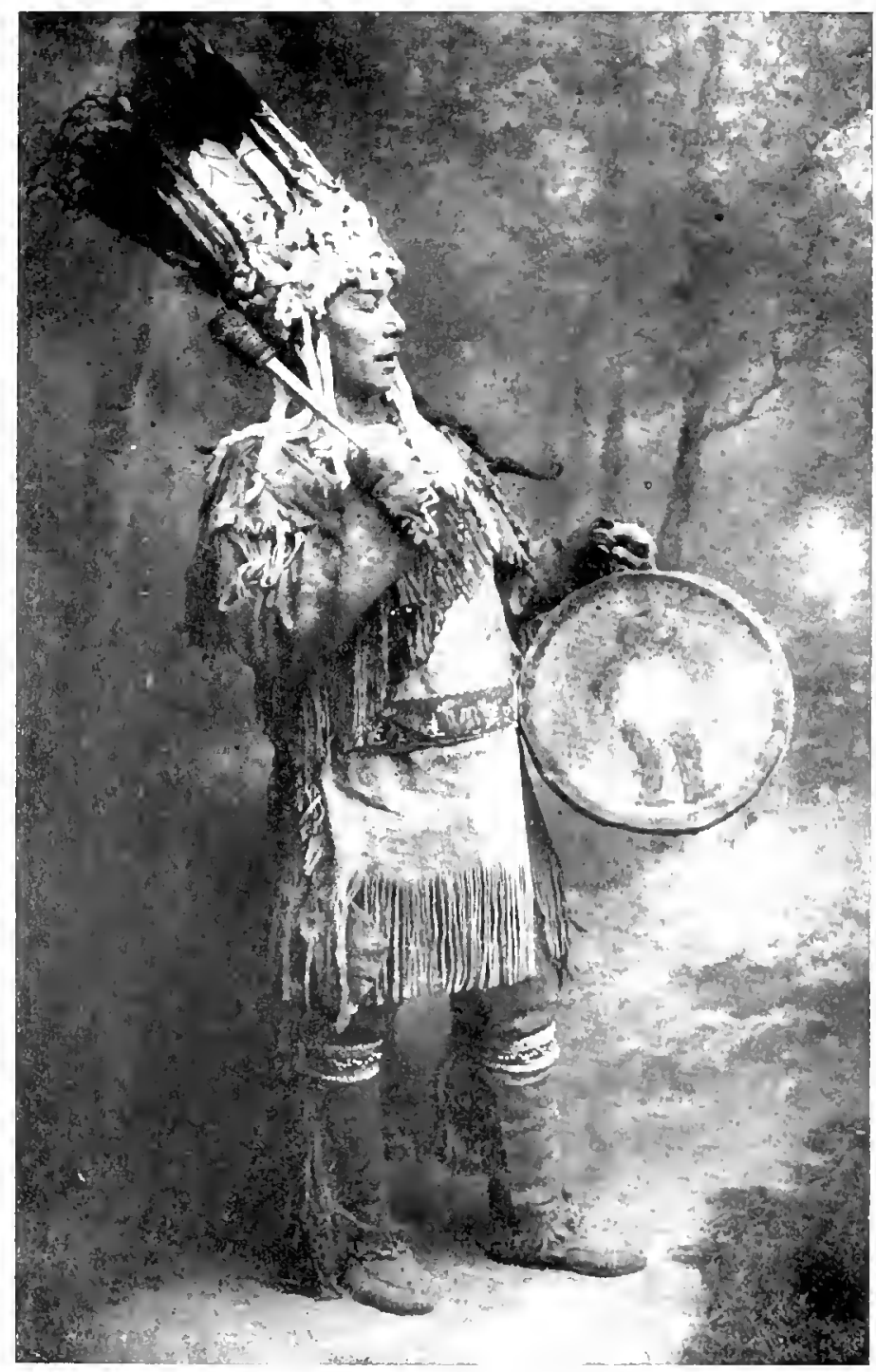

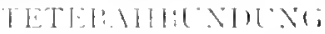




\title{
AMERICAN PRIMITIVE MUSIC
}

WITH ESPECIAL ATTENTION TO THE

\section{SONGS OF THE OJIBWAYS}

\author{
BY \\ FREDERICK R. BURTON \\ Composer of "Hiawatha," "Legend of Sleeny Hollow," etc.; \\ Author of "Strongheart," "Redclond of the Lakes," etc,
}

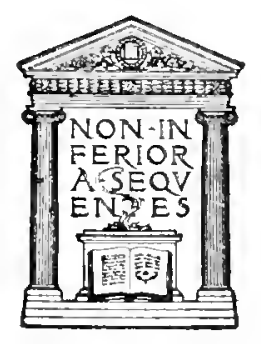

NEW YORK

MOFFAT, YARD AND COMPANY

1909 


$$
\begin{aligned}
& \text { C:A }
\end{aligned}
$$

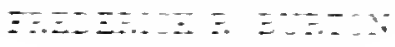

$$
\begin{aligned}
& \therefore \quad \therefore=\therefore=
\end{aligned}
$$

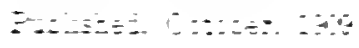

$$
\begin{aligned}
& \because 1 \ldots
\end{aligned}
$$




\section{ACXNOMIEDENENT}

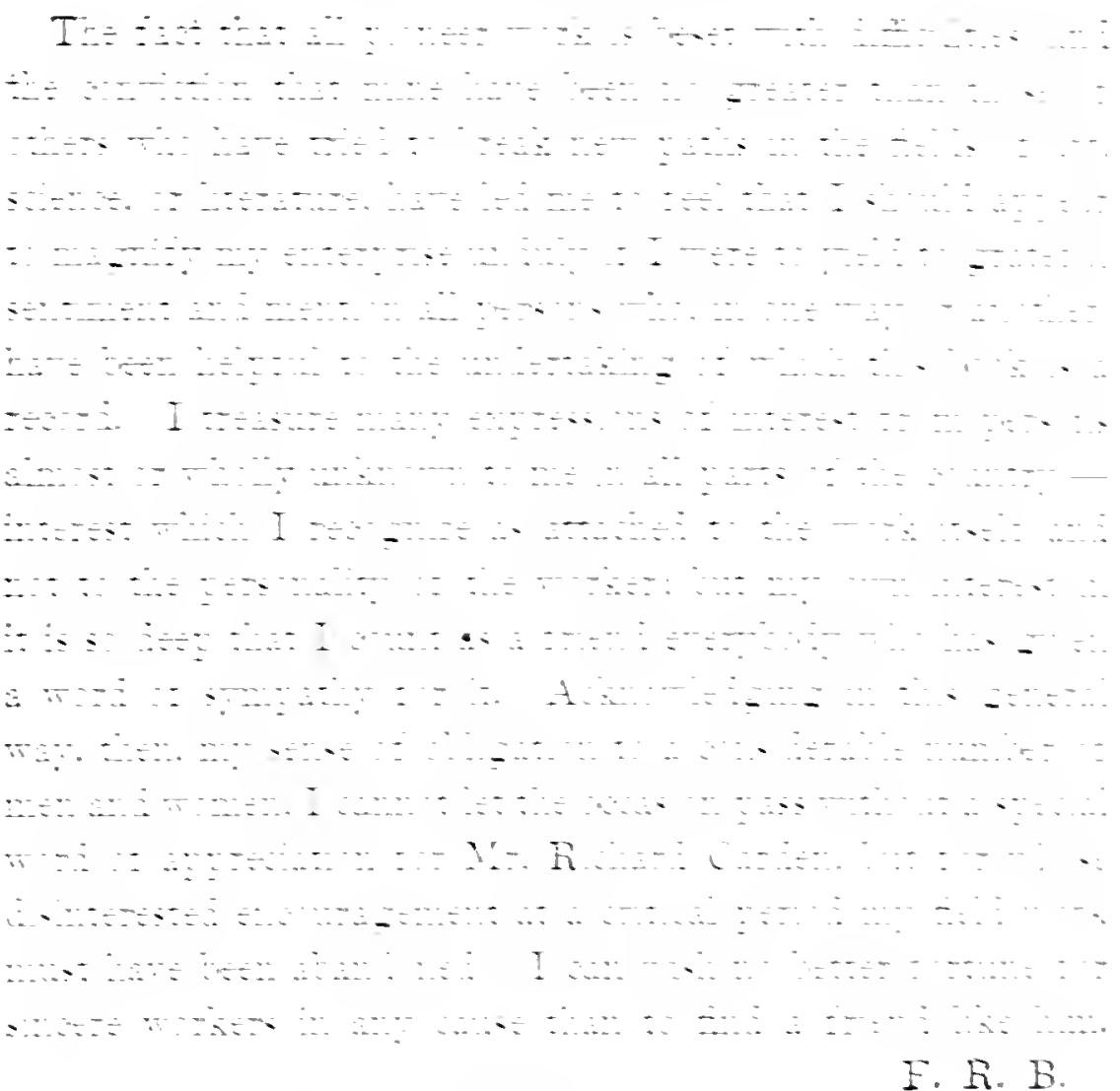

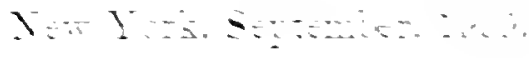




\section{TABLE OF CONTENTS}

Part I.

PAGE

Chipter I. A general survey of the field of Mnerican Indian music, with a summary of the work done by previous investigators. Tenint of riew of this work: The utility of the material for the purposes uf art . . . .

Chaptro II. Scales - I discusion of the quarter-tone question in the light of

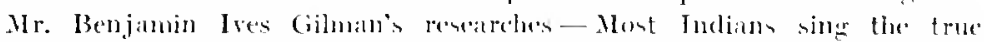
Greck intervals - Scalen deducible trom ojibway songs . . . . . . 20

Chapter III. Rhythm - In examination of the phenomena of en-ailled comflicting rhythms - Ethmolugints in aror when they assert that Indians lave dereloped rhythom further than have eivilized laces. . . . . . .

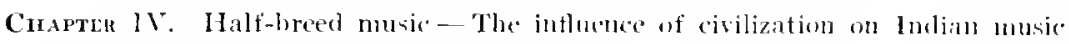
shown hy analysis of I roquein somers . . . . . . . . . . . . 67

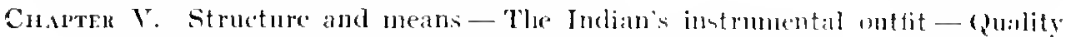
and ringe of Indian voices - The erolution of formal melorly which reaches its jerfection in the somes of the ojihwigs. . . . . . . is

Chaptere VI. Music from the Ojihway point of riew-One worl for musir and poetry - Music not regarded an an art, but as a thing of daily ure and necessity - Conception of abmolute nusic shown in the survibal of wort-

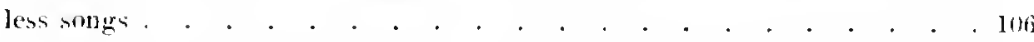

Chapter VII. Insic in Ojibway daily life-Various incidente narrated to show bow music enters into every phase of Indian activity - l'agan jateals. . 121

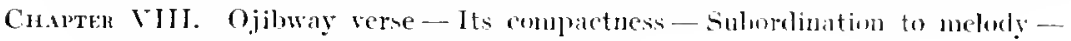
Difficulties in the way of the translator . . . . . . . . . . . 145

Conpter IX. Art value of Indian songs - In appeal for consideration of our primitive thenes as a basis for a distimetive style in Imerican musical art 1 ir

Cinapen X. Ojilway songs and their stories- I collectim of Ojihway songs notated by the author, each nelody accompanied by the story ur attendant circumstances-necessary to a full comprobension of its signifiane. . zoo

\section{Part 11.}

A collection of twenty-eight Ojiluway nongs for single wies with pianoforte acompaniment and Engliuls worls; and four songs arranged for mixed quartette . . . . . . . . . . . . . . . . . . . . . 285

Detailed index 
PART I 


\title{
AMERICAN PRIMITIVE MLSIC
}

\author{
CHAPTER I
}

\section{GENERAL SLRVEY}

PHE matter contained herein was obtained. firt. by personal research while living with the Ojibwars in the region north of I akes Iuron and Superior: second, during emplorment as musical expert in the ethological departments of the American Iuseum of Natural History. New York. and the Field Columbian Iuseum. Chicagn: third by incidental contact with Iroguois and Indians of other tribes, and. fourth. by reading the writings of other investigators. By far the greater part of these pages is a record of my own discoveries and observations. and orignally it was my intention to limit the book to a consideration of what may be regarded as my especial field of work. the music of the Ojibways: but the whole significance of Ojibway music camnot he appreciated without attention to and comparison with the music of other Indian peoples. and I have therefore, undertaken a brief' resume of the general subject. I felt that I could do this with some degree of confilence owing to my unusual opportunities for studying Indian muic and the several years during which I have given the best of my time and thought to the work. Moreover, the general subject has begun to 
aronse widespreal interest, and, as infinitely more remains to be done than has yet been done, it has seemed to me that a surver of the whole field, compled with a reeord of my inclividual researeh, might be stimulative to a comprehensive organization of effort for the preservation of our primitive musie while it yet lingers in the memory of Indian singers.

If my research eontributes in any slight degree to the science of cthmology, such result should be regarded as its by-produet, for this book is the work of a musician whose astonished attention was attraeted to the subject by hearing a party of Ojilways sing a rarely beantiful song, and who followed that "lead" in the hope, well foumled as it proved, of diseovering a type of gemuine and useful folksong indigenous to his native soil. That Indian songs may be useful to civilization, that is, that they have great art value, I thorough!y believe, and I should be lacking in the eonrage of ny convictions if 1 did not make such demonstration of my belief as lies in my power. To this end, in addition to a discussion of seales, rlyythm, form, and other technical and non-technical matters kindred to the subject. I have selected twenty-eight songs from my eollection, adipted to them Inglish rerse suggested by the Indian originals, and provided them with pianoforte aceompaniments. Some of the songs I have also arranged for malecompanied mixal quartette. All these will be found in the book in addition to notations of the entire collection of melodies whieh it was my good fortune to find.

The foregoing parngraph needs an apparent qualification, for the disarowal of any ethmologieal significance may be 
hastily interpreted as an expression of contempt for scientific principles and method. On the contrary, although antistic enthusiasm inspired the work of which the book is a result, the spirit, if not the method, was that of the scientist who permits no preeoneeptions or desires to blind him to f'acts. 'The crusle and ugly in Indian music has been set down as faithfully as the beantiful, and every possible effort has been made to reeord an exact expression of the Indian's musical thought.

There is a science of music as well as a science of ethnology: and the scicnce of music is twofold. The subject mily be regareled from its material, or acoustical side alone, or from the side that is usually expressed by the phrase "musical theory." The latter has to do with the structure of the art: it concerns itself not with the number of vibrations to an interval, but with the artistic relations of intervals. It is analytical of the asthetic content of the art, and it is with that phase of the matter that I have to do more than with any other. As will be olsserved later, the acoustical side of primitive music cannot be ignored even by one who applies himself mainly to the asthetie, and I shall feed free to dissent from the conchsions of some of our ethnological investigators who have rentured to write on the subject of Indian songs.

\section{TIIE FIEID.}

'To the white man generally it is still matter for surprise that there should be any field whatever for serions study in Indian music. The facts are, indeed, amazing. Archaeologists recognize on the North American continent north of 
Mexico fifty-eight distinet ethnic families of aborigines. All these in the popular view are supposed to speak dialectic variations of the same language, but in reality each language of the fifty-eight is more distinct from every other than English is from German. There are common roots in English and German, to say nothing of common words that differ merely in spelling, or slightly in pronunciation. The fiftyeight Indian languages are not linked together by the presence of common roots. The relations between English and German might, for the purpose of illustration, be likened to that between Ojibway and Abenaki. The languages of these peoples abound in commion roots, and ethnieally they are the same people, that is, Algonquin, and their languages at base are the same: yet no Abenaki conld understand an Ojibway, or vice versa, without special study of the other's tongue. The habitat of the Abenaki was and still is in the cast, where Maine and New Brmuswick now are; the Ojibways live north, west, and northwest of I alkes I Iuron and Superior. Between them in the old days were. among other Indian peoples, the Iroquois, and contiguous to the Ojibways on the west dwelt the Sioux. 'There is no common root in the Ojibway" (Algonquin). I roquois and Sionx languages; and this remarkable dissimilarity applies equally to the rest of the fifty-eight families. Powell summarizes the matter thus (Serenth Annual Report of the Bureau of Ethnology): "It is believed that the families of languages can not have sprung from a common source; they are as distinct from one another in their 
rocabularies and apparently in their origin an trom the Aryan or the Serthian families."

Here. then. is a field for musical inturiry of abundant amplitude and complexity if only it be known that the tifty-eight different peoples practise the art of music to any noteworthy degree. Of that there is no lack of eridence. Sunficient latil have been uncovered by travellers and inve-tigators of rarion, kinds to warrant the assertion that music is not only an important but an esential t'eature of Indian life. Some of these fitty-eight peoples have already disappeared from the fiace of the earth. but. on general is the use of music among thoe that remain. it is sate to ay that when all were in existence there was no exception in their derotion to music of a kind. Concerning the that are still arailable for -tudy. it is known that music enters more intimately into their lives than it does into the lives of any white nation. I hall wo into this matter in some detail in speaking of music in Ojibway daily life. the obervations in the chapter under that head applying rery generally to all Indian peoples. For the prevent it will suffice to state that music is no mere diversion from the Indian point of riew: it is not separated from ordinary experience by being classed as an art. but is a feature of daily. homely ne and necessity. The Indian has a song tine ererything-his gods. his friends and his enemies. the animal he hunts. the maiden he wooes. the torest that sighs around him and the lake that glistens hefore him. the fire in his teepee. the whiskey that excites him. the babe in the cradle his gar- 
ments, from picturesque headgear to shabby moccasins-every conceivalble thing in which he has an interest becomes the subject of a song. II is prayers are conched in song, and no cerenony, public or private, tribal or individual, sacred, mystical or secular, is complete without the music designed expressly for it and treasured in most instances from unknown antiquity. The Indian boy danns the legendary history of lis nation coineidentally with its songs, and the vocally gifted youngsters are carefully tanght by the old men and women to the end that no song of the tribe or family shall be forgotten. I believe it to be true that anong no people, the world over, is music so loved and so generally used as among the North American Indians.

TIIE INVESTIGATORS.

Occasional allusions to Indian music in the works of travellers and historians are of little value to the student. In the main they are the expressions of persons who have no special knowledge of music, and are restricted to descriptions of songs that sounded uncouth and harbaric to the narrator. Ifere and there in the miseellany of history. travel, and ethmological research, may be found what purpolt to be notations of Indian songs. Some of them may be correct, but if all were correct, and all notations published previous to 1881 were gathered togrether in one volume, they would not make a total sufficient to justify gencralizations, or give any certain impression with regard to the subject. It is remarkable that everything clse pertaining to Indians had been the 
subject of speeial study at the date mentioned. Not that everything discoverable had been discovered, but that every other phase of Indian activity, mental and physical, had been investigated and the results turned out in numcrous volumes. anl that music had not been considered even cursorily, is true. It is still more remarkable that the first serious effort to learn and state the truth with regard to Indian musie should have been made by a German, and his report published in Europe in the Creman language. Iis essay, of nearly one humdred pages, and with notations of several score songs, is alwars honored with mention in bibliographies of the subject, but I fear that few American students have read it. I myself did not read it until this book was almost reary for the press.

'Theodore Baker was a student of music at Leipzig Lniversity. He elected to take the music of the North American Indians as the subject of his thesis for his doctor's degree, and he eame to this eountry in the summer of 1880 to gather his material at first hand. I is time and means were limited, and the whole field of his personal researeh inchuded only the Seneca reservation in New Jork, and the govermment school for Indians then reeently established at Carlisle, Penusylvania. What he accomplished under such circumstances has aroused my keen regret, first, that his essay was not published in English, so to reach American readers readily and stimulate further research at that period, and, seeond, that he could not have given his whole life to the work. So far as Dr. Baker went he was thorough, as would be expected of a German student; he fell into quiek sympathy with the Indians, a matter 
that is a sine qua non in work of this kind, his mind was free from preconceived notions, and his conchusions were astonishingly somd. IIe was anything but dogmatic in the assertion of his conchusions, and yet most of what he stated tentatively after sturly of his few score songs, may now be set down as established facts and principles after observation of the immensely greater quantity of material at the command of the student. By reason. donbtless. of the publication of his essay in Germany, his work harl little if any influence in stimulating further research. Several years passed before any other contribution was made to the subject, and then came Miss Alice C. Fletcher's monograph on Omaha songs. supplemented by rarious magazine articles and her later book. "The Indian in Song and Story," as well as her article. "The Hako, a Pawnce Ceremony," included in the twenty-second report of the Bureau of Ethnology. 'The monograph mentioned was published anong the Archaological and Ethnological Papers of the Peabody Museum, Cambridge, Mass., in 1893.

While Dr. Baker's work, published in 1881, has priority in point of time, Miss Fletcher's mats the real begimning of serious attention to the subject. She is the holder of a fellowship in the Peaboly Musem, Harvard University, founded by Mrs. Mary Copley Thaw for the study of American Archeology. In pursuance of her special work. which was not music, she had gone among the Omahas. While there she fell ill and for many months lay helpless in a teepee attended by Indian men and women. 'They did 
everything in their power for her confort and recovery. 'The medicine men sang their magie songs to cham away her illness, the mothers crooned to their babies within her hearing. old men and women sang for her entertamment. So perforee she heard many songs many times over, and the more she heard them the more they pleased her until at last she came to something like the Indiams point of view with regard to them. and perceired in them an asthetic value that she hard not thitherto suspected. IIer own aceomt of this transition from the unappreciative attitude of cirilization to sympathetic mulerstanding of the prinitive music is so illuminating to the whole subject. that I renture to quote the following from lee monograph:

"I well remember ny first experience in listening to Intlian music. Although from halhit as a student I had endearored to divest myself of preconceived ideas, and to rise above prejudice and distaste, I found it diflienlt to penetrate beneath the noise and hear what the people were trying to express. I think I may safely say that I heard little or nothing of Indian music the first three or fon times that I attended dances or festivals, beynd a sereaning downard movement that was gashed and tom by the veliemently beaten drom. 'The somnd was distressing, and my interest in this numsie was not aroused until I pereeired that this distress was peculiarly my own, everyone else was so enjoying himself (I was the only one of my race present) that I felt sure something was eluding my ears; it was not lational that human beings should screan for hours, looking and acting as did 
these Indians before me, and the sounds they made not mean sonething more than mere noise. I therefore began to listen helow this noise, mueh as one must listen to the phonograph, ignoring the sound of the machinery before the registered tones of the voice are canght. My efforts in listening below the noise were rewarded by my hearing the music, and I discovered that there was in these Indian songs matter worth study and reeord.

"My first studies were crude and full of difficulties, diffienlties that I afterward learned were bred of preconceired ideas, the influence of generally accepted theories concerning 'savage' music. The tones, the seales, the rhythms, the melodies that I heard, which after months of work stood ont more and more clearly as indisputable facts, lay athwart these theories and conld not be made to coincide with them. For a considerable time I was more inclined to distrust my ears ihan my thenries, butwhen I strove to find facts that would agrce with these theories I met only failure. Meanwhile the Indians sang on, and I faithfully noted their songs, studying their character, and their relation to Indian life and ceremonial. During these investigations I was stricken with a serere ilhess and lay for months ministered to in part by Indian fricuds. While I was thus shut in from the rest of the world, with the Indians coning and going about me in their affeetionate solicitude, they would often at my request sing for me. They sang softly because I was weak, and there was no drum, and then it was that the distraction of noise and confusion of theories were dispelled, and the sweetness, the beanty and 
meaning of these songs were revealed to me. As I grew stronger I was tanght then, and sang them with my Indian friends, and when I was able to be earried alont, my returning health was eelelmated by the exemplification of the "Wawan' eeremony with its music."

In the preparation of her monograph Miss Fletcher obtained the assistanec of the late John Comfort Fillmore, an aceeomplished nusician, who not only hamonized the tunes she had collected but contributed some interesting observations of a theoretieal nature with regand to a possible subconscions harmonie basis for Indian melody. 'The publication of this pamphlet came at a rather opportme time. It was nearly coincident with the sojourn of 1)r. Drorak in America and the produetion of his "New World" smolnony, over which there was a considerable controversy among musicians, and no end of misconception. It was rather generally understond that Drorak had based his beautiful work on the plantation and other melodies indigenous to our soil, and that he somght thus to give American composers an objeet lesson in the writing of music that should have a distinctively national flaror. The facts are that a fragment of one plantation melody appears as al theme in the symphony, that the rest of it is as Bohemian as anything in Drorak's long list of works, and that the distinguished visitor had no faint shardow of the intention credited to lim.

With all its misstatements the eontroversy was of value in that it aroused composers, crities and other's to some degree of interest in native American music. The matin question con- 
cerned the possibility of music in this comntry that should not be a more or less pale reflex of German and other European models, but that should be distinctively American, and speak for our country as our poetry and prose had spoken for generations. 'There was little dispute over the assumption. that such a music, whether desiralbe or not. must be based upon something analogous to the folksongs of European comntries: and, as folksong depends upon an illiterate peasantry, and the Enited States has no such elass among its people, the conchusion was inevitable that the sonrce of thematic material must be sought either among the plantation negroes, or among the 'Indians. It was natural, therefore, that Miss Fletcher's monograph should cone in for much study, and there were not lacking instances of attempts to make use of the melodic material contained in it. 'The most conspicuous work, the origin of which may be traced to the disenssion of nationalism in music, was MacDowell's "Indian Suite." Its thematic material was taken in part at least from Indian songs, and the work hals its permanent place in the repertories of the world's best orchestras; hut $\mathrm{Mr}$. MacDowell was apparently content to make no further effort in this direction. It might indeed be safe to assume that he was discontented with the results of his single trial. probably feeling that his indiscinal musieal nature was not in suflicient sympathy with the melodic expression of the Indians to justify him in wearing their strains into his own pattern.

'The influence of Miss Fletcher's monograph threatened not to outlive the controversy with regard to nationalism in 
music. She was, and still is, an enthusiastic. tircless champion of what appealed to her as a cause; that is. she worte, and spolee, and pleaded without ceasing for the recognition of Indian music as something wortly of study and that affectionate appreciation in which white penple hold the music of civilization. There were reasons. to be noted later, why most musicians tailed to be convinced by her arguments, or attracted hy the mekdic material she uncorered. and presumably there was some sort of reason why the govermment Burean of Ethology and the sereral great musemos of the comntry did not institute organized. competent and systematic resealeh in the immense field to which she had drawn attention. Whatever were the reasons for the neglect of Indian music on the part of those whose life work it was to stuly American prinitive man. the fact is that for gears Miss Fletcher pleated apparently in vain-alppalently, because the time cance when some of the younger musicians began to take the subject serionsly. and hecause improvements in the phomograph made it practicalole for the museums to give some incidental attention to musie when they sent out their expeditions for field work. By this latter means a rast anount of material has been gathered of which only a small fraction has yet heen made arailable in printed form. Travellers and investigators who have gone anong the Indians have been encouraged to include phonographs in theij outfits and to induce Indians to sing into them. The records thus obtained are stored in the sereral musemms, and some of them have been relnced to notes for the purpose of giving completeness to articles on ceremonies in which music 
figured: but I am not aware that any institution has ever set a musician to work on the records with a view to making a comprehensive study of the subject, or of putting in intelligible form such of the material as has asthetic value. The collection of records is, however, a gratifying step-not quite in the right direction, but something rather better than the absolute neglect of the subject previous to Miss Fletcher's time.

The next specific effort to discover what there might be in Indian music was, I think, my own, begun in 1901, eight years after the publication of Miss Fletcher's monograph and incited by causes quite apart from it. About the same time Miss Natalie Curtis began her remarkable studies among the Hopis and other Indians of the Southwest. She has put a great number of aboriginal songs into permanent form, and has so extended her observations as to include in her chief published work, "The Indians' Book" (Harper's), representative melodies of eighteen tribes. She does not take up questions of theory in her book, and she does not harmonize the songs, but her work is of great value to the student, especially in the side lights it throws on the attitude of the Indians themselves toward music. Another musician to undertake the gathering of material at first hand was Mr. Arthur Farwell, whose research was giren to the Indians in southern California. He had previously been an enthusiastic exponent of Miss Fletcher's ideas, having published pianoforte arrangements of several of the tunes in her monograph, some of them retaining the Indian melody in its naked simplicity, others being thematic 
developments of the material worked ont with excellent taste antl slill.

During all this period, that is, since about 188\%. the ITemenway Sonthwestern Expedition was at work among the Zunis, Hopis, and other pueblo Indians. and before the conclusion of that great undertaking musie came in for its proper share of attention. The musical study was mainly in the hands of Mr. Benjamin Ires Gilman, whose methods and conclusions will be considered in sone detail in the pages that follow. Dr. Franz Boas, now of the American Museum of Xatural Iristory, New York, an ethnologist with more than a superficial knowledge of music. has contributed notations and discussions of Esquimo and Kivakintl songs to the Burean of Ethnology and the Lnited States Musenm leports. There have been. besides those named, rarious witers who have made brief excursions into the Indian conntry and brought back tunes, many in the aggregate. which have embellished magazine and newspaper articles, and so contributed a share to general linowledge of the subject.

Finally: the bulletius of the Burean of Ethnology, and various publications under the auspices of the Carnegie Institution. of Washington. contrin incidental allusions to musice. sometimes with notations of songs used in religions ceremonies, accompanied oy more or less comment on the part of the notators. All these contributions to the subject are firagmentary. and so scattered in papers whose main theme is not music, that they are of little help to any who would take up 
the study of our primitive music seriously. Adequate study of it ean be done only when music is the chief thing to be considered, and not the incident.

\section{THE POINT OF VIEW.}

My work has brought me to pleasant personal acquaintance with most of those who have investigated Indian music, as well as with very many who, while not musicians or investigators, have had intimate contact with Indians and have fome much that is admirable in their songs. It has appeared from numerous conversations that my point of riew with regard to the subject differs somewhat from that of the others, and as, presumably, that difference extends beyond the boumds of my personal acquantance, it seems advisable at this time to indieate it brietly.

I have maintained since early in my experience with the Ojibways that their music surpasses that of all other Indians yet known; that they have mased native Ameriean music to a higher plane than that attained by any other of our aborigines; and while I am not aware that anybody has disputed my assertion. I have frequently been besonght by f'riends of other tribes to hear, for example, the Hopis, or the Arapalhoes, or the Omalats sing, the inforence being that, if I heard the singing of these Indians as I have head the singing of the Ojibways, I might qualify if not reverse my estimate. I should have been wad during the past nine years if eircunstances had been such that I could have listencel to the singing of the Sionx on the plains. or of the Hopis in the pueblos; but the mere hearing 
them, no matter how well they simg, would not have tended in the least degree to modify my conviction: for it is the thing sung that interests me, and not the manner of singing it: and the thing sumg has been arailable to me in the notations of Miss Fleteher, Miss Curtis. and others.

Again and again it has come to my attention that few persons make elear distinction between performance and composition. Even men and women who have had the advantage of some degree of instruetion in music are often misled by the excellence of a performance into overestimate of the music performert. Caruso eould make a cheap), common-place song interesting. So conld Tetelabbundung, an () jibway singer whose tenor voice is of the most appealing timbre. and whose untaught roeal method is well nigh perfecetion. Not all Ojibway songs are beautiful. Some of them when reduced to notes, as may be seen in the chapter on "Ojibway Songs and 'Their Stories," are barren of asthetic value. (One of the most barren of Ojibway songs is in 'Tetehaldbundung's repertory, so to speak. and I have heard him sing it many times to white andiences. Often have I seen sympathetic listeners wipe away tears at the end of the song: of ten have listeners asked me with sone degerete of indignation why I did not inchule that song in my harmonized versions. The answer may peatlily be found hy tuming to the somg I am so frankly herating. It is No. 17 (a) in the chapter named. It was the mans voice that hought the tears, his native ant as a singer that made the inquirers imagine they had heard something of value in itself.

I have a eomparatively languid interest in the person who 
it at the pianoforte. or plays the riolin. or sings. My attention is centred alway on that creation of the imagination which las giren the performer lis excuse for activity. It is the comproition that survive and is of consequence. not the pertornance of it, or the performer. Sehubert's songs have rutlived three or four generations of singers. and will sutlive many more. Thone sones of the ojibways that are beautiful will continue tr give their benign serrice to the world long after the present ingers are silent. So. then. no Indian soner. wh matter hrow alluring it may be when heard in its native surronulinge. can appeal to me as having artistic vahe unle.. it prores when reduced to notes to be eapable of stirring the enrotions under rother circunstances. That is the test of bealuty. of athetic. or art ralue. The printed notes. read by an entire stranger to Indian life. must reveal to him a beauty inherent in themselves. else the song fails. When the music of any perple can be transfered from its place of origin to any r.ther place in the world and there stir the emotions of strangers withrut the adrentitions aid of preconceived romantic interest. then that music is of permanent value; and the measure of its value can lie tiken only after a lapse of many years from the time of its transplanting.

Iy attitude rears ago toward the Omaha songs collected by Miss Fetcher was doubtless that of many another musician whe exanined them. Nost of them repelled me by their manifent crunlity. I saw and felt the rudiments of form in some of then. but they inpresed me as incomplete and dull. considreed als tunes, and wholly barren of suggestion. I was 
eager to find thematic material in them and could not (d) w). Iy eagerness may be fully appreciated when 1 explain that I was then at work on the composition of " II lawathal." and that I wished to give the music a distinctively Anerican color if I could. The best I coukd do wiss to nse a Kwakint enner an a theme for the Dance of P'anpukkeewis in which I ained frankly not at beauty hut at something bizare and barbaric. So, when I heard Ojibways sing. I was won to adnination of their whes from prejudiee a gallnst them. It was the exquisite unity-witlvaliety in the song I call "My Bark Cance." that openet my mind to the pomibility of real and useful beanty in our prinitive muse: and from that time to this I have not fomul on phoungraphic records. or in the songe published by other investigators. any music that compares fimorably with that of the Ojibwars in structure and asthetie value.

It must be elear. then. that my point of riew is not that of the ethnologist. fin I would not have taken the trouble to collect and record Ojibway songs if the had appealed to me merely as curiesities in human expresions: and that it is not the point of view of a friend of the Indian. I hasten to add that my studies have made me a triend ot the Indian. and I shall be disippointed if my contribution to knowledge of them does uot have its share, howerel slight. in awakening a more human interest in them on the part of whites. and a better undere standing of them as men and women: but that is apart from the present purpose in which I pose merely as the musician. observing certain phenomena in a critical spirit. seekings. it you will. to gain some good f'ron the Indians for my own people rather than. primarily, to fo the lndians a serrice. 


\section{CHAPTER II}

\section{SCAILES}

W IOEVER undertakes to give information concerning Indian music is met at the outset by an incuiry that has often taken this form when atdressed to me: Do Indians use the quarter-tone?

The quarter-tone is a loose expression for a division of the octare into more and. therefore. smaller intervals than are recognized in the chromatic scale. It is well known that certain Oriental peoples recognize and adjust their voices to minute intervals that are in some instances less. and in some instances greater than one quarter of what we eall a full tone. or whole step. or interval of the second. 'The musie of such peoples is insusceptible of harmonic relations. and it cammot be expressed in terns of onr five-line staft. If the Indians employ such sublivisions of the semitone. that is, if their scale is atiatonic. the man question conceming the serviceability of their melodies to art is answered at onee in the negative. Civilization, in its present stige of musieal advancement. cannot make use of motives insusceptible of harmonic treatment and inexpressible in the present scheme of notation. The question. therefore. is of rital importance, and it deserves to be met without prejudiee. with an eye single to the truth. Its hearing on the integrity or aboriginality of the Ojibway songs that I have adapted to the 
uses of eivilization will be appreciated best by indieating the attitude of most inquirers. They are good enough to take for' granted the intellectual honesty of the notator, and also to credit him with a eonsiderable degree of talent in the composition of musie; for they suggest, when he sets forth a eoherent, beantiful Indian melody, that he has mwittingly written into it a finish that really is not there: that, being a musician trained in the diatonie seale, he has instinetively, nay, mavoidably dosen the nearest diatonie interal to express what. in the Indian's singing. was adiatonic: that he has been misgnided by his axthetie sense into correcting the Indian's false (adliatonie) intonation. and that he has, therefore, presented a garbled report of the Indian song.

One of the fairest statements of this attitude that I have seen is to be fonnd in a monograph issued by the Smithsonian Institution. "Contributions to the IIistory of MInsical scales." by Charles Kasson Wearl, of Washington, D. C. Diseussing stringed instruments, he says:

"All musieians know that this number of notes. twelve, is found confusingly great for ordinary playing. and know the principles by which the player selects eertain notes for any tume. But this multiplieity of notes has an important bearing on all studies on uonharmonie musie made by harmonic numsicians. For every sombl within the compass of the instrument eomes very near to some one of the fwelve notes and may readily be represented thereby, owing to the difficulty the hearer has in estimating deviations from the familiar series and in noting them down. The results of this approximation 
alre to mask all deriations from the twe ke-tone piano scale, whether intentionaly or aecielentally made. and to make it appear to musicians that nearly all the music in the world is performed substantially in our scale."

\section{ISIBUITTY TO ERROR.}

I have considered this matter with all the candor that lies in me. My answer, so far as the Ojibways are concerned, will appear in due eonrse. With regand to the music of other tribes I conceive it to be incumbent on me, after examining the cridence, to lay before the reader a digest of it with such conclusions as have been expressed hy other investigators.

Ererghody who has undertaken to reduce Indian somgs to notes, whether from phomengraphe reeords or from the lips of singers, confesses f'rankly to the bewiblering diffienlty of the task. There is much vagueness in the Indians frecpuent slurring from one tone to another, the intervals are oftern, to say the least. mexpected, their seate relationship hard to determine until long familiarity with both style of song's and performance chables one to listen in much the same spirit with which the song is sung. 'These difliculties are heightened when notating frem phonographic records by the foredgn moises which accompany the operation of the maldine, and, when taking from the singer:s lips, by the clamorons thodding of the drum, without which the Indian usually declines to sing. There is, therefore, abundint room for error, and, in instances where the singing was probably out of tune, that is, from onr conception of seale relations, it is moloubtedly the tendency of the civilized 
musician to correct the apparent errou by writing the cherematic ar diatonic note that lies nearest to the one donlatfully intoned.

It is this tendency that lads most witers who speculate concerning the origin and nature of musie to discard ats evidence all notations of primitive music. holding that the motes on our staff that purport to represent the primitive song can be but alphoximate statements of the facts. Thus discredited by those who pose as anthorities in matters secentific the musician who has triled hard to gralsp and retain primitive somen finds himself in a position of peculiar embarrassment. Ile cammot well assert that his sense of leearing is so aleute that he can infallibly detect deviations from diatonic pitch to the extent of an eighth. or less, of a tome. and if the man of science asserts that such deriation is accomplished at will on the part of the aborigine according to a eoneeption of scale relationship of which the eivilized musician is ignomant. he must be a bold investigator. who would insist that his notations were allsolutely correct. If he replies that this is the tume as he heard it the man of science tells him that, heeanse he is civilized and a "harmonic musician," he has not been able to hear correctly: that certain tones sung by the aborigine ineritably escaped him: and that what le put down in motes nay he beatutiful but is nut what the aloorigine sang.

There is a good deal to be said. nevertheless, on the musician's side of the controversy. for such the discussion really is, and that he is by no means defenectess has been proved to my satisfaction by the latest and most striking statement from 
the purely scientifie point of riew. In all that follows, the dual nature of musical science shonld be borne in mind. The composer. who is so far advanced in the seience of musieal structure that he thinks in eomuterpoint and dreams fingues, need know nothing whatever of acousties. It is no eoncern of his whether the A has 490 vilmations, or 49000 . His work is securely grounded whether or not he is aware that in true piteh relations certain full steps in the seale are larger than others. II is seicnce is hased on matter's of which usually the physicist is blandly ignorant, and he is entitled by his knowlcdge of such findamental matters to doubt the validity of the plysicist's conchusions when the physicist presmmes, as he often does, to invade the provinee of musical astheties.

TILE ACOLSTICAL, TEST'.

Now it happens that one who is as competent to discuss music in one seientific aspeet as the other, Mr. Benjamin Ires Giluman. has studied certain Indian songs from the acoustieal viewpoint and, by resort to a motern mechanical device, has conc to a close nuderstanding of the exact intervals used, and, further. has invented a method by which very minute deviations from diatonic pitch may be graphically expressed. Mr. Gilman's look, IIopi Songs [IIoughton and Mifflin, 1908] is not only the most reent publication with regand to Indian misie, lut the most valuable in that it points the way to answering the vexations cuarter-tone question, although, as will be indicated, he has not yet answered it convincingly even with respeet to the precise Indians whose musie was the subject of his ob- 
servation. I may add bere that his method points the way to soncthing of more inportance to art than the determination of anything eonnected with prinitive someg. We may discoser throngh it a great deal about the relation of tones in the music of civilization that is not now suspected. Throngh it eren maly come such a recomstruction of musical theory als to malke the compositions of Richand Straus appear to conform to sombl

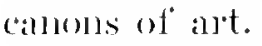

Mr. Cihman was connected with the I Ienenway Sonthwestern Expedition whele hate to de with the Zunis. Hopis. and other Pueblo Indians. 'This scientific expedition. to the aredit of its fomder and members be it said, ald not neeglect music als a feature of' Indian life worthy of special incuinery, and Mr. Gilndin, a profound student of musice devoted limself to an eximuination of Zunii and I Iopi somge from the acoustical point of view. In a paper contributed to the Hemenway archeological reports published some years before "Hopi songs," le expressed the conchusion that the Kanis have no sense of scale relations:

"What we have in these meluclies is the musical growths out of which scales are elaborated, and not compositions undertaken in conformity to noms of interval order alleady fixed in the conscionsmess of the singers. In this atrchate stage of the art. scales are not formed hut forming."

Mr. Cilman procedad along this line in examining IIopi songs, and undertouk to test the alecurace of the notations lee had made in the terms of the staff by ascertaining the exact pitch of every tone in every song. Ile first reduced the songs 
to notes on the standard staff, relying only on his sense of hearing. thus following, of course, the procedure of other investigators. The songs were reeorded on phonographie evlinders, and his next step was to establish beyond reasonable doubt the faithfuness of the phonograph as a reprodueer of its eontents. This required a long series of experiments, and, when he was satisfied of the phonograph's integrity, a mueh longer and more arduous series followed in conneetion with an instrument designed to register the exact pitch of a somnd to the hundredth part of a semitone.

Without going into the details of the operation, whieh Mr. Gilman deseribes fully in his hook, it must be evident at onee that the question of the quarter-tone would be answered unequivocally in the case of every song subjected to this method of inquiry. For the sake of eonvenience in expressing the results graphically. by means of an amplification of the fiveline staff, Mr. Gilman restrieted his considerations of deviation from diatonie intervals to the one-fourteenth part of a tone. That is, his scheme of notation provides for a graphie representation of fonrteen different degrees of pitel between, for example. $\mathrm{A}$ and B, which, it must be admitted, is variety enough for the present inquiry.

Working ont his songs by this method, le found that the phonograph caught and reproduced some sounds that he had failed to hear, and that many of the intervals as expressed in his own standard staff notations were radically ineorreet. In other words, when depending on his unaided sense of hearing lhe believed he heard, or made himself believe he heard, tones 
on. for example, $G$, which in reality were some fourteenths of a tone above or below that pitch. 'The melodic line of the song tonched here and there notes of the diatonic seale, but for the greater part it wandered with astonishingly iregular approach to regularity among intervals that were adiatonic, that is, between the piteles represented by two successive chromatic steps. The inference seemed to be inevitable that the singer sought and tonched these internediate intervals by conscious effort, and that, therefore, any expression of his song in the terms of the standiarl staff would be misleading.

'laking the results of this study in bulk, it would seem at first glance that Mr. Gilman had established the adlatonic character of Ilopi music berond question: and inasmuch as Miss Curtis. who approached the music of the same people from the other viewpoint, and notated a great number of their songs in which she fomd expuisite beauty, also fommd qualitics that defied her ability to express spaphically, it will be well to see what she says. She does not enter upon theoretical discussion, or mention the quarter-tone question clirectly, lut the following parapaph appears in her introduction to the pages in "'The Indians' Book" deroted to the 1Iopis:

"To seize on paper the spirit of Hopi musie is a task as impossible as to put on eanvas the shimmer and glare of the desert. IIopi music is born of its environment. 'The wind sweeping among the crags and whirling down the trail has carved upon the rocks in curioms fashion the record of its presence. Its echo is heard in the song of the Itopis yodelling through the desert solitudes. There, in that wide land, under 
the blaze of the Arizona sum. and the shitting color of the tinted sands and the purple-blue of the sharp-shadowed rocks. must the songs be heard to be heard truly:"

It I interpret this paragraph aright it is an admission on the part of Uiss Curtis that Hopi wongs fail under the test outlined in "The Point of Tiew." Chapter I: that is, they will not. when transplantel. stir the emotions of men to any degree comparable to their performance in their native surroundings. To per-ons who have heard them there the notations may revive the mood they then induced. but if other's cannot "hear them truly" when sung from the printed notes. then their limitations in erviceability to musical art are very sharply drawn.

EXIMIXATIOX OF THE ACOLSTLAL TLNT.

I would not appear to disparage either the accuracy of $\mathrm{Mr}$. Cilman's results, or the worthiness of his method. and yet I must raie a question or two conceming them. On his evidence and that of Miss Curtis. I am inclined to think that the Hopis habitually sing interrals that defy statement in the terms of onr stafr, but Mr. Cilman's patient labors have not yet proved so much. There are serenteen songs in his collection to which le alplied the acroustical test. a rather small number on which to base conclusions with regard to the music of a people. It is clear from an examination of lis notations that the singers either did not utilize the minute subdivisions of the intervals with any conscionsness of system. or that they were incapable: of clirecting their voices with certainty to the intervals they desired. In otleer work, if the IIopis sing aceording to an 


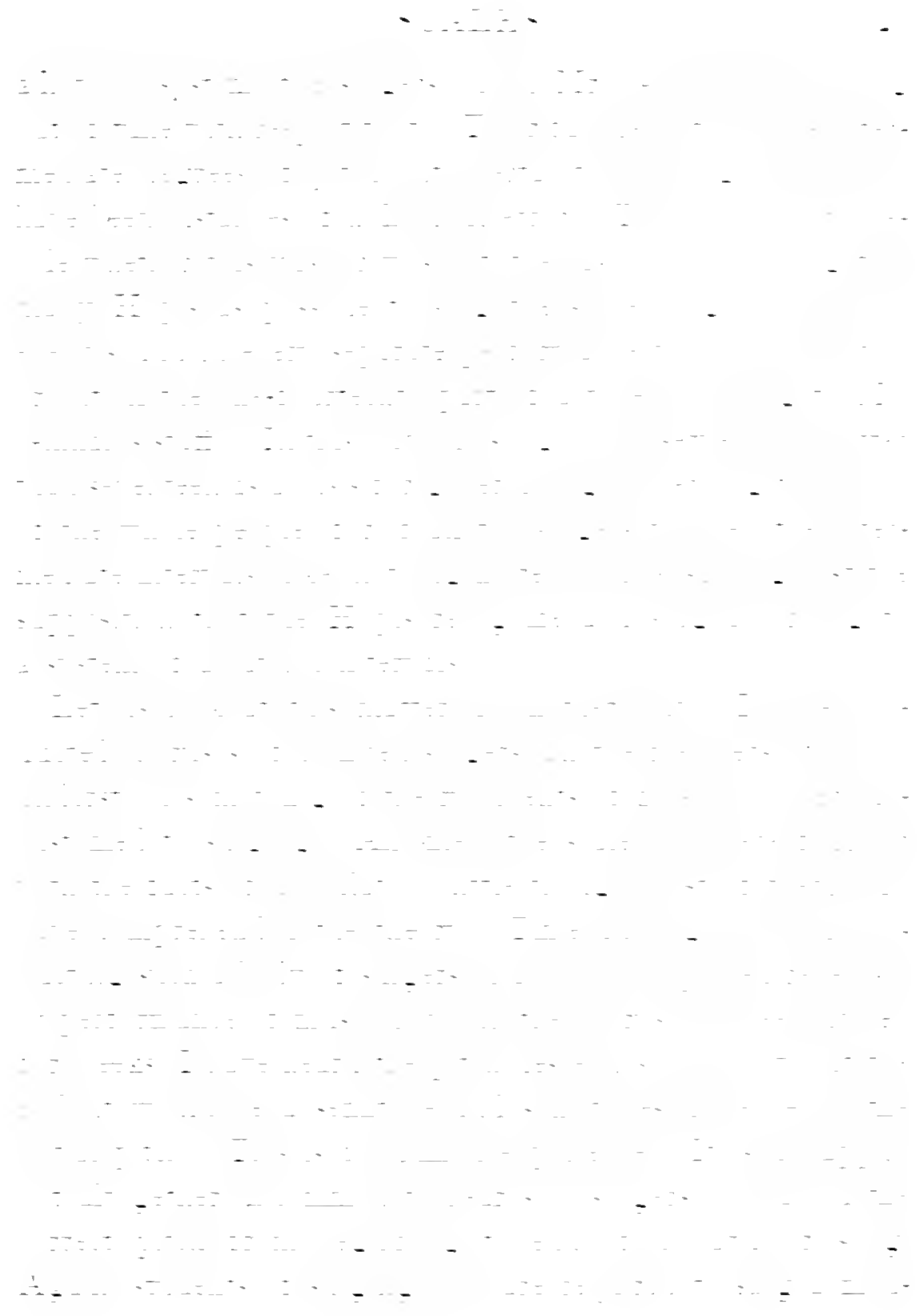


crately long piece witlout accompaniment, plume themselves promely if they come to the end preedsely in tune.

Now let us suppose that the music of eivilization had no sclieme of notation, and that the only evidence of its eharacter arailable to. say, an inrestigator from Mars, consisted in phonographic records of choruses that flatted, opera tenors who sharped, and soloists generally, with their multitude of sins. Suppose the emolite Martian subjected his recomeds to a specially tuned harmonical and notated the exact pitch of every tone in every piece. Would le not be likely to eonchule that Earth's choruses had an amazing conception of pitch relations in that they were able to descend from a given tone by minute gradations, sonetines only one one-humdredth of a semitone, to a point fifte or more hundredths below the starting point! 'The argument to this enelusion womld be inrincible, for he would observe that, although the choms was divided into separate choirs. each with its own harmonic part, all descended togeiber, the sopranos ariving at as relatively low a finish as the basses: and, therefore. these singers. one and all, must have proceeded upon a well-estahlished system. which proved clearly, to say the least, a conecention of adlatonic intervals. Then suppose the Martian wrote a treatise to that effect. who conld controvert it! What damage suit against him in behalf of Earth's standered ant would lie?

'Tlac foregroing is intended merely to be suggestive. Seriously, I should be glat if some physicist would test the singing of civilization aecording to Mr. Gilman's method and record the results on the Gilman staffi. It is a faret that the singer 
who maintains absolutely true pitch is rare; nevertheless on music is based on the diatonie scale, and he is a ranely had singer whose false intonation ean deceive a well-copuipped musieal theorist as to the melodie contonr of his song. Mr. Gilman's experiments lead me to wonder if the line of a somg, so to speak, that is, a graphic representation of the exact pitch tonched firom tome to tone, might not properly be likened to the edge of a sharp razor. Cuder a powertul microseope tie razor edge proves to be in irregular line, worse than a worllout saw, marked by rageged indentations and extensions, ntterly unlike the straight, eren line that it appears to be to the nalked eye. The microscone modoubtedly tells the truth and yet the razor cuts. It would not be smprising if a craphie representation of a good singer's performanee proved that he aroided the diatonie intervals by a tew humdredths of a tone here and there, thus projeeting a "line" for the melody as uttered by him that would be misleading to one who reganded nusic merely from the viewpoint of the physicist. If this should prove to be the ease, the singing of civilized persous would be only approximately correct, and the staff notation of their performances would not be an aceurate representation of what they do.

\section{THE INTERPRETATIVE UETHOD.}

In view of the fact that most choruses do fall from pitch unless sustained by instruments of fixed intonation, and the further fact that highly trained singers do on occasion, and in some distinguished instances, habitually aroid the key, there 
is no need to take my suggested parallelism between the melodic line and the razor elge as a bit of hamiless fantasy. I believe that an application of the Gilman method to civilized singing would necessitate the use of the Gilman staff to record the exact performance; but the stability of the art of music would be undisturbed thereby. The asthetic value of the song represented by the notes would be undiminished. It might be well, and, indeed, very exact, to say that the notes pemed by the composer represent an ideal to the expression of which man bends his vocal efforts withont always, or perhaps often, attaining aceuracy. It does not follow and nobody would suggest that composers should cease to express their ideals in the rigid terms of the staff, or that we should try to conform our scheme of notation in accordance with the imperfections of the human voice.

"In this archaic stage of the art, scales are not formed but forming." say's Mr. Gilman, which, I think, is the same as saying that the Zuñis are groping for a satisfactory system of interval relations. This is precisely my feeling with regard to Inclian music generally, atthough I believe that some tribes, among them the Ojibways, have groped their way out of the confusion of adiatonic music. Here is primitive man, conscious of the beanty of modulated sound, stirred by the tunefuhness of tones uttered, one after another, at different pitch. With no knowledge of acousties, with no instrument of the string type to suggest to him the nature of vibrations, he gropes vocally for such tone relations as shall satisfy him. Now it is certain that among the meagre contributions which 
Nature has made to the ant of musie, one of her gifts was the relation of tones in the seale as discovered ly Aristoxenos six centuries before the Christian era. It took the white race unknown centuries to find so much of certainty and stability in the seience of music. Sixtecu centuries at ter Aristoxenos the white race was still groping for its next step forwarl. It had not even then settled upon what we now call the major seate as the basis for it: musieal art: it was eren then only beginning in a crude way to experiment with harmony.

We whites, then, have come to rest on the intervals of the diatonic scale only in modern times. The Indian is still gloping-for what! Sonce difficult, muntural saale such ats the comparatively sophisticated peoples of the Orient hare sncceeded in mastering to a rery limited degree? I'nlikely. It seems to me that they are groping for the Greek intervals. and that if they conld fully express their melodic aspirations they would ntter melodies as susceptible of representation on the staff' as are the molodies of cirilization. It is worth while to discover that the Pueblo Indian does not sing in our scale: it is arlmirable to invent a method of indicating to the one-fourteenth of a tone just what he does sing, but let no details of that material kind forefend the champion of that other science of music from diseovering and interpreing the beanty of Indian song in such terms as the stamdard staff nukes available to him. We may not thereby get a faithful reproduction of Indian song; for the purposes of art we do not want it. We want what there is that is lovely and suggestive in it: we would approximate to its spontaneity, if it has any. to its simplicity, 
if that be its general character; we would be drawn by it closer to mature to the end that our music eventually should be the expression of subconscious sympathy with our comntry, and not a laborious effort to square our original thought to Enropean models.

'This is no fantastic dream; neither is it in conflict with any science. 'The ethnologist, naturally, will have none of it, and properly, for it is his business to store up obvious facts, hut he cammot object to this other work, this search for the facts that are not obrious, this rescarch for the spirit of things, the results of which tend to enliven as well as inform a people. 'The two kinds of work may go hand in hand. The properly equipped musieian may not only set down the bald facts of the Indian's imperfect musical utterance, and thus contribute to exact knowledge, but he may apply his knowledge and perception as an artist to correct their utterances, expand them even, and so dress them with the devices of civilization that they become apable of a wider influence than is possible when they are preserved merely in their primitire form.

It is this double work that I have tried to do-the presentation of exact record of Indian song, and the interpretation of it in terms of music as molerstood by civilization. I shall have ocasion again to discuss the interpretative method briefty in relation to Ojibway songs, where more enters than a consideration of scales and intervals. 'The foregoing excursion was induced by what seems to me the incompletencss of Mr. Gilmain's examination of Pueblo Indian music. It goes far enough to confuse the general subject, for the extraordinary 
care bestowed upon seventeen II opi songrs, added to his palper on Zuni songs, gives an appearamee of erreat weight to his "belief" that aloriginal Ameriean musice is a lype apart. whose essential remoteness from the music of kurope and L lsia may be symbolized. as it donbtless was eonditioned, by the physical isolation of the Americias."

It is gravely to be dombted whether Mr. Cilman expressed exaletly what he meant to say in this sentence foum on the first page of "IIopri somess." It is not, to be sure, the assertim of a scientifieally established fact, but, viewed in the lisht of the anthor's distinetion and his painstaking work, the inferenee is likely to be drawn that the musie of all North Aneriean Indian peoples is structurally similar to that of the I'uchlo tribes. Presumably Mr. Gilman would not justify such an inference fiom an examination of a f'er Zuni and IIopi somgs. Granting. for" the sake of argmente that P'nelsho Indian musie is arliatonie and "a type apart . . . from the musie of burope." it does not follow that the music of a single one of the more than fifty other ethnic families is of the sance chatracter. The fact is that, judged ly such tests as musicians usually enploy, the somgs of the (Ojibways are diatonice, and a considerable part of the songs of other plans and forest Indians are munistakibly expressed according to a scheme of intervals recogrnized by civilization.

TIL MESIC, THT.

Presumahly every musician who has notated Indian songs has molertaken in one way or another to test the aceuracy of 
his notations. Dr. Baker's method eonsisted of singing his notated songs to and with the Indians from whose lips he had taken them. Ifis conclusion was that the Indians whom he heard, sang aceording to the intervals established by Aristoxenos. It may be worth noting that I expressed this eonelusion with regard to the Ojibways in a paper witten some years before I had real Dr. Baker's essay, my phraseology being close enough to that of Dr. Baker to pass for a translation of it. Miss Fleteher and Miss Curtis pursued much the same method, and Mr. Fillmore, Miss Fleteher's associate, eondueted some interesting experiments at the pianoforte, the Indian singers listening to his harmonized arrangements of their songs. Miss Curtis's indirect evidenee as to the aldiatonie nature of IIopi songs has been quoted. Miss Fleteher makes but casual allusion to the subjcet, but she says [Omaha Monograph, page 11], "The Indian's management of the roice, which is similiar in singing and in speaking, make Indian music secm to be out of tume to our ears eonventionally trained to distinguish between the singing and the speaking tone of voice. Although the Indians lave no fixed pitch, yet, given a starting note, graduated interrals are olserved; not that any Indian ean sing a scale, but he repeats his songs without any material raliation."

Mr. Fillmore and Miss Fleteher both observed that grace notes in several songs "were struck by the Indians about a quarter of a tone above piteh." 'The essential tones of the melodies, lowever, appealed to them as in tune and were so 
notated. In one ease. Mr. Filhnore olsserved that the second part of a song was sung in a key a semitone fower than the first part. There was an "uward skip of an octare and the singers fell short of it. 'They proceeded, however, from their false start and sang the second part relatively fike the first: but when Mr. Fillmore played the song to them on the pianoforte and earried through the second part, as they hard sumer it, in a lower key. his Indian listeners were displeased. Ite had made a mistake. When he played the piece throughout in the same ker, they were sitisfied.

I have been at some pains to present all the evidence there is of adiatonic singing by Indians, and it should be added that the writings of Dr. Franz Boas concerning certain Indian peoples on the north Pacific coast indicate that deviation from diatonic intervals prevails among them. Against this evidence must be set not only my own observations, but the presmuption that so appreciative a musician and so distinguished an archacologist as Miss Fletcher would not have persisted in notatmg the songs of the Omahas. Dakotas, Pawnees, and other tribes, on the standard stafl' if' she had not been convinced that the notes penned were a correct statement of the musical facts. Further, aside from her confession of doubt albout IIopi music. Miss Curtis has eomplained of no difficulty with regard to the interval relations of the hundreds of songs notated by her. She is a thorough musician, and her sense of hearing is extraordinarily fine. It is preposterous to suppose that she would continue to reduce the songs of tribe after tribe to 
notes of the standard staff' if there were such deviations from the standard intervals as to make those songs "a type apart from the music of Europe."

It might be fair to say, then, that from our present knowledge there are three general kinds of primitive musie on the continent north of Mexico: that of the Pueblo Indians, that of the north Pacifie coast. and that of the Indians of the plains and forests. A complete inventigation of the sulject, which, I fear, will never he made, might reduce or add to this elassification. 'The Indians of the forests and plains far outummber the other two elasses together (there are rpwards of 30,000 (Ojihwars alone) and ats an ereat part of their music is diatonice. the proper conchusion seens to be that, generally spealing. the Nortis Aneriean aborigines developed nusie to a stage where the so-called true intervals prevaled.

My own methed of testing notations was that of the other musicians. 'The unfamiliar nature of the rork led me at first into many errors, some of which were ludierous in the light of further experience, but I was far more hampered in determining rhythm than intervals. During one summer that I passed in Ojibway lind I hat a pianoforte in my cabin. and I often batd the Indians sing their songs to my aecompaniments on the instrment. This in addition to singing with and to them without acempaniment. All musieinns know that the pianoforte scale is a empromise: that our harmonic music is possible only by tuning our intervals so that every key is slightly out of tume: and no musician need be told that anybody who sings aceording to the Greek intervals can and does uncon- 
sciously adjust his voice to the tempered seale when there is a hamonie accompaniment. It was thus with the Ojibways. If singing out of tume had proved to be mirersal anong them. I should have suspected that their apprehension of intervals was different from ours: but there are Ojibwass, like 'Tetebahbundung, who sing in tome. I have often areompanied him on the pianotorte, and neser has there been the slightest sense of disagreement between his voice and the piteh of the instrument. IIe is a full blood and uneducated: he is exceptionally fond of music. but I never heard him sing other than Indian songs which, he tells me, he learned from obler Indians, most of them from a great-uncle still living on the north shore of Lake Superior, lut too feeble to sing now.

Tetehahbundung is by no means the only Ojibway who sings always in tune, but there are others who sing persistently false. It these latter constituted a large class, and if their deriations from piteh were committed according to a reeognizable system, we conld admit the argument that they represented the true Indian manner, and that men like Tetebahlmudmo either were exceptions, or that monscionsly they had andapted their intervals to our scale after having had some contact with the music of cirilization: hut they are not a larger class. relatively speaking. than the palefaces who amoy chorus condnctors by a tendency to flat: and their deviations from piteh are not consistent. 'That is, these singers seldom or' never' depart from the apparent pitch at the same place or to the same degree. Noreover, a faulty singer will seldom err twice in just the same way in a song. Again and again I have noticed that 


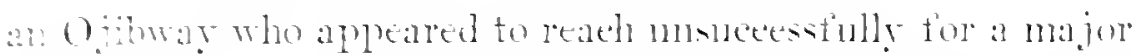

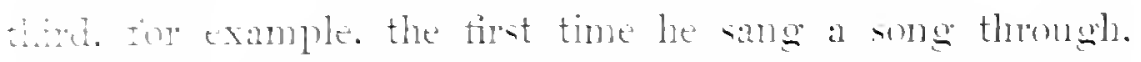

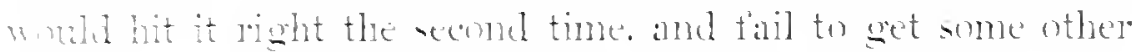
arceral in thene that he hald -me correctly the fir time. Fiandy, in the majority of ojihway -ouge the intonation. from

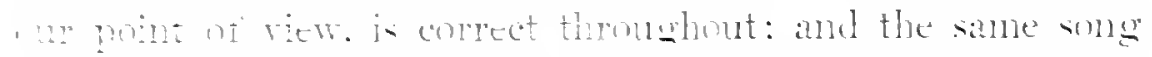
nary be intalerably ont of tune by one singer and perfectly

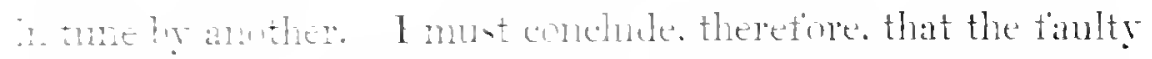

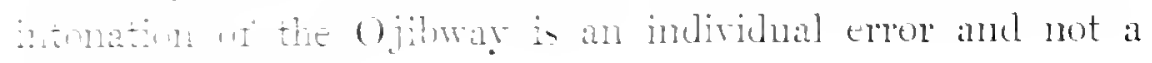
ackil peculiarity.

\section{DOTDWAY SCALES.}

It : proper to preak of sale in connection with ojibwar

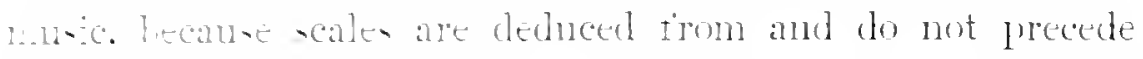

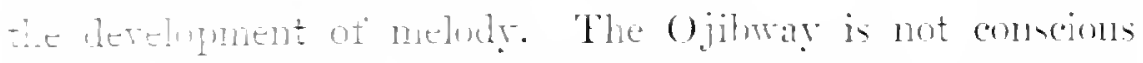

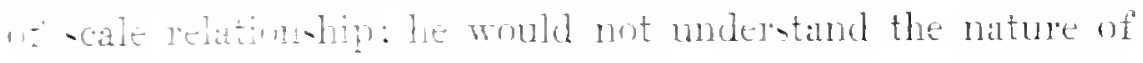
a -cale it it rere explained to him. Nuate to him i:s not a - cence on tar an concions knowledge goes. II know noth-

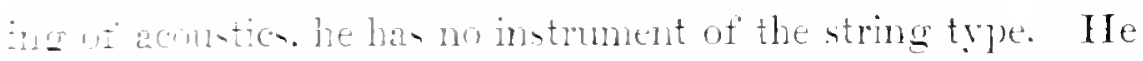

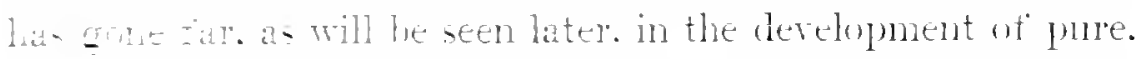
tompal meindy. hiv propress in this direction being the not to knowledse. but taste. No Ojibway so far as 1 know. has now undertaken to analyze the art of which he is so remarkat an exprent: Inde has erer adranced the crudent beginane of at theory of music: get he has come to all apprehemion $\therefore 1$ aprecciation of the fundancental principles of netolic

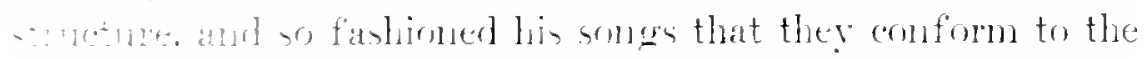

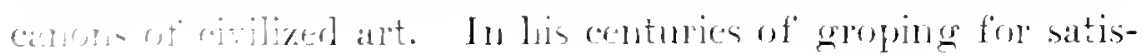




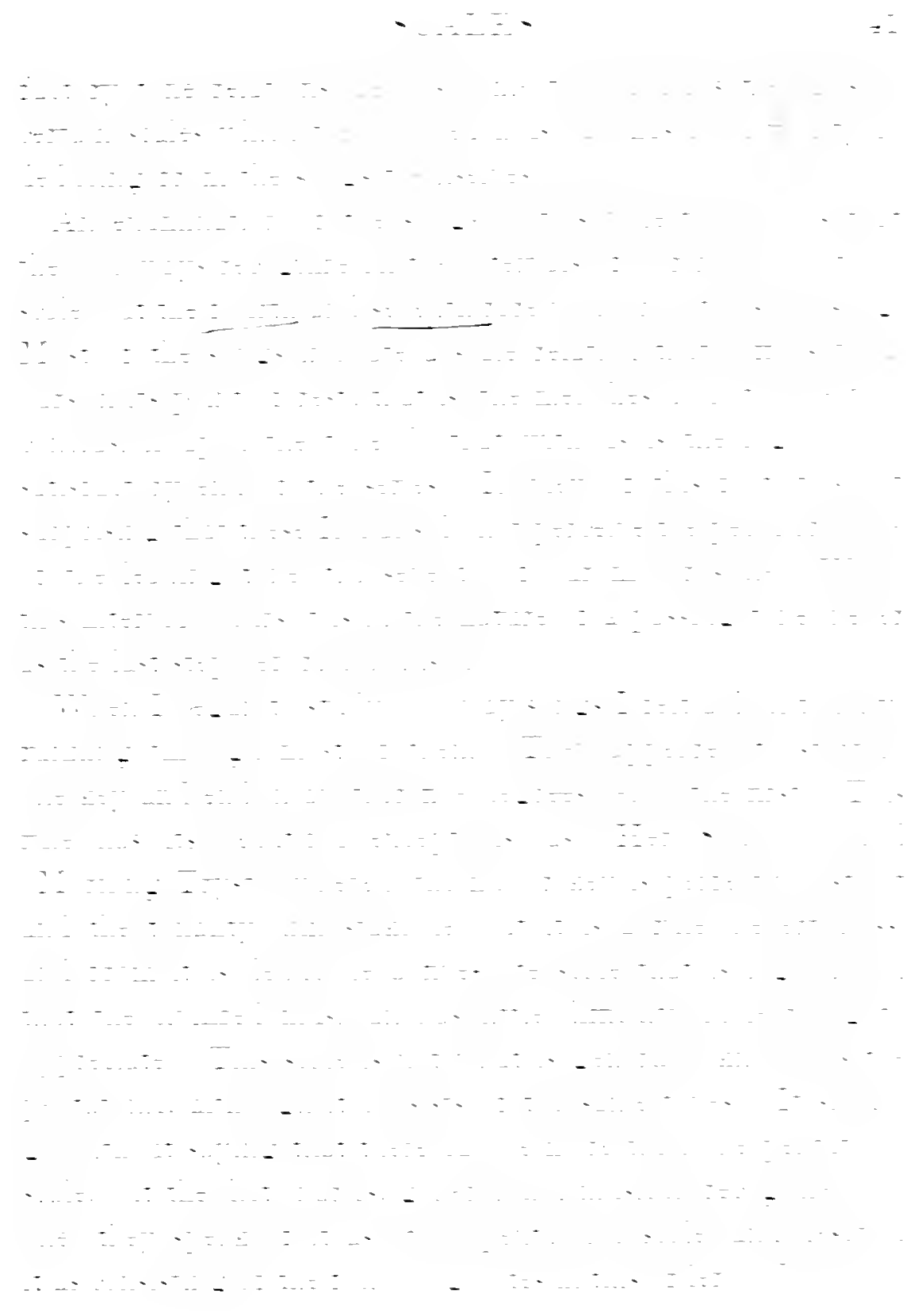


mi. re, do. I bave written the scale downward beeause it will be convenient in making comparisons to follow the general Indian tendency to downward steps. The Ojibway seale begins and ends with sol, so that it would syllabize thus: sol, mi, re, do. la, sol. That there is a vital distinction in this order of intervals hardly needs asserting, and if there be any doulht, it will be resolved by analysis of the songs. Note, for examples, "My bark Canoc," "Winter," "The Naked Bear," "Mlorning Star." This may be regarded at the major seale in Ojibway musie, the songs comprised in it being bright in character (from our point of view) and hamonizing inevitably in the major mode. Corresponding to it is a minor scale, also pentatonic, which reads downward as follows: mi, re, do. la, sol, mi. In this scale the final note of the song is more often la than $m i$, which gives it a semblance to onr melodie miner, the seventh (sol) in the Ojibway scale never being sharped. Examples are "Parting," "The Coward," "The Lucky 'Trapper." and so forth.

Fach of these seales is dereloped by the addition of one tone which brings about a scale relationship elosely analogous to the ancient hexachord. The Ojibway hexatonic major scale reads thus: sol, mi, $r$, do, si, la, sol; and the hexatonic minor: mi. re, do, si, la, sol, mi. Examples, najor-- "A Song of Absence and Longing," minor-_-"Lonely," "In the Forest."

'l'here are also Ojibway songs that appear to be lased upon the diatonic major seale of civilization, notably "IIer Sluadow," a remarkalule example of spontaneous, spirited melody that cones to a normal conclusion on do. This song is noteworthy 
SCALES

$4: 3$

also as an example of the variety that may be attained with a very limited number of diatonic tones. Examination of the song will show that only four scale intervals ante employed do, re, mi and sol. Following is a comparative view of the serferal scales referred to, (grouped under signature of one sharp for convenience in writing:

STANDARD SCALES

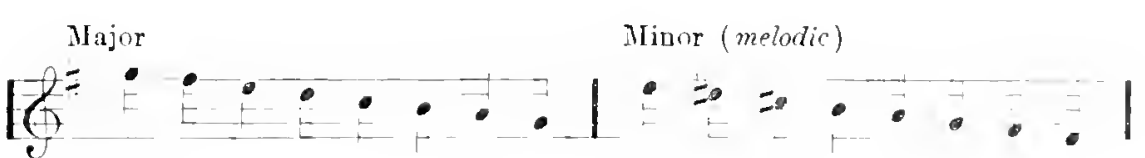

Pentatonic

The Hexachord

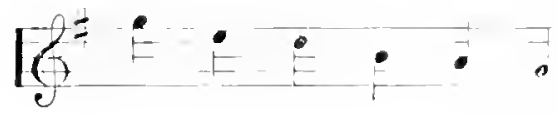

OJBWWY SCALES

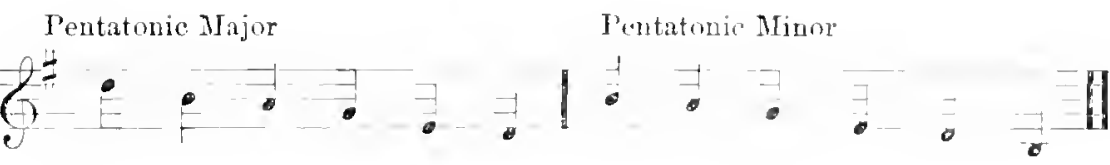

Hexatonic Major

He atonic Minor

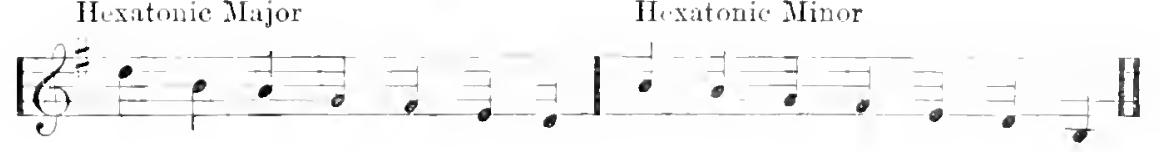




\section{CIIAP'TER III}

\section{RIII'TIIM}

T $N$ the spring of 19041 eximined a large number of Pawnee songs for Dr. Creorge A. Dorsey, curator of

1 the Department of Ethmology, Field Cohmbian Museum. Chieago, who was preparing a work on the religion of the Pawnees under the auspices of the Carnegie Institution, of Washington, D. C. 'The report I made of my observations eovered some of the gromul that is to be considered here, and I have incorporated in the pages that follow sueh portions of that repont as bear on the topic.

By far the most difficult snbject in a study of Indian music is its rythmie structure. We meet here phenomena that appear to be in defiance of ordinary homan intelligenee; we seem at times to be confronted with the maeeountable. even with the impossible. The phemomena are so bewildering that scholars otherwise sane have been led to dectare not only that the primitive red man has developed rbythm to a plane higher thin that attained by civilization. but that he has a conception of rhythm wholly at vallianee with ours.

When this latter observation was first brought to my attention I was so staggered by it that a long time passed before I reeovered. It had been uttered by a scholar of world-wide repute and in a tone of finality that banished dispute from 
his presence. What had led to the oraenlar deliverance were some remanks I rentured to the eff'cet that the puraling phenomena of Indian rhythm indieated not the red mans's superiority in this regard, but on the eontrary his inferiority; that he hatd. instead of a higher sense of alcecutual relations, a lower; and that his disturbing performances in so-called irregular and conflicting rhythms were lust manifestations of a helpless groping for the truth which, rhythmically speaking, is order, and regularity, and simplicity.

In the outer dinkiness to which I found myself and my heretical ideas condenmed, I came to something upon which I conld take firm lold when I realized that if the Indian's enneeption of rythm were different from ours, it would be vain to discuss the matter because on musical symbols are inealpable of expressing any conception of rhythm other than our own. We shoukl have to content ourselves with admitting that the Indian had acpuired pereeptions of shythmie relationships that are herond onr ken, and make imperfect effort to show the nature of his arlvancement hy pointing to the general belicf that he drums in one rhythm and sings in another.

On the heets of this thought came the query: Cin there be more than one conception of light? Yes: as many as there are blind men; hut besides all these there is cxactly one possible for those who sec. Rhythm is a fiact, not a hypothesis. It is patent to those who are capalble of perceiving it, and it underlies not only life itself' but all forms of ant. 'That a universal fact should be imperfectly grasped by most persons the world orer. that it should have bech recognized in musie 
at a late period in the evolution of the art, that no adequate treatise on the subject has yet been written, are matters that suggest a volume of philosophical speculation. For the present it will be proper to consider merely a few elementary propositions pertinent to Indian music.

\section{RHYTIMIC PIENOMENA.}

Let us see, first, what is the nature of the phenomena that lead observers to different eonchusions: second, let us come to a common understanding of rhythm; and, third, let us see what actually happens in Indian unusic so far as that can be made known through ny stucies.

The prime purpose of the drum in music is to mark the rhythm. It has been ohserved repeatedly that the Indian's roice has little or no regard for the rhythm strenuously established by his drum. Travellers have often bronght home aecounts of Indian musie, and embellished their accounts with examples in on notation, that told of a drum beat stadily in 4-4, for example, and the accompanying song in 3-4. I am so far from discediting any report of this kind that I will say at once that I have heard Indian music wherein the conflict betreen drum and voice was much more marked than is the ease between 3-4 and $4-4$. What I shall object to, with even then no disparagement of the notator"s sincerity or ahility intended, is the use, actual or implicd, of the word "steadily." 'The presentation of an example in printed notes, with no qualifying explanation, implies that the relation between drum and roice expressed in the printed measures was maintained indefinitely, 
or for as long as the performance lasted. This I gravely doubt, and the reason for the doubt lies in my own experience as an investigator, and the discovery of errors on my own part early in my work.

Perhaps I cannot quote a better example of eonflicting rhythms than the Indian song that formed the basis of $m y$ first attempt to utilize the musie of the red man for the purposes of art. At that time I had heard few Indians sing, and knew Indian musie only through the writings of other investigators. Two measures will do to represent the rhythmie seheme:

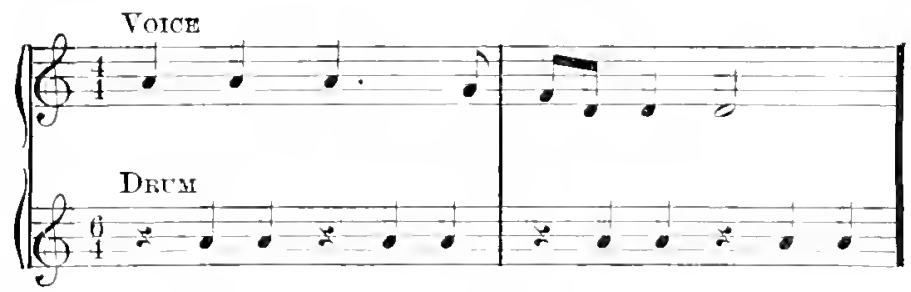

This scheme, four beats in the roice part against six in the drum, with the eonfusing omission of the first of every three, continued for seren measures, which was the extent of the song as printed, and the implieation naturally was that the Indian, repeating his song ad infinitum, held firmly to that all but tminthinable relationship to the end. Maybe he did. I rentured to develop the theme, giving the fantastic drum beat to the tympanist, and have fomd that by stremons endeavor on the part of the conductor, chorus and orehestra can be held to the seheme for the two minutes during which it is maintained. The piece referred to is "The Dance of Paupukkeewis" in 
my cantata, "IIawatha," composed long before the origin of the Indian play of the same name, and long before I had heard Ojibways sing. The theme is a Kwakiutl song. It may be of interest to know that cireumstances have led to the performanee of the piece before many Indians of various tribes, all of whom become greatly exeited when they hear it, reeognizing doubtless the native eharaeter of the theme, and stirred by the incessant thudding of the drum.

I cannot help suspecting that if the original notator had eounted time during the Indian performance for the same period, he wonld have found lapses in the roice part analogous to those described in the Pawnee song discussed below.

Other phenomena that have puzzled investigators are concerned with the distribution of accents withont reference to the drum, that is, in maccompanied singing. It sometimes happens that two strong pulses will oceur without a weak pulse intervening. The execution of such an effeet by a cirilized singer is almost impossible, and, when aceomplished, is grotesque in the extreme. Not so puzzling as this, but still foreign to our manner, are the numerons abrupt changes from one rhythmic scheme to another, as the injection of a $5-4$ measure into a series of $3-4$, or vice versil.

THE NATURE OF RHYTHM.

So much for the nature of the phenomena. An attempt will be marke presently to reconcile them with our "eonception of rhythm," but preliminarily it is neeessary to arrive at an 
understanding of rhythm whieh Frederick Corder, Esq., writing in Grove's Dietionary, calls a "many sided term," and defines is "the systennatic grouping of notes with regard to duration." Later in the same artiele, he says: "Rhythm, considered as the orderly arrangement of groups of aceents . . . naturally came into existence only after the invention of time and the bar lines." Here we have two definitions by the same writer. 'They do not necessarily conflict, but they are not in absolute agreement, and I think the general understamding with regard to musical rhythm is that it applies to the orderly arrangement of accents. But that rhythm, the universal faret. was not reeognized as a factor in music until something else had happened, is deeply significant.

IIere are two quotations from the Standard Dietionary definitions of rhythm: "Movement eharacterized by regular, measured, or harmonious reeurrence of stress, or impulse. beat, sound, acent, or motion:" "The musical property dependent on the regular suceession of accents or tone impulses." Other dictionaries that I have consulted agree with the Standard in making accent the basis of rhythm, and all regard orderliness. regularity, or recognizable șrstem, as essential to it. Duration has much to do with the matter, but duration alone, withont aceent. would not estahlish rlyythm: and duration may enter either to conceal one or more aceents, or to introluce a mumber of secontary accents. For example. suppose a piece that consists rhythnically of a regular reeurrence of four pulses. the first strongly aceented the third a little less strongly, and the others without pereeptible aceent: that is, a piece that would 
naturally have the time signature 4-4. Fill a measure with a whole note and the aceent on the third beat disappears; break the measure into eight equal parts, and not only does the acent on the third beat remain. but there are introdnced secondary aceents to mark the relationship between the eighth notes comprising each group of tro.

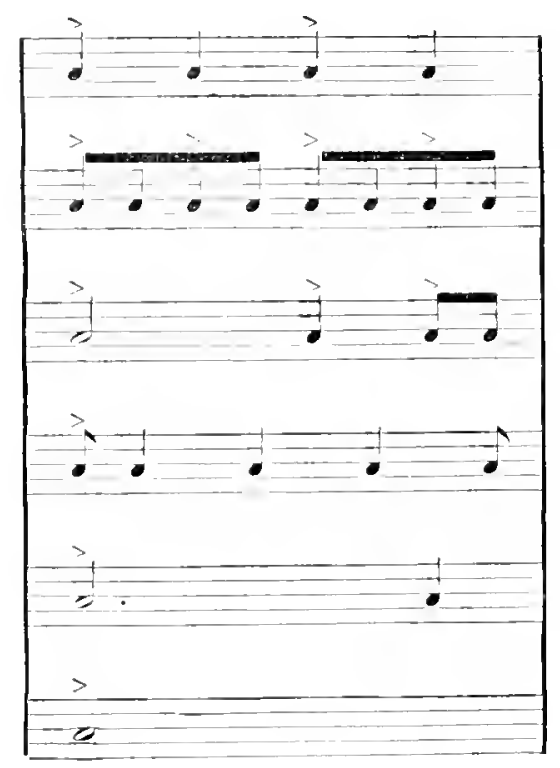

The diagram of notes is but a suggestion of the well-nigh infinite variety that may be attained in a rothmical schene of the simplest character. In Indian, as in civilized music, we find that the cluration of notes representing the voice part often differs from the notes that represent the aceompanying instrument, he it drum, or pianoforte; but in civilized musie the notes of the accompaniment, be they few or many, are in 
an orderly proportion with regard to duration to those of the roice; in Indian music there is often mo possibility of orderly proportion, so that there appears to be. and often is for a limited period, a concurrence of rhythmie schenes that are in riolent eonfliet. If this eonflict coukl be malutained with perfect steadiness in each part, voiee and alecompramiment, indefinitely, it would be incontestable that the Indian is calpable of conceiring molated rhythms at the same time. It is impossible for me to prore that this is not the case, for I have studied but a fraction of all the Indian musie that exists; but close obscrvation of the music of several tribes leads me to infer that the appearance of sustaining umelated rhythms coincidently is appearance only and not fact.

POSSIBIA CONFLICTING RHYTHAS.

The phenomena that justify this inference are similar in gencral character to those discussed in the chapter on seales, the Indian's own deviations from his seleme in the course of several repetitions of a song. Let us ohserve in approaching this part of the discussion - the thirel in the plin outlined albove - that not all civilized singers are gifter with a clear perception of rhythm. The arerage chorus must be reminded frexuently. that bar lines in written music are drawn as a guide to time and accent, and that the first note in every measure deserves a special stress. In other words, the rhythmie structure of familiar music often fails to manifest itself' in the work of the chorus, the reason being that the singers are not conscious that 
there is such a thing as rhythm. Again, solo singers, left to their own sweet wills, delighting perhaps in the sound of their own roices, are prone to dwell unduly on some tones and give scant attention to others until melodic contour is all but destroyed and rhythm is lost utterly. It will do no harm to remember these things when we come to glance at what the Indian does.

More essential still to a same view of the subject is it to remember that from the days of the earliest measured music until the present, educated composers have been capable of sustaining conflicting rhythms in the imagination, and educated singers and instrumentalists have been capable of executing them. It requires a ecrtain effort of the will to conceive of two shythms at the sime time, a greater effort to execute them; and to both it is essential that there should be some definite proportion between the pulses of the rhythms if they are to be sustained beyond a few pulses of either, the tendency of each being to force the other into correspondence with itself. For example, every pianist has to learn to play double rhythm with one hand against triple rhythm with the other. 'There may be three notes for one hand and four for the other, but the time given to the group of four is the same as that given to the group of three, so that at regular intervals there is a coincidenee of pulse that cnables the performer to take a fresh start. We will now amalyze an Indian song in which there is no coincidence of pulse hetween drum and voice, and no conecivable proportion between the drum beats and the natural aceents of the vocal part. It is a Pawnee song about 
a boy who was turned into an eigle. one of the series I rednced to notes for Dr. Dorsey from phomographic cylinders. That series was remarkably finitful in examples of rhythuic oddities, and "The Boy 'Turned to Gagle" was the most striking of' all in its coincidence of unrelated rhythms. For the satie of throwing all possible light on the subject I shall venture to detail the process by which the song was realuced to notes.

\section{EXINIXATION OF A COXFLICT.}

'There are several repetitions of the song on the eylinder from which I took it, and no two ane exactly alike, rhythmically speaking, in the rocal part, but the drum remains perfectly. steady thronghout. In recording musie of this type, my attention is given first to the drmm in the hope that it will le found to be rhythmically proportionate to the roice; for', if such proves to be the ease, the timc value of the voice notes is immediately established. Perceiring. in this instance, that the rhythms were dissimilar, I ignored the drum until I had set down an outline of the melody. This was not difficult. so far as piteh was eoneerned, for the singer's intonation was true, but the matter of estahlishing the time ralue was distressing. I was not disturbed by the drum, considerable experience in this manner of work enabling me to forget its presence: it was the fiact that the singer not only distributed his aceents aceording to no recognizable plan, but broke up measures that shomld have eorresponded with each other in a way that no arrangement 
of dots and stems could express. Moreover, in the repetitions he frequently mutilated measures that previously he had eonstrueted with firmmess and regularity.

Erentually I had on paper, as a result of observing all the repetitions, the notes that may be seen in (a), of the following. The accents are indieated by the sign > orer the various notes. 'This, in a way, was striking an arerage to obtain a correet statement of the song, and the division of the piece into measures followed readily. It may be seen in that form under (b) and I hazard the opinion that if the Indian had sung without the drum, he would have sung according to that scheme. But it must be understood that in no instance
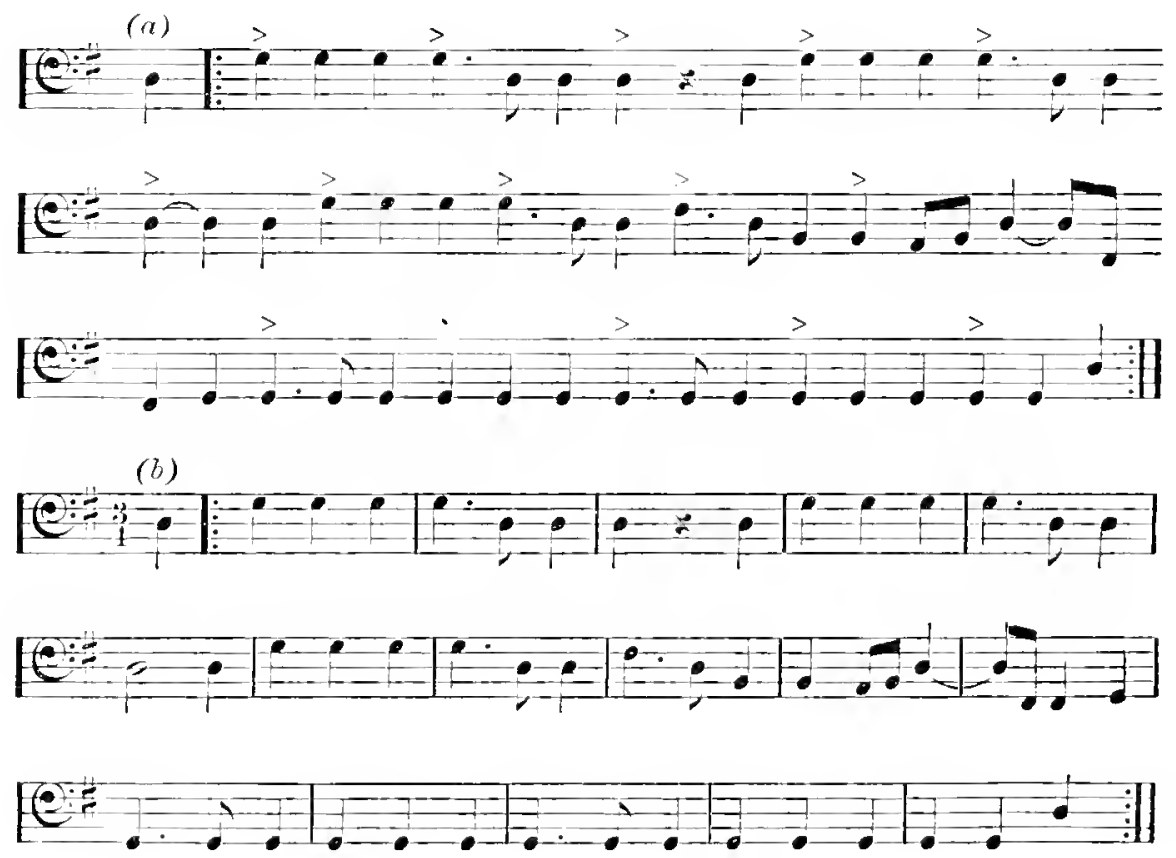
(c)
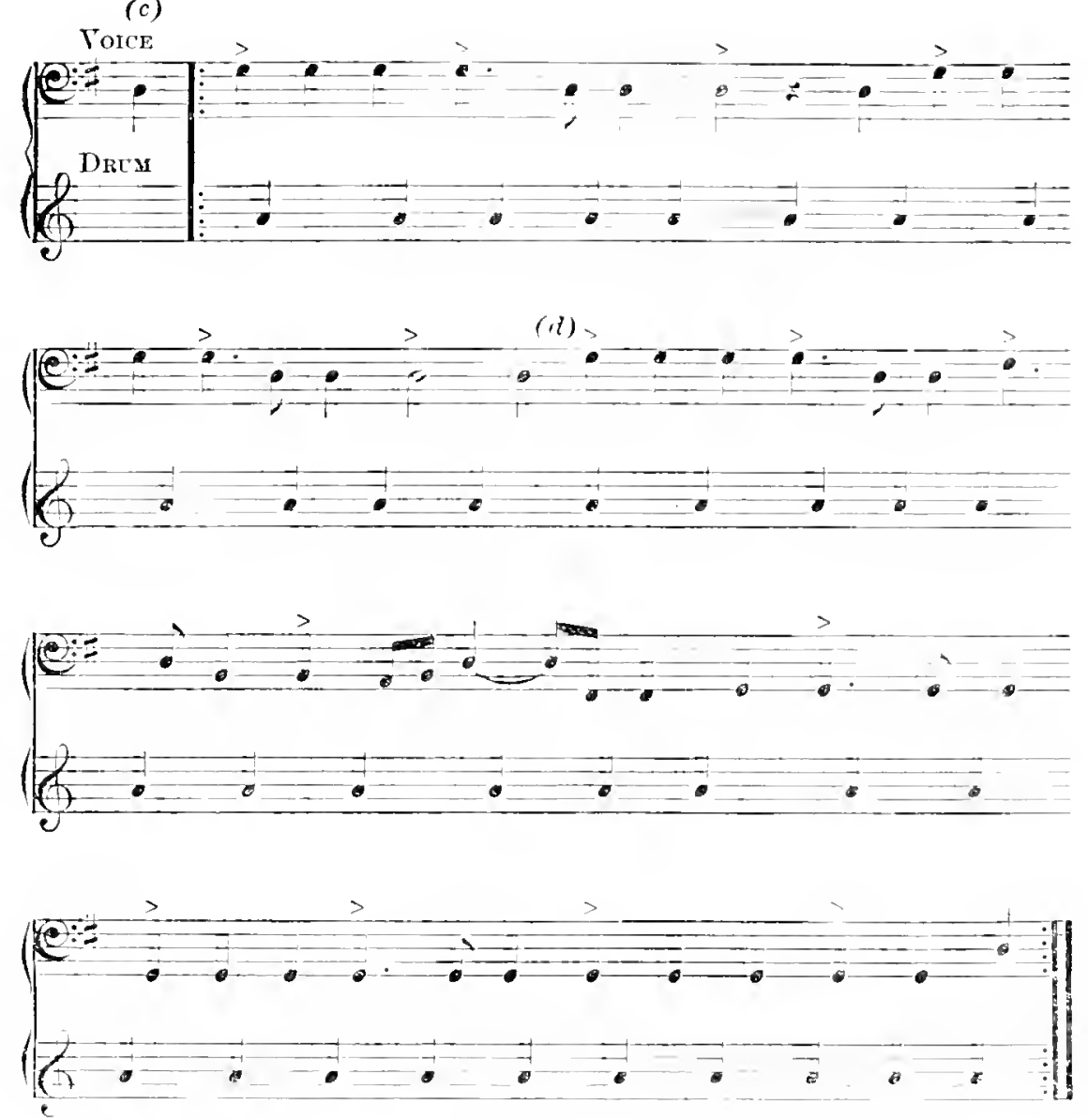

did he sing the whole in that way. What he did do was to present every measure at least once in the way indicated. From the viewpoint of detail, therefore, I have not "fixed up" the Indian's work for him. Taken as a whole, the piece as expressed in (b) is at least eomprehensible and perfectly 
singable. It ought to end three neasures before it does, but the prolongation of the real finish in nowise affects the consideration of rhythm.

My next effort was to set down the drum strokes just where they occurred beneath the roice part. It was impossible. One measure could be done, but not another. After much fussing orer the task, I made the arrangement shown in (c) which indicates approximately where the drum beats fell in relation to the voice. 'To the eye they appear to have fallen irregularly, but that is an ilhusion. The strokes were as stealy an a metronome, and at only one spot in any of the repetitions was there exact coincidence with the roice, (d) in (c).

Now, the voice part in (c) not only shows where the accents of the song would logieally fall, but where they did fall, and it is also a correct presentation of the Indian's rhythmic scheme in the terms of our notation. Comnting the beats, we find that there are 48 in the roiee part (omitting the initial note which, according to the custom of writing music, is supplied in the last note previous to the repeat sign) and there are 35 in the drum pert. If only there had been 36 ! 'There then would hare been a proportion-four to three-which would have brouglit alont either regularly occasional coincidence of pulses, or a regular clistribution of them whieh would have enabled a strong-willed singer to sustain the rhytlmn of the song. But no end of comting would make any more, or less, than 3.5 strokes.

I think no homm being conld drum and sing this piece and keep both rhythms intact. The Indian certainly did not. It 
would take pages to put into notes my attempts to express the variants of those measures in which a dotted fuarter note oceurs as the logreal symbol. I fomd that what the ludian actually sang could not be written without some medhanicil device to measure the length of each tone in the minutest subdivisions known to the printer's outfit. In fact. a little figuring of an arithmetical problem will show that it woukl be impossible. I believe the one-hundred-and-twenty-eighth note is sometimes used, but there is no perfect mathematical relation between 48 and 35 in 128 . For example, the Indian hat great difficulty with the fifth measure. On one oceision he mantaged to $\operatorname{sing}$ what is witten at that point. but at other times it was neither $d . \int d$, nor $d \delta d$, nor ddd. The difliculty of indicating what he did might be craded hy this deviec: $d \mathcal{d} d$ : but that is merely a confession that the phrase is incommensurable, and this device: dese or something like it, wouk still fail because 48 and 35 and 128 have no common fiactor.

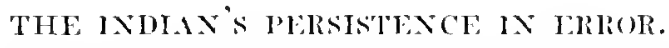

I could multiply examples from my note books. but this one is sufheient for illustration. It follows that in sones of this type it would be misleading to draw bal lines. In the first place, we should be in doubt as to whether the voiec or the drum should be regarded as establishing the measure. In the sceond place, the Iudlan speedily brealis his own arrangement of accounts through shecr inability to maintain his scheme. I find that the Indian usually lieeps time when the drum is in 
eorrespondence with the voiee, or in no more violent confliet than 3-8 against $2-4$. When the eonfliet is worse than that he never keeps his roeal measures in order. IIe will start his drum in 9-8, for example, and begin bravely to sing against it in 4-4; but after a fer measures of suecess he breaks away, and from then on the value of his notes ean be expressed only approximately.

'The inferenee is inevitable that the Indian singer's "conception of rhythm" is so exactly like ours that the drum disturbs him and draws the voiee away from its special morement. That it is the voice rather than the drum that wealeens is readily explainalole through the fact that melody, as distinguished from chanting, is a comparatively recent development of musie. 'The Indian has not attained a high plane in the invention of musie: his pereeption of the melodie relation of tones is weak; the definite, forectul pulse of the drum, appealing dircetly to his ear, orerwhelms the sense of mythmie pulse in his imagination, thus bringing about a distortion of the rocal part that depends upon the imagination for its form and elaraeter.

It is pertinent now to inquire why, if the Indian has any pereeption of rhythmic relations. as is indicated by the eorrected version of his meloxy, he permits himself to dram in sueh a way als to obscure or destroy it. It seems to me the answer should be obvious to any who know the Indian well enough to appreeiate the immense importance to him of the dance. For untold centuries the dance has been his rehicle for the expression of his deepest fechings. It is eommon knowledge that the warrors of the tribe are stimulated by it to molertake deeds 
of desperate valon; it is not so well known or realized, rather, that the Indian dance is a form of prayer. Dance and song almost always go together: the Indian's prayer is conched in song. and through the dance that acempanies it he gives his petitions and aspirations more obvious expression than could be attained by song alone. Add that the Indian is, up to his lights, very religious, and it will be seen that he bas inherited tendeneies of the most powerful kind which impel him to respect the drum, for upon that instrument the dance depends. 'To drum is instinctively with him to set the tempo and mark the rhythm for a dance. Inabitually, then, nay, irresistibly he drums with steadiness, according to a set plan, varying the stroke only when some uncommon feature of the dance calls for a change of step or tempo.

Slowly insensibly with him as with the race of whites, grew a perception of heauty in melody. Bom somewhere within the recesses of the soul, melody will often fall within the rigid rhythmic lines marked by regularly reeurring drum beats, but sometimes it leaps beyond them and demands a rhythm of its own. 'The simple-minded Indian eoukl not possibly pereeive that his incessant double rhythm, as uttered by the drum. was in conflict with the oceasional demand of his spirit for triple rhythm in his song. II must have been a self-antalyst equal to eivilized man if he perceived the conflict and rectified it conscionsly. Melody, therefore, beame distorteri; it was hindered in its normal derelopment, strugghing always to assert its spontaneous f'reedom, and always restrained by the hallit of the drum whieh the Indian would abandon no more readily 
than he would abandon any other of his numerons traditions. But, so great is the inherent strength of melody that it dereloped measurably in spite of untoward ciremmstances, and, among the Ojibwalys at least, overcame at last the obnoxious, disturbing drum stroke, the Ojibway himself, meantime, being blindly, childishly unaware of what was going on within him.

So it appears that the conflict is a radical one, as deepseated as life itself; a struggle between truth and error; on the one side, the sense of beauty in tone which in all races has led to the making of some mamer of music; on the other, traditional regard for the dance and its obvious ryythm; vague groping for melodic form on the one side, a familiar, easily comprehended habit on the other. The truth in this confliet is the artistic mion of spontaneity and symmetry. That, the Ojibways have obtained. Among some other tribes babit still overemes spontaneous melody to the cxtent of warping it, or keeping it confined in narrow, rigid lines.

The foregoing answer to the query is an attempt to reason backward from knowledge of present conditions. It would be simpler, and might be more satisfactory, to summarize the speeulation in one word which agrees with known faets, and attribute the Indian's persistence in error to ignoranee. He who has never stepped outside eivilization cannot comprehend the Indian's derotion to his drum, but I camot remember that 1 have met one white man who has lived with Indians who will not acknowledge frankly that he learned to like the instrument. I think I can enter appreciably into the Indian's interest in it. Perhaps it is the sarage in me, latent from long 
past ancestry, that is stirred by its resomeling damor. But while 1 have no ancient superstitions ansociated with the instrument, the Indian has, and he is not aware that the drum beat is in conflict with the scheme of alceents he invents for his song. Both. drum beat and song. are ingemums expressions of his nathe. One is extremely prinitive, the oflecremparatively advanced, and, as he still primitive he clinges to his cheerlul mise, understanding it, aroused by it, whike bis musical soul toils darky on toward an expession that aims exer at. and sometimes attains. symmetry. All of which is to say that he drums as he does becantise he knows no better.

When I began to study Indian musie seriously. I did so with the eomiction. learned from the writings of others, that the Indian had developed rhythm more highly than had the white man. I have come to exactly the opposite conchusion through olssersation of many songes like "The Boy 'Turned to Eagle." It should need no saying that the highest derelopment of rhythm is that which is most orderly: and if no order ean be recognized in a given piece of music, it would be fair to speak of it as without rhythm. Better this dictum than the assertion that the Indian has acemplished more in this field than have all the civilized peoples in the world. But that. also. wonld be misleading. for it has been shown that the applieation of rudimentary principles of musical art makes it possible to discern and set down the Indian conception of melody even when it is distorted by an unwitting attempt to link it to a complex rhythmie scheme that is impossible of executions. 


\section{RHYTHM AMONG THE O.IHWAYS.}

If the Indian really had a highly dereloped sense of rhythm, he would modify his drum beat and bring it into correspontence with the accents of his song. When, in a precerling paragraph I spoke of the Indian's perception of the nelodic relation of tones as weak, I made a mental reservation in favor of the Ojibways. 'Thesc people have a remarkialy strong perception of melodic relations, and their sense of rhythm is indieated by the symmetrical character of their songs. It is emphasized by their use of the drum which, in the hands of a good Ojibway singer, ordinarily performs its proper musical function, that of making the rlythm. I have come upon eximples of conflicting rhythms in Ojibway music, and in every instance the effort to sustain them resulted in a mutilation of the seheme, but, as compared with other tribes. there was this signifieant lifference: the drum part weakened quite as often as did the voice. 'Time and again I have heard an Ojibway singer interrupt the accompanying drum heats to bring the aceents into at least temporary correspondence with his voice. 'The inference, of course, is that. his perecption of melodic relationships being keen, he was sensitive also to the interference of the drum accents; and that he wats highly enough dereloped musically to seek to adjust his accompaninent to the scheme of the song rather than sacrifice the melody. Another manifestation of the singer's sense of discrepancy might be indicated by drum notes in the following orker:

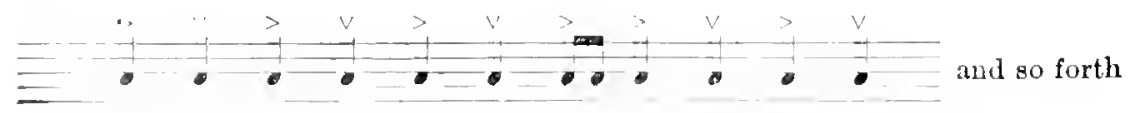


On all snch occasions the quick strokes were injected with evident irritation. Soncthing was wrong: the singer harlly knew what had lappened, presmmably, and likety enongh condemued himself' for having forgotten how to drum. 'The fact was that the scheme of accents in his imagination was strong cnough to overcome the mechanical, purposeless ponnding on the deer skin.

It is worth noting that instances of the kind just described were always in connection with ceremonial songs of undonbted antiquity. In the old days, before the appreciation of this people for pure molody had fully developed, it is probable that the ceremonial songs were as little related to the drum as they are still in other tribes; and any thing connected with tribal ceremony would be less subject to change than, for example, Jyric songs, the expression of the individual. In all Ojibway songs other than eerenonial, I have always heard the drum beaten consistently with the rocal aceents.

It appears, then, that if the discrission had been limited to rhythm as expressed hy the Ojibways there would have been little to say; but it seemed proper to make comparative obserrations and through the musical superiority of the Ojibways to other tribes to dispose of the fallacy that the savage Indian had outdone civilized man in grasp of rhythm. As for the minor phenomena referred to in the foregoing als offering diffieulties to the investigator, it is to be sadid concerning the distribution of accents in nuaccompanied singing, first, that the Indian, like the white man. is fond of the sonnd of his own roice. IIc enjoys, as we do, the effort of producing 
modulated tones, and he dwells pleasurably on those tones that are must congenial to his throat, or on syllables that, from his viewpoint, are most pregnant with meaning. Second, if we will but reengnize that the Indian is primitive in music as in other things, we will cease to look for an abstruse conception of rhythm in his songs and will give our mind no further concern with the matter.

The grouping of measures containing different mumbers of beats in the same melody is interesting, but, so far as the Ojibway songs are concerned, calls for little comment. Sometimes it appears that the injection of an odd measure is due to basing the rhythmic accents on the natural pronumciation of the words, but quite as often the words are transposed from their usiral order for the sake of the musical measure. I am inclined to think that these irregularities should be regarded as manifestations of the groping for simplicity and directness of expression which is attained only in the perfectly balaneed period. On the other hand, as so many of the songs indicate a firm grasp of periodic structure, it may be proper to look upon them as the normal expression of a people who have passed the bounds where appreciation of music is confined to the simple period. 'The songs are here, and each student may form his own conclusions from them.

\section{THE OJ1BWAY SYSTEM OF NUMERALS.}

Before closing this chapter I wish to direct attention and a query to one rhythmic feature of Ojibway music that has been 
highly interesting and troublesome to me from the begiming: the frecpuent oceurrence of somes consistently in quintuple rhython throughont. 'This is hy 110 means anknown in civilized musice, but it is mot commom. and it appeals to most persoms ats almormal. It has been tionblesome to me becandse af the enmfusion made on my note paper in the work of recording it.

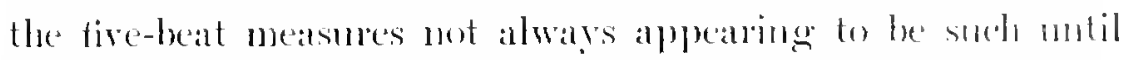
attempts to expless them in three- or four-beat measmese hare failed. So oftem is this selemes of aceents fomm that it might be regarded as an idlosprerasy of the () jibwatys and d hate womedered whether it may be commected with their system of mmbers! 'They have the decimal system. but exambination of' their inmerals from one to ten shows that it wals based upon five the sugenestion being that in the ohl diags tive was the greatest mmber the Ojibway could graspe. He comnts to ten thus:

$\begin{array}{ll}\text { one. bayzhig } & \text { ningotwasswe, six } \\ \text { two. neezh } & \text { necahwasswe. seren } \\ \text { three. nesswe } & \text { neshwasswe, eight } \\ \text { four. newin } & \text { jangwasswe. nine } \\ \text { five. naman } & \text { midwasswe, ten. }\end{array}$

The first five Ojibway numerals are independent words. the second five, compounds. Bayshig, one, in certain grammatical relations, becomes ningo. It will be setw, therefore, that the words for six, severn and eight are clearly componnded with the words for one. two and three, respeetively. I camnot ex- 
plain the formation of the words for nine and ten, but they are clearly compounds, also. That is, the Ojibway counts as far as fire and then takes a new start. After ten there are compounds analogous to those found in the languages of all peoples who use the decimal system. The question, a curious one, merely is, whether the Ojibway's grasp of numbers was to any degree responsible for, or comnected with his predilection for five-beat measures in his nusie? 


\section{CHAPTER IV}

\section{IIALA-BREFD MUSIC}

PIE reader camot have failed to notice the vein of
controversy muming thromgh the preceding chapters.
It was matroidable, for I conld not forget the reception aceorded to my reports on Indian music when first I eame from the region north of the Great Ialkes and sallg the songs I had heard there. 'There was nothing unkind in the reeeption. On the contrary, the interest evinced was plainly gemine, and the enconragement of kind words was generous. I was given to understand, among other things. that I was in a fail way to contribute sonething of value to etlonology, a riew of the matter that surprised while it gratified me, becanse, as stated herefofore, my ain was artistic and not seientific. But when I fell in the way of men of seience. I diseorered that ney notations were helel in dombt: that the artist in me gave gromuls for diserediting the results of my reseirch.

This was quite right, althongh it was hard to believe so at the time. for I knew the eare I har taken to set down the melodies exaletly as the Indians samg tleme and in sulusequent visits to () jihway lathel I took even greater pains to collect my material in such form that, if I ered mowittingly in my notations, anybody so inclined conld detect the errors and cor- 
rect them. To this end I went armed with a gramophone, and hat all the songs I had heard reeorded on its eylinders, and these erlinders I deposited subsequently in the Ameriean MIseum of Natural History, New York.

But even this was not enough. There was still a point of difference between me and the men of science that troubled me greatly, and that still gives me fool for thought. Satisfied that my notations were at least substantially correet, some of my seientific friends made light of the matter by presmming that the music of the Ojibways had been influeneed by eontaet with eivilization, and was, therefore, not properly to be ealled primitive. Now, when there is a difference between a seientist and a layman, the natural presumption is that the seientist is all right and the layman all wrong. Nevertheless, I must venture to dissent wholly from this view of Ojibway music. From the viewpoint of art, musie is musie wherever it is found. A beautiful melody appeals to us whether it be the eomposition of a full-blood or a half-breed. A trpe of follsong that is distinctive is no less distinctive because it happens to be the product of a mixed race, or of one that has taken measurable steps toward civilization. To sueh observations as these, my seientifie friends have responded in effeet that there can be no possible objection to the attempt of a musician to find artistie material wherever he ehooses to seek for it, but that sueh work is none of theirs. as they have to do with the study of actual primitive life; they will weleome anything that throws light on it, but they cannot be expeeted to take interest in phenomena that have been modified by the influenee of civilization. 
It has been very diflicult for me to molerstand this, and if I misrepresent the seicntific attitude it is because I state hrictly the substance of what sereral cthologgists bave said to ne. I can quite molerstand that a student who has set himself the task of discovering and informing the world what wals, for example, the religions doctrine of the Ojibways before the aldent of Europeans, should thrust aside as negligible and untrustworthy evidence what an Ojibway born and realed on a reservation might tell him. Such an Ojibway conld handly fail to confuse the misty traditions of his people with Bible stories learned from missionaries. I can mulerstand that men of seience have not the time to bestow on subjects other than those in which they have elosen to specialize. The trouble lies as I apprehend it, in the general attitude of scientific men, who appear to ignore that which is not of moloubted antignity, that which is not ummistakably and purely aboriginal. This attitude is open to eriticism, so fiar als the study of primitive music is eoncerned. on two grounds: tirst, that it tends to obstruet the study of primitive musie; second, that it is in itself mscientific.

As to the first eriticism. from the time of Dr. Balier to the present. it is the muqualified opinion of every musieian who has sought to learn of our primitive music at first hand that it is a subject to which a great deal of attention and effort should be given. We who have worlied in the field know the immensity of it; we know how comparatively little can be aceomplished by the sporadie efforts of individuals: we know something of the material cost of such work. and that it camot 
and ought not to be borne by the enthusiasts alone. It is work that needs and deserves support, a difficult matter to arrange under the hest of circumstances. How much more difficult when men of distinetion in ethnological science manifest indifference! 'Those persons who miglut take an active interest in the preservation of such primitive songs as still may be found, are readily deterred if Science utters the disparaging remark that the beanties of Indian song are merely the results of contact with cirilization. Let it be admitted for the moment that the musician's work is not germane to the general pursuits and purposes of ethmology: is it not clear that an attitude of reserve. if not of hostility, on the part of men of distinction is bound to have a deterrent influence on those who might otherwise be aronsed to an interest in the musical work for its own sake? I cammot. to mention but one instance, aceount for the persistent refusal of the Carnegie Institution to aid and sanction musical researeh on any other ground than that, the matter having been refered to seientific men, a report has been made that minimizerl the value of such investigation.

As to the second point, is it possible that there is no room in the seience of ethmology for the observation of living phenonena! We know that there is. We have only to recall the recent death of William .Jones at the hands of Philippine savages whose customs he was studying. to linow that Science sacrifices much to learn what there still is of primitive life in the world: but when it comes to the exolution of a primitive people to or torard civilization, should science turn aside her 


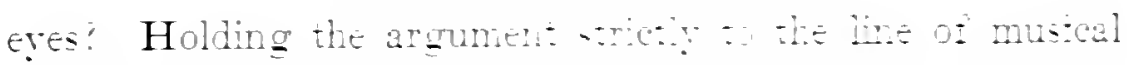

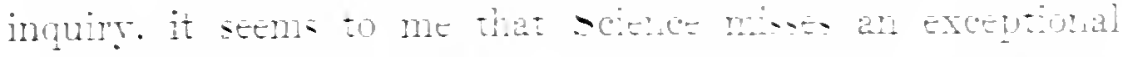

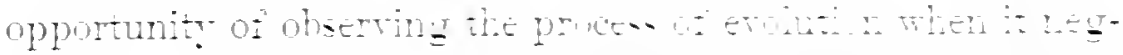

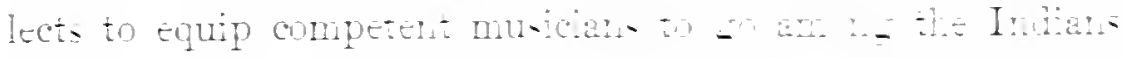

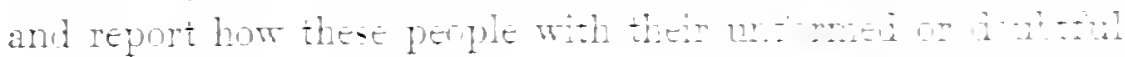

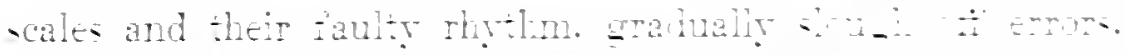

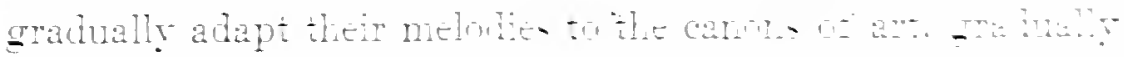

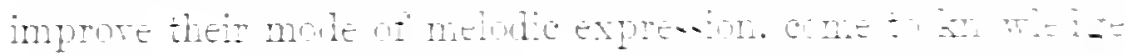

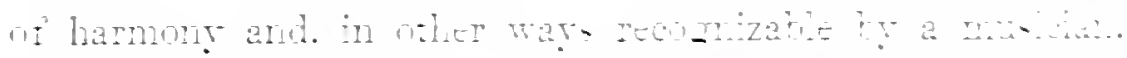

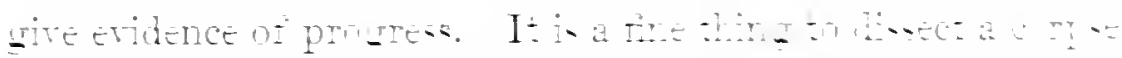

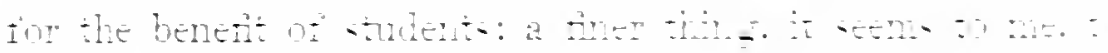

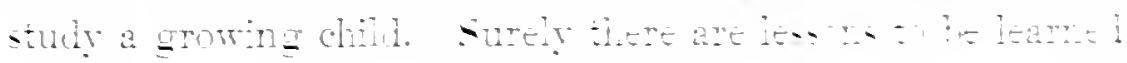
from a well conducted ohertas n the pryon a tace

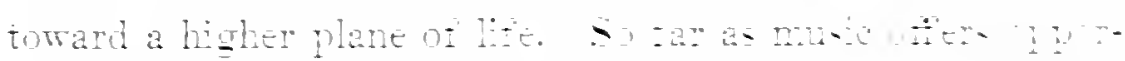

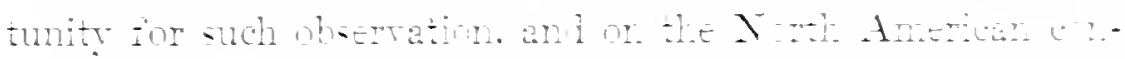

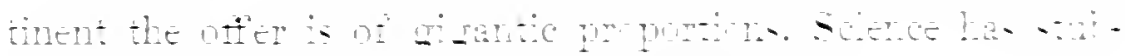

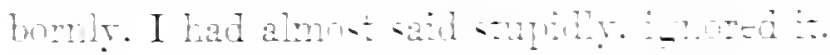

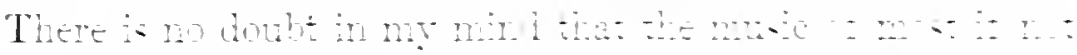

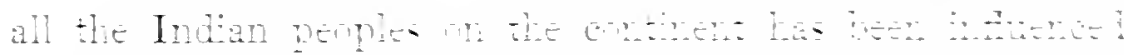

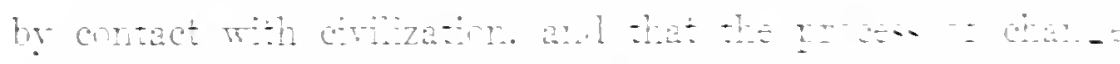

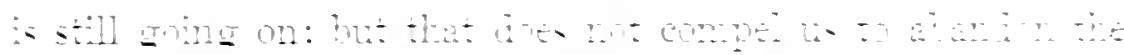

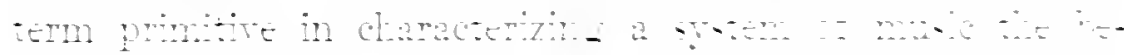

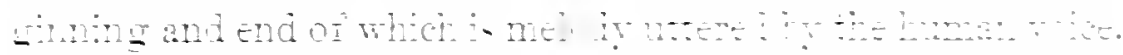

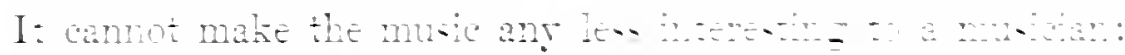

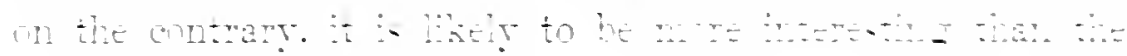

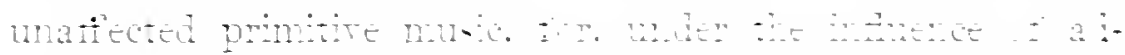

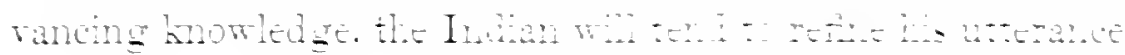


and do away with whaterer is grotesque, martistic and useless.

This is precisely what has happened with regard to the Ojibways. as I shall show in subsequent chapters, and the point I wish to make with all emphasis is that it is still Indian music. No white man has tanght the Indian to correct the erros's in his musie. no white man has even called the Indian's attention to the errors. No deliberate effort has been made by anyody. Indian or white. to improve the red man's music. Sueh change as has come about is due to the Indian sown sense of melodic beauty. IIaring leard the white man's periodizcd tumes, he has conscionsty or unconscionsly instituted comparisons with his own music, and. as his taste deredoped, he has lopped off here and there a conventional ending, a needless introduction, and onitted numberless excrescences in the shape of erurle appoggiaturas that deformed his native melody. The Ojibway has done this in considerable measme. but ohserve, it is the Ojibray who did it. Probahly the same could be said of the music of the Siour. the Omalas, the IIopis. It is the prinitive man himself who effects the changes, and, in adrancing his ant to a higher plane, lue does not eopy from civilization: he gratts no white-man tunes upon his native stock. What he does is to improve and refine his own. No layman coukl display an unscientific spirit nore obviously than by ignoring the wonderful opportunity afforded by our aborigines to ohserve an ant in the process of transition: for the Indians, advancing rapilly toward civilization, are making strides in generations, so far as music is concerned, that the white race crawled ores in centuries. 


\section{A GLAXCE AT IROQLUHS MTSIC.}

As I deal with this matter in some detail in chaptede that concern the Ojibway nume expecially than other Indians. I will try to indieate at this point some of the effect of cirilization on prinitive music. A hriet comsinteration of I ropum sons will serre the purpose. The people have had more intinate contact with civilization than the Ojibwar. and they

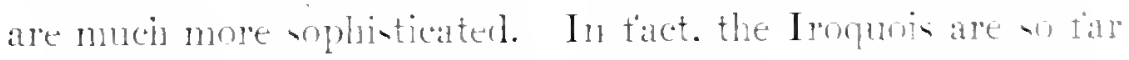
adranced in ciriization on their reetration in Canala that it is Jenurkible that they retain any teature of the ancient lite. They are Chrietianizerl. nunt of them cam real and write. they are nearly all billed lathorer. they were born and hrousht up in houses. they know more of camnel meat than of the

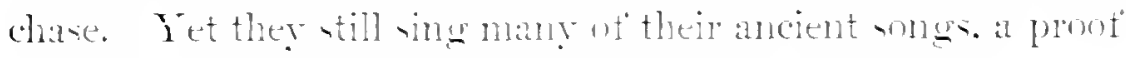
in itself of the inberent itrengeth of Indian melody.

There are certain earmark of eivilized muse that a musician recognizes realily. Among tluem are tonality: that is. ummistakable relatiom hip of the tones in the melouly to a licyote: and torm. which is the uhblivioion of the melorly inte contrasting phranes of equal lenerth: and the interral of a halt-step between the kegnote and the tone next helow it: this interal. technically the major erenth. is repreanterl wally in primitive muse the worh orer by the nimor. or that serenth. Let us now exinnine the -tructure of a popular l an-

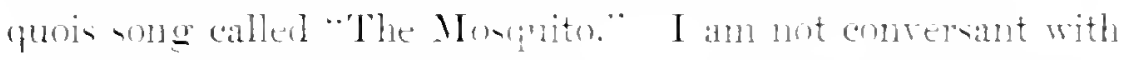
the Iroquois language and have nerer undertaken to et dom the original words of this song. but nuy daughter, who has 
given me eonsiderable assistance in my song-hunting, patiently extracted the meaning from several singers, and our Irotuois friends assure us that her "translation" is quite eorreet.
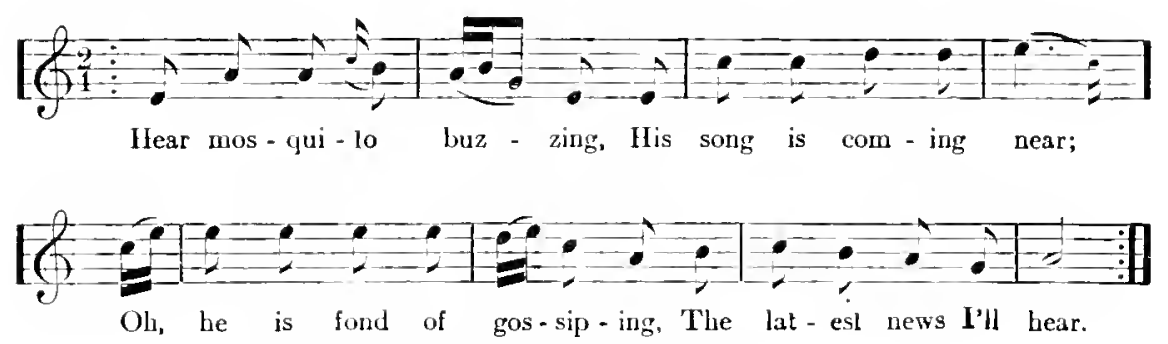

'Slkeeter saw me drinking.

Saw me acting queer-

Oh! then he went and buzzed a tale

Unto my sweetheart dear.

'Skecter male his story strong,

Nade me barl appear,

So when I went to call on her,

She boxed me on the ear!

The tonality of this quaint little song is mmistakable, and it is as regular as a square. 'There is more than a suggestion of civilization in the obvious modulation to the relative maljor in the closing the first half of the period; that is, the end of the seeond line. Traees of Indian eharacteristies are found in the ornamentation inclicated by grace and sixteenth notes, and in the flat seventh. If the grace notes were omitted, and the seventh were sharped, it might well pass for a produet of civilization-not of a high order, but distinetly non-barbarie.

What happens in the singing of the song by the Indians is interesting and instruetive. The old men sing it as above 
notated: many of the youngere whe hate lecen familiat with the white man's was since halyhoul. not only onit the ormamentations, but, at the conchesiom of the smeng shanp the seventh. The young fellows, for eximple, sing-

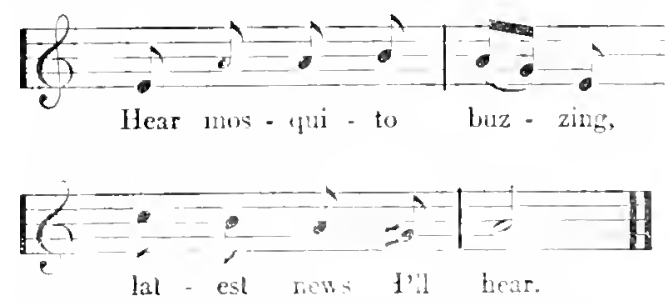

When old and yomes sing together there is a blumping at the points where the sixteenth moter oredr. and strident divend

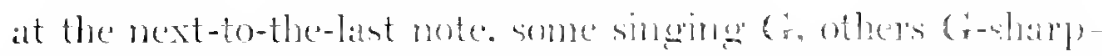

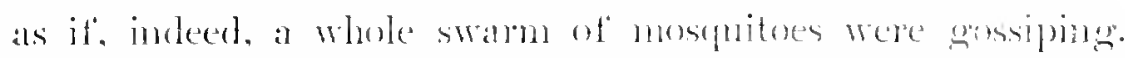
It is impossible, of compere to tix the time when this solne wals composed, but, while it may be al molemized rersion of atn ancient Iroquois tme. its mechanical rewularity inclines me to think it the product of a period suberpuent to the aldrent of the whites. In either calse it retains to-day certain charaleteristies of both cirilized and mocivilized musice and its treatment by the yomger generation indicates how native musical art may be influenced by contact with cirilization.

A more interesting example of I rocuosis music is the song that alecompanies their suake dance. The significant words in this song are very few, meaningless syllables being used for the most part. The general sensce als I am told, is an invocation to the suake. Voice part and an indication of the drum- or rattle-beat follow. 
76

AMERICAN PRIMITIVE MUSIC
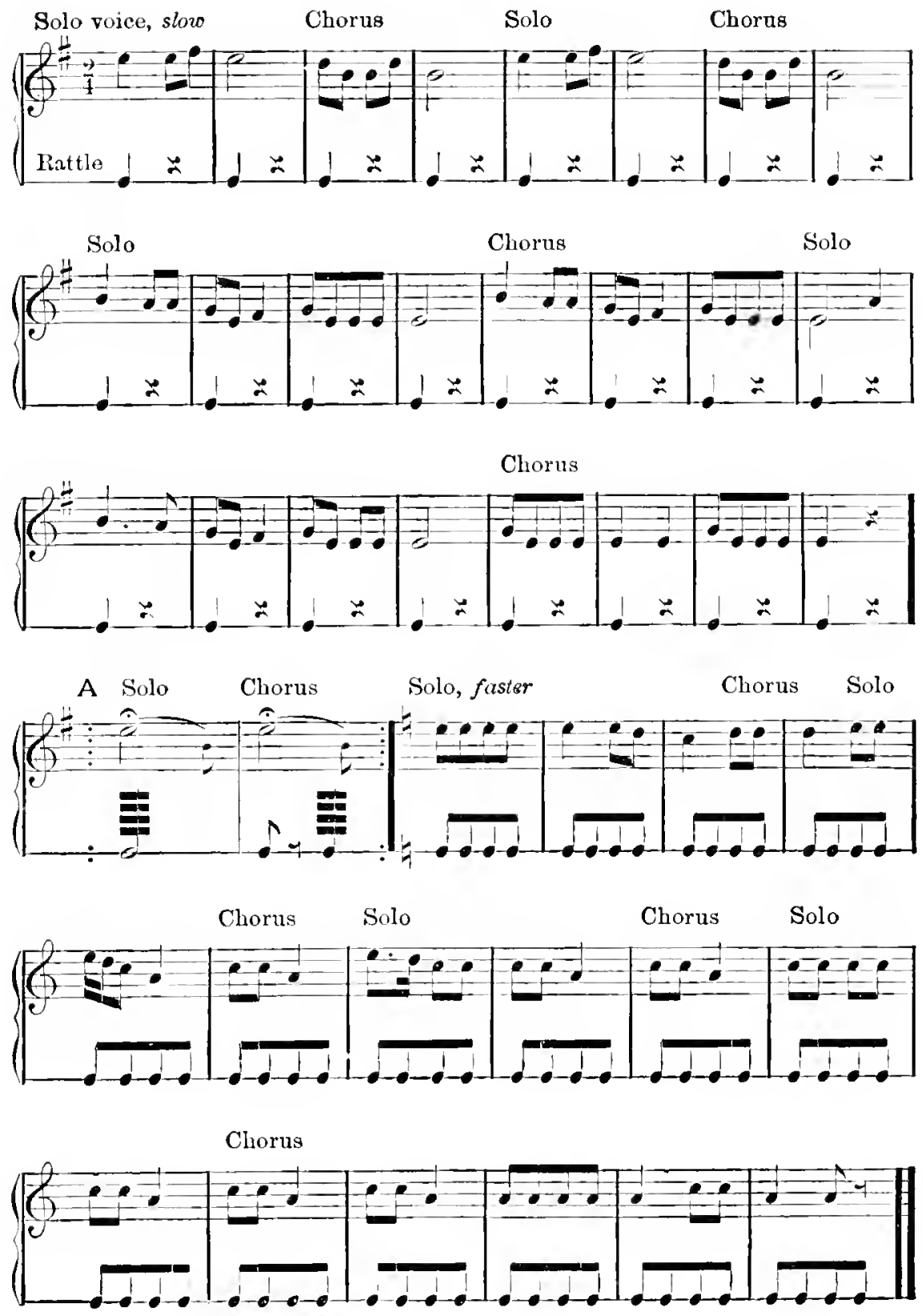
The barbaric effect of this song, when given by a good leader and from a dozen to twenty strong-lunged men, is thrilling. I have beard it hundreds of times and, bare though it seems on paper, I never fail to be stirred by it. 'Tlue alnost umbroken sucession of two-bar, or four-bar phrases suggests the influence of civilization in polishing the ancient original, but the modern Iroquois has retained the flat seventh in the first part (to $\mathrm{A}$ ), throughout which the underlying harmony is obviously E-minor, and the duality of key so of ten observed in Ojibway and other Indian nusic. as evidenced by the obrious A-minor harmony under the second part. Moreover, in performance the Indian characteristic of indefinite repetition is manifested by reduplicating at will the last four bars before $A$, as well as the last barrs of the second half.

This is one of the few Iroquois songs that I have heard that retains so much of the ancient atmosphere. Most of them go much further than "The Iosquito" in the employment of features identified with the music of civilization. 'The largest Iropuois reservation is at Caughnawaga, near Montreal. To anyboly who might be inclined to make a study of Iroquois music at first hand 1 would recommend as a preliminary work, consultation of the Ammual Archeological Reports to the Minister of Education, Ontario, for 1898 and 1899 , and an article on the subject by A. T. Cringan, Mus. B., in the Report for 1902. 


\section{CHAPTER $V$}

\section{STRUC'TLRE AND MEANS}

PONG is the beginning and end of Indian music. The means to its production, therefore, are limited. with one almost insignificant exception, to the human voice and simple instruments of pereussion. So far as rocal gifts are concerned there is no essential difference between the Indians and the whites. Their volees may be classified in the same way, that is, there are tenors and bisses among the men, but the great majority are harytones; there are contraltos among the wonen. but the great majority are sopranos. I am inclined to believe that the compass of the average Indian's roiee would be foumd to be sreater by sereral tones than the roice of the arerage white man. The opinion is based partly on observation, partly on logic. So far as I know there has been no attempt to gather definite information on this point. It woukl be a difficult thing, even if it were worth while to establish the precise compass of an Indian's roice. for he cannot sing up and down the diatonic scale to the end of his capacity in each direction, as a white man can. We can estimate his empalss only by his songs and by hearing him sing them. Every Ojibway whom I have heard had a command of at least two oetaves without recourse to the falsetto. Under certain circumstances, as in cries of joy, and in the warwhoop, every Indian uses the fal- 


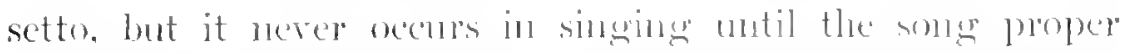
is emeded, when there often is a collat, or flomish. ustally an

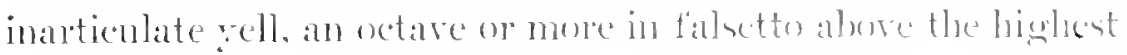

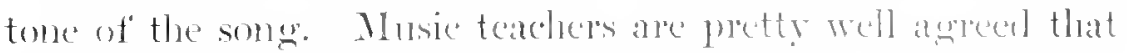

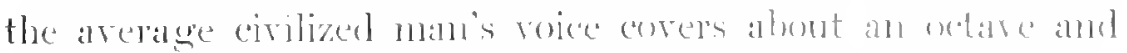

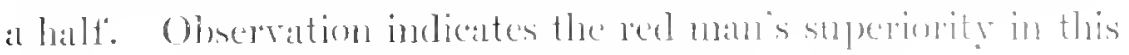

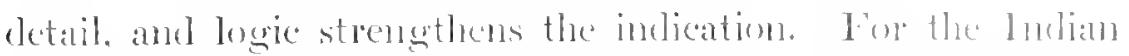

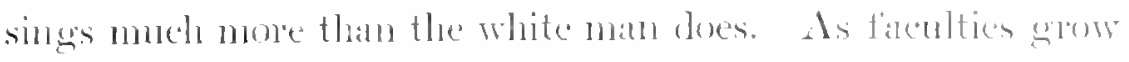
he exereise, it tollows that the Indian will maturally be allole to produce more and higenere tones tham can covilized man.

Concerning suality of Imbian volces. let me puote a line

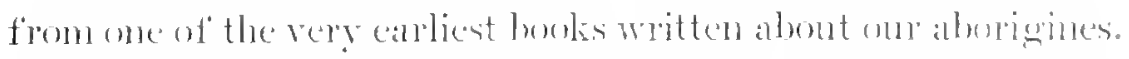
William Wood visited the Plymouth and Massidedusetts Bar colonies not lomge affere their settkment, and wrote alu alceonnt

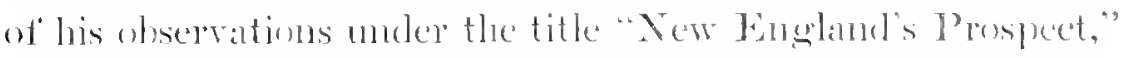
which was published in landon in raist. In the comse of at chapter alevoted to Indian women he says:

"Their musick is lullabies to guict their children, who generally are as guiet as if they hat neither spleence or lomgs. 'Tu hear one of these Indians unscene, a grood eare might casily mistake their untaught royee for the warbling of a well tuned instrument. Sich conmand have they of their voices."

My own testimony woulel be that there is nothing whaterer in the Indian's voice to distinguish it from the white man's. Much singing in open air and foreguent foreing of the volice to sommel extremely high tones. combine to produce a rather hansh, enencrally nasal quality that is expecially apparent in the upper register, but in the nedium and lower registers the 
quility is moch more andeeable: and when the singing is of the quiet sort that goes on in the tepee or wigwan, the harshness disappears altogether. The nasal quality is much less noticeable among the Ojibways as compared to the plains Indians. I have heard many individual voices of exquisite bauty in Ojibway land. One of the purest, freshest sopranos I ever heard anywhere was the possession of an ungainly. eklerly, almost repulsire-looking squaw. In this instance I algree with the observer of three centuries ago, above quoted. IIer voice, herself unseen. heard in meaningless rocables would lave seened like a rarely sweet thute. In general, if differenees in language conld be ignored, the unseen Indian's singing would readily pass for a white man's.

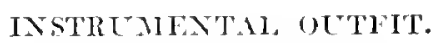

The Indian's meagre outfit of instruments was not designed for the production of musie for its own sake. but either to assist the roice, or to take the place of it in certim rare contingencies. ITis one important, essential instrument is the Arim. This is made of a frime, or hoop of ash across which is stretched untanned earibon or deer skin. Its size varies from a few incles to more than two feet in diameter, and the depth of the frame varies also, the average distance between the skin surfices being somewhere from four to six inches. It is held in the left hand by a thong attached to the frame. and beaten with a short stick bedd in the right. Among the Sionx and other tribes the drum usually has only one surface. and 
the instrument is often as large at a warlstub. in which ease it is set on the ground. open side down. and two or more player pound upon it at the same time. Every Ojibraly drun that I have seen in aetual use had two surfices, each stecorated with crude designs in color. and provided with the thong handle so that it might be held free lefore the singer while lue accompanied limselt.

This instrument when well made and played enthusiatically has extraordinary force. One was presented to me by an Ojibray friend. Wabena Obetomoway. with the earnest injunction always to wam it before wing. The Indian invariably holds his drum orer a fire betore playing upon it. and he is keenly distressed when the humidity of the atmosphere prevents the skin from remaining perfeetly dry. I have myselt become sensitive to the difference between the sund at' a warmed and perfectly dry drum and one that has not heen properly prepared tor pertormance. The sin surtices aborh moisture from the air and. in damp weather. repond to the stiek with dulhess that is the reverese of impiring. In faet. the drum is a good baroneter. Its tone will foretell yain many. hours in adrance of its coming.

AX EAPERIEXT IN ART WITI A DREX.

I had occasion to test the power of the drum in the winter of 1903 when some of my Ojibway triende were giving entertainnents in New York. I had written a set of rariations

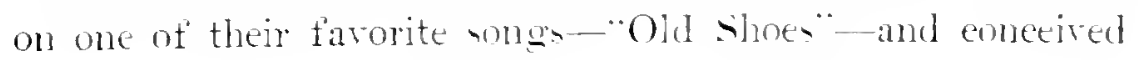


what seemed to be the happy notion of substituting the aboriginal instrument, with an Indian player, for the conventional tympani; for the Indian's chom, though it generally has recognizable pitch, does not enter into any harmonic relation with his melory. In the song as given by the Indians in their own way, the drum is beaten in a perfectly regular alternation of strong and weak strokes. and as in my variations I had not departed from the original time or tempo, it was evident, theoretieally, that all the Indian drummer would have to do wondel be to pound his instrument in his acenstomed manner, the white musicians undertaking to follow him.

We redearsed the piece first without the drum, and when the orchestra had "got the hang" of its somewhat disconeerting rhythm. I sent for 'Tetebahbundumg. about whose charming personality and umusual musical gifts I shall speak later. I explained to him what we were about to do and told him to drum "Old Shoes" as slowly or as fiast as he liked, and that we woukl join with him after he had made a start. The orchestra was of the eonventional symphonie make-up, strings, wood, horns and brass, numbering forty-two pieces. 'Tetebahbundung began plaeidly, and in the first statement of the theme all went well. 'The sneeceling variations naturally introdnced more and more eomplexity and increasing volnme of sound. As the rolume inereased, so did the reverberations of 'Tetebalbmelung's drum. Ile was not disturbed in the least by the many transformations through which the fimiliar song passed. but he was eonsiderably exeited as the shrieking of woot and the blare of brass rose up in waves to overwhehm him, and he 
increased the foree of his stroke's concompently until, when we were about half way through 1 seconed to he:al little more than

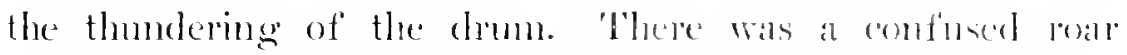
from the band, but not a shed of theme was distinguishable.

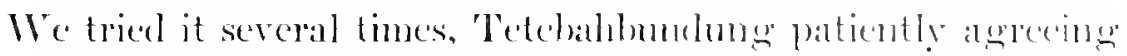
to hold himself in check. but he wats not equal to the demands of the occasion. II is enthusiasm got the better of his, jundement every time to the end that the picee sommed like a drum solo faintly accompanied hy forty-two instrmments played at rambon. We hat to give it up. and when the variations were presented to the publice the tympanist marken the rhythm on the comparatively sublued bass drom.

The Indian drom is usially supplemented by rattles of various shapes and sizes. 'The eommonest type consists of a gomel partly filled with pebhles ol shot. Iloms of aminals are sometimes used for this purpose, and there are many quant contrivances like tily shallow drums provided with worden handles. The rattle is shaken in rhythmic unison with the dirum.

THE SO-CAILLE FLE'TE AND ITS ESE.

Besides these two iustruncents of pereussion there is one otlere improperly called a thute, for it is of the flaceolet type. It comsists of a straight ceedar stick, alkent ans long as alu ordinaly flute. that has been split in halt, both portions enrowed the entire length, and then phed together to form at tube. (Jue end is whittled away for an monthpiece. A few inches from this 
end the tube is partially stopped. and just beyond the obstruetion there is a longitudinal opening partially elosed with a wooden block fashioned usually to represent an animal. This is slightly movable and is held in plaee by a thong wound around the tube. Six finger holes, at approximately equal distances from one another, are bumed along the length of the tube, and just at the further end the tube is eneireled by five boles to provide for the freer emission of air. I eamot find that there is ever any attempt to place the finger holes scientifieally, and the result is that the instruments are lndierously out of tune and no two are ever alike in fundamental pitch, or seale. 'The example in my possession, whieh I found and bought after weeks of search, for the instrument is rare among the Ojibways, has a soft, rather melancholy tone that would be agreeable if the intervals were in alecordanee with any recognized seale. Its lowest tone is approximately $\mathrm{D}$ in the bass elef.

So talr as I ean learn there is only one use to which the flute is put. No tunes are composed expressly for it, but it always serves as a substitute for a bashful lorer's roiee. If the young man has not the eomage to deelare himself openly to his sweetheart, he hicles himself in the bushes near her family teepee at smrise. lnowing that, aceording to Indian domestie constom, she will be the first to rise and go to the neighboring spring for water preliminary to preparation of breakfast. IFluen she appears he pliys a love song on his flute. This is lis declaration. It must be understood that words are associated in the player's mind with the melody. The maiclen may 
not know what they are, for the song may have been composed expressly for her, hut she knows that it is a love song and that it comes from an eager suitor. In all probability the concealed lover will repeat his serenade many consecutive mornings, for the maiden's endearor will be to find out who he is before she gives him any sign whatever. She will discorer his identity--what maiden in any nation or cline woukl not! - and if she favors his suit she will make her fedings known. whereupon the lover will forego the flute and join her at the spring. On the other hand, if she disapproves, she may tease the hopeful swain by giving no sign, thus eompelling him to repeat his serenade day after day until discouragement orercomes desire.

The flute, therefore, does not figure as a means to instrumental music, which was wholly unknown to the aboriginal Indian, but as a substitute for the roice: and in the making of love songs care is often taken that they shall be capable of reproduction upon the flute. In view of the custom described it is not surprising that very many Indian love songs contain references to sumrise and the spring, or fountain.

Coming now to consideration of the structure of Indlian musie. I nust make perfectly elear, what has been implied previously. that the aborigrial Indian had no conception of hamony. and that the modern Indian never employs it in his songs. There is. of course, the relation of voices in the octave. for men and women sing togetler: and now and agalin there is momentary harmony in ecrtain ceremonial songs where two singer's alternate in stating the theme. The seeond some- 
lines begins before the first has finished-after the manner of the stretto in contrapuntal writing-so that for a measure or so there seem to be two indivichual parts; but this is to be attributed cither to accident, or the solemn enthusiasm of the singer, and not at all to any pereeption of hamonic relationship. I have heard one Ojibway who moletook oceasionaly to add an independent part to a chorus. II called his eftort "molertones," and it consisted in singing the melody a minor third below the other voices. The effect was barbaric in the extreme and so disturbing to the other Indians that the song usmally broke up in confusion when far from the end, or the others changed their pitch and sang the conchusion in mison with the imovator. It is fair to presume that this albortive attempt at part singing was due to the individual's desire to make music in white-man fashion.

\section{PRIMITIVE CONVENTIONS.}

Study of the nusic of any prinitive people has a special value in that it brings us in touch with the rery beginnings of the art; and the music of our North American Indians offer's umusual adrantages for observation inasmuch as it inclucles several stages in the process of evolution. We find in it perhaps not the rudest music of the world, but a type of song wherein specel melts insensibly into singing, so that the notator is puzzled to find where declamation ends and song begins: and from this crude suggestion of musical expression we pass in review ludimentary melolies wherein the art prin- 
ciple of form manifents itself" mly in the slightest dearee. then

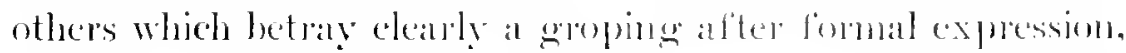
until, in the somgs of the ojilwaly, we conne npon examples of perfect tumes, periodie in structure, anthetically interesting. in hrief, a type that marks the last step in protely medorlice music. If the Ojibways hat becen so situated that they could have proceeded with the derehpment of their monic minflueneed by contace with eivilization. the next step would ineritahly have been hammog. Whether this step wombl hase leen taken in one or twenly centuries is matter for uneless opere-

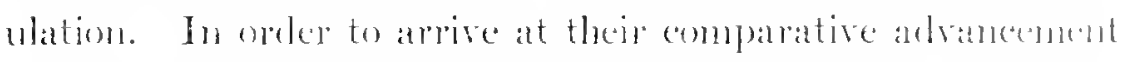

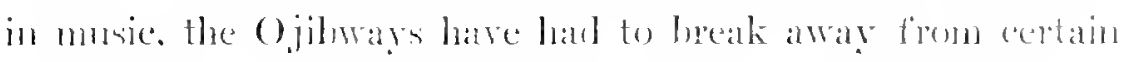
traditions of conventions of the red race. We are not anterened at present with how they eame to do so, of why they are

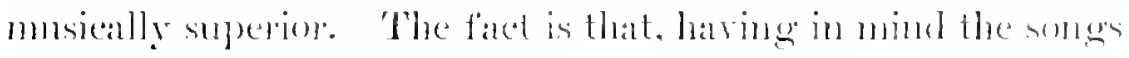
of such other tribes as are now arailable for stuly. Indian music is the all hut hopeless ricetim of eomrentionality. It is pessible to classify the somges aceording to rarious categonles. lout in so doing we are gnided by the words rather than the melodie structure, for thomgh an londian never would mistake a exemonial for a love somes supposing the tune were surge to meaningless words, yet after all, the somere melodically contsiclered are of pretty nuch the same type. I great proportion of them begin with an introluetion that is rudely analogens to the eceitation seceo with which the eldere masters preeeded their arias. This introduction may be melodice in character, or a monotone; it may be brief, or as long as the song proper that follows: it may have words, or meaningless syllables, or 
simply the rowel somm ah. A Pawnee once sing for me eight love songs and every one of them hegan with the following:

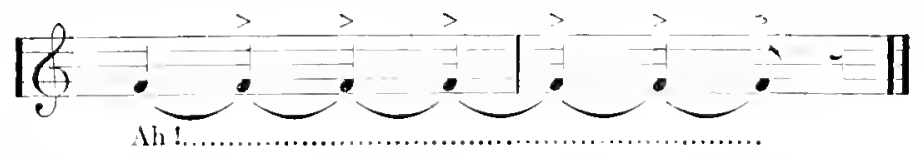

'The song proper then started on the fourth beat of the seeond measure.

Oftentimes the introduction is barely distinguishable from declamation. and the more earnest the singer the less like music is his utterance. 'The song proper, which may consist of no more than one word, will lave at the least a melodic impulse; that is, it may be recognized as the heginning of a possible tume, but though there may be repetition, and even some sort of imitation, there is anything but a logieal development of the musical idea. On the contrary there is a speedy lapse into conventional phrases, or fragments of phrases, leading generally to a conventional ending far down in the gamut. 'Time and again in notating songs of this type I have had my interest gemunely stirred by the melodic impulse only to eome swiftly to a sense of keen disappointment becanse the promise of beanty was not fulfilled. 'This is another way' of saying that civilized man demands that musie shall be not only fluent but symmetrieal. He may not insist upon the eight-ibar period. but he does crave some manner of proportion, and in this respect the Indian generally fails to satisfy him.

A less number of songs, but still a large proportion, begin withont introduction, but, as in the other's. the melodic impulse is lost in conventional phrases almost as soon as the listener 
becomes conscions of it. Very rarely there are fommd songs that have neither introduction nor conrentional ending, and in these there is the elosest approximation to periodic structure.

\section{MONOTONY.}

The familiar reproach of Indian music is its monotony, a characterization that has almulant truth and yet that is somewhat misleading. Remore the drmm, and listen patiently, and it will be found that no little valrety is infused into the conventional introductions and conchusions. I, us see, then, what it is that gives the appearance of monotony. There are the conventional introductions and endings, conventional in that they work orer and over a f'ew brief fragments of melody that in themselves have little significance or appeal to the sense of beauty in tone. Again these same fragnents reappear in many of the songs proper, slightly expanded at times but seldom so modified as to come to us with all impression of novelty. Tlece are two groups of three notes cach, so similar in form and effeet as to be regarded as the same nootire-one a variation of the other-that crop out in the majority of the songs of all the tribes whose musie I have examincal. 'These groups are:

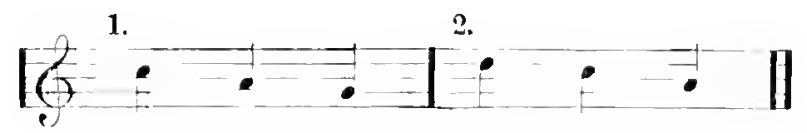

They occur in all parts of the seale, often varied in the relative time values of the notes, hut manifestly the same melolic impulse always; and, speaking of them as one and the 
same. it might properly be regarded as the Indian's leading motive. It will be fomd in most of the Ojibway songs presented here. and it forms part of the principle metolic idea in "My Bark Camoe."

Proceedine with the discussion of monotony, it is evident that a rather high degree of constructive skill would be required to infuse gratelul individuality into tmes that harped well nigh incessintly on one motive. Funther than the points enmerated is the fact that the majority of Indian songs have at least one rather long passage of absolute monotone. or chant. and that the prevailing tendency is to begin as high as the singer can somel a tone and descend gradually to rest on a tone an octave or more below. I have heard the Ojibways thenselves utilize conventional endings that compelled them to whisper the final words beause the repuined tone was betow the range of their roices. 'This continnal reaching for the depths necessarily gives an impression of sameness, as if all Indian songs were cut from the same piece. or constructed upon a rigid formula. an impression that is deepened by their lack of structural proportion. It is not cunomgh to say that form is essential to beanty in the art of tone, for form, as the musician molerstands the term, is boundless in its rariety; let us say, rather, that civilization demands resting points, or punctuation in its music, and that without them the civilized ear finds difficulty in grasping a melody In the early days of Wagner's "infinite melody" how many were they who deeried the master hecause of his monotony! 'To the uninitiated his music was meaningless noise because he ignored convention 
and would not condeseend to east his metolies in periodic form. The mint does not perceive a melody ats a whole in the same way that the eye takes in a statue. or a painting. at a glance. and the reason for this lies in the fiact that music is not stationaly. The very essenee of musie is motion, not merely in the sense that it depends upon ribration, but that it consists in a succession of tones that have relation to one another in the order of their coming to the ear. While we are in the very at of perceiving the relationship of two tones, a third relationship is making, and so on to the end. 'The possibility of making an art out of tones depends upon the capacity of the mind to hold the impression of several sueceding relationshipss as a whole, this whole enustituting but a fragnent of an entire melody, or period. 'This fradgment may be ealled a motive, or a phrase, and the end of it is marked hy a pause of some kind. usually the sustaming of the final tone. which thus becones a new point of departme for the next phrase. If the following phrases were wholly dissimilar to the first, the angeealobe impression mate by the first would not. could not be retained. and at the end of the last phase the average person of musical intefligence would not renember the first plirase sufficiently to reproduce it. so it will be found that in the eonstruetion of those melorlies that appeal most strongly, the sueceeding phrases are moditications of the first. the emonper seeking to reinforce the initial inpression until. when it is seemrely fixed. le introduces a phrase in contrast, of entirely different relationship: and that eontrasting plurase he is at paibs to re-introdnce literally, or witl slight variation, hefore the melody as a whole is eomplete. 
Let no layman infer that the composer is eonscions of the process deseribed. Civen a sense of proportion, in other words artistic feeling. and creative talent, and the entire tune sings itself so far as the composer is concerned. Cold analysis snlsequently proves the symmetry of the nelody and indicates the sulhtle process by which it came to being.

Mention of Wagner was made for the purpose of illustration, not to institute any comparison between his marvellous creations and the ingenuous musical utterances of the Indian, but it is well to bear in mind that many were they who had to listen repeatedly to Wraner"s music and study hand before they contl receive it gratefully. It needs no saying now that there is ample deference to form in Wagner"s compositions. We were staggered at first by his vanting genius which compelled us to grasp and retain melodic relationships gronped in long successions of tones. The Indian, deficient in sense of proportion. neglects necessary pauses, and rambles on, to onr perceptions incoherently, until the end; and after all my observation of his music $I$ am at considerable loss to moderstand how he himself can retain a permanent impression of his melodies-that is, how he can remember them sufficiently well to sing a given song always in the same way, which he seldom fiails to do.

\section{STINDARDS OF COMIPARISON.}

There is this further to be said before we leave consideration of monotony : our own popular songs are stecped in convention. 
It is impossible to survery the art of any foreinn people without instituting comparisons. We may not be amascons of it. hut in listening to the Indiais we are forever ganging his eflorts by the stamelard of' our own. 'There in mothines wome in this. and it is so self-evidently a necessary part ot our ofoervation that mention of it is sufficient: but we mary fall into error he setting up an unfair stambard. The stanclard I try to madntain in my own mind is suggested ly the term ned above"popular songs." - for the music nt an uneducated people camot property be empared with the creations of gentuses, or talented men who have lad every opportunity for the cultiration of their gifts. Comsirler for a moment the matter of' conventional endings. ("ivilized compusers have derined at considerable number of endings. but they are incaleulaty few in comparison with the total output of songes: and in our popular songs of the day the ending's are limited to a still smaller proportion. And how much real rariety is there in the melodic impulse of the anmual aralanche of "new" songs! It has been my painful duty on sereral occasions to examine sonte dozens of new songs, and the utter absence of originalitr. of any recognizable departure from the safe. beaten track which the public is supposed to en joy has been depressing in the extreme. It has come nigh to making me a pessimist so far as our musical possibilities are concerned. I am no prude in this matter. I do not despise popular songs but, on the contrary, try to find good in them. Sometimes I am rewarded. In its day I rather like "Bedelia," and my blood stirred to the swing of "Annie Rooney." After this contession I am sure I shall not be mis- 
understood when I aftirm that the white man's popular song outdoes the Indian's in its appeanunce of construction according to a rigid formula.

'These things depend upon point of view, that is, education and enviromment. I am inclinel to think that the Martian investigator suggested in a previons chapter would find our hymus cast pretty much in the same mould, and our secular songs well nigh indistinguishable one from another. Speculation aside. I once sent two exceptionally musical Ojibways to a song recital in Carnegie IIall, New York. It was given by one of our most distinguished vocalists, and the programme consisted in the main of choice songs hy Sehubert. Schumann and Franz. Business unluappily prevented me from going with the Indians, but I had a friend accompany them to observe the effect. Poor fellows! I fear the experiment was rather cruel, but they sat like statues throughout the performance, never manifesting by yawn or restlessness anything but the most studions attention. They made no comment to my friend and were extremely reticent in discussing the erent with me. When the Indian frees his mind, he is the most outspoken person in the world, but he is also most polite and considerate of others feelings. My firiends were rehetant to tell me how they enjoged the treat I had set hefore them, and they wonld not lie. At length one of them, urgently pressed, said: "It was undoubtedly very fine. It was a beautiful hall and the man had a great voice. But it seemed to us as that he sang the same song orer and over, only that sometimes he 
made it long and sometimes short." Which is to say that the Ojibways were ineffably bored by the lack of varicty in Schubert, Schumann, and Franz.

A GLIMPSE AT AN EYOLTTONART PROCESS.

The Ojibways to-day are musically in a period of transition. We cammot tell when the movenent begans. or why: we can only gness that it was subserpuent to the coming of the white race, but, in spite of the negrlect of music as at subject for scientific researeh, it is possible to trace its progress for substantially a century and establish some significant facts. One is that the Ojibways, in refining what was and is their own, have not disearded anything that was essential to a distinctive style. Their music still stamls the test of analysis and is indubitably Indian. What they have discarded consisted not in original melody, but in incefrective mamerisms. Many of their songs still have conventionial endingss; some of the oldest singers still begin with a conventional introdnetion: the line of monotone still appears in the majority of the songs. What might be the eventual resnlt of the gradual change of expression will mhappily never he known, not because they will not continne to refine their songs, but hecanse, under the inthence of civilization they will forget them: but that result may be inferred safely from what has been accomplished, and that is clearly indieated in the songs that accompany this volume.

In selecting songs for publication I have ineluded some that 
are distinctly in what may be called the ancient Ojibway style, for example, the "Visiting Song," "A Song of Faith." and others. They show not only that the Ojibways had the musical mannerisms common to other tribes, but that such melodic impulse as was hidden in the mamerisms was superior in form and asthetic value. How progress has been made toward a more artistic expression may be demonstrated by an example which also illustrates the gradual decay of the native art throngh neglect. For this purpose I choose the song known in its English version as "The Lake Sheen." It is one of the most popular songs among the Ojibways themselves, more widely known, I think, than "My Bark Canoe." I may say at this point that not all the songs I hare collected are known throughout the length and breadth of Ojibway land. Many" appear to be known only in special localities, but "The Lake Sheen" must be in very general use for I have heard it from a dozen different Indians representing as many places. That this is not a modern song is attested by the fact that Schoolcraft, witing more than sixty years ago, made a rersified translation of it. Its extended distribution. too, is suggested by an episode in one of $\mathrm{Mr}$. Stewart Edward White's chaming stories where he tells of an Indian girl singing a sweet song and quotes a line,

"Mahng o doogwin nindenendam."

When I first heard the song, the Ojibway words and music were as follows: 

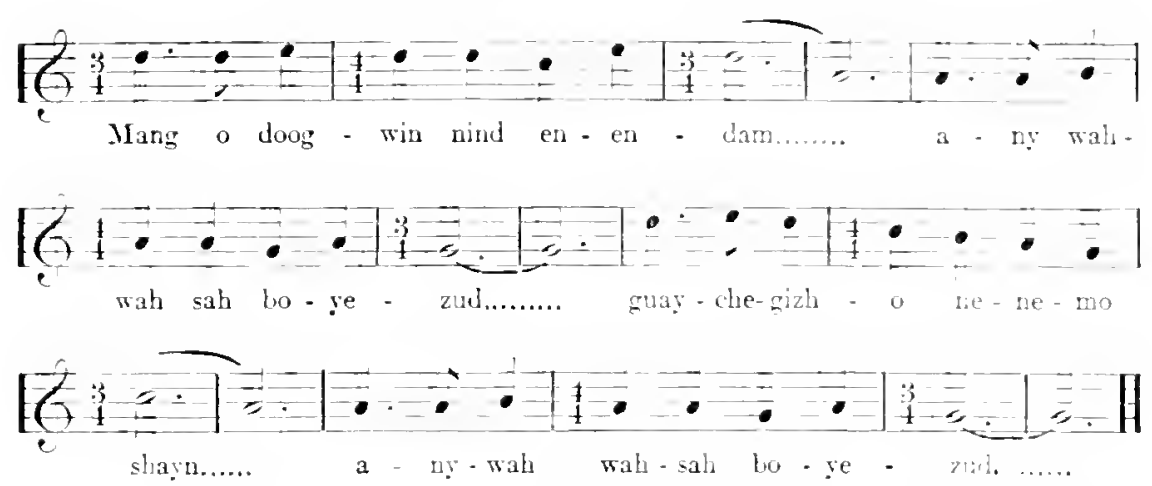

In this form I heard it many tintes from men. wonten and children. That was early in my acpualintance with the ()jibways. when 1 molerstomd not a word of their language and I had no drabt that I laal ohtanined the entire songe. The Indian of whom I sought a translation spolie Euglish very imperfectly, and such words as he conld master were all but unintelligible. I gathered as much as this: that the text was in the first person. that the singer was seeking for his sweetheart. and that he was in cloubt abont the significanete of a distant flash upon the surface of the lake. It was clear that he connected the flash with his sweetheart. and at length I asked the Indian it the general meaning was this: "When I see the flash of the sum upon the lake I think it is my weetheant heckoning to me." With politeness that I have since fonmel to be mdesignedly mislearling. he replied that that was alwont it. In his attempt at interpretation he had used the word "lonon." hut what he meant by it he could not make me mulerstand. I had forgotten my. Schooleraft and never dieamed that I was dabbling in verse that he had preserved. So. quite eonvinced that I was on the right track. I mate the verses that accompany the 
harmonized version on other pages of this book, and to this day nobody, Indian or white, has called me to task for misinterpretation. As I came to some knowledge of the lamguage, I saw that I was in error, but then, as now, the music was my first interest, and that was ummistakably correct.

Some two years after the first publication of the song, the Indian who liad tried to translate for me, amounced a discovery. He had met an aged Indian who told him that he left out more than half the song. From the old man my friend had learned the entire song in the following form:
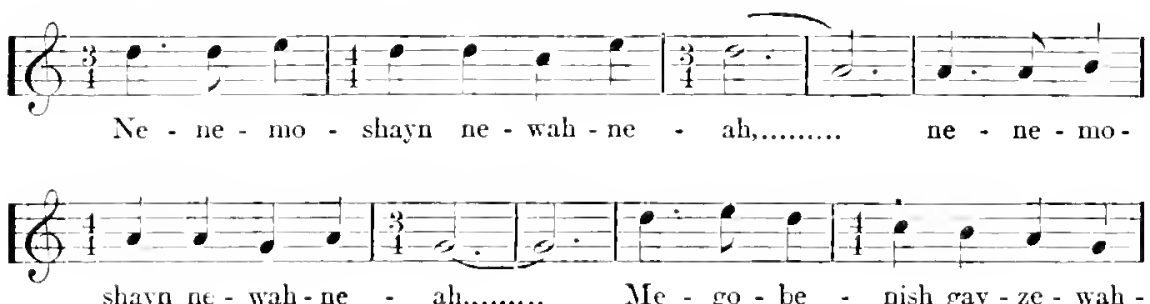

shayn ne - wah - ne - ah....... Me - go - be - nish gay - ze - wah -
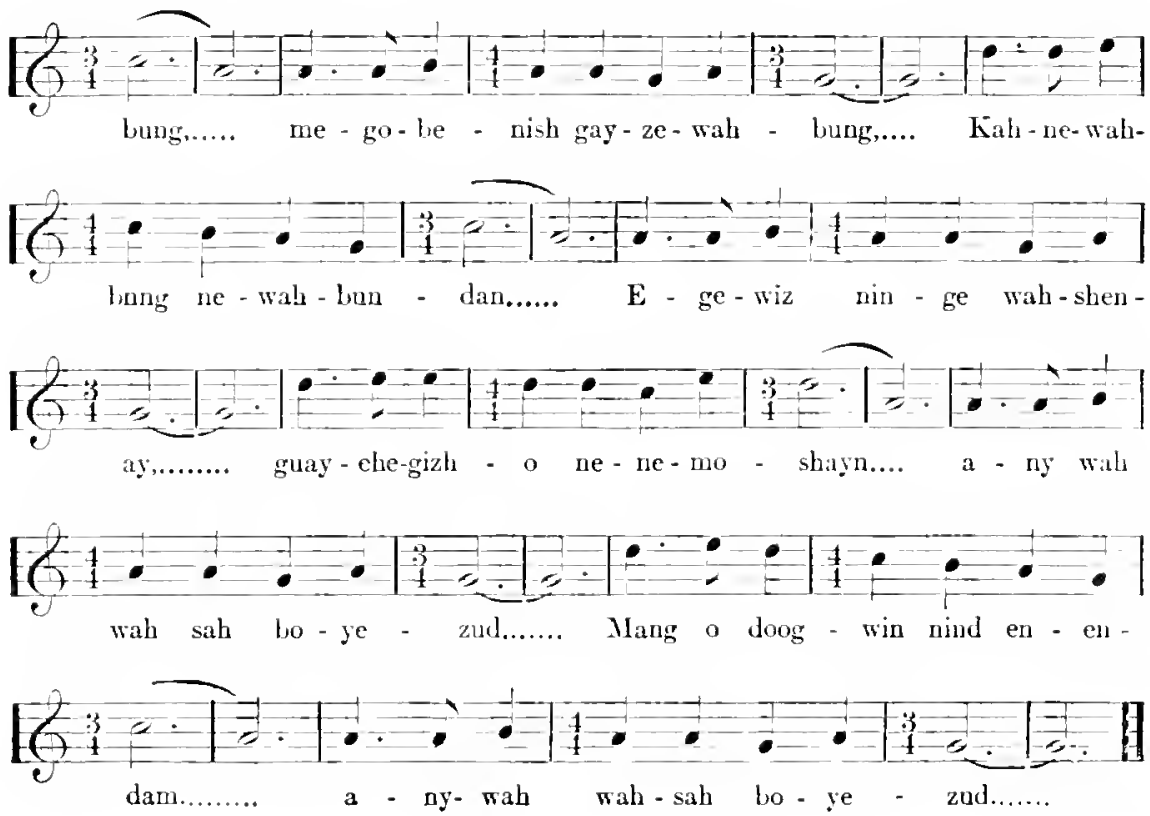
The words me:m: "I have lost my sweetheart. but I will kave no place unsearded and will find here if it takes me all night. As day breaks I think I can see her in the distance. but as I draw near I find that what I saw was the thash of a loon 's wing on the water." It will be observed that. though much of the verse had been forenotten. nothing meleslic harl been lost. expansion of the song being effected by literal repetition. Inasmuel as the compression of the song to the form in which 1 first heard and notated it is quite general, and unt the freak or carclessuess of a few individuals. I am inclined to believe that the change from the older to the modern version was due to the Ojibway's gropung for formal. that is, artistic. expression. Musically the song is far letter in the modern version lecanse there are fewer repetitions of the latding phrase. It appears that the Indian singers felt the tendency. to momotony in the older version, and as they were not edueated in music and knew nothing of thematic development, they solved the art problem ly discarding some of the repetitions. thus evolving at last a perfectly made tume that happens also to be exquisitely beantiful. This speculation as to the reason for the compression of the song may appear to he valin at this noment: but it will be more convincing when we have given some consideration to the nature and strueture of ludian verse.

Still another rersion of "The lakte Sheen" is necessaly to a eomplete view of the process of transition. It was smog to me by a very old man. one who clings so tenaciously to the aneient ways of his people that the younger men complain that they camnot sing with him becanse "he does not get the 
songs light." I have heard his disturbing roice in choruses and know, what perhaps the yomg men lo not realize, that he is harking back to his boyhood when shakes, and graee notes, defianee of measure and derotion to conventional phrases were established features of song, and when the essential portion of "'The Lake Sheen" ran in this way:
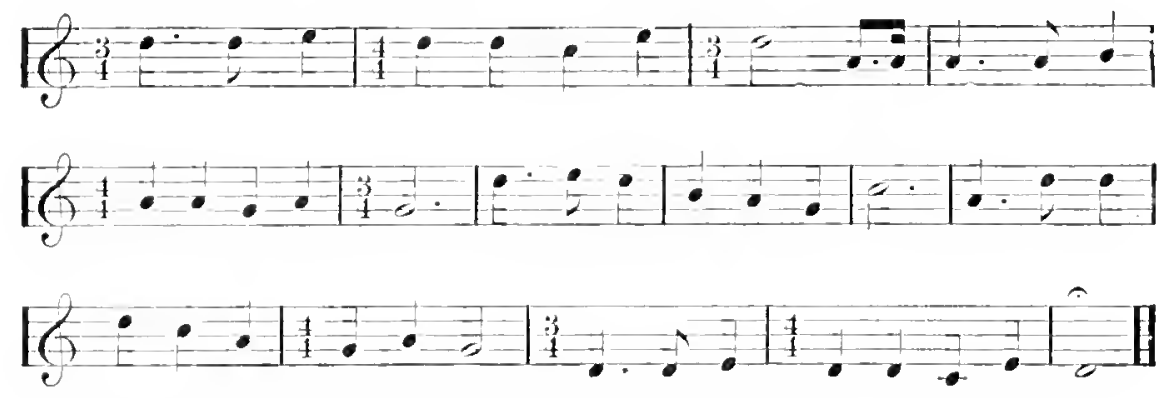

A SONG UNINFLCENCLN BY THE PROGRESSIVE MOVEMENT.

Let us now glanee at the strueture of a song in whieh there is no trace of the influence of transition. It is a "Visiting Song," a class of which there are many cxamples still lingering in the memory of the okler Ojibways. The aneicut Indian was greatly given to risiting. It was common not only for an cntire family, but an entire village to pack up necessary utensils and tramp or paddle long distances to pass some days with friends. When the visitors came within earshot of the homes where hospitality was expected als ingenuously as it woukd be extended, the leader of the party lifted up his voice in song for the purpose of giving intimation that visitors were approaching. In this instance he begins with a long introduction with meaningless syllables in which he states the theme, so 
to speak, of the song proper, and all, presmathy, join in when he cones to the words that convey a definite messigge. There follows then a long, meaningless pitssige similar to the introduction. This leads to an innerfecet conchusion and to recurgence to the song proper when the meaningless passitge is repeated with a perfecet close. Sometimes, and I think it woukl prove to be generally, if we could get bike to the old days and olsserve the songs in actual use, there is a second recurrence to the song proper hefore the conchsion. 'This would matke three separate statements of the somg. which wombl be in atecordanke with a rule of () jibway music t!at certainly wats observed in former tines. The song which 1 employ for illustration was used in winter, when the visitors hate to tranpl over the snow and iee, and when the prospective hosts would either be smogeded within their dwellings or oecupied near by. As the Indian is inmed to cold to a degree that amazes the paleface, it is quite presumable that the hosts would be seated on the iee and snow by the wigwam dont. smoking their never neglected pipes. Linder such eiremustances the queer words of the somg take on a shatow of meaning to us. Their literal significance is. "Who sits on the iee will hear me singing." By implieation there is an added signifieance-"and linow that I am conning. and you can galless how many alle with me by the somnd of our voices." It may be that the Indian had a subtler meaning in mind to the eflect that if the hosts were indoors they might not receive courteons waming of the alporenching party. but that if any one were sensible or lucky enough to be withont. he would know all alwont it. Be that as it may, the 
song was a serious one to the Indian, and no faint suspieion of humor entered into his eoneeption of the situation or the expression. As the singer did not maintain a fixed time value I canmot arange the notes in measnres, but the aceents are indieated by the grouping of notes and by the sign $>$.
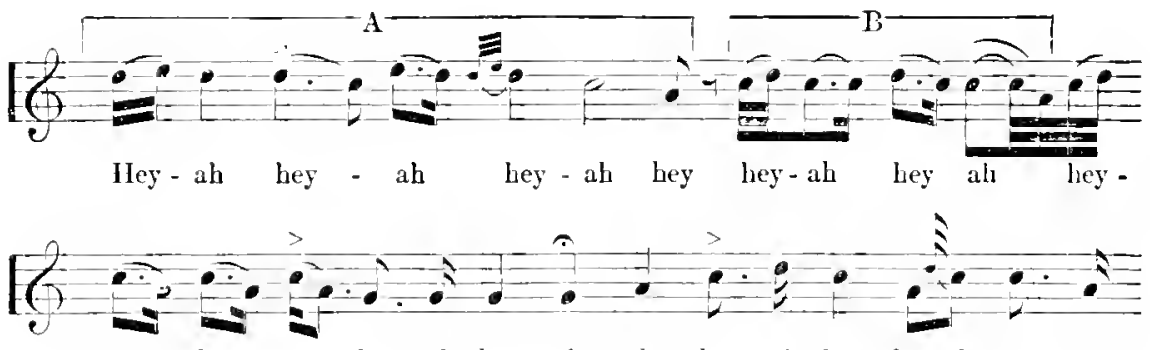

ah bey - ah bey - ab bey - ah ab! bey - ah hey hey-ah bey - ah

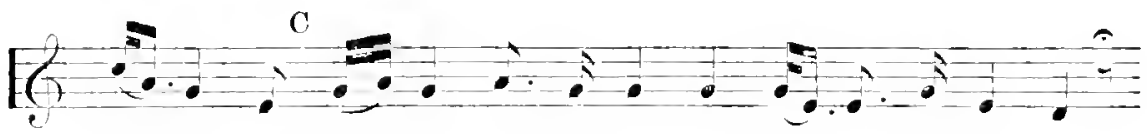

bey - ab bey hey - ab bey - ah hey - ab bey - ah hey - ah hah.

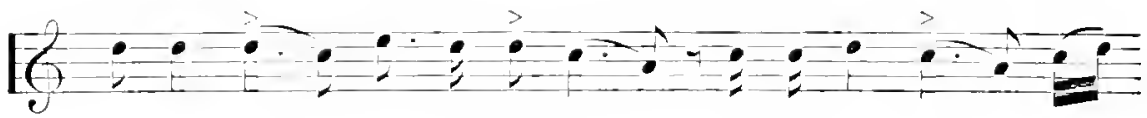

O - git - ko..... new - ab - dah - bil..... nin - gah-nom - dog..... he. -

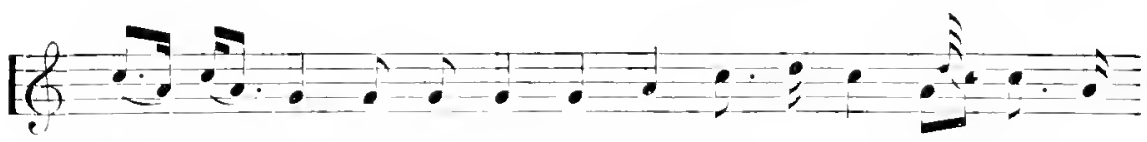

ah hey ah hey - ab bey - ah ab hey - ah bey hey-ab bey - ah

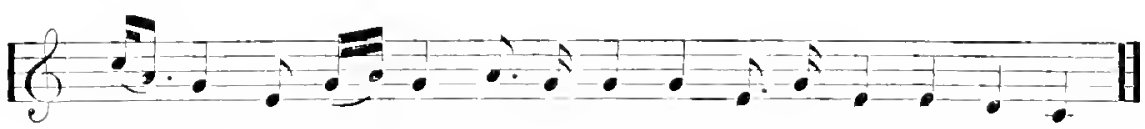
hey - ah hey hey - ah hey - ah hey - ah bey - ah hey - ab hey - ah.

It will be secn that the notes grouped under $A$ in the introduetion are a sulstantial statement of the notes erentually used for the song proper-that is, the fragment sung to in- 
telligible words, "Ogit ko nemalabit ninganomulog." What follows under $B$ is a rude initation of the last part of $A$, and the rest of the meaningless passages might be regarded as rudimentary thematic derelopment as far as (", after" wheh the notes comprise a conventional ending. There is mantest here no high degree of melodic invention although the leading phrase has distinctive elaracter, that is, it seems like the begimning of a possible tune: lut there is a trace of torm, a faint perception of the ant principle of imitation: and the tonality. consistent throughont. is clearly established by the final notes.

Songs of this type constitute a link that bincls the Ojibway's not only to their own past, hut to many other Indian peoples. It may be said to be the crude material out of which they have developed their shorter and perfectly finished tmes. When that process of derelopment began never can be known. I have tried in rain to trace these tunes to their origin. Once I thought I harl snceceded. I was assured that (hief Shingwank eomposed both the words and musie of the song he sang on the occasion of the Prince of Wales's risit to Canada. 'That was only about forty years back, and yet the melody. as sming into the gramophone by the chief"s granddanghter, was of deciledly ancient character. I inferred that the areat chief had not been elose enough to civilization to acpuire its musieal manner, but it was ny method. whenever possible. to rerify the songs by asking different Indians to smen them. When, as wals often the ease, an Indian declined to singe a given song on the gromel that he was not sure he conld geet it right, I would ask him to listen to the phonographic record of it. 
Nore than once this led to further information of value. Some weeks after the "Prince of Wales" song was reeorded I was working with an old Indian, John Squaguan, a citizen of Michigan, who remembered the oceasion of Chief Shingwank's jonrney and the song that was male for it; but Squaguan doubted whether he conld recall all the "tones" of the song. IIe was sure he would know it if he heard it. I put the cylinder in the machine and he listened with a smile of delight. "Yes," he said, "that's it. It wals an old, old war song that onr poople used when they started out to meet the enemy. Shingwank used the tume but male new words for it when he went to meet the Prince." 'The song and further information abont it may be found under Songs of Travel aud Deatl, in Chapter $X$. It is not in common use at present, but it represents a large class of tunes that have persisted after the original words were forgotten. By unconscions selection the Ojibways have preserved many melodies that woukl have become extinct with the passing of their aneient exremonies. An instance is the "Morning Star," once a sacred song. but now used as a lore song to three different sets of words that I know of', and quite likely to a dozen more.

In discussing the strueture of Ojibway songs, I have not dipped into analysis of the melodies that I have hamonized because they will speak for themselves to any student of theory. 'The contrasting and balaneing phases eannot eseape attention. lout it may be well to point ont the eomparatively rare ocenrence of the eight-ban period which has come to be the standard form of the music of eivilization. It ocenrs, but 
rather more frecunent is the perion of six hars, subdivided into phrases of three bars each, and of ten with a concluding phrase of three bars. 'There is a noticeable tendency, too, for stracture in which five is the mit. This sometinues brings about a ten-bar periox, but instances of the eight-bar or four-bals' period comprised of measures having five beats each are more frequent. 'The fire-beat measure is substantialiy a three-leat followed by a two-beat, and, for the sake of rearlier aratsp of the songs I have sometimes arranged such melodies in a regular alternation of three- and two-beat measures. It will be observed, further, that in some instances, like "IIiawatha's I eath Song," and "The Song of a Coward," there is a glorious freedom from the restrint of regular bar lines that yet does not result in misymmetrical structure. 


\section{CHAPTER VI}

\section{MUSIC FROM THE OJIBUAY POINT OF VIEIV}

PHE Ojibway's respect for music is profound. It means more to him than it does to us, for it implies verse also. 1 He has no word for poetry. Whatever departs from plain prose is nogamon, song, which means that his poctry is not only inseparable but indistinguishable from musie. Even in his oratory the voice is modulated to a manner of utteranee that is beyond the pale of declamation, and a long step toward singing. Among all civilized peoples the art of expression throngh rerse is one thing, and the art of expression through modulated tones is quite another, linked though they often are by the deliberate intent of the composer, and always associated, though they are, in the popular mind: in the Ojibway eneeption the two arts are not merely linked inseparably, they are fused in one.

If there is any difficulty in grasping this eonception, let us recall for a moment the attitude of uneducated whites toward musie. I have often observed a confusion in their minds with regald to song that, belore my acplaintance with ojibways, was quite incomprehensible to me. This was once expressed by an amazed inquiry as to how I conld make music for words written by a man who died years before I was bom. Sometimes I have hummed a tume, or sung it to meaningless syl- 
lables, and asked the listener if he knew it. On receiving a negative answer I would sing a line or two with words, whereupon the listeneres face would lighten. I'es. he knew that song. and inmediately would proceed to sing it to a wholly different tume. II aring had his attention called to the melodic differenee, le would appear to be deeply puzzled, and it would take some measure of patience to explain to him that the tume I hummed was not the same as the one he sang: and at the end I have never been sne that the discrimination was well establisher in his mint.

Of eourse I was dealing with a low, or rather, moleveloped order of intelligenee, but it is lairly dear to ne now that the confusion was due to a mental association of womes alid music so firmly fixed that the musie as such mate no impression upon the man's mind, and was merely a halt morealized vehicle for expressing the words. The contemporary ojihway has taken one step beyond this, as is evidenecel by his conversion of ancient ceremonial songes to love and social songs; but his diffieulty in apprehending musie als al distinet. sepalrate creation, is still apparent. Time and algain, after I hatl eome to intimate terms with the tribe, a man would conce to me saying he had thomght of a new somg. My musie paper was always at command and the peneil shatp). The Indian would sing his "new" song through only to reveal to me a set of words that I had not heard before. the medody iseing substantially. and often cxactly the same ats I had taken form his lips on a prerions oceasion. Some of the Indians could not be made to perecive that moler these ciremmstances they lad 
nut contributed a new song to my collection. 'The tones might be "very like," yes, but the nogamon was different,--and get nogamon is a form of the repl, that means I sing. 'This was brought out in a most interesting way in the course of special search for the original of the lines in "I Hiawatha" begimning,

"Ewayea, my little owlet."

I had already heard and notated the song from which Longfellow derived the line.

"IIush, the naked bear will get thee."

a literal translation of which would rum thus: "I Iush, little baby, go to sleep: do not cry or the naked bear will eat you." One after another I tried the squaws who came ny way with suggestions and direct incuiries intended to revive memory of "Wwayea, my little owlet." 'They shook their heads. They didn't know "ewayea;" it was not Ojibway, sone other language, Sioux, perhaps, but not Ojibway. I may note in passing that the Sioux are traditional enemies of the Ojibways, which may account for the presumption of the squaws that this strange word was of the Sionx tongue: and I have been told recently that the original of Longfellow's cliaming quatrain is actually to be found in the songs of the Sionx. I hope some musician will lear and reduce it to notes before it is forgotten.

Of' conse I explained paticntly to the Ojibway squaws that "Ewayea" meant nothing in any language, that it was merely a malse-believe word like those that abound in Ojibway 
songs to fill up when real words alle lacking. but still I made no progress. 'Then I eoneentrated attention on owlet. Did they never play fully call their palpooses owlets! or little owls? They seened to see a grim humor in the gnestion but denied knowledge of owlet as a tem of endeament. So, reluctantly I was forced to aceept the dietum of a chief, who lent the sanction of his interested presenee when I was questioning a number of spuaws at one time, to the effeet that "we Ojibways do not know owlet," lut incidentally I had every squaw sing every lulliby or cradle song she could remember. I hoped yet to trace in one or another a suggestion of the quatrain, and failed not only in this attempt, but also in getting a new song. Every single hullaby sumg to me by the Ojibray squaws on that oceasion was but a direct repetition or slight rariation, so far as the tune went. of "IIush, the naked bear will get thee."

\section{SINGING CONTESTS.}

Whenever you come upon a party of these Indians, be it a whole village on a journer, or a seant half dozen, you may be sure that at least one among then has his drum with him. Unless he is thoroughly familiar with palefaces that chanee his way, he will keep the instrument concealed, but when night eomes and the party is secure from intrusion, it will be produced from its bag and long hours will be filled with music. The drummer always sings. The others generally listen with apparent interest and satisfaction. Now and a gain they add their voiees to the song, and more rarely the drum passes from the 
first singer to some other member of the party, but by no means every Ojibway would presume to take his turn at drumimng. It is not only a skilled art, and not only do the Indians recognize the fact that some are musically gifted, and some not. but there enters also a certain jealousy, with which white musicians are not unfimiliar, to keep the accompanying instrument in the hands of one performer. I have many a time hat to repress my smiles at sight of the offended dignity of an Ojibway musician when I have loaned my own drum to another that I might induce the latter to $\sin g$.

In olden days this rivalry in music led to friendly contests that lacked only pageantry and a judge, or jury, to be quite analogons to the toumaments of song in the times of the Master aud Minnesingers of Germany. It is likely that such contests are held to-day in the remotest wilds of Canada, but it has nerer been my good fortme to witness one. An old man told me of a eontest at which he was present when a small boy. Ilis father was the ehief of the village, and to him eame another chief on a friendly visit. The second chief brought a number of his people with him. In the evening the chief's sat by a campfire, the sub-chiefs, warriors and other members of the tribe being seated at appropriate distances. One of the chiefs was a visitor, and some of his people were with him. The host took his drum and sang, all listening intently. At the ent he passed the flum to the visitor who sang in his turn. After several songs had been exehanged, and enthusiasm had risen, the host asked his guest if he knew a certain song. Ies, and he would like to hear his host sing it, whereupon the 
host eomplied on eondition that the risitore would sing it afterwards. 'This was done, the visitor making some changes on the ground that the host had not smong the somer aright. 'Then

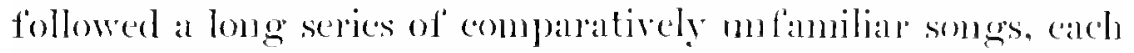
taking his turn, correcting the other, singing better if he conld, while the audience applanded in chantecteristic fashion. the partisans of each singer trying to ont-yell the ofluces. 'There was much langhter as impromptu jokes were interpolated in the songs, and the contest ended only when diy broke.

As a rule the learling roice, als the drummer is often called. is respected only secomil to the chief because, I suppose. he is the repository of so much that the tribe venerates, fon it is certain that the fealing roice learned his songes from some older singer who was great in his diy. I have observed another link in this that helps to bind us and the red men in al common hmmanity, i e., the singer of the shadowy past was always a great man, a much better singer than any who lives torlay.

PMGAX JWEAS AXU IHEALS.

There eould be no fince exemplification of the Ojibway's respect for music than the experience I had in the summer. of 1903 with a venerable paganl. I Ie was a visitor to the (amp) where my actor friends were griving open air performances of their play, "I I lawatha," his son-in-law hejeng an incomspicnous nomber of the company. (One diay this actor canne to me.

"I thomght mebbe," said he, very slowly, "you like to see an old gentleman. She is my wife's father." 
I'es, I answered, it would give me pleasure, and the Indian added, "She is a great singer, she knows many old, old songs, for she is not a Christian like us."

II went on to explain how the old gentleman-the Ojibway seldom says man or woman; it is always gentleman, or ladyhad resisted every attempt to convert him. Wearied with the appeals of missionaries and the nembers of his family to forsalke his ancient religion, he had once consented to be baptized. but he had gone on worshiping Gitehe Manito and the four winds and never had given any further recognition of the strange fiaith.

"She was haptized," said my friend, to "stop her wife from too much talk."

At the time of this conversation the old gentleman was absent from the eamp pieking berries, but in the early evening I called on him at his son-in-law's birch-bark wigwam. A light but severely persistent rain was falling. The women and ehildren had gone inside and chosed the door, before which, seated on stones, smoking their pipes and serenely indifferent to the downome, were the actor and the old gentleman. Never, it seemed to me, was the designation, gentleman, more aptly applied. I saw a man whose enaciated frame, white hair and quarcring voiee proclaimed that he had attained at least the span of three score years and ten. After the manner of the modern Indian he had allowed his sparse beard to grow so that his dusky face was framed in white. Ile wore the most ill-fitting, shabby garments I had erer seen npon human being, but his face was a fine picture of benignity, and his manner 
dignified without affectation, or that somewhal chanacteristic pomposity of the Indlian that is apt to prorolic ammsement. Our conversation was eonducted mainly by the aid of his sonin-law as interpreter. for he knew nothing of English and I was timid in Ojibway. We talked first of the play, which interested him greatly, though he rentured to protest mildly against Longfellow's perversions of Ojibway traditions. "It is not all just as we understand it," he said, and added with fine gracionsmess, "but it is very hard for the white min to understand the Indian's thought and feelings. It does rery well. it is very gooml."

In due course I brought the conversation around to music. I had heard that he was a great singer, that he knew many songs. II gravely acknowledged the tribute. Would he let me hear some, or one of them? "Not on the stage," he replied quickly, but gently, and went on to explain that the hand of actors had their singer and it might hurt his feelings if another were put in the work beside him. IIere was delicaley of teeling, it seemed to me, that might shame some of our white vocalists, and I promptly disclaimed any intention of subjecting him or his rival to comparison. I told him about my desire to learn the songs of his people partly that I might inform the palefaces about them. and partly to preserve them: and his son-in-law explained at length how I had a way of making signs on paper by means of which I conld remember any song I heard, and by which, tro, other persons who never had leard the songs could sing them.

The old gentleman noded from time to time and eventually 
expressed approval of the plan. "It is good," said he, sadly, "for the gomng men are forgetting onr songs." But he modestly doubted whether he knew any songs that would serve my purpose. I assured him that I would he glad to hear any song that pleased him, and, to stimulate his menory, suggested a hunting song. "The Indians have hunting somgs, have they not?" I asked. Tre bowed gravely and replied that they had many, one at least for erery anmal: he supposed he knew most of them. 'Then he relajesed into thought and I knew that 1 had ande as far as eonld he gone on that first oceasion. for the point had been reached when the Indian must be allowed to commune with himself. 1 Ie is a remalkable silent debater. So we said "bozho," shook hamds, and I left him to his thoughts, and tolaceo, and the rain. Next day came his som-in-law.

"The old gentleman," he began diffirlently, "she eamot sing you a lunting some."

"What's the matter?" I asked. "Cant he remember" any?" "Yes."

I let this answer stand for a moment to eall attention to its ambignity. Apparently nothing could be more direct and mmonstakalule than a plain yess, or no: but tine and again I have been momentarily confused by the Indian's athmation. Ask him a question in the negative form and invariably he answers, yes. Take a weatlerwise glanee at the clonds and remark, "It won't rain to-day, will it!" and the Indian reply will be, yes, by wheh he means that it will not rain. Ask him, sympathetically. "Aren't you feeling well to-day?" and his yes will mean that lee is feeling ill. In this instance the actor's yes 
meant that the old gentlennan conld remember as many lumiting somgs as need be. There was a different reason for his inaldility, or refusal, rather, which canne out on farther inquiry.

"It is not the right season." explaned the actor.

So, then. I had bhumered. I did mot compredend fully the meaming of "out of' seatson." as it appeared later, hut it wats clear that I had erred in suggesting to the old gentleman that he sing me a lunting some. IIowerer. there was hope still. for the old gentleman. with that courtesy that is characteristic of the Indian, wished to retum my call, and an appointment wals made for hin to spend the evening at my lodge. I I came and devoted the first half hom to fluent speech explanaltory of his refusal to simg al hunting song. It was apologetice. regretlul, the rery refinement of contesy, but firm: and this Wals the substance of it - that the hunting soms. ine it the carrilum. the red deer. the partridge, or any other, was a prayer: it was smeng only when the hunter set fortlo to seek game: and this derout worshipere of Gitele Manito could not profine his ancient faith by singing such a song for the mere purposes of entertaiment, or to gratify commembalule eminsity.

It seems to me that comment is monecessary, hut I suggerest to those who despair of the Indian, and there are many, including some missionaries. that they take this fine old gentleman's lonest piety into prarertiul consideration. IIow many pallefaces are there upom whom their religion has taken sueh a hold that the wouk regard it as profinity to sing a hymm to pleatse a stranger! Does not the episorte convey this further, prateticable suggestion: that if we superior whites endeavor to malse 
something of the Indian, it behooves us with all our might to get within and behind lis point of view to the end that we may understand the material that we try to mold to our own ideas and purposes!

Needless to say that I yielded the point but I besought the good old pagan to $\operatorname{sing}$ something for me. He was reluetant still. and, at the risk of another blunder, I suggested a love song. The idea at his age of indulging in such sentiment was so manifestly amusing that again I retreated, and another half hour of speech-making followed. I was beginning to despair, thongh intimate contact with the red man's method of thought sustained me in patient endeavor, when at length it oeeurred to the old gentleman that he eould, with entire appropriateness, sing me a visiting song. And this he did with much gusto, though, oddly enough for such a stickler as to the proprieties, he sang me the winter visiting song reprodnced On one of the foregoing pages, forgetful, perhaps, as we sat by a blazing $\log$ fire, that it was mid-summer.

The song found its way to paper in a hurry and with a sense of long deferred triumph on the part of the note-taker, but I was not content. In the matter of songs I was forever wanting more, and on this occasion I resorted to a daring experiment. I made a speech of my own to the effect that the old gentleman's courtesy demanded a return in kind, and it' he would be pleased to listen I would sing him an Indian song. Te manifested lively pleasure at the suggestion, and forthwith I samg two of the Onaha songs in Miss Fleteher's collection that I hat memorized years before. The language was strange 


\section{THE OJIBWAY VIEW OF MLSIC}

to him, but the downwald progressions. the startling gratee notes and the exaggerated portamento that I had learned to initate, evidently awoke a responsive ehord and stirred his blood, for his eyes glowed with almost fierce joy, and the ealm benignity of his face was transfigured to something well nigh eestatie. It was a most snecessful experiment. 'Thereafter songs of love and war came from his trembling lips until it was I who had to ery enough and bring the long night's session to a close.

The old gentleman's name is Innéquahung Shawanihenayse, whieh the whites have turned into John Shawan. He was born somewhere on the north coast of Lake Superior and now lives on Drummond Island, Miehigan.

\section{DISTREST YANQTLSIED BY HARAIONY.}

Further light on the Ojilhways regard for musie may be had from their attitude toward me and my self imposed work. At first they were distrustful and put every obstacle in my way except physical violence. For a long time I cond not persuade man or woman to sing for me in private. Indians whom I approached for this purpose dereloped sudden and maceountable diffienlties with the English language: or they discovered sore throats a half hom after a performanee of the play in which I had heard them singing: or they were too busy. When I came upon them singing by themselves, they stopped abruptly. Some of them strolled away, the others sat staring at the ground. or out upon the lake. In the course of time I had memorized a few songs, having haird them daily in the 
play, and I wished to rerify my notes, for having eanght them through the noise of the drum I was cloulotful as to their contire accuracy. After nearly three weeks of persuasion I induced a singer and an interpreter to spend an evening at my lodge for the purpose of going ower these few songs. 'The work went smoothly enough for a time. and then there was rebellion. 'The singer mate a specelh to the effect that he wonld be accounted a bad man by his people if he should give me the songs. I asked for a frank explanation, and there was another speech which the interpreter reproduced substantially as follows:

"Sir", we do not understand it. We like you, but we do not melerstand what you are loing. We ask what has the white man done to uss? II has mate ns live in reserrations, forbidelen us to hunt in the forests. taken away om land. IIe has taker from us everything Indian that we possessed execpt our songs. and now you come and would take away those, too. You will have our songs sung all orer the world where white men live. and when that has been done you will turn upon us, like the white men who eame before you, and say, get ont! I have no fintlier use for your."

We had a long argument. I tried to show them that I left behind all that I took away, and that I was trying to save their songs from being forgotten. So fiar as the iwo men who heard me were eoncerued, the argument was comvincing, but there lingered even with them a reluetance to help me to eertain songs because they belonged to other persons. Nearly all the Indians of my acpuantance recognize this proprietary interest in songs. A hals no right to sing B's songs: I did 
not compose them, hut they canne down to lim through lis family, or from some chief' who tanght him, and 13 alone slonkl say whether they might be given to another. 'To this day there are some () jibways who refuse to sing for me. still influeneed apparently by that well fommled distrust of the palefiace that was voiced so framkly in my lodge.

'The confidence of those Indians who were coneemed in the play was won by a rather hazardons experiment. I malde a four-part arrangement of "My Bark Canoe" and gare it to a guartette of white singers who chanced our way. This was in the afternoon. In the evening the Indians were called toenether and I fold them that I woukd show them what I was doing with their music. I satid that if they wonld sing "Chekatbay teloik" in their way, my friends would sing it in the whiteman way. After eharacteristic besitation the Indians complied. The quartette, taking the pitch from the Indians, imneriately repeated the song in English. The excitement of the Indians knew no bomds. 'They yelled an if they were engaged in fieree combat and. smonounling the stantled puartetle, demanded a repetition of the piece. Sereral repetitions were given before the Indians were satistied, and then they eroweded about ne. asking eagerly if they conld learn to sing like that - meaning ill parts.

My aroption into the tribe follower not long after this eprsole. They named ne Negannucelsallbols, the man in front, the signifieance of the name arising from the fact that the first time this group of Indians saw me I was conducting an orchestra. 
In answer to a question that is often asked I will say that the Ojibways seem to be very appreciative of the harmonized versions of their songs. There was a piano in the hotel near the Indian playgromul, and the company of actors would gather at the windows whenerer I undertook to sing the songs of the play to visitors. Often when the musie room was deserted one or more of the Indians would go in and try to piek ont the songs and find those elusive effects that came from striking more than one key at a time.

\section{MESIC IN INDIAN HOMES.}

Many of the more prosperous Ojibways have parlor organs in their eabins at the reservations. In some instances there is no one in the family who can play, but there are chiblren growing up who some day may be tanght, and the instrument is provided for them. At Garden River, where most of my Ojibway friends live, there is a music teacher from whom sereral of the younger Indians have leamed to play simple piees. I have listened to them with mixed feelings. It savored of romance to call Tecumseh Bukwujjinini in from his layfield and lear him, in overalls and shirt-steeres, play voluntaries. Ife is the oreanist in the Hopeopal church at the reservation. I grieved when be turned from his chureh music and played the trivial stuff that hat run its brief period of popularity in the cities a few years before. In defanlt of aceess to any thing better, he was accepting the white man's trash; and the exquisite melocties of his own people were not available because 
they had not been put into notes. In his house, and in others. I have smog Ojibway songs in the Ojibwaty langnage with hamonized accompaniments, and the result hals always been at homrica gathering of such neighlon's as were within call: and sometimes the people have overeome their shyness sufliciently to join with me in singing their own songs. The men and women who take part in the Indian play may often be found of an evening going orer "Ny Bark Canoe," or "Alsence and Ionging," or the "Death Song," and trying to put in the valrious hammonic parts. Nost of these long ago reeognizce. the value of my work to themselves and eheerfully put themselves out that I might record their mowritten melodies.

The attempt to amive at an mulerstanding of the () jibway's; riew of music has been made thus far by consideration of obvious evidence. 'There is possibility of more complete muderstanding he inference from the music he hats composed and preserved. I call attention elsewhere to the fact that the words of some Ojihway somges are alrchaice, so long ont of conninn use, indeed, that the modern Ojibway does not know what they mean. Ile nevertheless sings the songs with manifest satisfaction. I note also the fact that I have often hand () jibways sing songs in which every word was meaningless, that is, the voeables were made up exchusively of nonsense syllables which are employed eonventionally to pieec ont lines which are too short for their respective tunes. 'Tle inference is inevitable that, in respeet of these song's, the Indian is appreciative of music in precisely the way that the cultivated man of eivilization is appreciative of it: that is, he i.s stirred by musie purely 
and simply, withont any association of the melody with tangible ideas; in other words, the Indian has risen high enough to appreciate absolute musie, a plane that he might not have been expected to reach in view of his linguistic failure to distinguish between musie and poetry.

It is the fact that eivilized man finds pleasure in humming or whistling melodies that linger in his memory that makes the Indian's mocedure espeeially striking and signifieant. We take it for granted that civilized man will do just this, and the phenomenon ealls for no special comment or analysis. It is different with the Indian beeause he has no notation for the preservation of his music. Words of some sort, therefore, are essential to him as pegs for his tumes. Having in mind his generally backward condition in eompanison with our race, we are inelined to infer that his appreciation of melody should be measured by his words, and that, words lapsed from memory, the tune also would disappear. Presumably some of the wordless songs I have heard were originally composed to words of precise meaning, but I lo not know that to be the faet. It may be they were the invention of meloclies on the part of some nursical Ojibway whose tunes eame too fast for joining them to significant words. In either event, the preservation of a tume of this type has been on its own merits, so to speak; the significant words lost, the singer treasures the tume and hands it down to the next generation as a thing of absolute beauty that ought not to be neglected. Can we imagine civilizci man going to such pains to preserve his favorite tunes from oblivion? It is not, of course, a conseious proeess on the part 
of the Ojibway singer: that is, I doubt if he singes his wordless song for the precise purpose of kecping it allive in the memory of himself. family and friends: he sings becase he enjoys the musice and he is far enough adraned in musieal development to be indifferent to the presenee of words in connection with his ant.

'Thus it has often appeared to me when, after hearing a song given with great rigor and earnestness, I have sought to gret the words and have diseovered that they meant as little to the singer as they did to me. From the manner of the singer one might have supposed that he were uttering sentiments of the profomdest import. In fact, his earnest manner was his ingenuous tribute to the beauty of modulated tones. to the art that inspired him. 


\section{CIIAP'TER YII}

\section{MUSIC IN OJIBWAT DAILY LIFE}

I AXI often asked whether the Ojibways have industrial songs. In the general aceeptation of the term, no; but we must take into aceount the nature of Indian industries before learing the answer there. Before the ojibway came in touch with civilization he hat no conception of factory life, or of systematized labor. Contrary to popular belief, he was not improvident: he had thought for the coning winter and dricel his meats and laid in his cereals aecordingly. II linew that the bired tree yields its hark best in the moon of strawberries--liate June-and he did not neglect then the making of the canoe that might not be needed till the summer hat passed. When he chanced upon medicinal roots he gathered them against the ilhess that happily might nerer come. In other words, he provided for his simple needs with such diligence as was necessary, hut he was not possessed of greed to the end that he must work for more than he needed. Accommlation of property was limited substantially to furs and galments. 'Therefore, the word industry, standing in our eommercial age for systematic toil: lay ontsicle the pale of his experience. When he wanted anything, he hunted for it. or malle it. In some things, the mamufacture of canoes, for example, the Ojibway excels all people; but canoe-making conld 
not be ealled an industry. for he did not strip a thomsind trees in June that he might have stock for the making of canoes throughout the entire year.

'This conception and manner of life is not conducive to the making of industrial songes. Man sings of that which interests him. Itis interest may be aroused hy religions aspiratjon. human love, the beanty of Nature. the excitenent of conffict against man or heast. or the very joy of idleness: and it may also be aroused by the force of circomstances, as when he is habitually engaged. day after day at some momner of oreupation not in itself interesting. 'The sailor, tugging away at a windlass, finds in the rlythm of arduous exertion an incentive to song, and in the song a stimulus to renewed laber. The Maryland negro, "shueking" oysters in a dismal cabin, relieves his pent up soul in melody through sheer necessity for something brighter and more wholesome than his environment. The peasant's foot on the treadle that keeps the spinning wheel a-whirring. stirs the spimer's soul to rhythm, and song issues from the lips as readily as breath itself. Man would not be human if, under such cirenmstances, the words of his songs were not suggested. occasionally at least, by the niture of his toil; and thus industrial songs cone into being.

DEPEADEXCE ON THE DREM.

There is little analogous to this in the Ojibway's daily life, but he does have songs eharacteristic of, or applicable to his few oceupations. IIe has a multitude of hunting songs, sec- 
ular as well as sacred. Not as many, but still a great number, are the canoe songs, that is, songs whose appropriate place and time are in the canoe while paddling. There are also corn songs, which are religions rather than industrial, although applicable to planting and caring for the grain, and inasmuch as tending the baby is an occupation with the Ojibway as it is among all peoples, there are cradle songs. Furthermore, the Ojibway is so much given to visiting that this might almost be regarded as an occupation, and there are social songs and songs of hospitality without number.

'The modern, or reservation Ojibway, who has learned something of carpentry or agriculture, does not employ song at his civilized labor as freely as does the plantation negro, though the tendency to sing while at work is very noticeable. I have often hearl a dozen or more men, busy with their saws and hammers, lurst into a roaring chorus, some one among them having started a song alone. But work halts while the song is in progress, and the diversion is not long continued. The early cessation of music under such circumstances, is to be accounted for partly by the fact that the Ojibway is a conscientious workman, deroting himself to his appointed task with rare faithfuhess; but more by reason of his own regard for music and his dependence upon the drum for the expression of it. When he sings he is disposed to give himself up to song and to that alone. IIe is absorbed at once in his music to the exchusion of all other considerations. II is dependence upon the drum for entire satisfaction is the feature of his art that separates him most widely from the musical manner of 
civilization. The Ojibway ean sing withont the drum, but he misses it. Even those who have grown up in semi-eivilization prefer the thumping accompanment, and when atn Indian sings for me without his instrument he usually marks the rhythm by patting the table, or his knee with his hand.

Perhaps it will add no interest to these observations and speenlations, but I camnot refrain at this juncture from stating that this part of the book is being witten, and the aeeompanying musie prepared, in Ojibway land. Around me is the wilderness but recently and slightly broken by Canadian pioneers. From my cabin window I look upon the western waters of Lake IIuron where Nature has ontlone herself in loveliness. Ojibways are my daily eompanions; I visit them in their teepees and log houses, and they cone of an evening to smoke their pipes by my fire and eudgel their brains to revive memory of songs they heard when they were ehildren, their interest in my attenspt to preserve their songs being a mighty stimulus, if one were needed, to its continuanee. So, what I rednce to writing is as near as ean be a series of snap-shot impressions of daily oeenrences intensified and corroborated by their reduplieation of experiences in year's past. It was but yesterday -I was disenssing dependence upon the drum-that I ealled at the Ojibway dwelling where for eonvenience I store my phonographie reeords. While I was busy with them an aged man sat on the floor taking eare of his chubly, eighteen-monthsold grandson, his wife and daughter engrossed at the time in preparation of dimner. The white-haired old man sang to the baby, songs of war, of the chase, of love, and cradle songs; and 
while he sang he drummed incessantly upon the floor with a stick of firewood. Now and again the soft treble of the child's voice rippled across the wavering, uncertain tones of the song, sometimes in the inconsecfuential remarks of babyhood, often in faulty attempts to join in grand-pa's singing. I wish that whites who regard the Indian as a stolid brute could look in on such a scene!

TETEBAHBUNDCNG, "THE SWEETEST OF ALL SINGERS."

Iet me pass to another instance. almost as recent, where drumming played a part in music necessary to the Indian but at odd variance with our coneeption and habit. I was working at the Garden River Reservation and set forth one evening to eall upon 'Tetebahbundung, the finest Indian singer I have heard anywhere. Allusion has been made to him before, and several of the hest songs in this collection were taken from his lips. He is about forty-five years old, a full-blood and extremely sensitive upon that point. It offends him deeply when palefaces who hear his superb tenor voice and note the exquisite graee with which he sings, jump to the eonelusion that his superior gifts are due to a strain of white blood.

"It is not so," he says quietly: "I am all Indian."

'Tetebahbundung usually appears in the drama, "Hiawatha," as Chibialos, the sweet singer, his son, Adamosa, taking the part of Iliawatha, the boy. Longfellow never risited Ojibway land, and his personal acquaintace with Indians was very limited, facts that impress us who haunt the region as remark- 
able tributes to his poetie imagination, for his lines reflect the beauty and character of the landscape with unerring aceuracy; and in nothing did the prophetic vision of the poet arrive at truth with more eertanty than in his delineation of Chibiabos. 'This personage in the poem might well have heen drawn from Tetcbahbundung. All the supertatives in Longfellow's deseription fit him as a well made garment. His roiee is pure tenor with that human quality that can be suggested only by the word luscions: it is so powerful as to be heard distinctly orer a chorus of fifty men with the drum banging fortissimo, and yet, so keen is the man's mwitting artistic insight that when he sings in a small room, like a concert hall. or al parlor, nobody dreams of his power. for he modulates his rolume of tone to the demands of the place and occasion. Furthermore, though he never has had other than Indian instruction and knows nothing of written music, his tone production is the despair of professional white tenors who have heard him. and he sings with such a wealth of feeling that no. andience fails to be stirred in spite of the fact that lis words are meaningless to the listener, and sometimes to himself, for I have heard him repeatedly sing entire songs that had not one intelligible word in them.

This tribute to the Ojibway singer may read like enthusiastic exaggeration, but if so I must be content, for I know the truth and I am not alone in my estimate. 'Tetebalbundung is, indeed, all Indian, with the shorteomings of his race, but he is a musician from the ground up, and, als a man. singularly attractive; quiet, unassuming. absolntely lonest and faithful to 
his promises, gentle and affeetionate. Ilis relations with his little son are those of ideal parental and filial companionship. Altogether 'Tetebahbundmog appeals to my heart with special forece, perhaps because he was the last Indian to become my friend. For a long, long time he held aloot, resisting me with stubbornness that was the more diflicult to meet beeause it was so deathly quiet. No need to dwell on that now, for he has become a firm friend and one of the most raluable collaborators in the work of recording the songs of lis people.

I knew that Tetebahbundung was at home when I was yet at some distanee from his house, for I heard his drum. He was not pounding had, but the night was still, and the instrument evidently had been thoroughly warmed, for its tone was resonant and penetrating. I pansed at the door, mwilling to interrupt, fearing to make an ill timed intrusion. He was singing a love song, and in true Indian fashion he sang it many times over withont stopping. At length the end came with disaster, for he beat with added rigor, and of a sudden the tone was dull. Drumming and singing ceased abruptly, and I heard 'Tetebahbundung mutter a low "Ah!" 'Then I knocked. He canne slowly, and the open door revealed a room dark save for the dying embers in the fireplace, empty sare for himself.

"Come in," said he, by way of greeting, and I responded that I had heard him singing. "Ies," he admitted ruefully, "and now my drum is broke. I heated it too hot, I suppose. My wife and boy she gone, risiting. I was lonesome. So I 
got my drum and sang. Xo nome somg now, "and he langhed a little.

Is comment necessary! simply to point out that the white musician under such ciremmstances might betalie himself to the pianoforte to calse his soml. Shombl the strings snap, he would no longer sing. failing of instrumental support. 'To this musical Indian, the tmeless drom was as the responsive keybard. and without it his diversion was unthinkahle. I asked him how he would manage now that his drum was broken, and he replied simply that he would make another.

Tetebahlmudung is an exception among Ojibways only in that his gifts in and love for musie are greater than the arerage. The men, it secms to me, sing much more frequently and more freely than the women do. Gentlemen who gon to the Camadian forests for game return with tales of the tacitumity of their Indian gundes, and the casual visitor at a Reservation fincls little respouse to his questions. If he should speak of songs he would probally get no answer whatever, and might go away with the conviction that self expression through musie is unknown to the Ojibway. Such, certainly, was the case wth a distinguished gentleman whose seientific studies have taken him among the ()jibways of Camada for the past fortyeight years. Ine learned their langnage and, incidental to his main research, made a special study of their myths and traclitions. Coming upon me in the midst of ny work in the summer of 1904, he frankly expressed amazement that I foum anything to do. 
"A few years ago," said he, "a wealthy Bostonian who contemplated a season in the wilds of Canarla for his health thought of taking along a phonograph for the purpose of recording Ojibways songs, and he asked me for 'points.' I told him that I could give him one that would be of great value. and that was to leave his phonograph at home, for the Ojibways had no songs. Of course I had heard the Indians howling to the drum now and then, but I never had heard sounds that appealed to me as musie."

The gentleman's amazement was equaled by my own at this revelation, for, with me, it is the conmonest experience to come upon an Indian singing softly to himself as he sits idle and alone after the day's work. I follow the unseen bark canoe across the lake at night by the melodions roice of the paddler. By the campfire-at their social gatherings-beside the dead - wherever they are, alone or in familiar company, I hear them sing. "He that hath ears to hear, let him hear!"

\section{MUSIC FOR THE DEAD.}

It is said that the eary missionaries won the attention of the Ojibways more by hymn tunes than by exhortation. 'This is entirely credille, but I have evidence that the Ojibways adapted themselves to the white man's melodies with no little diffiulty. My first hint of this fact was conveyed to me through hearing part of a touching ceremony at a house where one lay dead. It was in the Garden River Reservation. Somewhat remote from what might be called the centre of the 
long, straggling village, is a cabin where four aged sisters lised. One was blind, another lane, the third bad been a helpless paralytic for years, and the fourth was afflieted with the fechleness of old age, if by nothing more acute. With no assistance save that a man hanled their winter's supply of wood to their door, they attended to their cow and their acre of regetables, splitting the wood, fetching the water, weeding the garden and gathering their crop. Two of these women were Episcopalians, the others Roman Catholies. Of the latter was the paralytic who was the first of the four to join the maljority. Long hat glowed the embers of her life; long they smonldered after the darkness gathered upon them. Her mind was the last to flicker and go ont, and while the end delayerl. her sisters cheered her by laying upon the table and calling her attention to them, the clothes, the finery, the farorite articies that would faithfully be placed in the coflin and buried with her. She died at sumrise. During the day the kind offices of neighbors were administered in much the same fashion as would have been the case in a eommunity of whites.

At sunset eame Megissm, "the singer" as he is called, a stannch Episcopalian and older by a long span than she who harl departed. He brought with him his Protestant hymnal, a eollection of hymms translated into Ojibway, but with no note of musie between the covers, and sat beside the dead. The surviving sisters took their plices neall. No word of enrecting had passed, no eonment of any kind was uttered, no moan of grief eseaped the lips. I pon the table at Megissmin's elbow was a lamp, and beside it a saucer of lozenges and a plate of 
plain cakes. Shortly after Megissmn's entranee three neighbors, a man and two women, drifted in, more silently, more mobtrusively than if they had been antumn leares impelled by an idle wind. By not so much as a nod, or a glanee from the eyes, did they recognize the presence of the singer or the bereaved sister's. Megissun stirred not, neither did the monrners. Presently another silent figure blotted out the loorway for an instant and joined the expectant group, and then still others, till the narrow room was full. All these, Christians every one, were there to go part way with their friend upon her long journey to the land of the hereafter. In the presence of death, sectarian differenees were forgotten, the new faith itself faded and fluttered before the persistence of aneient enstom.

Megissm did not wait for the room to fill. In his own good time he opened the hymmal and began to sing. Through nearly the whole of the first line his wavering roiee bore the tune alone; then one and another joined in mison and sang the lymn throngh all its slowly toiling stanzas to the end. A pause ensued while Megissun turned the pages of his book. Presently he selected another hymm and began. As before, the assembled neighbors joined as soon as they recognized the tune. Now and again a single voice stmmbled over the worts of an ill remembered line, but nohody was disturbed or abashed thereby, least of al! the person who committed the error. While yet the hymm was sounding, other neighbors drifted in. Some of them had walked miles from the far end of the Reservation. Silently, unobtrusively, reeggnizing nobody, they found their 
places. Between hymns the clatter of crickets beat noisily upon the car, and the sudden hoot of an owl shoeked as might profinity before the altar. There was no unealsy rustle of garments or shufling of feet to indieate that the minisden risitors had wearied: ther seemed not to breathe. Only Megissun stirred, and he all but inaudibly turned the patges of his oft-thumbed hymual.

Some time between ten and eleven o elock, two of the guests arose and, withont word or alance of parting, drifted ont into the darkness and came not again that night. By midnight others had gone. but the places of a few were filled by bate comers. At rare intervals als the night wore on with its suecession of hymus, Megissun relieved his throat with a lozenge, and such guests as were so minded sought the table for a piece of eake. When the sun rose, the room was no longer crowded, but a loyal handful of neighbors yet remained singing a final hymu for the eomfort of their friend upon her journey through the darkness. With the full light of day Megis. sun elosed bis book and went home, and the others, with no word to him or the sisters, departed also.

\section{THE CONHLICT OF STYLES.}

To the wondering Yankee who ohserved and heard this ceremony, the musical interest lay in the unwitting perversion of the tunes by Megissun and the older singers. So dominating was Megissun's voice that at first I did not realize that some of the others were not keeping strietly with him; and at 
that time I was hard put to it to know whether the tunes were aboriginal, or the product of civilization. The occasion was well calculated to befog critical observation, but presently. when the human interest could be subordinated, I perceived that the fresher, younger voices were inclined to shorten the phrases, and that they followed. as if with some timidity. the shakes, turns and slurs with which Megisssm crowled every line. Fixing attention upon what the rounger voices actually did, and eliminating as much as possible those instants when they followed the lealer with hesitation. I began to perceive the ontlines of a eirilized melorly, and eventually recognized it as one that is to be fomd in many hymn hooks. Regarding IIegissun's voice alone. I night have persuaded myself that he was singing the Christian words to an ancient Ojibway tune, so completely did he cover and disguise it with the mannerisms I had become fimilial with as characteristic of ancient Ojibway song. 'The older people kept with the leader easily, for he harked them back to childhood when, perhaps, to every one the Christian faith and its music were muknown: but the others. who hal learned their hymns from the lips of a white missionaly while they were young enongh to receive and retain strange impressions, found the old leader's manner disconcerting.

I can give no more than this indication of the mixed style that resulted from IIegissun's perversion of the civilized tune. for I could not introduce a phomograph into the scene; I could not take notes in the darkness outside the house, nor profane the occasion by note-taking within: and my memory would have 
been an insecure guide. But I lonked into the matter at another time and. mainly through the coriperation of William J. Shingwak. phonegraphet ereral hyme-ne in the manner of a byegne atge. This man. a lineal be-endant ut that

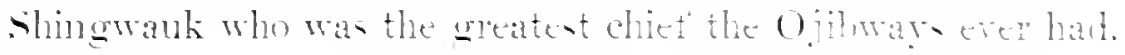
tell we that in the early dar the Indians. finding that they could not expres their emotions freely throngh the wlite man', melody. either ahnomed it altogether and alapted tune w

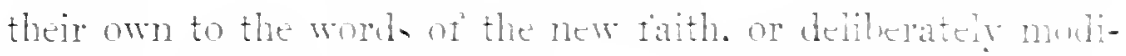

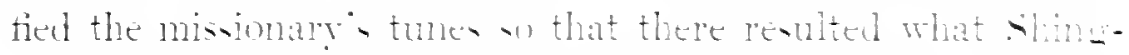
wauk characterized with humomen grarity an "half heed music." The printed noted do not give a ritidactory representation of this mixed strle. There is no doubt abut the melodic outline. hut there lack the tome colon. the infinite -lurring and drageing that no type can set forth and no cirilized singer reproduce unless he has heard the Indian many times and is good at initation. Xerertheles. I give one of the hymm, on page 2333. partly hecaue it has a certain hatorical interest. and in the hone that the reader can deduce from the bald symbols an approximate conception of the older Indinn mamner of singing.

\section{DEITH SOIGS.}

This was Chief Bukw jinini"s tarnite hrmm. and the Gar-

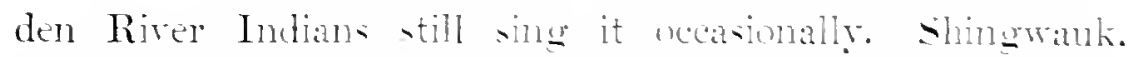
grand nephew of the chiet. and other well intormed ojibwas. believe that the tune is aboriginal. "It is very ald." they say. 
"and was madz orer for this hymn by Chief Bukwujjinini himself:" I think they are mistaken in this. Lp to the present I have not been able to identify the tune with any in the hym books. but it appeals to me as a white man's tume made orer rather than an Indian's. Whether or no, it was sung at Bukwujjinini"s bedside by the members of his family while he lay dying. the incident illustrating another conventional use of musie among the Ojibways. for every Indian has his death song. one that he will sing himself, if possible, at the very moment of dissolution: and if roice fails him. his friends sing it for him. In the old days the words of death songs befitted the occasion, heing expressive of courage, faith, doubt, defianee, as the ease might be. I am thinking of the nonChristian Indian when I use the term "old days." the fact being that the pagans of the present adhere to the custom. Lnited States Army officers have told me that when it is neeessary to excute an Indian, the rictim marches to his place hefore the firing squad singing his death song, and that his voice never falters till the bullets stop it forever. The Christianized Ojibway tends to modify this striking custom as he does all else that belonged to his ancient life, but not infrequently he preserves the poetic atmosphere. A good old friend of mine fell fatally ill in a foreign city far away from his home. Sympathetic whites sent flowers to him in the hospital, and these he appreciated witl pathetic joy-I fancy they symbolized the forest home that he was never to see again. Death lingered for hours at the threshold after his unmistakable knock on the door. The old man knew the signs. 
"I should like to hear a son s.." he whi-pered.

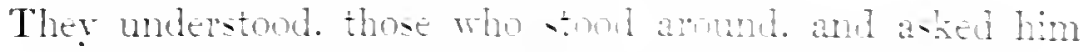
if there were some particular - neg le whit lite an hear.

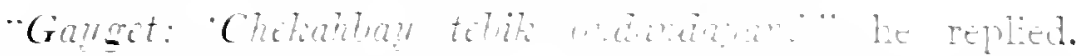
laping into his native tongue: "Ie. 'Thmughut the nith I keep awake."

These are the first word or the lnve sing to whit. I have

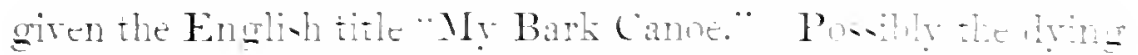

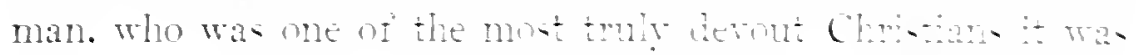

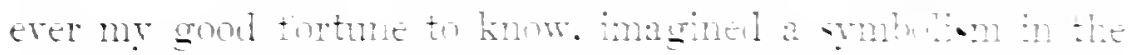

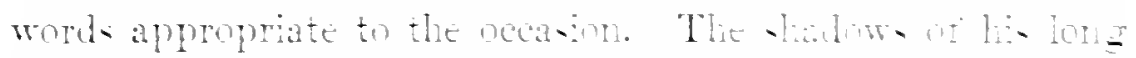
night were upon him eren then: the ong tel- wi a atean that

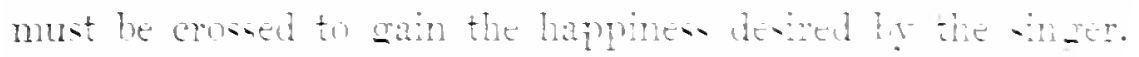

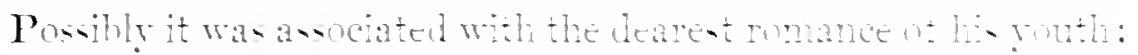

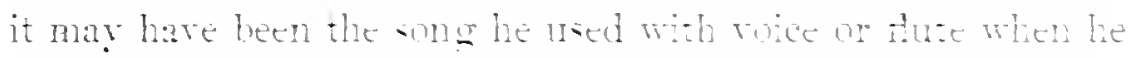
went hopetuly a-moing. We can hut speculde. Wht the

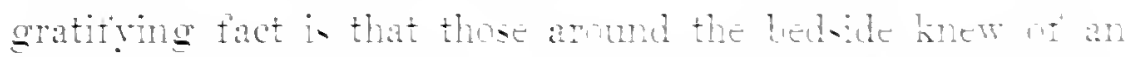
Ojibway revident in the city: that the ent wrent word of tim: that he came. knew the cong and and it: and while get the sweet strains were throbbing. the ohit man diea.

OLD HTINRED AT SOCAL GATHETXE.

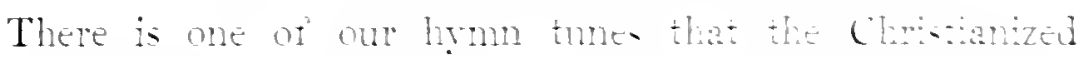

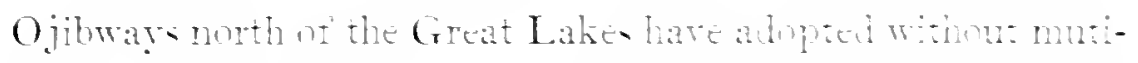

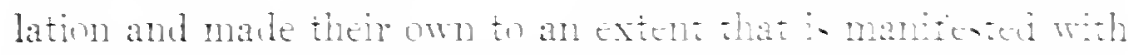

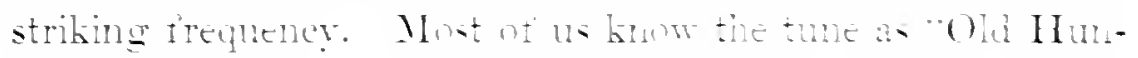
dred." To the Ojibway it is the "Doxntugy." the work be- 
ing a translation of "Praise God from whom all blessings flow," and so forth. MIy first encounter with it in this form was at a wedling supper early in my accianintance with the Ojibways. It was not an Indian function, but a social gathering organized by Mr. L. O. Armstrong. friend and employer of the bride and groom, to which a half a dozen whites and nearly a lumdred Indians were invited. The wedding, according to the Clurch of England rite, had taken place in the open air at four o'elock in the afternoon. It may throw a little light on the Indian's attitude toward civilization if I explain that the bride and groom were the "Minnehaha" and "Hiawatha" of the Indian play to which reference has becn made heretofore. Theirs was a charming romance while it lasted, sadly brief, for "Minnehalla" died within two years after the wedding. 'Tekumegrezhik Shawano, a young man of modest demeanor, great physical strength and handsome face, had been promoted from the ranks to play the principal part at a time when circumstances made it advisable to reorganize the cast, and, at the same time, Miss Millgaret Wambunosa had been assigned to the part of "Minmehaha." Both, I think, were selected for their looks, and both justified the choice. It was not suspected that a real courtship was in progress every day when "IIiawatha" made his visit to the lodge of the "Ancient Arrowmaker" and laid a deer at the fect of "Minnehalna," but the revelation came when shawano asked for a day "off" in order" to get married. He was persuatled to continue playing his part even on the day of the wedling, and the Garden River missionary, Rev. Frederick Frost, journeyed to the playground 
and officiated at the marriage ceremony immerliately after the performance. Of course there was a great to-do about it. IIundreds of persons, palcface and red, came from great distances to witness the event, and it was suggested to the bride and groom that it would add to the general interest if they would kcep on the picturesue eostumes worn in the play. This they politely but firmly refused to do on the aromel that it would profine the new faith if they shomld wear the ancient costumes of their race in one of its most saered ceremonies. And all the other members of the II iawatha "band," as the Indians call the dramatic company, conciding in this riew, humied to their teepees when the play was over to don the habiliments of civilization before presuming to assist at the ceremony in the lumble guise of spectators.

In the evening, too, the Indians preferred to go to the white man's supper in white-man elothing. 'There was manifest much of the traditional shymess of the race at first, but the ice was broken by abundance of good food and a succession of songs and stories until all except Mr. and Mrs. Shawano were quite at ease. Presently a monster cake was bronglit in. Two men, Tetebahbundung and Obetossoway, carried it on their shoulders all aromml the room, meantime dancing as grotesquely as the safety of their burden permitted and singing a most lugubrious tune which, from the Ojibway point of view is a joyous festal song. until at length they deposited the eake on the table before Mrs. Shawano. She was then told that she must cut the eake so that every person present might have a piece, and there ensued an awkwarl panse. All eyes were turned upon 
the bricle who, donbtless, never had heard of this paleface enstom, and was painfully embarrassed. None of the whites present saw just what to do to relieve the situation, but it was taken in hand by an aged Indian who stood up and, using his native tongue, spoke substantially as follows:

" $\mathrm{N}_{y}$ friends, this is a very large cake and it will take some time to cut it. It is evident that the bride fears she will make a slip of some kind with so many persons looking on, and it is plain enough that it will be easier for her if we give onr attention to something else. Therefore, I suggest that we all rise and sing the Doxology. This will take our eyes from her and it may give her eourage for what she has to do."

At once, lnit deeorously, all the Indians stool up, and the whites who had not understood the specth were first astonished and then awed as the solemm strains of "Old Humdred" poured in a majestie unison upon them. Before the end of the first line, the bride arose and applied the knife to the eake, and althongh her task was not finished with the hymn, the diversion had done its appointed work and she kept eutting in faithful observance of instruetions mil the last possible slice had been disposed of.

Then, as always in my assoeiation with the Ojibways, I siezed every opportunity that gave promise of hringing a previously unheard Indian song to light, and on that oeeasion, when it was time to disperse, I ventured to ask if the Indians would not bring the jollification to end with a rousing, old-time ehorus. By then all were in fine spirits. We hat had a number of love songs from the Ojibway men and women, all given 
as solo performances, and most of the whites present had contributed humorous song's or stories to the entertaimment. Shyness had long since taken flight and the rom was yet echomer with langhter when I made my suggestion. The Indians listened to it with enstomiry respect. and such was the atmoswhere of perfect aceord that 1 actually stationed nysell" behimd at friend so that, mobserved, 1 conld jot upon a scrap of music paper such notes of the fortheoming norelty as 1 conld. 'There was no apparent consultation anong the Indians. All stood np and looked at 'Tetebahbundung. for he wats their "leading volee" that night. and it was natural that they should defer" to his choiee of a song. ( nuite in accordanee with custom there was a distinct pause. impressive to me in my eager quest for new melody. 'Then the singing began, and nearly every voice was in with the second note. My own was anded at the third and my serap of music paper was hmriedly pocketed, for the "rousing, old-time chorus" wals the Doxology?

At the end one of the Indians, who seemed to pereeive that I had missed something, came to me and said, "We always close our social neetings with the I)oxology." I have had many occasions sinec to test the miformity of the rule. One was fuite as striking as the wedling supper. I had invited about thirty Indians and a dozen whites to a eamp fire on the island where I lived during the summer. It was about a mile from the mainland. 'The camp fire was purely a soeial gathering where red mon and white met on even terms. There had been songs and weird dinces, light refreshnents and nuch tobacco. The moon was well up in a cloudless sky and the 
lake was as smooth as glass when it eame time to break up. A lady, who had been deeply impressed by the beauty of the Ojibway songs given that evening, asked the Indians if they would not sing "My Bark Camoe" when they paddled homeward. I said nothing, wondering if they would eomply and hoping that they would do so. 'They did. Paddling slowly, and keeping their canoes well together, they erossed the moonlit water singing that farorite song. We sat by the dying fire and listened. the strains fading pereeptibly as the eanoes beeame indistinguishable in the distanee; but the night was so still that the melody eame back to us distinctly long after the flotilla had been lost to sight. With eharaeteristic faithfulness, the Indians sang the song over and over again, and if they tired of it we did not, though we wondered how long they would keep at it, and if they were standing on the mainland to sing until our fire should go out. That they were not on the mainland was proved by a minute of eareful listening, for the melody steadily grew fainter; but we knew to a eertainty when they reached shore, for aeross the calm surface of the lake came, as a benedietion and farewell, the Doxology. The soeial meeting was then, and not till then, at an end.

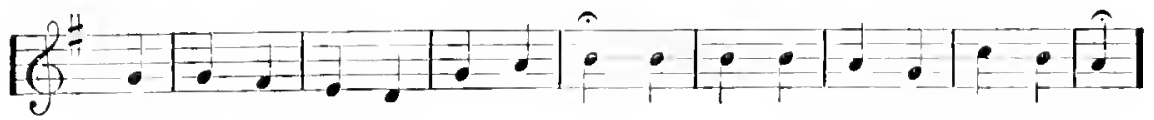

Mah moo yuh woh mah dah mah buh, Wan - ge shuh wau dau - goo-ze yong;

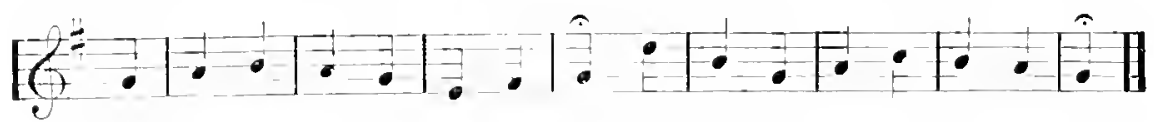

Wa yoo se mind wa gwiss se mind, hub ya pah ue zid oo je chaug. 


\section{CH.APTER VIII}

\section{OJIBWAY YERSE}

$\mathrm{I}$

IIAVE said as mequirocally as possible that the Ojibway hals not engrafted white-man music npon his own stock; that under, or despite, the inthence of civilization. he has developed a distinctive folksong. Indian in character as well as Indian in the making of it. There is nothing in the observations of the preceding chapter at variance with this assertion. The Ojibways who first embraced Christianity struggled with its music, but musuccessfully and were orercome by it. They attempted the grafting process. Init eventually. the hymm of civilization won its rictory. There lingers in Megissm and other aged Ojibways eridence of the struggle between the two tonal systems, but the gounger generation have succumbed, and the songs of the church when they sing them to-day are substantially free from the conflicts with a past style. On the other hand, what they have retained of their ancient music remains their own, resisting successfully the tendency to mix the styles, and developing to greater refinement along its own peculiar lines. Nothing conld be a more convincing demonstration of the inherent strength of Ojibway melodies than this, that they retain their distinctive character in spite of the overwhelming inthence of cirilization which is 
steadily destroying everything else that marked the Indian as an individnal in the human fimily.

Inasmuch as we are dealing with a musical sistem that finds its expression only in songs, it is necessary to give attention to the verse that underlies or accompanies them. I have foumd this an agreeable necessity. for Indian rerse is almost as interesting as the musie; not that it is equally ehaming; on the contrary, it often startles and shocks not alone by its rugged form. but by the sentiment it convers. It must be approached with patient regard for the fact that it is the expression of a primitire people: in a spirit that ealmly seeks for facts and as calmly aceepts them. In nowise, it seems to me. could an investigator profane his research more than by vieldiug to a sentimental or romantic disposition to read into his sulject what, from the Indian riewpoint, is not there; but the same disposition to look the facts calmly in the face should guard him from accepting the apparent meaning of a song's words as the reality. The oceasion for this warning will be clear from the illustrative examples that follow.

\section{CONPACTNESS.}

What strikes the paleface first in his consideration of Ojibway rese is its extraordinary compactness. I an assuming that the observer has passed quickly over the stage, if he crer traversed it, where Indian verse appealed to him simply as ludicrous, or hopelessly crude. I think my conclusions in this matter would apply to most, if not all other Indian tribes, but, 
for the sake of safety. will linit my tatements to the Ojinway. He wastes no words in his petry. and. being primitive he usually restricts his poem to the exprewing of a ingle thought. Now this thought may frame itelf in word saticiently clear to him and yet so few that they cannot fill out the meholy to which he attaenes them-it will be bune in mind that to the Ojibwa all rewe is necesarily music. and we mut theretore keep the music somewhat in riew while discumb the rere. In this dilemmal what does he do: what does the ciritized oomposer do! He repeats words and phraces in order to mate then corer the entire mebdic strain. The ojibway not only does this but resorts to still another derice for the ompletion of his tune-he runs in rllable that have no meaning.

Let us recall for a moment that one of the stock jests of the proteronal humorist is ained at the mutilation of language in the setting of potry to muse. It may be doubted if any conposer erer penned an anthem that obliged the soprano to $\sin g$

"Oh for a man, oh for an man. ol for a mansion in the skies." but the greatest masters of English song have justified the quip by constructing long arias from couplets. a proces that necersitates the repetition of work and phrawe to a highly. ahourd degree. Here are the work of an ojibray wedling song:

Bayshig cquaysos ni monigonun. gallget semah negohcdaybe-igo. 
'They mean: "A girl has been given to me; yes, I am glad that she has been given to me." 'That is to say, "I am glad because ny sweetheart's parents have eonsented to our marriage." From our point of view this is the entire poem, hut the composer of it, who, be it remembered, was of neessity also the composer of the musie, was so tumultuously stirred by emotion orer the great event in his life that musie was awakened in him to an umusual degree, and his tume could not be confined to a plain statement of his joy and one or two repetitions of it. The paleface under the circumstances might have amplified his original thought by entering upon a glowing description of his sweetheart's beauty of face and form; he might have deseanted upon her vintues and graees: or, following the immortal model set hy I Ienry Cary in "Sally in Our Alley," he might have narrated his present relations with her and forecast the future. Not thus the Indian. That one thought of jubilant satisfaetion was all that his mind eould earry with confort at one time: so, bless him! with a better sense of proportion than was manifested by the English masters, having sumg his line twiee, he forbears to repeat it ad infinitnm and ad uanseam, lut proeeds to the conchusion of his tune with "IIcyall, heyah, heyah," whieh means nothing at all, not even to hinself.

Doc's this literary device prowoke a smile? it has never failed to when I have spoken of the matter in conversation, hut was it not Shakespeare who ended the stanzas of a song with "IIey nomny, nonny?" did not the same poet picee out his comprehensible lines with "O, willow, willow?" ls there a world of 
meaning in these words! Doubtless as much as in "IIeyalu, herah," but no more. And think of the hundreds of songs to be found in our anthologies that end with fal hals, and equally portentous syllables, and comnt, if you can, the English poems that end every alternate line with a meaningless " $O$ " introdueed for rhythm. or rhyme, or, at the behest of the tune, for the purposes of melody. It will do mo hism. brethen, to smile at the Indian, but let us turn a fair share of the laughter. upon ourselves.

\section{TRANSLATION AND INTLRPRETITION.}

A better example of compatetness may be found in the following to whieh I have previously referred as the soug that awakened ny interest in Ojibway music and led nue to this prolonged investigation. Short as it is, the Indian does not piee it out witl "heyall." The entire poem is here given als sung by the Indians, with the meaning of the words under the Ojibway equivalent:

$\begin{array}{ccc}\text { Chelahbay } & \text { tebik } & \text { ondandeyan } \\ \text { 'Throughout } & \text { night } & \text { I keep awalie } \\ & & \\ \text { cheliaybay } & \text { tebil: } & \text { ondandeyan } \\ \text { throughout } & \text { night } & \text { I keep awake }\end{array}$
all gallemale-sibi
ondandeyan
upon a river
I keep awake. 
I am quite sure that this literal tramsfer of manings from one linguage to another wonld enver nothing to the English paleface who knew mothing ly direct eontaet of Indian life. Ilis poetic faney might erolve a meaning from it, brat it is hardly likely that it would he in consonance with the Indian's meaning. I renture to take the reader over the conrse that was necessarily mine when I mulertook to translate the $30 n g$. At that time I knew not one O.jibway word. The intelligent Indian whom I asked for a translation slowly dictated the followiris:

"I an out all night on the river seeking for my swcetheart." This impressed me as poetic in feeling, hut I wished to get eloser to the words themselves which I had earefully spelled from dictition and written as above, leaving spaces bencath for the English equivalents. I conld see that there were only four words. By dint of patient, detailed questioning I arrived approximately at the English equivalents above given. 'Then I was purzled and disturbed.

"Where is the word for sweetheart?" I asked.

"It is not there," replied the Indian, trancuilly.

"Then," said I, "how do you make ont that the song means 'I an secking for my sweetheart"?"

I Ial he been a paleface he would have smiled pityingly at my lack of comprelension, lut, as he hat all the traditionial courtesy and dignity of his race, he put my own patience to the blush by pointing to the word "ondanderan" which ocenrs three times. "That mean," said he, "I keep awake.' I get tired, yes. and sleepr. but I no sleep. I lieep awake. That word (tebik) 
is night. Now you see. Why does a man licep awake all night when he want to sleep?"

Like the true orator and debater. he paused for reply.

"Well," I suggested, half in weakness, and half" in determination to make him work out the meaning. "he might be hunting for deer, or something else to eat."

"No, no!" he responded gravely, "not this time. See: I keep awalie all night long on the river. Only one reason. I go to find my sweetheart. The word is not there but we understand it. We know what is meant. Perhaps mebhe her family has gone away. Perhaps methe she said she would meet me and something happened so she conkln't. I don't know; but we know that the man who marle this song was looking for his sweetheart, and we do not need the word there."

With this hewildering light thrown on the suljject. I retired to my own quarters and pondered. It wats my eager desire to make the attraetive melody arailable for paleface singers. To this end it was essential that there should he singable verses. Observe the use of the phural. One verse, on one stanza would not do for the demands of eivilization. The Indian is eontent to sing his one line over and over again, but the paleface must have rariety in his langmage even in so short a songe ats this. I confess that my first impulse was to string together some rhymed lines that woukl tit the tune, and let it go at that. as the easiest way ont of the diffieulty. hut it seemed a shame to diseard the suggestion offered in the ludian verse, and doubly wrong to put forth an Indian song that shonlel not at least reflect the Indian thought; but so mueh was implied and so 
little expressed! And that despairing reflection was the key to the problem. So much implied! I set myself to studying how much more might be implied than the search for a sweetheart, and it oecurred to me that if an Ojibway were on the liver he wonld neessarily be in his eanoe. Here was promise of singable results and of the rerbal repetition withont which no represcutation of the original conld be regarded as satisfaetory. It was with eonscions excitement that I hurried to my Indian friend and asked the question-would not the singing lover be in his canoe!

"Of' eonrse," said he, and then a ghost of a smile lit up his dark features; "but you don't find the word chemann there, do yon!" he asked.

Chemann means canoe. "No," I answered, "but it's understood, isn't it?"

"Yes," said he, "we understand it so," and he tumed away as if that settled it, or as if a contimumee of the conversation would learl him to inquire sarcastically if I supposed the lover wonlal he swimming the river all night, or balaneing on a perilous, unconfortable log?

It did settle it, and before I arrived back at my table I was humming the first of the stanzas with which the song has been identified since its publication-

In the still night, the long hours through,

I gride my bark eamoe,

My bark eanoe, my love, to you. 
While the star's shine and fialls the dew

I seek my tove in bark cinne.

In bark canoe I seek for you.

It is I, lowe your lover true,

Who glites the stream in hark eanne;

It glides to you, my love, to you.

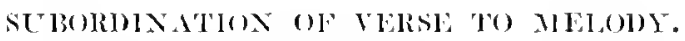

I was slow in coming to perception of what maty be called a general principle applicable to Indian rerse that accounts ar its compactness and for ecrtain negative characteristics. 'To summarize them: it is rague: it lacks forme, that is nothing is there that answers to rhyme, there is seldom a sugenestion even of corresponding or contrasting pharases, and it is only by good fortume, apparently, that it erer assumes a metrical aspeat. In other words, it is prose, for the most part. unembedlished by metaphor, or any other trick of the imagination with which civilized poets enhanee their expressions. This may aceasion some degree of astonishment in view of the fact that all we have read of Indian oratory gives us the impression that the Indian is flowery, indulging in metaphor to such an extent as to he ambigunus, that he farors the inagination at the expense of perspicuity, caring more for striking fignres of speech than for an unmistakable presentation of his inleas. This certanly was chatracteristic of the Ojibways. 'T'u refer to but one anthority, Alexander I Ienry, in his Tracels and Idicntures, 1760 , 1776 , more than once alludes to his diftieulty in following the 
speeches of chiefs, even after he had mastered their language, becanse of their excessive indulgence in flowery figures: and he says that it was a part of their education to learn to speak fignratively. How comes it, then, that imagery is conspicuous by its rarity in Indian rerse! I think we shall find that the answer lies in the subordination of rerse to melody, the Indian laring no conception of poetry apart from its association with nusic. In order to work ont this speculation, as well as to deduce the general principle referred to. I shall dip again into narration, and not unwillingly. although one of my stories conviets me of amusing error.

It was not long after I had begun my quest for melodies that I chanced upon 'Tetebahbundung drumming and singing for his little son, Adamosa, to dance. They were quite by themselves, indulging in the diversion for its own sake with no thought of spectators. The boy threw himself into the fantastic and diffieult morements of the dance with extravagant cuthusiasm, and the father applied himself to his part alnost as seriously an if the erent signalized an important decision by a comncil of chief's-almost, for he was not dmmming londly, and in his grave eres ghowed the light of parental satisfaction. 13y reason of his comparatively light drumming and the clearness of his voice, I lueard the furaint tume distinctly and it eanght my faney at once. I had no difficulty in notating it, for by then I laad beeome accustoned to the alternation of triple and double rhythm, and, moreover, 'Tetebahbundnug sang it over and over nutil the boy stopped dancing from shees exbanstion. My next consideration was for the words, and 
Tetebahbundung shwly dictated them. rllable by syllable: "Muije mulicsin awyarinon."

Three words, the most compact poen discovered up to that moment-I have since found one that is limited to one word. I doubt whether anybody could imagine the inten wity of my eagerness to leam what they meant. I was all excitement over the melody. my imagination even then leaping forward to the use I subsequently made of it in orchestral writing: and it was so indiridual. so perfectly rounded out. so impiriting. that I suppose I unconscionsly forecalst a significance in the words that should be worthy. to say the least. of the tune. It all events it was with something like a shock that I heard the Indim's answer to my incuiry as to the meaning.

"I use bad shoes." salid he.

I had no distrust of Tetehahbundung's intentions. but there was abundant reason to doubt the accuracy of his translations. for at that time he knew little English and his pronunciation was most impertect. So I found occasion to ask another Indian about the words. and from him receired identically the same answer. "I use bad shoes."

Therl, as in the case of "My Bark Canoe." I withlrew to the solitude of my own thoughts. What porsibly could be implied that was not expressed by these words! I asked myself. There was no f'ant shadow of poetic suggestion in them: they were simply tumy. and I came not unwillingly at last to that acceptation of the song. for the tune itself sparkled as with humor. So I undertook to reproduce the Indian humor in English. 'This was easy enough. for a grotesque. or even a 
commonplaee phrase subjected to ineessant itcration beeomes irresistibly laughable, and it was merely a question. therefore, of conveying the literal meaning of the sentence in words that would fit the rhythm.

Very well: the only use to which shoes eould be put was for wearing, and bad shoes, from my own eornful experienee, were those that pinched: but it was well nigh inconeeivable that an Indian should pineh his toes in rielding moccasins, and I readily eoneluded that from his point of view the only bad shoes would be those that were past repair, worn ont: and so a line adjusted itself quickly to the rhythm of the tune:

"Worn out shoes I am a-wearing."

I eommitted many absurdities that first summer among the Indians. anong them being the installation of a maehine that in a bygone age had been a pianoforte in my lodge. To it I took my new song, and in my confident enthusiasm I invited two or three whites and such Indians as were in eall to listen. 'The whites responded to the humor of the piece and I was vastly satisfied with myselt. Tetebahbundmeg was there and I asked him what he thought of it, but I am sure that my question was disingennons. Anybody, red or white, eould have seen that I expected commendation. 'Tetebahbundung politely gave it. Not a hint did he renture that I was in total error. II is mental attitude doubtless might have been expressed thus: "It pleases him, it pleases his friends; who am I that I should presume to instruet him in the use of his own language?"

At all erents no shadow of suspicion erossed my mind that I had not made a correct interpretation, and, as the song proved 
popular with all whites who eame my way. I samg it many times. eventually to a kindergartuer who begered al copy of it that she might teach it to her chidren. She tried it on. formd that the elibldren tackled to it eagerly, spoke to other kindereartners about it. and before very long I was in receipt of urecent requests from varions parts of the conntry to print the songe. I did so. and "Old shoes" speedily found its way to kimergartens and primary schools. and even to the concert platform. Meantime I contimued to sing it myelf whenerer I was in conpany with Indians entertaining white andiences and for a long time nobody anong my Ojibway friends said a word.

One day. nearly a vear after the publication of the song. Obetossoway confonted ne. II is the wittiest Indian among my acquaintances. quick to see and to make a joke. but portentously solemm or dignified when he has something of importance to say to one whom he regands as his superior. It that time I was his emplnyer. and I imagine that he must have nerved himself mightily to correct me.

"Sir." said he, in his most dignified manner, "You have got that song all wrong. It does not mean that I am wearing worn ont shoes at all, sir."

"Well," I responded, "I want to he set right if I have made a mistake. What does it mean?"

"It means "I use had shoes," sir."

'This was almost ammoring. Ohetossoway speaks English fluently, and, with bis bright mind, I thought he should have grasped my interpretation and not insist on bald literalness: but I was anxious to encourage just the kind of service he 
was trying to perform for me, and I went patiently into my argument.

"Worn ont shoes are bad shoes, are they not?" I asked, and he admitted that they were. "Well," I proceded. "in English we do not speak of using shoes, but of wearing them. Don't you understand?"

"I do, sir." saicl he.

"Then, if I an weiring worn ont shoes, I am using bad shoes. Isn't that so?"

"It is," Obetossoway admitted, adding firmly, "but, sir, the song means 'I use bad shoes.",

In weariness of spirit, I gave it up, silently abusing the Indian for an mususpeeted bloekhead, and I was so eertain of my interpretation that I was disturbed by no doubt about it.

The revelation of my error eame a few days after the conversation with Obetossoway. At that time the play "IIiawatha" was being performed daily in the open air. I had notated most of the songs that are introduced into the play but hat not paid attention to those that figure in the gambling scene for the very good reason that I never eould hear them. The drum is pounded incessantly while all the Indians danee except the few who are direetly eoneerned in the game. Now and again I could hear the singer's voice, but never sufficiently to catch a complete musical phrise, and the words were wholly inaulible. The faret that nusic cntered eren into the gambling of the Indians suggested that it must have speeial signifieanee there; and that was incentive enough for investigation. In 
order to get some notion of the song. or song's, I eonecaled myself among bushes close to the stage with music palper on the gromul before me. From this vantage I conkl hear every word and nearly every note. Imagine my hewiderment when the gambling hegan. to hear Tetebahbundung sing "Muije mulicsin axyazyon." But I am not altogether blind, or deal'. or stupid. In a monent the significance of the song flashed upon me, for I recalled what was visible from the riempoint of the andience. The Indians were playing what they call the "Moceasin Game." One player hides a small object. no matter what, under one of thee or more moceasins; his opponent tries to select the moceasin that conceals the object. That, in brief, is the whole game, and it is said to be the origin of that infamons swindling device known to whites as the shell game. But it is picturescue and dramatic as the Indians play it. The process of hiding is aceompanied by a variety of eonfusing gestures, and it takes a long time: and while the first player is lifting one moceasin after another. pretending to hide the object. distracting his opponent's attention in every possible way, the singer is industrionsly warbling "Muj.je mulicsin awyaryon."

Obetossowaly was right. Of course the song means "I use bad shocs:" it can't mean anything else. hut what is implied and not expressed might be put this way: "I am using bewitehed shoes: they will fool you: you re not smart enomgh to get aroumb these wieked shoes of mine." Worn-out shoes, indeed! $O$, the superior discerment of the paleface! I felt some chagrin as I lay there in the bushes with my needless music paper 
before me, hut presently yielded to the humor of the crent, and at the earliest possible moment after the performanee I somght ont Obetossoway and made anends for my obstinacy.

Before I left my place of conceahment, howerer, I had canght another song. It is a seguel to "Bad Shoes," as the first onght to be ealled. When the first gambler has hidden the object and sufficiently confused his adversary, he sits baek and it is the other's turn to play. Seldom is the adversary so confident of sucess that he indieates his choice of moceasins without delay. Ife first assures himself that there has been no cheating. It would be unfair, for example, if the first gambler should palm the object instead of slipping it under one of the moceasims. So the seeond gimbler demands that the first expose both his hands and also open his mouth to show that the object is not there. When he is satisfied that nothing has been done contrary to rule, the second gambler usually makes a feint of picking out the moceasin that he thinks eonceals the object. 'This he does by pretending to strike at it with his war chub, meantime watching his adversary's eyes warily for any involmtary sign of fear or confidence. This feint may be repeated sereral times, or for as long as the second gambler likes, and the game does not reach its final stage until he actually strikes a moccasin with his chab. That mocasin is then tumed orer, and if the objeet is found under it, the second gambler wins; otherwise he loses. The scruel to "Bad Shoes" applies to the play of the second gambler. While he is making up his mind the drummer is singing- 
Gayget wahbod nege wahlod ge.

"Indeed! I know where it is," whieh is to say, "yon can't fool me with your barl shoes; I can find the thing."

\section{A SONG OH MINTER.}

A brief examination of one more song will bring us to the prineiple underlying nearly all Ojibway verse to which allusion has been made. Farly in my association with these Indians 1 notated a song to the followiner words:

$\begin{array}{ccc}\text { Keshoygh } & \text { ishquandaym } & \text { baybogin } \\ \text { Warm } & \text { door } & \text { in winter }\end{array}$

Several Indians told me that it meant "My door is warm in winter time," which is literal but not illuminating. The poung fellows sang it with great gusto at all sorts of times and occasions, and not one of them seemed to comprehend the difiiculty I had in understanding them. I did get an impression that it was in some way a song of hospitality, but it was not until good fortune bronglst me in toneh with shingwank that I was enabled to look at it from the Intlian point of riew and grasp its full significamee. I referred nearly all these sorges to him after they bad been phonographed. When he had listened to this one, he said:

"When I was a boy I often heard my grandfather tell the story of that song and sing it. The story goes that an Indium 
hunter was overtaken by a furious snow storm that speedily obscured the trail and made all ordinary landmarks mreeognizable. Night fell soon afterwards and he knew that he was lost, but he kept wandering on, for it was so cold that if he had stood still he would have frozen to death. When morning came he was more bewildered than ever. The snow still fell and the wind hlew a gale. Ife was mml, with eold and faint. with hunger, for his stock of food was exhansted and he stumbled on no game. All that day the north wind blew and the snow piled in sueh deep drifts that he eould hardly struggale through them. When darkness eame again he was still flomdering along. almost minded to give it up. lie down and sleep the sleep of death, but in a lull of the tempest he heard the faint beating of a clrum a long way off. This gave him hope, but fear, too, for how conld lie know that it was not the drum of an enemy? Cantionsly he followed the direction of the somnd which grew louler and louler mitil at length he diseemed a wigwan from within which it eame. And then he distinguished the worls that the man within was singing-Ke $\mathbf{K}$ hoyah ishruandaym baybogin-they were Ojibway words, and he knew that he had come upon one who would be a friend. So he went directly to the wigwam, opened the door and entered. The man who lived there stired the fire, gave the visitor abundance of food and kept him until the storm abated.

"Near the end of the story." Shingwauk concluded, "my grandfather would pause and $\operatorname{sing}$ the song, though sometimes he did not sing until the story was finished." 


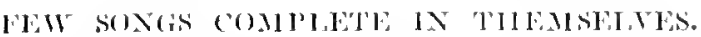

From these examples, and many otleers that need not be quoted, it appears that, with lew exceptions, no () jibway somen is complete in itself. For entire eompredension it depends upon something external, a story, or a ceremony. The moecasin game mily be elassed als a eeremony, for. in view of the regular procedure of the game, the somes that alre associated with it beene definitely signifieant. In the case of the warm door song. the story presents to the imagination al vivid pieture of Winter, the sufferings of the lost homiter serving to set forth the terrors and perils of the season whel the man within doors moeks trimmphantly in his three-word somg. The song, then. may he regarded as a monemonic smmary of several thomghts and impressions.

It is not in the mamner of evilization to eonneet its songs with explanatory stories, though our modern lecture-reeitils indieate that a erreater degree of appreciation of songs is gained therehy. Is it not rather impressive to reflect that the untutored o jilway had lecture-recitals econturies before le knew the white man! 'The enstom of preluding every somb with an explanation of the circumstances alluded to in the text is evidently as ancient as any lodian constom that survives to-rlay: a eustom, be it melerstond, that wats not invented for the benetit of incuisitive whites. Jut that was and is mantaned by the Indians for themselves.

But, aside firm elegance of dietion, and highly developed form, and some other superticial features perlatps, the essen- 
tial difference between Ojibway verse and the verse of civilization is just this: that our poetry is of aims to be self dependent; our songs are or should be complete in themselves; the Ojibways' are consciously incomplete statements of the situation, feeling, or events which find expression through them.

It must be obvions, therefore, that, in adapting these songs to the uses of civilization, the adaptor confronts a problem that is at once nice and complex. ITe must refleet the Indian thought, and a precisely literal translation would most effectively conceal, or at hest misrepresent it. In words that fall maturally in the Indiam scheme of accents he must convey not only an interpretation of the words actually employed. but a sufficiently complete statement of the explanatory story, or the attendant situation, to make the English song self dependent.

When I came to realize this principle, I saw at onee that many songs that hitherto had seemed impractieabie of translation, hecamse of the minalginative hrevity of their texts, might be turned to accomint if the stories were known. and I begin a fresh pursuit with stories in view. So, withont seeking to cxcouse the shorteomings of the rerse now linked to these melodies, let it be understond that, in all eases where not specifically stated otherwise, the contents of the verse have been suggesested by Indians' statements to me as to what is their melerstanding of the song. In the process by which the Ojibway verse makes its way to English there must nceessatily be taken on some color of the adaptor's individuality: and 
there is no end of liability to error. I should rejoice if other persons should interest themselves to the extent of turning the subject matter into verse more truly exprensive of Indian life and spirit: in fact. one thing only would please me mole and that would be the harmonization and derelopment of these melodies by other composers.

Following is my attempt to interpret the warm door song-

Freeze. re northern winds!

Blow. re finsty blasts!

Here within tis warm

While the Winter lists.

Whirl. ye driven snow.

Healp in smothering dritts!

Winter lese lies low

Nor his cold hand lifts.

In passing this part of the subject I will allude brietly to another peculiarity of Ojibway verse that has been al troublesome stmmbling-block to my work-the finet that many of the words in the songs are archaic. There is doult among the most intelligent londians themelves as to the meaning of some of the aneient songs. for the words have either passed wholly out of current use. or their meanings have evidently been modified with the lapse of years. 


\section{SENTIMIENT AND INCONGRUITIES.}

Next to the compactness of Ojibway verse the feature that most disconcerts the musical observer is the startling incongruity that is frequently manifested between the sentiment of the text and the character of the melody. 'There is at least one Indian, Tetehahbundung, who feels this. Ite came to me one day saying that he hat remembered a new song, adding at onee. "But it onght to be a love song and it isn't." Then he sang it, slowly, seriously, his rieh voiee dwelling lovingly upon the appealing phrases until the non-Ojibway listener must have felt that here was a song of human tenderness, the cry of a pure soul for affection, an expression, whatever be its detail, of the very refinement of love. The melody appealed to me instantly as the gen of the colleetion, and thongh I have found many beantiful songs since then, none, in my estimation, smpass it-but here are the words:

Me ne nahe gangnahge ne nahe liecriahshquanbe ah beding

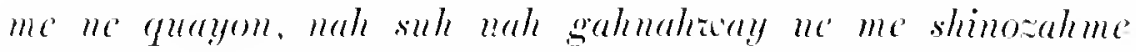
beyod goshu neen.

"I don't suppose I'll get drunk if' I take one dlink; if' I stoukl get drunk, take eare of me."

Comment seems mmecessary. Incongruity is the soul of humor, and a smile at this ill fitting combination is incritable. lut I confess that ny smile was one of regret. I tried to confort myself with the speculation that this was originally 
what the melody scemed to make it, al love somg, and that some roistering seoffer had parodied it: but eren if there were anything in the fanciful theory, it would not arail, for the Ojibways of to-day aceept the song as it stands, finding in it merely an expression of humor. I have heard it roared ly men and women, solo and in cholus, with no trace of the refined sentiment infused into it by Tetebahbundung, sare that it was always smog very slowly after the usual Ojibway manner: and on one occasion, at a campfire, a elever six-year-ohl boy aroused much enthusiasm among the Indians by singing it with alppropriate action. IIe staggered, hiceoughed from time to time, dwelt with extravagant emplasis on the word liecacahshquaybe-drumk-and at the end of the second repetition fell full length to the grouml.

\section{A FANTASTL GXPREATEXT.}

It may be noted that this is an exception among Ojibway somes in that it is conplete in itself. I condel not bring myself to profane the exquisite medoly by singing it to a translation of the Indian words. Tetebalhbundung laad said that it ought to be a love song, and I tried a fantastic experiment, the inevitable result of which I was too optimistic to foresece I smgegested the making of a new set of words. 'Tetebalshnmdung placidly agreed, and we had sereral solemn pow-wows over the matter. It length, with the assistanee of an exlucated Indian. Chief Charles Obetossoway, of Crand Manitonlin Island, brother of the (Obetussowaly to whom allusion has been mate, we evolved the following: 


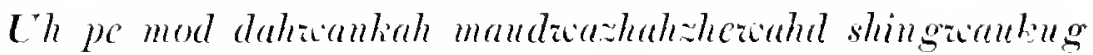
me suk uh ne nemoshayn ue dathatum.

"When I am in the forest I hear my sweetheart sighing through the pines."

Then the trouble began. The new words do not fit the tune, and although Ojibway syutax permits of all manner of inversions, and the songs abond in repetitions of words and phrases, the singer eould not make a satisfactory arrangement. Of course it was too much to expect that he would do so, and the song will remain a drinking song for as long as the Ojibways sing it: but ior the uses of civilization I have rentured to expand the new set of words and call it "In the Forest." nnder wbich title the song may be found in the collection.

\section{INTERSION OF SFATIMENT.}

Another instance of incongruity may be found in the song I call "Wanbunosals Longing," from the name of the man who first sang it to me. It is very popular among the Ojibways, and from their point of view it is a song of joy. 'The words, omitting meaningless syllables and repetitions, Konemashaynon dalguishid nesale acnahowquasans me sul ga!y galpedalgnishing, man, "My swcetheart has returned: I am glat because she has come back to me." 'To the ear of civilization the song does not appeal as joyful when given in the Indian's best manner; on the eontrary it seems ineffably moumful. At the last amalysis this is a matter of conventional asso- 
ciation. 'The melody in itself is neither sarl, nor gay, the listener's characterization of it depending upon its approximation to the manner in which he has been accustomed to hear one emotion or the other expressed through the tonal art. The Indian is accustomed to express his joy in musical terms that we are accustomed to employ for expression of sorrow: but that settles nothing. 'To him it is a joyous song, and no tinge of melancholy overeasts his feelings when he sings it. It is impossible to force conviderations of this kind upon a people who are just as much the slaves of tradition and convention as are the red men. No amount of philosophical arenment will make this melody appeal as joyous to the average white man. Therefore. believing it to be impossible for any white singer to make the song efrective with a translation of the Ojibway words, I have inverted the sentiment and arranged words that seem to aceord better with civilization's sense of fitness.

Hopelessly ineongruous are those love songs that give utterance only to carnal passion. The melodies are no less pure than the others, no less worthy to contribute to the delight of refined persons: and, riewerl plibosophically, there is nothing in the words to disturb equanimity. The Indian is frank where the white man is reserved; he does not mask mote desire moler vague euphemisms: he is primitive, and honest. and speaks according to his lights. It is only when we approach the words in a spirit of sentimentalism. which is a halsh war of stating the musician's ingenuous attitude.-for this musician, at all events, was eager to find good, and good only, in 
all phases of Ojibway life and ant-that we experience a certain pain that is not to be confounded with prudery. It amomints to this, and mo more than this: that it is regrettable to find so keen a pereeption of beanty in one phase of the Ojibway's joint art, for such his music-poetry is, and such erude insensibility to the tiner enotions in the other. There need be no pharisaical contempt for the Indian in reeognizing his defieieney in this regard. I et us bear humbly in mind that 110 inconceivable span of years separates us from the time when English rerse was open to the same criticism. There is nothing further to be said on this matter unless I need confess that I lo not feet myself bound hy any consideration for archacological exactness to translate verses that lie without the pale of civilization's tolerance.

last there be any shambew of misappredrension, I hasten to add that lewhess is by no means the prevaling characteristic of Ojibway love verse. (On the contrary a large proportion of the songs appear to me to have been inspired by what we term romantic lore, and my own contact with the people establishes beyond possibility of doubt the existence of romantic lowe anong them. From a diserect distance I have watched courtships that differed f'rom our own only as the minor details of Ojibway daily life are at valiance with ours: and I have seen many instances of marial derotion, on the part of men as well as women, that woukl serve as high molets for any people.

Retuming to the discussion of verse, I would not have it understood that incongruity is universal. We must never lose 
sight of the difference in point of riew, hut in this collection will be found not a few songs in which the points of view appear to eoincicle: that is. the Indians somg, so fiar as the sentiment behind the words is concerned, is equally expressive to us and to him. For eximple, it seems to me that "Winter" (tlee warm-door song) is abundantly expressive within its narrow limits of the boisterous seasm and the exultation of the man who hats a weather-tight dwelling and a fire in it. 'The two lulkabies speak well for mother lowe that, even among eivilized peoples, js ustally voleded to brief phratses and nutaningless syllables. In "I conely," where the English text is, I believe, a literal translation of the original. there seems to me to be perfect adjustment of sentiment to melody.

\section{LACK OF VARIETY.}

As might be expecterl there is no great rarjety of subject in Ojibway love verse. When it comes to the last analysis is there orer much rariety in the love verse of eivilization! Does it not generally take on an appearance of variety from the emviromment of the poet? Sot to make too much of this conparative observation, it is to be achnitted at once that the civilized poet attains variety by the manifestation of his indivicluality. With the Ojibway. als, l presume. with any prinitive people, individuality is not highly developed. content to sing his one line orer and orer. he also is entent in the making of a new song to paraphrase what has been sung before. IIe does not realize it. but I think that it is often the melody and not the words that individualizes his some for him. Spet- 
ulation aside, there are many Ojibway love songs that speak of loneliness; usually they purport to be the wail of a girl whose sweetheart has gone to war, or upon a long journey. A class apart might be made of those that tell of being on the way to meet one's sweetheart; and it appears that the Ojibway's sweetheart was forever losing herself in the forest, which made it necessary for him to tramp, or paddle the streams and lakes all night long to find her. According to the songs he usually found her, or gave up the search, at sumrise. I have tried to avoid reduplication of thought in the Euglish stanzas, sometimes giving to a melody words that were translated from another song of similar character. Where this occurs al special note is made of the fact.

COMPARATHE OBSLRVATIONS.

In Ojihway music the general lack of development, speaking technically for the moment, is the chief mark of its primitive character; and it is much the same in Ojibway verse. Often is the poetic impulse plainly manifest, and with equal plaimness the inalhility to work it out. The Ojibway is more gifted in music than in poctry; he has wrought ont a type of beantiful melody, much of it perf'ect in form; his verse, for the most part, has not emerged from the condition of raw material. The spirit of music, strugaling for expression through his primitive soul, finds its way to utterance in spite of the words with which he associates it. 'The Indian, like the avcrage paleface, is incapable of grasping the conception of nusic as a thing of absolute beauty. Does a melody sing 
in his head and insist upon rocal utterance, he must forthwith invent a series of words that fit the rhythmic scheme of the tume. for thus alone can he correlate his sense of pleasme in modulated someds with his habitual resured of other phenomena that appeal to him through the material senses as plain, eomprehensible facts. We might. Wy strenuons excerise of the inagination, conceive of an Indian voicing a meloly tentatively to meaningless syllables. and wondering as to the nature of that tomal entity that comes from-lie knows not where-that allures his soul. that eompels him to sing. Ile might wonder at it as a hermit who is risited ly angels in a rision. It might awaken awe, as if it were a message from another world. the very holiest of holy speech of Gitche Mimiton himself. 'Thrilling with the pure delight that musie alone of all the arts and things upon or above the earth can arouse, he might yet hesitate to link it to words lest he offend the maniton who sent it. lest he misinterpret the message so subtly and eonvineingly spoken to his heart: and thus boring in hmolity before the mysterious presenee mantested in new meledy. he might content himself and the visiting impulse with a worlless somg. leaving the meaning of it to be revealed at the maniton ss own pleasure.

'The fact probably is that no Intian erej went so fitr as this in speculation. Ilis process of composition, so fal as that process can be manifested. is identically such as I have suggested. Ile does sing his new melody to meaningless sylables, tentatively. correcting it leve and there. hut meantime experimenting with words that convey meaning: and the prob- 
ability is that the preeise sentiment of the words finally aeeepted is established by rhythmie considerations, those that fall readily into the scheme of aceents appealing to him as the most suitable veliele for the melody. And, aside from dependenee upon the scheme of aceents, the charaeter of the words that suggest themselves to him must depend upon his own charaeter, his mode of life, mamner of thought, the exigeney of his immediate situation, whatever that may be, and not upon the muborn tme.

I am quite aware that there is room for speenlation of a contrary sort on this point: that those who perceive a fixed relationship between sentiment. or emotion, and musieal beanty, may assert that the words actually chosen for the song are suggested psychologieally by the nature of the melody; and I im eontent that speeulation of this kind should be carried to the end of the thinker's pleasure, lout it will be well to keep the faets rigidly in riew. The last fact of all is that the Indian words, from the riewpoint of the civilized observer, are often at radieal variance with what would be the civilized conception of appropriateness to the melody. Let us think of this with patience and tandor. for we are here considering the very begimings of musie: we gain here a glimpse, shadowy, but a glimpse, of its real relation to the human mind. The musieal expression eomes; the red man vojees it; the form is melodie, and in all musie that, at last analysis, is the potent, distinguishing factor; he must give it a name, place it sonehow in a category that rekates it to other things familiar and eompreliensible. IIence, words; hence, from his point of riew, 
a meaning: henee, from his point of view, the daraneter of the composition. The words enreys it may he idcals of repulsive

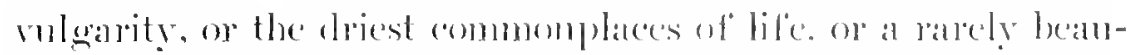
tiful aspiration; it does mot matter: the medoly is there, beantifoul appealing to us as abstract heanty when we hear it linked to worls that fortunately we do not molerstand. Does mot this primitive methoul aml its results sugegest- if ant demonstrate- that musice is mot only almore and beyomel all language, lut that it is alart liom any definite emotion! ()hserve: the melodieally gifted () jibway gives it forth and in his moreflecting way identifies it with joy: the paleface. listening but not

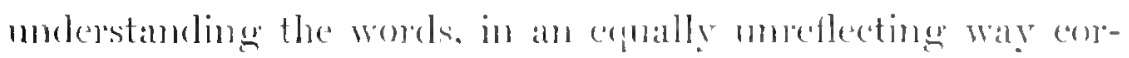
relates it with something leard lectore and identifies it with sorrow. IJow much truce and more apprectiative of musical beanty it woukl be if all of ns conld regated the eompositionsimple Indian melody of complex smatat-als what it is: an appeal through tone to the rery fommations of being, to that heart of the senses of which joy sorgow. fear, loye, hate, and the rest, alle but ramifying manifestations!

But the ingemons Indian does mothing in this regard that the pallefice comproser does not do. The lndian gives his piece a name. he undertakes to interpret its messagge to his fedlows, and with him it is a simple matter. for instrumental music is outside his experience. In the musice of civilization, discarding for the moment all the songs and hymus. do we not find pieces named noctmme, pastoral, tragerice, joyous, melamcholy this, that and the other! And when the composer sensibly refrans from attempting to linit the meaming of his 
message, there are commentators quiek to discover moonlight in a Beethoren sonata, a ghastly tale of physical suffering in a Chopin prelude, and, as if this sort of thing were not enough, we have to-day a moisy prophet who presumes to dishonor the spirit of musie by giving us a day out of his own ineonsequential life in the form of a "Domestie Srmphony!" The Indian ean be forgiven the incongruities in his art, for he knows no better. 


\section{CHAP'TER IX}

\section{INDIAN SONGS IN TIHEIR REIATION 'TO AR'T}

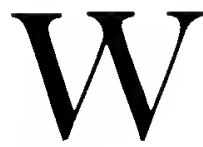

IIIEx we come to disenss the relation of Indian songs to art. we find that there are two distinct purposes which they may serve if. on carcful examination, they seem fit for any purpose whatever. 'They may be used, first, as are the songs of civilization, for entertainment and the gratification of musieal taste; and, second, they may furnish thematic material for (a) extended compositions, either instrumental or voeal, and (b) incidental color in works that otherwise are original and conventional.

\section{HARMONIZATION OF INDIAN MLSIC.}

If the songs are to serve the first purpose, they must be hamonized. 'To me, this has always heen self evident, and it is so obvions that I have hesitated to take space here to defend the practice: but I have been astonished on several occasions by protests agaiust it, as if the hamonization of an fudian song were some sort of saerilege, and inasmuch as there are some persons who do not approve deeking out Indian melodies with the derices of civilization, it seems wise to wo into the matter briefly. As I understand the objection, hamony does violenee to the Indian coneeption of musie: it was not, and could not be conceived by the Indian, and his musical output is, therefore, misrepresented when his songs are sung to piano- 
forte accompaniment, or in harmonic parts; and that harmony destroys the charming simplicity of the original, so that. "My Bark Canoe," for example, ceases to be Indian when it has a harmonic aceompaniment.

I have considerable sentimental sympathy with these objections. I would rather, myself, hear an Ojibway sing "Ny Bark Canoe," in his simple way than hear it with pianoforte accompaniment; but that is because I would rather walk in the sombre forests, or guide a canoe along the wilderness waterways, than dwell in a city flat; and the circumstances of civilization having compelled me to dwell in a flat far remored from primeral forest and flashing lake. I find in the hamony adeled to the meloly a factor for spiritual comfort that vies in sweetness with uncontaminated Sature herself. Not that the hammonies recall the forest and the lakes; not that they suggest the atmosphere of the song"s origin, for music does nothing of that lind: it is that the melorly, when sung under the conditions of civilization, demands the rounding out of its nature which is effected by harmony.

We are a harmonic people, we whites. We are born with appreciation of harmony, we are brought up in it, and, consciously or unconseionsly, we always associate halmony with the tunes we hear, whistle. or hum. We do not sing unadorned tunes for one another's udification or entertainment: in all my concert-groing, I reall but one instance where a singer sang without accompaniment, and he was a tenor of umusually appealing voice who was responding to an encore. In our haphazard social gathering's we sometimes resort to musie when 
there is no instrument at command, but that is because we have to, not becaluse we prefer to. The rery idlers of the strects, the jovial gronps in a popular cxconsion, aye, the fimily circle where refinement dwells, never resort to song but that one or more of the singers attempts to piece out the tune with an alto, or tenor. or hass part. 'The plain fact is that we whites cammot grasp the whole beanty of a melody muless we lear it with appropriate hamony. 'Therefore, if the heauty of Indian song is to be set forth to civilization, harmony must be employed in order to de justice to the Indian composer.

'This is to take the ibljections rather too scriously. I fear. The simple truth is that I harmonized the Ojibway songs I first hoard because I wanted to, which was quite enongh for me, and that, if I had not done so, they would not have been leard at all outside the forest and the reservations. Therein lies the real, and whole, and massailable justification for the employment of hamony. 'To hold to a fixed example, if " My Bark Cimoe" had been retained in its original form, it might lave been heard in the cities of eivilization by a few who would have had the patience and politeness to listen to me when I sang it in the comse of a lecture. 'That would have been the limit of white-man acepuantance with it. In its valrous!y hanmonized forms it has been sung by I dare not estimate how many thousand. It is nsed in many public schools: it hals figured on many concert progerammes; it hals been and still is in frequent use als a feature of lome contertalimment. In these lammonized forms it has chone no injustiec to the Indian; rather has it exalted him, for it never fials to camse 
unbounded surprise that an Indian eonld have composed a melody so beautiful. Thus has it scrved well its first purpose in art, and ineidentally it has been instrumental in awakening a sane human interest in the Indian, and in ineiting singers and hearers of the melody to the acquisition of some measure of twuth about him to replace the ignoranee and nisinformation that fester in the arerage white man's mind with regard to him. I believe that this little song has done more than all my writing and talking to apprise the whites of the eommon humanity of the red man, for the melody is obvionsly the ereation of a human being, and, presumalhy, of one with a considerable gift of fine feeling. As on ordinary estimate of the Indian is that he is a dull, if dignified, savage, such influence as the song has exerted towarl a juster estimate is for the good; and so much, or so little good, whatever it may be, could not have been accomplished if the melody had been left to the oceasional inspection of scientists and sentimentalists in its primitive form.

\section{NATIONALISMI IN AUSIC.}

I have suggested that Indian songs cannot be held to have any relation to art muless, on cxamination, they seem fit for it. That I regard Ojibway songs as suitable for art purposes needs no other demonstration than the fact that I have given myself the pleasure of hamonizing a considerable number. It would not have been a pleasure, and I would not lave taken the tronble to put them in civilized dress, if they had not appealed to me as beantiful. It generally follows that songs 
fit to be sung by persons of diseriminating taste are also fit for the second ant purpose named in the foregroing, i. e.. als the basis (a), or color (b), of extended comprositions. Consideration of this platse of the matter necessarily lrings up the question of nationalism in music, abont which musicians are not in agreement. There are composers whose patriotism is not to be chestioned who are opposed to any and every movement that tends to foster the infusion of onr musical output with a distinctive character. They maintain that musie is broader than the bommlaries of a nation; that, in its highest development, it shoukl and does speak to all peoples alike; that the deliberate selection of thematic material in folksongs of any type imposes limitations om the creative sporit of the composer and restricts that full and free expression of the individual which is the crowning glory of all creative work.

$1 \mathrm{am}$ far from heing inclined to controvert this riew, for I an in deep sympathy with it, hut it has other aspects than those indicated above, and to them I wish to imvite attention. No American musician can visit Europe without suffering mortification at the estimate of our music that is held there. In a German magazine leroted to musie 1 fomd, in a number published abont seventy years ago, the tunc "Yankee I) ondle" muke the descriptive healing, "Nordamerikanische Volkshed" (Nortl American Folksong). 'There was a characteristically labored translation of the words into German, and a harmonized accompaniment, if you please, supplied by a man whose fortume it was to bear the name $r$. Schulert. I hastcn to add that the great Franz Schubert died several years before the 
publication of the tune. 'The eruditc enlitor appended a footuote to the nusic, the purport of which was that the song was represcntative of musical taste in America. Perhaps he was right, and perhaps he would admit, if he were now alive, that we have made some progress since then, although I fear he wonld hesitate to do so in riew of the prevailing eontempoJary estimate of our musie. A recent German critic has discovered that Americal is national expression in music is found in the marches and two-steps of John Philip Sousa. and our enormous ontput of" so-called "rag-time" songs. Germans generally appear to agree with him, and Sousa's compositions, and many of the musieally vulgar songs ground out by writers for valubeville, appear on Gemman eonectit programmes as Ameriean numsie.

In the interest of a broad riew of the matter it should be noted that in the higher musical circles of Germany respectful attention is accorded to the works of Paine. Macdowell, Kelley, Bird, IIalley, and other American eomposers, but the fiact should also be reeognized that these men bave spoken frankly in the Emopean idliom. With no sharlow of disparagement of their achicrements intended, it must be borne in mind in this dieussion that they stand for the theory of world music as opposed to national, for the highest and completest expression of the individual as against a conscious effort to voiee the feeling of their people. World music to-day is European music, and those of our serions composers who have been well reecived abroad have suceceded because their works approximated so well to the European eonception of what music ought to be. 
The question properly arises, is the world music of the future always to be European! In the days of the disenssion that followed the profluetion of Drorak's "New Worlel" symphony I eame to this melerstanding of ny own view: I longed for an ontput of music that shonld somelow be distinctively Ameriean: but I was eonvincel that such a music in onr fintme would arise from the writings of an over-towering genens in whose eertain coming my Americanism male me tirmly believe. I still bedieve it. I must believe that the remarkable bend of many peoples that more and more is evolving the typical American will one day be distinguished by a composer who will speak to all the world through a broader. better music than erer hats or will be made elsewhere: lnt, whether or not we believe in the conning of the over-towering genius, shoulel we not try meanwhile to inpress our European eritics with a conviction that the native spirit of our eomitry is expressible through a better medium than Sousa marehes and "ral a time" songs?

I think there cam be no serious argument against this rery general proposition. It certainly will not do to assert that Americal is sufficient unto itself. and that we onght not to coneern ourselves with what Europe thinks of' us. 'This attiturle would do very well if we diel not eontinue to write on European models and ape European ideas. As soon als we have really broken away from tradition. dome something original and established a manner of our own. it will be time to cry indifference to European opinion. Argmment aside, and taking it for granted that every Anerican musieian would like 
to see the musieal output of his country take high rank in the world at large, let me urge upon young composers a view that combines self interest and broad patriotism. I limit my appeal to the yomng hecause their modes of expression have not become fixed, and hecause I recognize that it is hopeless to expect response from composers who have seen as many years, sar, as I have. There is a number of such in this eountry who are writing beantiful music, and I hope every one will continue to do so to the end of a long life, but I have no hope that any of them could be induced to renture from lis well beaten and charming path.

It is a proper wish on the part of every emposer that his works might come to performance meder dignified anspices. To that end the American composer toils faithfinly and generally withont snceess. If we were discussing an indiridual instance it would be hecoming and necessary to examine his work and seek scientific reasons for his failure. and we might, of course, find that his actual accomplislments were far below his ww estimates of them. Looking at the situation broadly, however. we can see one significant fact in which may lie a host of reasons for the rare appearance of American compositions on our concert programmes. Our conductors are, with rery few exceptions. imported. Let them come, as I think they do, with the very frendliest attitude toward American music and its makers, they neverthetess come also with their heads filled to orerflowing with the latest and, to their apprehension, the best that Europe has produced: and, therefore, they import a great quantity of European music which 
must be crowded into their programmes. It needs no saying that they are fixed in their admiration for European models. and that. insensibly perhaps. every manuscript offered to them is measured by European standards.

IIaring come thus far in the argument. the conclusion appears to be so obrions that expression of it may seem unnecessary: therefore permit me to interject a disclinimer. I an not about to take the gromel that music should be brought to performanee merely becaue it is American in origin. I have no patience whaterer with that attitude. Solomg as we persist in writing according to European models and seek the imprimatur of European. or European-bred conductors. we must be content to be measured according to Furopean standards. The composer who cammot satidy the critical taste of his time as manifested by the conductors. must be content with the joy of creative work and with oblivion as its aftermath. No. I do not raise the spoiled-child ery but I do maintain that the study of musical theory in America to-dar is so conducted as to give the rising generation of composers. say those who are still in the universities and conservatories, abundant skill in the manipulattion of the meams at music to enable them to write acceptably for the contemporary concert plattorm. I believe the taihne of American composers to make themselves telt to an appreciable degree is due not to the lack of attaimments but to imhaply selection of material. That material is wollally, it not always of their own insention. and rery deal to them. and by so much. apparently, they are the more condemmed: but it cones back to the fact that. writing with European music as 
their molel, with Enropean recognition als, conscionsty or unconscionsly, their ultimate goal, they fail at present to rise higher than the contemporary and recently dearl geninses of trans-Atlantic origin. Americans who enter this race will smely continue to be ont-distaneed until they manage to write something that is distinctive, something that is notably different from the European ontput.

Here, then, comes the snggestion that, in a preceding paragraph, I called an appeal. As a patriotic American, I would still call it an appeal, helieving that one end subserved would be the raising of the European estimate of our musical aldrancement. Merely as a musician of many dreams and some experience, let me call it a suggestion. Our alien conductors, with all their fixed ideas, are, in this period, singularly open to novelties. to imnovations in the art. They hold skilful manipulation of the material as a sine qua non of performance. but they have no prejulice for or a gainst any sort of thematic material. If prejuclice exists, it must be in faror of the fantastic, the outlandish. to judge from some of the up-to-date monstrosities in the way of symphonie rorks that they display to us. Now, granting that our young men have aecpuired skill in manipulation, which means intelligent thematic derelopment as well as orchestration of a high order, it seems to me the young conposer would have infinitely more chance of coming forward if he wonld hase his work on such clistinctive material as is to be found in the Ojibway songs than he ever will by conrageously adhering to themes of his own invention. It would be silly to prophesy that all or any manuscript thus based would be ac- 
cepted by the conductor of the Boston Symphony orechestra. for example. but 1 am sure that such mamscripts wouk be approached by the distinguished reader with a considerable degree of sympathy, with a desire to find them good and well done.

\section{FLEXIBILITY OF INDIAN THEMES.}

The foregoing is confessedly an appeal to individual selfishness, with patriotism as a secondary thought. I cet me turn now to another view of the general subject and urge patrotism as the prime impulse to a conscionsly directed poliey. As I am pleading for a use of Indian songs as thematic material, I must do what I can to prove that they are susceptible of such use. Actual examples to which the stuclent might be referred are rare. If they were abmulant I shomld feed that there was no rery good reason for writing this hook. The field is but just opened, and few have get rentured to cultivate it.

In riew of the rather rigid formula upon which a vast number of Indian songs appear to have been composed. by which they seem so like each other to our ears. it might naturally be supposed that they would not yield readily to development, and that they would therefore hinder the composer. But it shomld be taken into aceomt that no sane musician, much as he might admire Indian songs, would advocate huldling up an art that should prove to be but a refiuement of, or elaboration of the primitive stock. The composer who has once accepted a theme. be it a mere motive of one or two measures, or an entire tume, makes it his own and does with it thereafter whit he pleases. 
He is not concerned with what the original composer of the theme would have done in the way of developing it; he is not restricted in his extension of the material by the thought that the Indian would not have done thus or so; it is no part of his business to erect an art fabric that might be called Indian. He is concerned solely with the making of good music according to his lights; it is his business to construct a work that shall accord with his own conception of symmetry, that shall glow with color, sparkle with melody, and move to such conclusion as the inherent nature of the theme demands. In other words, having selected his thematic material, it is his right, if not his duty, to forget its origin and proceed according to the purely musical demands of the subject, guided only by his own highly developed sensibilities, and regardless of the circumstances, be they romantic. tragic, religions, or whatever, that attcnded the material in its primitive state.

The only question, then, is whether Indian songs are endowed with such extreme flexibility as is essential to their highest clevelopment as musical subjects.

So far as we can judge from the "Indian Suite," Mr. Macdowell encountered no serious difficulties in that regard. A criticism of the work which I have often heard runs to the effect that the music is not Indian at all; that the composer may have chosen Indian materiai to start with, but that he quickly descrted it for matter of his own making. Good! Why not? Analytical inspection will show that the matter of his own making was derived from or suggested by the original material. 
Therein lies the trimmph of the material, that, crude. imperfect though it may have been, through it, nevertheless, the composer succeeded in expressing his own individuality.

It may well be that Mr. Macdowell was not satisfied with his experiment. 'The raw material available to him was far from being as suggestive and interesting as much that has been meovered since. IIe had not made personal excursions to the Indian eountry to hear the songs and absorb the inspiring atmosphere attendant upon them there. If is was purely an acalemic view of the material, and his use of it was necessarily objective in character. 'The main consideration is, however, that such material as he had was made to serve his purposes in a varied and brilliant composition.

A work that adheres more closely to its thematie subjeet is Mr. Arthur Farwell's "Dawn," a romantic eomposition hased upon what has always seened to me the hest song in Miss Fleteher's Omaha collection. This has been published in pianoforte arrangement and is, therefore, avalable to sturdents. They will find it not only a lighly developed but a remarkably attractive eomposition. I may add that, before Mr. Farwell's work was pulbished, I had experimented with the same material, turning it into rather a long song for tenor voice with acconpanment for flute and pianoforte. It has not been published, and I mention it merely to show that two men working at the same material have found it sufficiently flexible for their resspective purposes.

Both Mr. Farwell and Mr. IIarvey Worthington Loomis have made several transcriptions of Indian songs for piano- 
forte, that have been published and are decidedly worth examination although they do not throw direet light on the immediate question--the suseeptibility of the material to thematic development. Passing montion must be made of them, not only to complete the record as to our primitive music. but for this signiticant reason, also: they chose for their pianoforte pieces songs that had so little appeal for me that I had discarded them as of no artistic value. I was mistaken. These gentlemen saw better than I clid. Theirs was the acadenic view, as was minc at the time $I$ cast the melodies aside. for I I had not then heard Ojibways sing, and had had no association with Indians. This circumstance I regard as extremcly suggestive and important. The harmonies of Messrs. Farwell and Loomis have revealed the medodies to me so clearly that I wonder now how they failed to interest me at first. The presumption is, therefore, that the entire primitive ontput is worth studying, and that composers will find in it somewhere a wealth of suggestion that will pay them well to discover.

I think the only other experiments in the extension of Indian themes have been my own. 'The "Dance of Paupukkeewis," previonsly mentioned, was witten years before I had beeme an enthusiast in our prinitive music. For the limited purpose it was designed to serve, the Indian theme was deeidedly useful, and development was spontancons. When the Indian play, "I Iiawatha," was hronght to the eities, in 190:3, I was put to the hurried neeessity of writing considerable incidental masic for it. 'The several pieces included an introduction, or overture, with a long, declamatory song for bass voice, a funeral 
mareh, a set of variations (on the song, "Old shoes"), interludes, and so forth, and a finale for solo voice, choms and orehestra. All of these were developed from Ojibway songs. None of the orehestral picees have been reduced to a comprehensible planoforte version, and they are, of conrse, mumblished, but a somewhat eompressed version of the finale is printed elsewhere in this book. I do not refer to it as a model, and if the other pieces were published I should hesitate to refer to them. Mention is mate of them in order that one conposer, at least, may give the tribute of lis evidence to the inspiring quality of the material. It proverl, so far as I was concerned, that the Ojibway songs developed themselves, and that the result was as eoherent and spontaneous as any thing of mine could be. I must believe, therefore, that other eomposers would have similar experience with such material.

\section{A CALL FOR SACRIFICL.}

Diseussion of the flexibility of Indian themes seemed to me a necessary preliminary to the appeal to patriotism. I an still addressing myself to young emmposers. 1 know their moods, their exaltation in ereative work, their exuberance, their dreams, and I think no one ean know better than I their firm belief in individuality, and their fondness for matter of their own making. The strains that sing spontaneonsly in their minds and find their way to paper are divinely beatutiful. 'They are the very voice of the Infinite speaking through a special messenger. I know, for I have been that messenger. I have eovered many pages of ruled paper witl notes that represented 
such a stirring of the blood, such aspirations, such supreme conficlence in the future, such worshipful awe, as the non-musical mortal wots not of. I know what rebellion storms in the soul when the professor condemns a melody, or luns his devastating pencil through a harmonic progression. (For "professor" in the outside world, read critics, conductors and publie.) How often have I glumly assented to the professor's changes in my manuscript in the classroom, only to restore the composition to its original form in the privacy of my chamber! My hearen-dirceted way was right; it could not be wong. because that was the way the music spontaneously came; the professor's way was pedantic, rigidly correct, with no regard for sentiment. I remember very well my early contempt for that process of composition which deliberately sought folksong as thematic material. When I could not inrent my own themes, I would not write. I was not so far removed from my storm and stress period when the suggestion was first made to me that my musie might be joined to that of the Indians in their play. I was offended!

The purpose of this heart-to-heart talk must be obvious. I want those to whom it is addressed to realize that $I$ am in hearty sympathy with them, and that I am conscious that my appcal for the employment of Indian themes is a call for a certain degrce of sacrifice on their part. In the same spirit in which I harked back to my storm and stress period, I urge consideration of the fact that a relatively small proportion of a composer's output is as divinely beautiful as it seems to be at the time of its creation. It was all worth doing, if for no more 
than the compensation of the glorions moments when it took shape; it was worth doing in the light of cold, after-years judgment in that it strengthened the creative faculty by exercise. 'The time comes when the composer recognizes that self criticism is quite as essential to artistic success as fertility of inrention, and he perceives that there is no exercise of eomposition better adapted to the cultivation of self criticism than the development of non-original themes. There truly is the artist at work, undertaking to get the best ont of a given material; and he finds, after some initial sense of restraint perhaps, that his individuality can manifest itself in the shaping of work from given material quite as well as in the development of original themes. In behalf, then, of the desire to give our music a distinctive color, if not style, I nrge that the composer sacrifice the demands of individuality for self expression and derote attention to native material of which the specimens in this book are but a minute fraction.

Here is proposed a definite policy to which gifts and attaimments may properly be directed. It might be adopted from a sane desire to see for one's self what worth there may be in music sprung from our soil, and it certainly should be inspired by patriotic eagerness that our country should prove to be not behind others in melodic resonrces, but as richly endowed as any land that ever had bomdaries. 'Thus I believe it to be, for, knowing that the field I have covered personally is a very small fraction of the whole, I am sure that similar investigation among other peoples than the Ojibway would be rewarded by an abundance of suggestive melody if not of pure 
song. The Ojibway field itself' has been but scratehed. Work therein remains to be done by somebody that wonkl surely uncovel not less than fire times the puantity of material that I have gathered. It may be that this work will continue to be neglected, but. even so. there is already in the musenms a great quantity of material on phonographic records. amb this will graduatly be reduced to notes. I am sure the time will come, after living Indians no longer remember their songs, when white men will turn to the phonographic records to learn what was the nature of the red men's music. and that they will certainly then regret that such a rast proportion of it should have been allowed to lapse into oblivion. And when that time comes be sure that the composers of the day will talie accomt of such native stock as is arailable. It behoores the present generation of composers. and the next that is to follow, to give attention to this matter without delay.

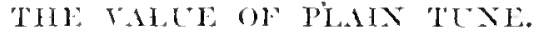

There is one final view of the subject that requires brief presentation. The art of music. speaking generally, bas been lorought to al condition of antificiality that is positively unwholesome. There is need for more direct utterance, which means that pure melory. or, as I prefer to call it. plain tune. shomld be adranced to a higher plane than it now oceupies in composition. Our masters have built a huge and wonderful fabric which called for gigantic skill in the manipulation of the material. 'The result is impressive for its workmanship: it amazes. startles, bewilders, and sends us homeward wondering what it 
is that we have heard. We carry awa little but an implession of overwhelming complexity. 'The intellect admires. but there is seldom a single shred of tunte to take hold of the at'fections. 'The sincere student of eomporition is in leal danuer' from the high derelopment of tednical ability that is manitert in contemporaneous works. I I teets that he must pertect himself in workmanship. and he know or ought to know. that it is the endless study of a litetime. In the triving tor technical finish he is apt to overhok the fact that what maker music vital is melody: and it he he not careful he will come to de-pine. or distrust the plain speede of tune as something trivial. fit only for the multitude.

The time is ripe for a change that might be regarderl als at reversion to an older style. The best critics roice the demind incessantly in their comments on enntemporineous programmes. It appears that our present day master either dare not. or cannot write a plain tune into their works. They appear to feel the necessity of proving their erudition by works of hewildering complexity in which the real. spontanteon musical thought. if there be any, is dettly encealed. This is remarkable in riew of the finct that the nost highly esteented concert work of our time is an example of the older style. Apparently the significint lesson it teacher hars not been so much als apprelended by the present generation. I allule to 1)rorak's "New World" symphony. Therein is manitented superh workmanslip: the themes are dereloped according to nethoh long extahlished: no conceited inmorter speaks there: within the limits of classical form the eomponer fomm the broulest room 
for the expression of his individual genius: and he based his entire work, every movement, upon simple, spontaneous tunes, deriving abundance of suggestion from them, and never finding that the plain melodies restricted the flow of his fancy.

I am glad that but one native American theme appears in the work. A master hand touched it and it became transfigured. So it would be with the songs of the Ojibways, for there is not one tune in the "New World" symphony that is more beautiful than are many that were created by my fellowtribesmen. 'They await the transfiguring touch of a native American, one who knows his country through acquaintance with its broad plains and lofty mountains; who loves the silent rivers of its forests, and exults in the roar of its waterfalls; who has somewhat more than magazine knowledge of the conquering pioneer and the subjugated red man.

By all means let us have workmanship, let there be no end of striving for the best that can be accomplished through it : but let us be very sure that the material to which the workman lays his hand is worthy.

It is a proper objection that music of permanent value carnot well be constructed on material that does not appeal to either composer or public. I am sometimes told that the Ojibway songs seem strange. A Boston critic once wrote of them as having "exotic" interest. Their strangeness is no discredit to their beauty. It is another way of saying that they are distinctive. It is a common experience to approach something exotic with timidity and eventually hug it to the bosom as a fond possession. Time is admittedly necessary in this matter, and a 
begimning has hardly been matle. 'The point for immediate consideration is this: leere is good music; shoukd we not. by putting it forward in one form and another, give the public opportunity to learn what it is, and to like it?

When all is said, it will remain for every composer to select his material aecording to his own predilections and taste. I (to not overlook the fact that Indian songs are not the only native material available. There are American critics who have taken the "rag-time" songs into serious account as an expression of the popular fancy. My opinion is that the popularity of such music is transient, merely; it is the whin of the moment and will give way presently to something else. Meantime I can no more regard the employment of "rag-time," which is nothing but a mannerism, as expressive of our national spirit than I could assert that John Sebastian Bach's employment of syncopation, which is the technical term for rag-time, was a forecast of the grand cosmopolitanism of my people. $1 \mathrm{am}$ mueh more in sympathy with those who would look to the plantation songs for distinetive color, still more with those who would approxinnate as closely as possible to the beginnings of an American folksong made for us by Stephen C. Foster. I do not feel that it is incumbent on me to diseuss these other sources of melody, my province being that of the music that is truly and wholly indigenous to our soil; and, in bringing this part of the book to a close, I am glad to add to the record of achierements in our primitive music the fact that Mr. Carlos Troyer has published several stirring songs, the material for which he found in the musie of the Zunis. 'These are the 
perple, it will be remembered, whose musical allancement is so slight that their seale's alle regarded as in the process of forming. and whose intervals are apparently alliatonice It is all the more signifieant, therefore, that an aecomplished musician has found in the material the inspiration for gool, thoroughly chatracteristic nusic aldapted to the uses of civilization. Another composer who has experimented suceessfully with Indian melodies is Mr. Charles Wakefield cadman, of Pittshurg, and 1 an more than delighted to record that he has muckertaken to go personally into the ficld for the purpose of gathering material at first hand. 'This is what I wish eould be done by all who take interest in the subject. Aearlenic consideration of the material is good. but far better is study of it in its place of origins. 'There insensibly the composer must find himself more closely attuned to Natmre. To flee from the artificialities of eivilized life, and dwell for a time among the simple people of the forests and plains, is wholesome in itself and must inevitably react happily on the emposcres ontput.

\section{CONCITSION.}

The foregoing pages contain some faets and a good many opinions. Facts are the main thing, and what may be regarted as the report propere of my rescarch in the ficld will be fomd in the palges that follow. Diseussion of seales, rhythm, verse, and so forth, secuned to me necessary to a thorough molerstanding of the somgs themselves. Let the opinions go; the salient fact remaniss that there is on this contincent a wonderful fund of primitive music that is rapilly clisappearing with the Indians' ad- 
vanee toward civilization. It is a fact that this music deserves preservation. It is a talet that it needs, and some daly such of it as has been preserved will have, comprehensive study on the part of" a competent musician, or musicians. It is al firet that this aneneration bick fair to be as remiss in the matter as were the generations that preceded it. There ought to be orsanized effort for the preservation and unclerstanding of this musie if for no other purpose tham to make of it an enduring momument to a rallishing race. So tall as the song's that follow are encerned. the fact that they were gathered for the most part in Canada is a point of no vital importance. 'This continent was the Indians before the palefaces came to it, the Ojibwals live on both sickes of the arbitrary line that separates the two conntries, and whaterer the Imeriean Indian has to offer is on spoil of concunest quite als much als it is Canadia's. If Camalian composers shoukl garasp the opportunity to base their art on aboriginal somgs fomol within their boukers, and thus erolve a music that should speak distinctively for their country, so much the better for them and so much the worse for us.

With this contribution to the subject I must regald my own work as finisherd. It has been eonducted in a spirit of lowe and enthusiasm, and I leave it with decp regret. It is work that rerpuires either the possession of independent means, or arganized support, and I have hard neither. IIopetinl that in the not distant future some persun or persons may undertalie to continne my especial work anmong the () jibways. I leaphy plectge myselt to aid by adrice drawn fiom experience, hy introdnetions to Indians, missionaries and school teachers, and by any other means that lic in my power. 


\section{CHAP'TER X}

\section{OJIBIVAY SONGS AND 'THEIR S'TORIES}

$I^{\prime}$ Thas been shown that thorough understanding of an Ojibway song depends upon knowledge of the story, ceremony, or speeial ciremmstance with which it is assoeiated in the Indian's mind. For this reason it seems to me that it will be most helpful to the student to present the melodies I have collected in eomeetion with their stories, rather than compress them into a few pages of printed musie. All the melodies, therefore, will be found in this chapter, and such as I have seen fit to harmonize may be seen also in their civilized garb in the seeond part of the book.

For various reasons it has not been possible in every instance to give the Ojibway words. Indian singers are as careless in the matter of enmeiation as are whites. It was seldom that I could eatch all the words of a song even after several repetitions, and when I asked that they be dictated to me slowly I found that I was setting the Indian a very diffienlt task. In his dietation he would sometimes omit words that I had plainly heard him sing, and as frecuently insert words that were not in the song as sung. Ilis spoken works, too, were often in an order that differed from those that were sung. and I eamnot recall one oceasion where an lndian in his dictation remembered to repeat words or phrases in the exact order, or as many times 
as the repetitions oceurred in the song. It might be thought, and I did think, that the phonograph woukl settle all doubt as to the words, but I found that that remarkable machine gives baek the singer's enmeiation rather less distinctly than the original, and on some of the eylinders the impressions are so faint that it is with diffieulty that the melody itself can be distinguished. In every instance the songs in this colleetion have been referred to at least one Indian besides the singer for a statement as to the words and their meaning. The Indians, listening to the song as reproduced by the machine, often distinguishes words that are unintelligible to me, but sometimes he has to eonfess to missing a part of them. In such cases he gives me as nearly as be can the "general sense" of the song. Rer. Frederiek Frost, of Garden River. Ontario, who hals been a missionary among the Ojihways for more than thirty years, and to whom several of these songs were refered for elucidation. tells me that many of the words are arehaic; that is, not in current use, and that the Indians themselves have forgotten what they mean.

Those who have pursued research among Indians will understand why in some instances. I conld not venture to pursue elusive words doggedly mutil the original and the correct translation had been obtained. Nowe than once I had an Indian singing after weeks of patient waiting: he would heeome interested, and if let alone. wonld singe perhalps a dozen songes: stop him to make particular incuniry as to words, meanine. or other details. and he womld almost aertainly lose his enthusiam and cease singing before he had finished his list. So, anxions 
in the main for melolies, I let the Indian sing on, trusting to the phonograph, and other Indians and missionaries for a digging out of the words.

'There are a few examples where I do not eare to give either the original words, or a translation of them. P'rimitive joleas of humor and love are not always in accord with modern refinement, and I camont see that any good is acemplished by making permanent recond of what the civilized Indian is slowly but steadily discarding as repugnant to his awakened sensibilities. That he is discarding vulgarity is fact, not sentimental fancy. Some evidence of it may be found in these songs. I orerheard an Ojibway woman nege her husband not to let MIr. Burton hear" a certain song, because it was a "bad" song. I heard it. and the words are untranslatable. but the melody is beantiful. On more than me occasion a singer, convineed that I wanted him to sing into the machine a melody I had heard, complied but numbled certain words so incoherenty that the most learned Ojibway could not tell what they were. They were words that gave an offensive meaning to the song.

In the translations that aceompany the hamonized versions I have tried, as herctofore indicated, to set forth the Indian's whole thought, turning into the English text not only the words actually sumg, but others to express the attendant story or circumstances. I have called attention to the faet that many of the love songs express the same thought, or deal with the same situation, with little rariation in the phraseology. For this reason I have rentured in two or three instances to take the suggestion for English words from a song to which the melody 
does not apply. All such liberties are acknowledged in the conrse of the text that follows where the songes lave heen arramged not in the order in which I found them. but alceording to classifieation with regard to their subjects and pmese. Is it is the largest class and melodically perhaps the most interesting. I begin with

\section{LOVE SOXGS.}

My Barle C'anoc. 'The story of this song has been told in Chapter VIll. There is only this further to be said of it - that I reduced it to notes at a time when the Indians were putting all possible obstacles in my way. I had to hear the song from a distance. and no Indian conld be persuaded to sing it to me in private. At that time the melody sounded to me as it is given in the harmonized versions. Iater when the Indians willingly aided me in my work, I noticed that at the end of the first 4-4 measure there occurred a passing note over the syllable kah. The variation is messential, and whether it was there in the begimning, or dereloped subsequent to my first hearing of the song. I do not know. As recorded by the phonograph words and music are as follows:

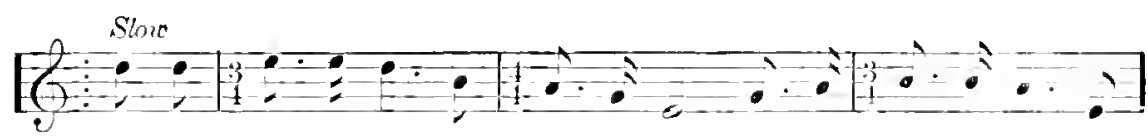

Clek-ab - bay te-bik on - dan-day-ahn Cheb-ab-bay te-lik on -

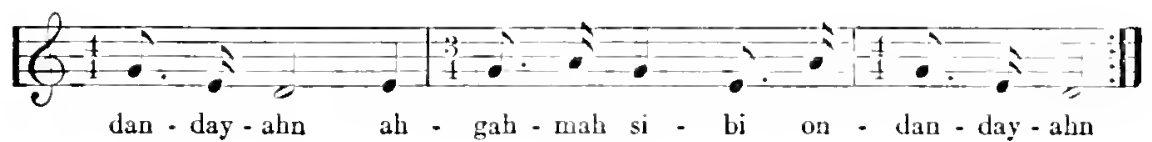

Translation: I am out all night on the rivers. 
Wedding Song. 'The attendant eiremnstanees by which this song is to be interpreted are suggested by the title. See Chapter VIII. Words and musie:

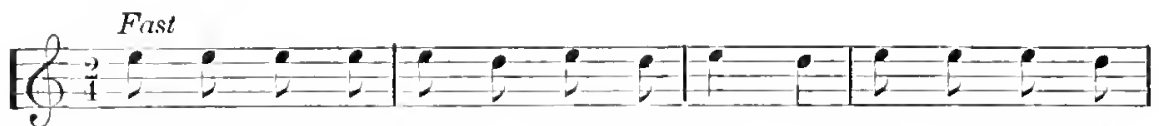

Bayz-hig e - qua - zess ne me ne - gon - un kay - get sen - nah
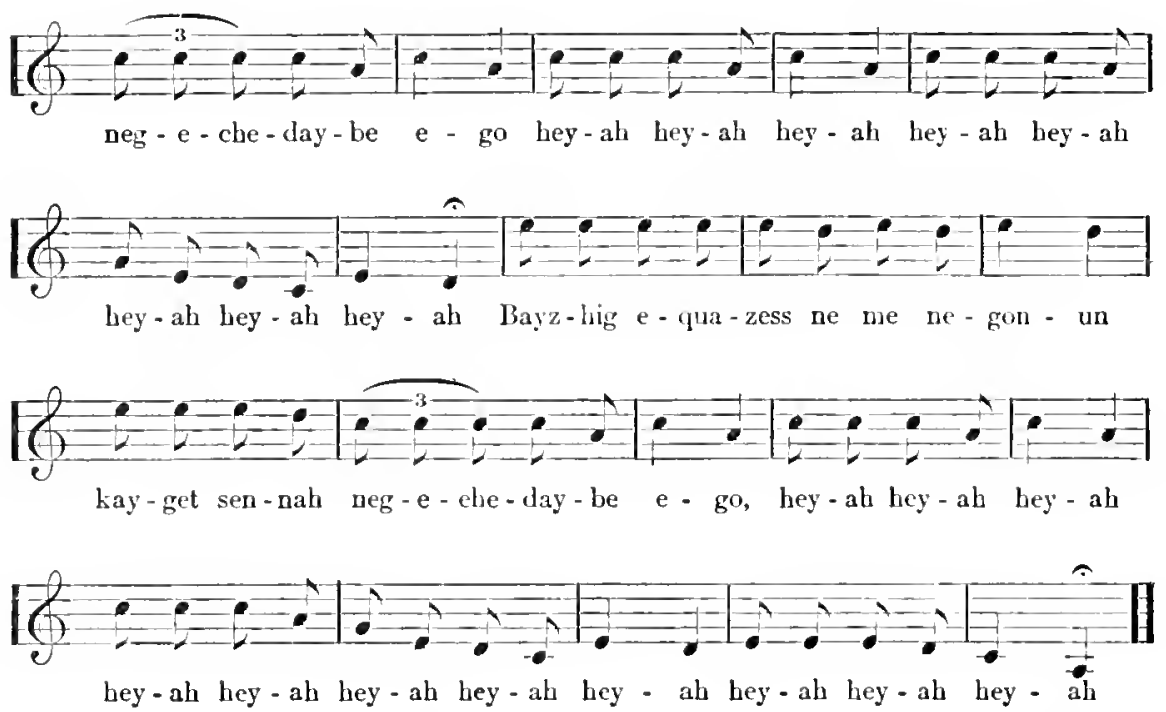

'Translation: A girl has been given to me; yes, I am very glad that she has been given to me.

Londy. Two versions of this song are on the phonographie eylinders. 'The first was sung by a woman who was so drealdfully embarrassed that hardly a word was intelligible, and the moment she had finished she fled. Her son volunteered to 
give me the English of the song. I copy here the translation he wote in my note book:

"do not worrie When you heain" that I am gon if you go away aginst my will I will have to go and my jumey will be to that island for Out in Lake I will be that Ioonsom loonsom loonson."

He explained that two persons are supposed to be spealking, the first a man who announces that he is going on a journey. Then his sweetheart breaks in with a protest, declaning that if he goes she will have to follow to the distant island, and crying that she will be lonesone. Another Indian who heard the song as reproduced by the phonograph, recognized it as one familiar in his youth. but could not distinguish the singer's words. He assured me, however, that the meaning. as he remembered, was substantially such as the singer's sonl had written. Some weets later a younger woman sang for ne, and onte of her songs was melodieally a variation of this one. the words meaning. "My" sweetheart is going away and I shall he lonesome. lonesone, lonesome." Both melodie rersions are given here, and both are used in the hammized version on other pages.

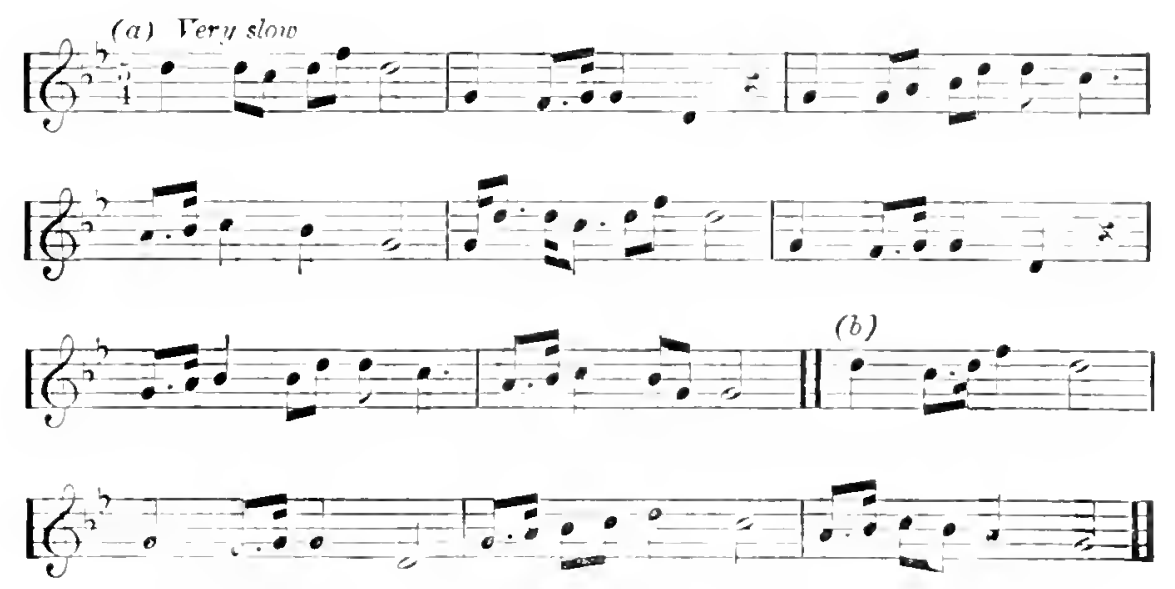


Her Shadow. Original words uncertain. They tell of a lover seeking his sweetheart in a canoe; he sees her shadow on the beach and says that when he is sure it is she he will shout to her to await his arrival. After several repetitions of the melody the singer always coneludes with a falsetto yell. The words are pieced out with nonsense syllables whieh, with the yell, are reproduced in the harmonized rersion.

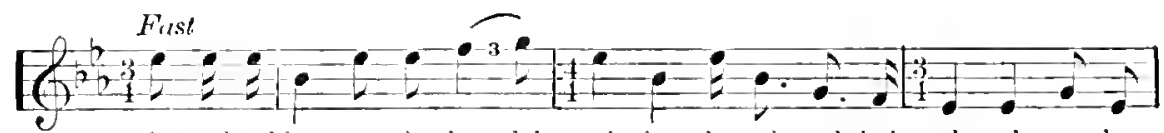

Ayquabnahkog pe ah be-dah goj-ing ke-gah wah-bah-mah nah non be

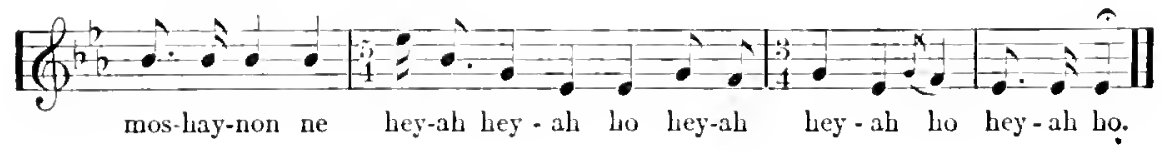

A Song of Abscuce and Longing. I notated and published this song before the idea of making a thorough study of Ojibway music had taken hold of me. 'To make it more available for white singers I transposed the ending an octare. Many of the Ojibways, having heard the English version, now use the higher ending. The original form follows.
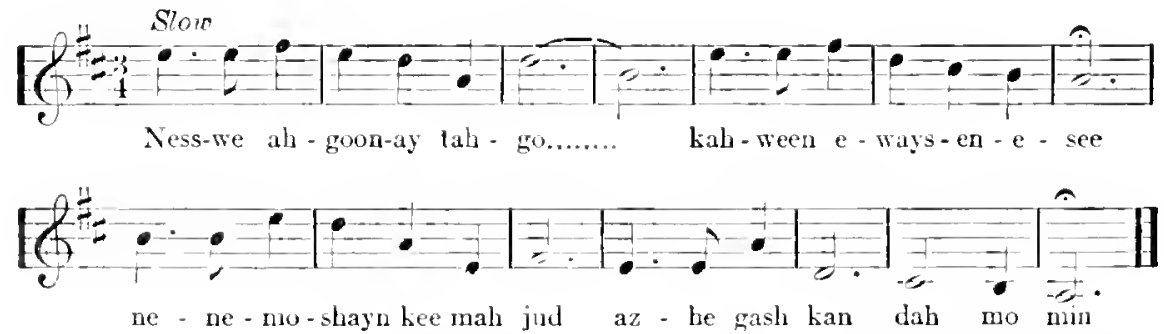

Translation: For three days I have been hungry; I have 
eaten nothing. My sweetheart is absent and I ame very sorrowful.

Morming Tryst. Originally another lonesome song. It is said to have been composed in the time of the great shingwank, the oceasion being the departure of a warrion on the warpath. Another version of the medody ocenrs on the phomographice eylinders to words of a radieally different character, unless we admit that remorse over drmkenness is at last analysis the same as grief orer the absenee of a loved one. 'The first version:

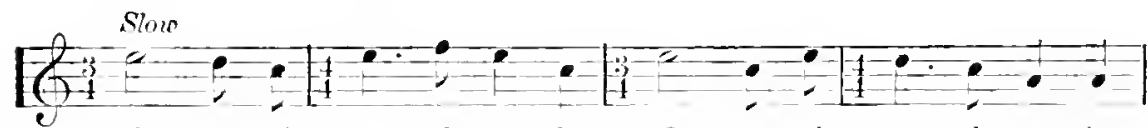

O ne-nah ne-nah-wen-dum $O$ ne-nah ne-nali-wen-dum

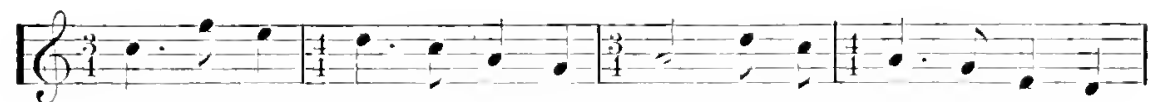

$O$ ne - nah ne-nah-wen-dnm ne - ne - mo - shayn ai - ah - sig

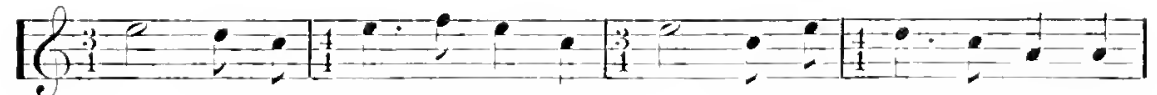

$O$ ne-nah ne-nah-wen-dum $O$ ne-nah ne-nah-wen-dum

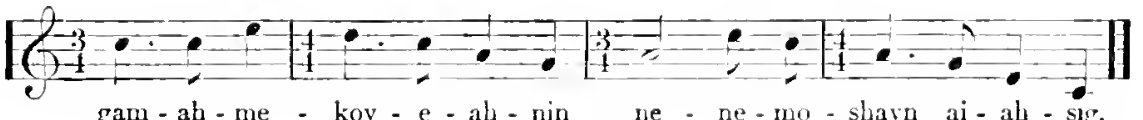

'Translation: Oh! I am very lonesome; my sweetheart is absent.

Second version:

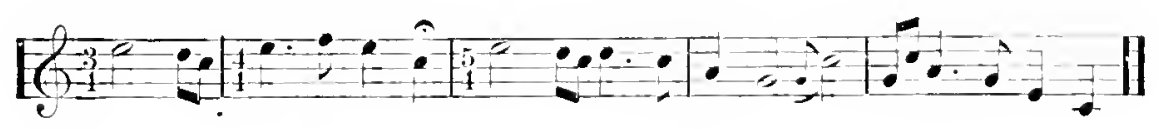

'The Ojibway words of this rersion are not quite elear, but 
they mean: Listen to me; I am full. It is all nyy own fanlt that I :m drimk.

In the harmonized version I have departed from both texts and based the words upon a type of Indian song that is frequently to be found among more tribes than the Ojibways.

The Lalic Sheen. 'This song was disenssed at length in Chapter $V$, where may be found three versions of its melody and words. It is also among the hamonized songs. The version generally heard to-day follows:
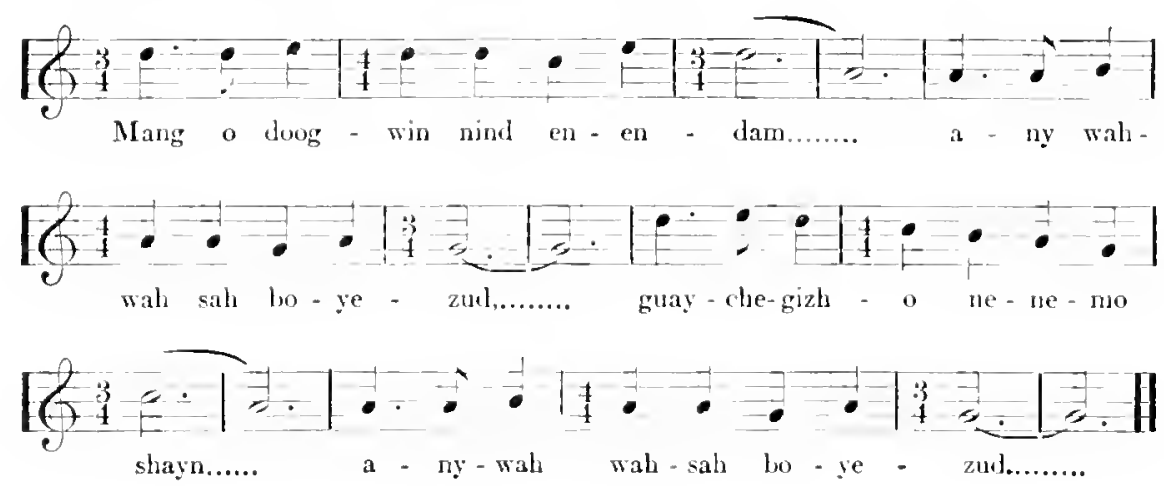

Wrabunosa's Longing. So ealled from the name of the singer. This was suffieiently disenssed in Chapter VIII. Following is the phonographie rersion of melody and words: 

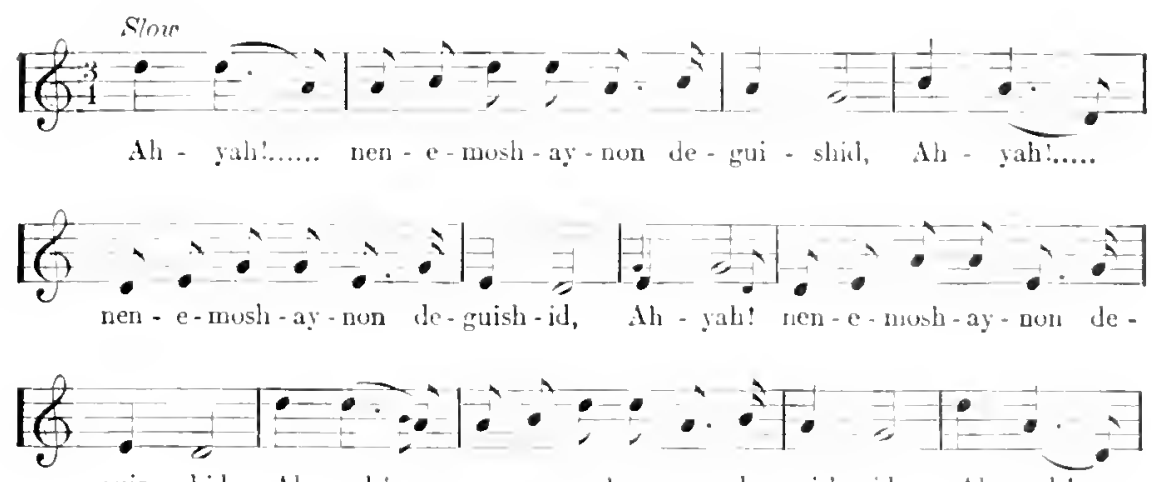

guis - bid, Ah-yah:... nen-e-mosh-ay-non de-guish-id. Ah-gah!...

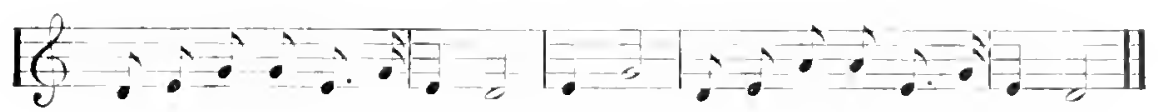

nes-ah we- aah-o-we- quay-zans. ah- yah! ne sul gay-gal ped-ah-gnish-ing.

Midnight Tryst. No eomment or explanation necessary.

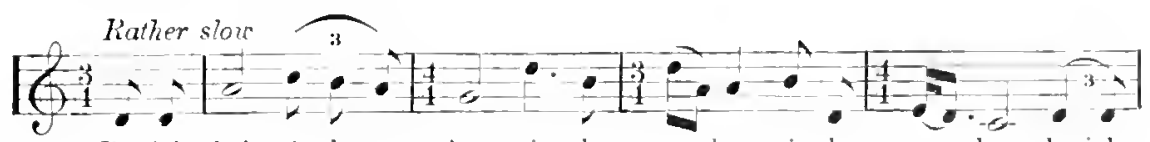

Be-jah-kah nin-de-go - bun nin-de - go-bun nin-de - go - bun be-jah-

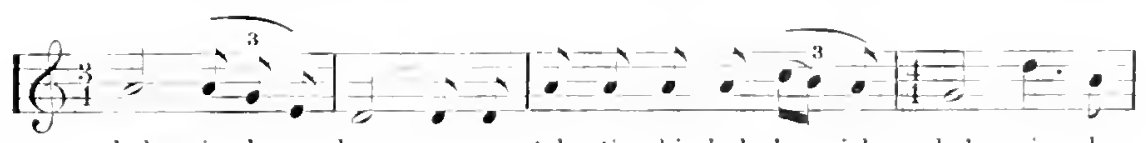

kah niu-de-go-bun a-pe-tah ti - bi-kuk be - jah - kah nin-de-

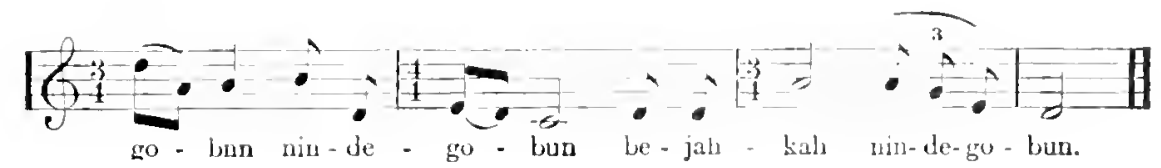

Translation: She has promised to meet me at midnight. 
Red Blanket. Although I heard this song early in my acquaintanee with the Ojibways I did not put it on paper until it hat been sung into the phonograph: for I had my doubt as to its origin. It is a lively trifle that somnls as if it might have been culled from an Offenbaeh operetta. But the Ojibways, men and women, insist that it originated with themselves ages ago. They get immense enjorment from it, apparently finding in it a meaning that is hidlen from me. As a rule a woman is ealled on to sing it, and slue heightens the interest by dancing while she sings. I am tolal that the bark referred to is the tamarack, and that the purpose of gathering it is to make a fire in the teepee.

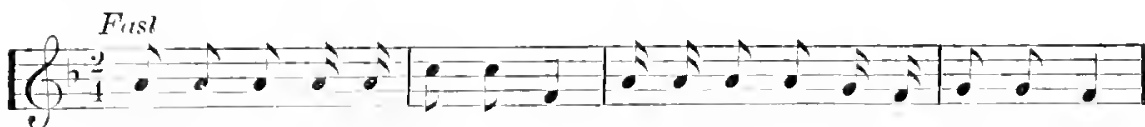

Ay-quay-quog nin-gah-de - jah min ne-ne-mo-shayn nin-gab-we - je - ah

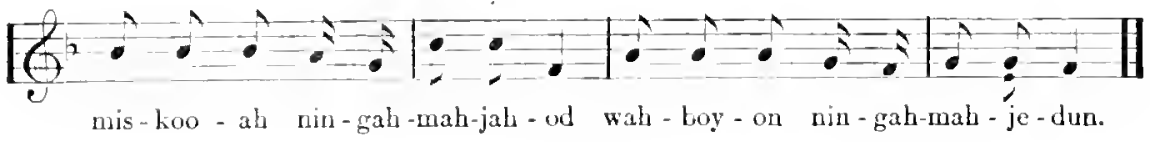

'Translation: I will go to the edge of the forest and gather bark for my sweetheart.

I'aiting: The words as sung cannot be reproduced with certainty. They were dictated as follows:

Bejecung ningahbedugaeshing licegee e nen ningahdayahmah liayaygecn layg go keaenemohliayn.

'Translated: I'll be here hefore long; don't get tired of waiting and don't disappoint me. 

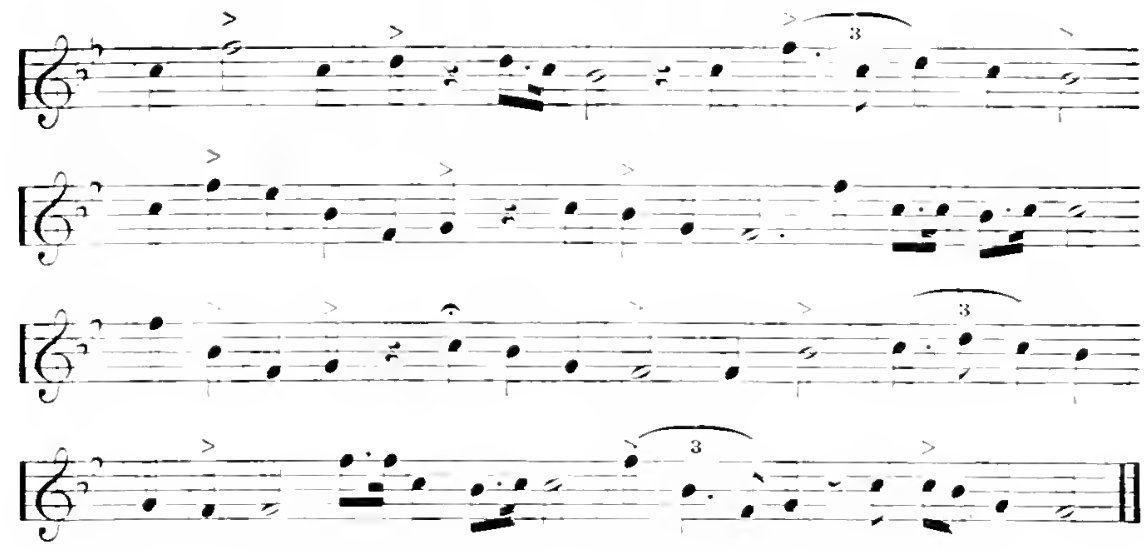

Bamished. This is a long song for an Ojibray. It was sung with such evident feeling as to be deeply impressive. I tried to get the words but the singer dictated a few and then stopped. The phomograph does not disclose the remainder with any degree of certainty but an Indian interpreter gives the following as the substantial meaning of them all:

There is a hill to be climbed, and you must keep elimbing if rou want to get home. Take a knife to defend yourelf. The way is long and you will weary, but you nust kete going.

'The song becomes clear in the light of an old enstom. A roung man's parents exereised ahsolute authority crer his marriage. If he brought to the parental wigwam a bride of whom the old people did not approve. they refuseel to receive her. and he hat to send her back whence she came. This song. then. is the heart broken lament of a lover who brought home a wife from a distant rillage and was compelled to send her away. 


\section{AIERICAN PRIIITIVE IIUSIC}
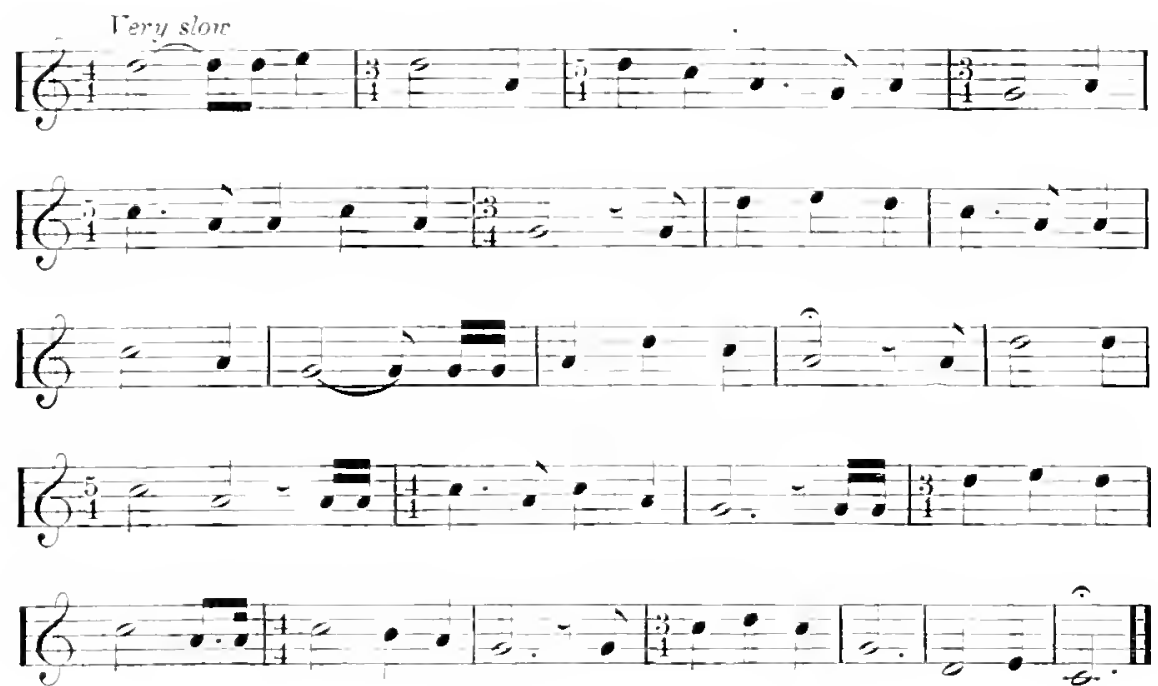

An Odoakh Song. The Ojibways of the Lake Superior region refer to certain Indians who live on or near their reservations as "Dowahs," or "Odowahs." They are presumably Ottawas, a branch of the Algonquin stock, whose language few Ojibways unlerstand. The man who sang this said that it was an "Odowah love song," and it is therefore ineluded among the love songs although nobody to whom it has been submitted ean get any meaning fiom it.
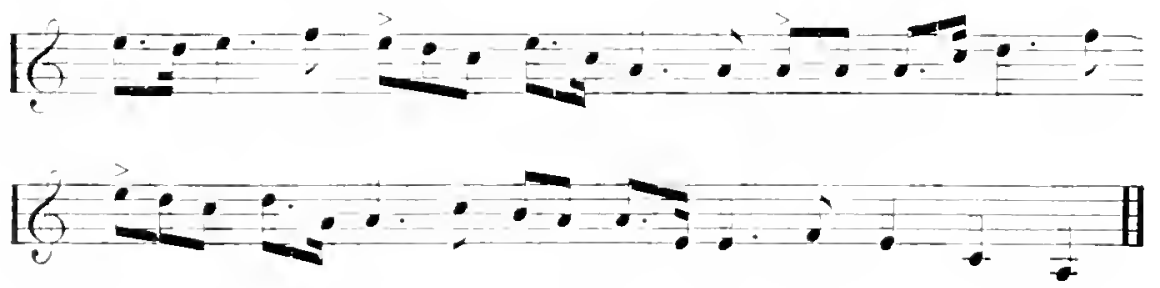
No. $31(b)$. This, and similar designations, refer to the number of the phonographic cylinder's whereon the song may be found. The words, many times repeated, mean: "I am going fir away, my swetheart."
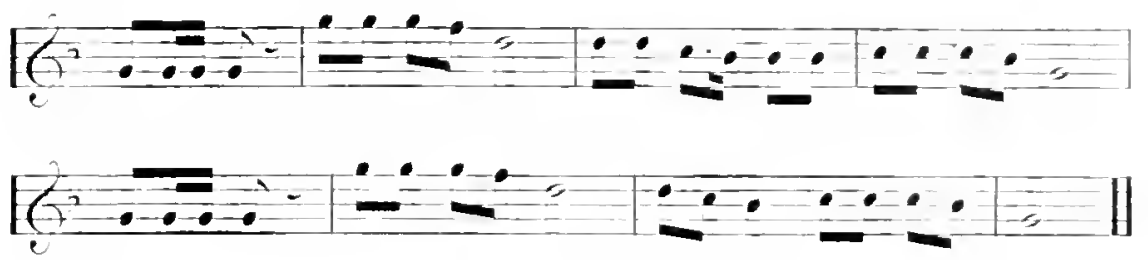

No. 32 (a). Lntranslatable.
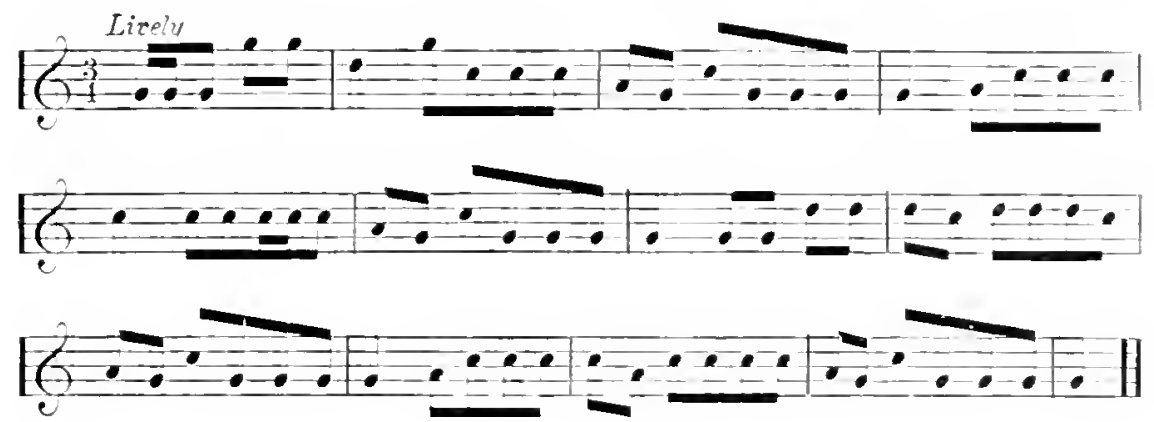

No. 33 (c). From the spirit with which men sing this the listener might suppose it to be a war song. The words as dictated: Jangwaysheques: ne dahguahdahmad go ne ningeyahgah me ahgo. Translated: They say I took away another man's sweetheart. but this is jealous gossip. 

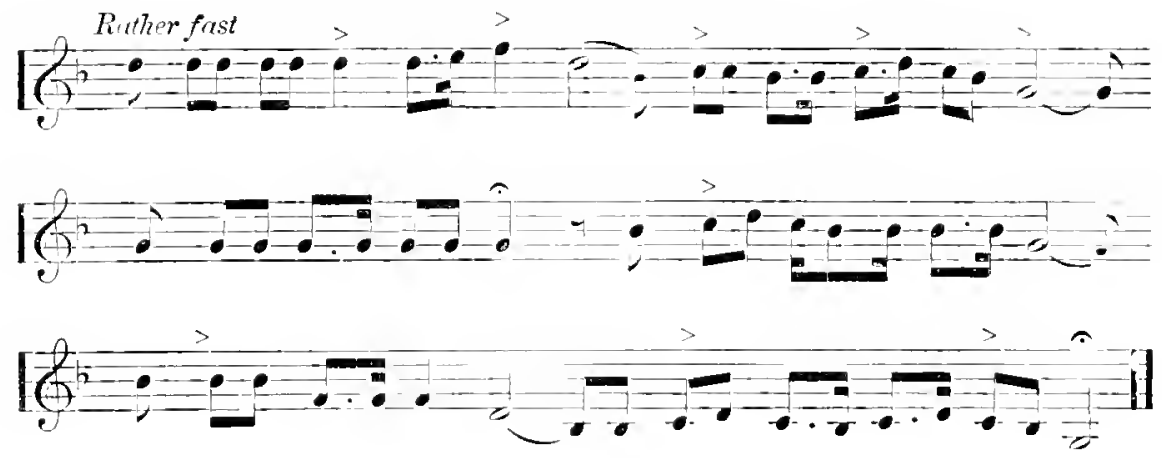

No. 39 (a). The only words that are audible mean, "I can see his face."

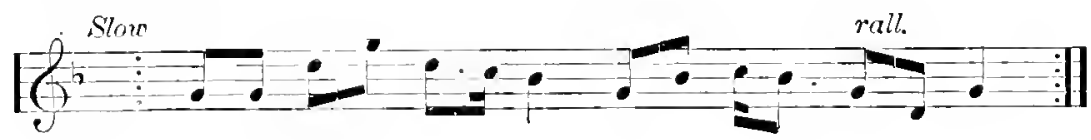

No. $39(b)$. The words mean: "I don't see why you disappoint me. I have kept my promises to you, but you have disappointed me."

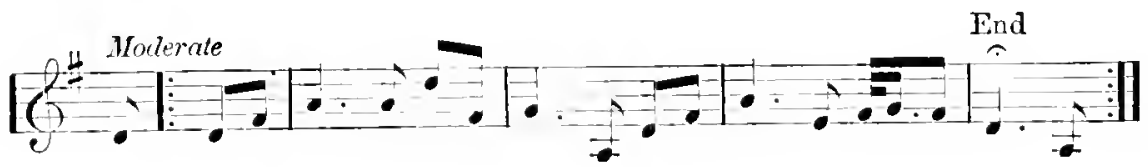

No. $39(c)$. The interpreter surmises that this is the utteranee of a man who has been rejeeted. He gives this as the meaning: "I am going to leare you; no use in staying any longer:" 


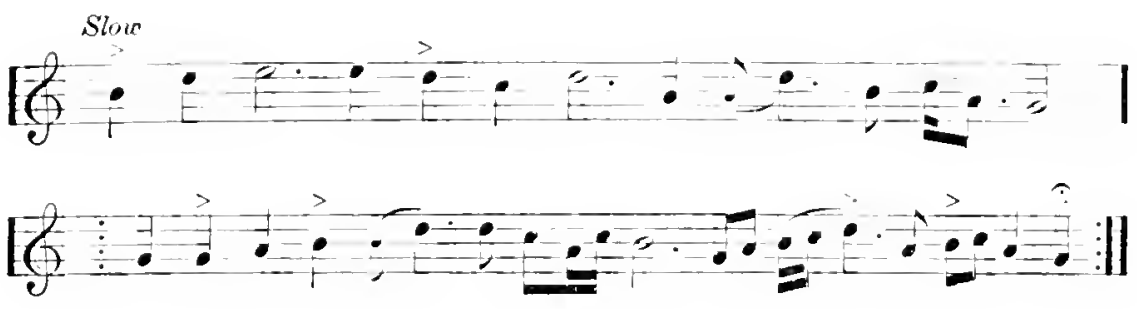

No. 41(a). Intranslatable.

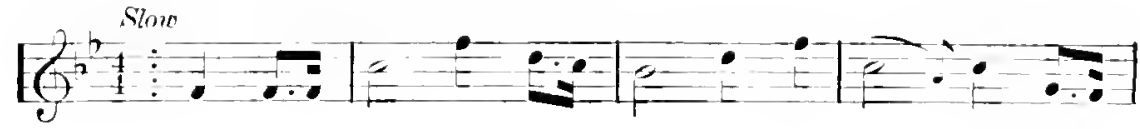

First time Second time
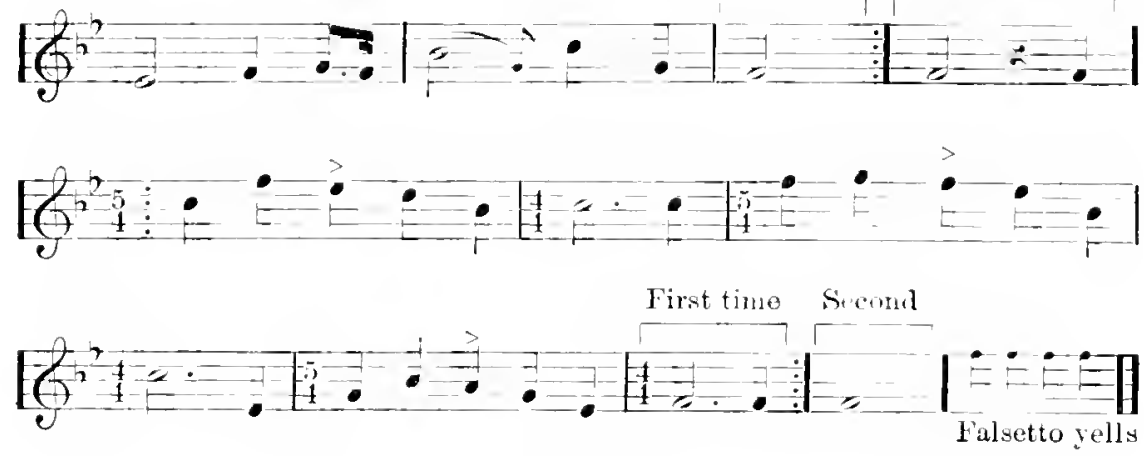

No. 41 (b). 'The words as dietated: Megowahbunger che h-

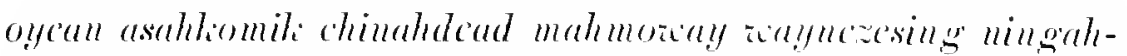

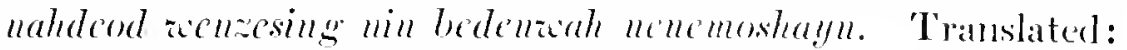
"Early in the morning I will take nyy canoe to go and gather the moss I am asked to get. and I will gret the best I can find. Afterwards I will bring it to my sweethe"ilt."

The moss referred to is a kind used by the Ojibways for wrapping babies in. 

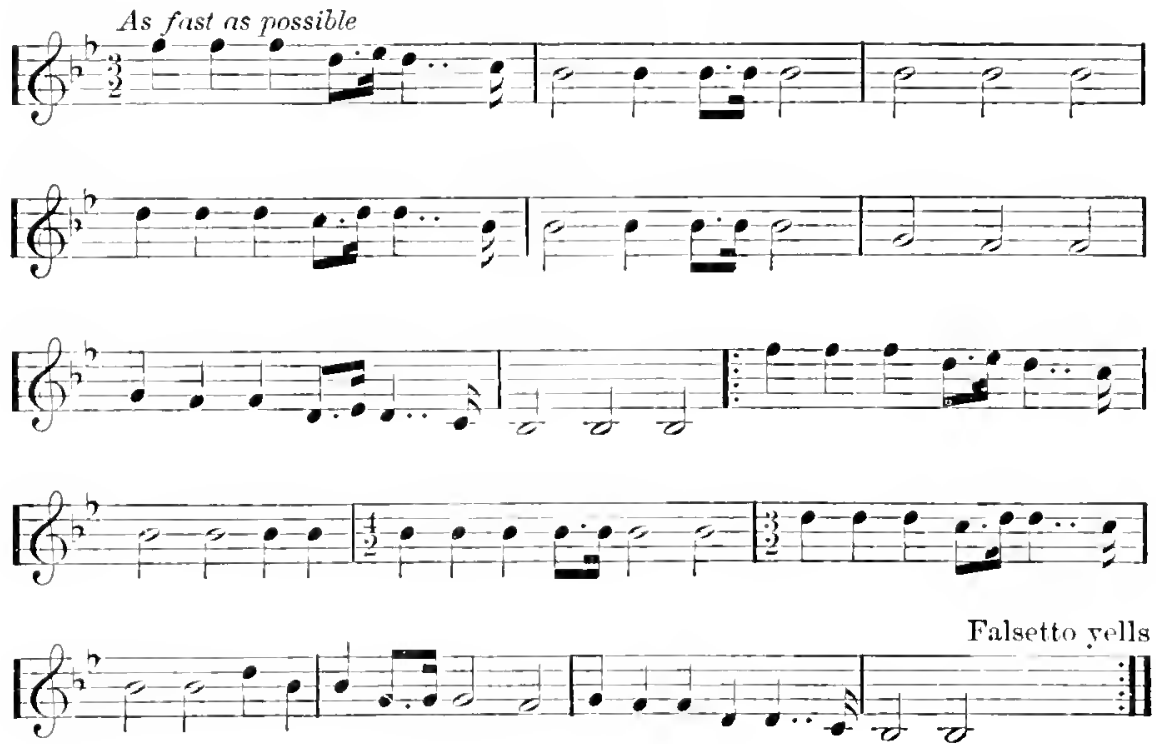

No. ta (b). This song is interesting as an example of Indian humor. Early in the summer of $190+$ I beeame aequainted witl a woman who was said to be a good singer, but I could not induce lier to go near the phonograph, or sing to me alone. She put me off with one excuse or another, always good humoredly and with so much joking that we never failed to laugh when we met. Often she declared that I never would persuade her to make a fool of herself by singing into "that thing," meaning the phonograph. One evening I joined a social party around a eampfire. Songs were sung, stories told, and there were several general dinces. At the height of the fun I managed to bring her to the eentre and make her danee alone. 'Then she insisted that I should danee with her, whieh 
I did to the best of nuy ability, and mueh to the amusement of the crowd. 'There was uo end of f'm osere it, and when I saw her next morning in the cabin where I kept my phomograph, knowing that she wonld be momsually good natured. I deceded to make another try for a some. I strolled in and the customary bantering began. Bringing the talk aromel to musie. I daclared it to be my eomviction that Ojibway wonnen knew only one cradle song. "The Naked Bear." She promptly denied it, saying that she knew another herself.

"What grood does that do," I asked, "when you don't know how to $\operatorname{sing}$ it?"

"I do know how," she cried indignantly. "I sang it times cnongh to all my children."

1 langhed at her, saying that what she sang was "The Naked Bear," and that she didn't know the difference. With a contemptuons exclanation she ran to the phomograph and demanded that I set it going. I complied with a fine air of indifference and she proceeded to sing the cradle song I call "Sleepy. 'lime," which will be fomm in its appropriate place. Then she said, "Now I will sing you a song all for yourselt," and she sang the following melody: 

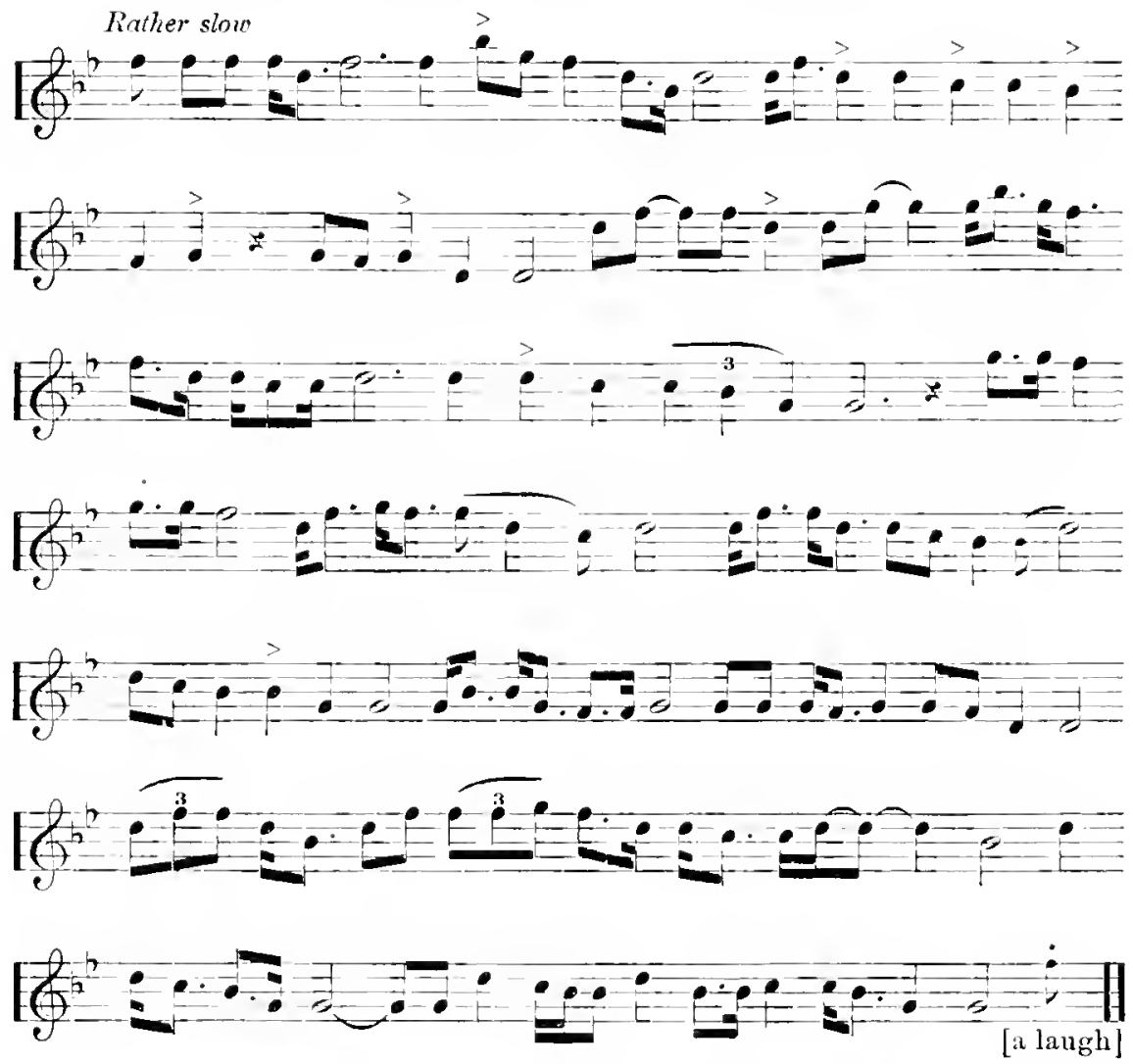

I was not sufficiently versed in ()jibway to follow it closely, but when I referred it later to my interpreter he laughed heartily. It seems that the melody is that of an old time love song, but that the singer had extemporized words that applied wholly to myself: It was her joke on the notator, and she was much put out when she learned that I had discovered the trick. I may add here that extemporizing words, especially names of persons, in songs to give them an immediate application is not at all uncommon at Ojibway social gatherings. 
No. $29(b)$. The singer amounced that this was a love song, but the words are indistinguishable and no interpreter has hazarded a guess at their meaning.
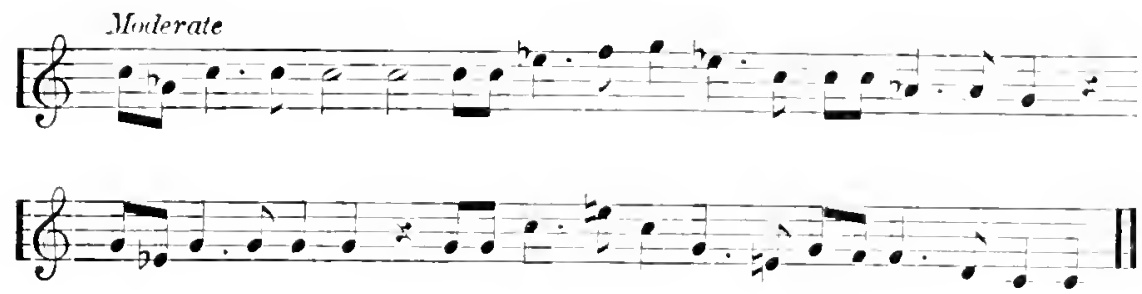

No. 35 (a). 'The words are not clear but the interpreter' gathers that the song is a lament orer the prolonged absence of somebody.
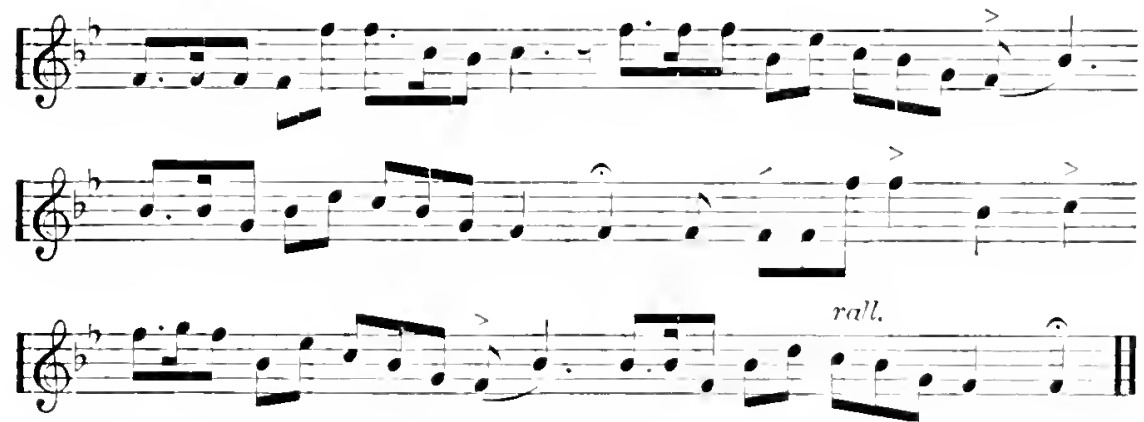

No. $85(b)$. The words appear to mean "I come from the momtain with my sweetheart."

Rether slow

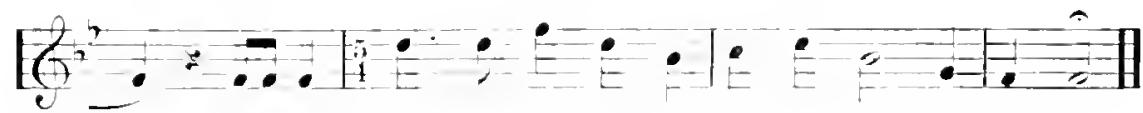


SOCIAL SONGS.

Under this caption are included not only songs that seem to be used only at social gatherings. Jut eraclle, humorous and drinking songs.

Parting: To me this is a most lugubrious tune, but it represents the Ojihway's conception of al jovial somg. It came to light muder romantic circumstanees. While the Indian play, "Tiawatha," was lomming during the summer of 1902 at Desharats, Ont., 'Tekmmegezhik Shawano, who played the title role, was married to Margaret Waubmosa, the Minnehaha of the east. As the werlding day approached it was suggested to the Indian actors that they take note of the event by introducing a festal song in the scone linown as "The Wedding Festivities." The word "f'estal" was not used in conveying the suggestion, hut pains ware taken to impress the Indians with the fact that what was wanted was such a song as they would sing on a jolly occasion. They were asked if they had any song of that eharaeter and replied that they knew many; they wonkl think it orer and select one. After three days of thinking it over they annomed that they had deeided on a very aneient song that was just the thing for the oeeasion. When I leard it roared forth by forty powerful voices at a solem adagio, I thought there must have been some mistake, lnt when I understood the words I knew that, from the Indian point of view, nothing could have been more appropriate. 

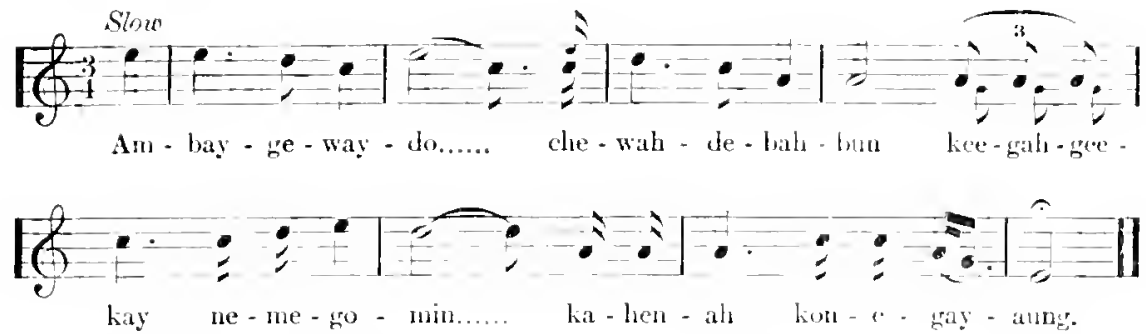

'Translation: Let us go home before daybreak or people will find ont what we have heen doing. .

Wrinter. 'The story of this song was told in Chapter VIII.
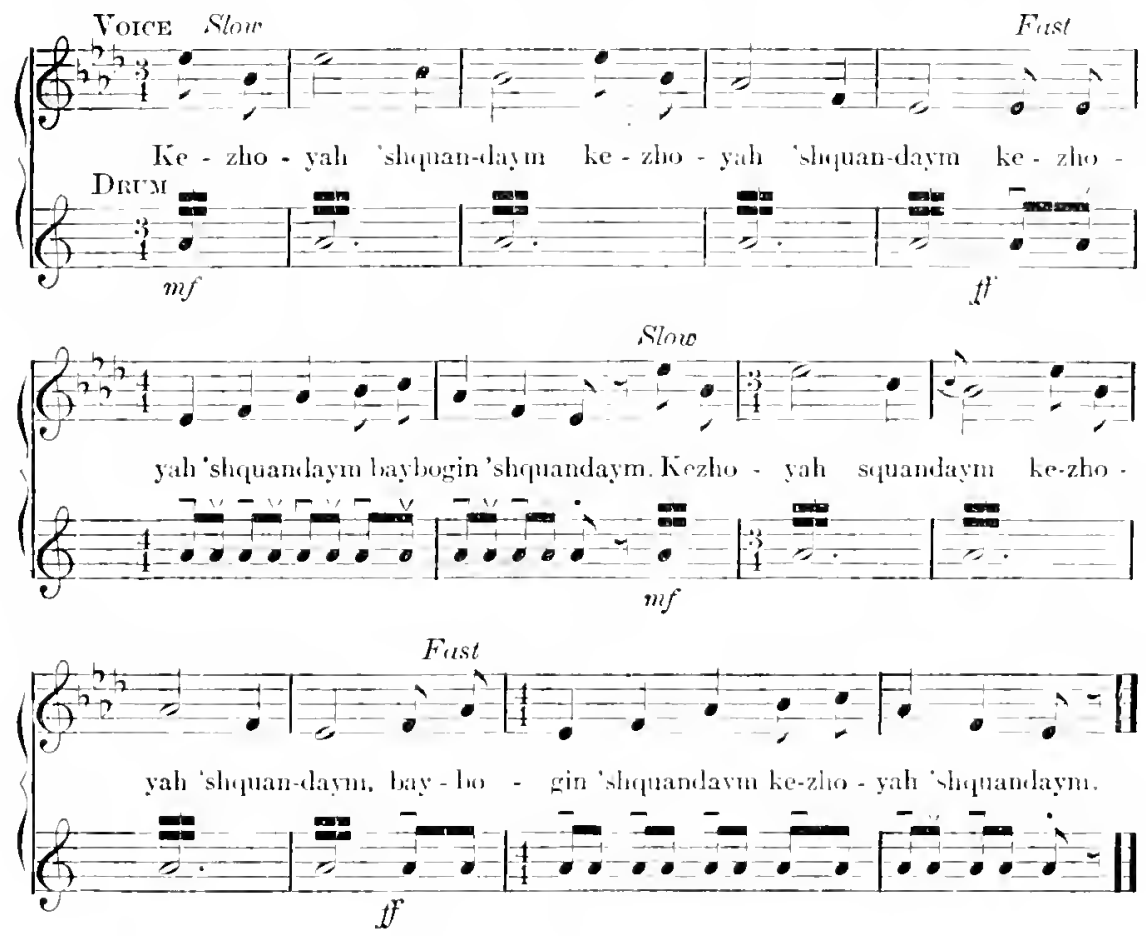

Translation: My door is warm in winter time. 
Forest song. See chapter VIII for story and revised words. The tune is varied shightly by some singers, the variants being indieated here by small notes, the large notes indicating the version reproduced by the phonograph.

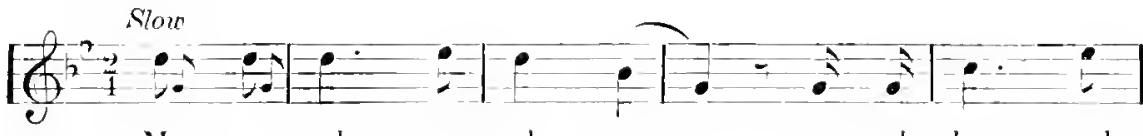

Me - ue nah - gay nah - gay.... ne - nah kee - wash -

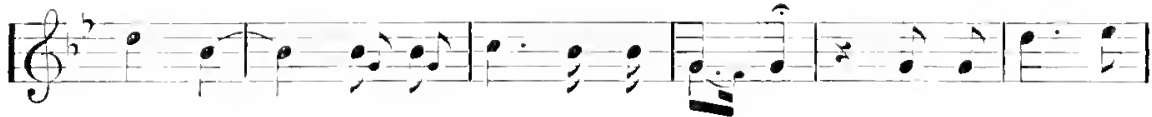

quay - be.....

ah - be - ding me - ne nab suh nab gah.

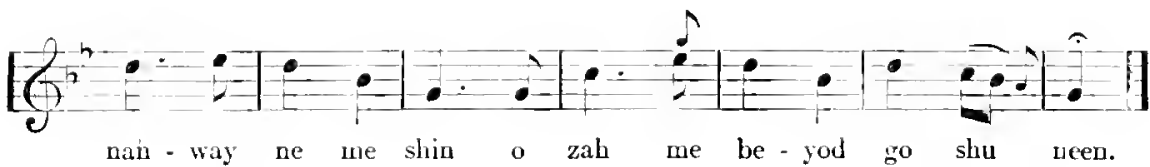

'Translation: I don't suppose I'll get drunk if I take one drink; if I should get drunk, take eare of me.

Ol.l Shoes. Originally a gambling song but often sung now withont reference to its application. See Chapter VIII.

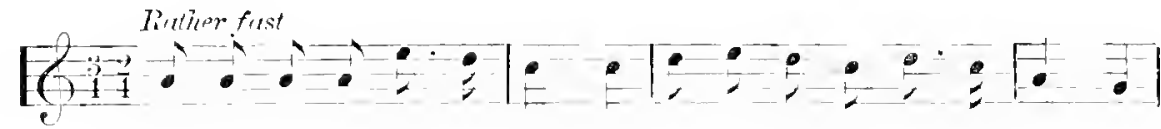

Muj-je muk-e-sin aw-ya- yon muj-je muk-e - sin aw-yaw-you

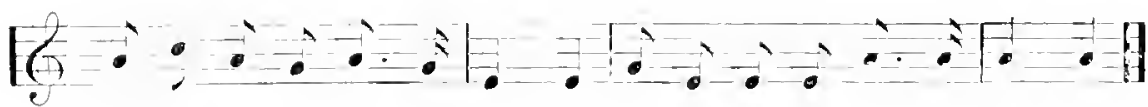

muj-je muk-e - sin aw-ya - yon muj-je muk-e - sin aw - yaw - yon.

Translation: I use had shoe's. 
Gambling Song. A sequel to the foregroing, sung only in the course of the moceasin game with direct applieation to a turn in the play. See c'lapter VIII.

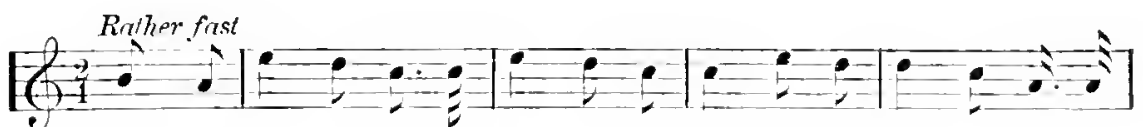

Gay-gel wah-bah-dud ne ge mah-guk ge gay-get wah-hah-dod ne

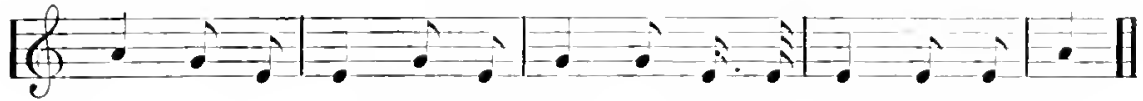

ge mah-guk ge gay-get wah-bah-dod ne ge mah-guk ge.

Translation: Indeed, I know where it is.

In the Sugat Camp. The Ojibways knew the delieious merits of maple syrup and sugar long hefore the palefiaee came to them. Alexander IIenry tells of one April during his ealptivity when be and the Indians with him had nothing but maple sugar to eat during the entire montlı. At this day even the civilized Ojibways lay in a stock of bireh bark every June to be fashioned into pans for catching salp at the end of the following winter. It is a season to which they seem to look forward with great joy. At the right tine whole villages move into the forest and pitch camp among the maples. There follow days of toil. men, women and ehildren sharing in the work. At length all the sap is taken, much of it already bas been converted into sugar, and time begins to hang heary on idle hands. As evening comes on and all are resting, the young nen take empty pans, and, headed by a drummer, danee grotesquely from one fanily shelter to another, singing this 
song. 'They hold out their pans for contributions of syrup or sugar, and though their words are not explicit their actions say "give, or we will take by force." Usually the contributions are fortheoming good humoredly, but when they are not, the roung men invade the shelters of the niggardly, drive out or overpower the ocenpants, and take as mueh sugar as they think will teach the owners to behave more hospitably in the future.

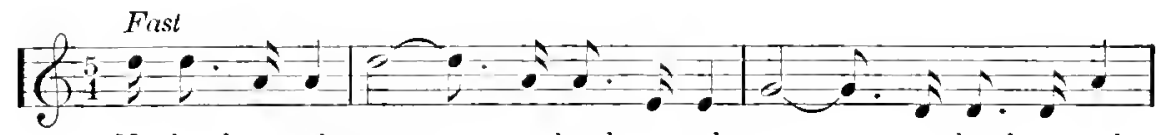

Ne-bayd - e - nah - geen... ne-bayd - e - nah - geen... ne - bayd - e - nah -
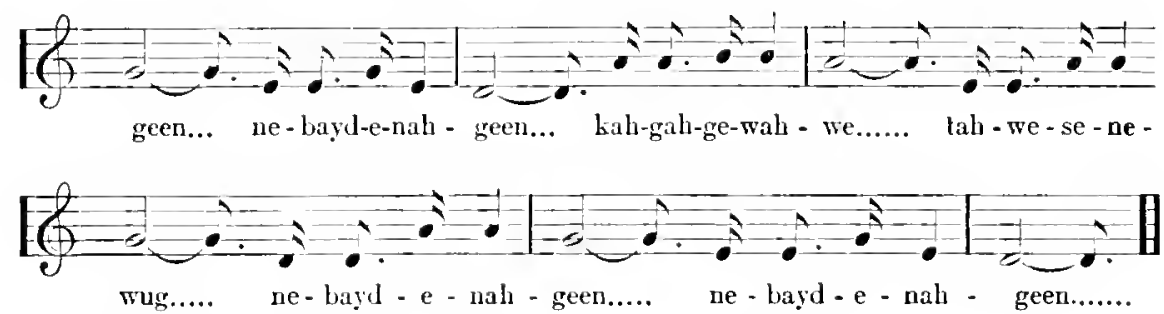

Translation: We look as if we conld eat.

A Drinling Ducte. 'This was sung by a man and a woman, but the result on the phonographic reeord is far from what was designed. It is a song with action, a dialogne with music. 'The mechanical arrangements destroyed all freedom on the part of the performers and embarrassed them so sadly that cren the musieal phrases are mdoubtedly distorted. It is unlikely that anything of melodie value was lost, but I should need to hear the duette several times to make sure of repre- 
senting correctly a form of entertimment out of which the Indians get much pleasure. In the dialogne, framenents of which are spoken but most of which is sme, it alppears that two tovers have been drinking and that the supply is exhansted. 'They lament this state of thingss, and the man intermpts his singing abruptly to exclaim, "I wish I had just one drink!" The response is to the effect that one drink would not be cuongh for two, and after further lamentations orer their enforeed sobriety they conchule: "It wonld do if we hat one drink between us." "The following meloty is what the phonogratph reproduces of the attempt to give ne the slucte:
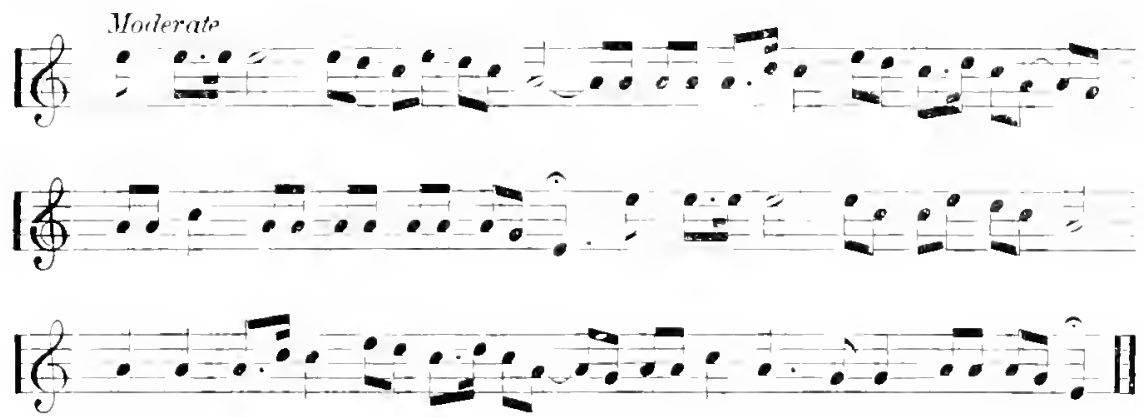

Realizing that the effort was a fitiure f'om their point of view, the man then sang the following. repeating most of the words that hasd oceurred in the dialogne:
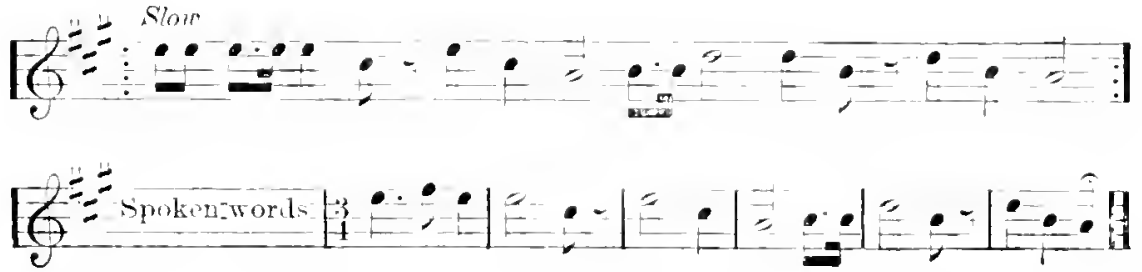
No. (b) (b): 'This melody is often sung in the nost spirited manner to meaningless syllables throughout. It hats drum aeeompaniment of a regular character, the beats falling on the eighth notes. As a rule the song is used for an old time dance. I am not elear as to the meaning of the few words that sometimes appear in the first two measures.

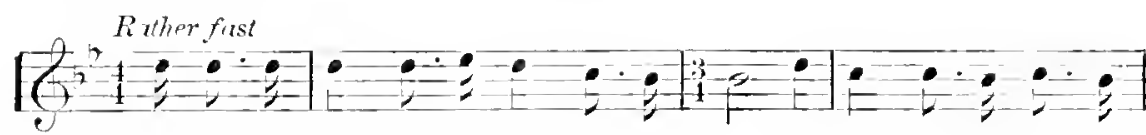

Ne-mosh-ke-nug we-we-se se-ne - wur hey-ah hey-ah hey-ah

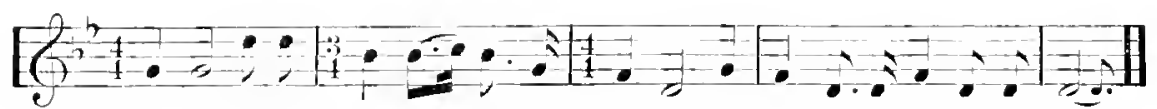
hey-ab hey-ah hey-ah hey-ah hey-ah hey-ab hey-ah hey hey-ab hey.

Carousal. Another song of the empty drinking cup. 'The usual explanation given to justify the odd words is that a party of young men molertook to have a drinking bont, but neglected to provide cuough liquor to bring on a satisfactory condition of incluiety. Inence, the tlask being empty, there was nothing for it but to go to sleep.

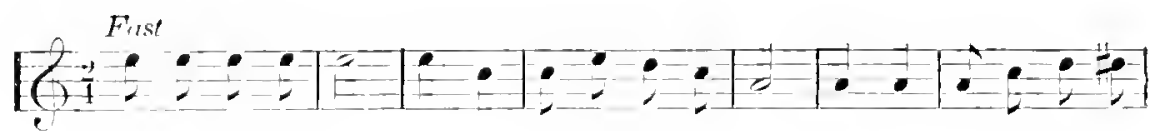

Kahnin-dah-ne-bah se-neen kah nin-dah-ne-bah se-neen ke tah-go-go-

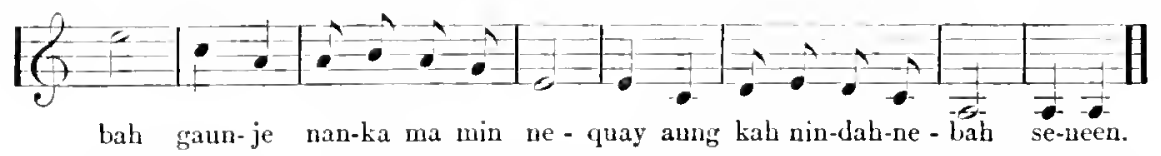

Translation: I wouldnt go to sleep if there was anything left to keep me awake. 
Visiting Song. 'This was discussed in Chapter' V.
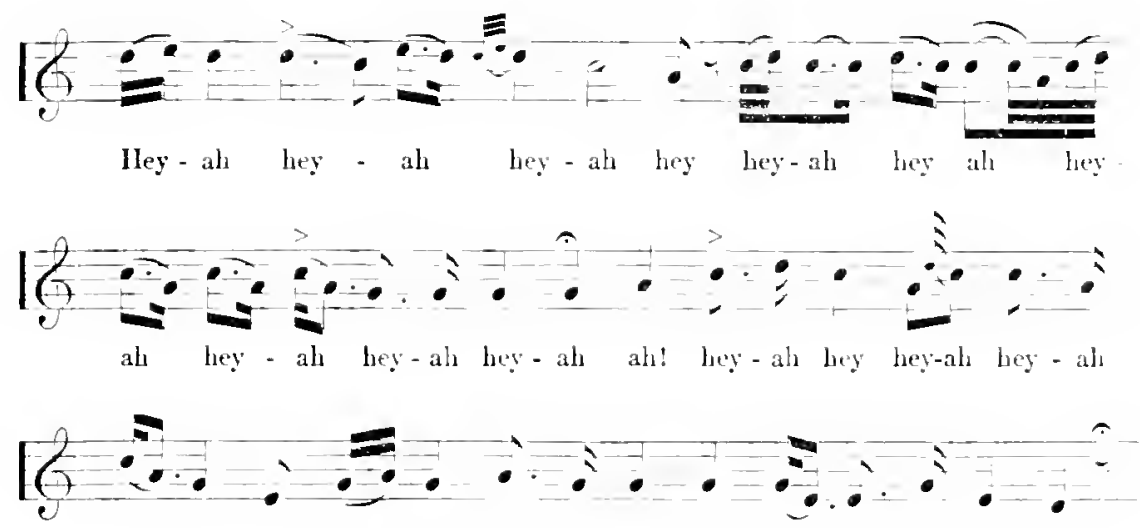

bey - ah hey hey - ah hey - ah bey - ah hey - ah hey -ah tah.

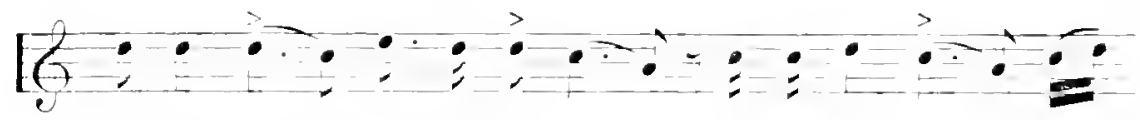

O - git - ho.... nem - ah - dab-bit..... nin-gah-num - dug..... hey -

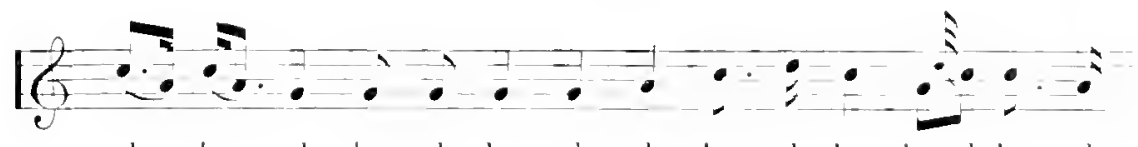

ah hey ah hey - ah hey - ah ah hey - ah bey hey-ab hey - ah

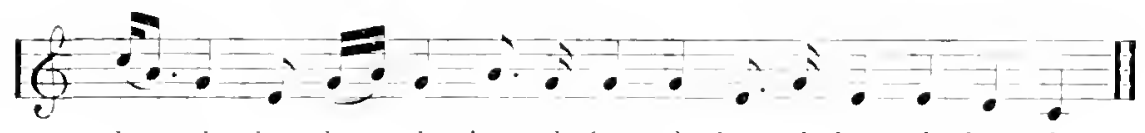
hey - ah hey hey - ah hey - ah hey - ah hẹ - ah hey - ah hey - ah.

Translation: Who sits on the ice ean hear me singing. 
The Nalicd Bear. It is this song from which Longfellow (through Schooleraft) derived the line in "IIiawatha,"

"IIush! the Naked Bear will get thee."

It is explained in the glossary that is appended to most editions of the poem, that the Naked Bear is a mythical creature inrented by Indian mothers to frighten their children into good beharior. 'The full text of the song shows that the screech ow was used in the same way. See Chapter V'I.

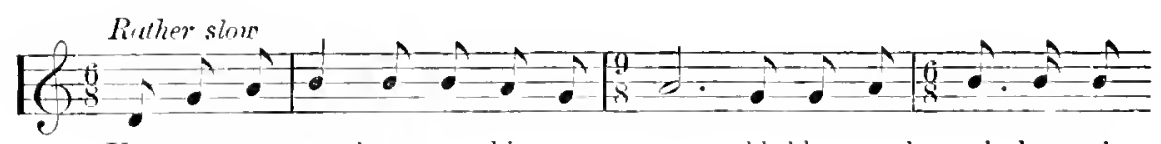

Kay-groo-mo-we-kayn a - bi - no - gees wahbshkee muk-wah kee-gah-

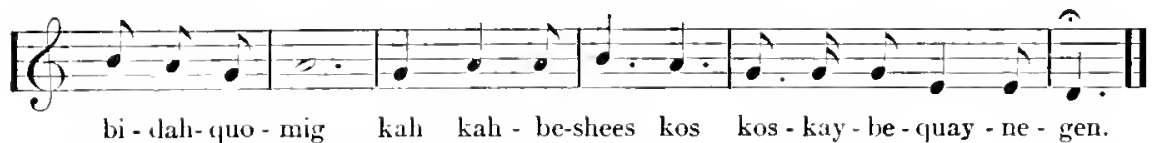

Translation: II ush, little baby, go to sleep; do not cry, or the naked bear will eat you.

Slecpy Time. A cradle song made up almost wholly of meaningless syllables, "ayah, ayah" and so fortl. In this respect it resembles many a lullaby that may be heard in civilized murseries, and I may confess that melodieally it appeals to me more strongly than any lullaby of palefaee creation that it has been my fortune to hear. For the sake of making the little song of possible use to my own people I have ventured beyond the suggestion of the few Ojibway words, and, taking my cue from the Naked Bear and the screech owl, have inrented a spider to figure in the harmonized rersion. 


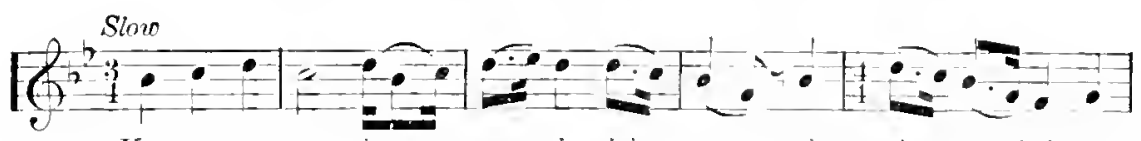

Kátgoo-mo-we-hayn ney-je-jahn-sigy ah - nin - e - bah ay -

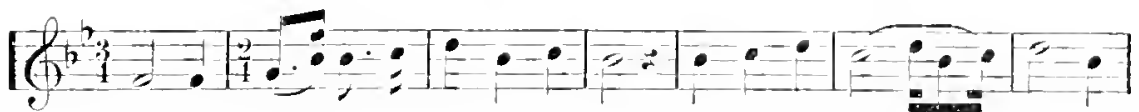

ah ne - ne - jah-ne-zess ay - ah ah! Ay-ah ay-ah.......... ay - ah

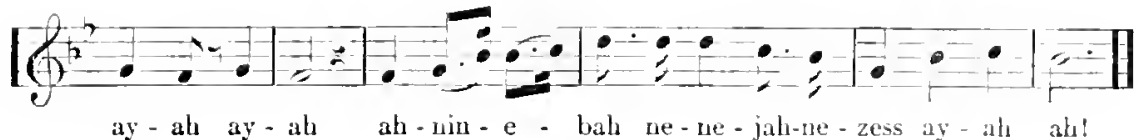

'Translation: Don't (ry, little one: go to sleep, baby.

Firctly. This is a song I lunted for in rain. Schooleraft heard it about eighty years before my visits to ojibway land. IIe set down the words and declared that they were the "wild improvisations of elildren in a merry mond." Schooleraft. further wrote that "in the hot summer erenings, the children of the Chipperal Algonquins (Ojihway) along the shores of the mper lakes freequently assemble before their parents' lodges and amuse themselves ly little chants of various kinds, with shouts and dancing." "That is, the dildren began eally to entertain themsclves after the manner of their elelers, and there were songs for children as well as gurown-ups. The historian was muloubtedly mistaken in assuming that the words of the Firefly song were wild improrisations of chitdren. IIad he been musician as well as historian. the tume would have told lim that the words had been carefully arranged by somelody who had rudinentary poetie talent. But no matter. Long- 
fellow tnmed the words to excellent advantage in "IJiawatha," and I was very desirous of eoming upon the tume which I sought for in the precise neighborhood where Sehooleraft heard it. I was not suceessful. Nohody thereabout remenbered the song, hut a missionary among the Ojibways of Minnesota heard it and reduced it to notes which he sent to Dr. Baker while the latter was preparing his essay. Dr. Baker included it in his publication, and, with his permission. I incelude it here, also, for I think any eollection of Ojibway songs would he incomplete withont it.
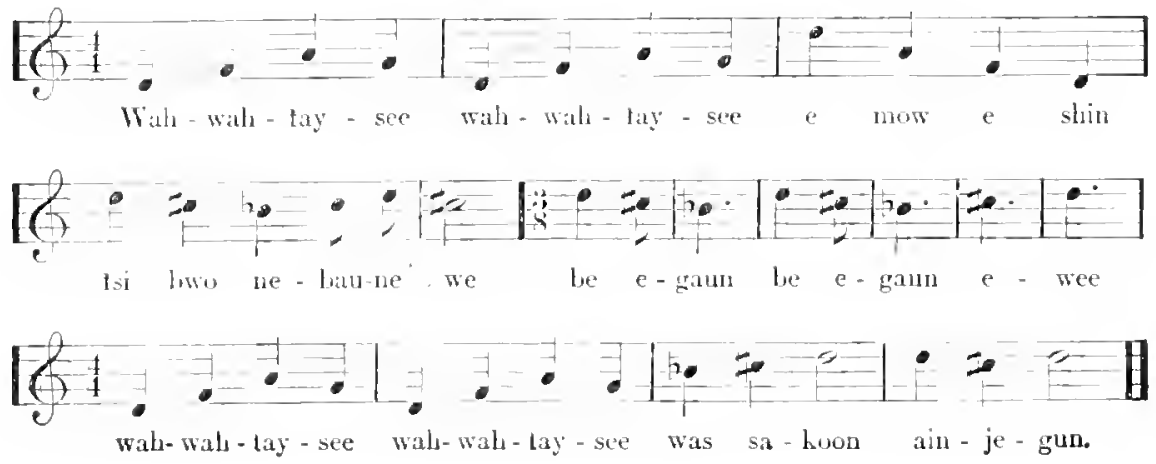

Translation: Flitting white-fire-insect, give me light before I go to bed. Light me when 1 go to sleep with your bright camlle.

Confession. This endless song is immensely populan with the Ojihways. I have heard thildren sing it by the hour, but its main use is in social gatherings when some singer, usually at wonall, sings it with a different proper name in each repeti- 
tion, and with gestures to give mmistakahle point to the words. The words here given are for a man to sing. Kannamahshaynon Quakahbahnolizes means. "Yon're my sweetheart, Quakahbahnokwes," the latter word being a girl's name. A womam, singing it, would use a man's name, and () jibway women arouse much laughter hy pointing to one man after another and calling his real name, or identifying him by some phrase the application of which is understood by all listeners. During a series of entertainments I gave with Indians in eastern cities I had a romen woman sing the song and made a point by following it with a translation, aceompanying it with gestures like her own. For the purposes of the entertaimment my translation ran, "My sweetheart sits just over yonder." On one occasion the young woman staggered me and convalsed the Ojibways on the platform bedind her by concluding the song with a gesture towald a man in the front row and singing the equiralent of "My swectheart is that bald-headed man!"
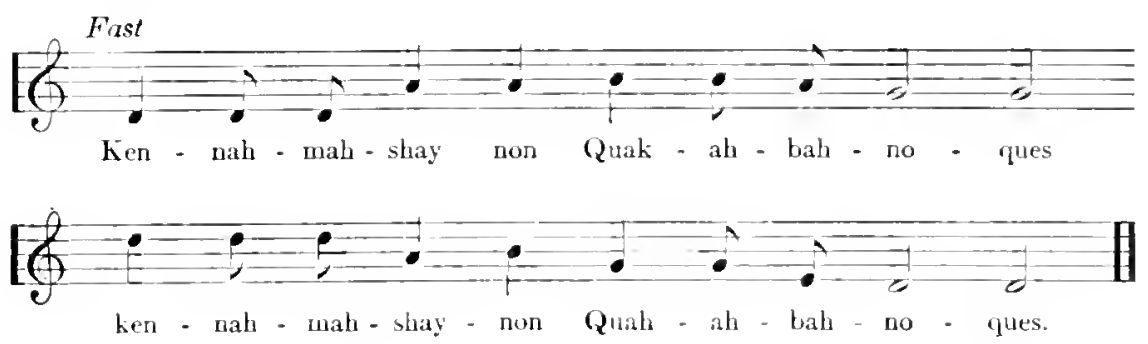

The Forest Choir. It is with deep regret that I find myself mable to set the Ojibway words of this song moler their corresponding notes. One of the oldest Indians of my acopuant- 
ance sang it. His name is Sagachewiose, but he is generally known by the easier, less impressire name of Clark. For a long time he was averse to singing for me, but at length. persuaded by his wife. who has been the Nokomis of the Indian play from the beginning. he sat down before the phonograph and in a businesslike way delivered sixteen songs to its cylinders. Of eourse there was no stopping him till he had done, and at the end I could get no assistance from him in the translations, for it is with diffieulty that he sustains the simplest conversation in English. Some of the Ojibway words are perfectly distinet, others are hopelessly hlurred, but Shingwauk, who renembers the song from his hoyhood, tells me that it is an adderess partly to the singer's human friends, and partly to the birds of the forest. Aeeording to Shingwank, "Listen friends," the singer says, "our neighbors, the birds, are singing. Pleasint are the sounds. Let us sing with them." Then, speaking to the birds, "Listen f'riends; you will enjoy" the sounds we malie."
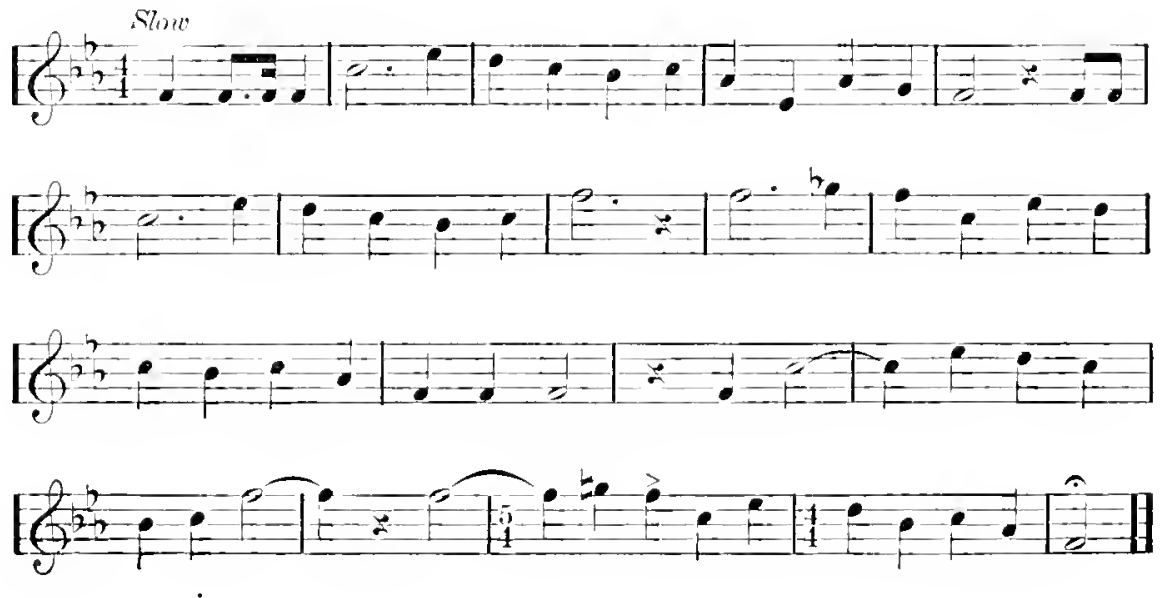
No. 26 (a). The words mean: "What are you looking around here for? I never had a call from you before. I belicve you are coning to court onc of 111 y daughters."

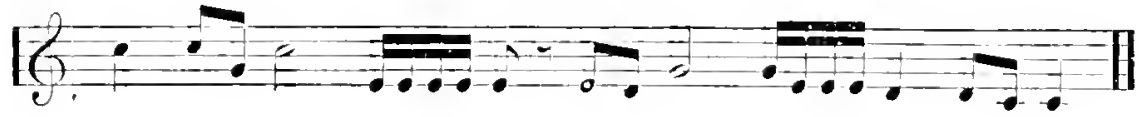

No. 1\% (a). 'To the eye this song seems to be barren of melody, and, reproduced upon the pianoforte, it is undenially dry and monotonous: but, as sung he Tetebahbmume. it is decidedly impressive. The man's rich roice somds to better adrantage in this song than in any other. All whites who bear him sing it are eharmed, and they usually ask for a repetition. 'The charm is moloubtedly due to the quality of' 'Tetebabbundung's voice and the appearance of deep feeling that le manifests in all his rocal work. It is the feeling of the artist, merely: the natural emotion of one who lores music and exults in the beauty of his own tones. 1 am hazamling no sentimental guess here. for the somg is calculated to arouse only laughter or disgust on the part of those who understand it, aceording to their respective eonceptions of humor. It is a ballad, and the story it tells is nulgar to the last degree. There is especial interest to the musician in its conding lorilliantly on a long sustaned high note, contrary to the Indian custom of ending in the depths. 
234 AMERICAN PRIMITIVE MUSIC

Slow

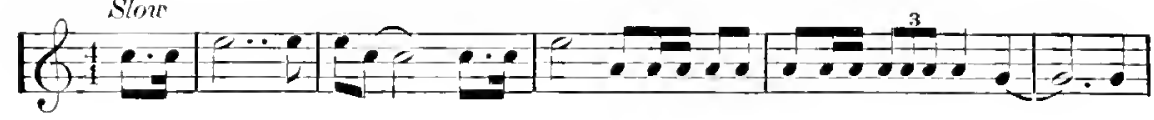

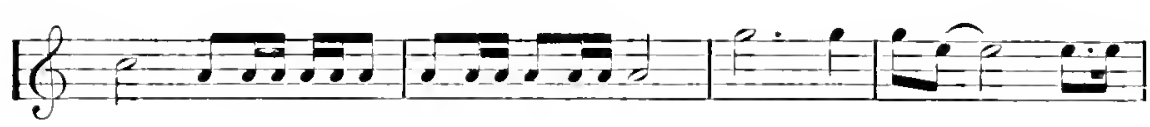

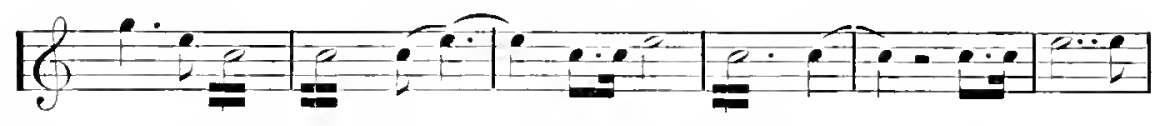

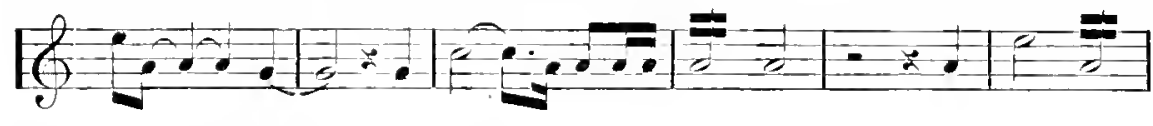
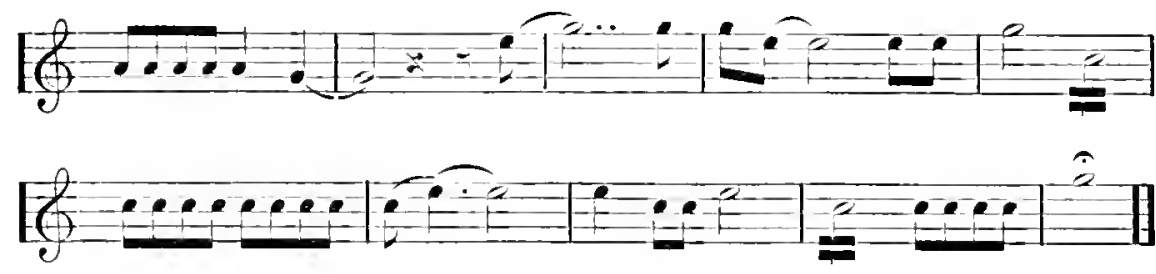

No. $99(d)$. A drinking song. 'The words mean: "I don't think I ought to be drunk; I didn't drink enough; I had only one glass.'

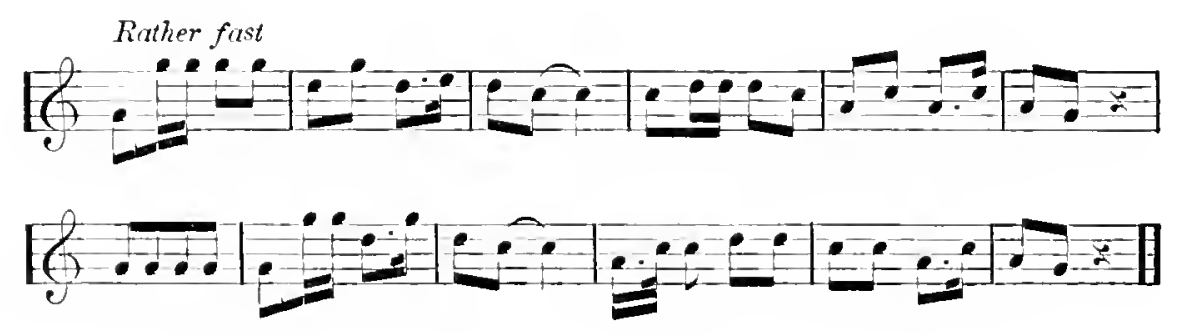


SACRED SONGS.

Civilized man divides his songs into two great categories which are readily distinguishable: sacred and seeular. In general. the sacred song has to do with the church. The line camnot be drawn in exactly the same way when ludian somgs are under disenssion. Any that had to do with religions cercmonies should mudoulderly be classed as sacred: but we have seen that, from the Indian's point of view, certain othere songs were equally sacred. In this group, therefore, 1 inchude not only ceremonial songs and prayers. hut snch hunting songs as appear to have been used as prayers in the old dirys. 'There are other songs of animals that may have been regarderl as sacred, and which even to-day serve for general dances, but as their character is obrionsly open to doubt, they will be found classified by themselves. 
1 Song of Faith. This song and the one that follows were sung by the good pagan, Imniquahumg, of whom some aceount was given in Chapter VI.

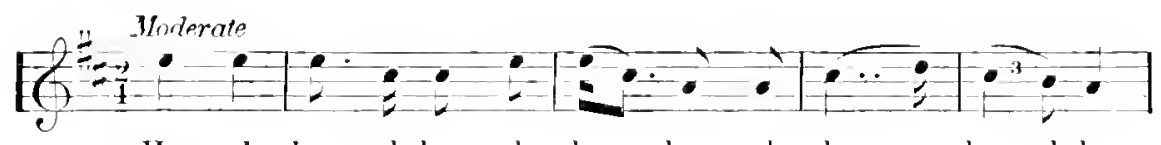

IIey - ab hey - ah bey - ab hey bey - ah ba.... hey - ah ha

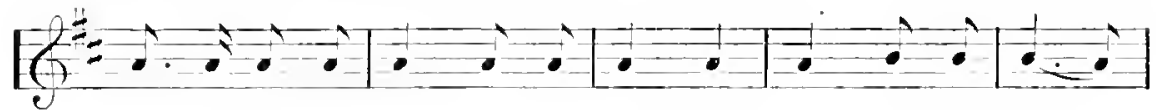
hey - ah hey - ah ba bey - ah bey - ab ha Cn - je - dn.....
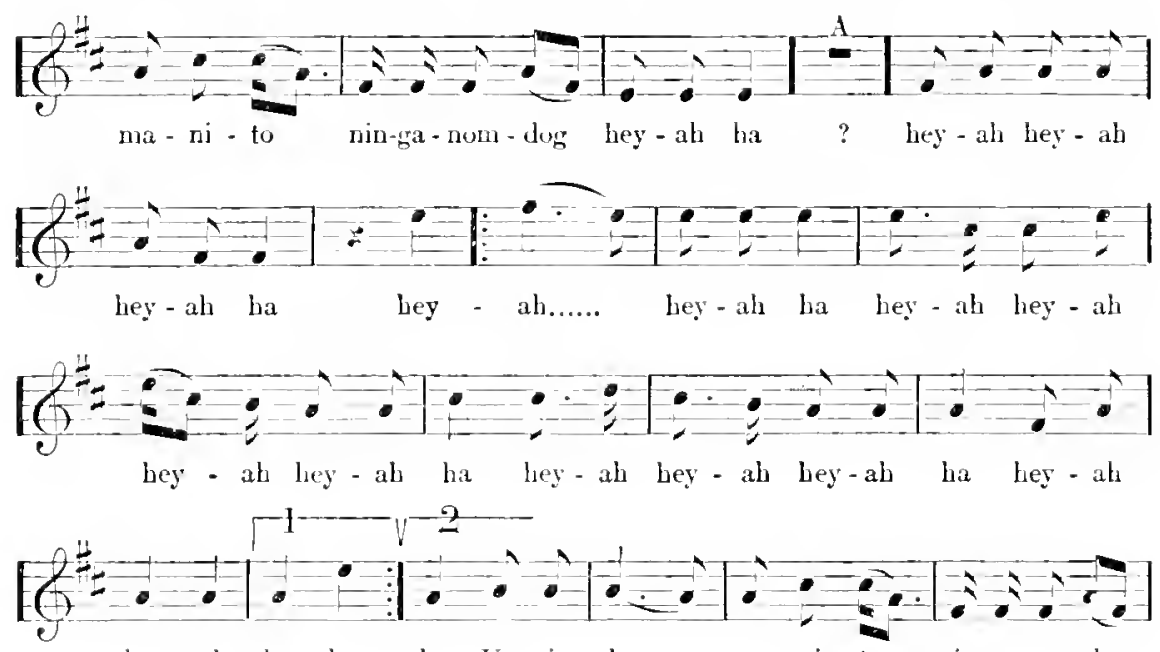
hey - ah ha hey - ha, Ln-je-du..... ma-ni - to nin-ga-nom-dog

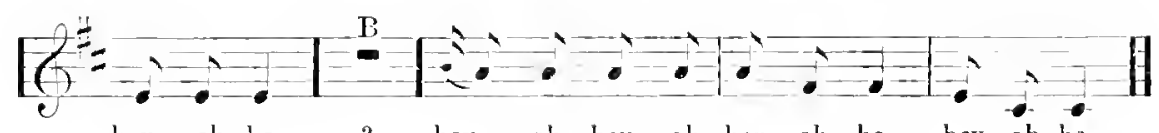
hey - ah ha ? hey - ah hey - ah hey - ah ha hey - ab ha.

A-syllables and notes are doubtul here, and at the corresponding place- $\mathrm{B}$

Translation: Surely the spirit will hear my prayer. Liter- 
ally, will heal me singing; but the deep significance of the verb nogom, to which attention wats called in a previons chapter. justifies the translation. prayer and some being inseparable; and, moreover, every Ojibway to whom these wonds have ben referred for interpretation has indieated in one way or another that prayer is implied.

The Omen. Ojibways tell of at hird larger than the largest eagle that used to be seen in their comitry. It is possible that they have referenee to mone creature now extined, but whatever it was, its appearance under certan conditions was reganded as an omen. For convenience the name of the bird may be translated "eniant ealeles." With that allowance, the song, literally tramslated, meams. "While 1 was erying. the giant eagles lit on the sky." Gxaletly what this implies omly an Indian eould say, and I have fouml none who will hazald more than a frank guess. "Lit on the sky" probably is an expression for the poising of a lirel in mid air, alpparently motionitess. One ludian guess als to the signitieance of the song has it that the anthor was in trouble, either personal or tribal, for he may have heen a chicf in doubt whethere le slould lead his people to war: that, in his grefet, he songht for an onen to guide him and fomel it in the appeanance of the ereat birds. In such case he would likely sibge the song to his people as a preluce to anmonucing what he deer from the omen. Another ludian has told me that in the old days this song was simg on the eve of battle. the inference being that the appearance of the birds was a sign of victory. 

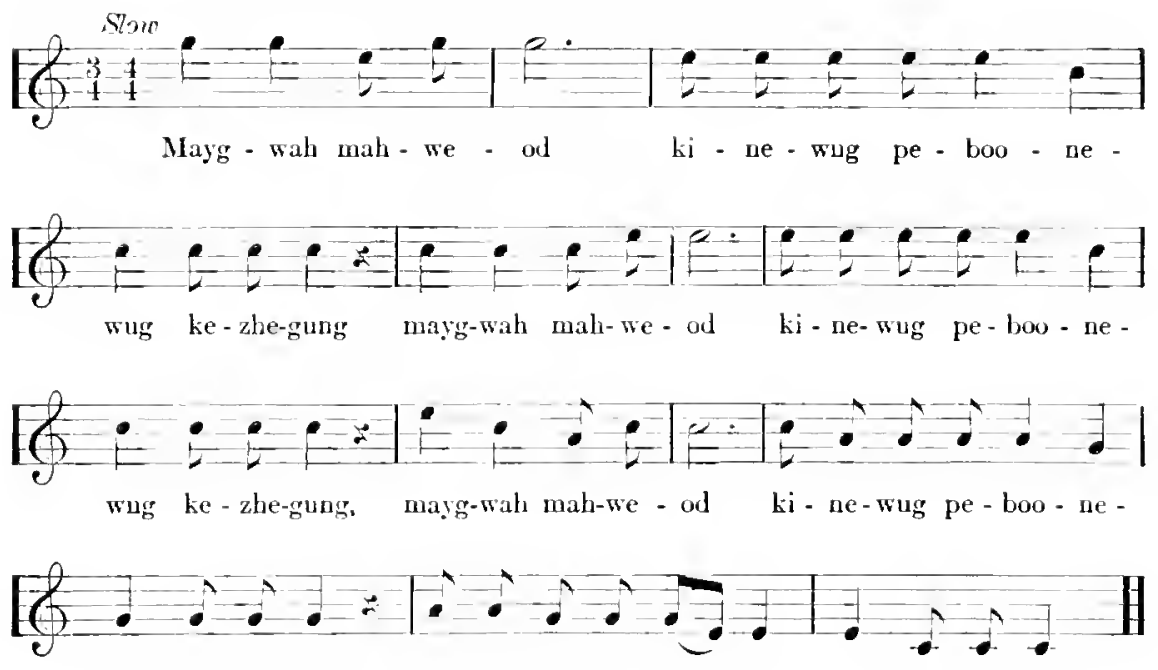

wug he-zhe-gung li - ne-wug pe - boo - ne - wug ke-zhe-gung.

A Song of Trust. No comment is required upon the words of this song which, translated literally, give an unmistakable expression of the singer's faith; but attention may be called to the fact that the significant words are interrupted by meaningless syllables. My inference is that, crude though the melody is, the Indian had a definite conception of its form to which his significant words could not be adjusted; therefore, after the word manito, spirit, he injects ayah hey to fill out the musical phrase and then proceeds with the statement of his ereed. 

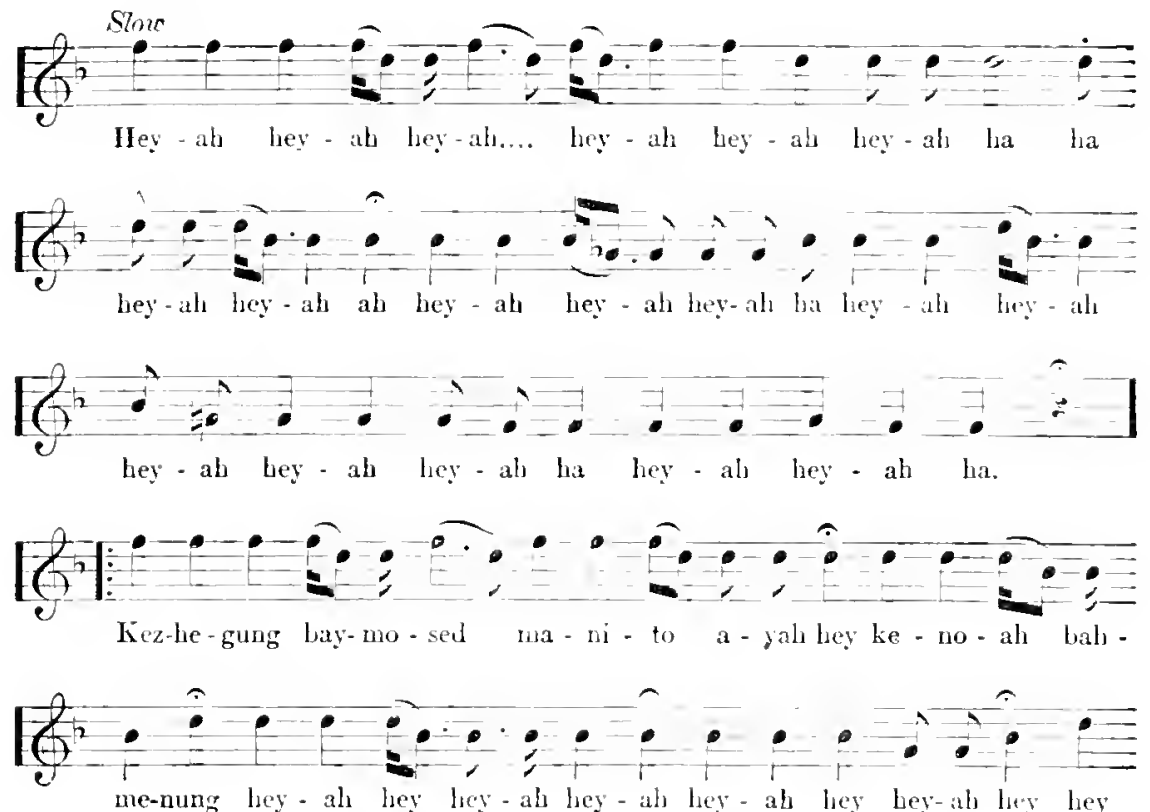
me-nung hey - ah hey hey - ah hey - ah hey - ah hey bey-ah liey liey

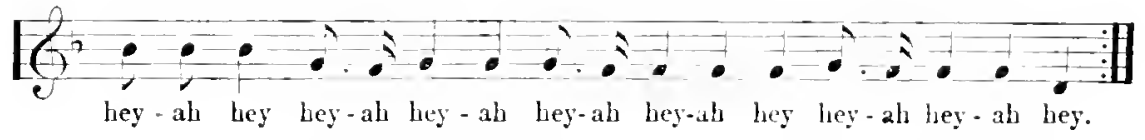

'Translation: The spirit walking in the sky takes care of us.

The Morning Star. Among the ceremonies of the ancient Ojibways was one that took place at daybreak and is often referred to as the "Moming Star." I have not come upon anybody who eonld deseribe the ceremony, hut MIrs. Silgachewiose, who is remarkably well versed in lndian lore, and an adept in everything pertaining to the ancient mode of life, assures me that this song was an important feature of the cere- 
mony, and that the words here giren were the ones nsed in it. 'The civilized Ojibways retain the melody and sing all mamer of words to it. 'The tune ocenrs several times on my phonographic eylinders, and no two sets of worls are alike.
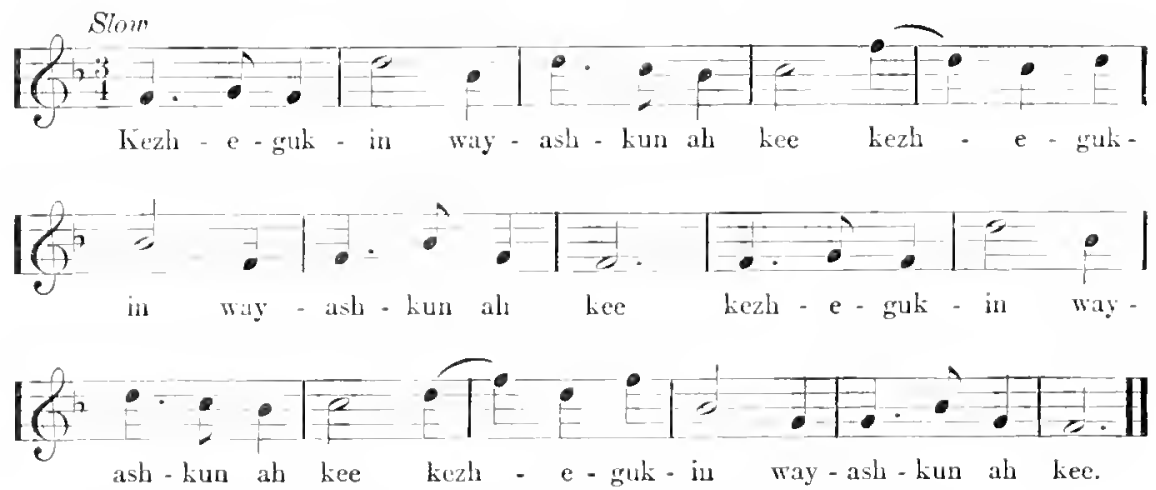

Translation: when it is day the earth is illmminated.

All Birds Follow Me. The title is a translation of the text and convers all I know with eertainty almont the song sare that it is widely popular. Melodically it is interesting on accomnt of the apparent lack of relationship between the main part of the song and the ending. I have heard it at least one humbed times and have wonkered often what tonal instinct it was that leal the singer merringly baek to the initial tone after he had come to the end. Not only does mo singer erer fail to hit the first tone spluarely in a repetition, but every singer chops a connt firom the fonth measure, as inclicated in the musical text. 'This appears to be one of the ancient religious, or mystical songs, the full significance of which has been forgotten. 


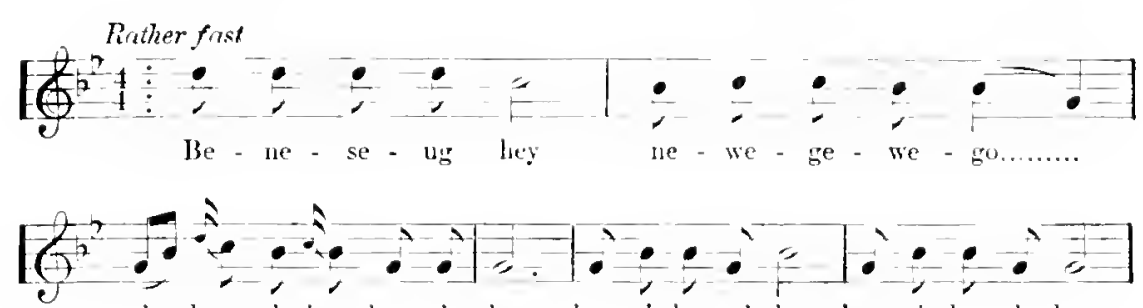
ab hey-ah hey bey-ah ha bey-ah hey-ah ha bey-ah hey-ah ha

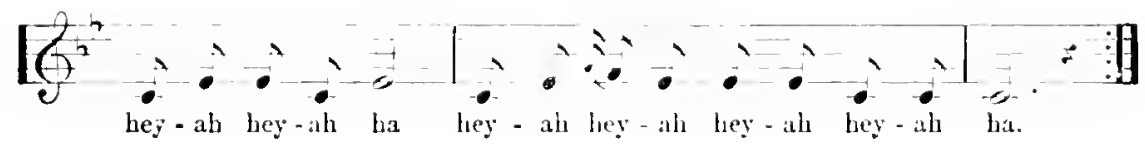

Wabeno Song Cycle. There are three classes of mystery men among the Ojibways, of which one is known as the Wabeno. W. J. Hoffman, writing on the "Grand Medicine Society" of the Ojibway, in the serenth annual report of the Burean of Ethonologr, has this, among other things, to say of the Wabeuo: "The term has been explained by various intelligent Indians as signifying 'Men of the dawn.' 'Hastern men, ete. 'Their profession is not thoroughly understood, and their number is so extremely limited that lut little information respecting them can be obtained. . . . From personal investigation it has been aseertained that a Wabeno does not aflihiate with others of his class so as to eonstitute a soeiety, but indulges his pretensions individually. A Wabeno is primarily prompted by dreams or visions which may oceur during his youtl, for which purpose he leaves his village to fast for an indefinite number of days. It is positively aflimed that evil manitous faror his desires, and apart from his general 
routine of furnishing 'hunting medicine,' 'love powders,' etc., he pretends also to praetice medical magic."

During my last summer with the Ojibways I beeame acquainted with an aged $1 \mathrm{r}$ abeno from whom I obtained this cycle of songs and the mnemonic chart which is always used when they are sung. IIe pledged me most solemnly not to disclose his identity, for he was certain that trouble would come to him if I should (lo so. Just what the trouble might be he would not say, but another well informed Indian with whom I talked about Wabenos in general assured me, eontrary to Mr. IIoffman's opinion, that there was a time when

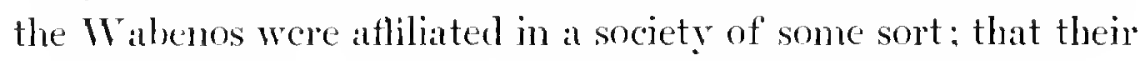
incantations were profound secrets: and that betrayal of them was punishable with death. I asked him what would happen if a $\mathrm{IV}$ abeno should give me his hunting prayers.

"Wrell," he replied gravely. "there are a few Wabenos still left along Lake Superior, and if" such a fact should come to their knowledge I think they would find some means of putting the traitor out of the way."

There may have been some vain imagining on the part of both Indians, possibly they sought to impress the paleface inquirer; but the fact is sufficiently established that these are peculiarly "sacred" songs. 'The man who gave them to me is nominally a Christian, hut he never sets out upon a hunt without secretly saying these prayers to Nanabozho, the mysterious being about whom cluster all those stories that Longfellow told under the Iroquois name, Hiawatha. 'Their phraseology will not appeal to the civilized reader as prayerful, 
but it must be taken into account that the () jibway prayer comprises more than words; the ene is ceremony of some kind. usually, as in this instance, a dance. Altugetluer it is at relignions serviee which, taken as a whole, constitutes a petition, and the songs with their few words ane but imperfect details.

'The Wabeno, with evident relnetanee-it hat taken him weeks to eonsent-gare ne a eopy of his "prayer board." "The original was probalbly drawn upon birch bark, but this wals serawled in pencil and subsequently bumed with a hot iron on two thin eedar slabs. The enotesque figures on the prarep board do not constitute any sont of musical notation. No derice for preserving their tunes was known to the Ojibways. (hasts of this kind serving simply to remind the singer of the words. Xo Indian coukd interpret this board muless he were himself a $\mathrm{VI}^{\mathrm{r}}$ abeno, and the one $\mathbf{l}$ dealt with bad great difficulty in making the matter clear to me. 'The central figure in talch pieture is Nanabozho. Ohserve that he is of gigantic statme als eompared with anmals and humbu beings. Tradition says that carly in the days of the human lance he ealled all the animals and birets together and informed them that thenceforth they must be subjeet to men. I have not been intomed als to what Namabozho tolel his ereatures in detail. but it is fair to presume that he did not base his edict on hostility; for with all the Indian's reputed savalgery. there is deeply ingrained in him a sentimental regard for aninals that is manilesterl at times oklly, and at times with wistom that shames the enlightened paleface. From the Indian's simple point of riew the animal has the same right to life that man bas. It is necessary 


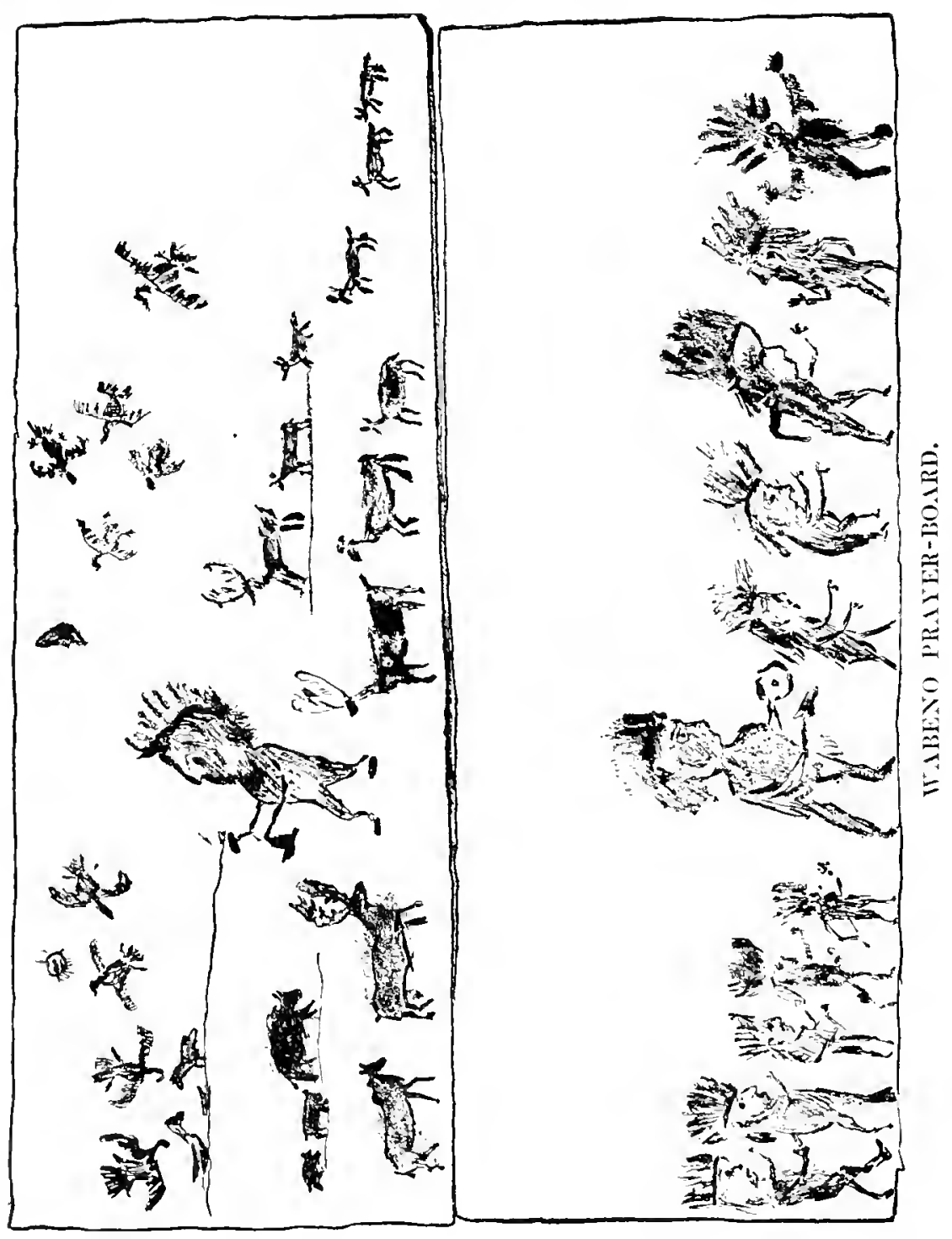


to use the anmal for the subsistence of man, but the animal is salcrified regretfully for this purpose. IIenry tells how the (Ojibways of his day offered a prayer of apology to the bear before going upon the hunt for him. They had ceremonies to propitiate the spirit of eertain animals slain by them. 'The Ojibway of that time and the present does not hunt for' the mere pleasure of killing. 'That he will pursue his game relentlessly, jesolt to any deriece to hure it to ambush, track a frightened deer for days over the treacherous crust and at last knock the exhansted aminal on the lead without a qualm of squeamishness, is true: and it is dombtless equally true that he exults in orercoming the forest beasts, big and little, that the death throbs of his prey awake a responsive thrill of joy in his breast: hut the Ojibway does not kill more than he needs. When he has all that he can earry home, the slaughter caases. It was not the Indian, and it never would have been the Indian, who destroyed the buffalo. It is not the Indian to-day who threaterus to exterminate all the beantiful wild life of the Canadian forests.

But. to return to the prayer board, Namalozho summons the animals and hipds by heating a drom of the kettle type. An indulgent inagination will enable the reader to identify many of the beasts and bireds pictured in the upper half of the

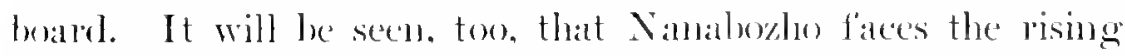
sum. In the lower board alle represented Nallabozho's farorites, the Wabenos, to whom he has given especial power orer

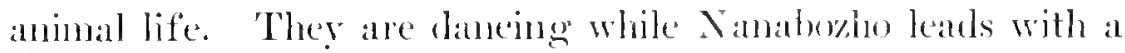
drum of the usual type, the dance and song being a grate- 
ful aeknowledgment of Nanaboho's henerolence. As I muderstand it, this part of the prayer board has direet reference to the fifth song in the cyele.

Malodically these songs are of the slightest value. Owing to the drum strokes by which they were aeeompanied they are rhythmieally distorted, and hal lines eamot be drawn with certainty. Neither the vocal nor clrum scheme of aceents was maintained rigilly in any of the songs. I most interesting feature of the performance was the fact that no drum was used. The Wabeno had instead a pair of "prayer sticks," pieces of cerlar abont eighteen inches long. slightly tapering. whittled smooth and charred Jy fire until they were blaek. With these in his hand he sat before the plonograph and rapped them together while he sang. Some idea of their rhythmic relation, or laek of it, to the song is indicated in the musie text. It first he sang from memory, but he missed his words at the begiming of the thind somg and had to refer to the prayer board. I was mable to see how he contrived to eorrect himself from a eonsultation of the chart, but he did so and then went on steadily to the end.

'The first song is merely a summons: Wrabeno ondass, "Cone, IValuenos." 
VOICE
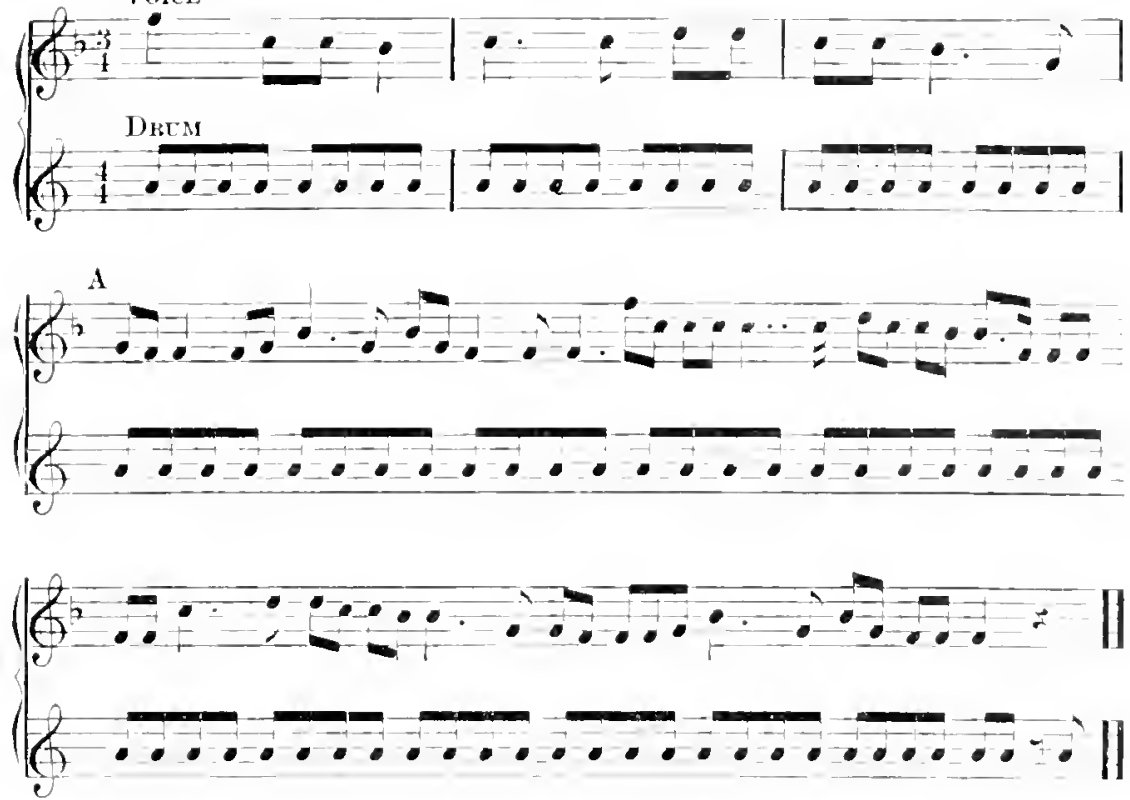

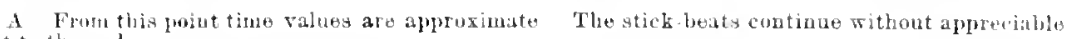
acesint to the end.

In the second the summons is mate more definite: W'abeno ondass gayso licerictindumon, "Cone, Wabenos. I have something to teach you."
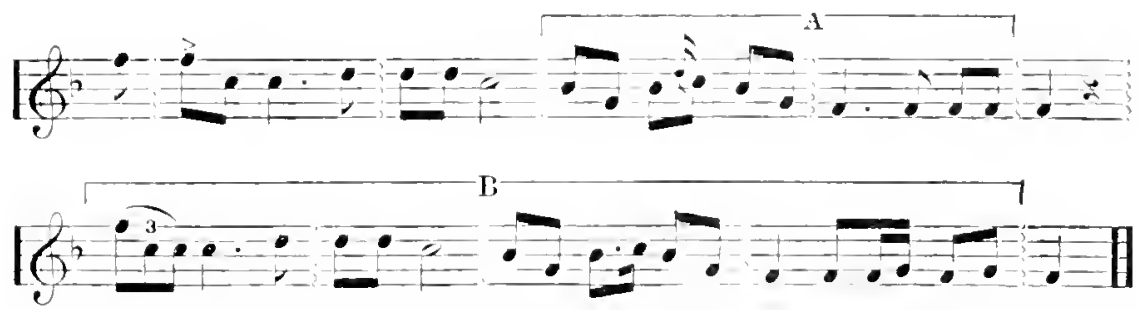

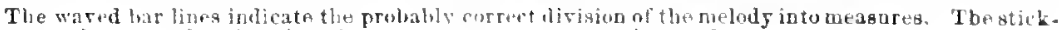
beats caunot becounted at tirst, but there are 14 in section al and $3 \div$ in $\mathrm{l}$. 
The third: Nimbahboog endenukongay ishlooday, "I am waiting for you all by my c:mptire."
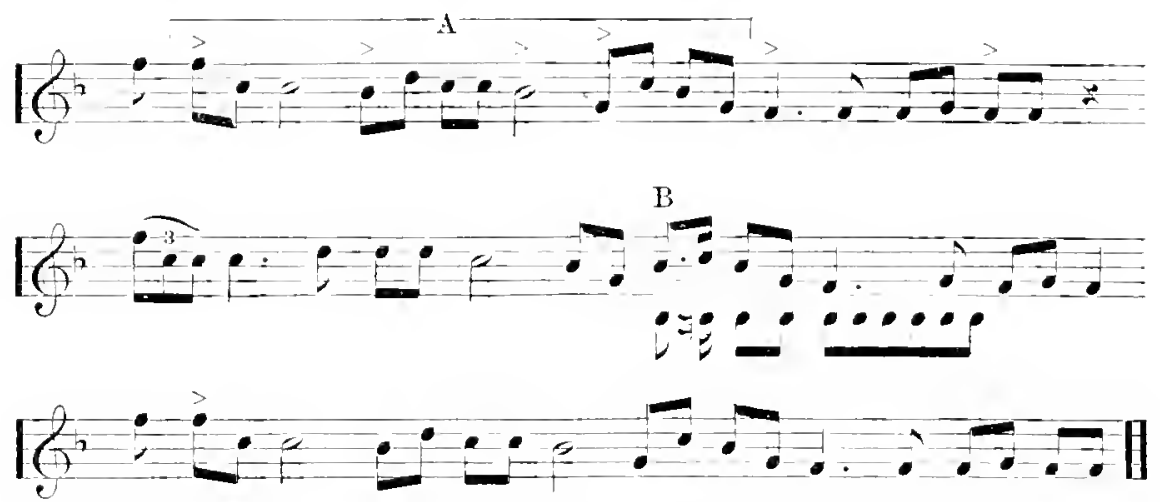

In sretion A there are 24 stick-beats. At $B$ the sticks coincile with the roice fur a moment and then aro beaten fiat agin.

The fourth: Nemlonayego, "I am looking for" you all." This song is sung much fiaster than the preceding three.
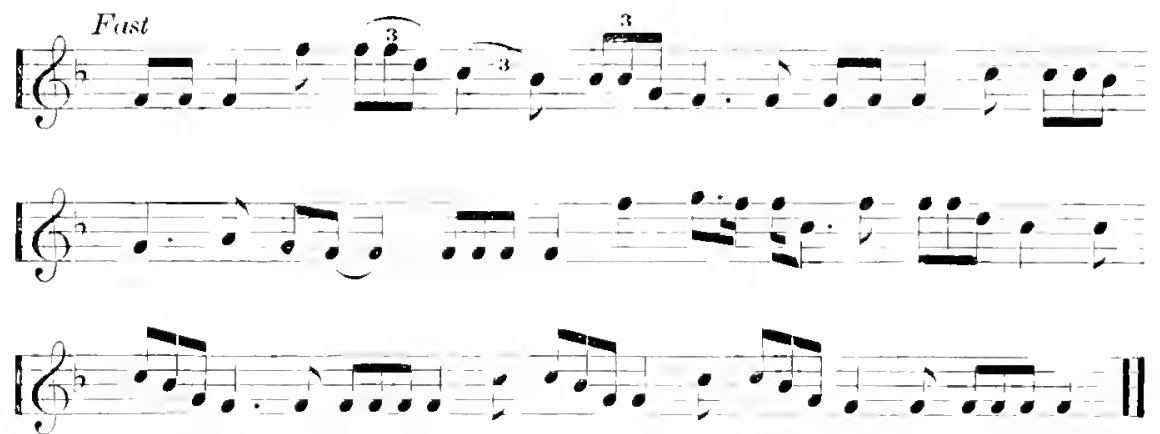

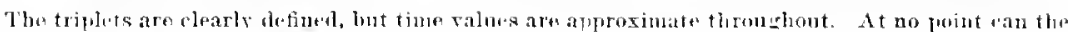

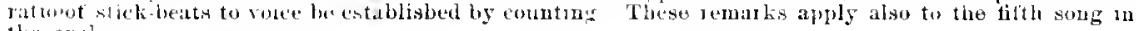
the cycte

The fifth: Nendomogzah mojegisezod gahinohmojelisewug amishinabeg. "Indians rejoice over what they have learned." This was sung at an exceedingly rapid tempo and with an appearance of considerable excitement. 


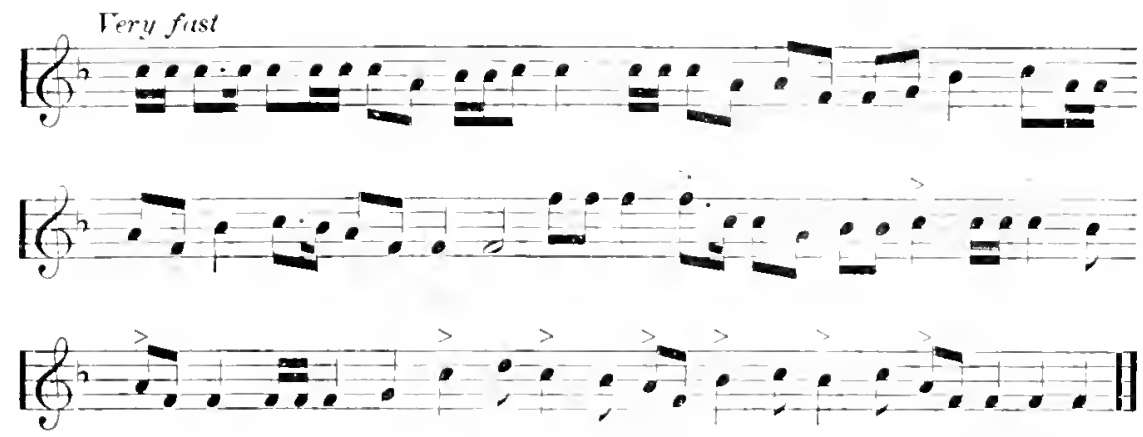

Buffalo Songs. The Indian who sing these for me evidently believed that he was making a great concession and eontributing something of rare inmortance. It had taken him a long timse to decide that he wonkd do so, and at the last moment he threatened to back ont because a young man happened to pass the house. "I don't want any of the yommg tellows to hear these, or know that I sing them," he growled. Assured, at length, that no one was in hearing, he sang, hut refused to dietate the words. Other Indians to whom the evlinders lare been subnitted say that the songs are pravers. They diam to understand the general purport of the songs but are not eertain of all the words. Acerding to Indian interpreters, the first song means: "I hear the treald of the buflalo in the distance; I wait for him in ambush."
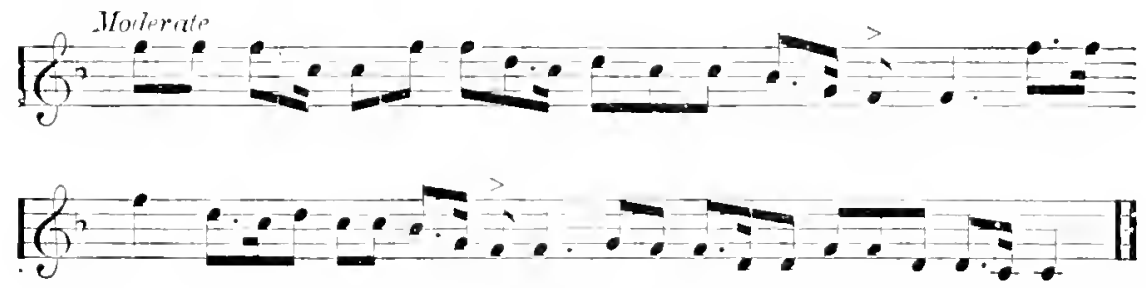
The interpreter explains that this is a prayer that the buffalo may not smell the enemy and turn aside. Second song: "I have found the tracks; all are going around this way; we will go aromul, too, and head them off."

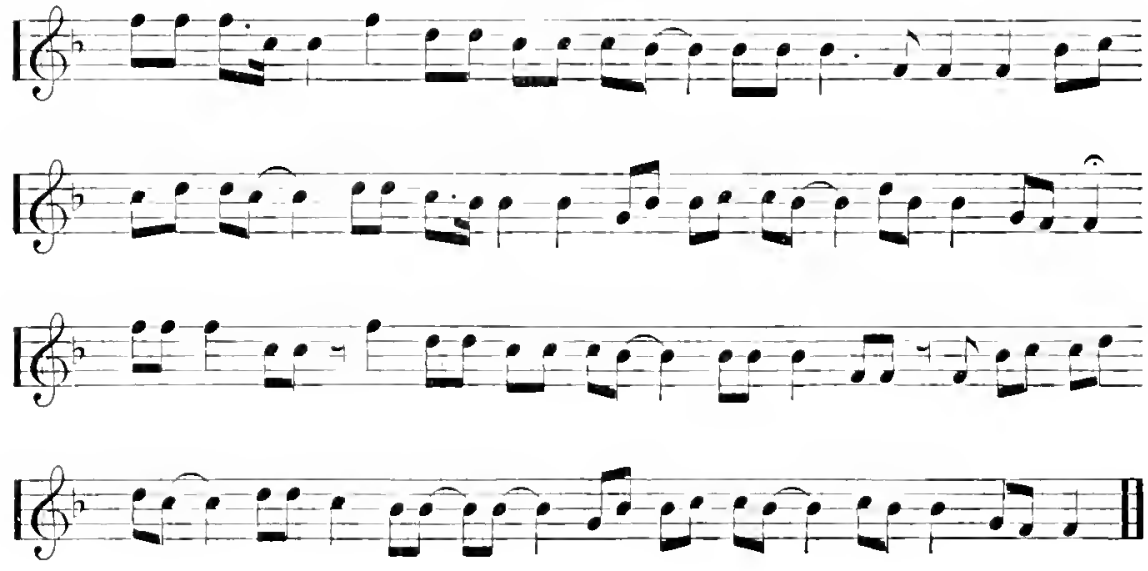

Third song: "I've followed him so far that his tongue is hanging out; he will have to go to the river to drink, and there I will kill him."

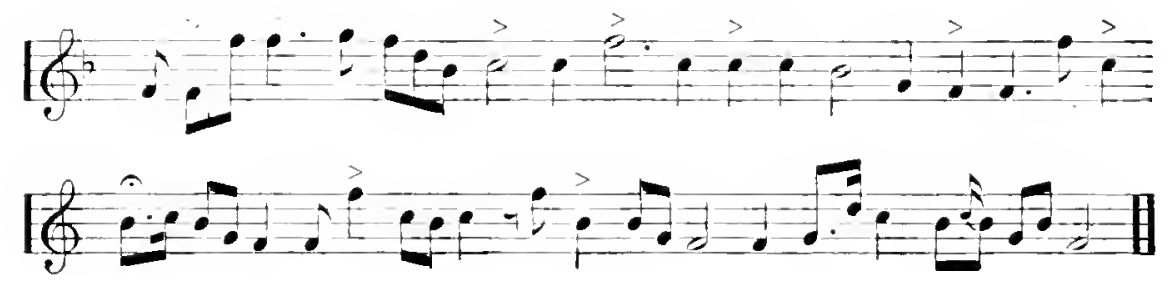


Beater Songs. Although this interesting cyele was smog for me withont any pretension of mystery or reluctance, it is probable that in the old days the songs were regarded als prayers. From our point of view the words have a decidedly secular character. 'The Indian singer was much wrought up as he approached the elimax, and he finished with excitement that was infections. As the songs give a coherent and rather virid description of a beaver hunt, I will treat them als a whole rather than separately. In the first the singer is ealm and sings as slowly as if the song were a hymn. He says: "My fire is burning bright before which I an sitting." That is, he has gone into the forest for bearer and piteded camp near a dam. He waits patiently and confirently for some sign of his game. The seeond song tells us that he hats seen a hearer, but the animal dived quickly and the hunter had a glimpse only of his tail. He philosophically sits down again and resumes lis waiting. In the third, where the words are so blured that they cannot be set down under the notes, he has seen the hearer again. The speed of the song increases, hut "while I was looking he went down and l lost him." The last, very latpid, is a song of trimph. "I got him by the baek of the neck and I threw him into my cinoe."

1. Hoderute

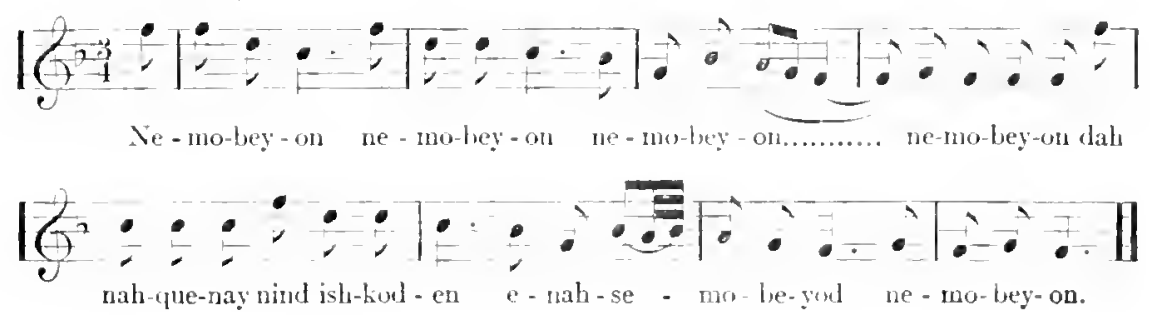


2. Fister Ay - ah yo ki-ne may mo kay - ab may ay - ah yo ki-ne

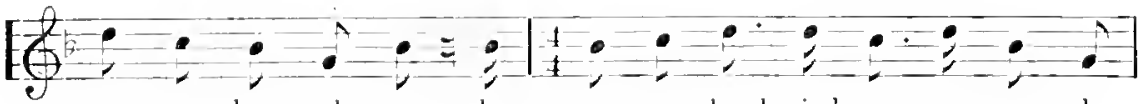
may mo kay - ah may zhegr - wo- mo-kwah nind e - ge - non - day
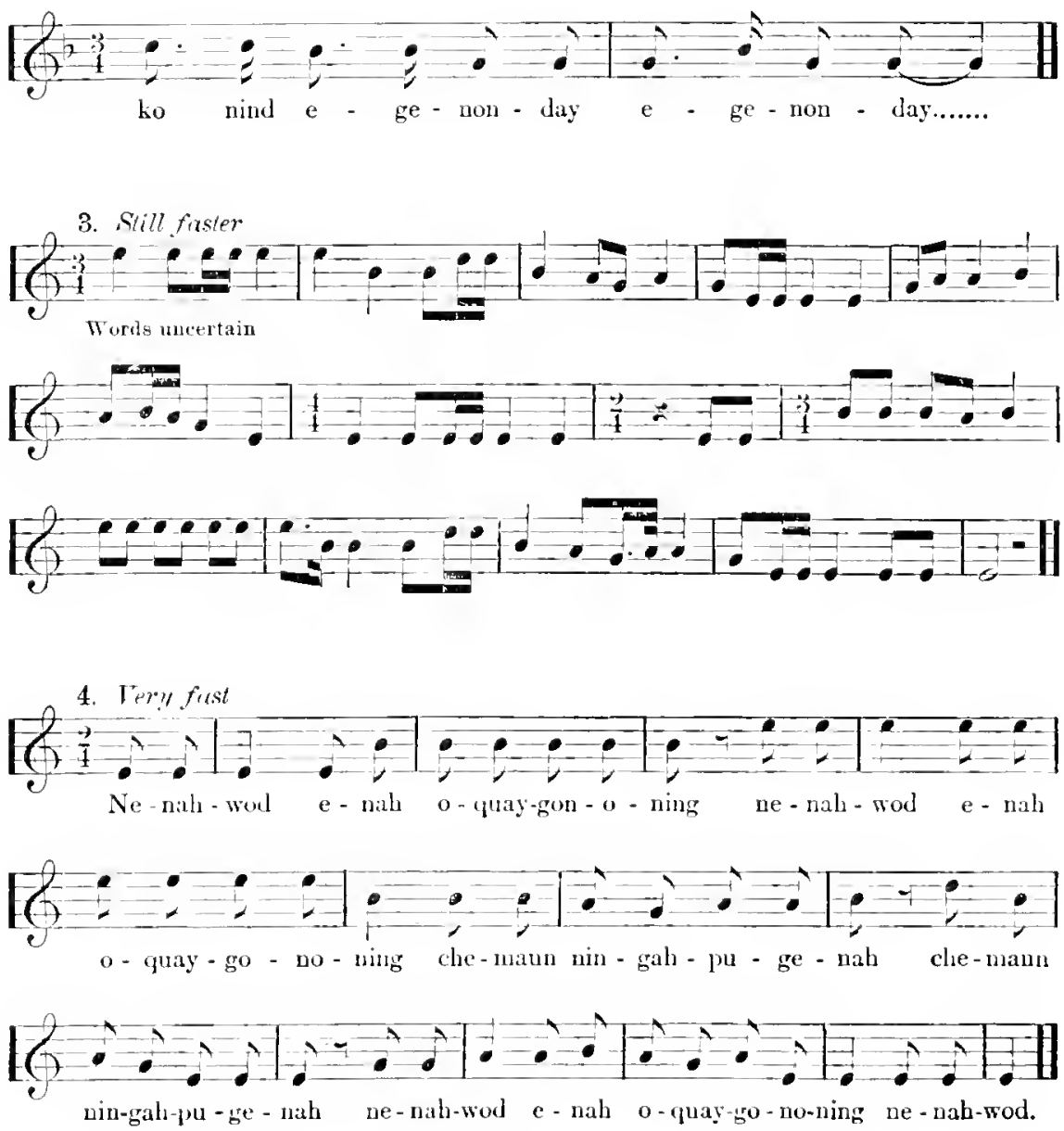


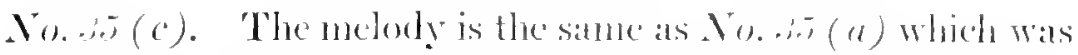

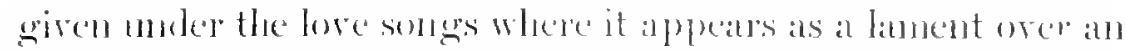

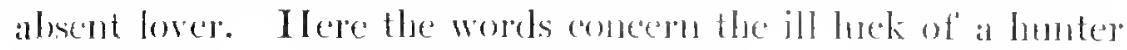
who was on the track of game and missed it. "l eet us be nune calreful," he says; "Ion can see the trateks again."

\section{SONGS OF ANIMALS AXI BIRDS.}

Here are inclided songs almot which there is douht whether there ever had any religions signifieance.

Caribon Dance. Often smug on sorial oceasions. 'The cartbou danee is an old time retigions ceremeny a prayer for plenty. Caribon antlers ale used lo the learlers in the dance, the signifieance of which is derived from the fitet that to the () jibwaty the caribon is the most useful of animals. From it he oldains some of his food, he makes garments from the skin, and he used to turn the antlers into bousehold utensils. An O.jibway proverb bas it that "there is nothing wasted alwout the eariboun." When Christimized Ojibway's give the earibou dance, as they of ten do for the entertainment of themselves or white visitors, they usually dance to this song; but the words ale so framkly lumorous that I infer that the real dance song was some otlede perhatps the earibon song designated No. $3 \%(c)$, the preeise words of which I have heen mable to obtain.

In winter the caribon finds food in a gray moss that grows on the roeks. It appears to be almondant enomght, and the animal browses upon it through the suow, but from the worts of this 
song the eonchusion is inevitable that the moss is not over nutritious.

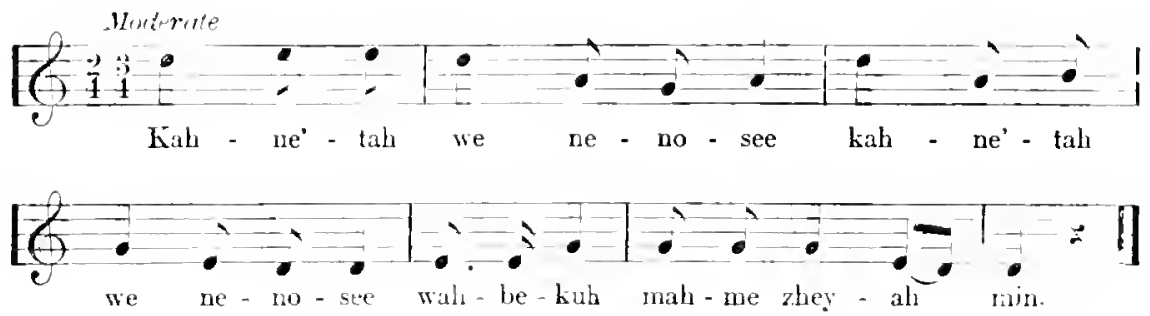

Translation: I seldom grow fat eating this gray moss. Following is another rersion of the same song:

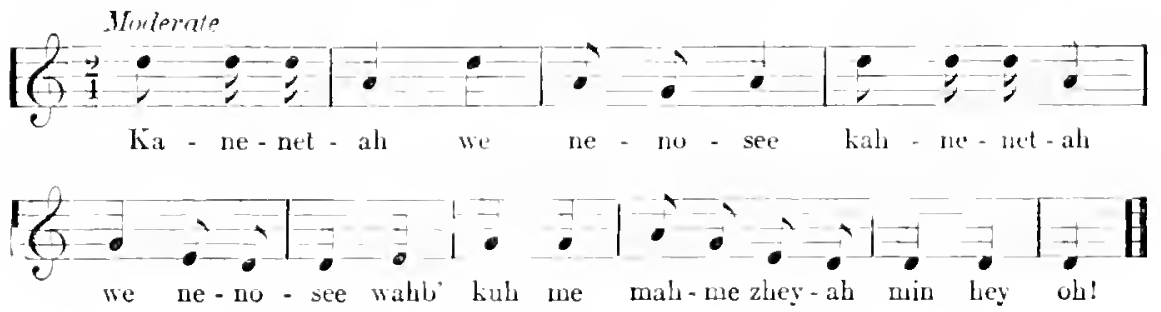

Slinnti Song. The eharacteristie head dress of the Ojibway ennsists in a skmb skin worn as a fillet with two feathers attadhed over the forehead and pointing horizontally in opposite directions. I have often hard this garment referred to an a cap. 'The skmk is taken in traps for the sake of its fur, and this jolly song has to do with the method of taking the catch home. For once the singer does not piee out his jubilation with heyah heyah, but repeats his two words till the melody ends and then begins again with the utmost enthusiasm. Shelog- 
quean baydahbahmug, "I drage the skmoks behind me," means that the trapper hats fomm his traps well tilled on a winter morning. II has oecupied himself ats long as need be in killing and skimming the anmals. Then he takes one skin, or more if necessary, and makes al sted of it, packing the other skins upon it, attaches a thong to the load and proveceds cheerfully homeward drawing his eateh hehind him and, theoretieally at all erents, singing the song as he goes.

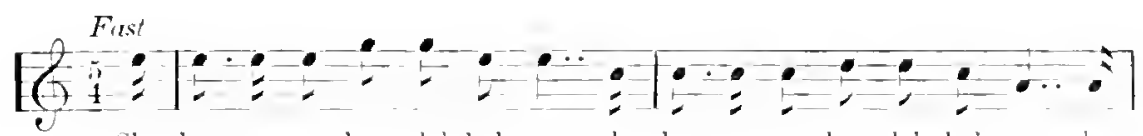

She-kog que - an hay- dah-hah-nug she-hig que-an bay-dah-bah-nug she-

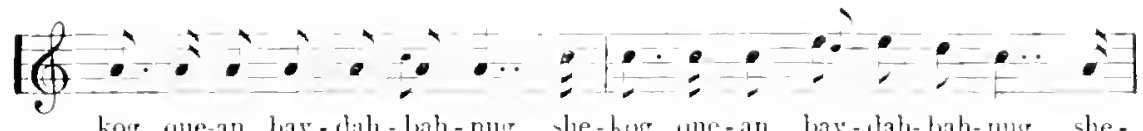

kog gue-an hay-dah-bah-nug she-hig clue-an bay-dah-bah-mag she-

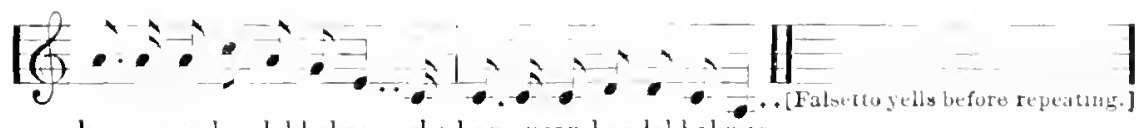

kog quean baydahbabnug she-kog quean baydabbahnug.

No. 2 (c). A earibou song. alluded to in the foregoing; words uncertain. The nueming is said to be: "There he is, right there! I cet us go and look."

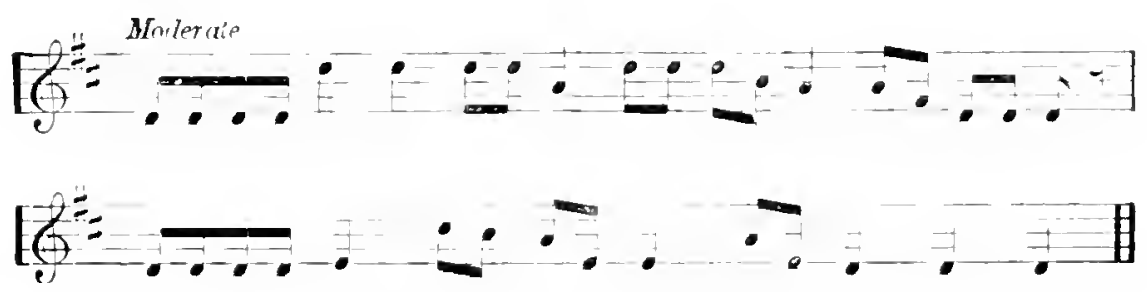


No. 3f (d). A hunting song which the interpreter thus translates: "I shan't be gone long. and when I come back you can help me carry the meat home." 'The interpreter explains further that the singer is courting. and the meat is a love token by which he hopes to gain his sweetheart's faror.
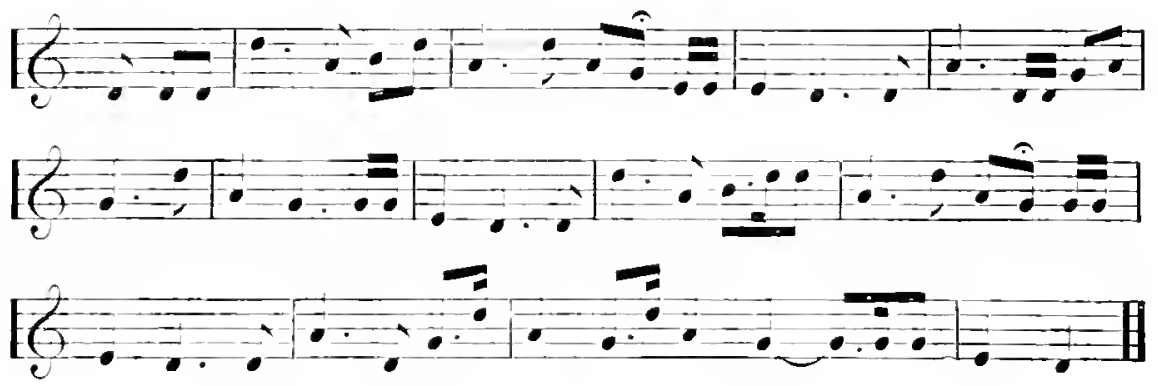

The Witch. An old woman undertook a prolonged fast. In the course of time hunger overcame her will and she asked for food. Her people refused to give it to ber. For two days she pleaded with them. threatening, if they persisted in refusing. to turn herself into an owl and haunt them. At the end of the second day she put her dire threat into execution, flying suddenly in the form of an owl to a neighboring tree where she perched and caused no end of annorance by incessant hooting. 

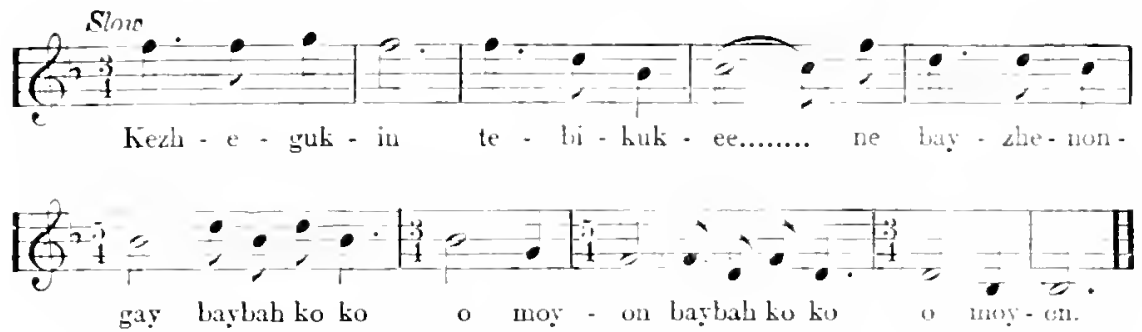

'Translation: By day and night you can heall my solenm roice erying ko! ko!

No. it (c). Another' owh song. 'The interpreter' understands that it is sung by a little boy to his sister. He says the words mean: "It is getting dark: let's go home. See the owl in the way! We'll tell father and he will eome and kill it."

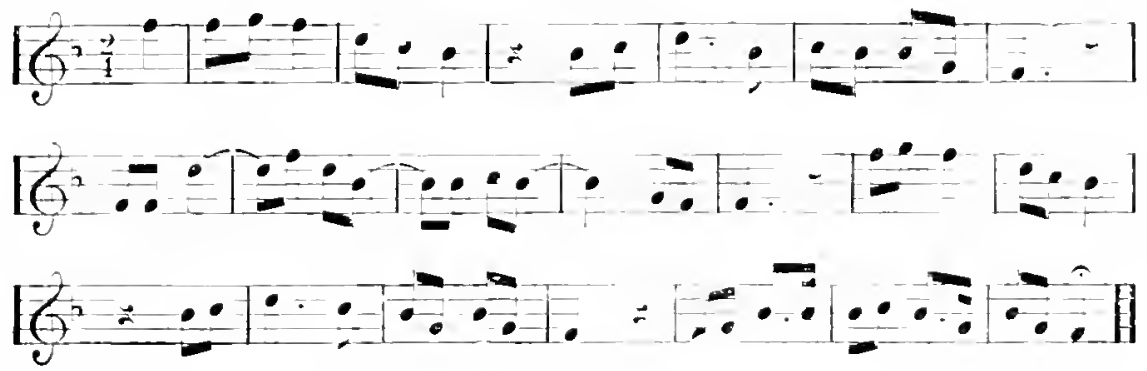

WAR SONGS.

The Braiest. There is only one significant word in this song: C'ngitchedah. It means. the bravest man. By implication it convers the utmost hoarting of which any warrior could 
be eapable. The Indians say that it might be used either as a boast, in whieh case it should be interpreted "I am the bravest of all men," or as a eompliment to another, when the meaning would be, "IIe is the bravest of all men." In a general way, therefore, it is the laudation of a warrior, and the applieation varies with eiremustances.

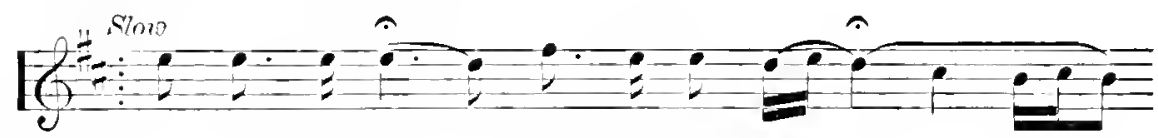

Un - git - ched-ah....... bey - ah hey - ah
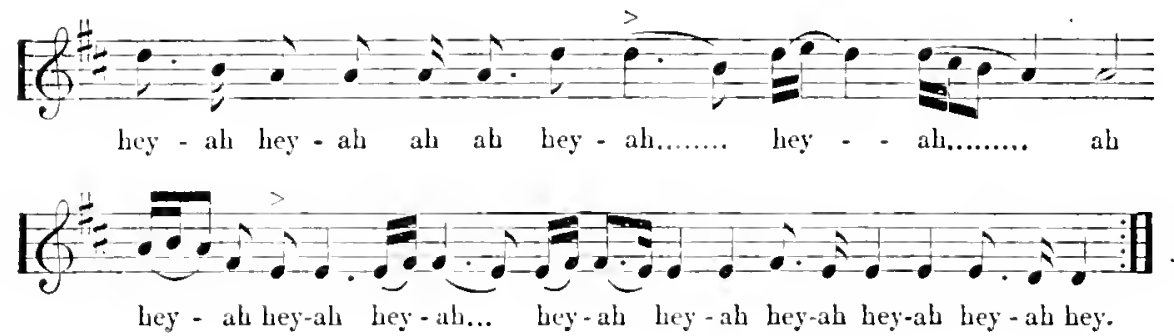

Song of a Cowarl. A party of warriors set forth to meet the enemy. One of the number sneaked away from the eolumn and went back to the place where the women and children were hidden for safety. 'The song is in derision of him. An aged weman tells me that this is only a fragment of the song. She refers, of course, to the words which presumably told what happened to the coward; but she camot remember the story and I have not found anybody who ean supply the missing lines. The song as here given is often sung at soeial gatherings and is very stirring when giren by a large number of men's voiees. 
SONGS AND 'THEIR STORIES

2.59

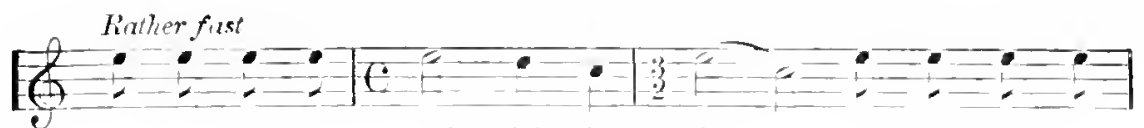

Da-ma-ine-no - wat dah- lie - dur..... da ma - me - no-
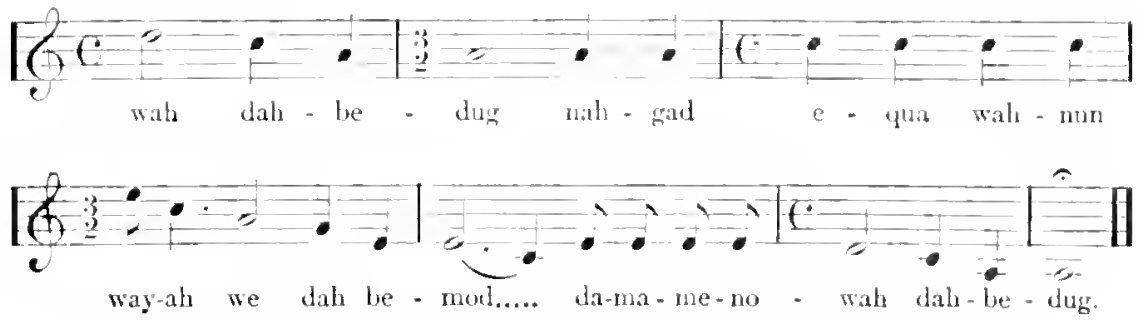

'Translation: See him sitting there among the women.

- Sole Survivor. 'This and the following were smog by a woman, and both are distinctively women's songs. The words as reproduced by the phonograph are not clear and do not seem to agree wholly with the dictated version which is as follows:

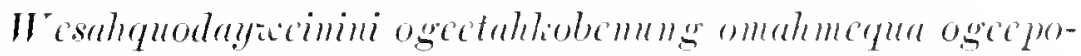

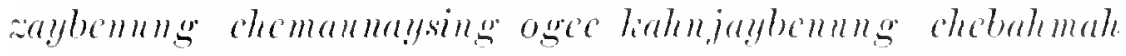
bomonid: All the men were lost: one woman only wats salved; she was tied up in a came. set adrift, and picked up by people of another tribe.
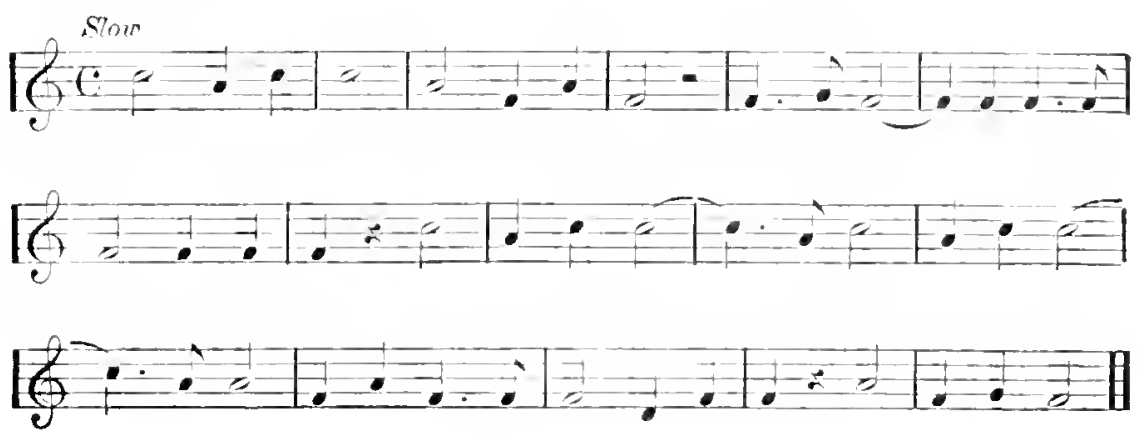
Apprehension. Dietated words: Pahbahmahdaymozun wenemoshayn wan nayndoobune jig loonemahdensahme: I am erying about my sweetheart who is fighting the enemy.
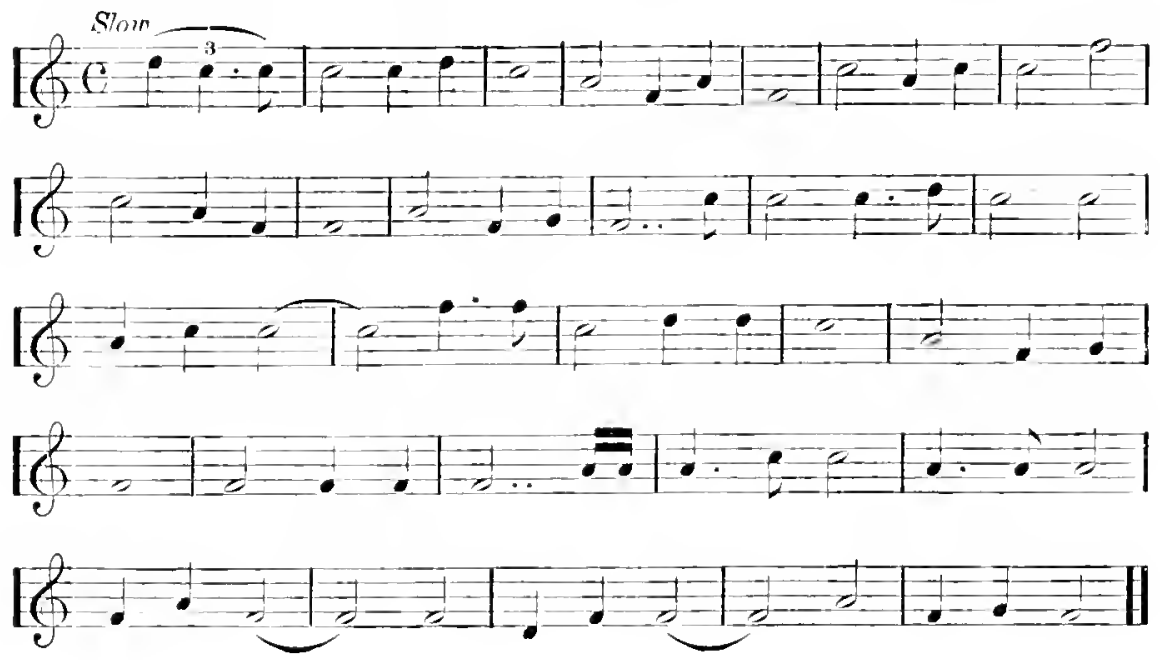

Small-Legs. A hero song of whieh both words and musie undergo variation with diff'erent singers. 'The general eharaeter' of the words, however, is always the same, and they mean: "See that man with the small legs, the son of Always-flying; he is the best among us for he is the bravest." 'The version on the phonograph follows:

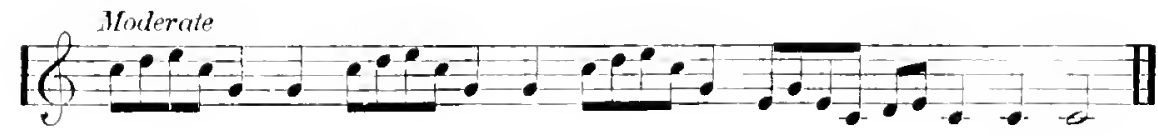

A more frequent version is the following which I never chanced to hear when the phonograph was within reach. 


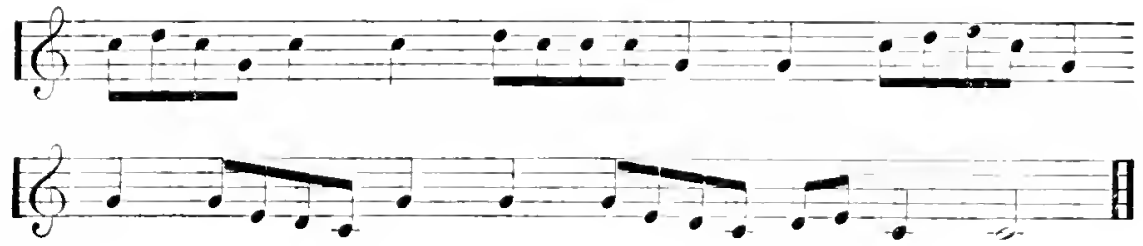

Song of a Scout. The words mean: "I was alone when I found the teepee and feared to attack lest they overpower me; so I waited for the others to come to help me."

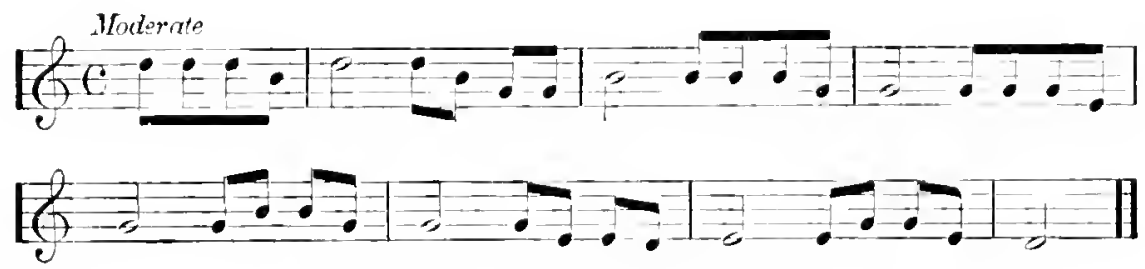

Bcfore the Batle. It is said that this was composed in the time of the great Shingwank when, under his learlership, the Ojibways joined the British in quelling some local disturbance. The chief had been making an adclress to his people af ter which he stepped into his eamoe and sang: "Kahlicenah arahiecngay ne mosho liahwah liahlicenah wahween gay anishinahbeg ne mozho liahiah:" I bid farewell to all nyy people as I go forth to battle." 

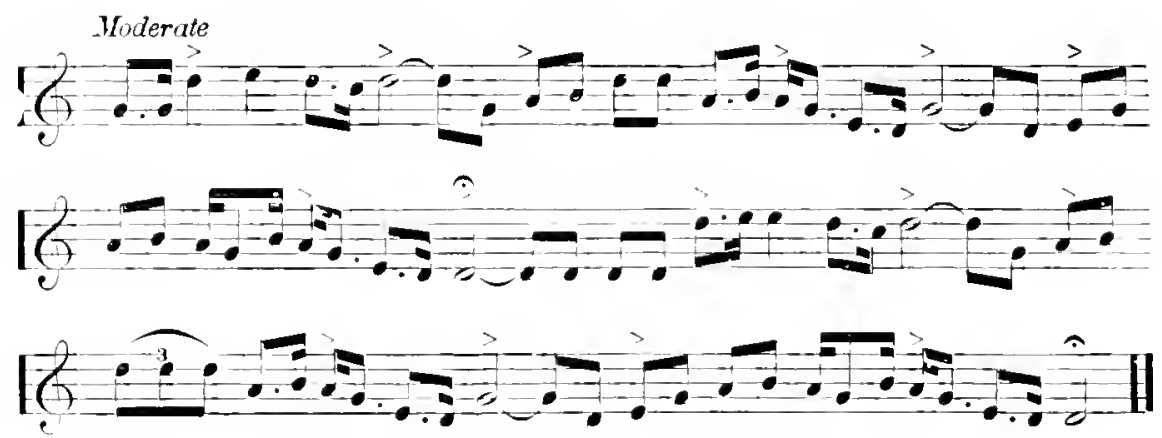

No.5(b). The singer of this song knew no English. Neither from him nor any other could I get further meaning from the words than is convered in a literal translation.

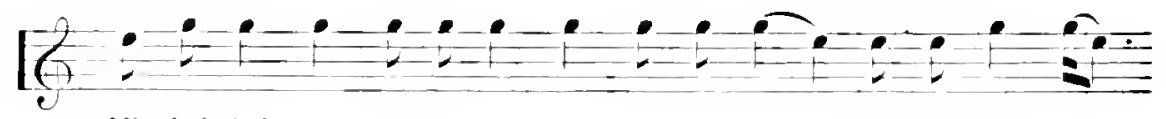

Nim-bah-bah me - wi- ne-go ne - me-quah- nugr... nin-gah-kee - way

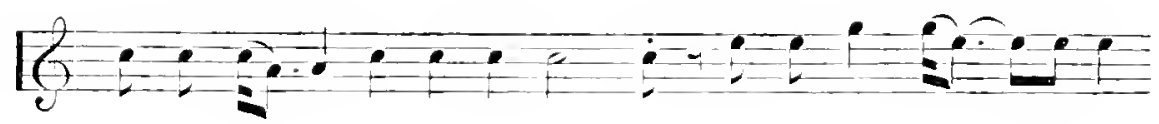
we - ne - go hey - ah bey - ah hey - ah hey - ah ha bev...... ab ha

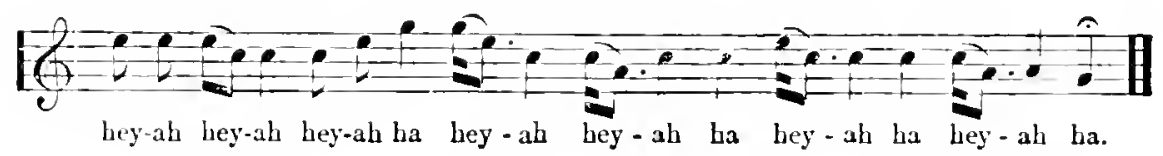

Translation: 'They are taking me away, but my feathers will bring me back again. 
SOXGS OF TRAVli, AN1) IILATII.

Inasmueh as the Ojibways were great trarellers in the old days, and no journey ever was begnn without an appropriate song; and inasmueh as every Indian is supposed to have a death song that he means to sing and cloes sing if possible at the supreme moment, it should follow that this class would be represented numerously in a colleetion. I was surprised and disalppointed while at work in the field that I did not come upon more examples. I was forever asking for death songs, and whenever it seemer possible to jog an Indian's memory, I suggested that he sing a travellers' song. Lntil recently I was mable to account for the scant result of this special search, and $I$ do so now only by theory, but I beliere the theory is somd.

My entact has been in the main necessarily with Indians more or less eivilized. 'The Ojibways are still fond of travel, but habituated now for a generation or two to the restraints of reservation life, they have disearded the trareller's songs with so mmeh else that pertained to the older manner. 'That is, the songs of this type have been forgotten. Futhermore I am almost conrineed that the traveller's song was usually a familiar tune to whieh words were extemporized to suit the occasion. In that ease it would he small wonder that the Ojibray singers failed to give me songs of travel, for, with their keen sense of appropriateness-whith is manifested in sueh a marked degree by the names they give their children and aldopted members of the tribe-it would not oceur to them to invent a set of travel words to a melody which they were accustoned to singing to words of another character. 
The argument is much the same with regard to death songs. As indicated in the foregoing pages, the habit of using a death song persists in a modified fanshion, but the song chosen for the occasion does not appear always to have a special bearing upon the event, or special application to the dying man. So far as I can learn, the Indian who had forethought to his last hour selected a song that should be his and made words for it: and it is hardy supposable that such a man would make public his song while yet he felt that death was afar off. It is probable, too, that in many instances the death song was extemporized, words and music, moler the pressure of the awful oecasion. Such a song would necessanily perish with the individual muless some frichd were near and remembered it. Army officers have told me of hearing death songs when Indians were led to military exeention. From their description it would seem that the words vamuted the victim's comage, his prowess in battle, catalogued his heroic deeds and expressed sarage confidence that in spite of death he would yet exult over his enemies; and musically they must have been little more than a highly dramatic chant. Finding the Ojibways so much more highly developed than other Inclians in most of their song's, I had naturally hoped that in the death songs, incited as they would be by emremmstances of such profonmel import, I should come upon melodics of rare pathos and majesty; and I frankly confess my failure, although the example known as "II iawatha's Death Song," quoted below, is to my mind, the finest aboriginal song that has been preserved.

Whaterer may be the merit of my theory, the fact is that I 
have taken hut one death song that was adnitted to be sueh by the singers. And it seems to me significant that this song. so far as the words go, is not at all of the type that would he expeeted; for it does not boast of the past or tell of eonfidence in the future. On the eontrary, it expresses the glomiest donbt as to what the future has in store. The Indian words eamnot be given exictly, but, according to an interpreter who listened to the phonograph, they mean: "I am dying. but I have my doubts as to whether I shall go where the good spirits are." The melorly follows.

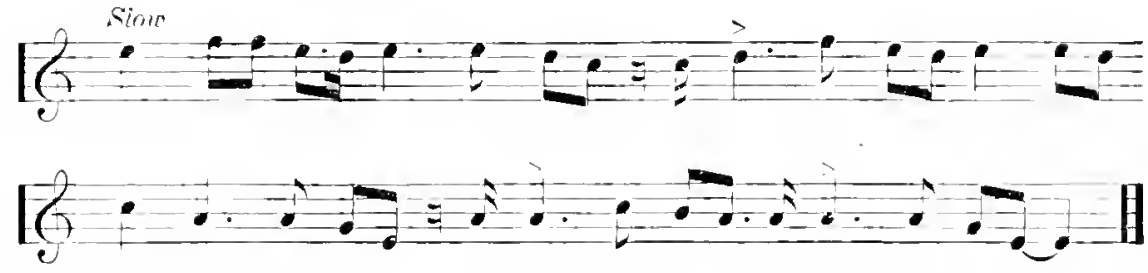

Prince of Wales Somg. Abont forty years ago didward Seventl, King of England, then the P'rinee of Wales, visited Camada. He went, among other platees, to Sarnia, at the southem end of Lake IIuron. At that time the chief of the Ojibways was the great Shingwank who lived at Garden River, some dozen miles east of Sanlt Ste. Marie. Shingwank, selected twenty warriors who saled the length of the lake with lim to meet the prinee. When the party left hone, Shingwank sang this song, and I an told that it was later sung before the Prince at Sarnia. As indicated on a preecding page, the tme was an old war song to which the chief adapted words of his own appropriate to the oeeasion. I heard the song first 
from Mrs. Sagachewiose, a granddaughter of Shingwauk, who remembers well how she stood on shore with all the village and watehed the warriors set forth on their journey I have referred the song to other Indians who were alive at that time, and all remember it. Melodically it is of little value, but its historieal interest makes it worth preserving.
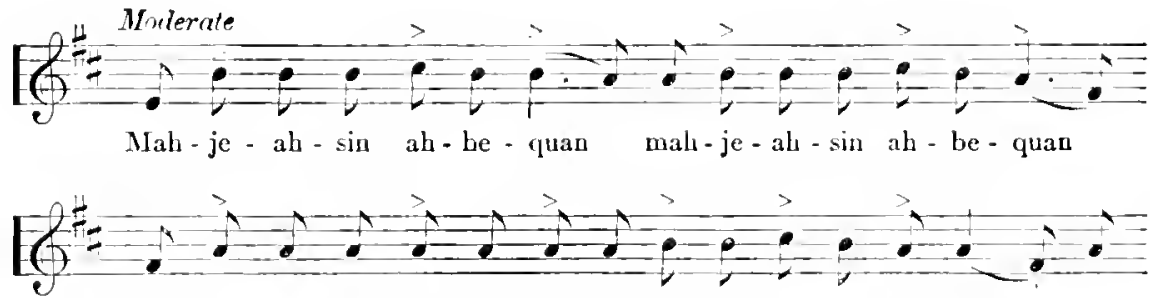
mah - je - ah - sin ah - be-quan me-sum - ab we - po - ze - an..... we -
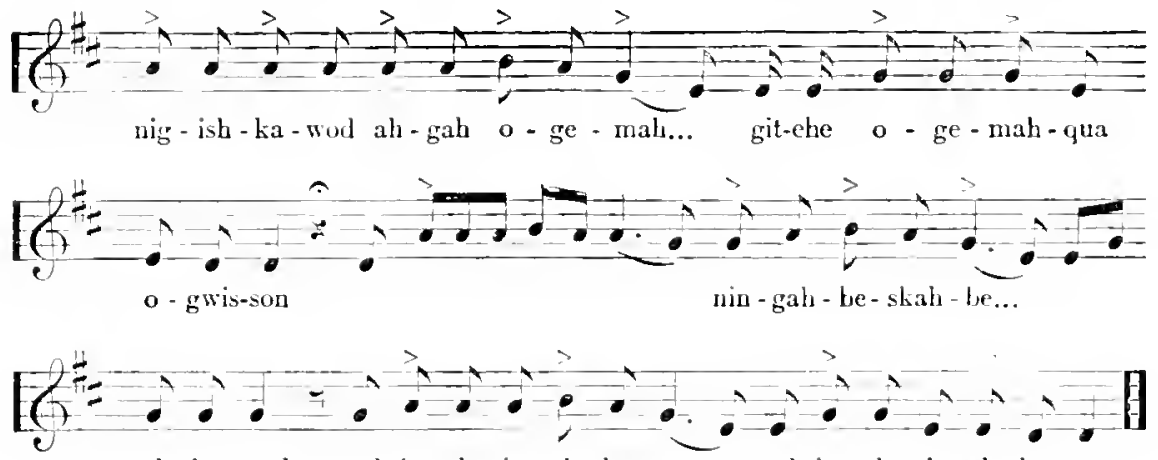
nah-be-quod mah-je-ah-sin ah-be- quan mah-je-ah-sin ah-be-quan.

The words in the above are what I hear from the phonograph, the blank spaces indicating that I cannot distinguish the syllables. Mrs. Sagachewiose dictated the words with erident care, but she dicl not $\operatorname{sing}$ them in the same order. The dictated words and translation follow: 


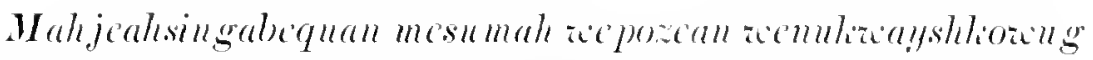
ogema litcheogemahqua ogaisson ningabestahbe nalibequaning bemalsing nahbequod: The ship sails away in whieh I embark to meet the ehief", the great woman-ehief"s son. I shall return in the ship when the ship sails back.

Hiaratha's Death Song. When the Indian play was in process of making, Mr. L. O. Armstrong, who originated it, had the Indians sing many songs for him and selected those that were used in the first performanee. Nost of them, like "My" Bark Canoe." "The Naked Bean," and this one. lave been retained in the play and probably will alwalys figure among its chaming features. The song now to be quoted was chosen as especially suitable for the departure of the prophet. a scene which was so well mamaged when the play was given at Desbarats, Ontario, that it warrants suffieient digression to deseribe it. The play was presented in the open air on the shore of Isake IInon, most of the aetion taking place on a tiny island a few yards from shore. The final seene began with an aldress by IIratatha to his people. He bade them fiarewell, prayed to the four winds, and stepped into his canne. Raising his pardelle in air he said: "Kabcyaymung," (westwand) and immediately the canoe started in a westerly direction. Withont visible means of propulsion the canoe ghted along the gleaning path of the setting sum, for the play was given in the aftermon so that this scene came when the water glowed as with fire. As he traveled thus mysteriously across the lake, the Indian ator 
sang this song, and his fellow actors. left on the island stage, shaded their eyes with their hands and watched his progress. When he hat finished the song, the people on the island repeated it in resonant unison. Then IIiawatha sang it a gain, and by this time he was so far away that his roice was perceptibly fainter. The antiphonal finale was continned until the Indian prophet disappeared in the shadow of the two small islands nearly half a mile distant. It was a wonderfully poetie, impressive scene, realizing, in fair weather, Longefellow's fanciful and glorions deseription of the prophet's departure; and the emotional force of the episode was strongly enhaneed by the noble, dignified strains of this song.

It is not, strictly speaking, a death song, and I am responsible for its somewhat misleading title. I ong after the play had become established I came to have some share in its derelopment. The song was there and I was deeply stirred by it. That it should be called "IIiawatha's Death Song" seemed to me a matter of course, and I so named it when I offered it for publication among the six songs from the play with which I sought to learn whether others would hold Ojibway music in the same estimation that I did. It is a matter of course now that the name should stick, but after I began to study Ojibway musie in earnest I found that originally it was a traveller's song. and that it was always used for the journey from Sault Sainte Marie rapids to the place where Detroit now stands. This, for the Indian in his rude Mackinac boat, was a long royage and justified the solemmity of the parting song. 'The Ojibway word 
for Detroit is Wrateryahtenung. Originally. then, the somg was as follows:

\author{
Mak noo ne nah ningamahiah

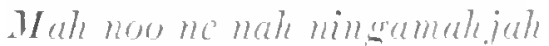 \\ It ahacyahtenung mingate iuh \\ Mah noo ne nahe ningamahiah

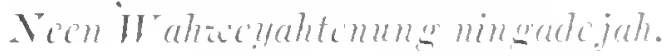

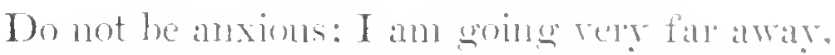

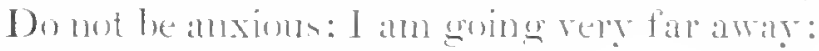

To I ectrit 1 an going.

1)o not be anxious: I am going very far away:

I to Detroit am enome.

'The Indian actors, to arlapt the somg to the purposes of the

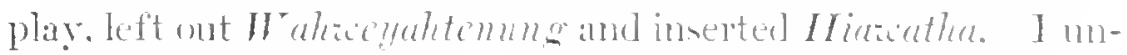
derstand that the fundian who dis the adapting incorpurated more new worls than Hiduathe in the text, and I should be surprised if such were not the ease. for the words as sung today are not. grammatically speaking, good ojibway some carelessness crept in with the mumeroun repetitions of the song called for in the performances of the pling until the present

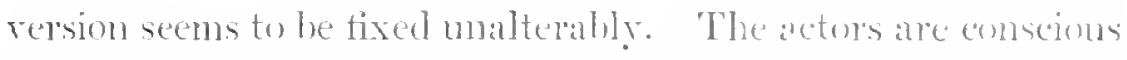
of the false srntax. but, an ome of them ald to me. "What does it matter: the white people do not linow one word f'rom another." Inamuch as I never have heard the somg in its original version. I give here the form which is noed in the play. 

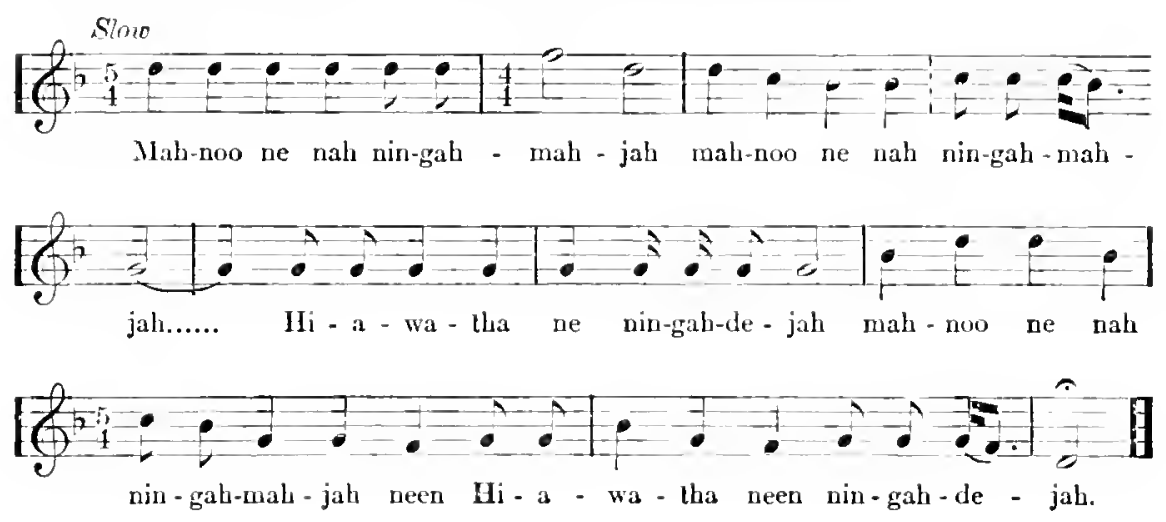

In the harmonized version will be found an interpretation of the words that accords with the idea of the scone in which the song is used. Many persons have remarked upon the fact that the melody is strongly suggestive of the music of the Roman Catholic church service. My own first impression of it was that the song had taken on this color from contact of the Ojibways with Jesuit missionaries, but I have fomd no evidence to support this view. Analysis shows that it is Indian from begimming to end. Its ecclesiastical manner is no more significant of white-man influence than is the "Scotch snap" which occurs repeatedly not only in Ojibway songs, but in the songs of tribes remote from them. It is shallow wislom that would jump to conchusions from such coincidences as these; and at the last analysis this song remains a noble melody, as inclividual as any in the realus of music, that was found among Indians, used hy them alone, utterly neglected and mappreciated by whites until a wandering enthuiast had committed it to print. 


\section{MISCELLANEOL'S ANI TNCHRTAN.}

Vanity. According to some lndians this is supposed to be sung by a roman, but Shingwank interprets it als the utterance of a rain man who has arrayed hinself in his best finery and is annoyed by the inconsiderate crowding of family and neighbors to look at him. It is a popular song. I have heard it from many singers. There are two song's to the words on the phonographic records, and the words reappear to the tume of the Morming Star song.
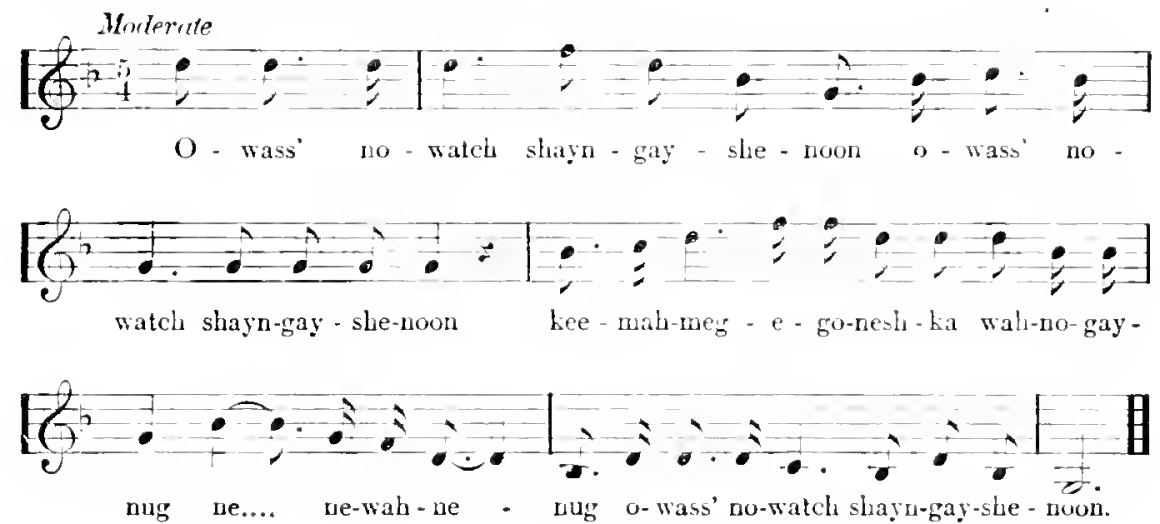

'Translation: Better stand f'urther off' or you will crush my feathers.

Another melody to the same words:
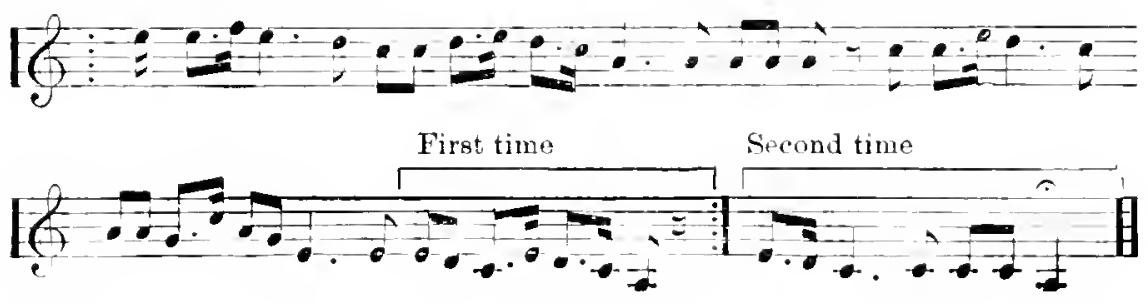
Allusion has been made more than once to the survival of melodies originally associated with eeremonies now obsolete, and the Morning Star song has been instaneed as an example. It may, therefore, be interesting to glance at another set of words to that tune. The following may be found on phonographie record No. 10 (e):

Nememoshayn liahlicelicdud, nchonahsass ningahnahdin lionecmahdah licescnah nencmoshayn liahkeclicdud: My lover says it may be eold to-night, so I'll get my little blanket.

My Big Lorer. 'The words as dietated: Ningitchenenemoshayn dush aid nindenahbun ahbetah tibihnk ne gahgaydalgueshin mindenahbun ningitchenencmoshayn: I have told my big lover that I will meet him at midnight.
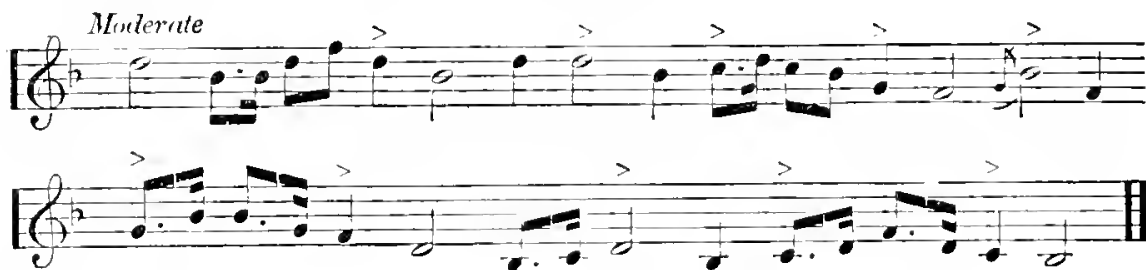

No. 13. Sung by a woman who eovered three quarters of the cylinder with false starts, giggling, and exclamations expressive of extreme embarrassment. Encouraged by another wonan who stood by she at last numbled the following melody and fled, her mind apparently in such disorder that she conld not gather her wits sufficiently to dietate the words whieh are almost wholly inaudible on the cylinder. The woman who stood 
by said they meant: "My lover and I ate going around drinking."

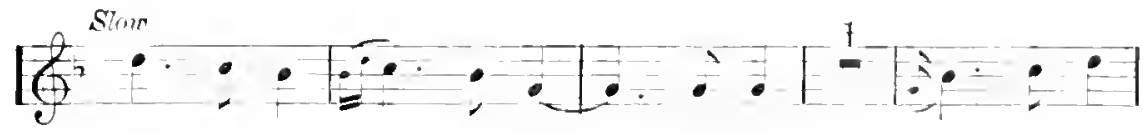

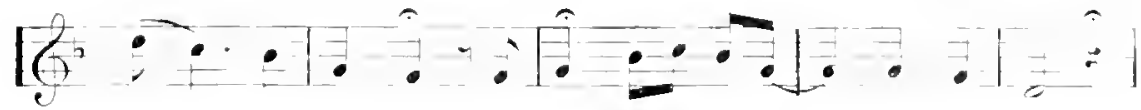

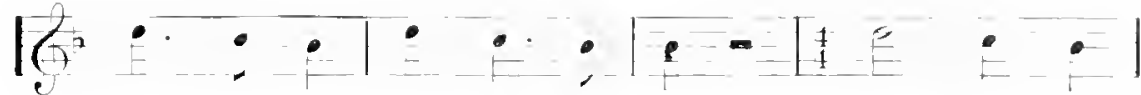

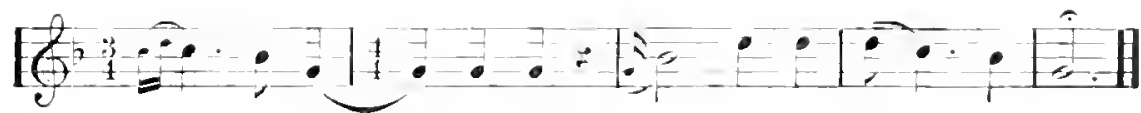

No. 20 (a). Sung to meaningless syllables throughout and often used in this form for dancing. Shingwank says that originally it was a eanoe song. the singer telling of going to meet somebody. presmmably a sweetheart.

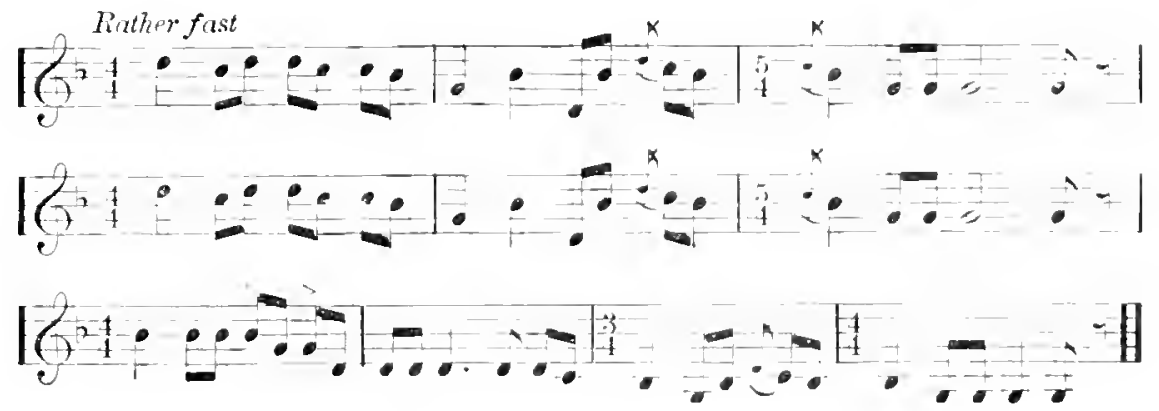


No. Sor (a). Supposed to be a Menominee song, for the words are mitelligible to Ojibways and the singer had lived among the Menominees.
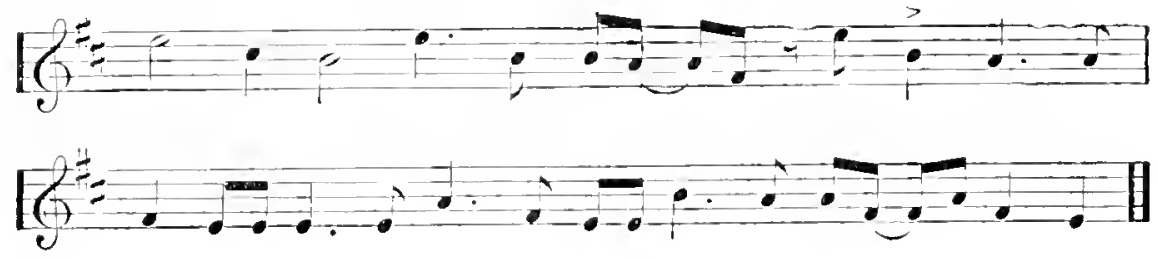

No. 99. (a). 'This is another "Odowah," or Ottawa song. The singer's interpretation of the words is to the effect that a chief"s daughter had two suitors; before setting ont on the warpath each of them ealled and proposed to her; she remarks upon the fact that eaeh of them said identieally the same thing, and she eoncludes, "You ean't believe what the men say."
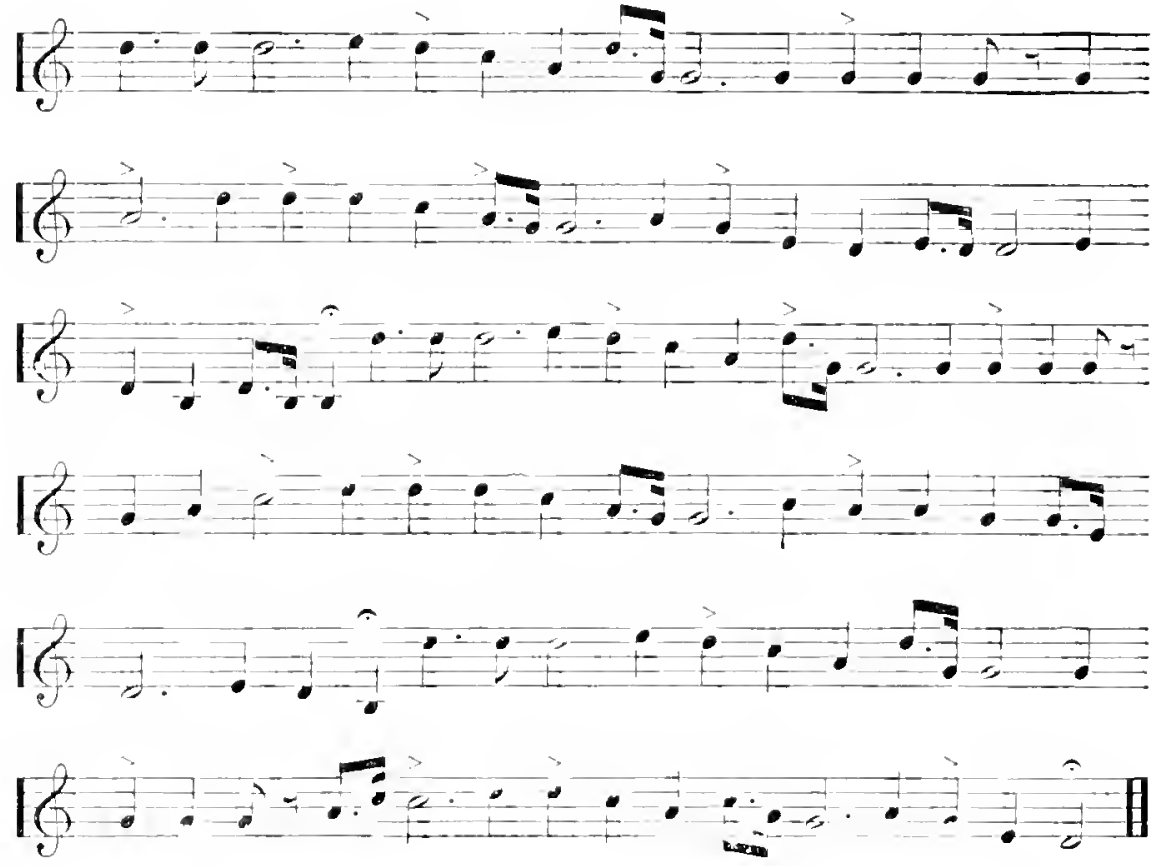
No. 39 (c). 'This was one of a series that I did not venture to intermpt for the purpose of making sure of the words. An Indian who stood by when it was smeg told me afterward that this was the meaning: "A gentleman calls to see the danghter; the mother meets him, and he says, "What are you making eyes at me for? It is your daughter I came to see!"

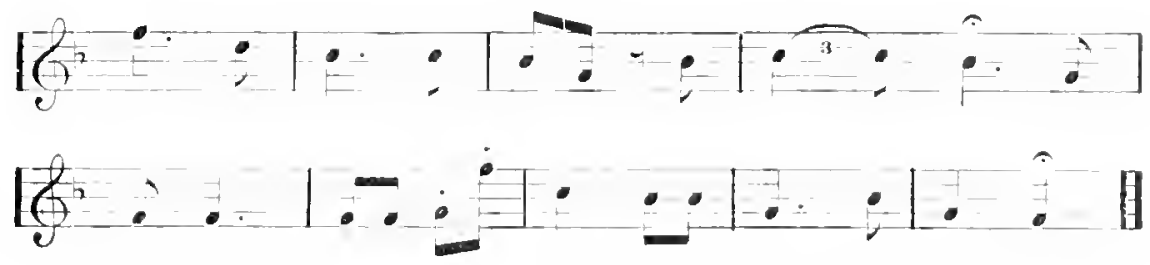

No. 30 (a). Entranslatable.

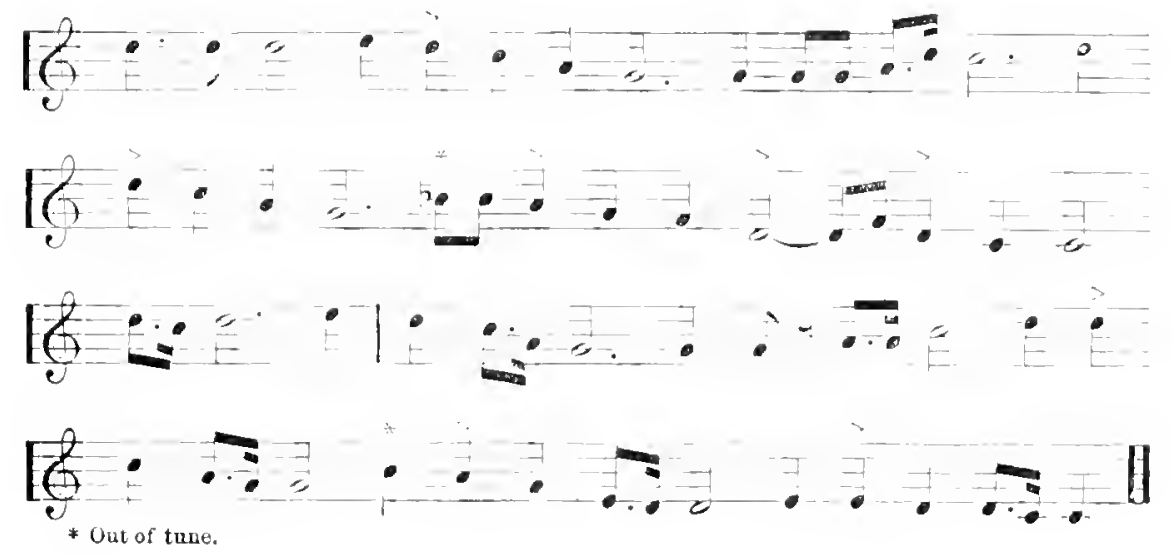


No.34(a). Words indistinguishable.
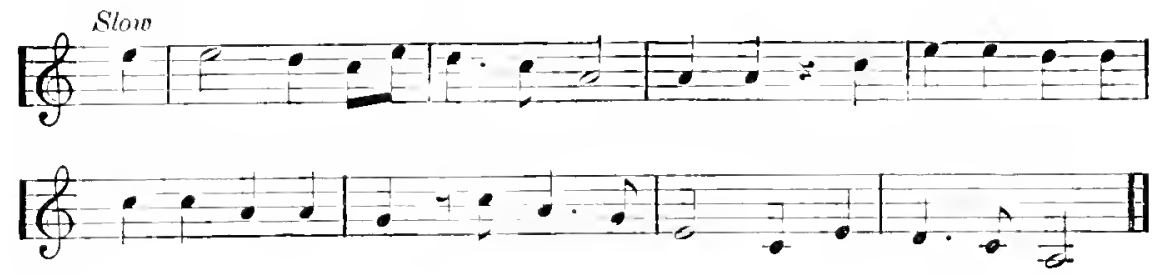

No. 34 (b). Supposed to be a Menominee song.

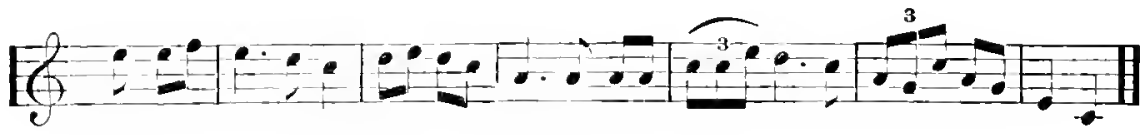

No. 34 (c). An interpreter hears the following words on the cylinder: Kahzin nindelayndevin laheegowanen; I camnot remember what was told to me.

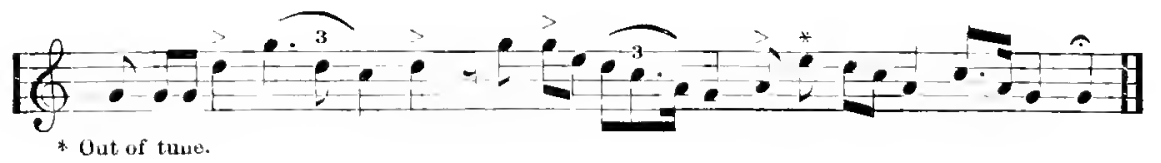

No. $3 \%$ (a). According to Shingwauk, the singer says: "I don't know what to make of this man; I used to think well of him, but he disappointed me." 

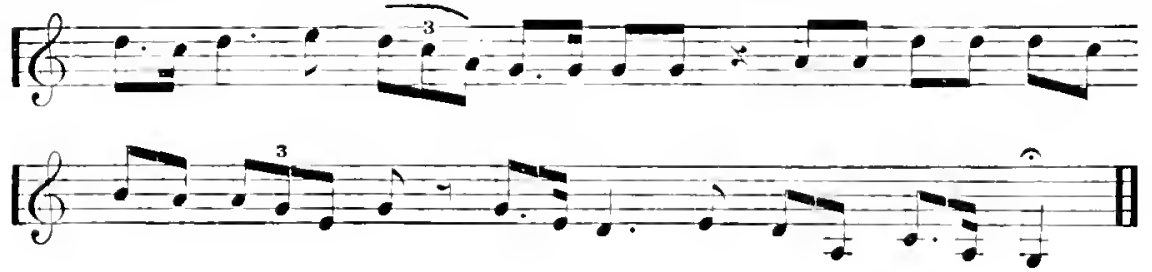

No. er (b). A man has come to a river and wishes to eross. Standing at the edge. he sings, "Come and get me; I've no way of crossing; come and get me."
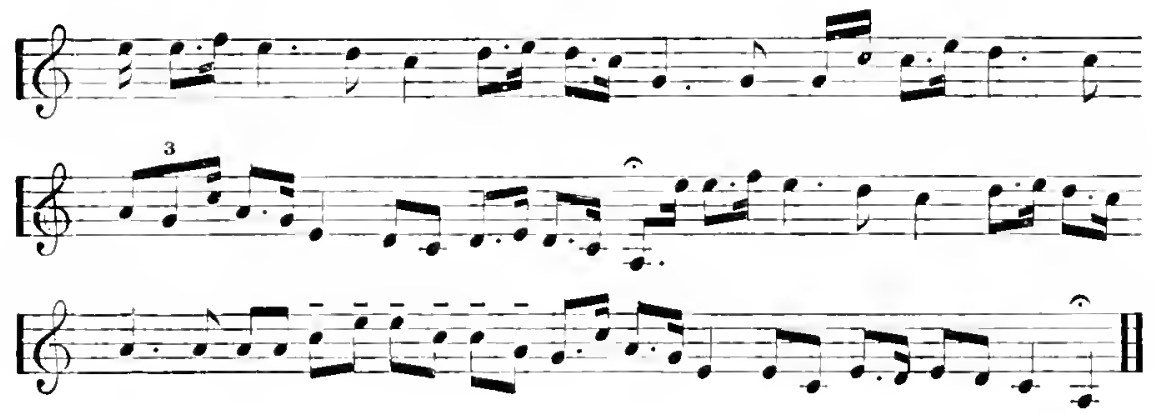

No. $3 r$ (c). Supposed to be a roman's song acensing a faithless lorer of broken promises. Shingwank thus translates the words: "You are walking around trying to remember what you promised, but you ean't remember."
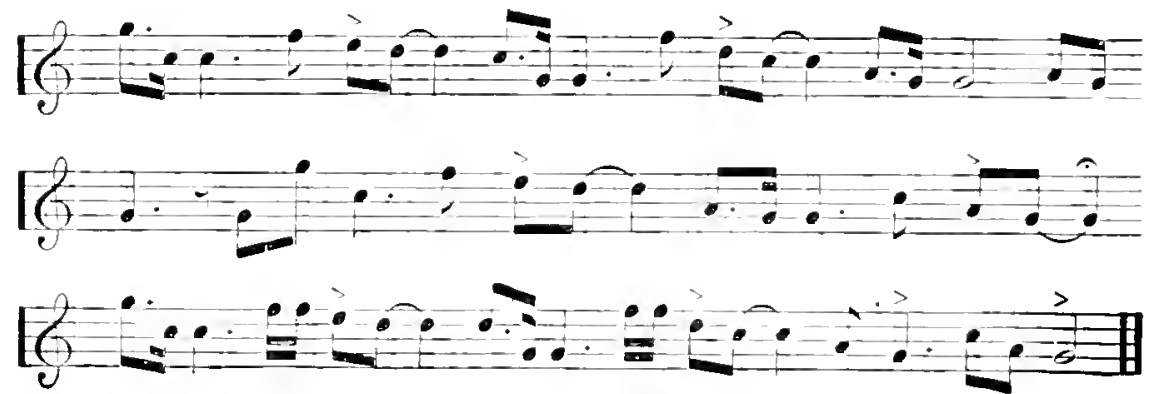
No.8S(c). Nenomince song.

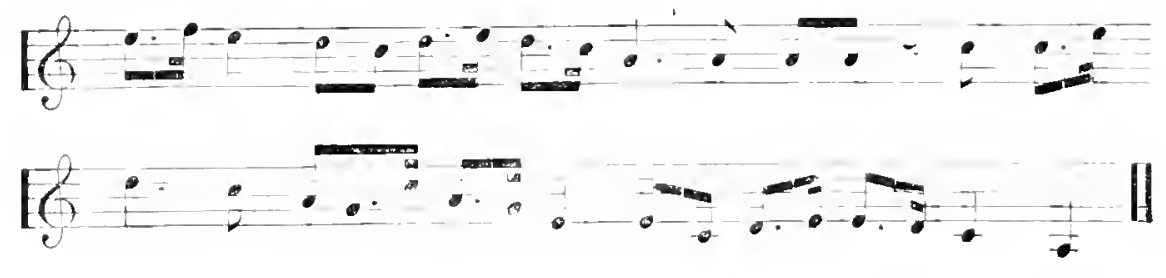

LAGHT ON A CONTROTERSY.

White I find that most persons are realy to aecept these songs as genuine products of Indian imagination, there are those who profess to discrininate and assert that some of them have undoubtedly been affected hy cirilization. Among the songs given in this chapter are many so cructe that civilization balks at assuming any responsibility for them: and I observe that the only melodies believer to be the result of paleface influence are those that are well formed and beantiful. 'That is. civilization is quick to claim coedit for what is goon in Indian musice, and equally quick to discham what is erude. I do not purpose to enter upon further argment in the matter but hope that the two songs that follow will throw some light on it.

I have alluded to the strugegle that took place between Indian and eivilized music when the Ojibwass were converted by Protestant missionaries. The two styles did not mix well or permanently. 'The hymu tume could not be grafted on the Indian stoek, nor the Indian melorly on the hymn tune. Shingwank has told me that the chief's tried to make over the tunes tamglit them hy the missionaries, seeking to arlapt them to the Indian 
manner. He and other Indians believe that some of the tunes still used in the ehurch service are "halt' Indian anul half" white," and he sang several to me as exanples. I reprohluce one as aecurately as may be from the phoungraphie record. (No. 22.) 'The words are a translation into () jibway of the hymm heginning,

A charge to kecp I have.

A crod to glorify.

Our notation is incapable of expressing with absohute exactness the manner of singing the hymm. It is so slow that it seems to be drawled rather than sung: time values are disregarded, and the voice slurs up and down from one tone to another in the most extraordinary fashion. I have tried to suggest the extreme portamento by a generons use of shrs and snall notes.
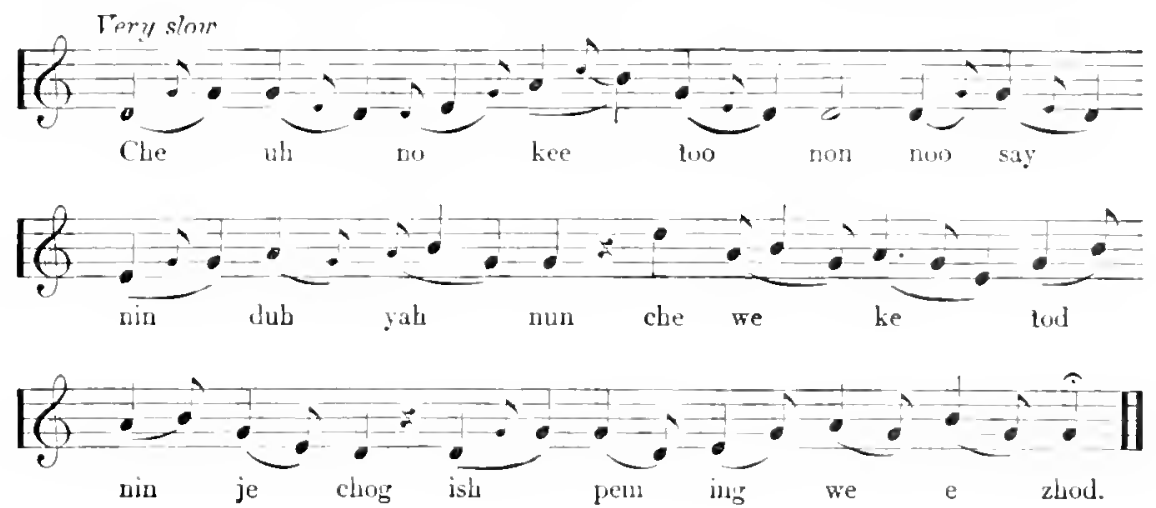

This mar, or may not have sonle similarity to an aneient Ojibway tune. With patience there may be dug from it a melodie ontline that eertainly resembles one of on own old hymm tumes. II aring heard the version above indieated, I 
would not need to be told that such a mixture of styles conld not survire. It has not. As a rule the tumes of the Protestant service are now sung hy the Ojibways substantially as the white congregations sing them, and songs of purely Indian origin, concerning Indian subjects and expressive of Indian thoughts, survive in their proper form, characteristic and distinct in type.

Contrast this deliberate attempt to graft one style upon another with the following. I was told by his friends that Jacol Akwenzs was a good musician, and of eourse I sought him out. After considerable persuasion he sang. IIardly had he begun before I knew that he was not giving me aboriginal material. The words were Ojibway, but the tme, poor as it was, disclosed its foreign character at once. When he had finisher, I asked him who tanght him the song.

"Nobody," he replied, "I made it."

On further inquiry it proved that he had been to school and had worked somewhere on the eastern shore of Lake Ifuron. Most of his life had been passed in close contact with civilization, and he had risen so high as to play second cornet in a brass band. IIere, then, was an example not of what might happen, but of what had happened when a musically inelined Ojibway yielded to the inthence of white-man music. The tune reveals no trace whaterer of its Indian origin. Instead of a native theme developed more or less aceording to the style of civilization, or instead of the native manner refined by pereption of form, there is neither native theme nor manner. 'The tune is simply a weak dilution of eivilized commonplace. 'The inference is ineritable that when the two musieal 
styles elash, one or other sucembs utterly. The Ojibway who is really influenced musically by civilization simply abandons his native art; he who feels the force of his native music, clings to it.

Akwenzs mate the words of his song as well an the tme. It is a sea song, telling of a young man who saw a sehooner eoming into port. He asks his employer for his "time," salys farewell and sails awar. Here is the melody:

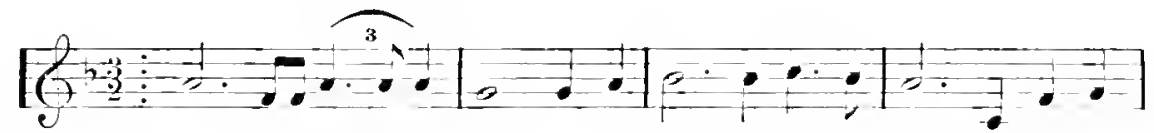

First time

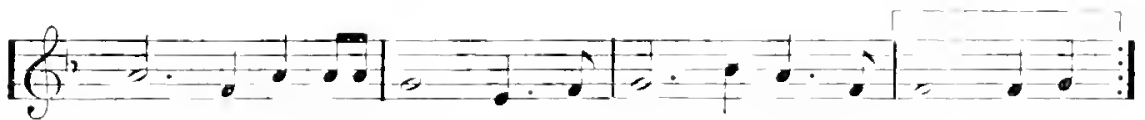

Second time

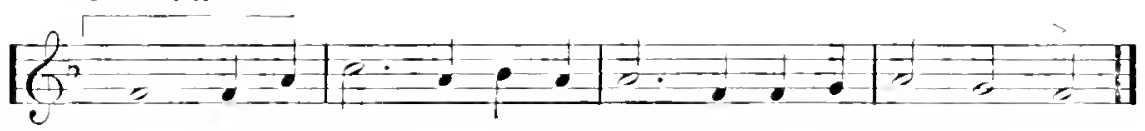



PART II.

'TWENTY-EIGIIT OJIBWAY SONGS, HARMONIZED AND PROVIDED WITH ENGLISH WORDS. 
The ojibway words are spelled phonetically. Consonants bare their nomal English somuls, hut $\&$ is always hard, soft $g$ being represented by j. Singers are cautioned not to gire the "continental" prommeiation to either rowels or consonants. Ml-n-d in Ojibway is mud, not mood. Broad a is represented by ah; without the h, prononnce a as in mate. Pronomee $e$ as in see, $i$ as in it, o as in rose, $n$ always as in tub. The sound of $\mathrm{i}$ in night is represented by ai. Sound ay as in say. The diphthong ch is soft, as in church: ng is not strictly a liphthong in Ojibway, both consonants being pronounced nearly as in finger. Exception: at the end of a word, ng sounds as in sing. 

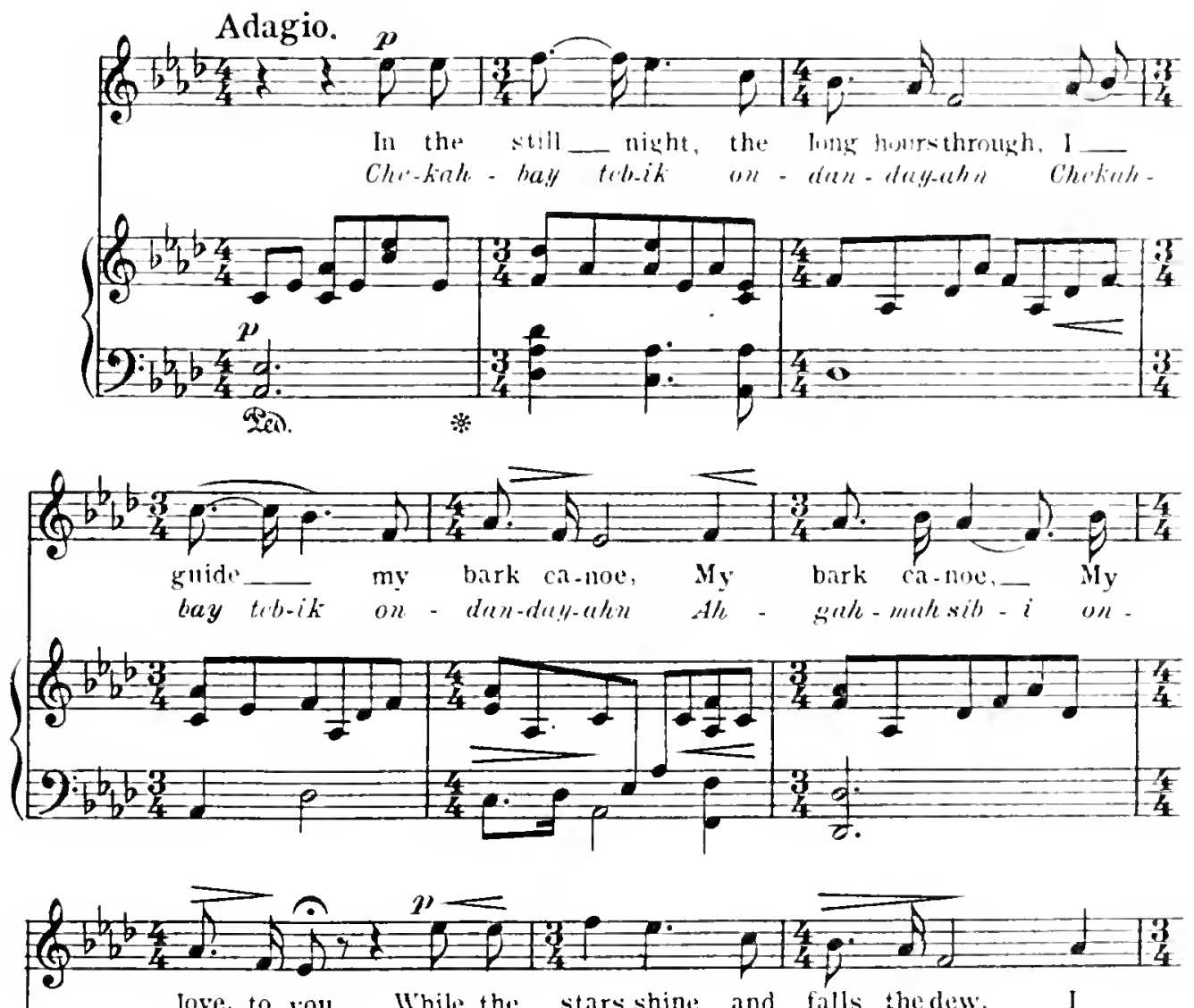
love, to you. While the stars shine, and falls thedew, I dure-da!y-ahn.
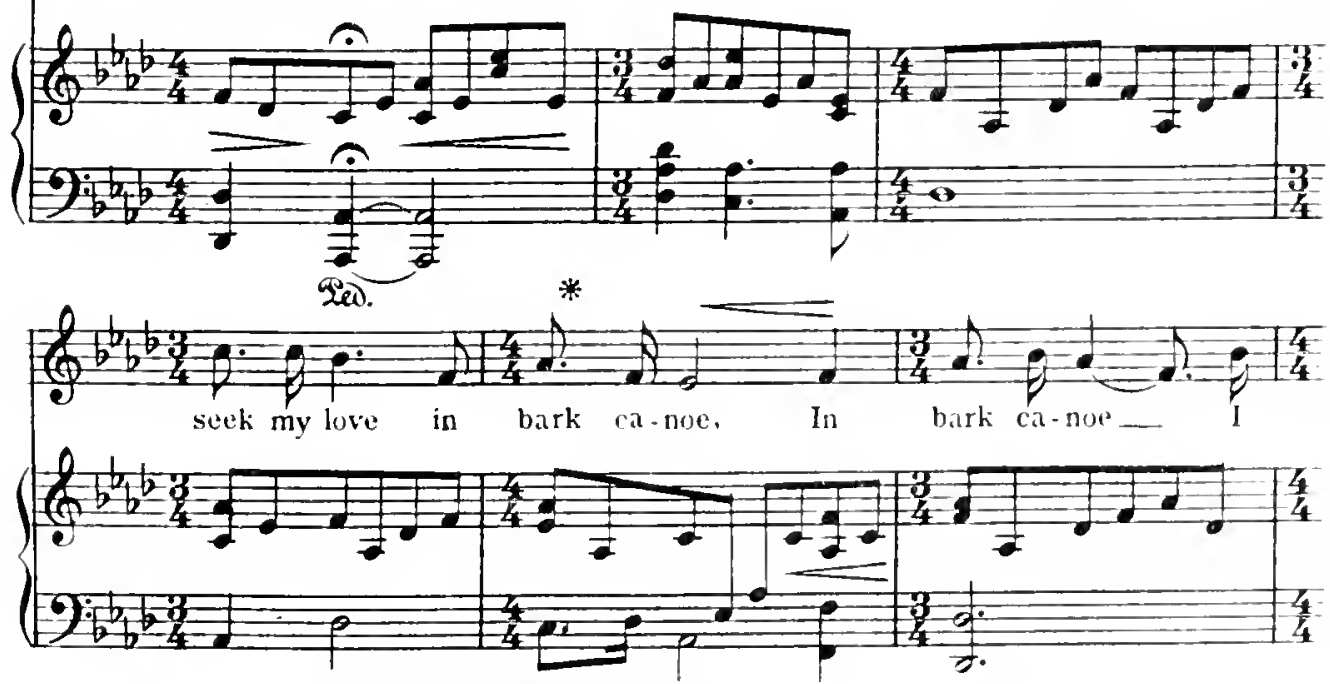

Copyright MCMIX by Frederick R. Burton. 

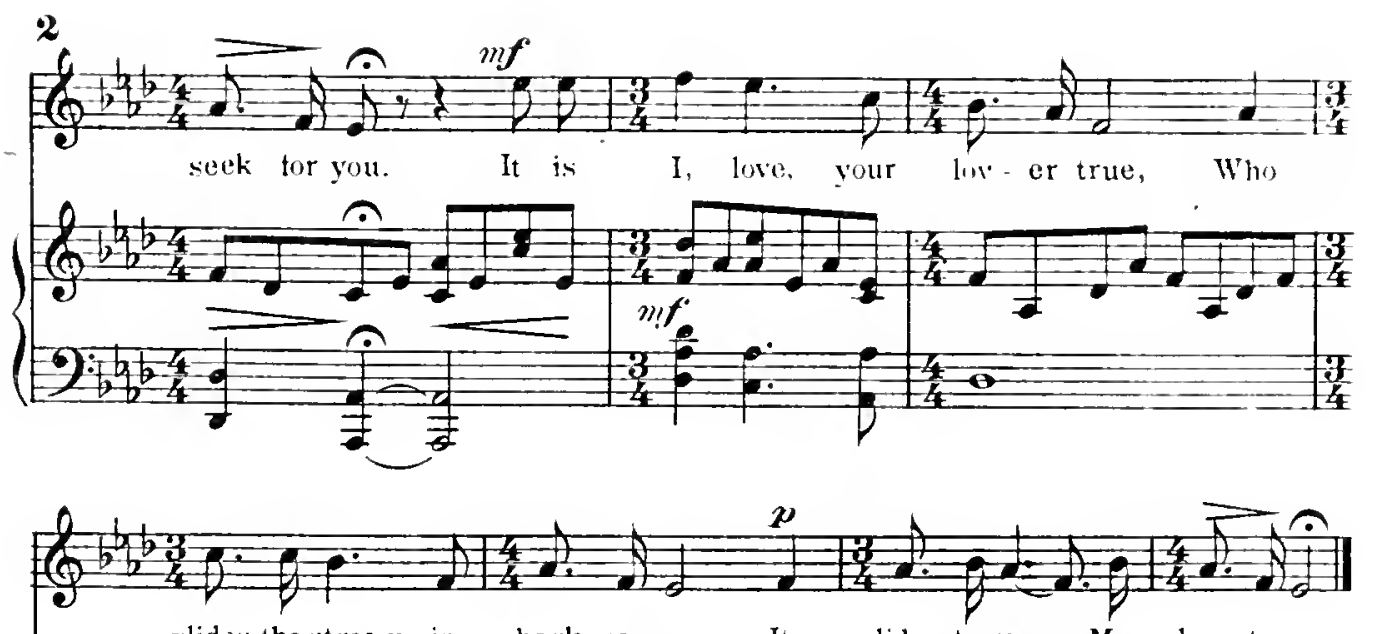
glides thestream in bark ea-noe, It glides to you, $\mathrm{My}$ love, to you.

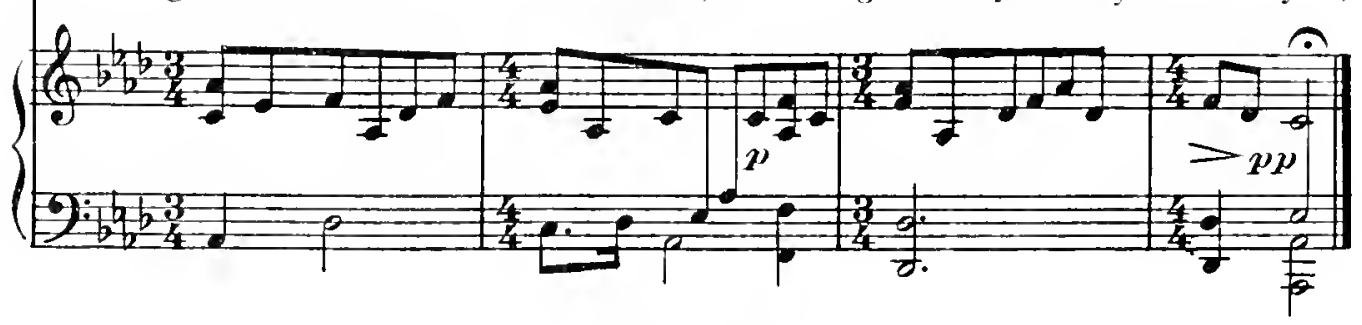

\section{Red Blanket.}
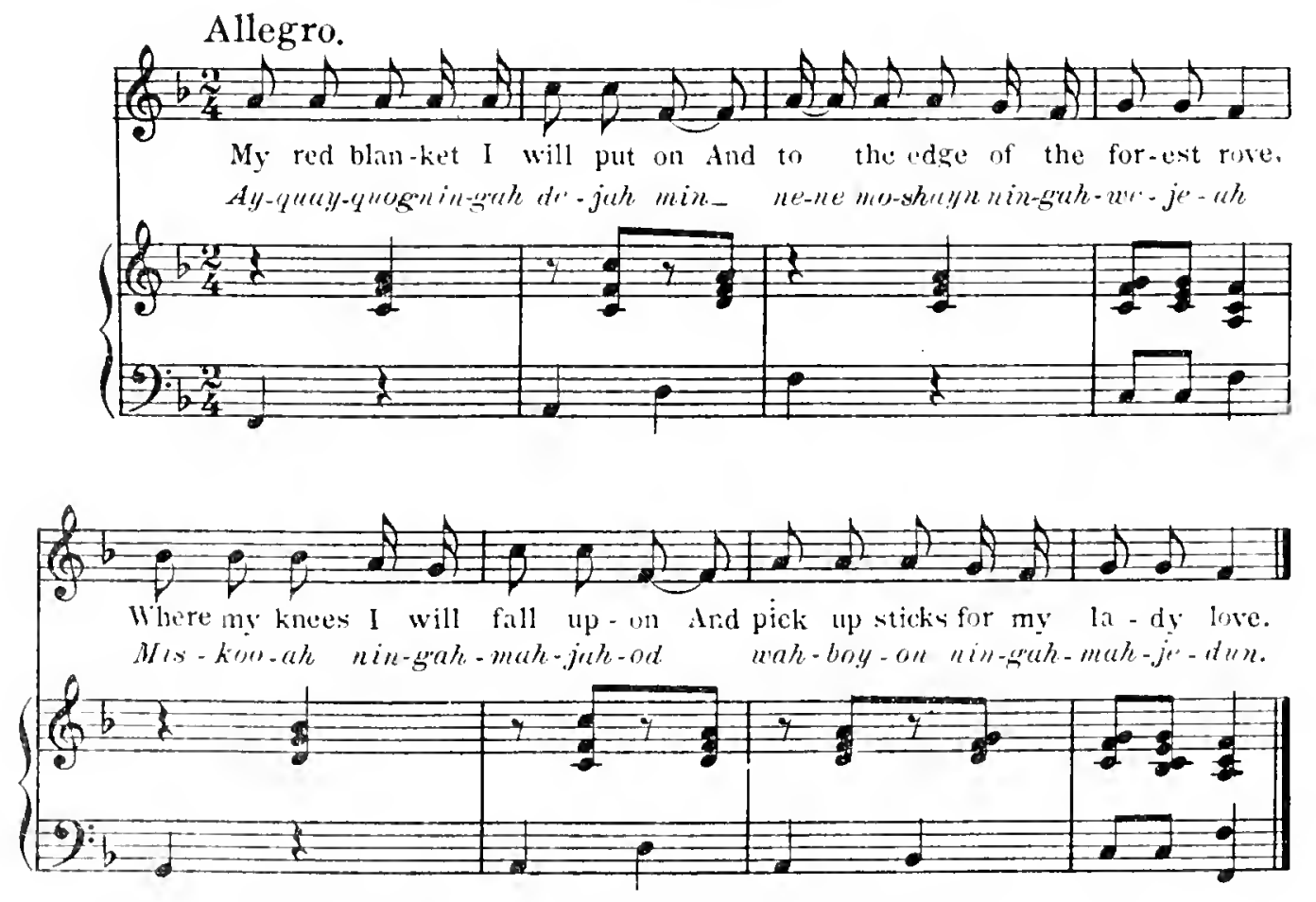

Copyright MCMIX by Frederich R. Burton. 

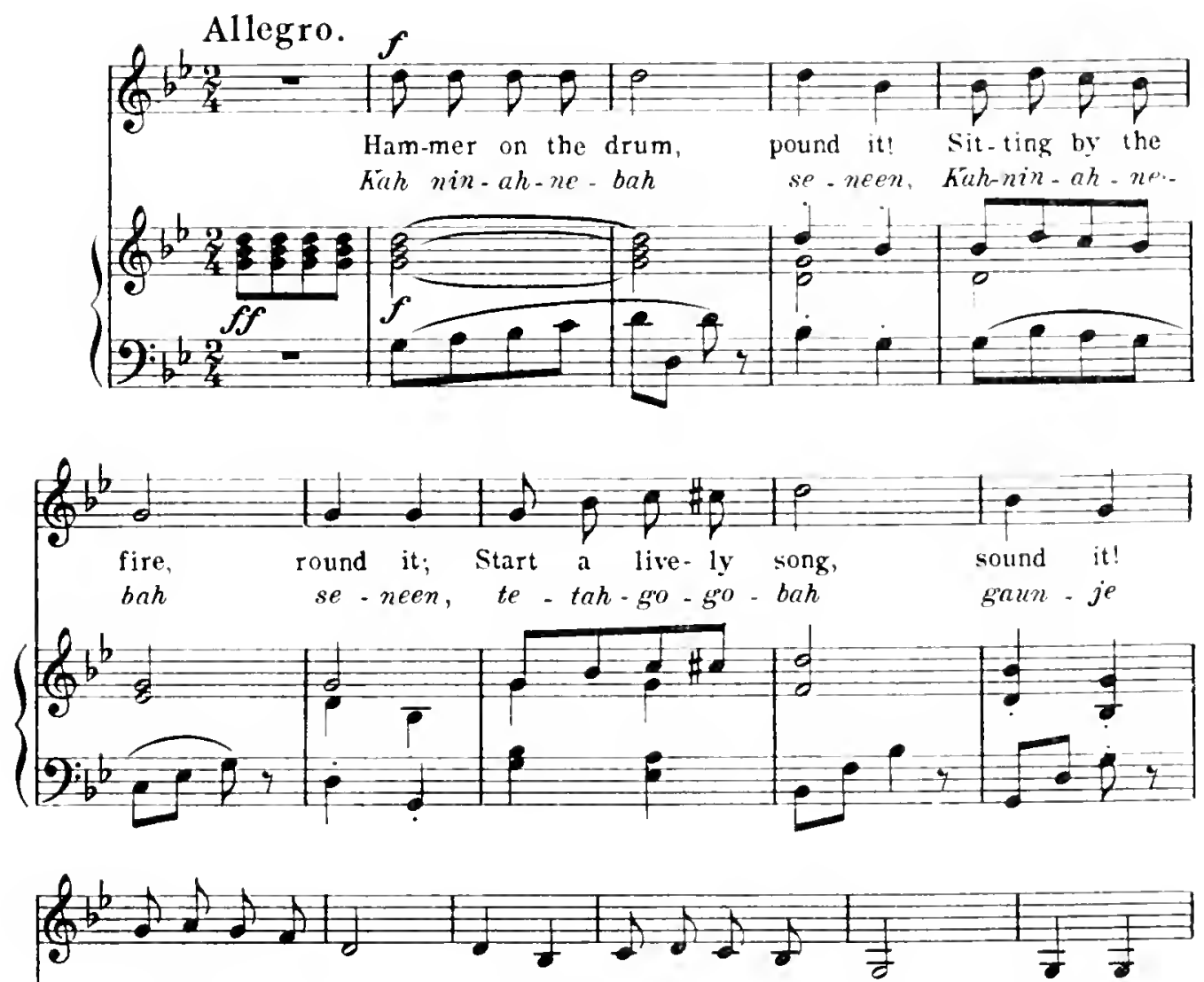

Whatshall be the theme? found it! Gloom-y is it, con - found it! nan-kah-mah-min-ne quay-aung, Kah-nin-ah-ne - bah. se-neen.
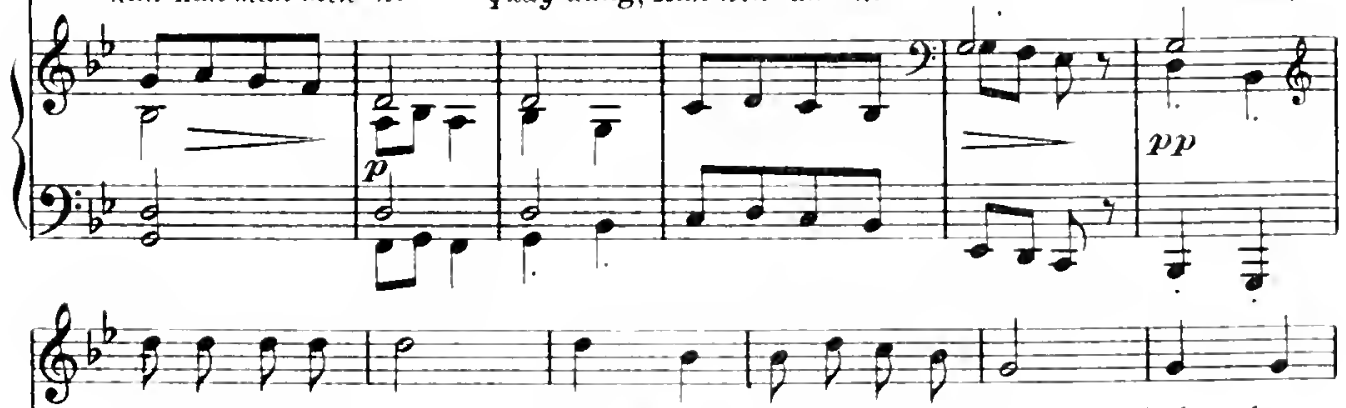
All the liqu-or's gone,
well,
oh! I.et the thirs-ty mob
bel - low,

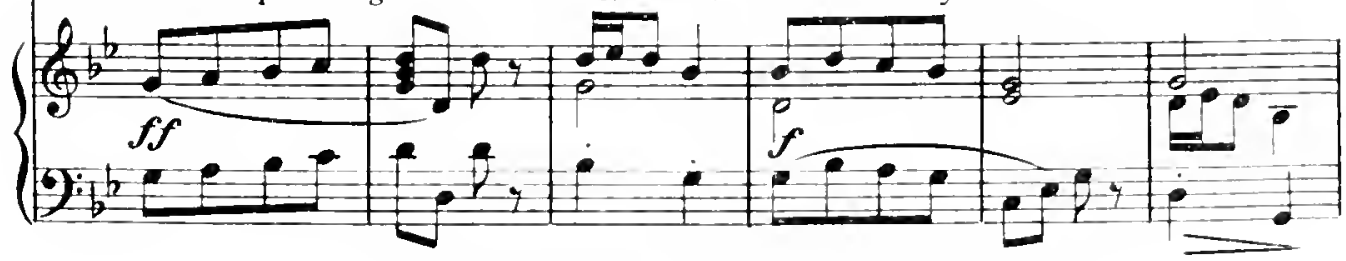

Copyright MCMIX by Frederick R.Burton. 


\section{4}

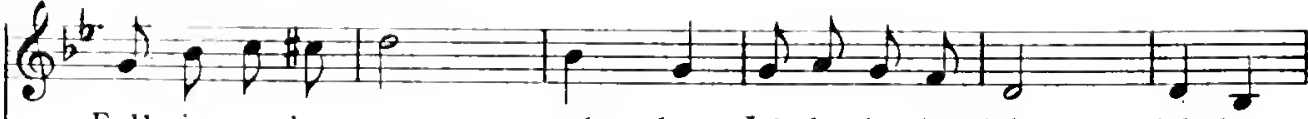
Full is ev-ry man, mel-low, Jol-ly is the tight fel-low,
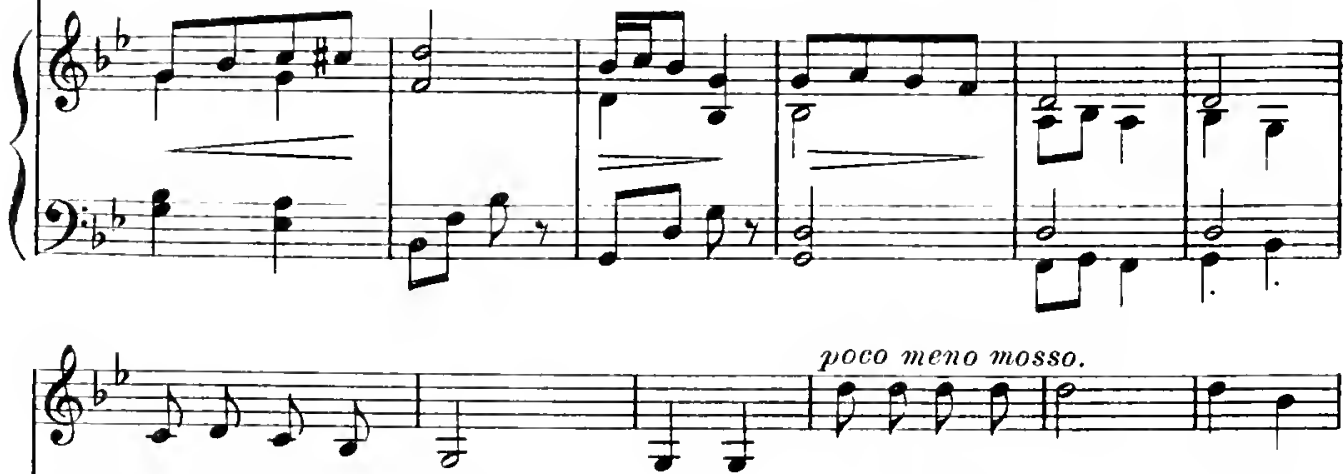

Full of fun the tight fel-low. At the emp-ty flask, blink-ing,

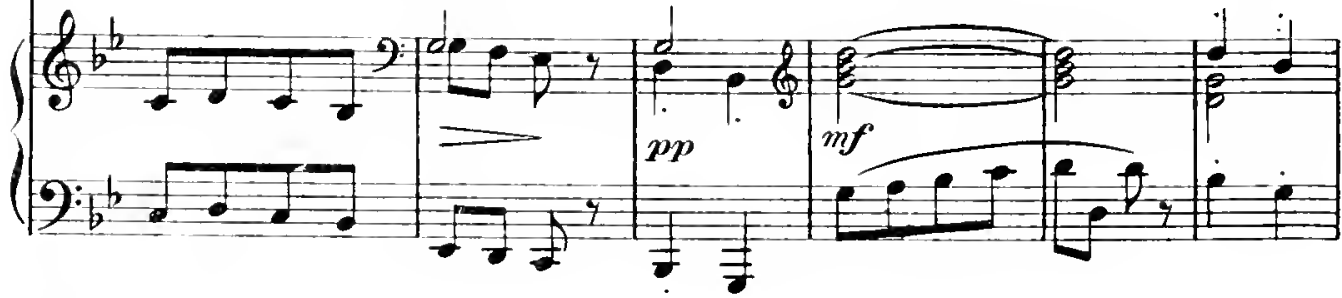

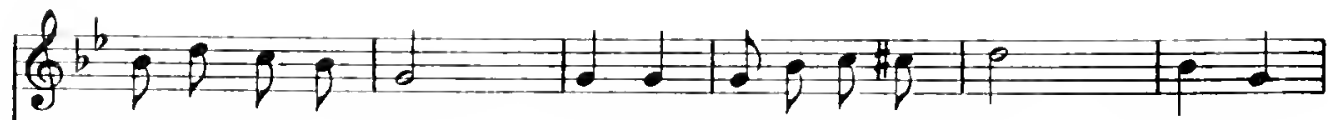
Eyes are drow-si - ly wink-ing, Got to go to sleep think-ing

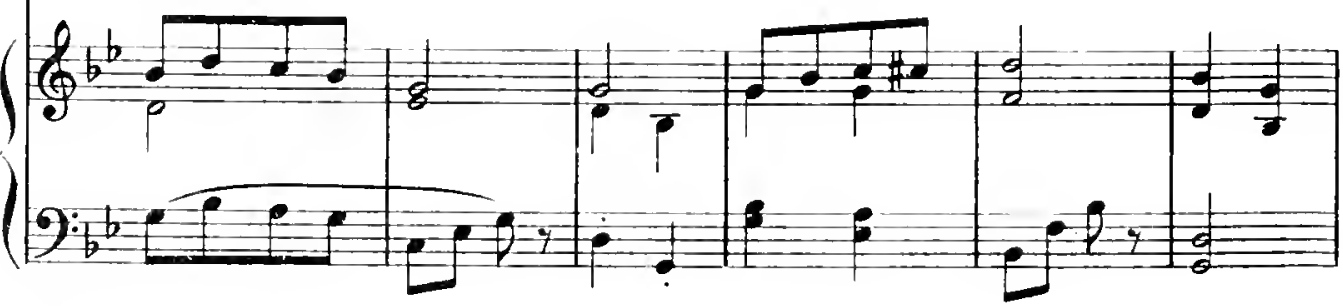

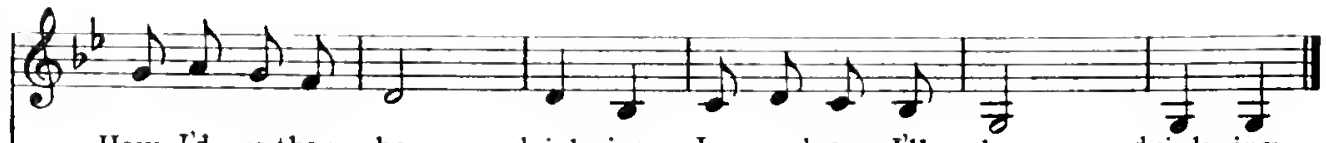
How I'd ra-ther be drink-ing; In mydream I'll be drink-ing.

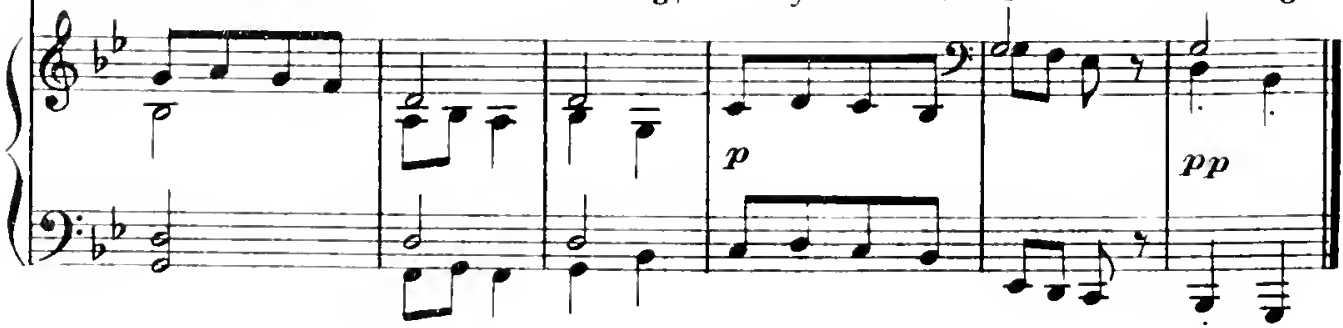


Waubunosa's Longing.
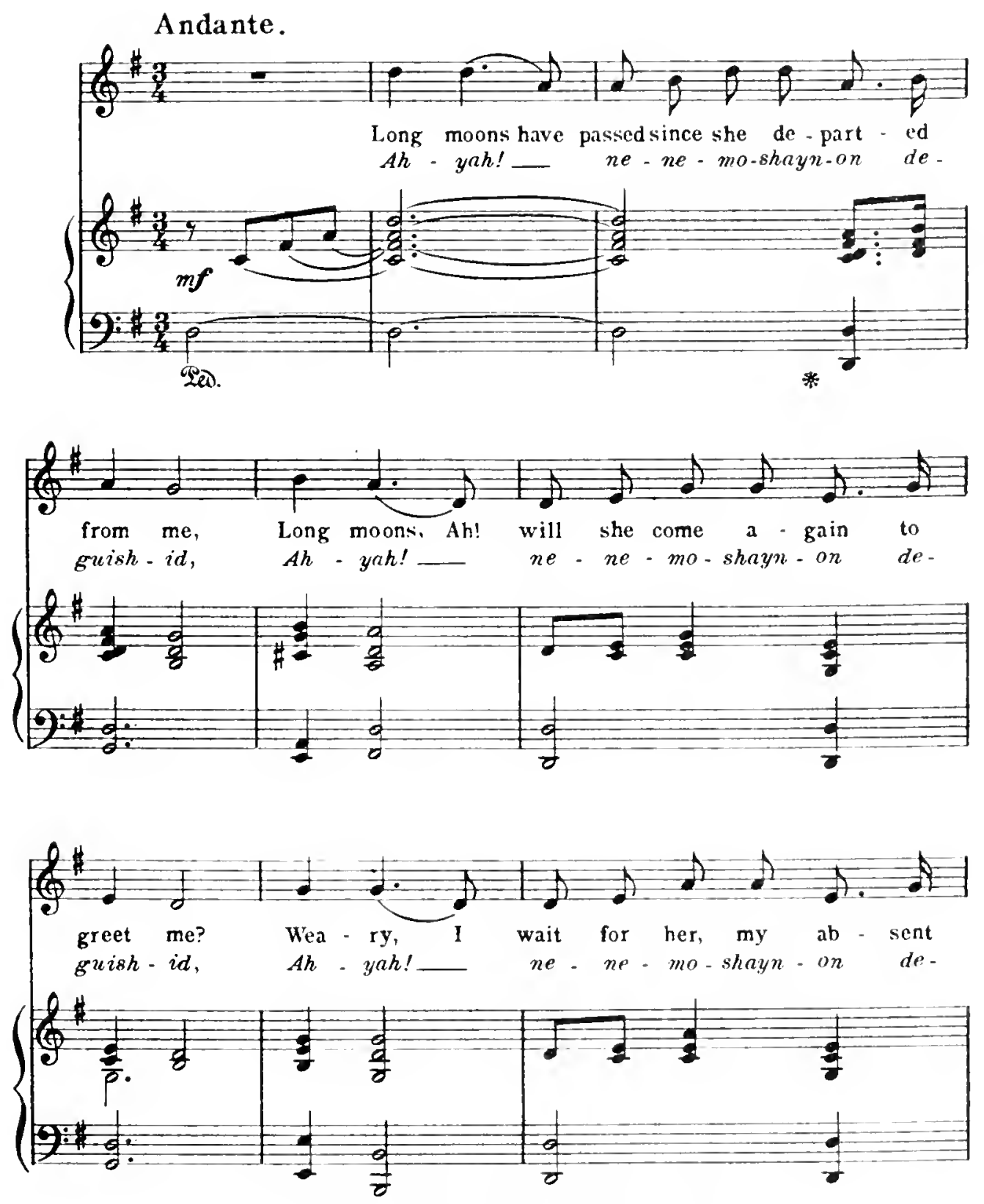

Copyright MCMIX by Frederick R. Burton. 
6

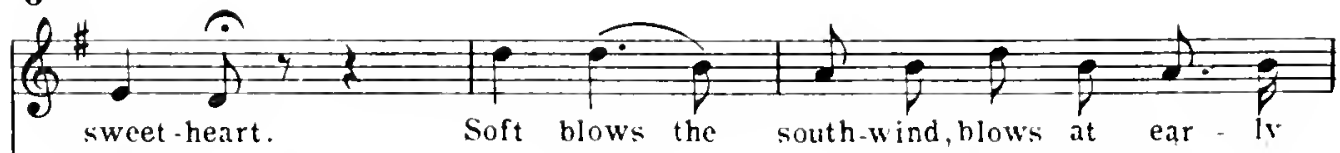
sweet -heart.

Soft blows the south-wind,blows at ear - is

rwish id, Ah - yah!

ne - ne-mo-shayn-on de.

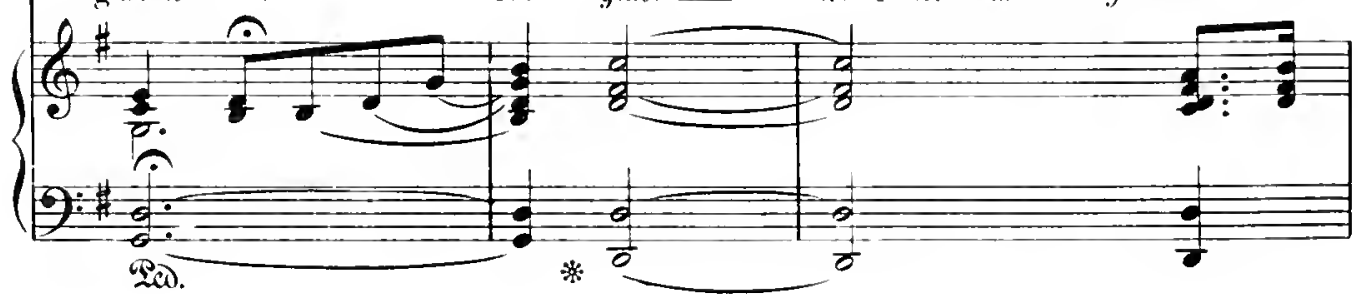

sa.
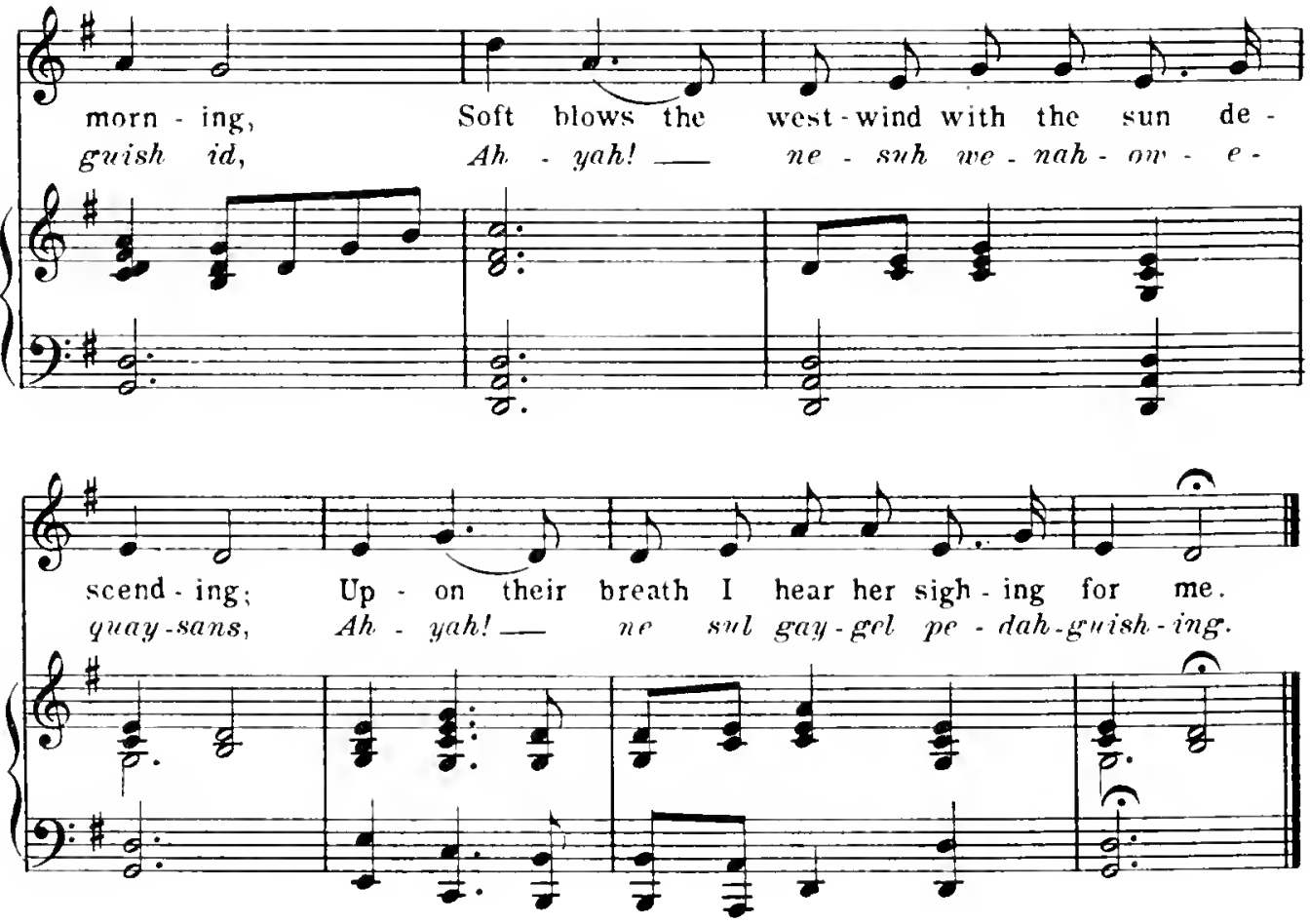

Sleepy Time.

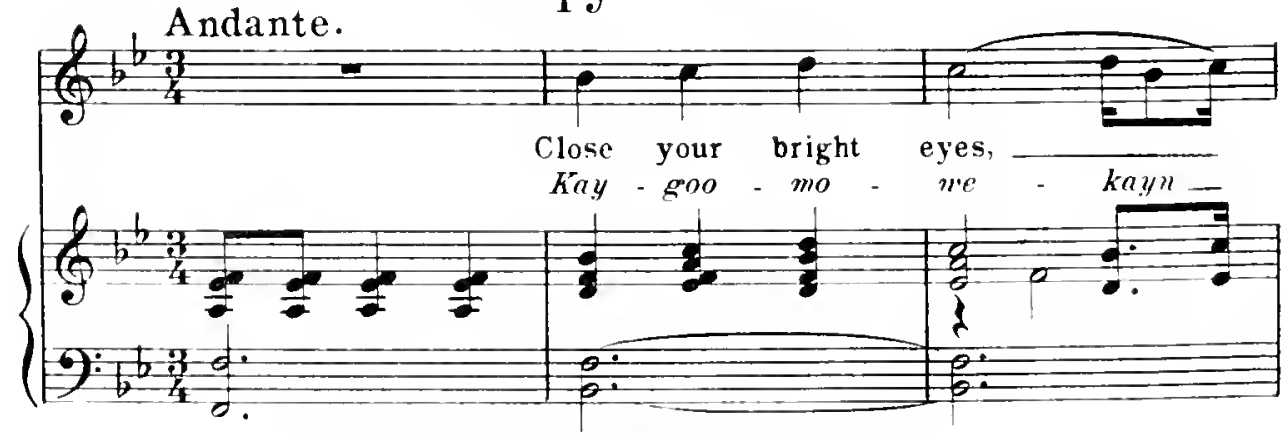

Copyright MCMIX by Froderick P. Burton. 

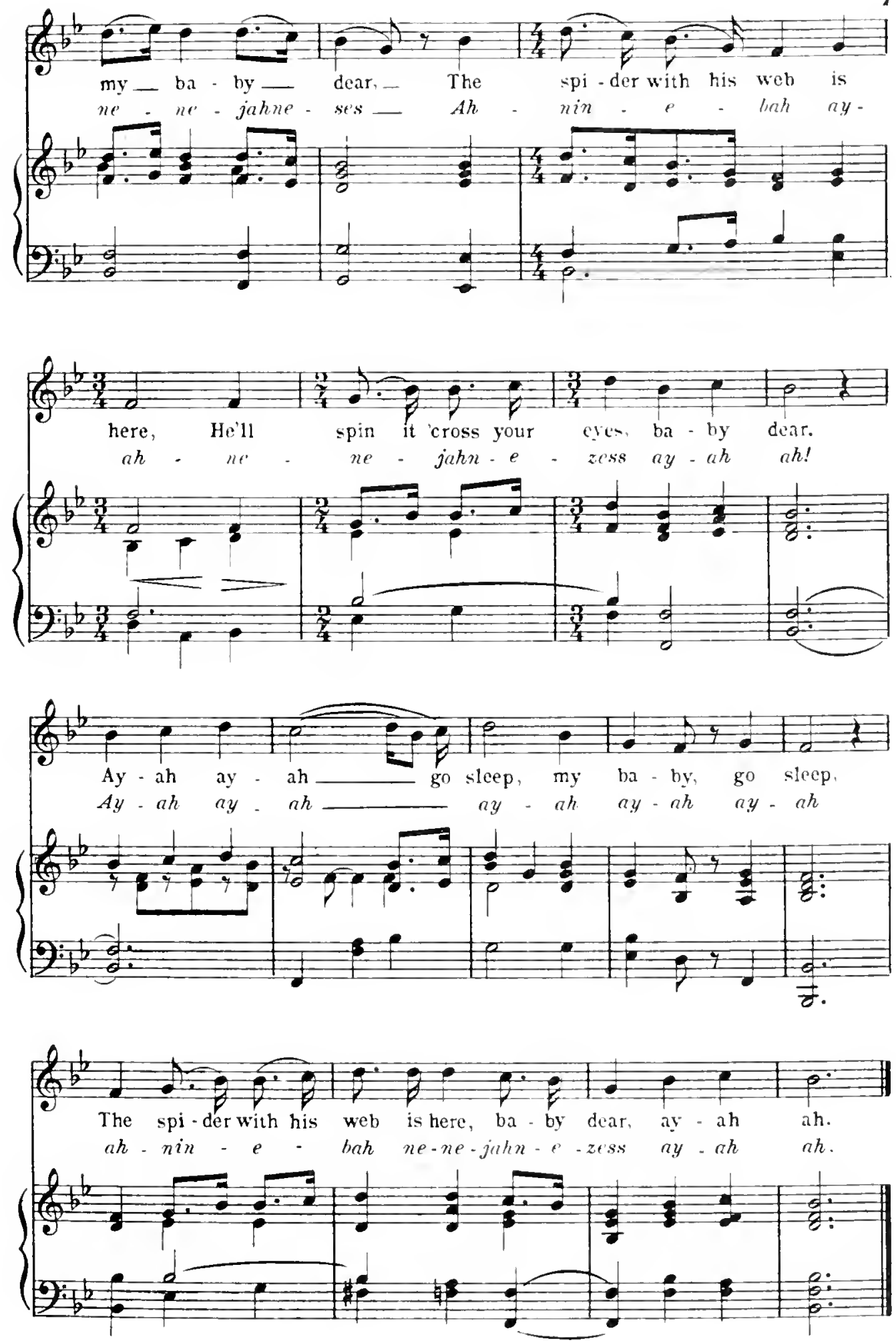
Andante.
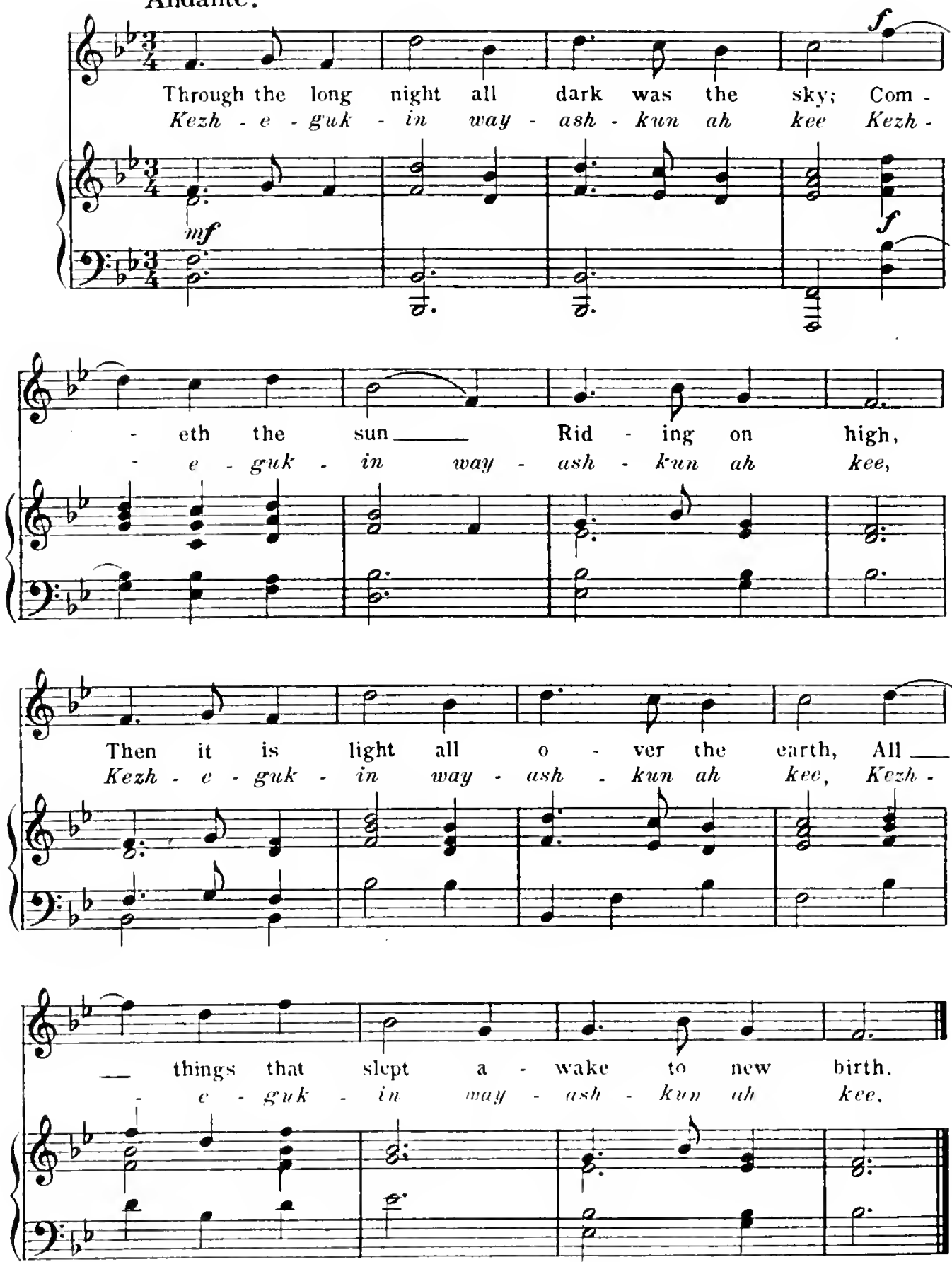

Copyright MCMIX by Frederick R.Burton. 
Wedding Song.
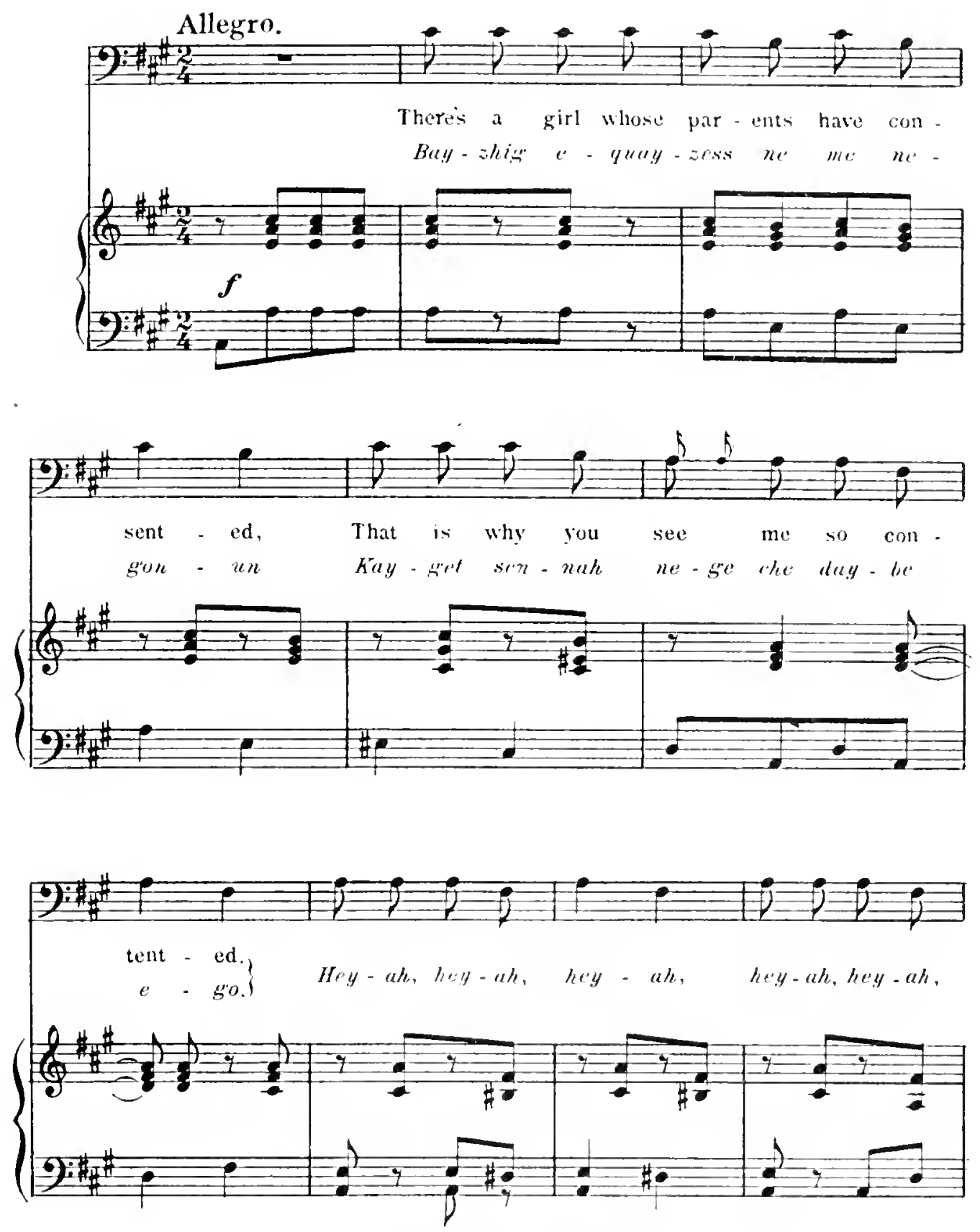

Copyright MCMIX hy Frederiek R.Burton. 

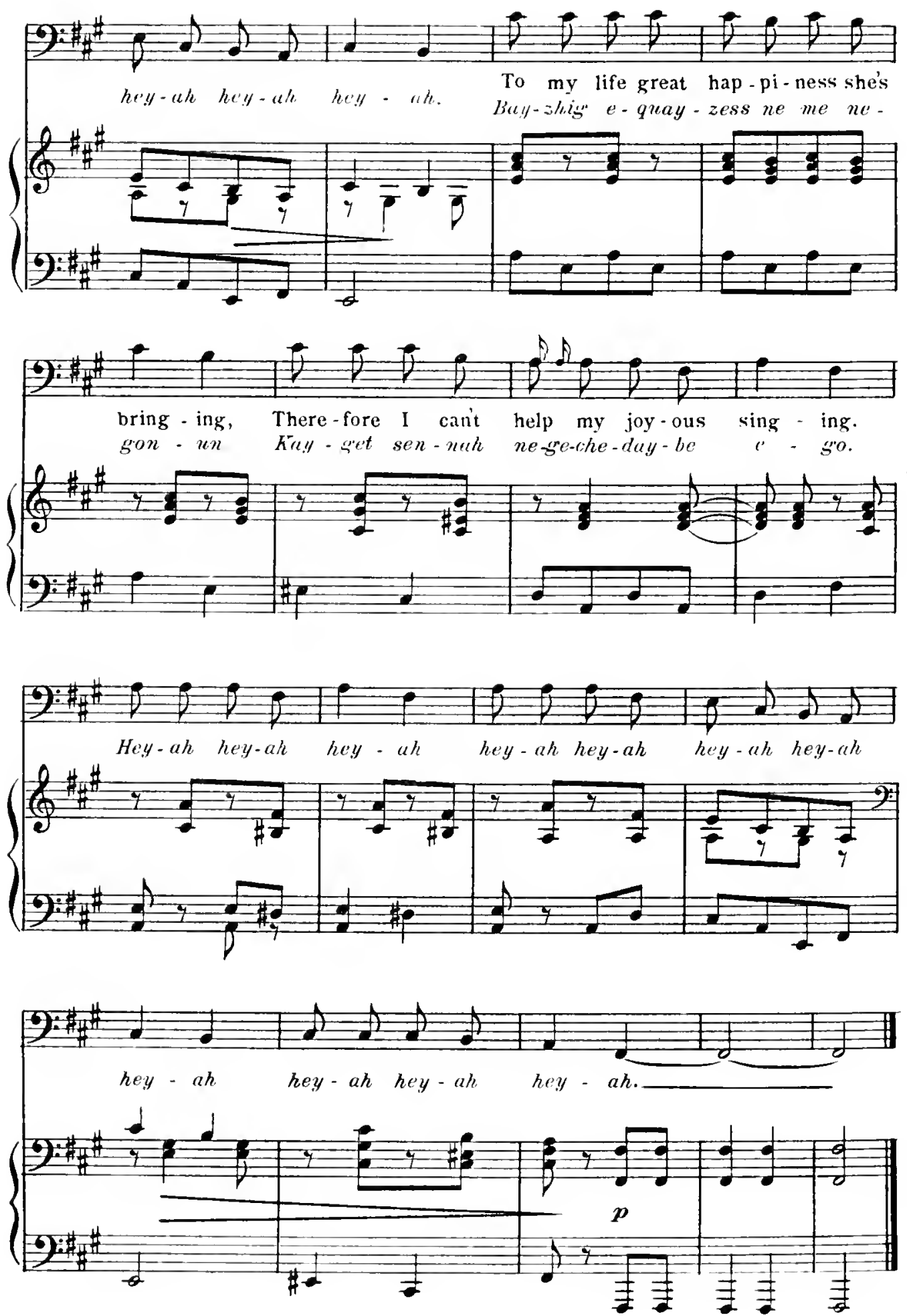
Lonely.
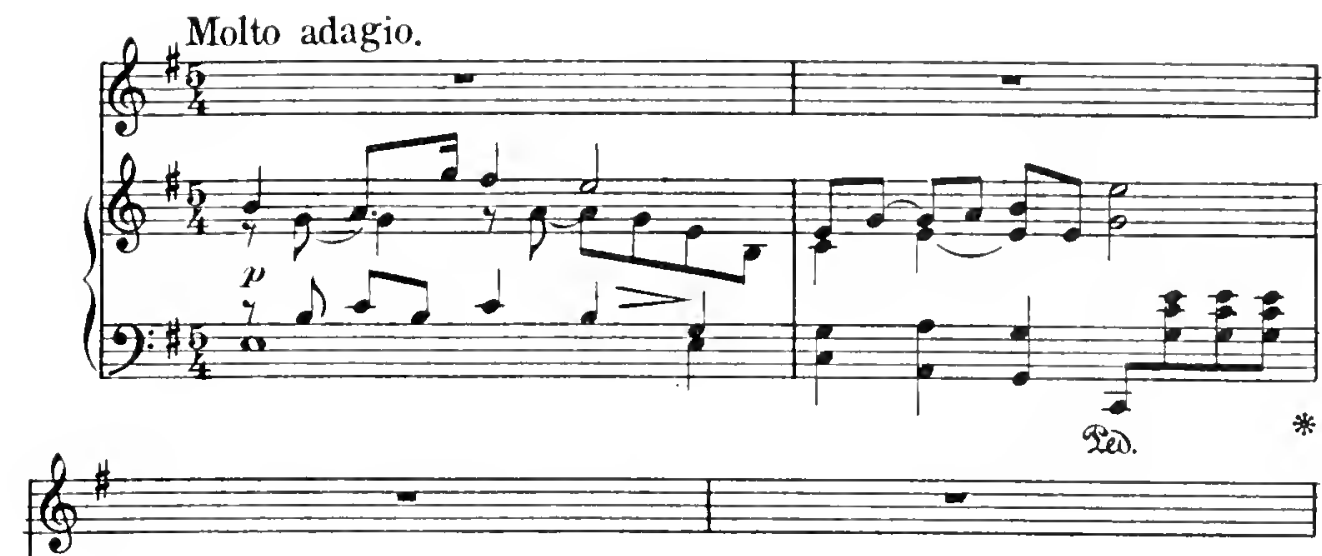

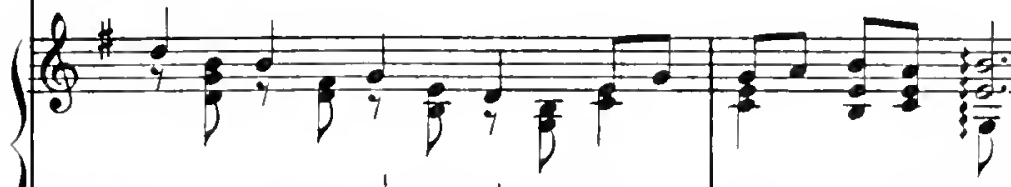

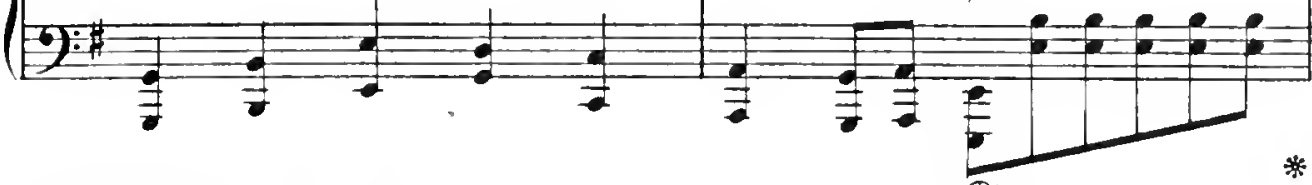

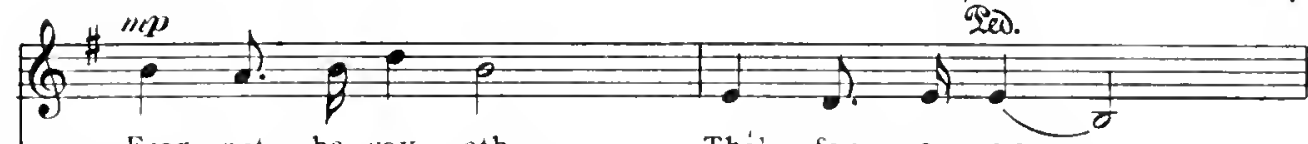

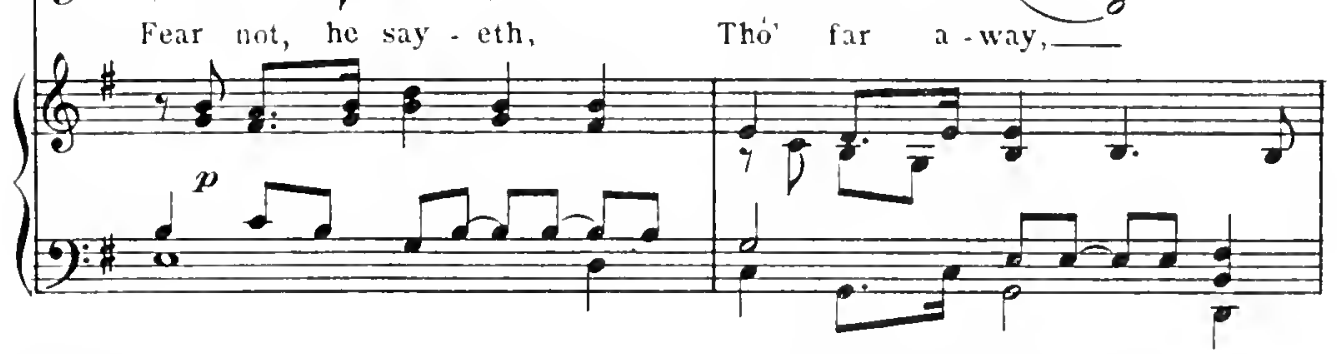

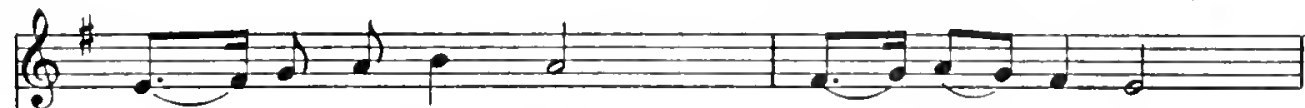

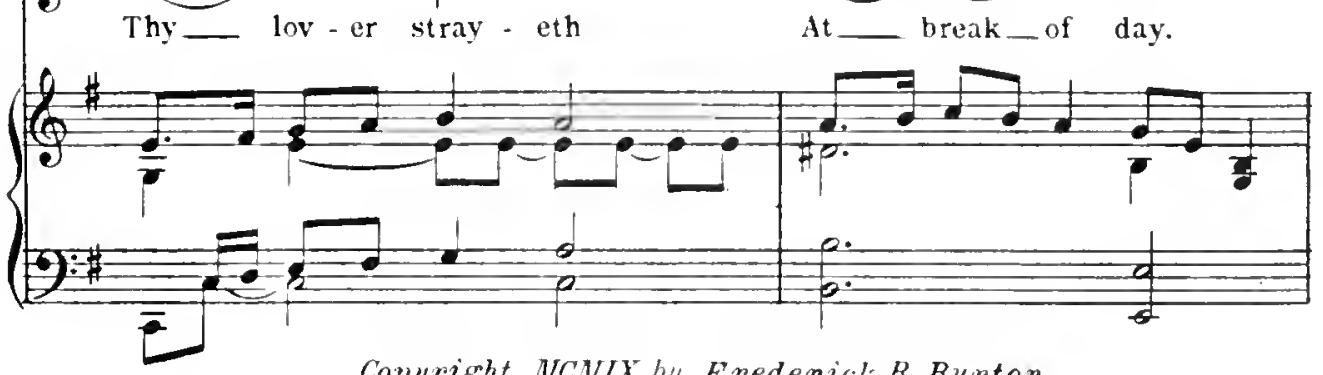

Copyright MCMIX by Frederick R.Burton. 

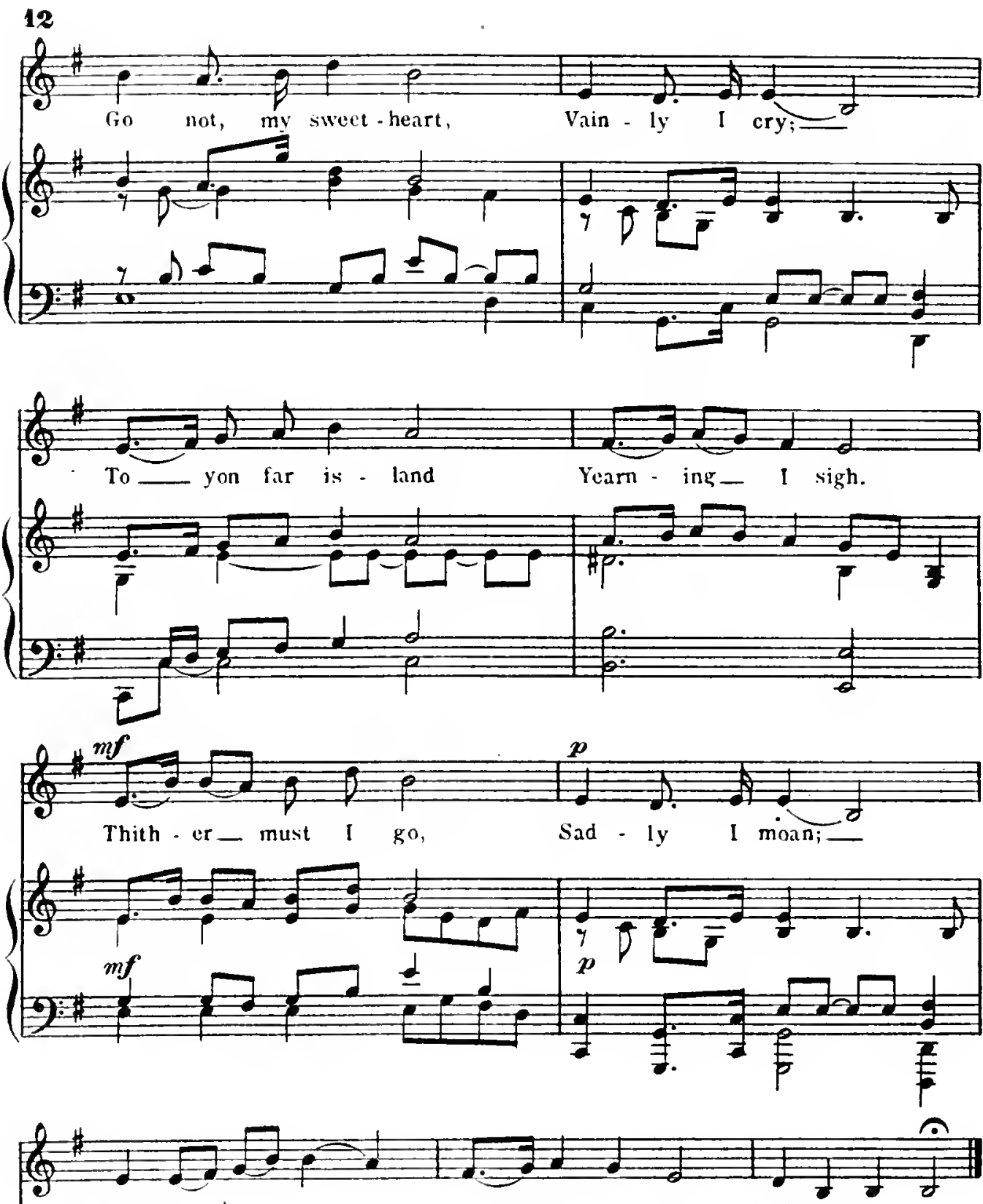

Heav-y - my_woe,__ Lelt _ here a - lone, Left here a - lone.

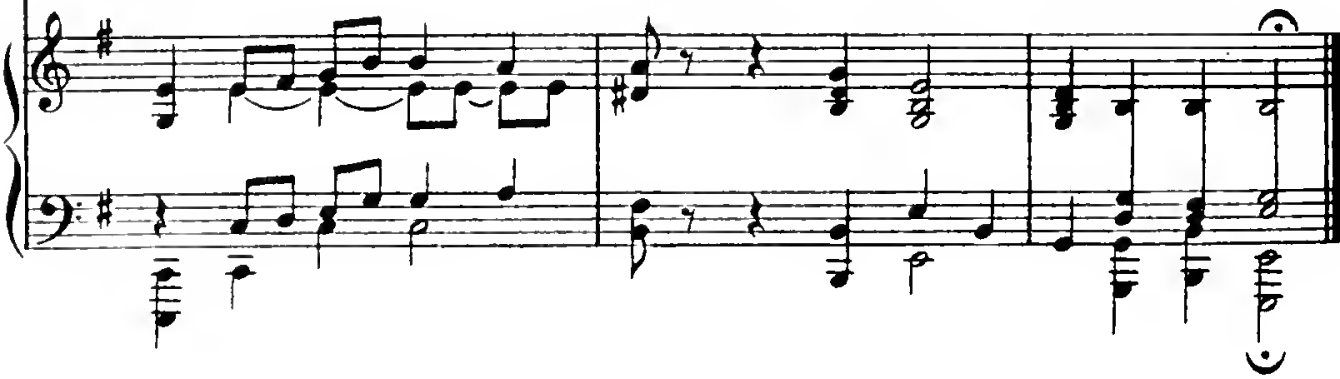


Midnight Tryst.

A Song of Elopement.

And $\stackrel{\text { te }}{\text { moderato. }}$
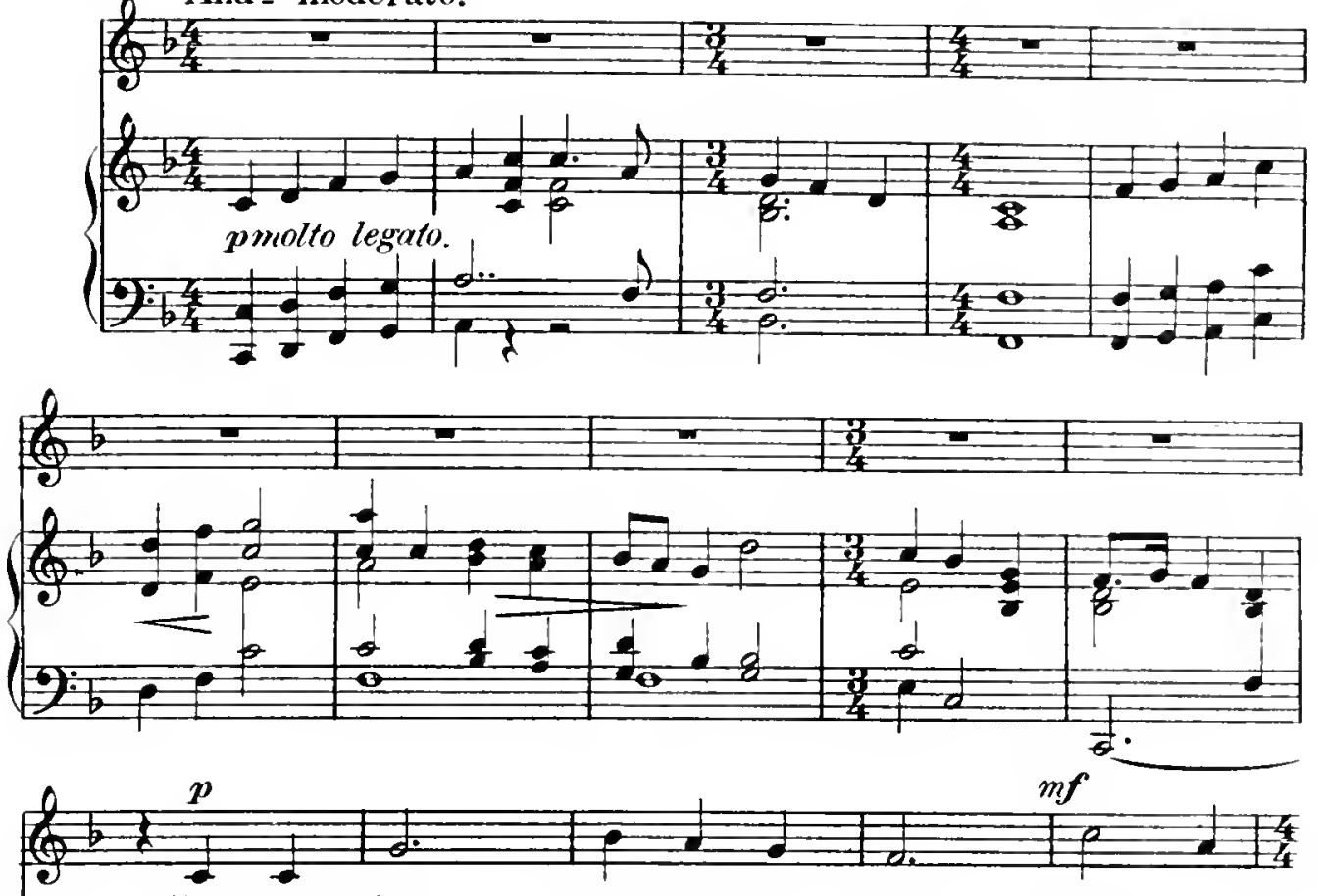

$\begin{array}{lll}\text { Here a }- \text { lone } & \text { wait }- \text { ing the hour, Here a - } \\ B e-j a h-k a h & \text { nind }-e-g o-b u n & \text { Nind - } c \text { - }\end{array}$
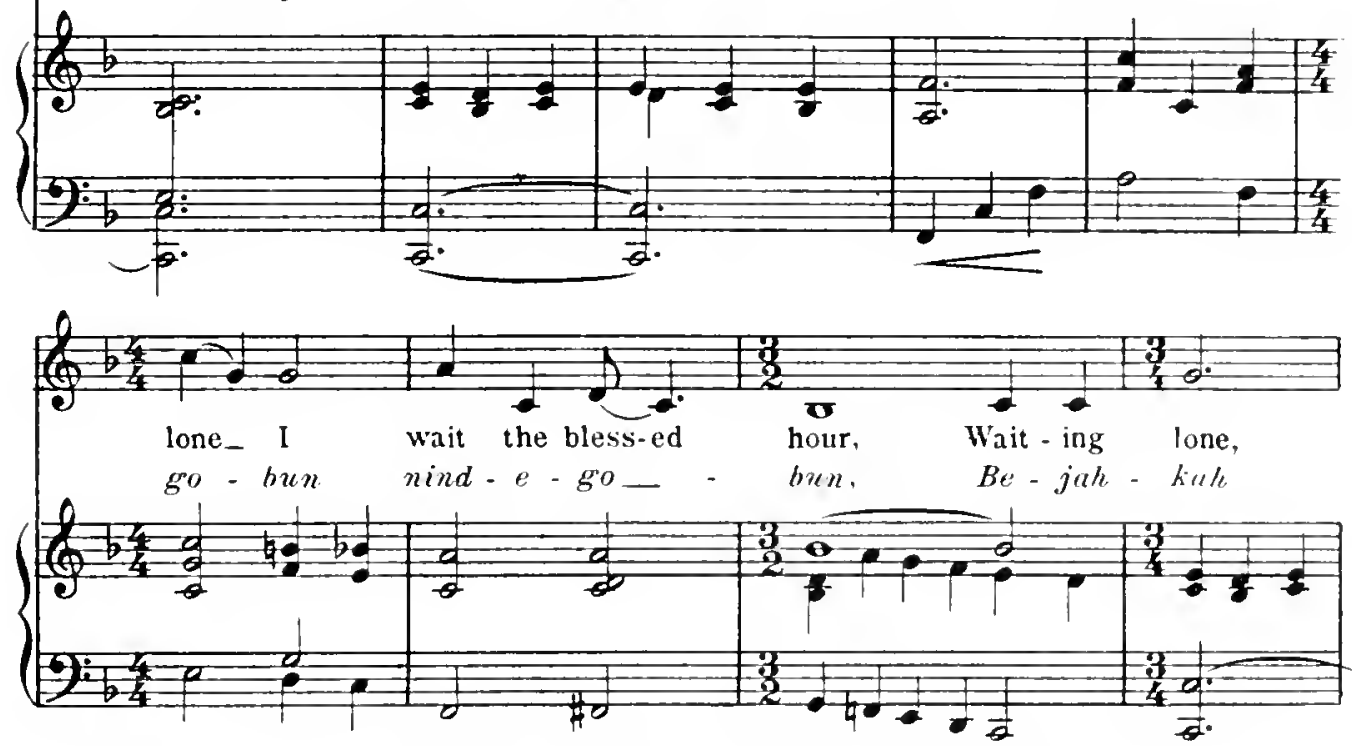

Copyright MCMIX b!l Frederick R.Burton. 

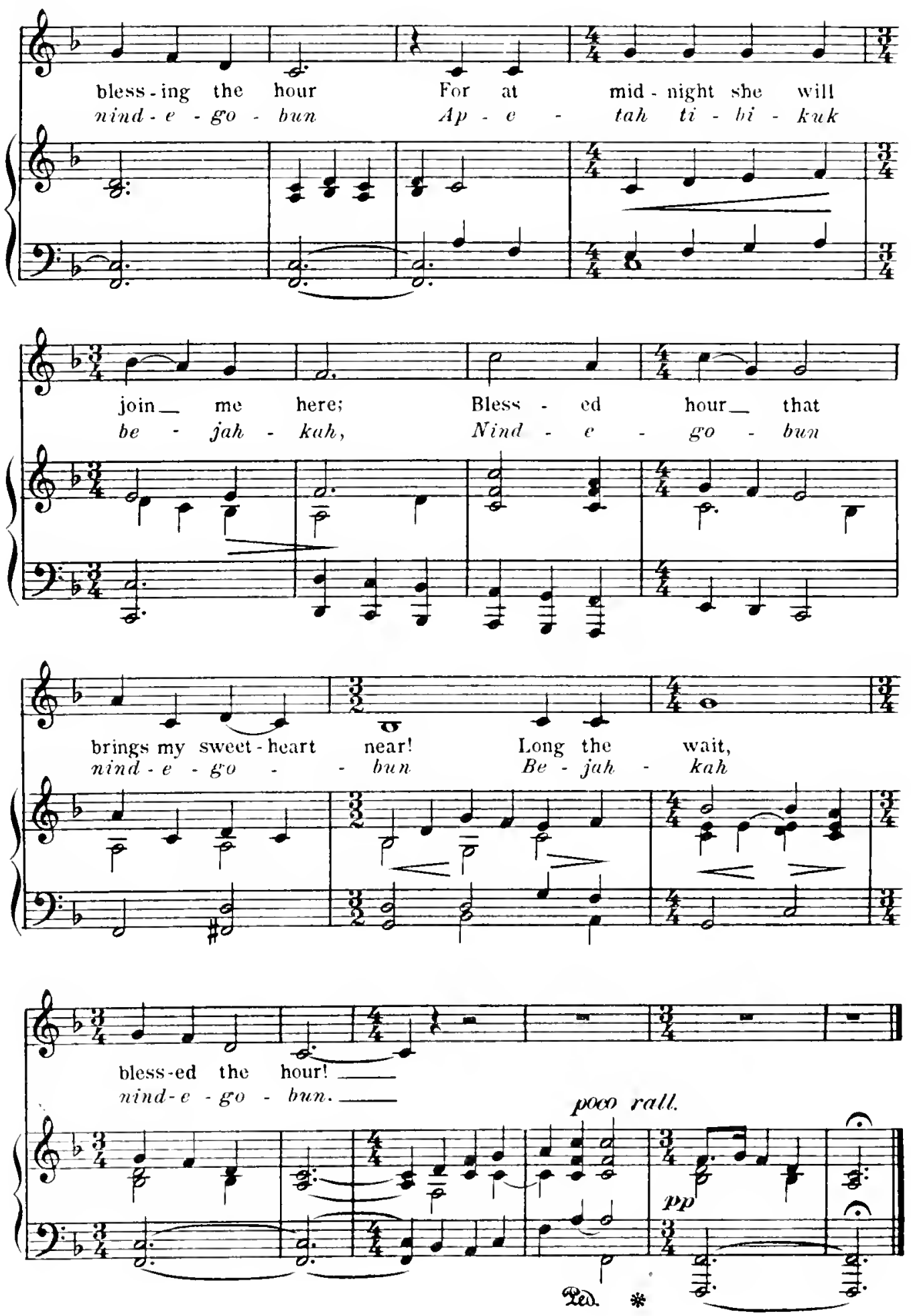
War Song.
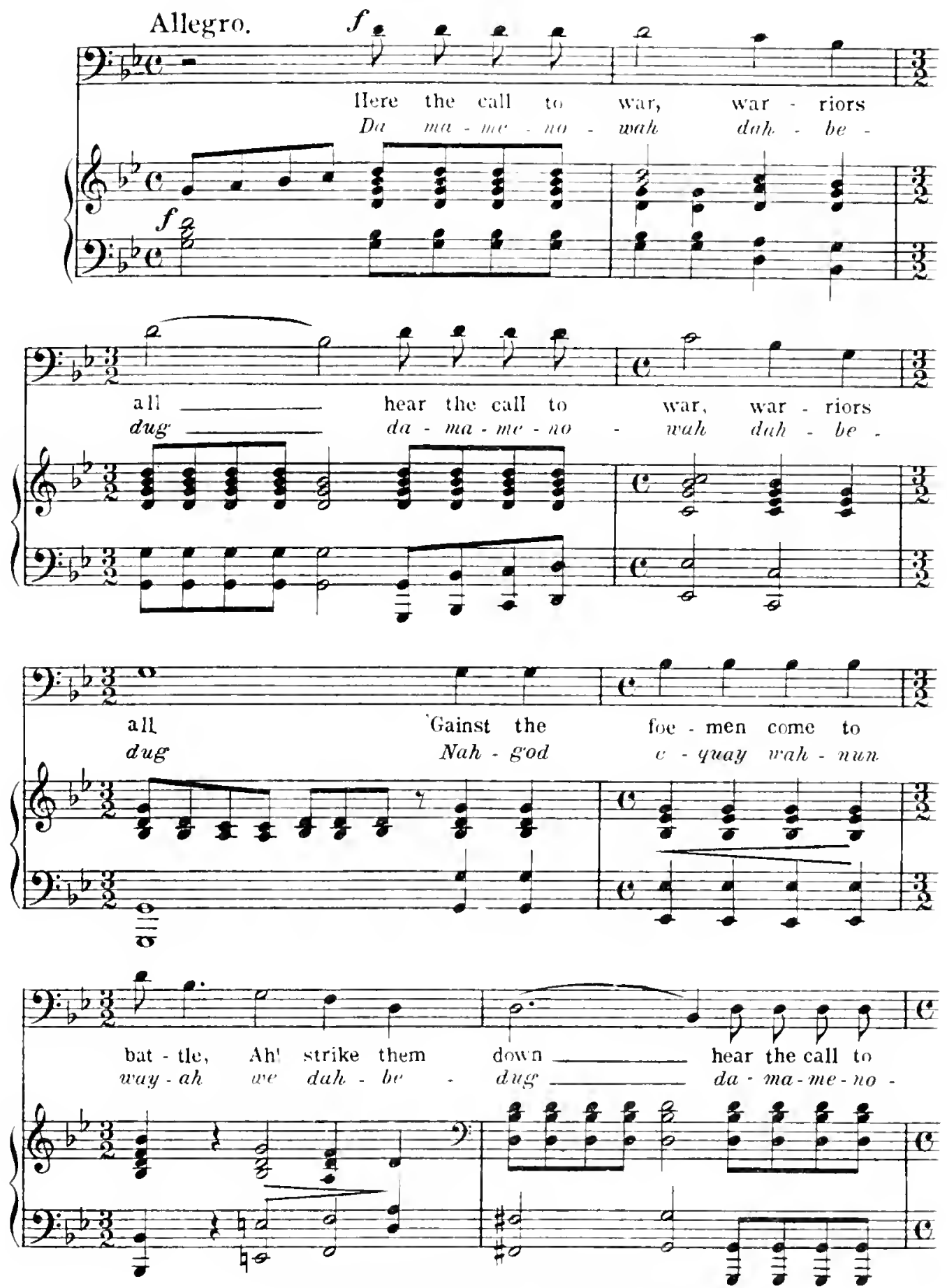

Copyright MCMIX by Frederick R.Burton. 
16

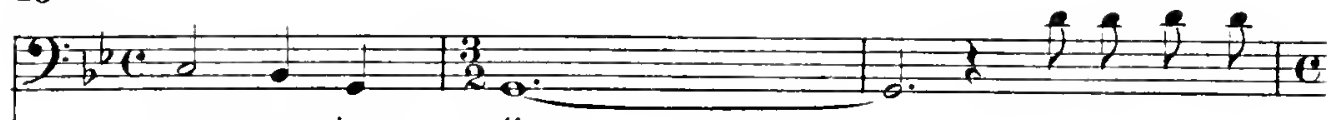
witr, war-riors all. wah dak-be - mod.

Forward to the

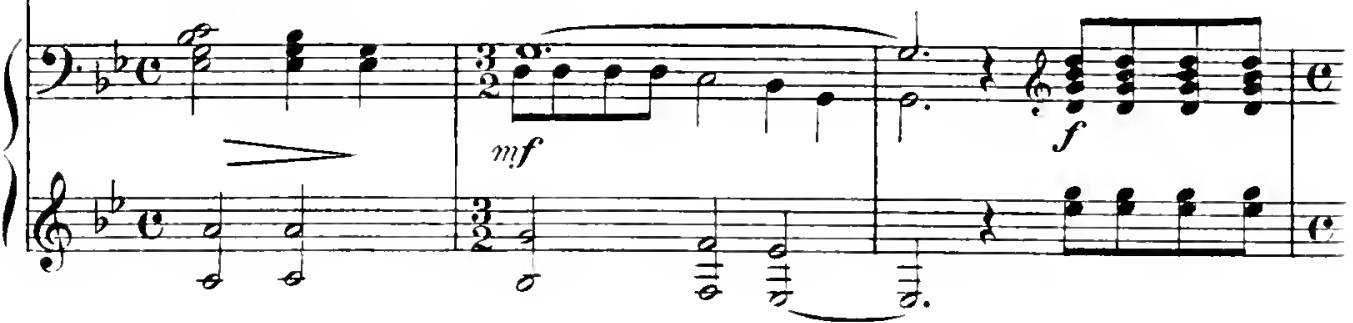

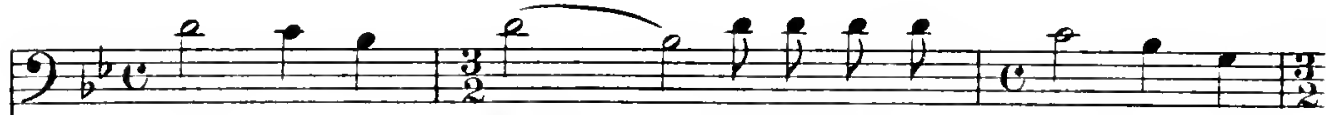

fight, war-riors all,_forward to the fight, war-riors

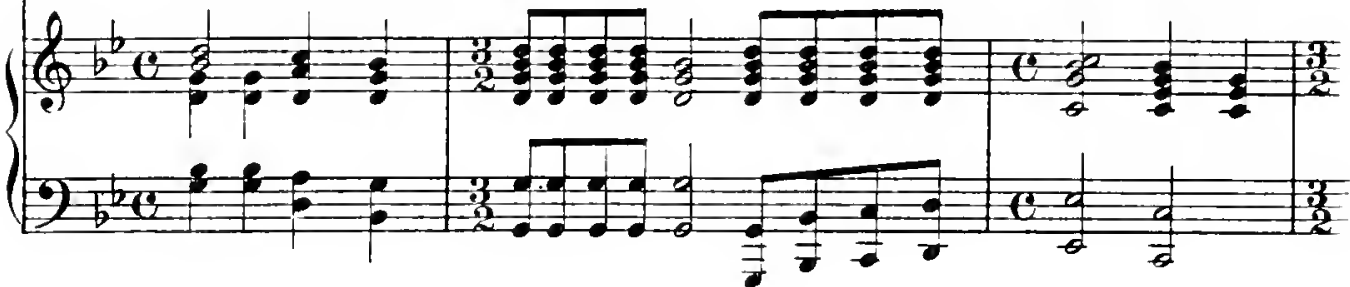

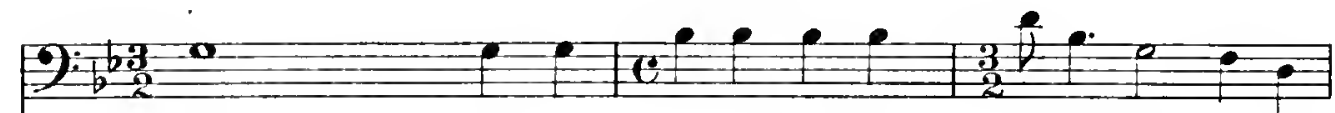
all. Let the cow-ardshide with women, yah! let them

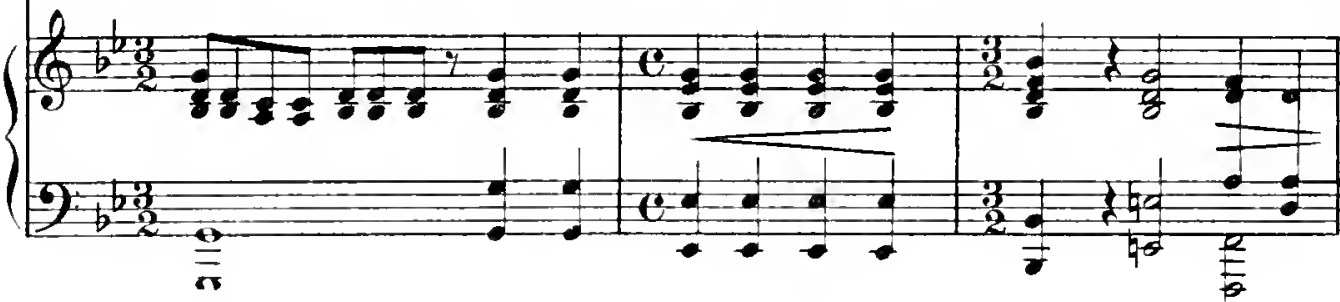

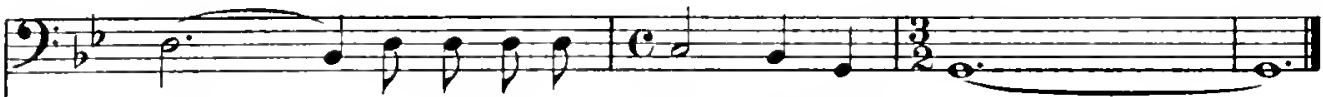
hide_for-ward to the fight, war-riors all.

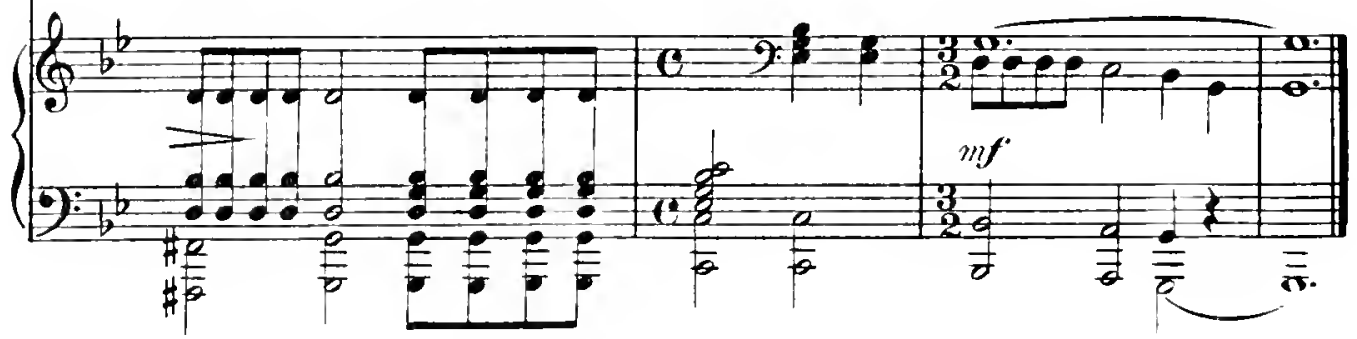


Parting.
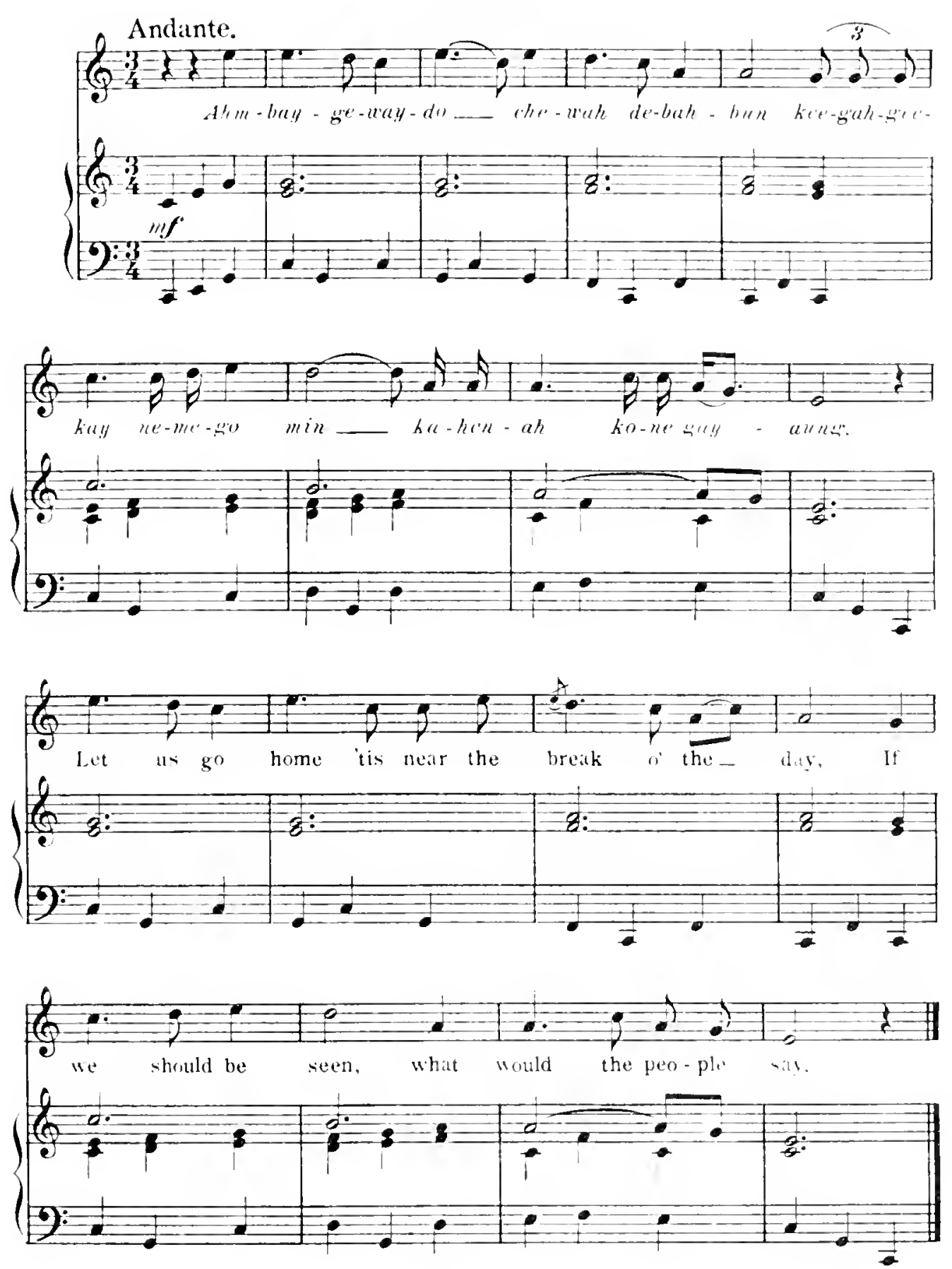

Copyright MCMIX by Frederiek R.Burton. 


\section{Doubt: a Death Song.}

Andante.

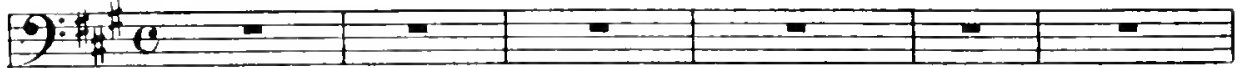

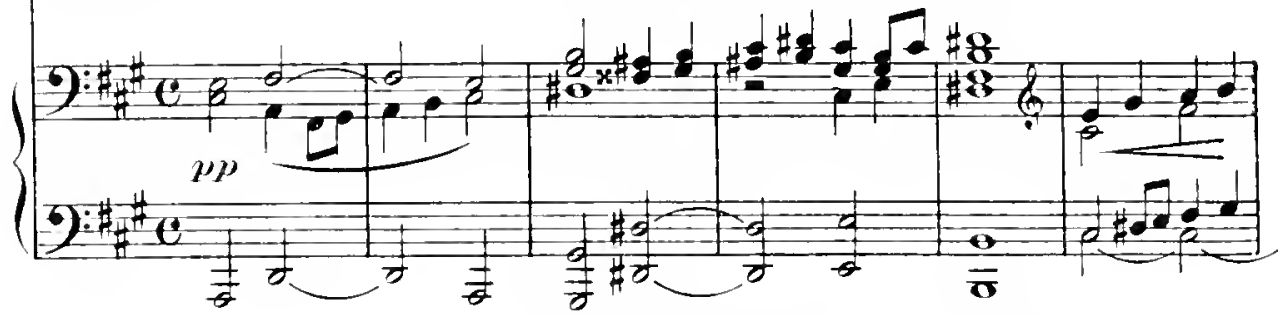

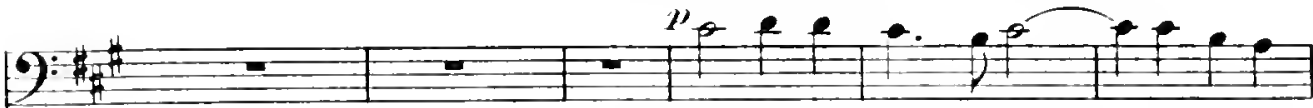

Dim is the poth be-fore - me ly-ing,

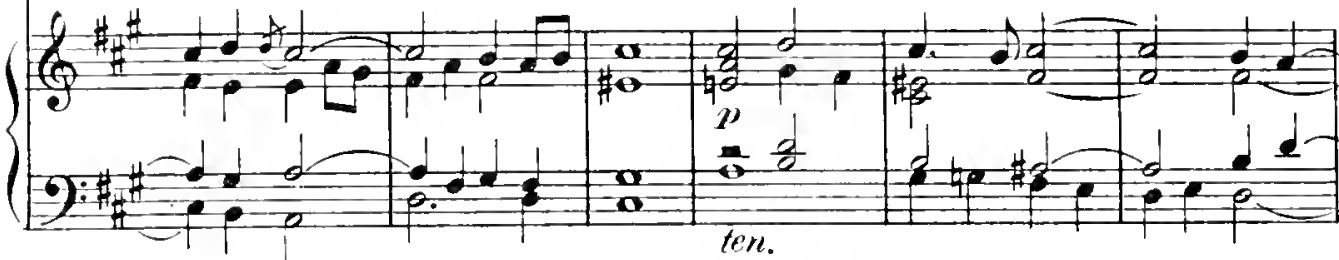

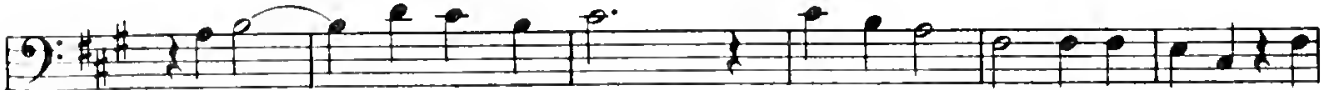
I know - notwhere it leads; Clouds of doubt hang oier me dy-ing; I

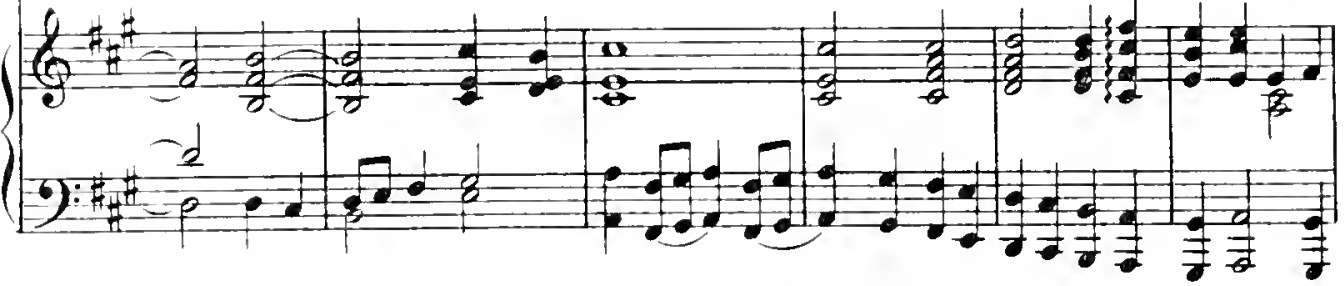

9): call tor yuid-ance; No friendly spir-it heeds. -

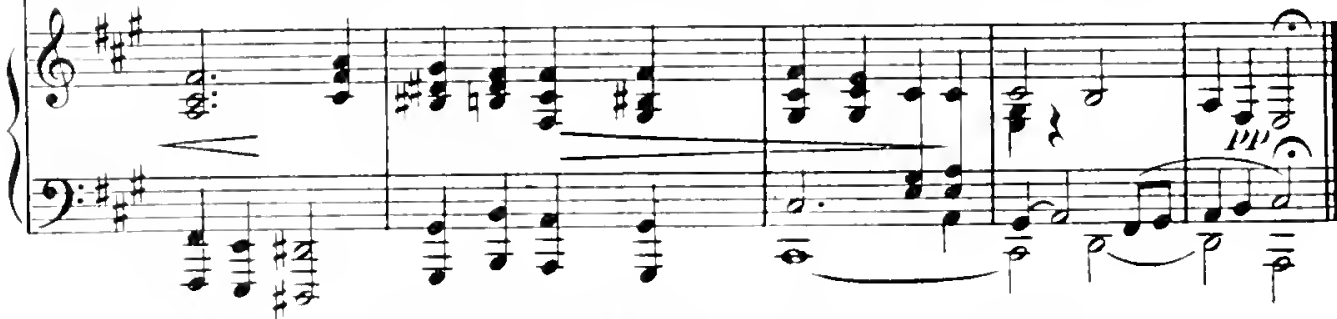

Copyright MCMLY by Frederick R.Burton. 
In the Forest.

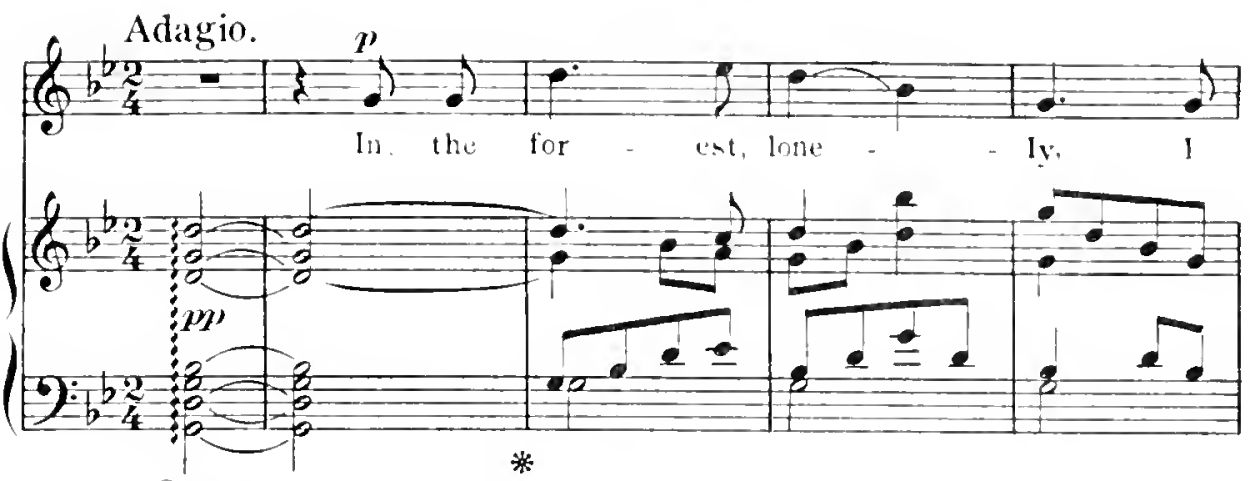

200.
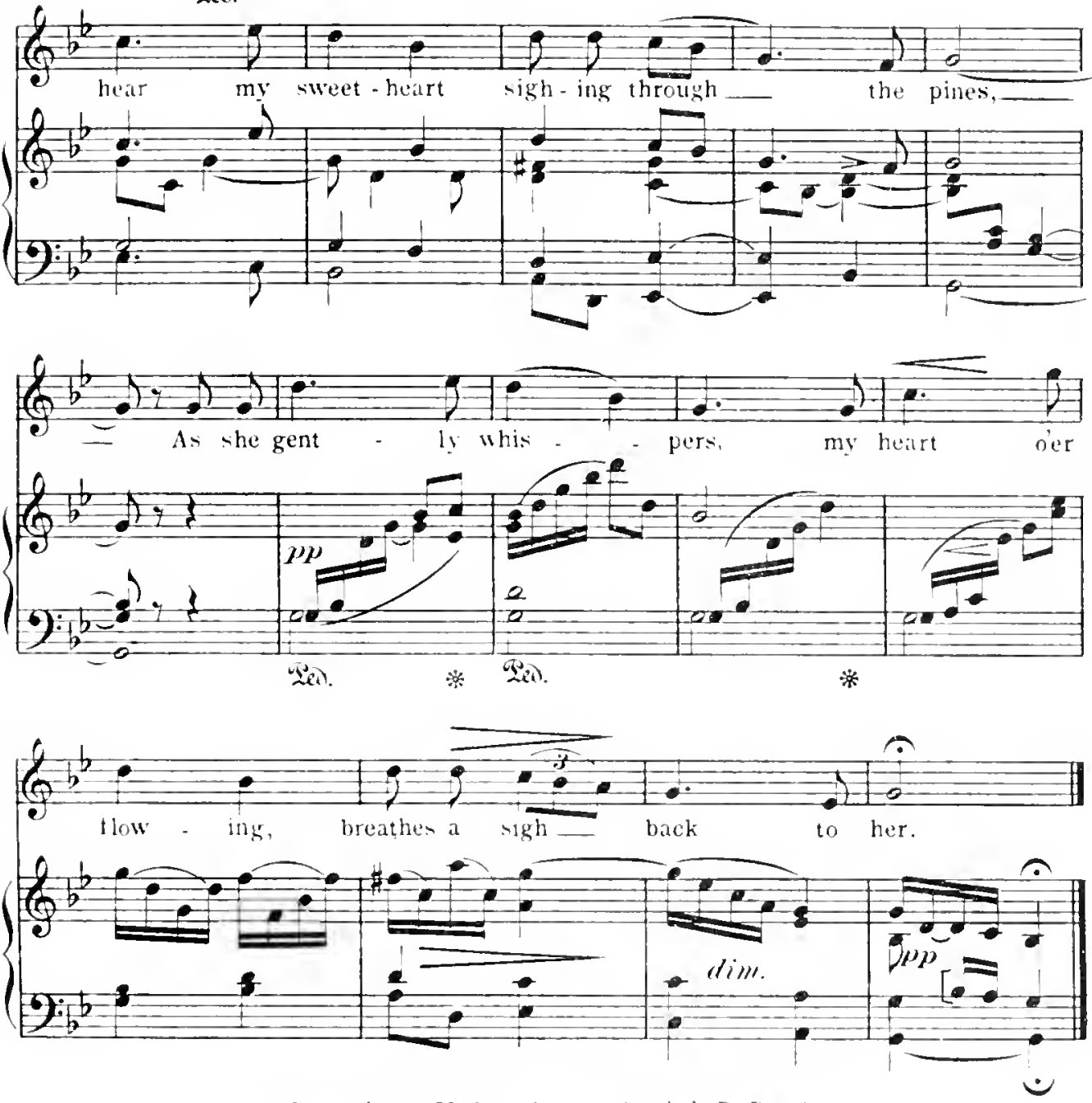

Copyriaht Wh if ${ }^{\prime}$ by Frederick $R$. Rurton. 


\section{Winter.}
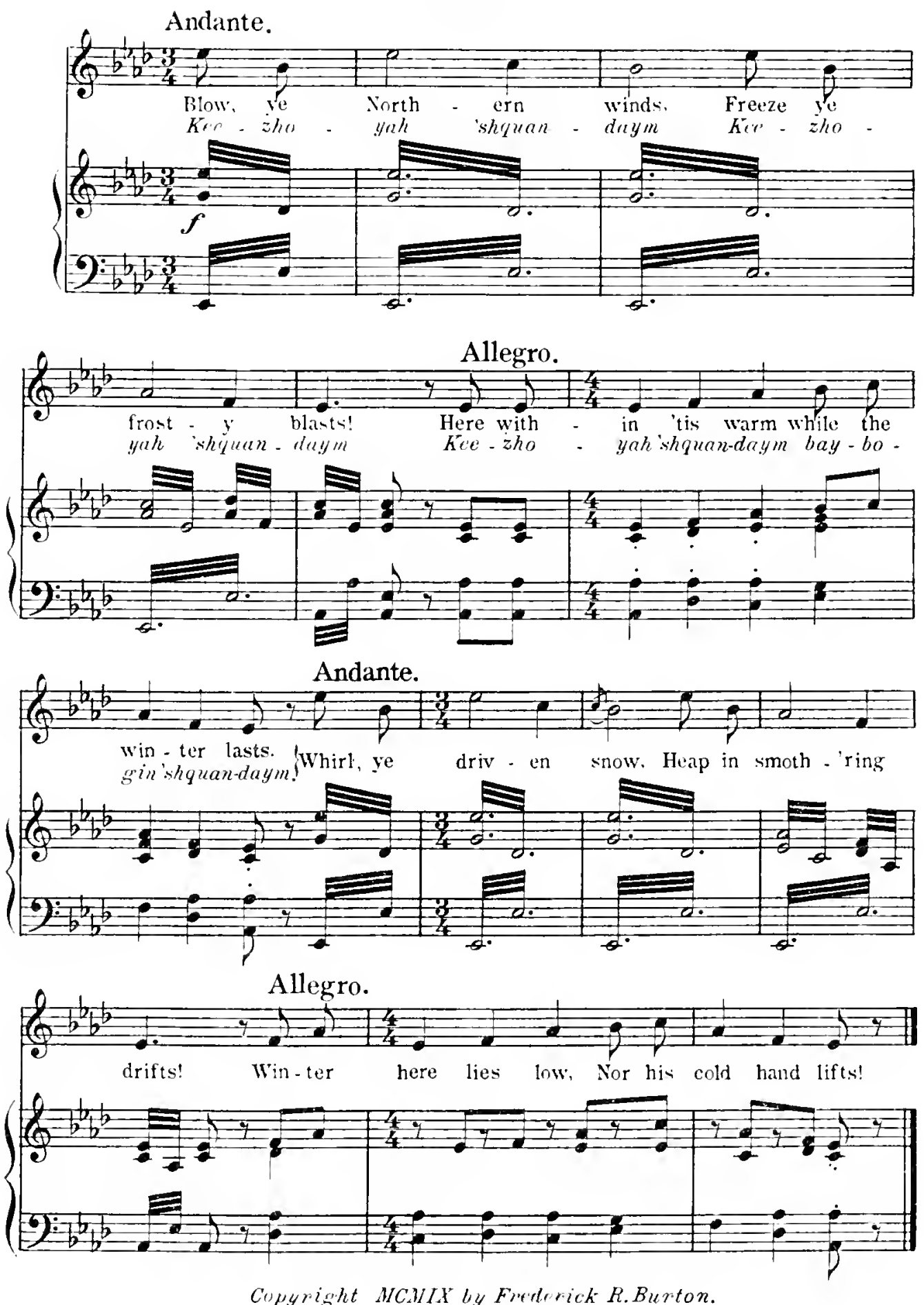
In The Sugar Camp.
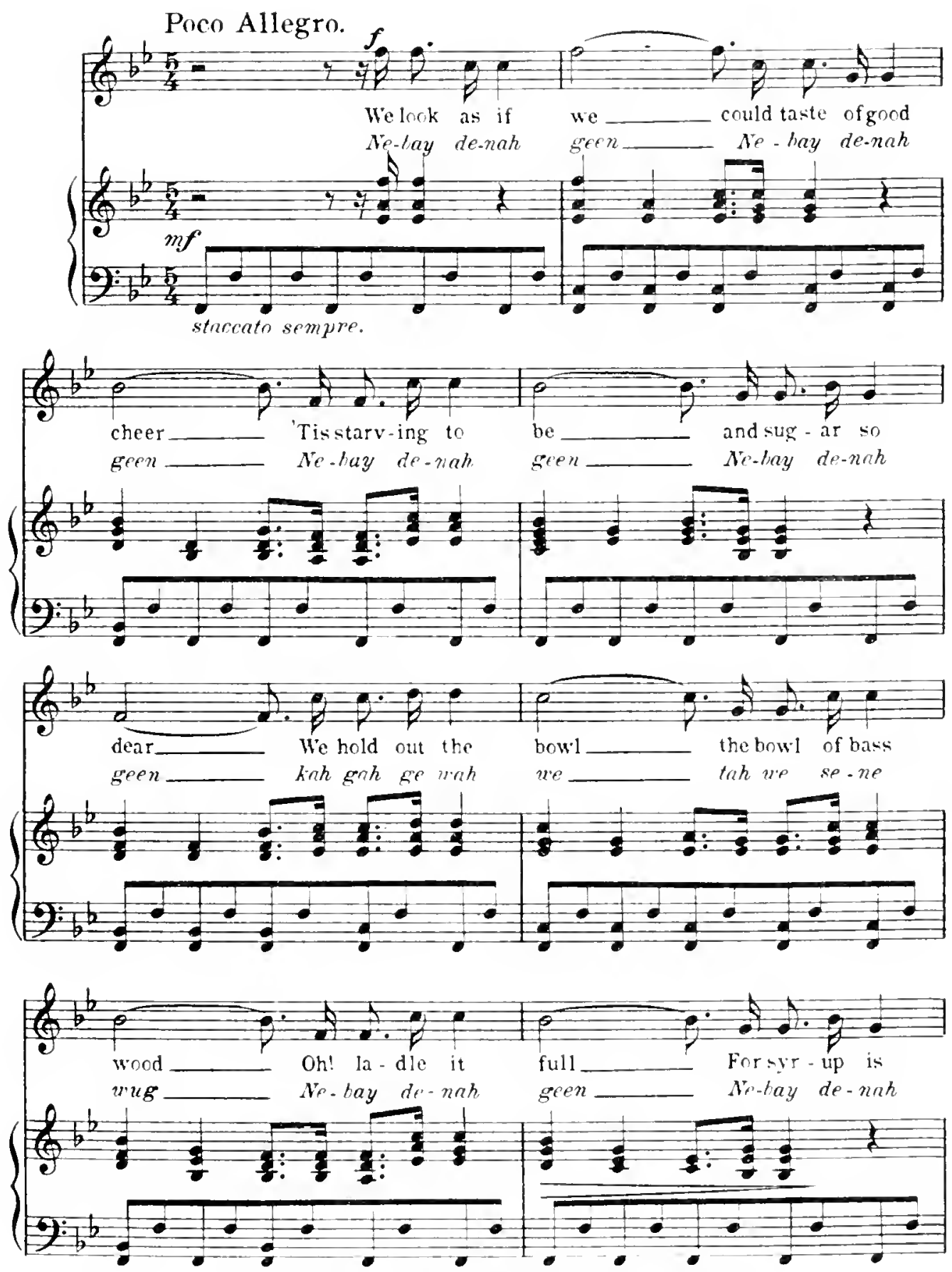

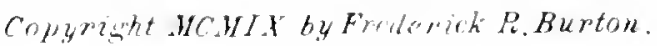




\section{2}
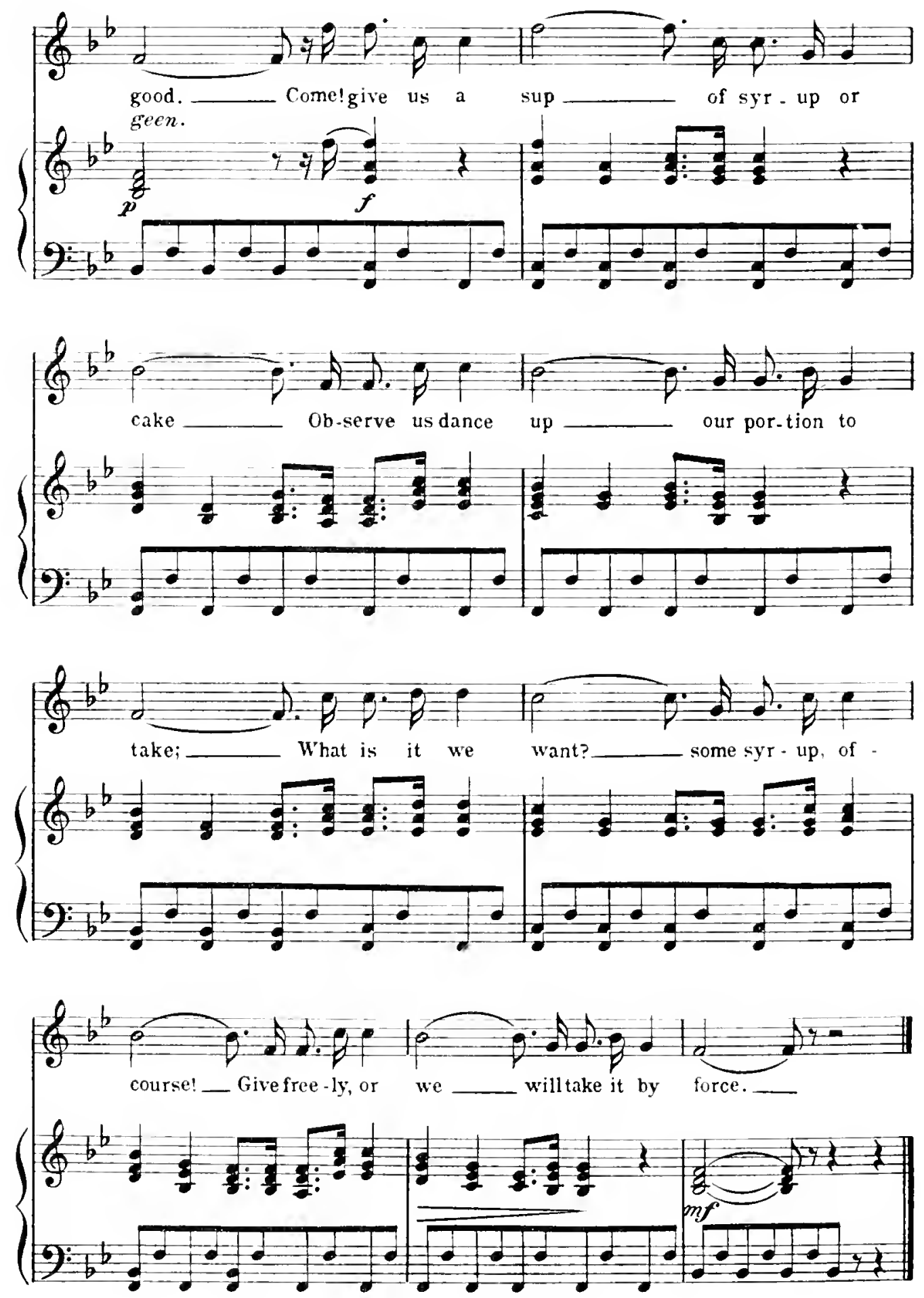
The Lucky Trapper.
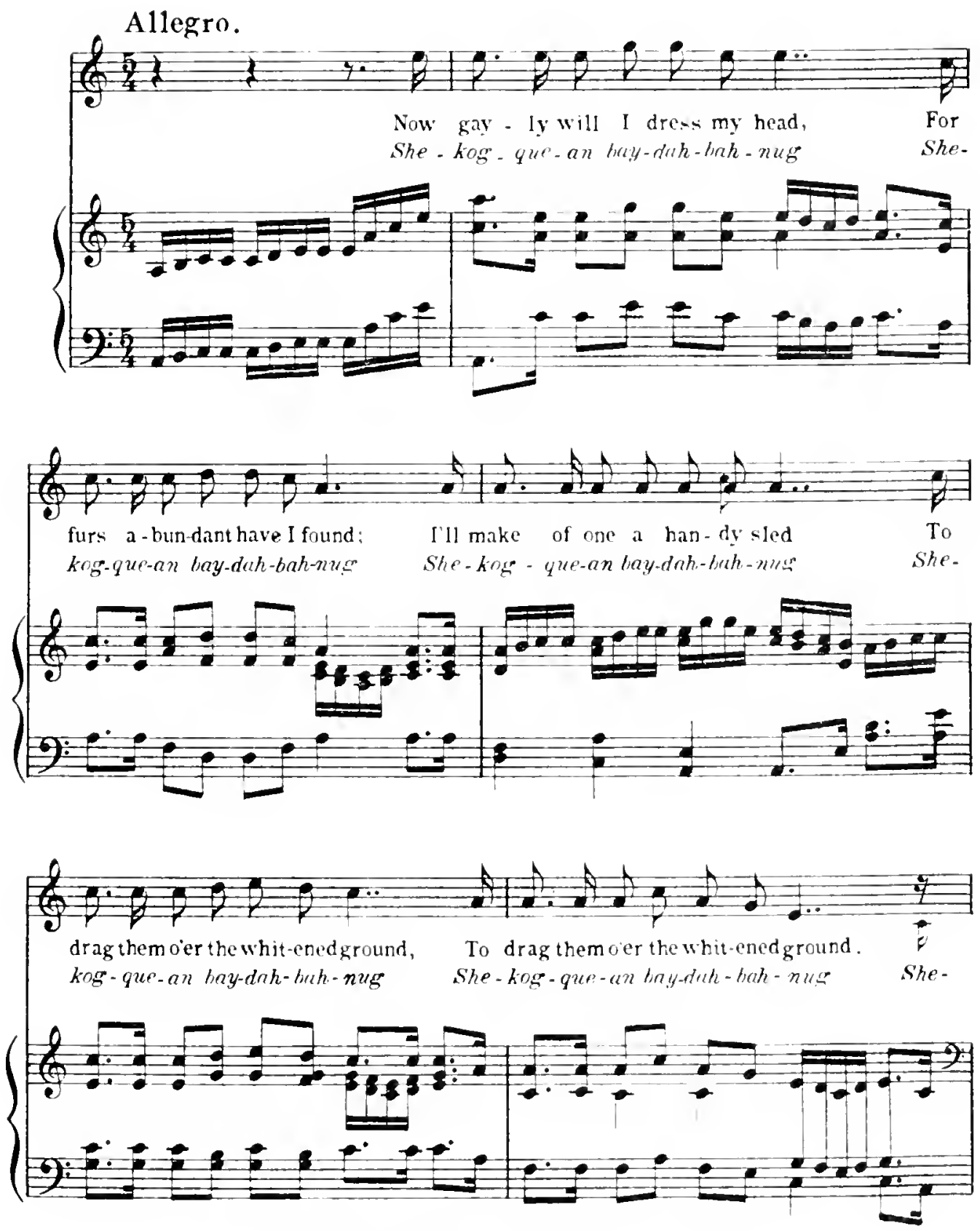

Copyright MCMIX by Frelerick R. Burton. 
12 kog-que-an bay-dah-bah-nug.

$4.2+2=2+2+2$

It caught its prey,each clev-ertrap.

It

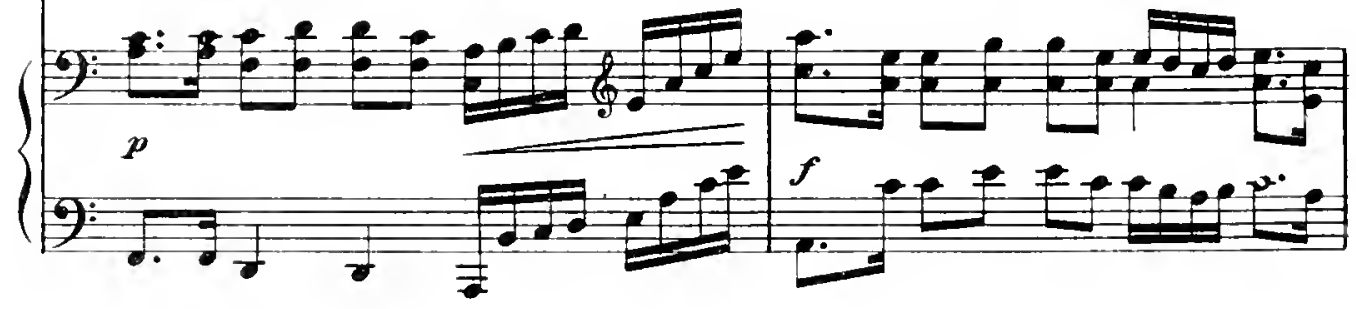

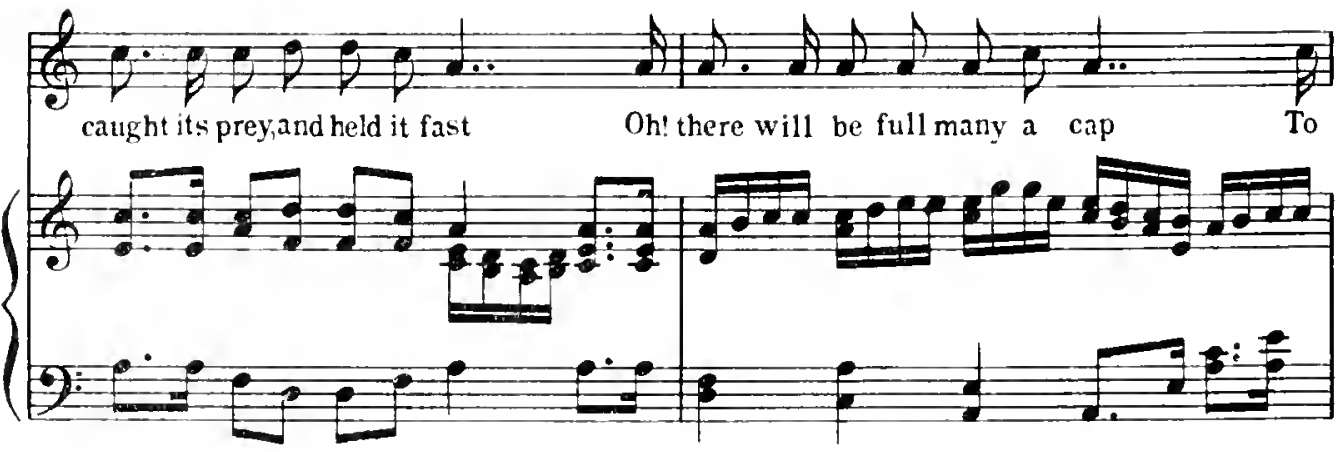

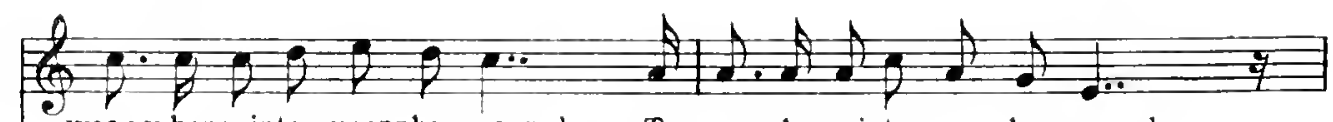
wear when winter moons have passed, To wear when winter moons have passed.
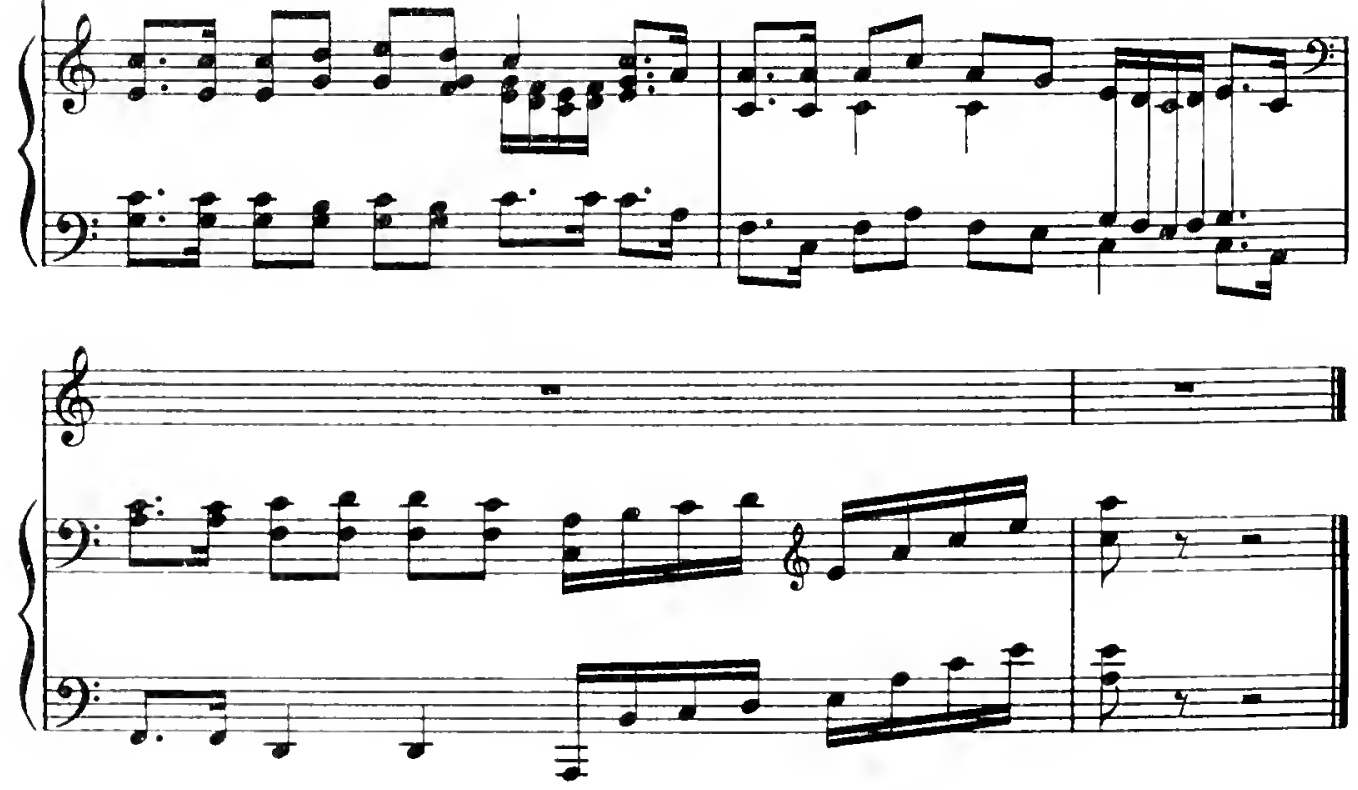
A Song of Absence and Longing.
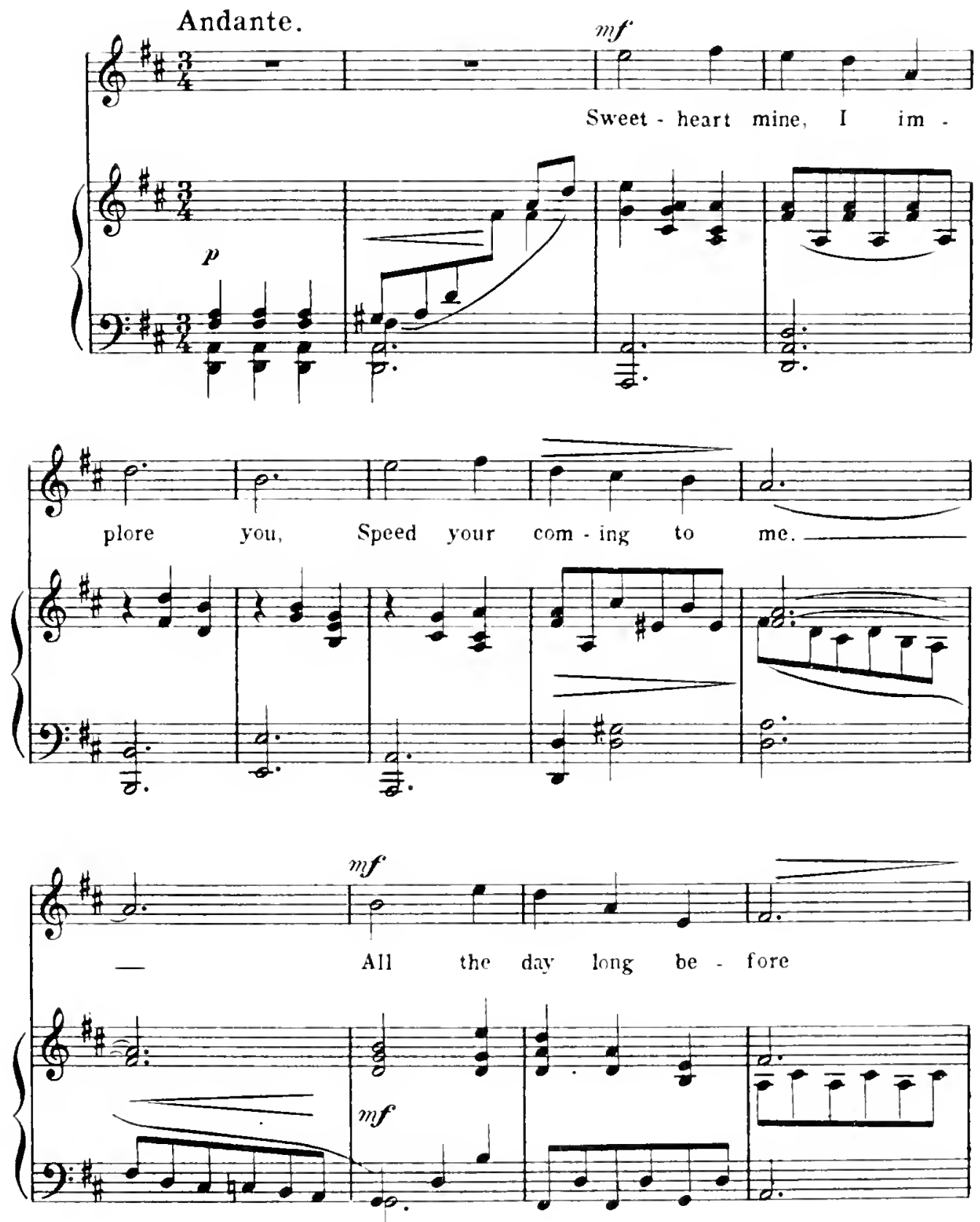

Copyright MC.WIX by Fiederick R. Burton. 

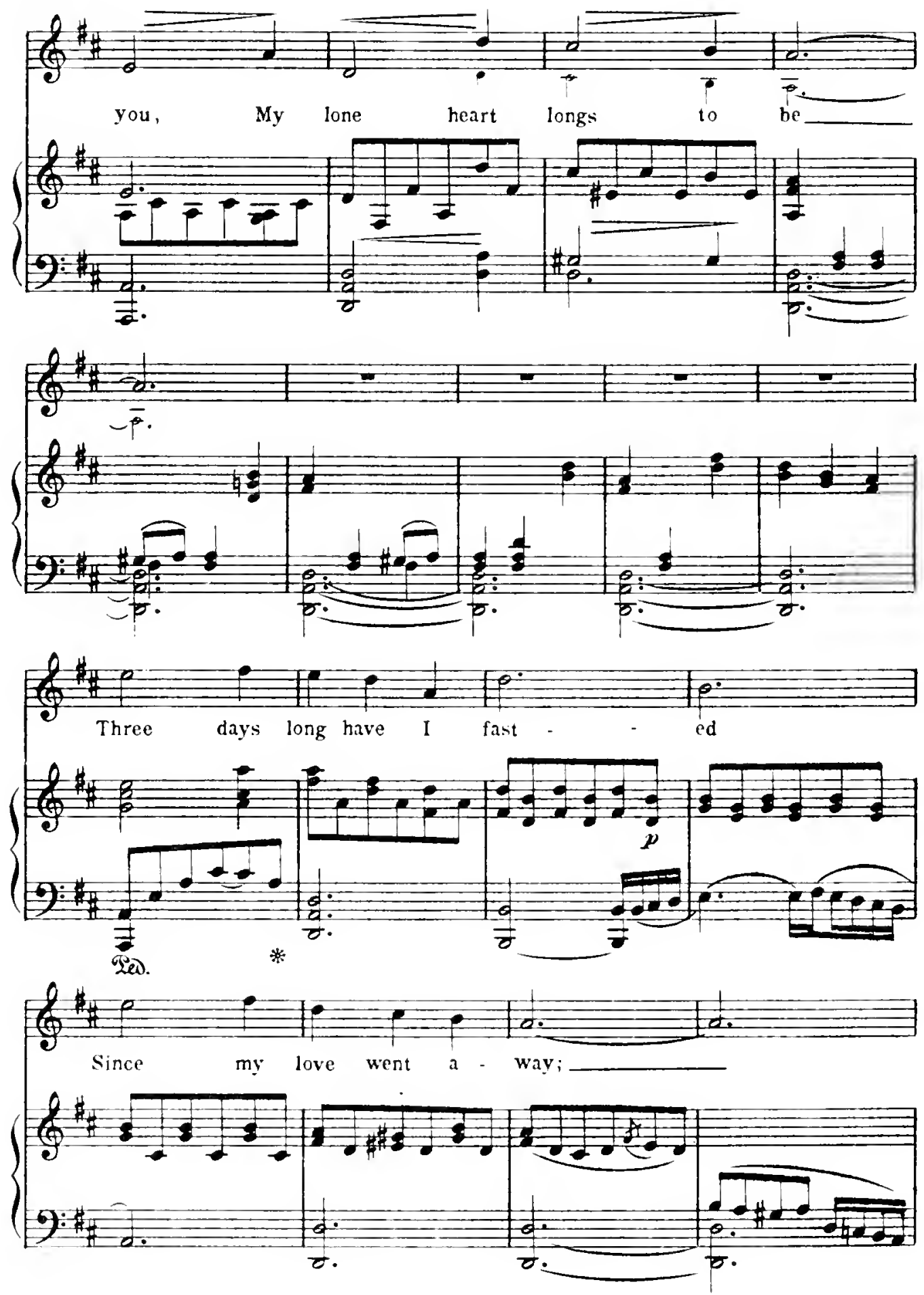


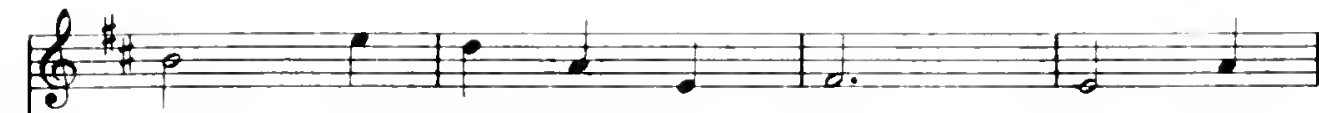
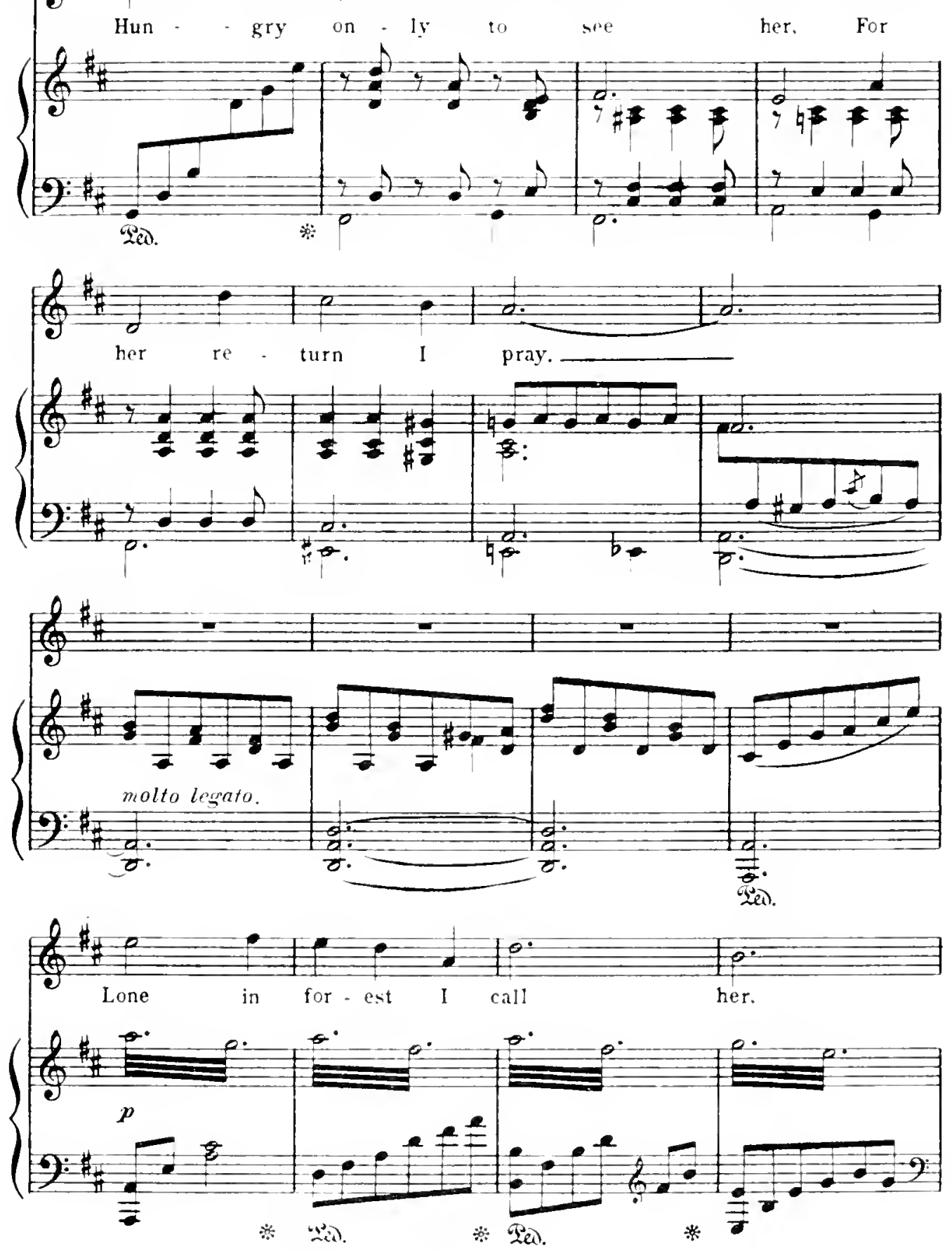

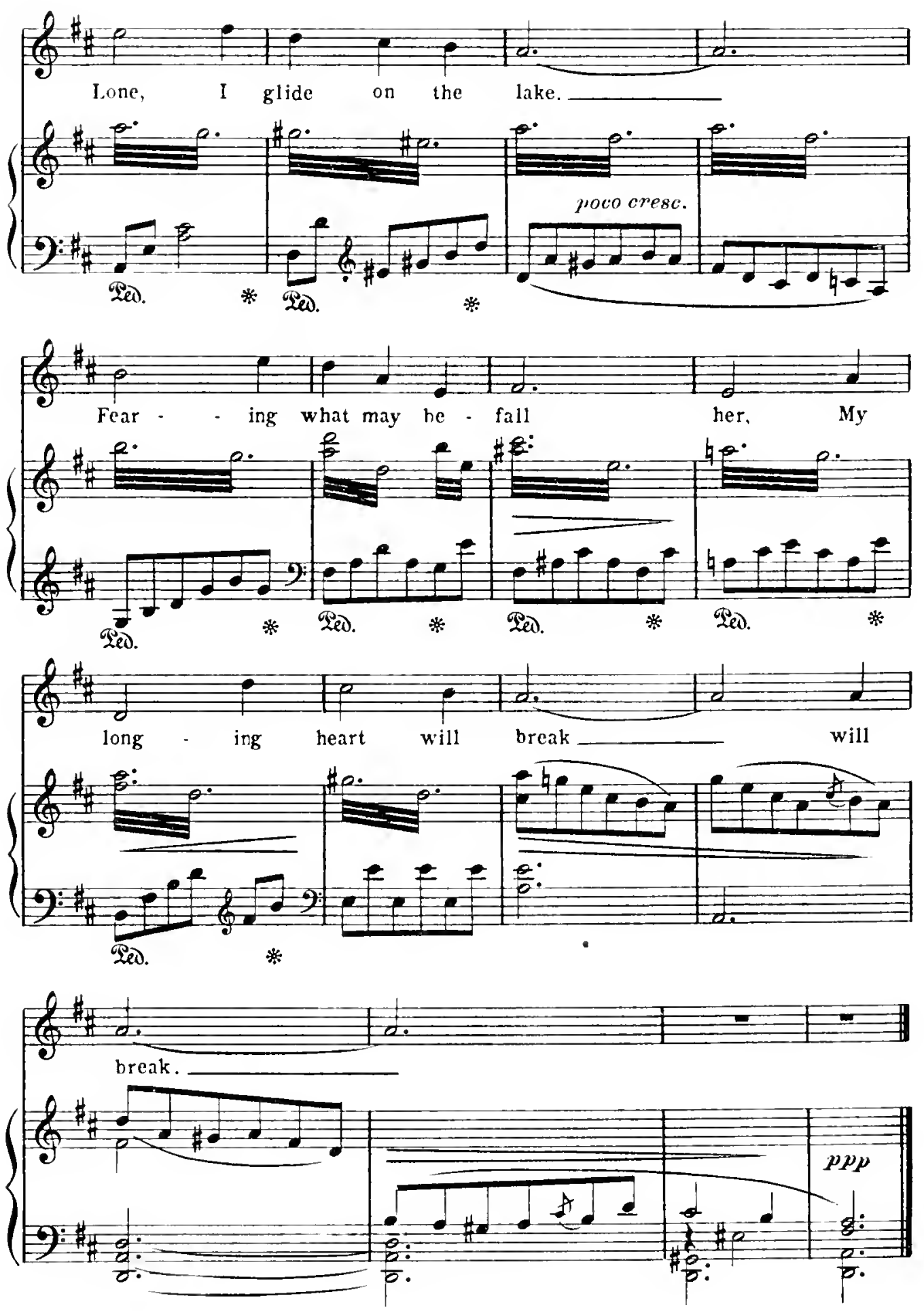
Her Shadow.
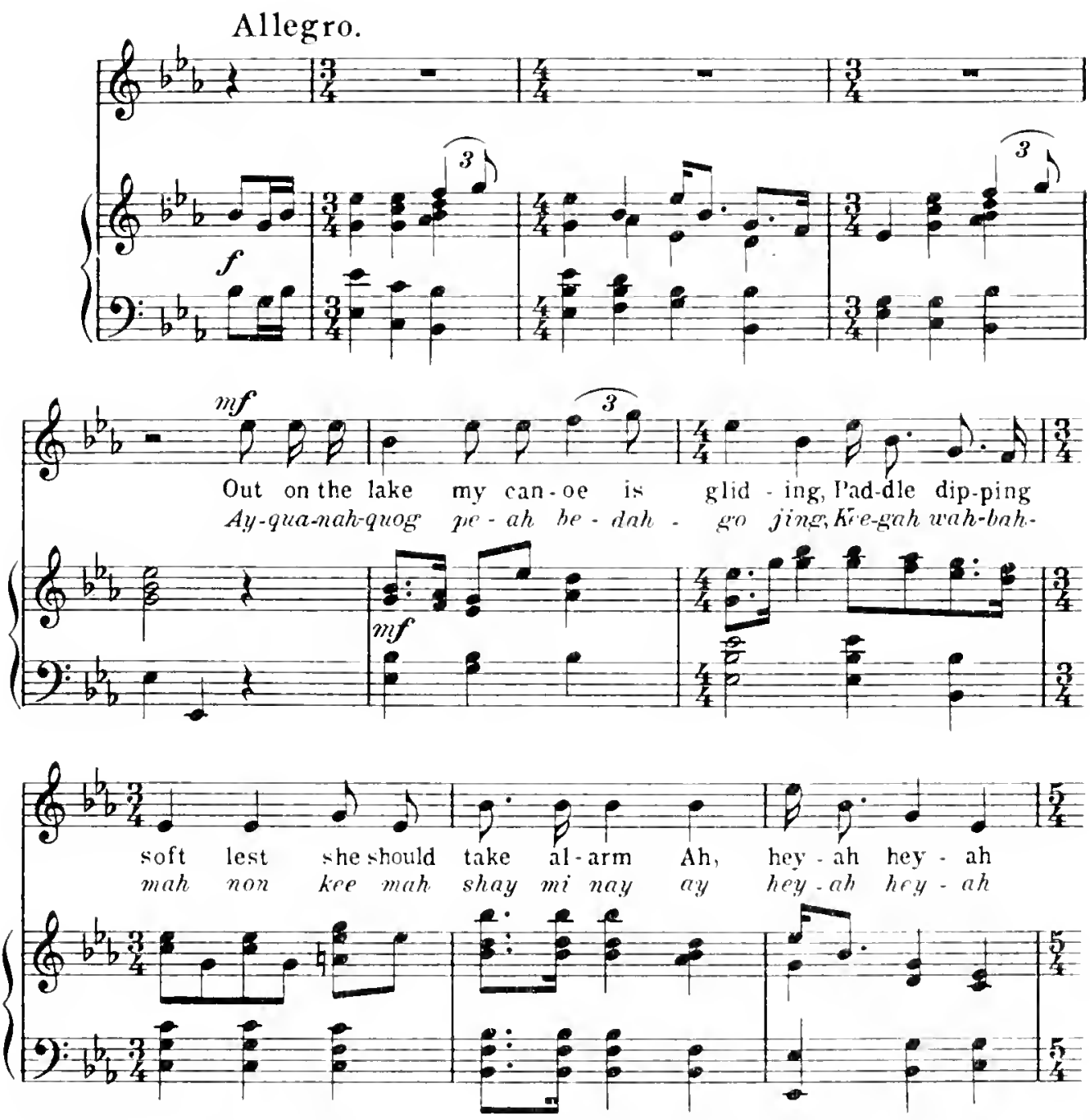

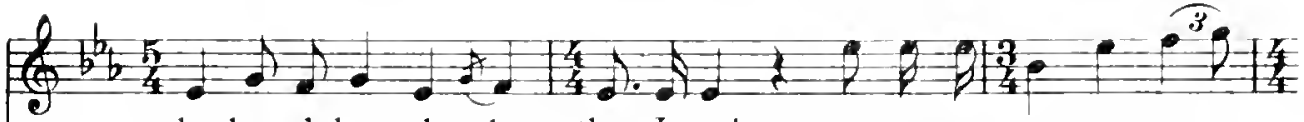
ho, hey-ah hey-ah ho, thus I go! Some-wherea-longshore she is ho, hey-ah hey-ah ho, hey-ah ho.

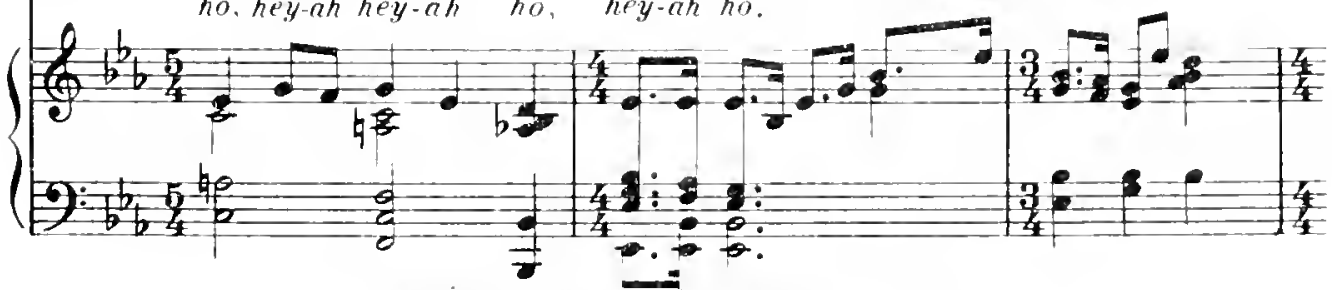

Comyright MCALXYy Frederick $R$. Burton. 


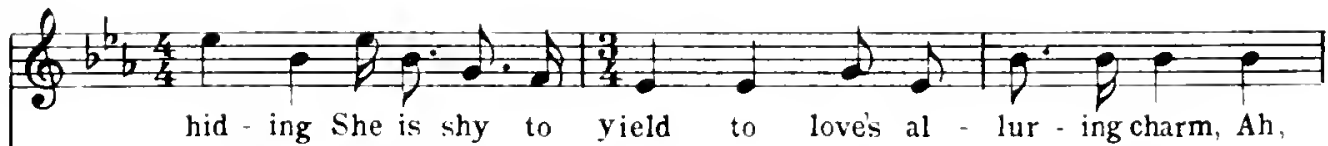

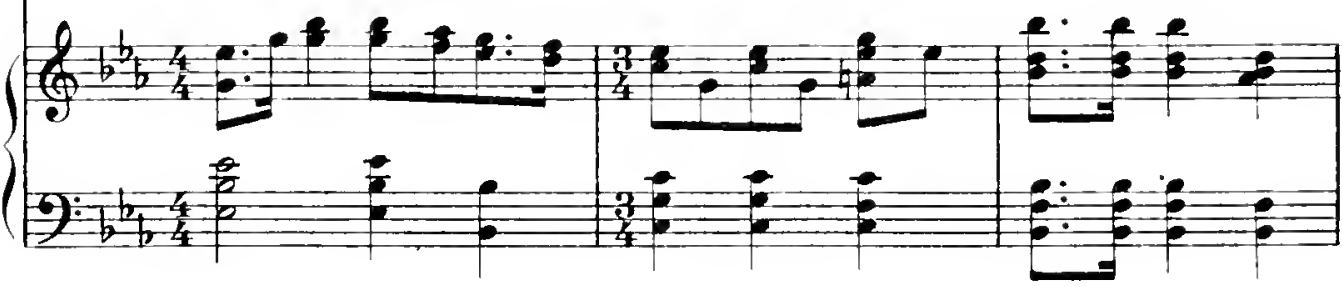

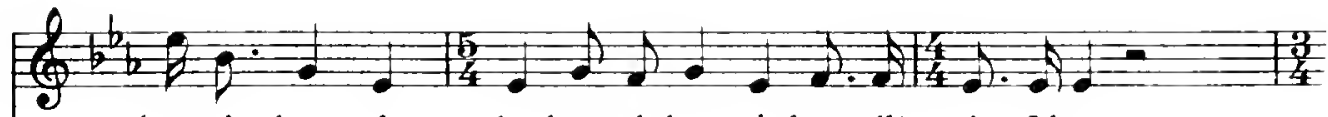
hey-ah hey - ah ho, hey - ah hey-ah, lovewill win, I know.

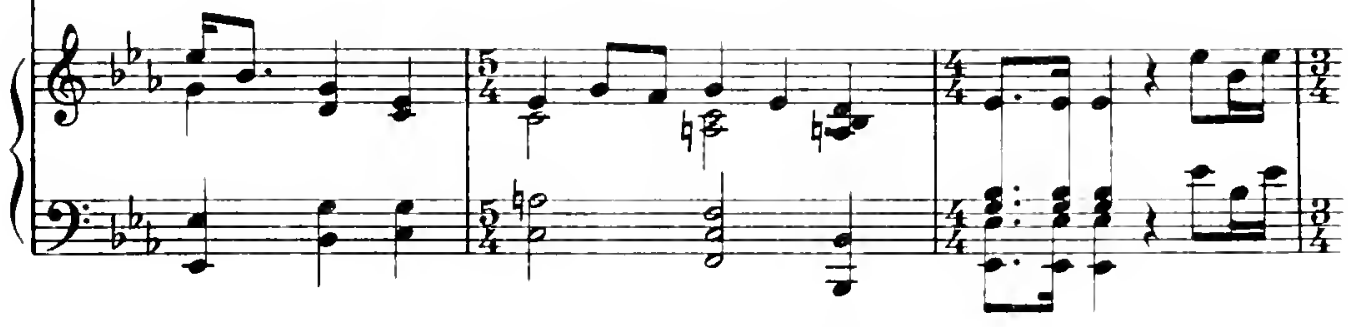

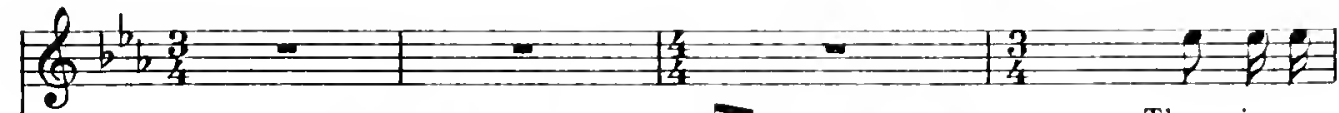

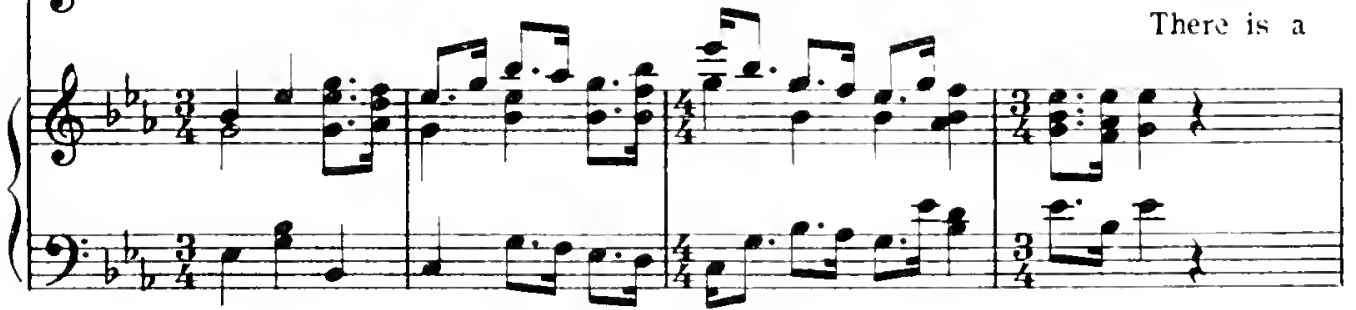

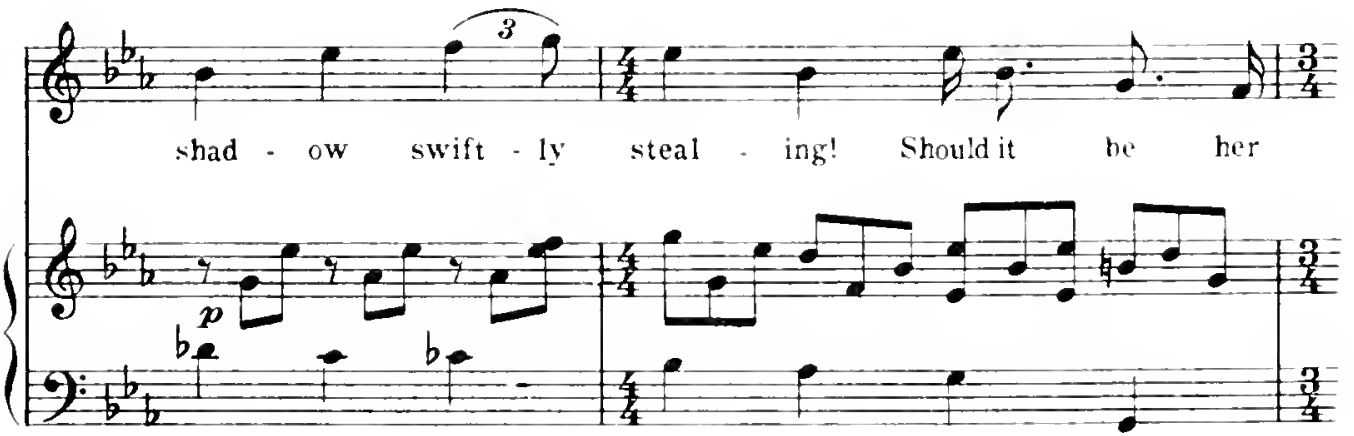



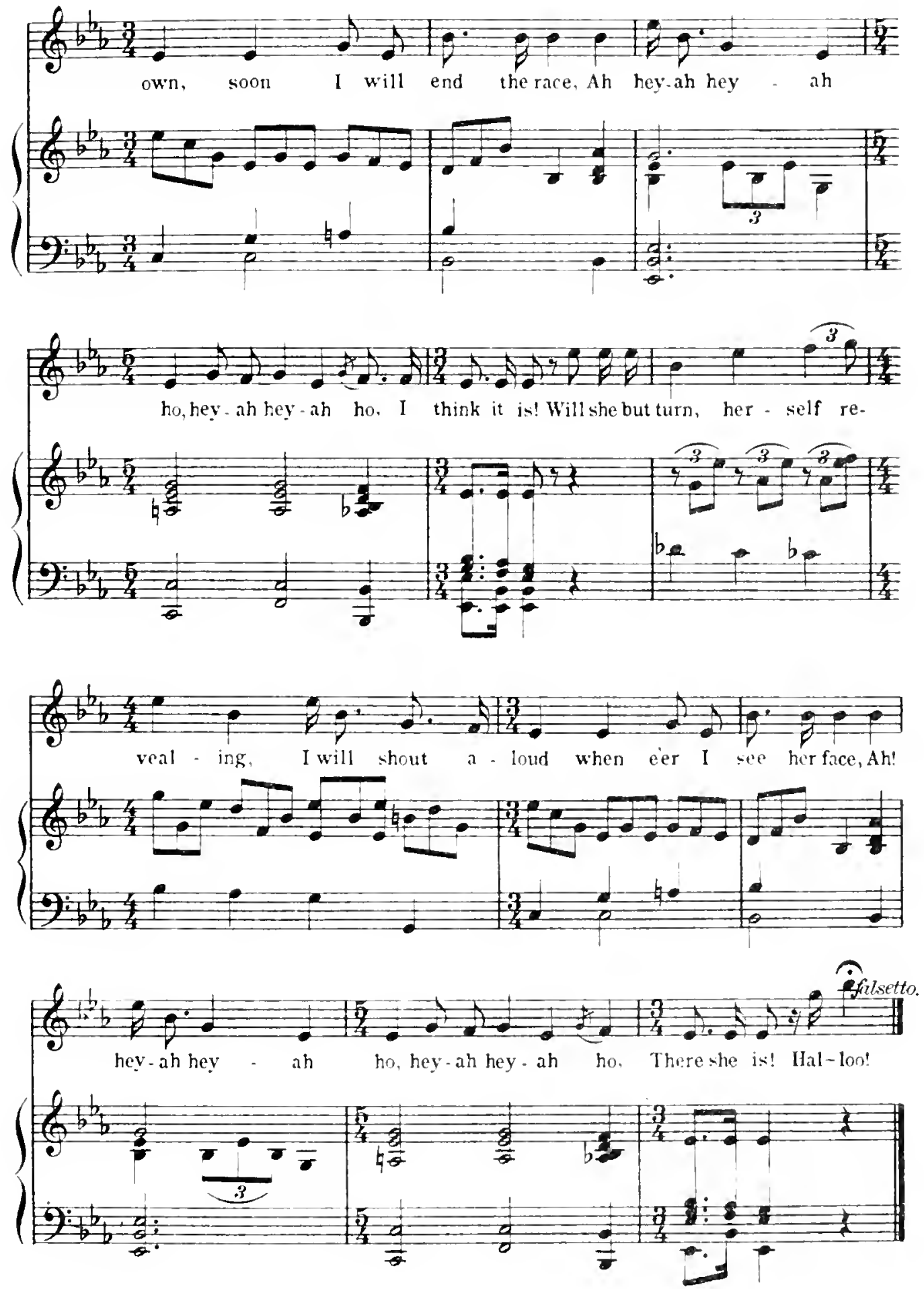
Old Shoes.

Allegro moderato.
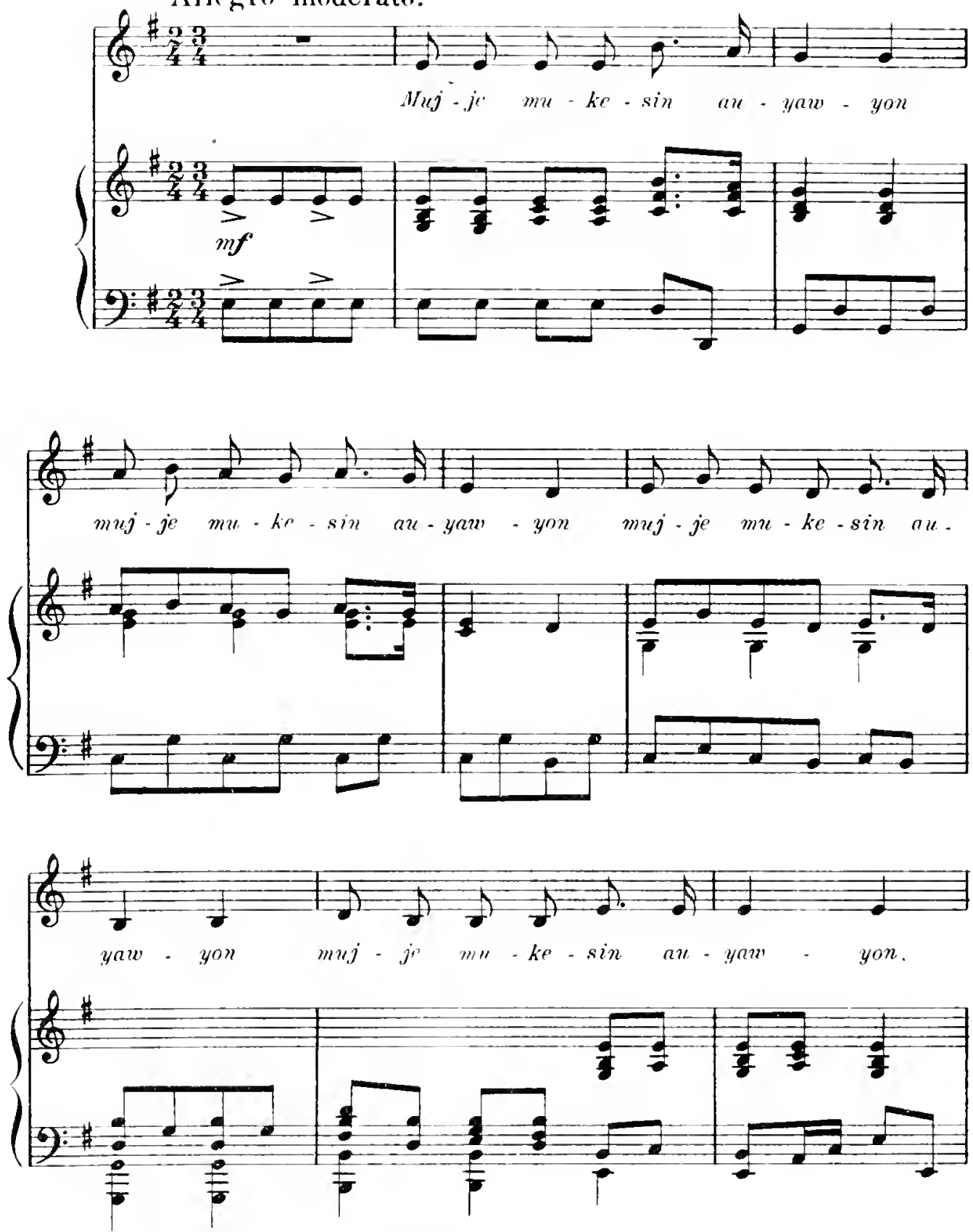

Copyright MCHIX by Firederisk R. Burton. 

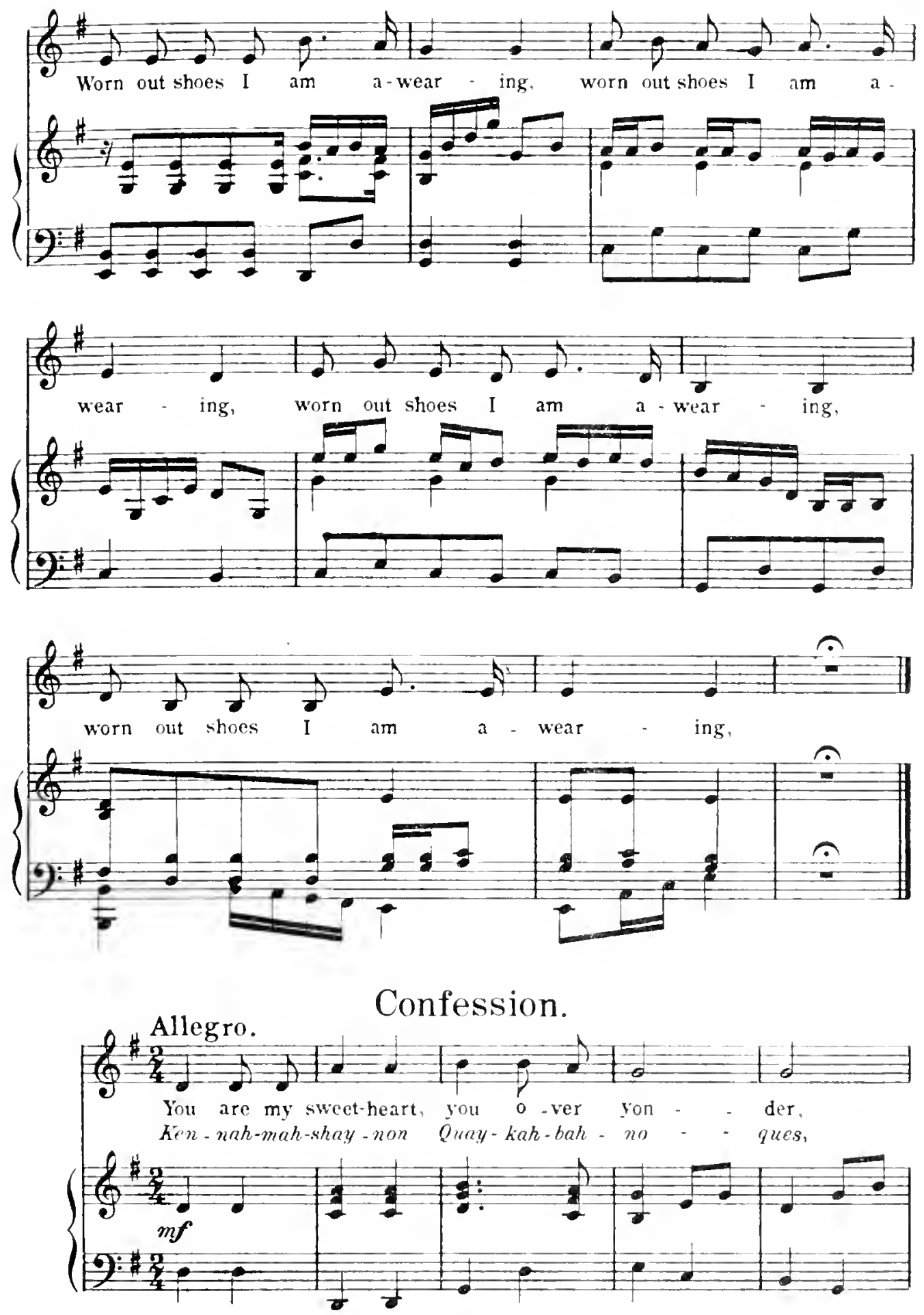
34
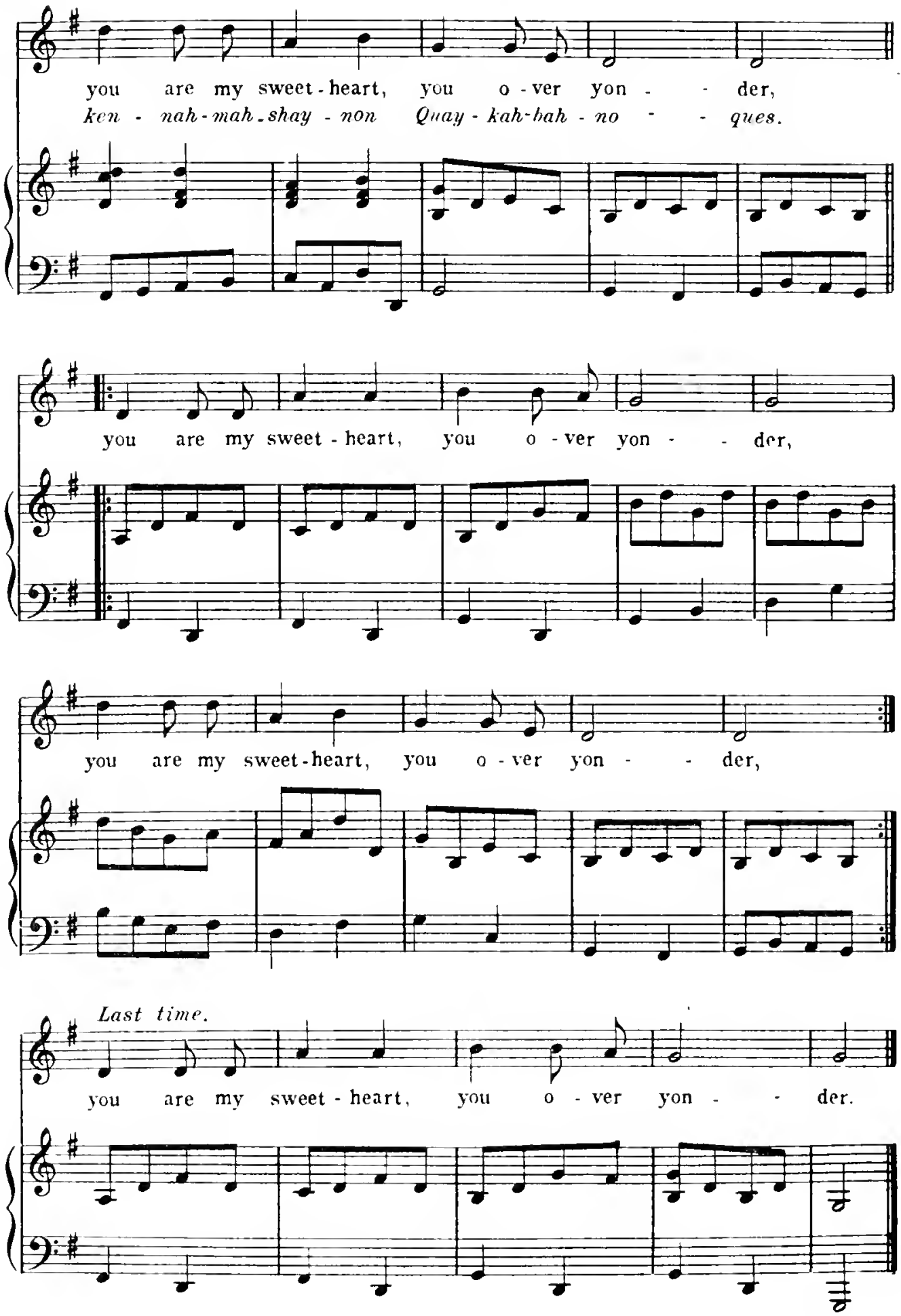
The Forest Choir.
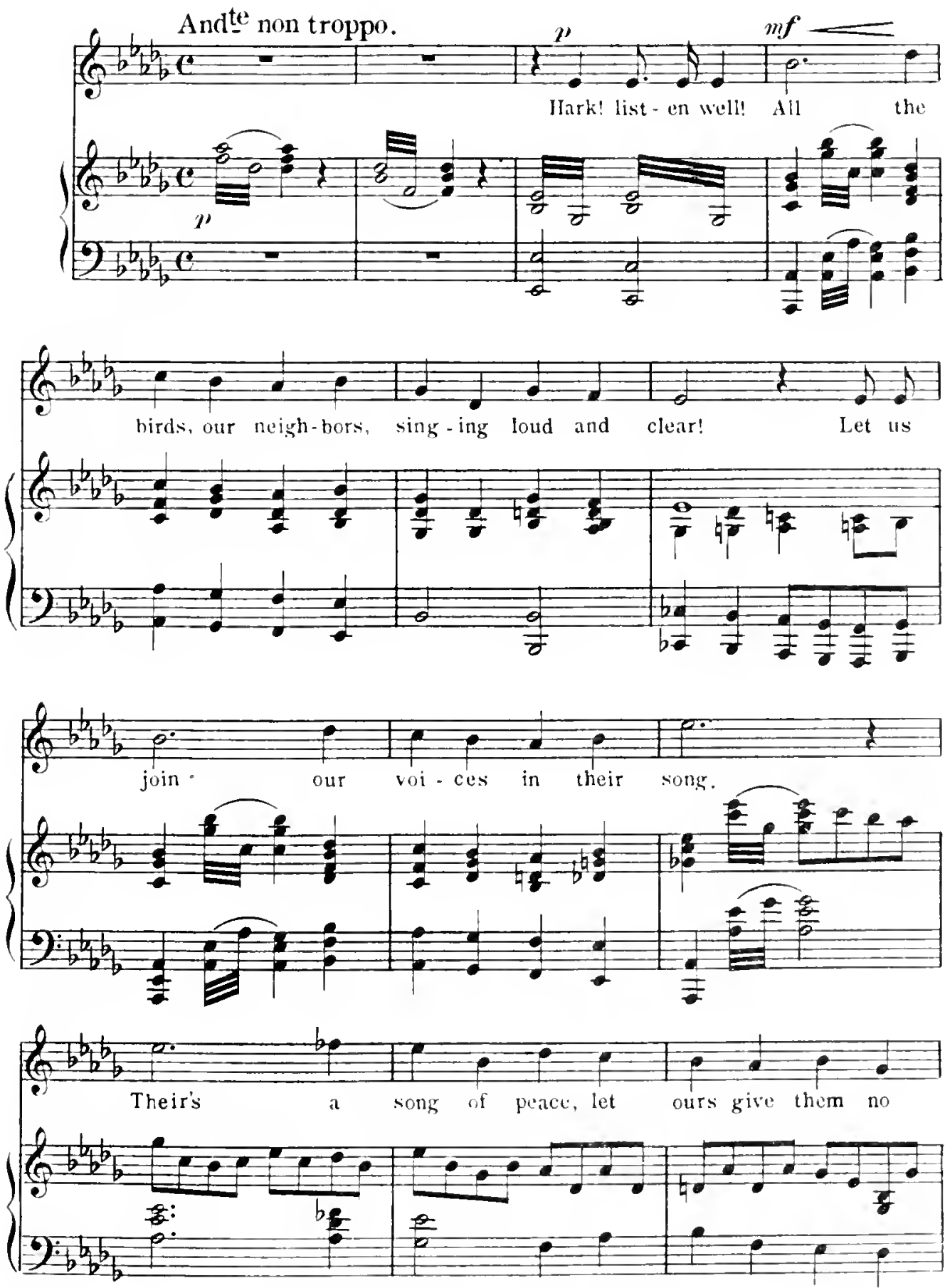

Copyright NCMIX by Frederick R.Burton. 


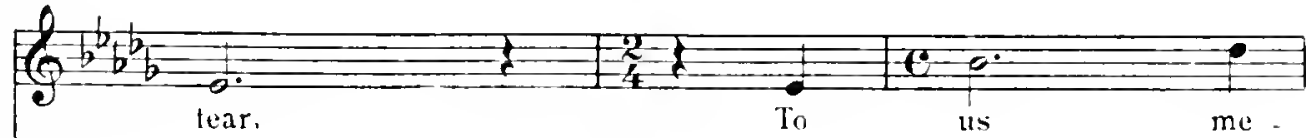

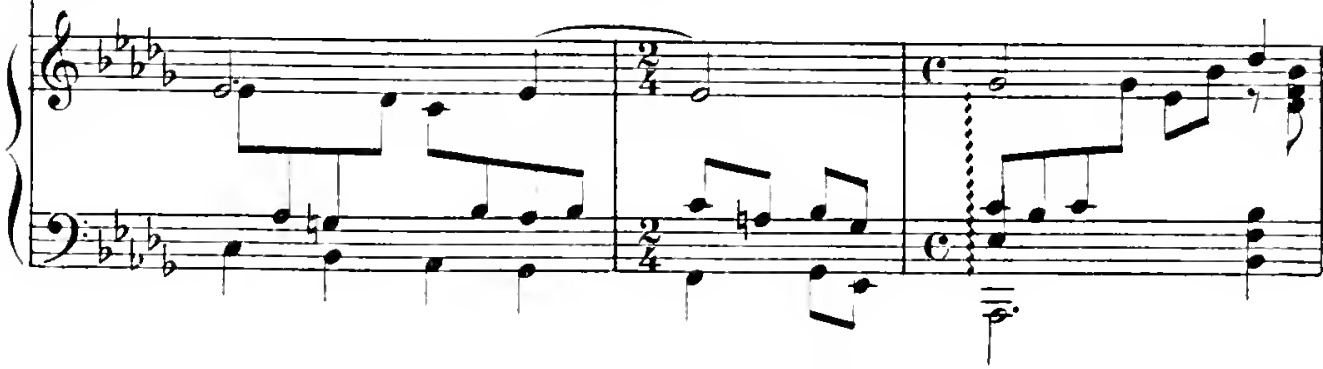

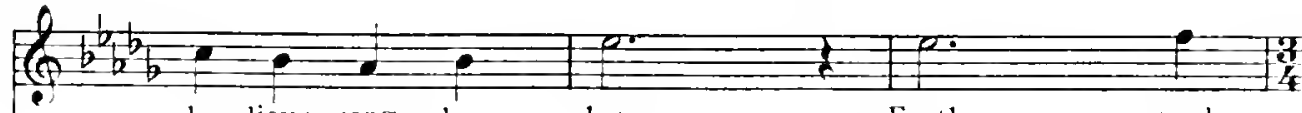
lo- dious songs be - long ;

Feath - - ered

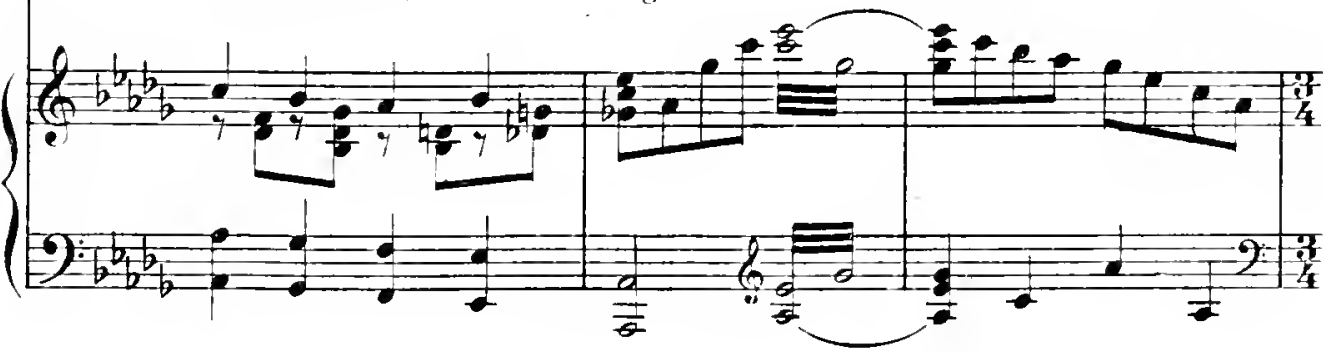

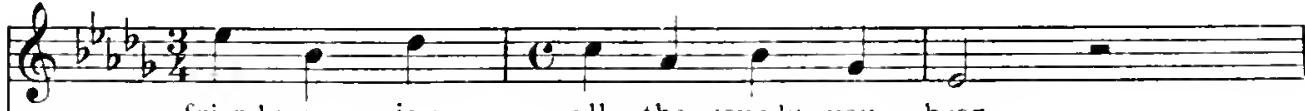
friends, en - joy all the sound you hear.

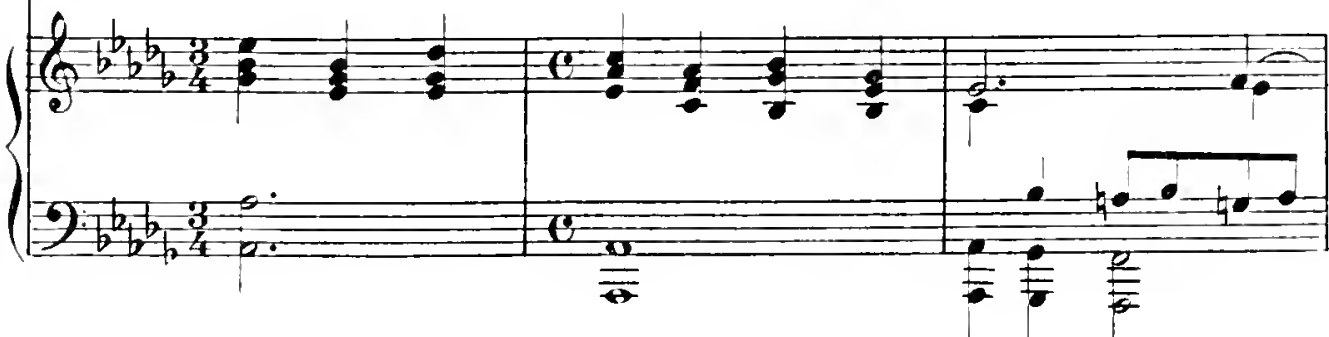

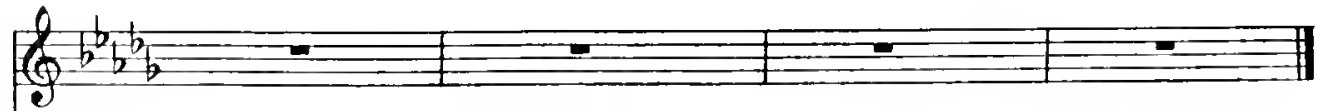

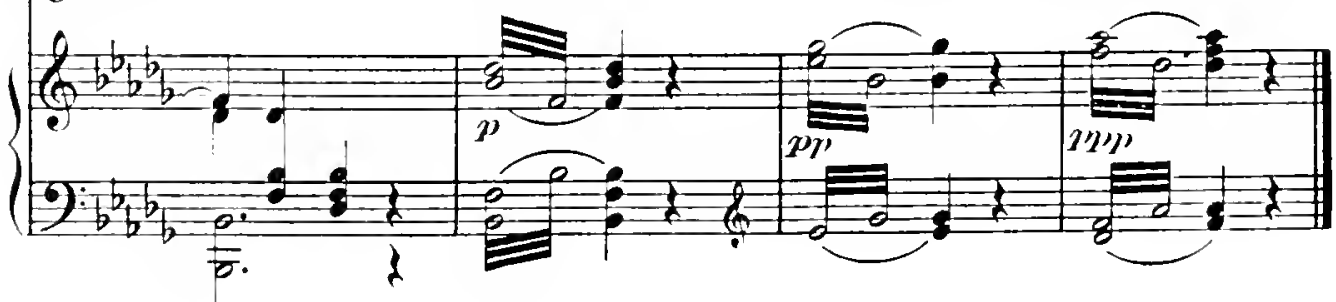


The Lake Sheen.
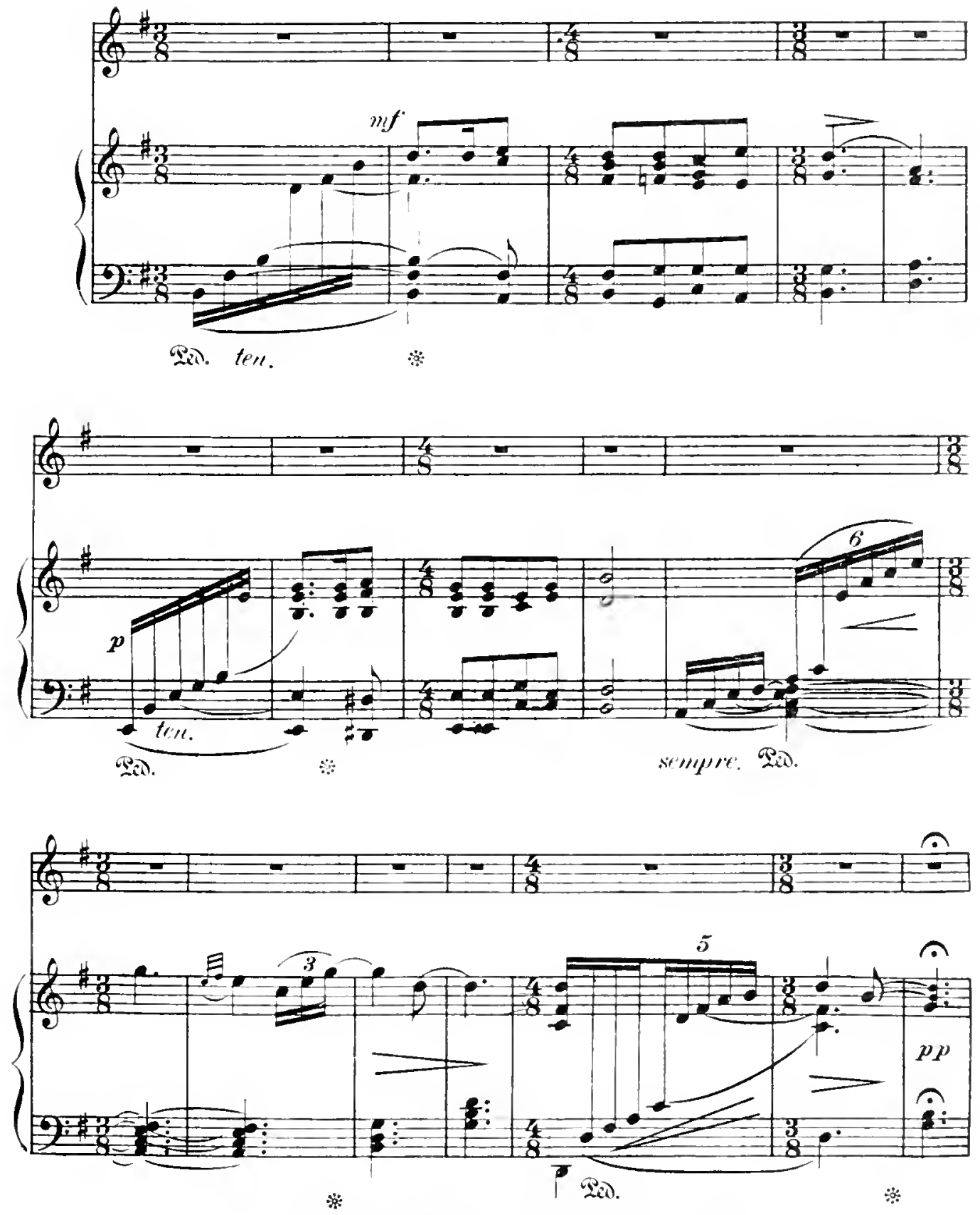

Copyright MCMIX by Frederick R.Burton. 

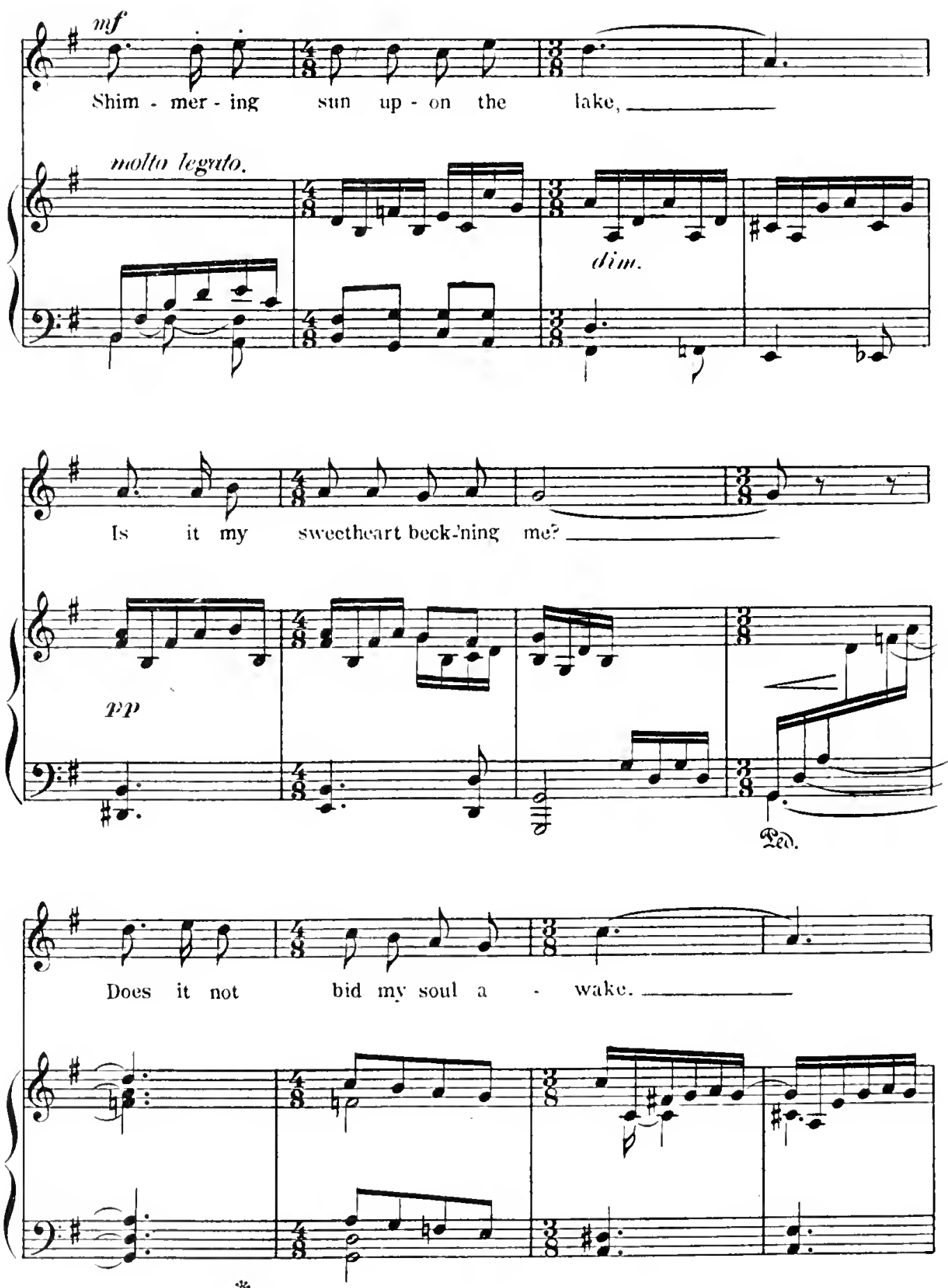

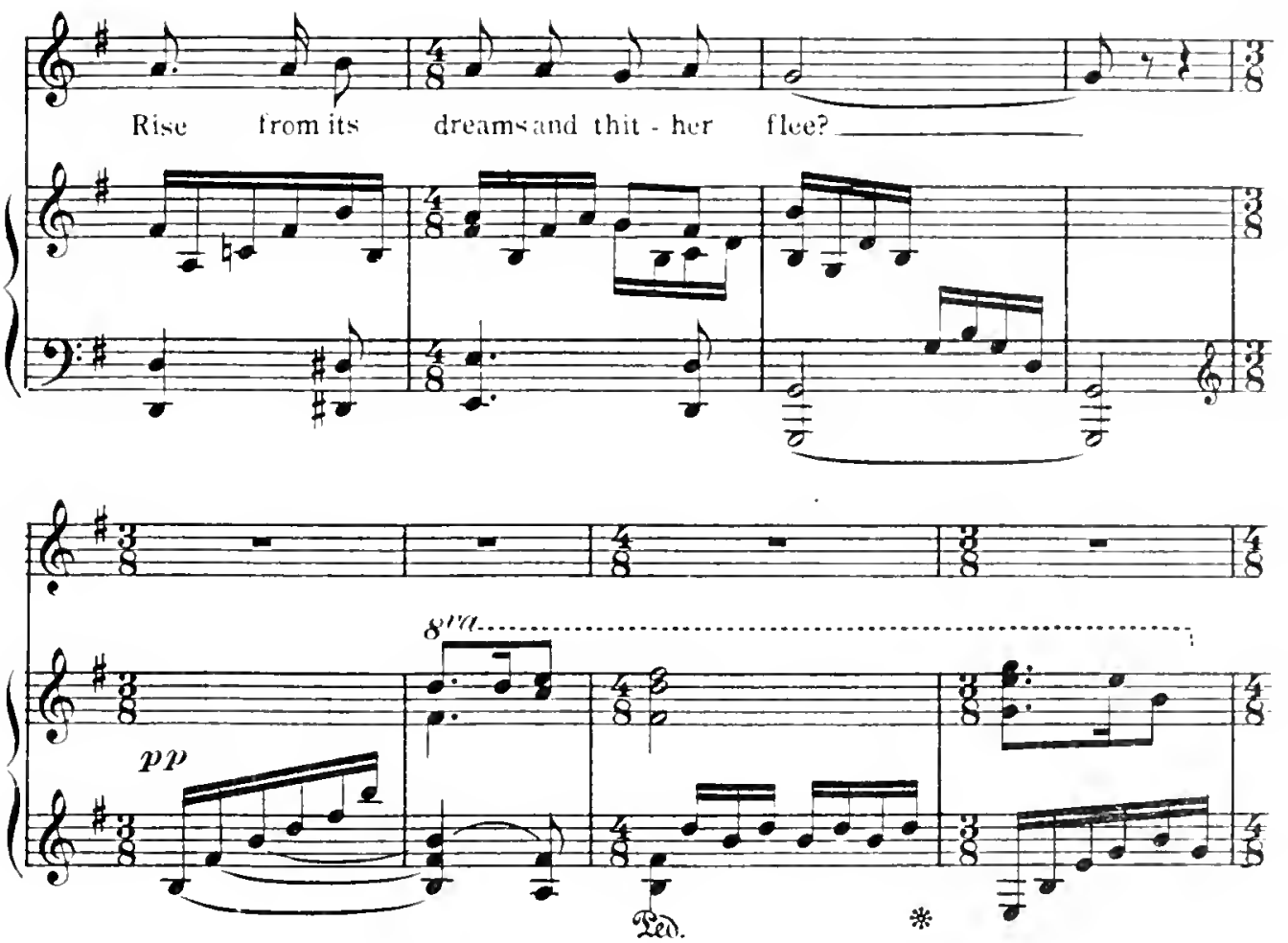

$8+3=$
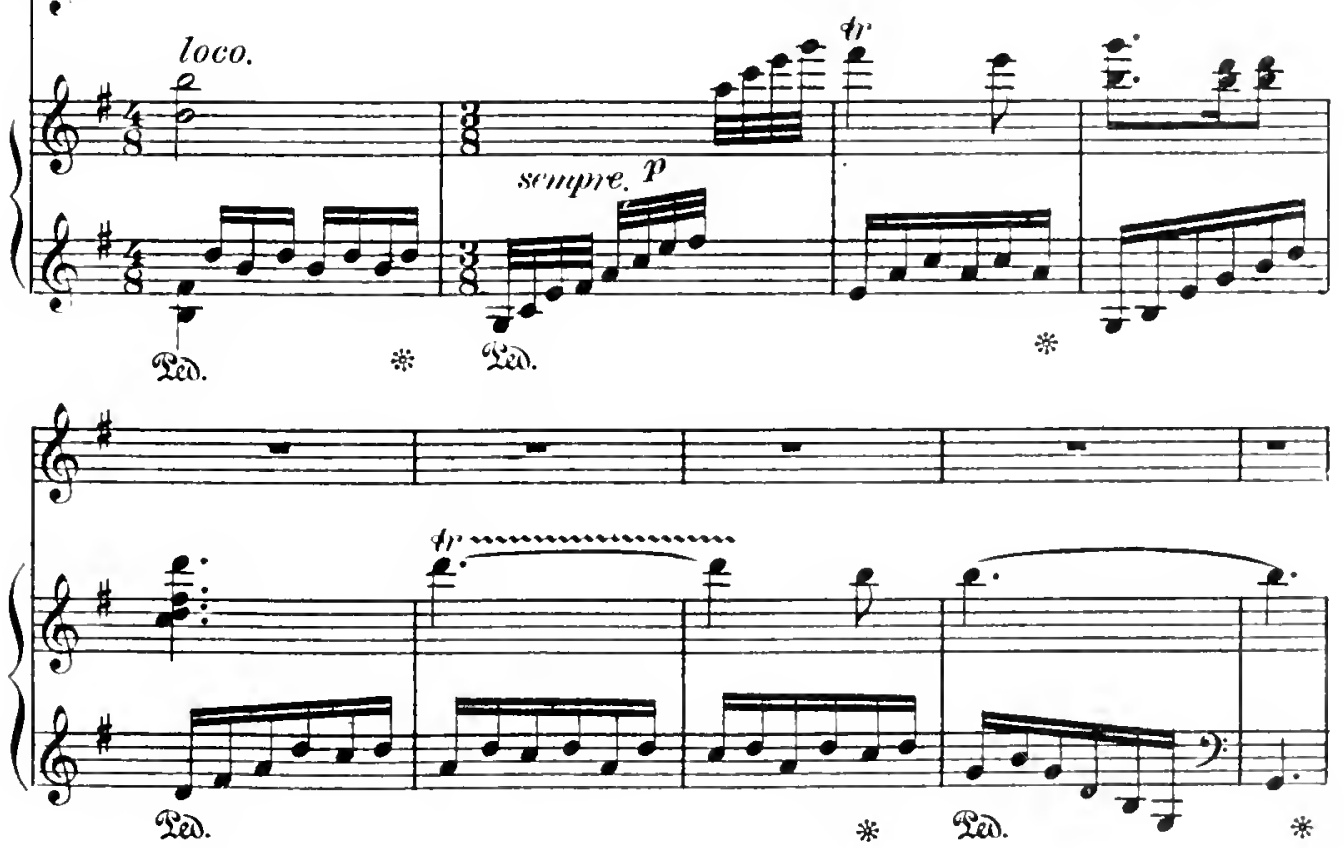


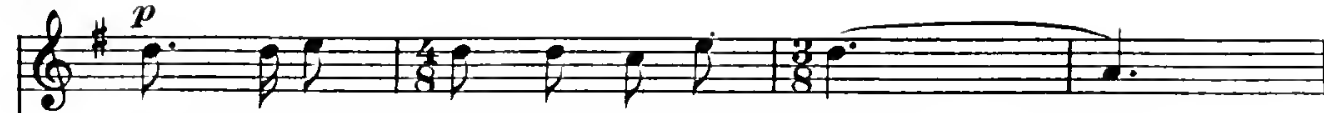
Rip - pleswith sun - light there at play,

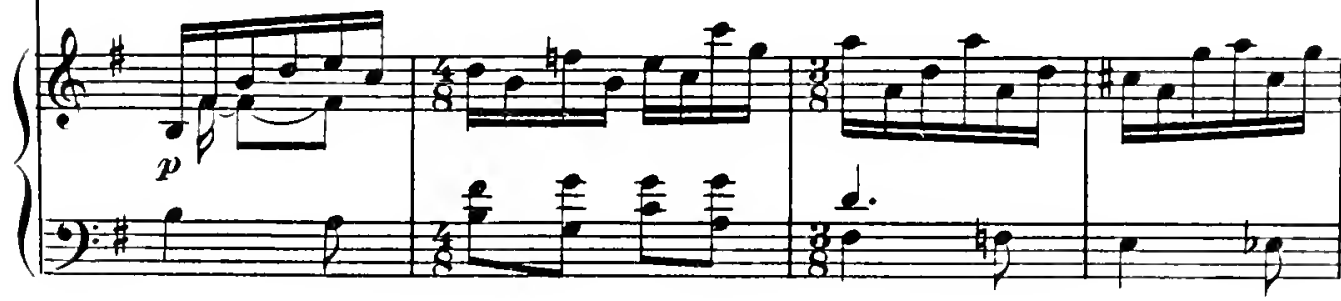

2.2. 2010 This, and no more is what $I$ see

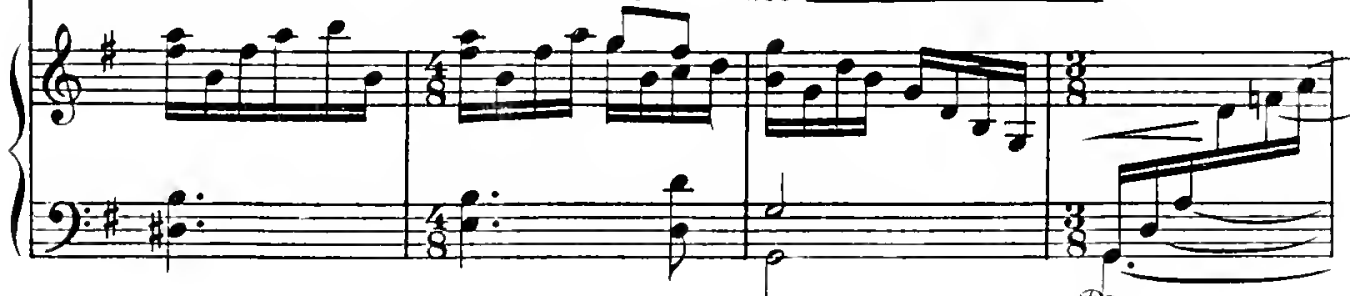
פed.

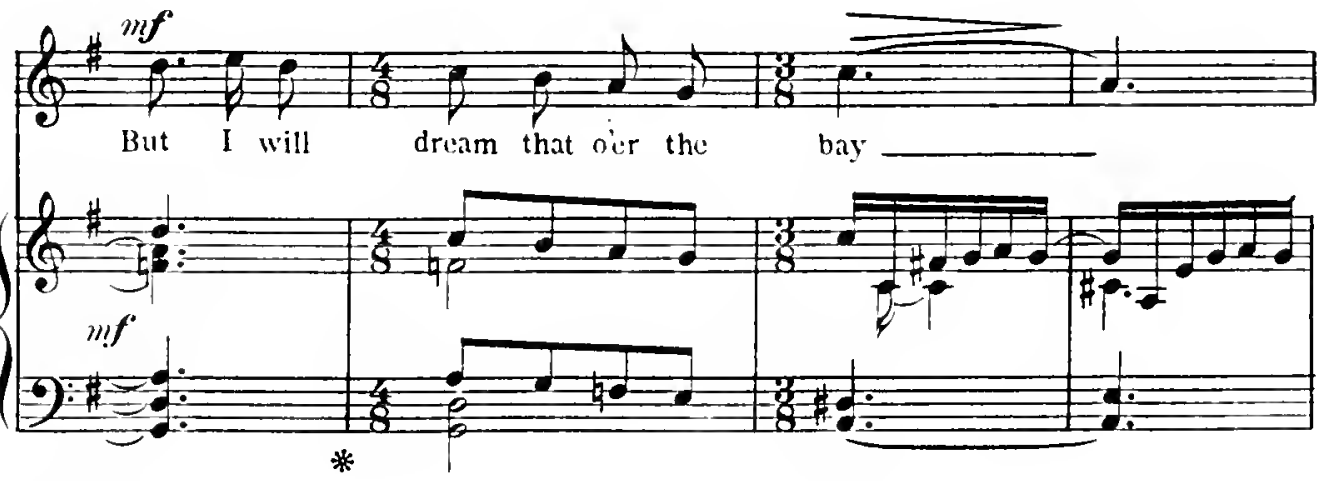

$220+202000$ is my sweet-heart beck-'ning me.

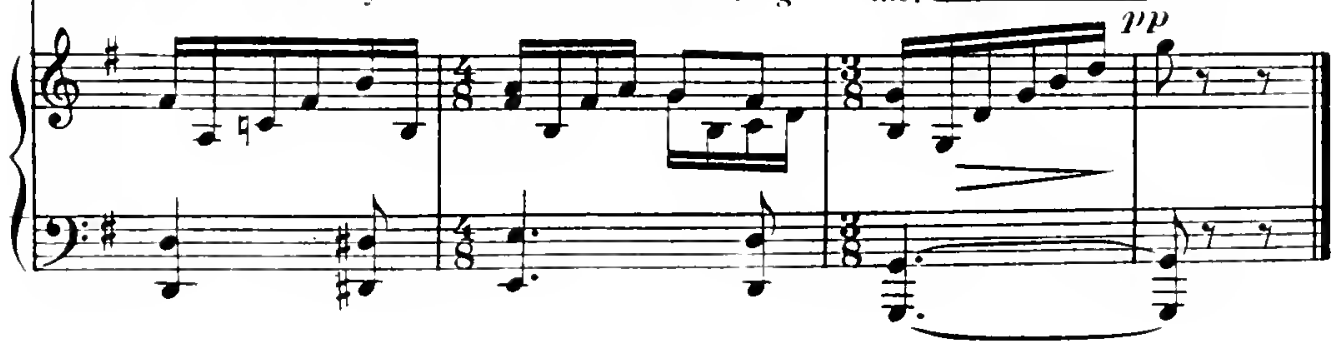


The Naked Bear.

And ${ }^{\text {te }}$ moderato.
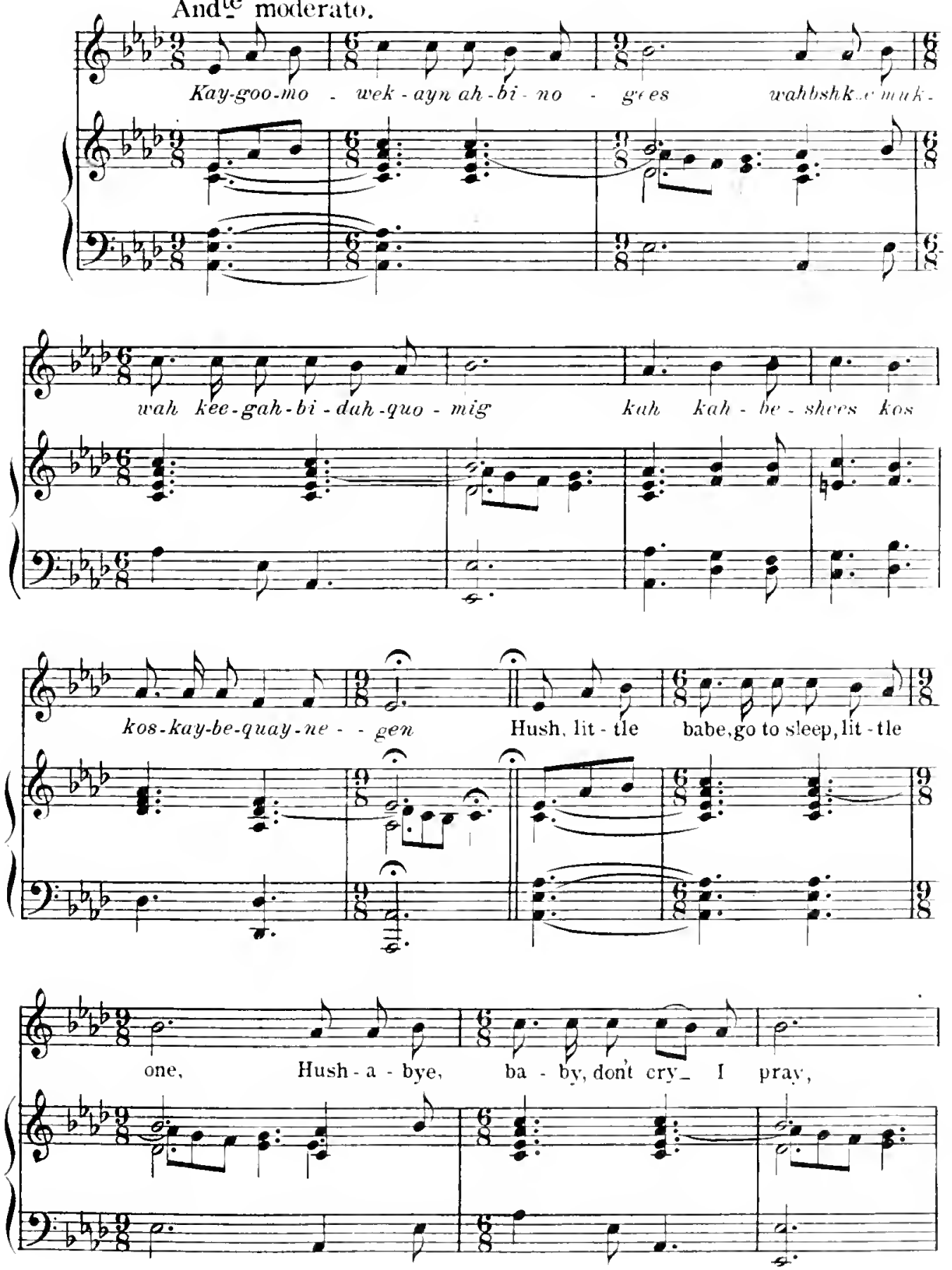

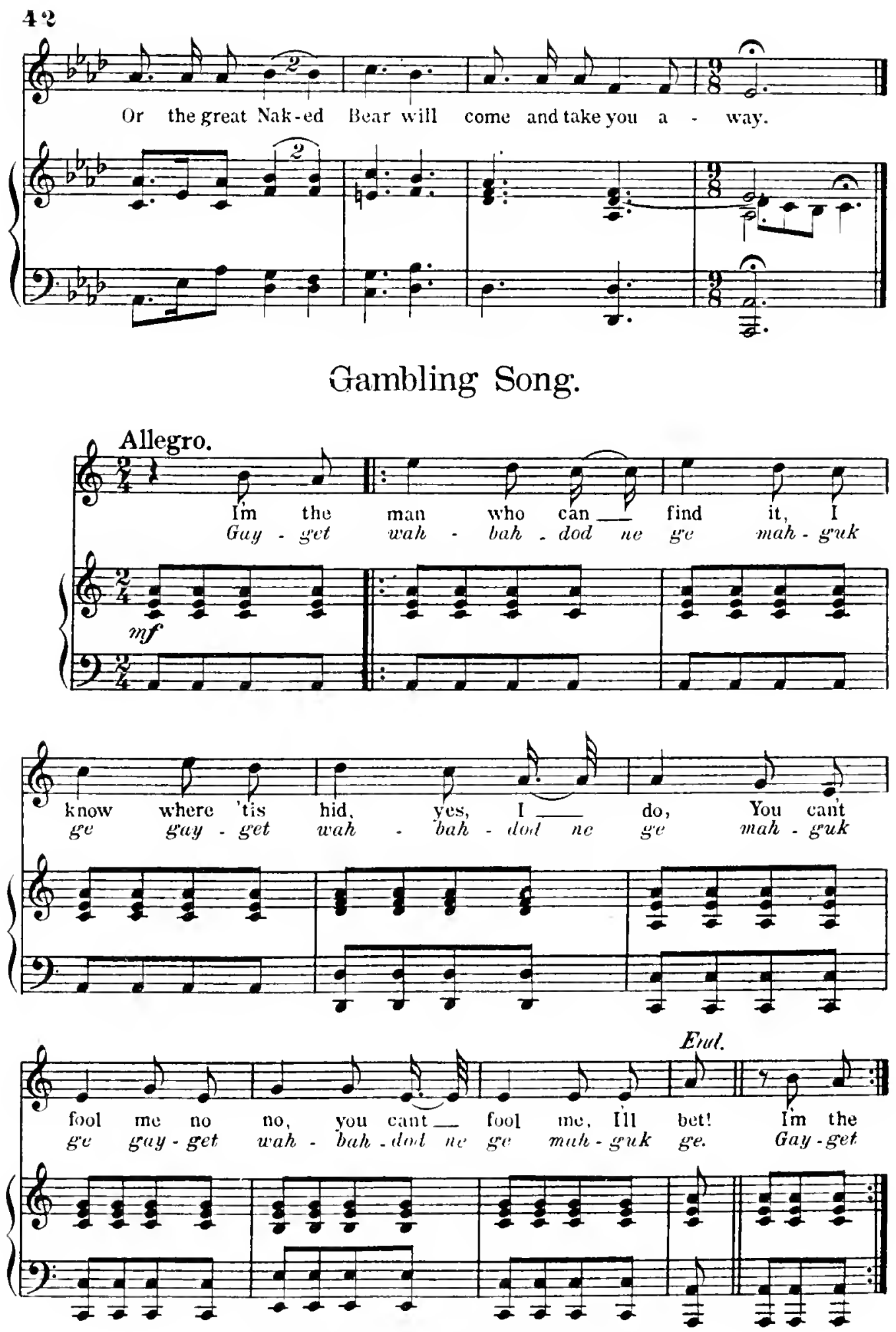

Copyright MCMIX by Frederick R.Burton. 
Morning Tryst.
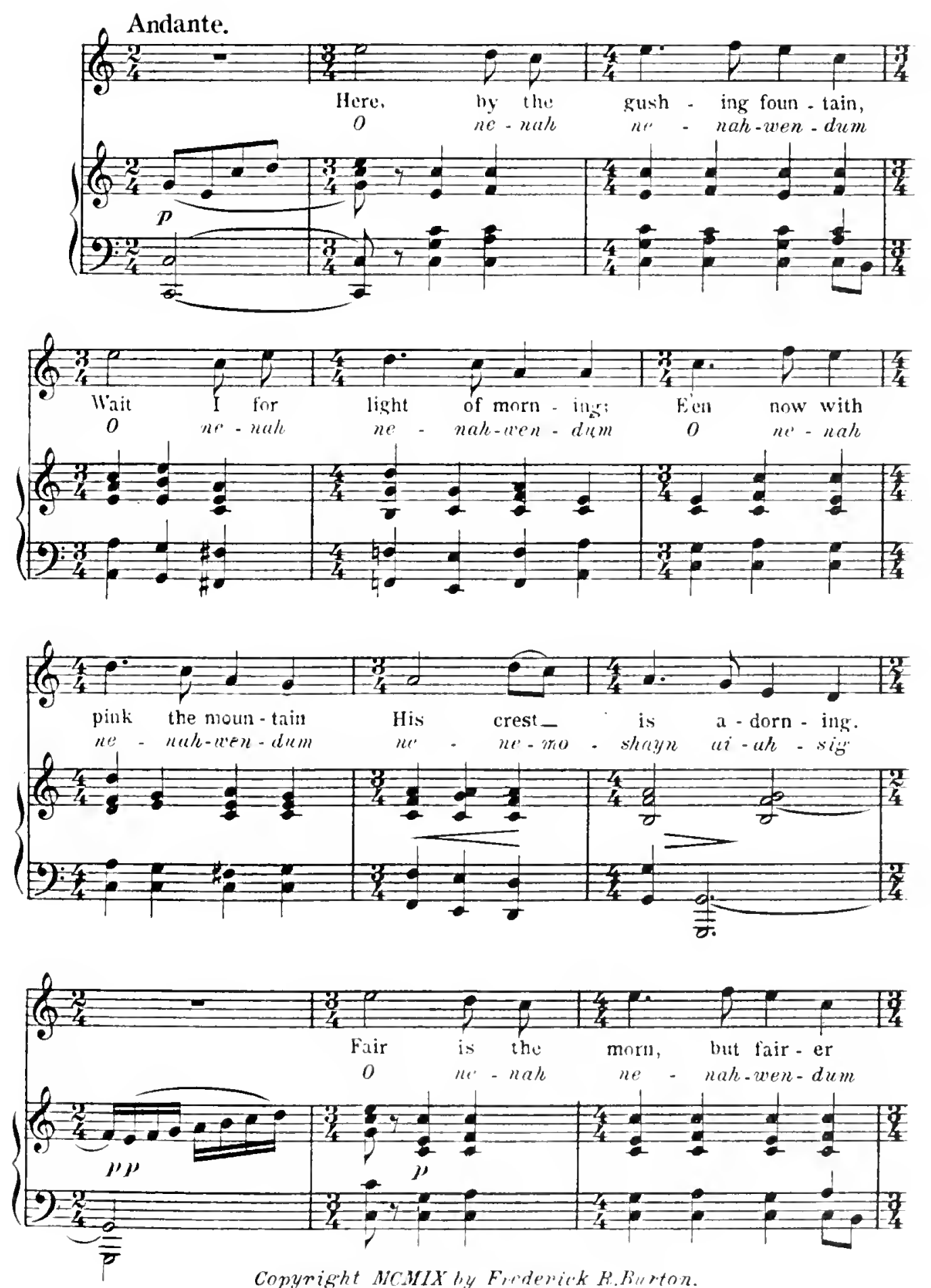

Copyright MCMIX lis Firderick R.hurton. 

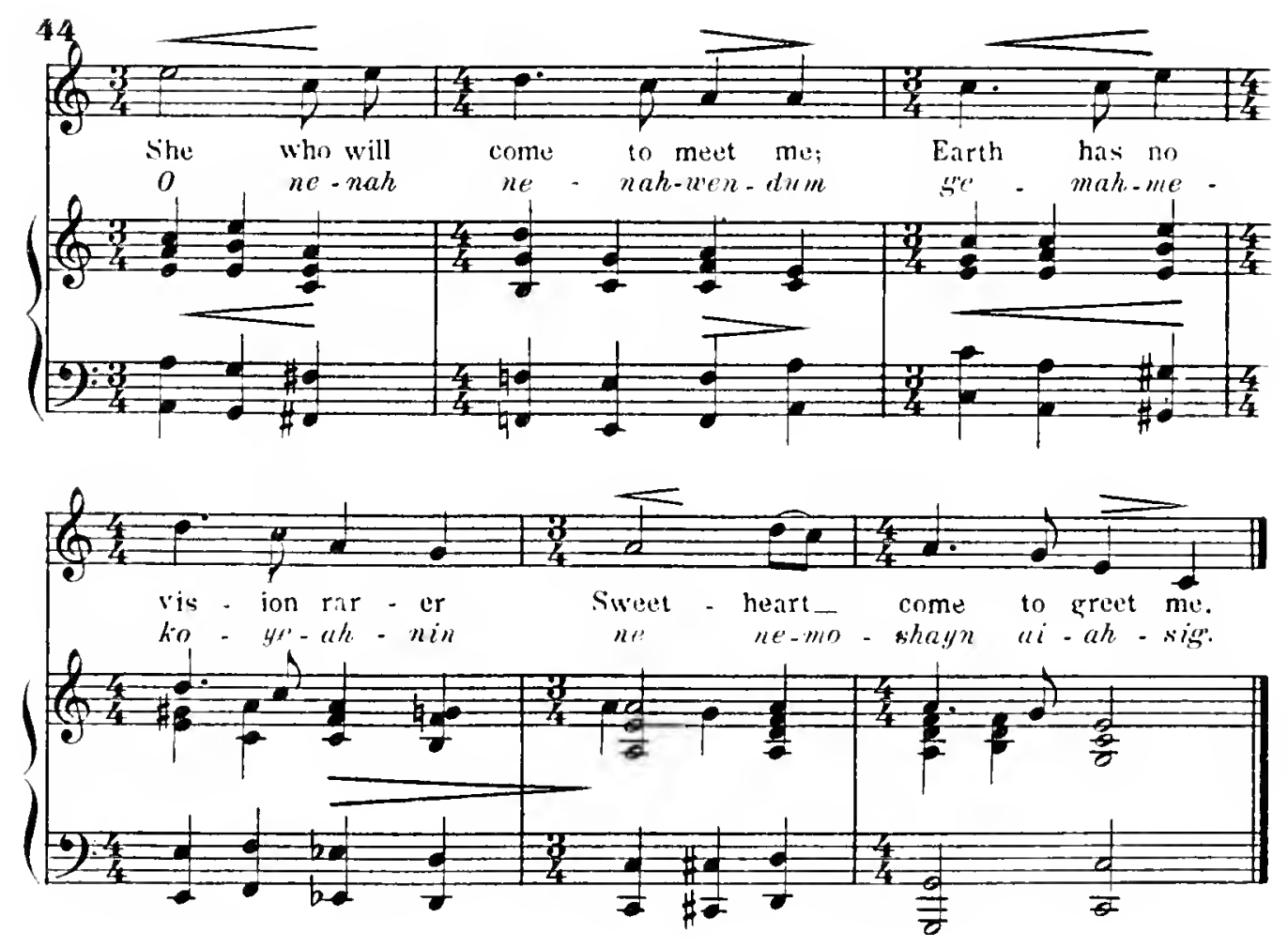

Banished.

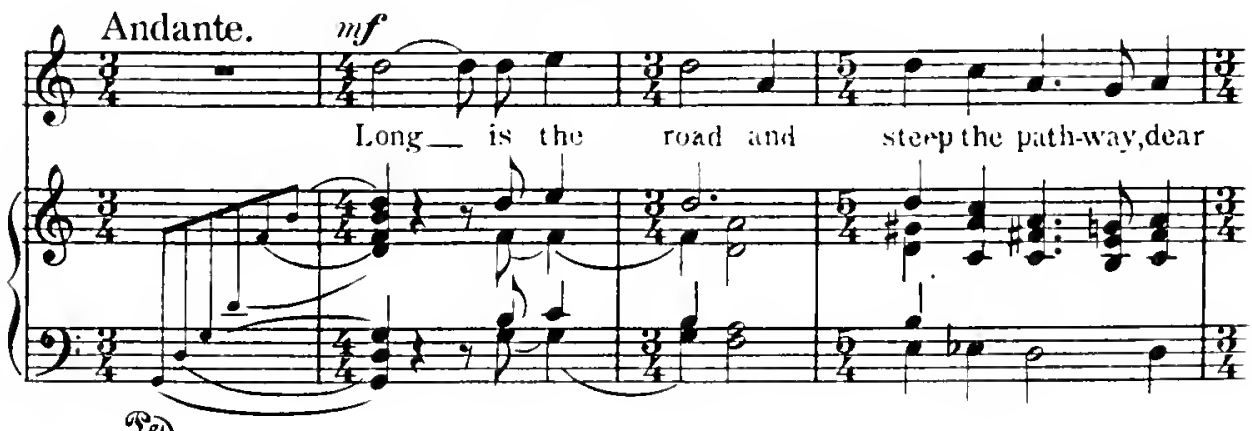

201.

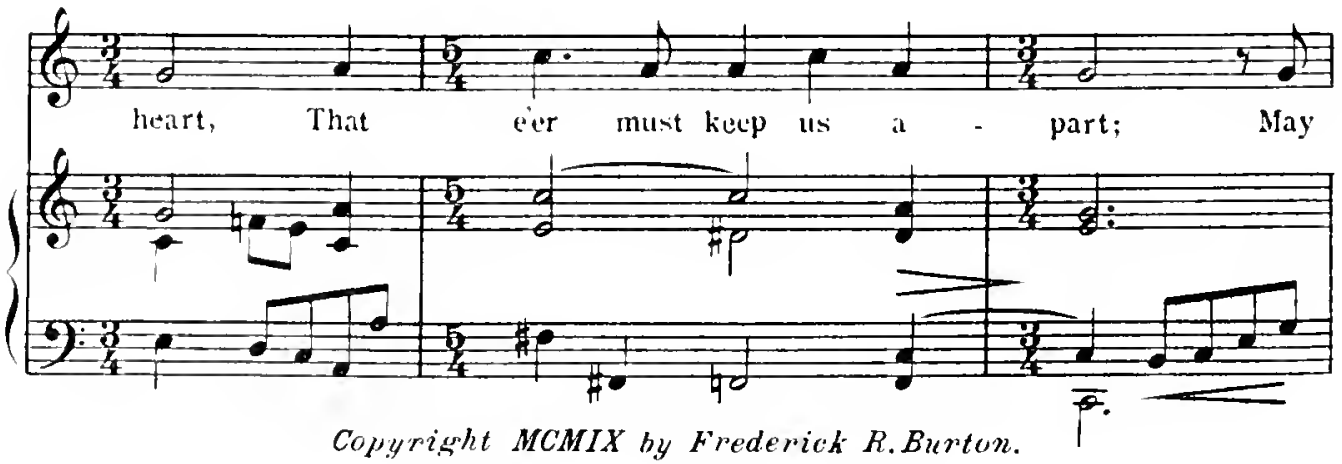



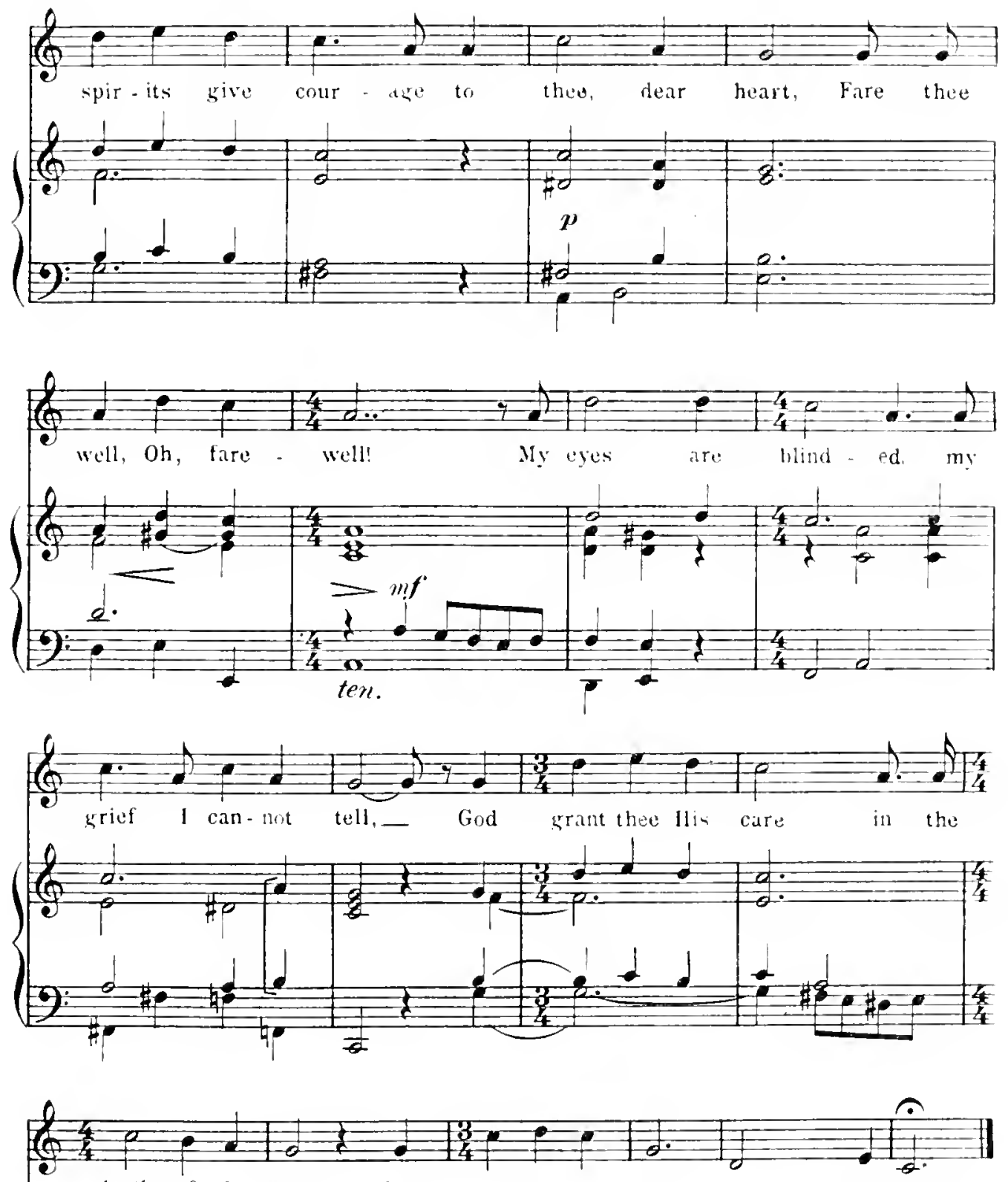
depths of de-spair! Good - byethen,dear heart, fare thee well!

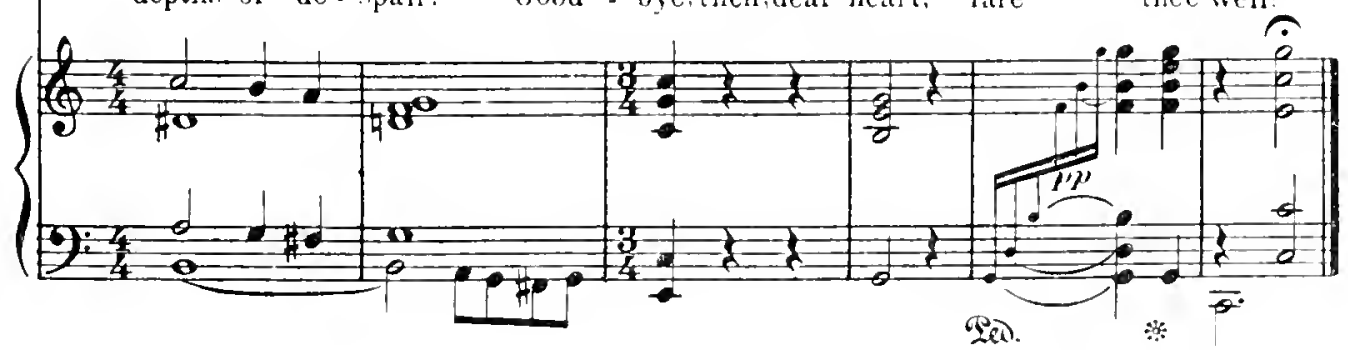



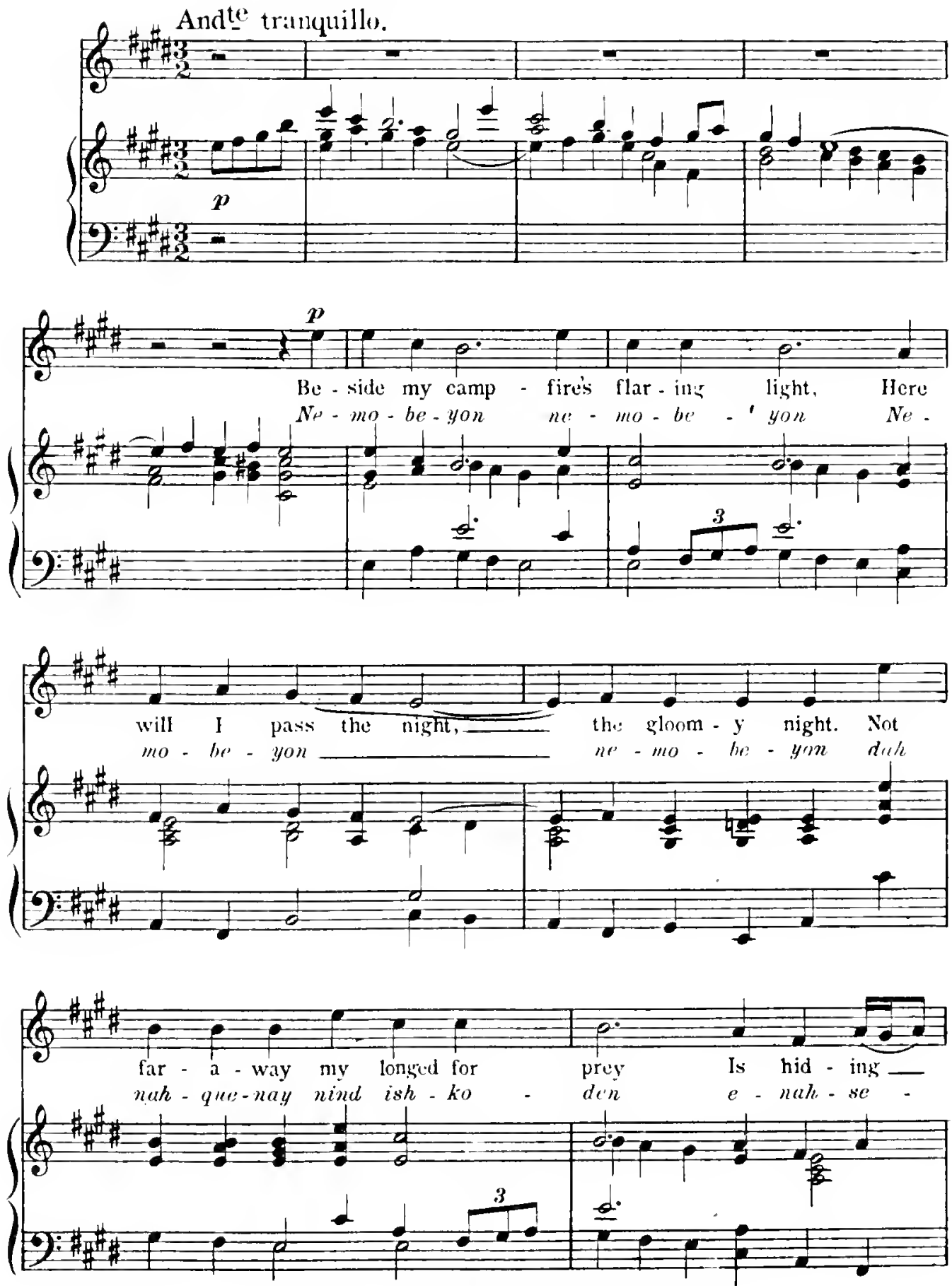

Copyright MCMIX by Frederick R.Burton. 


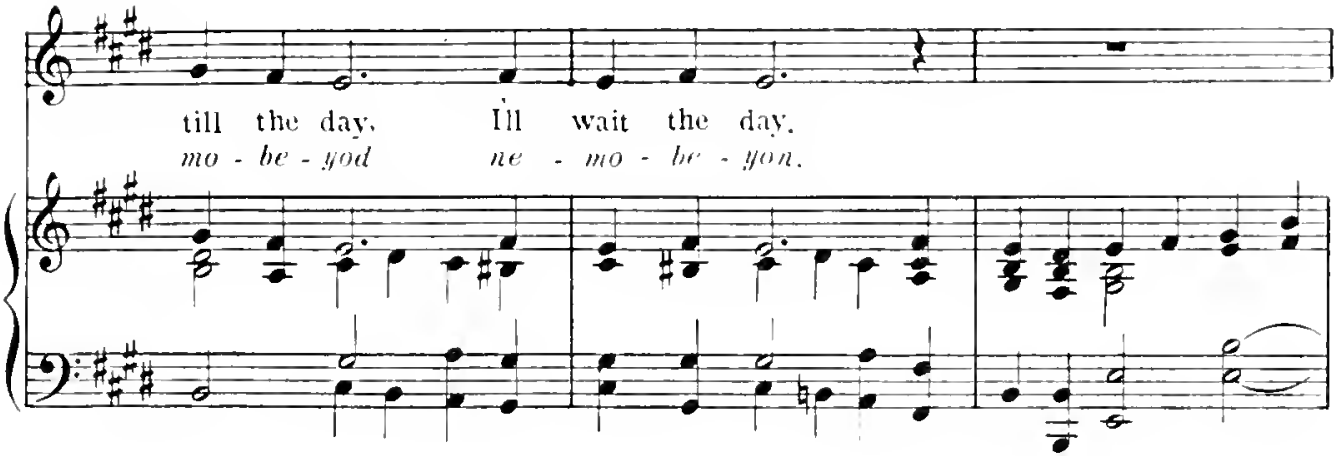
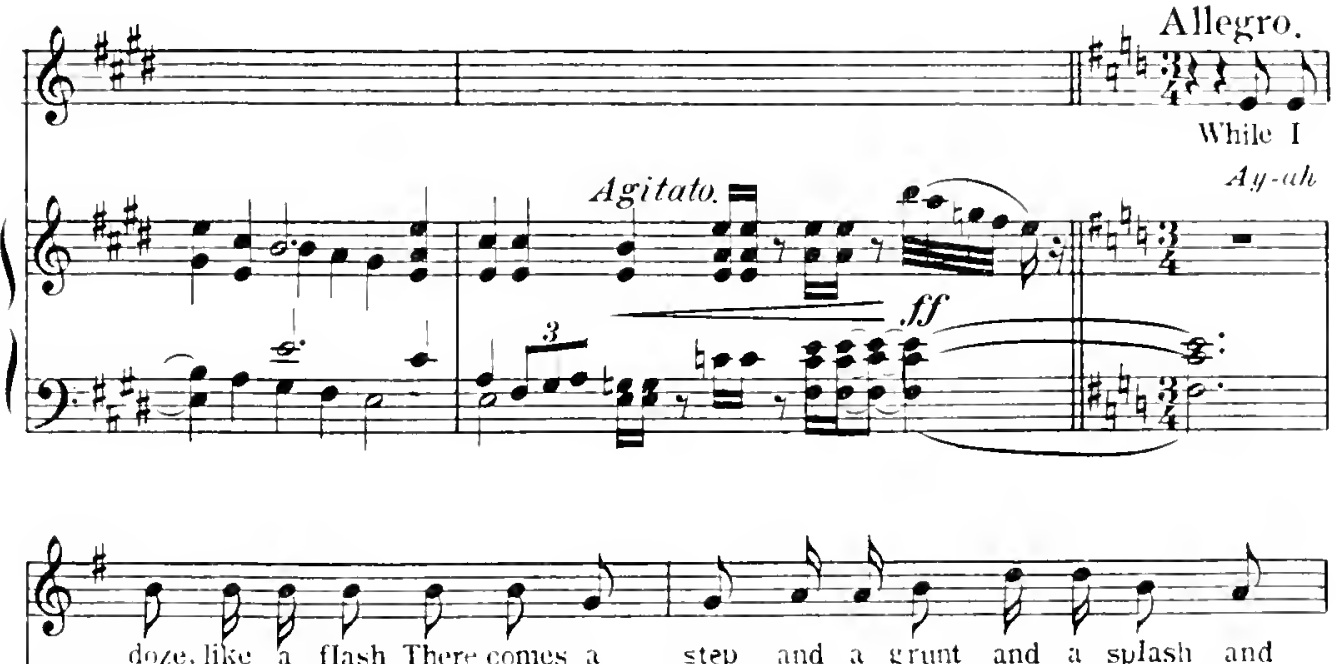
drae, likic a flash Thert cones a step and a grunt and a splash and
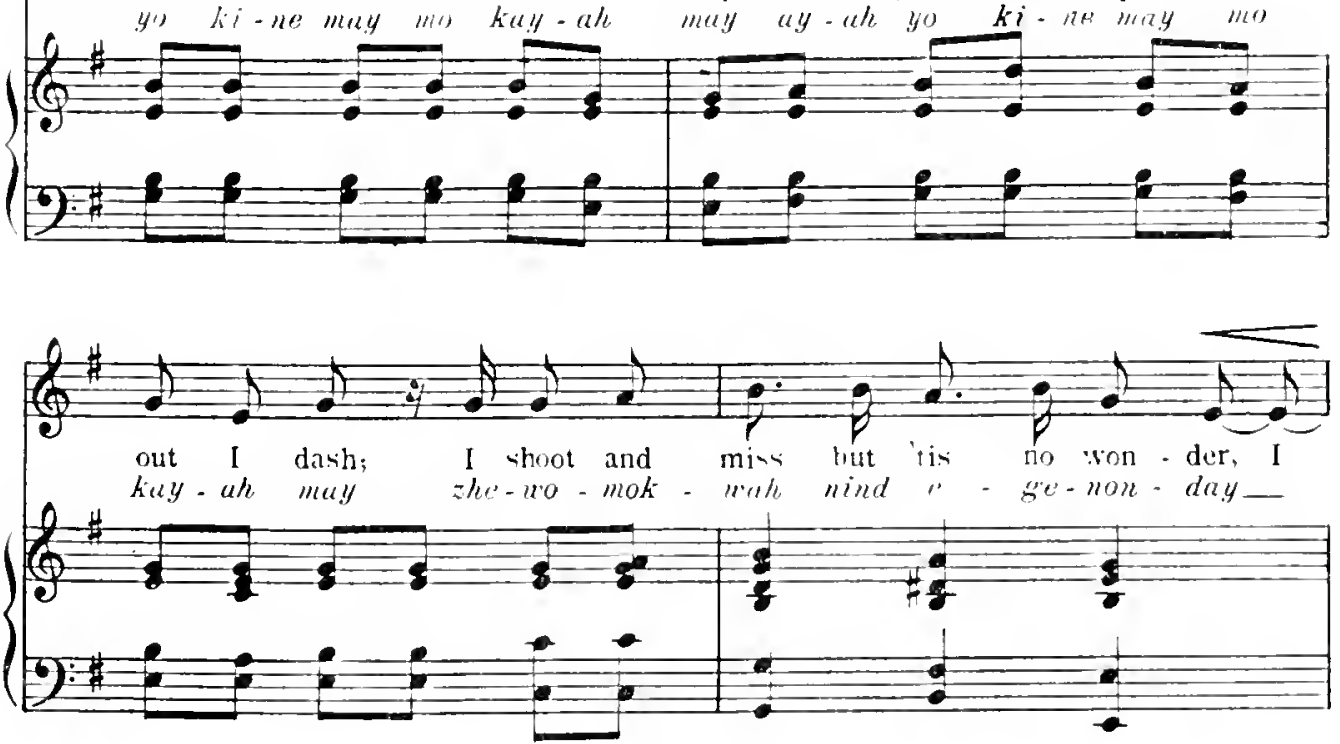


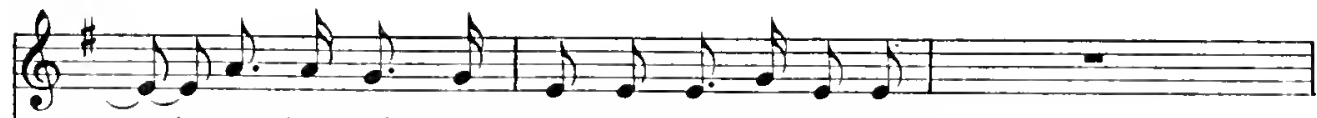
on-ly see his tail go un-der, tail go un-der.

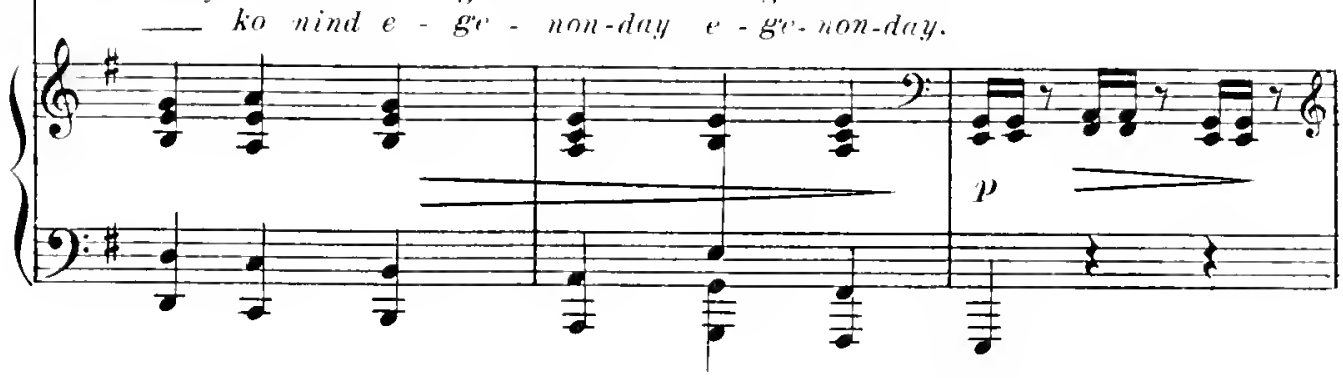

Tempo Primo.

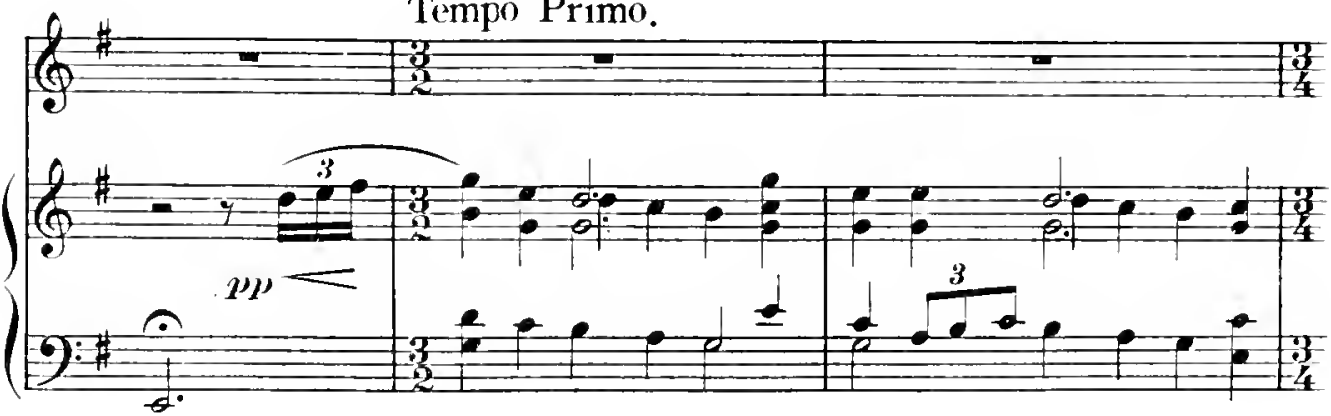

Allo molto.

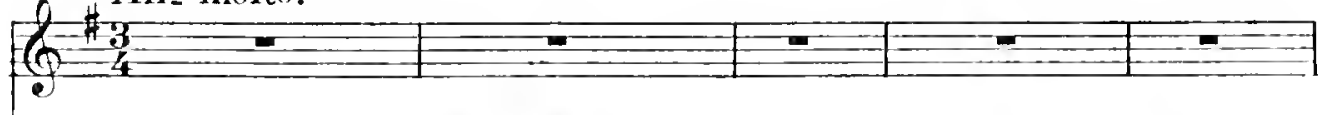

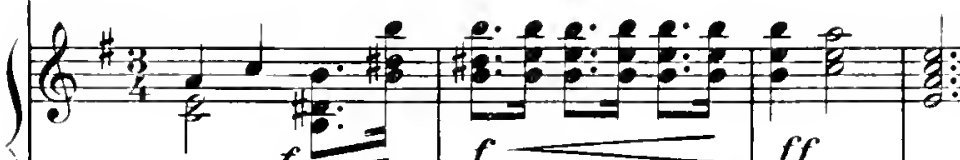

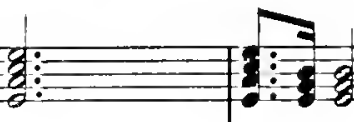

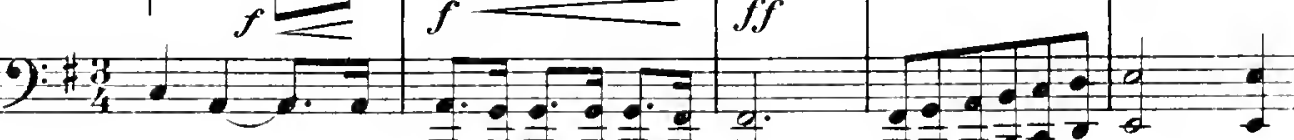

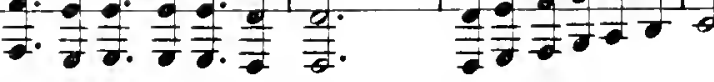

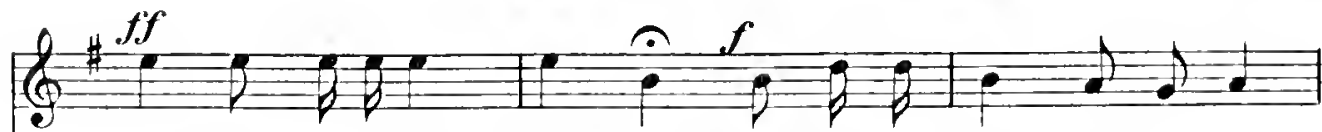

* Where now is myskill? Ay - ah! I shot a - gain, shot to kill,

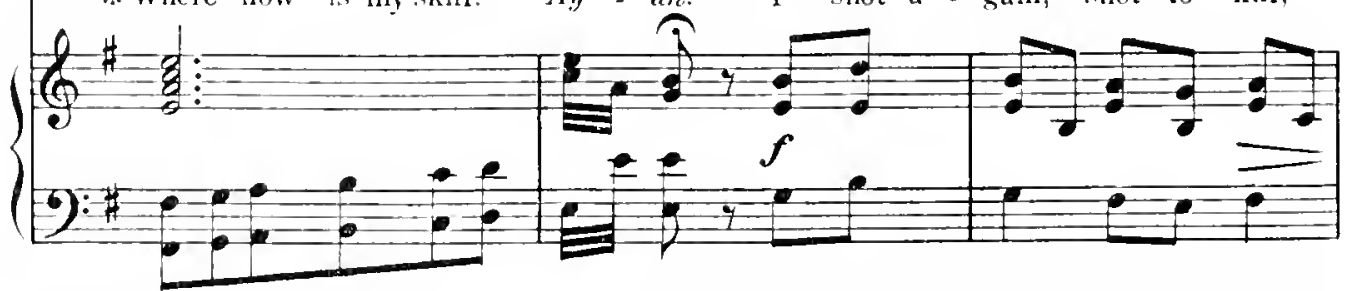

棌 Sume of the Ojihway words in this section cannot be distinguished on the phonograph record. These are clear: aynahbe'yon kecnundaygrogee menon, meaning "While I was looking he went down again." 

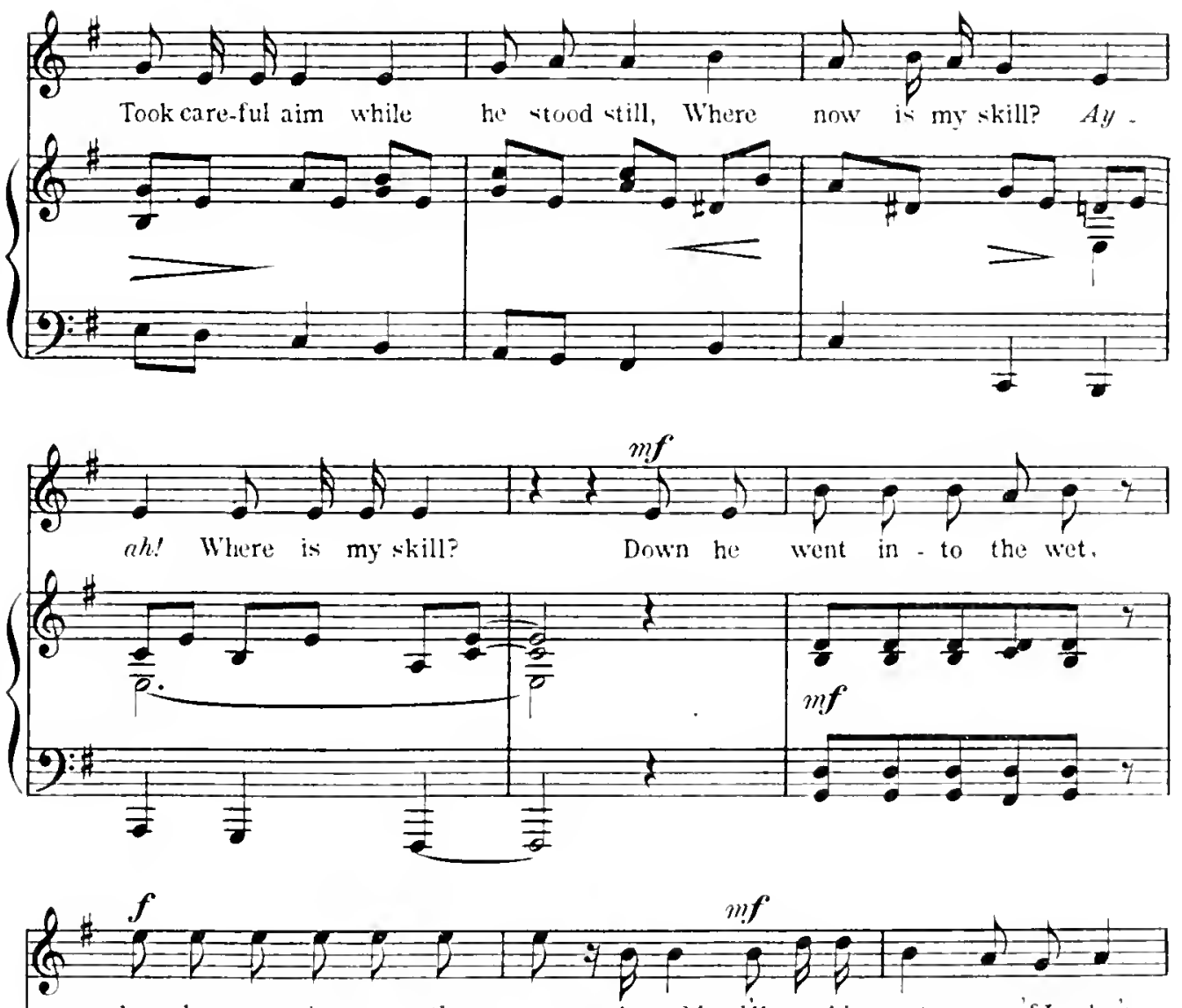
down he went in . to the wet $A y$ - $a h$ ! lil get him yet, see ff I dont
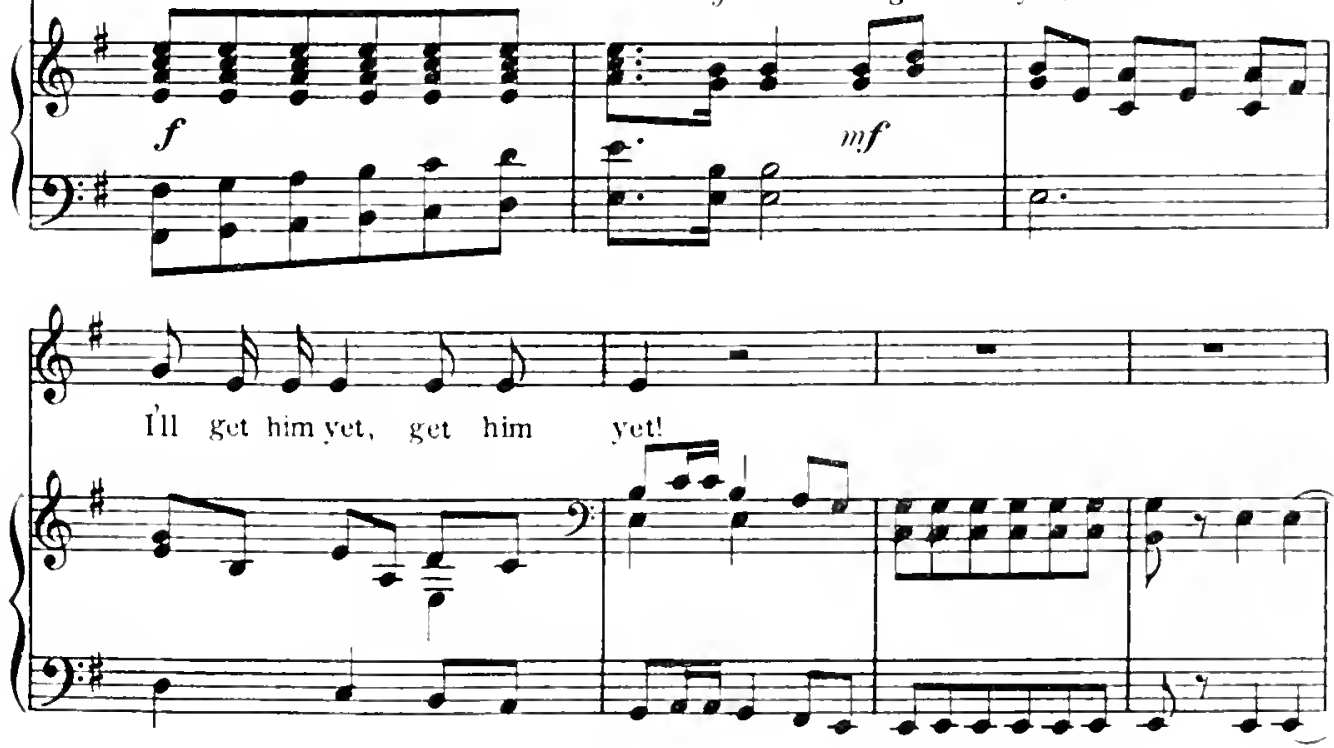

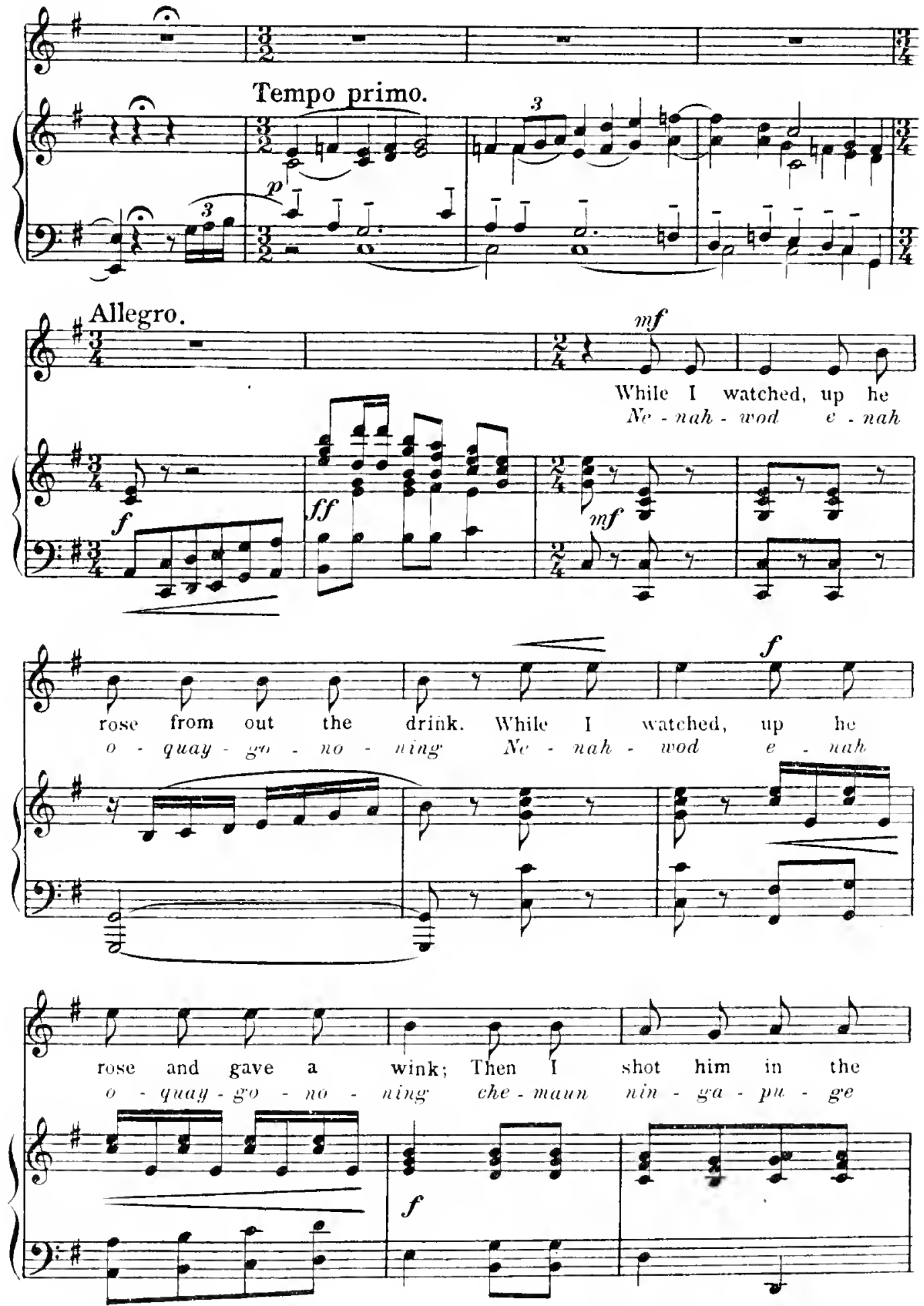


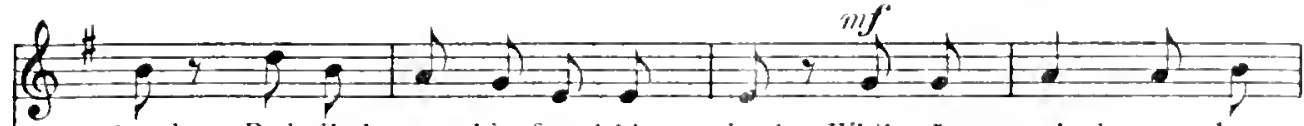
head, Pad-died to himfound him dead. While I watched, up he

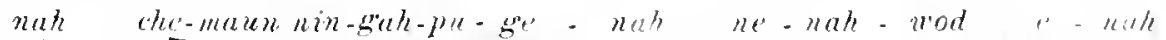

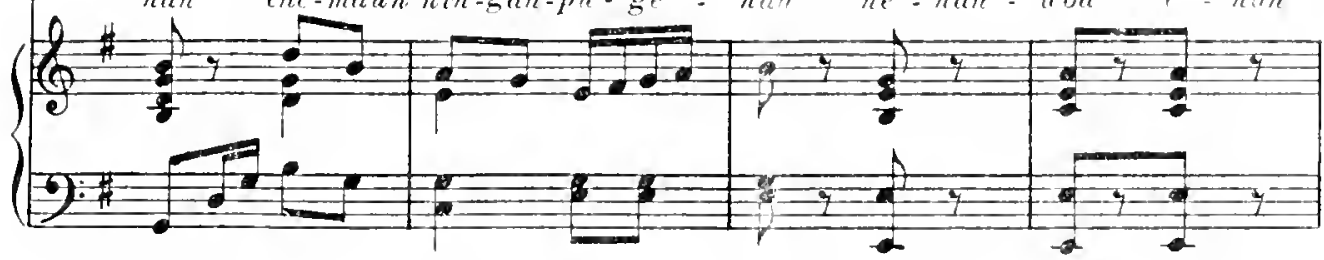

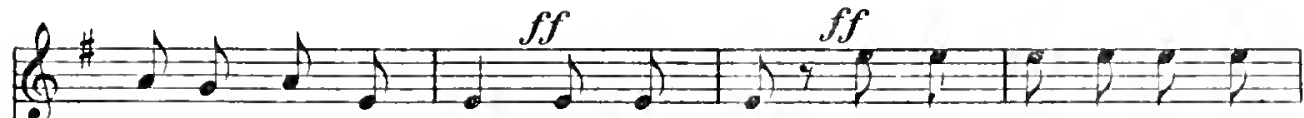
rose from out the drink, gave a wink.

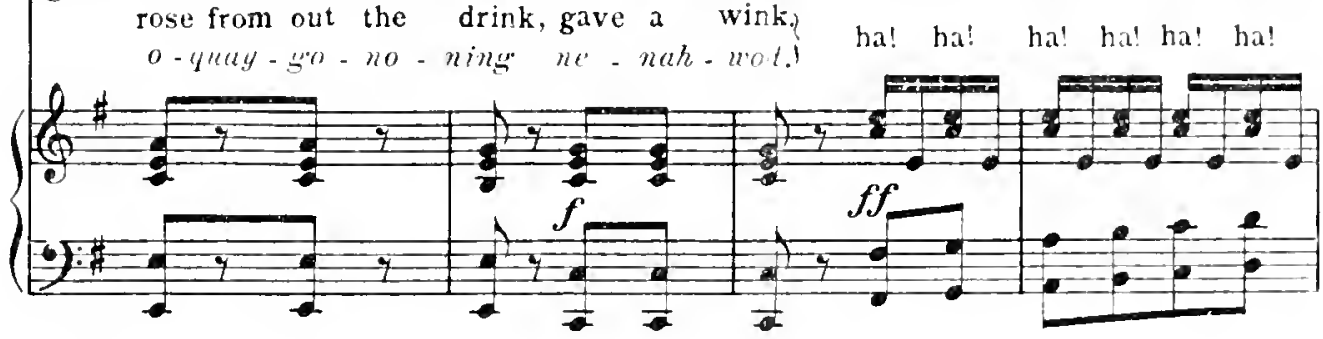

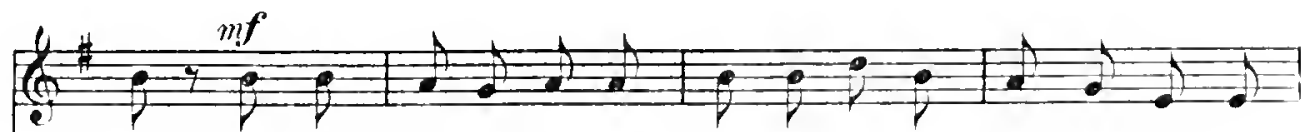
ha! Now theres noth-ing else to di But take him home in my ca -

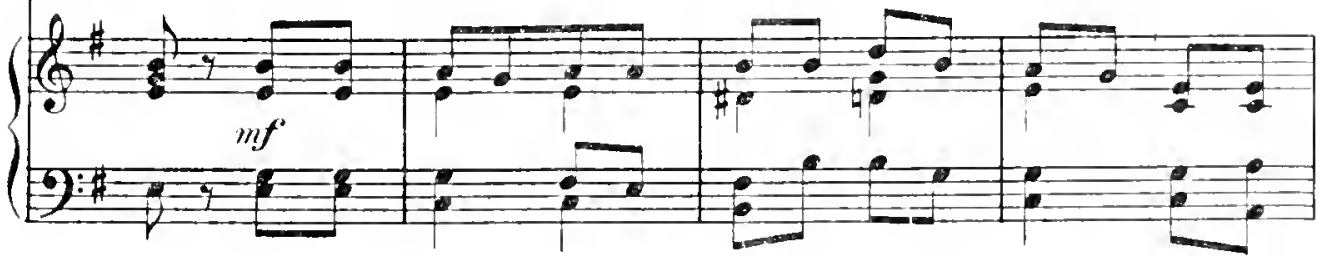

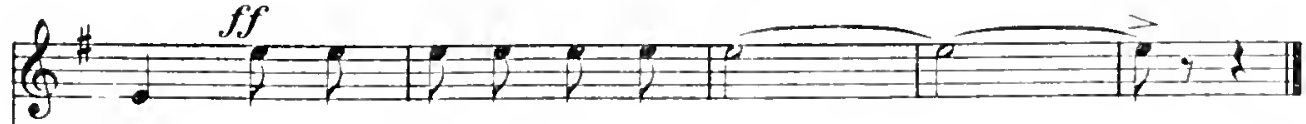
noe! IIa! ha' ha! ha! ha! ha! ha!

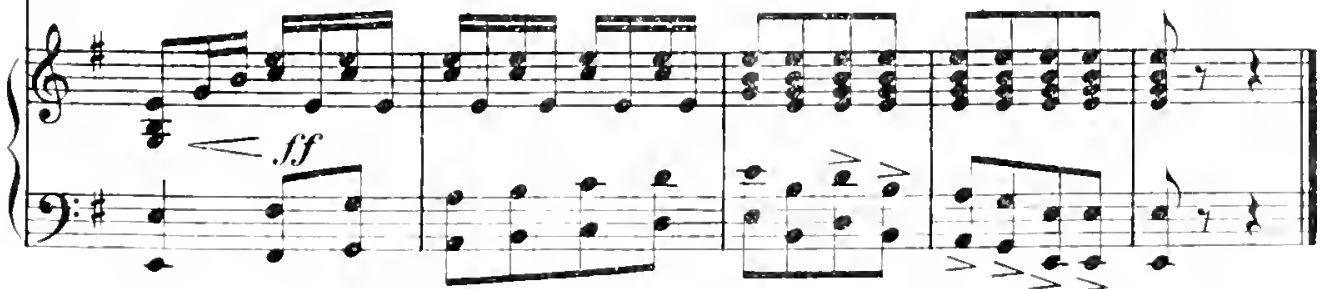


Hiawatha's Death Song.
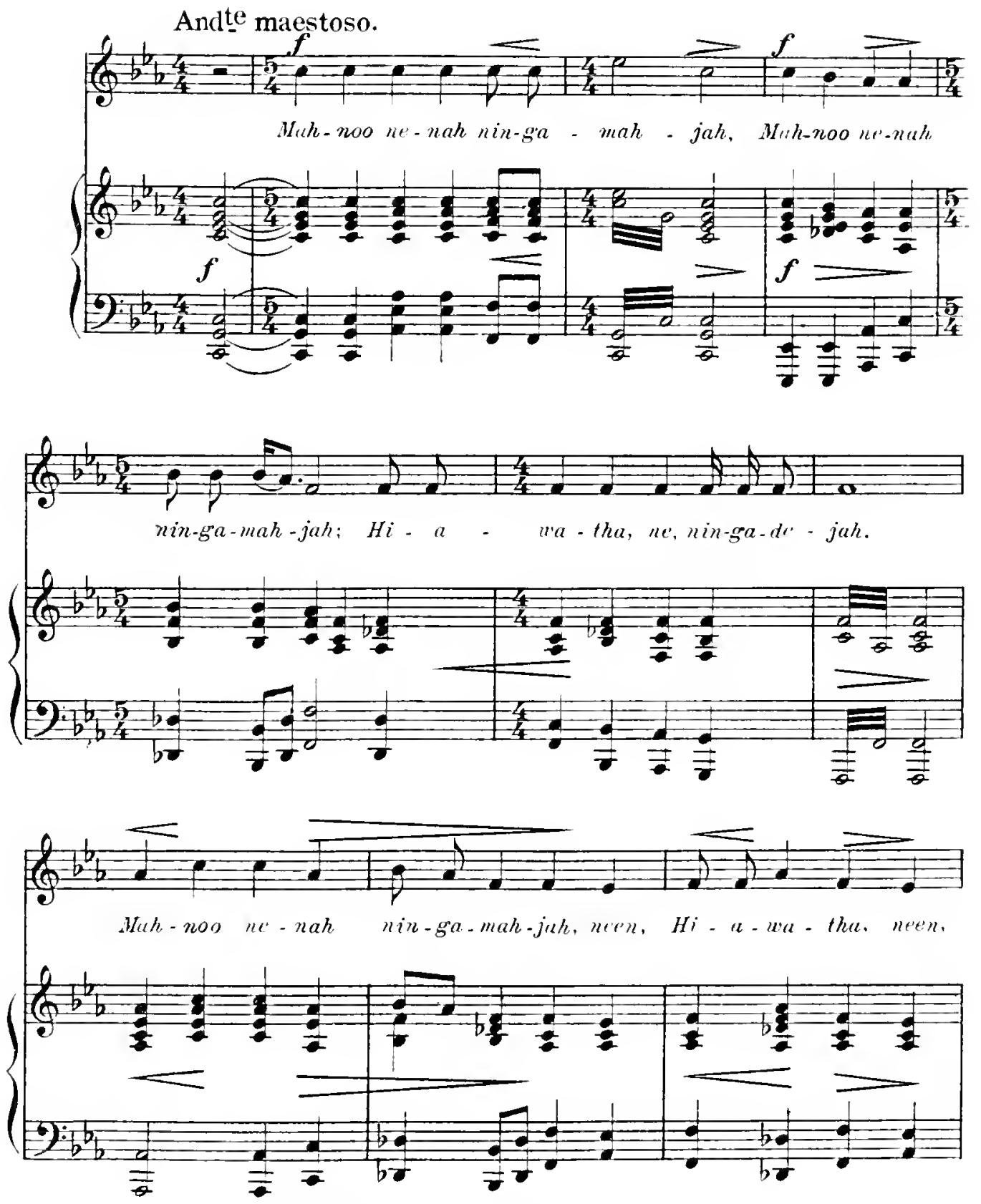

Copyright MCuIX by Frederick R.Burton. 

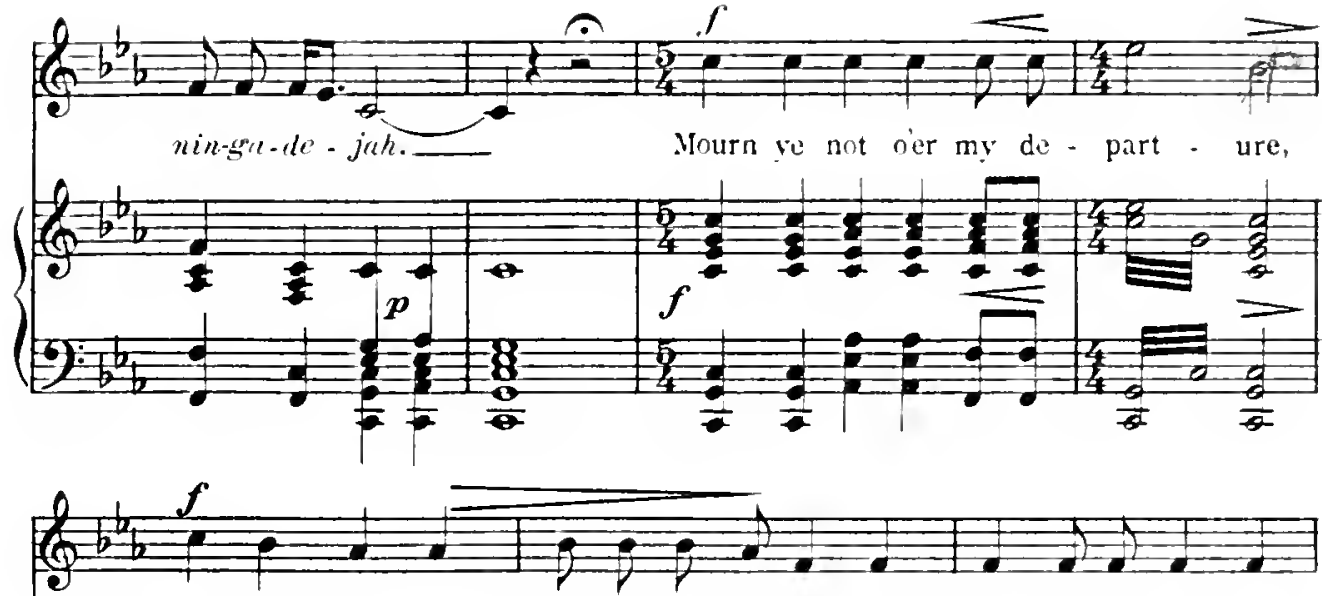
Mouril ye not; 1 go up - on a jour-ney, 1, Hi-a - wa - tha,
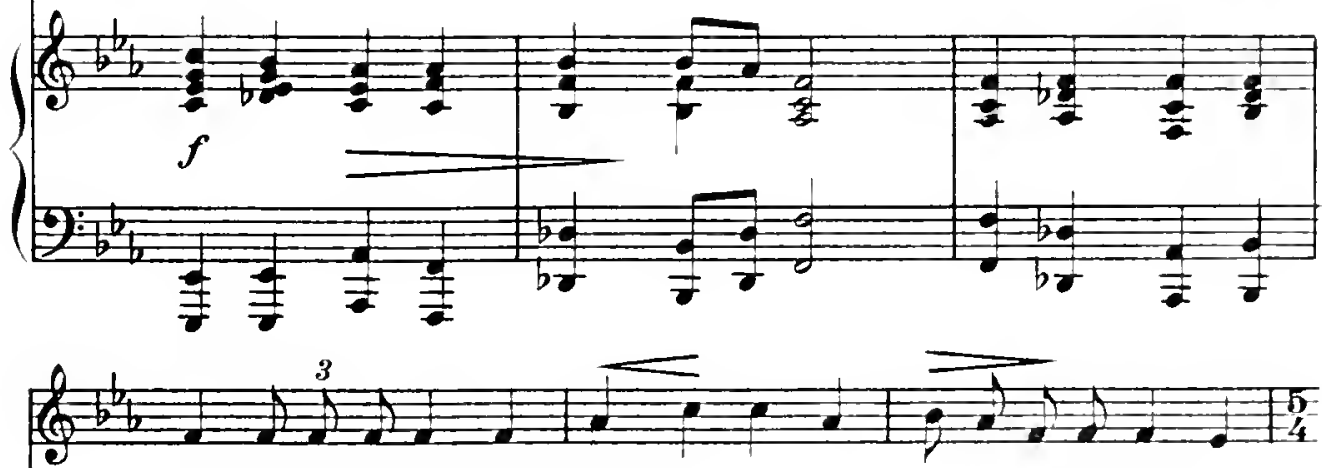
soon will have de-part-ed. Mourn ge not; my jour-ney is a - ter-nal.
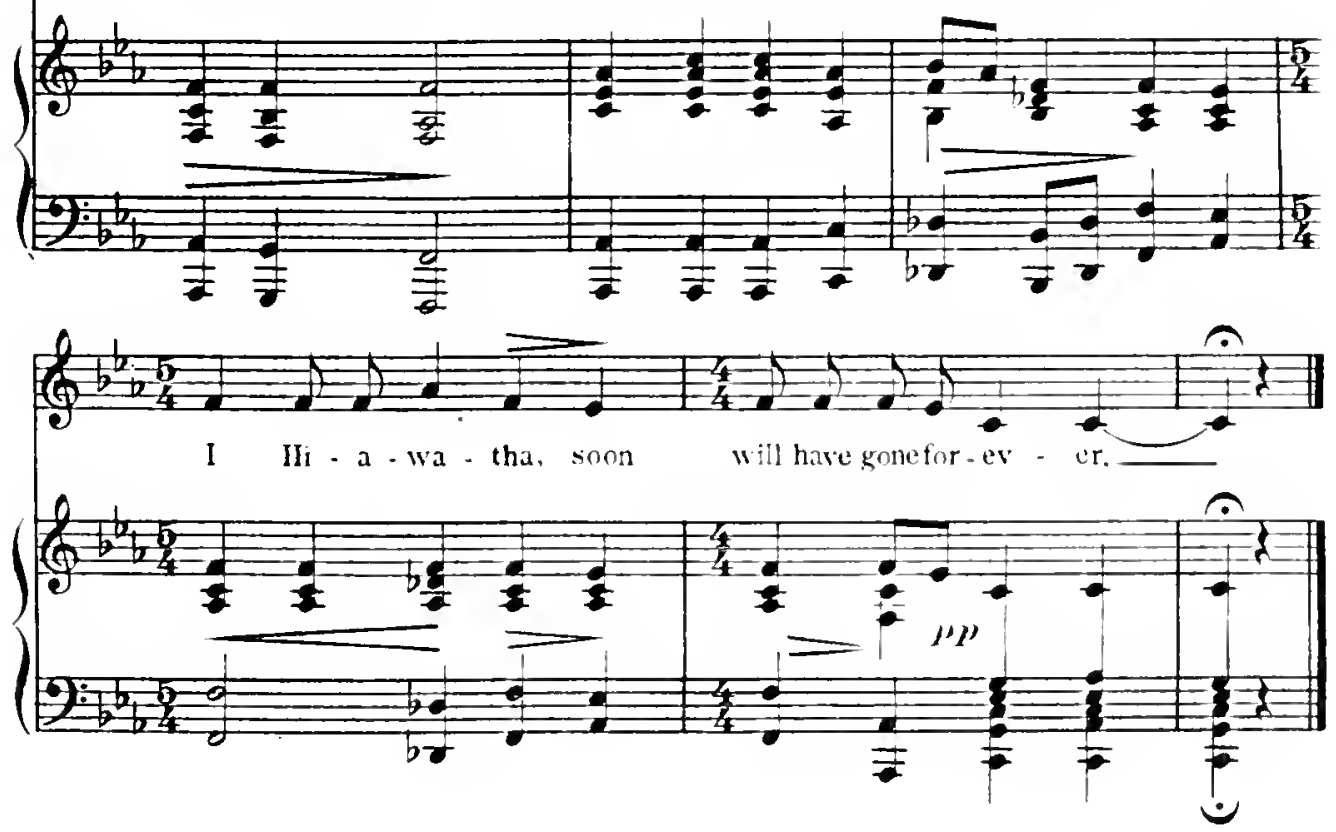


\section{My Bark Canoe.}

Quartette, unaccompanied.

Soprano.

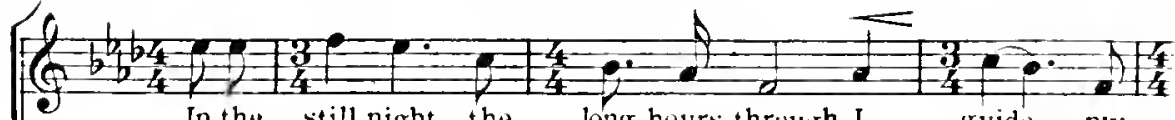

In the still night, the long hours through, I guide - niy

Al.o.

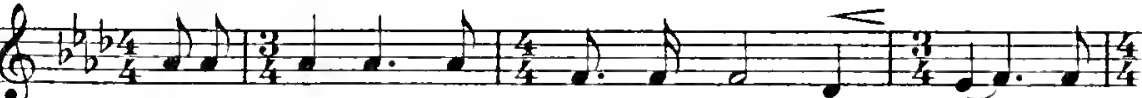

In the still night, the Iong hours through, 1 guide_ my

Tenor.

Bass.
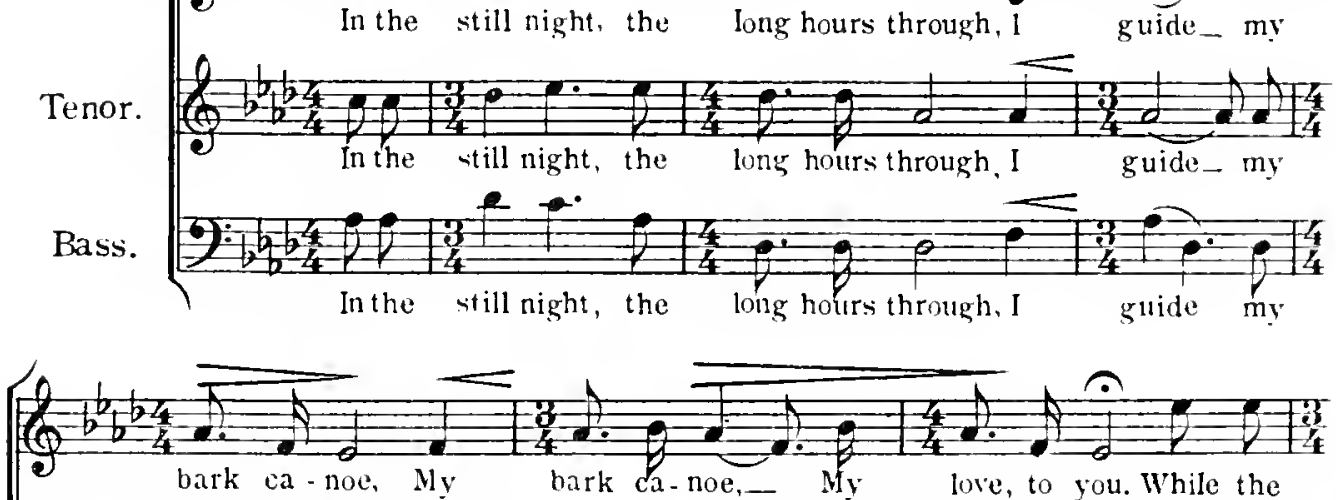

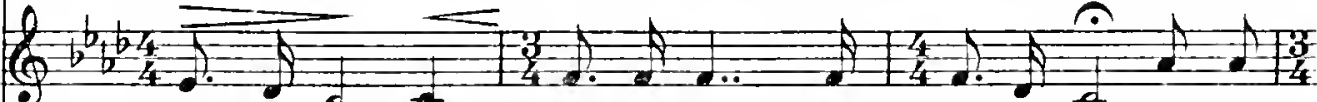

bark ca-noe, My bark ca.noe, My love, to you. While the
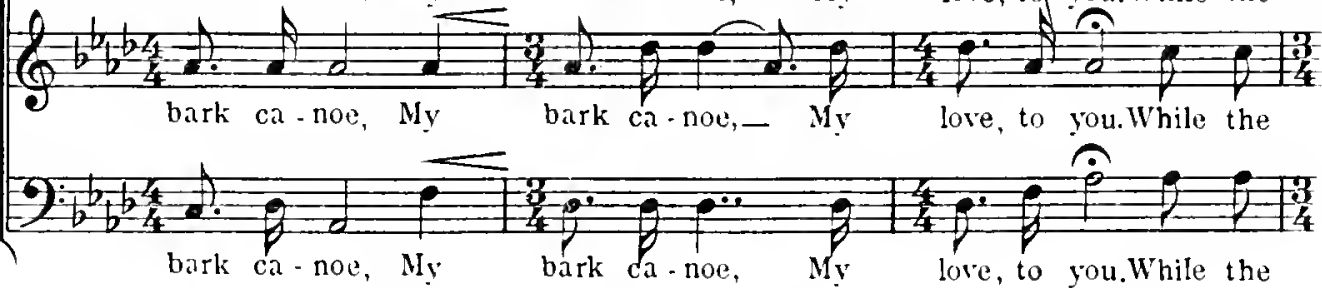

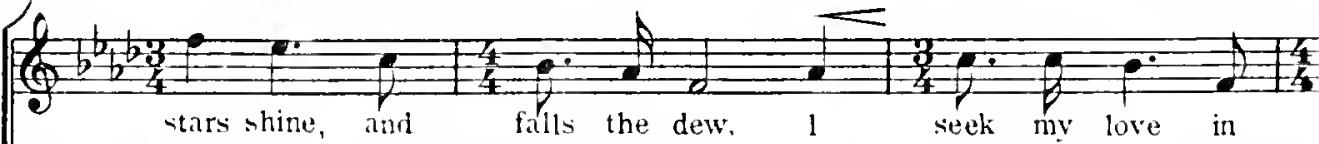

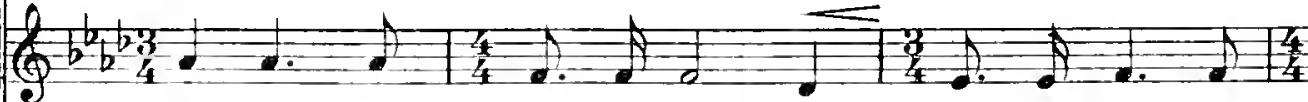

tars shine, and falls the dew, 1 seek my love in

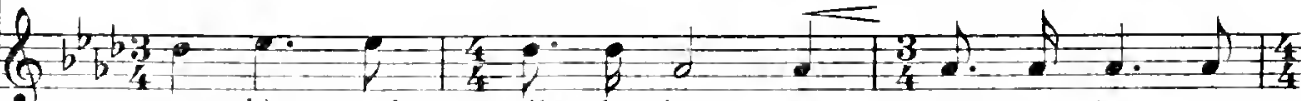

stars shime, and tiil the dew, 1 seek $m y$ love in

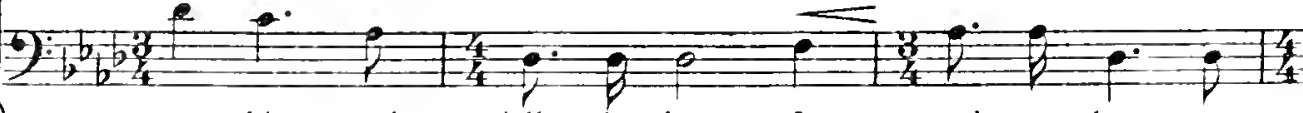

stars shine, and falls the dew, I seek my love in

Coyyright MCMIX by Frederick R.Burton. 


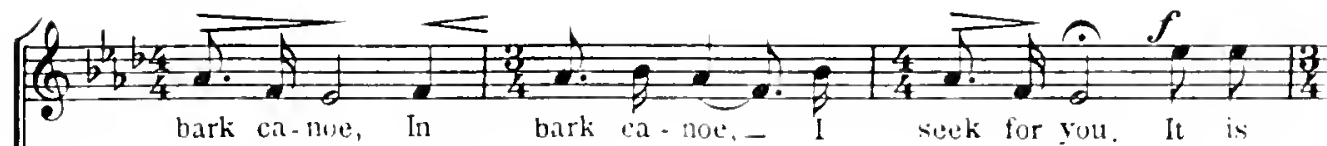

bark ca-nue, In bark ca-noe, - I seek for yuu. It is

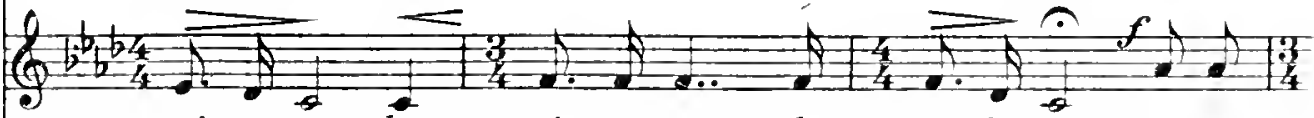
bark ea-noe, In bark ca-noe, I seek fir you. It is

$\frac{\left(g_{b} b_{4}\right.}{4=1}$

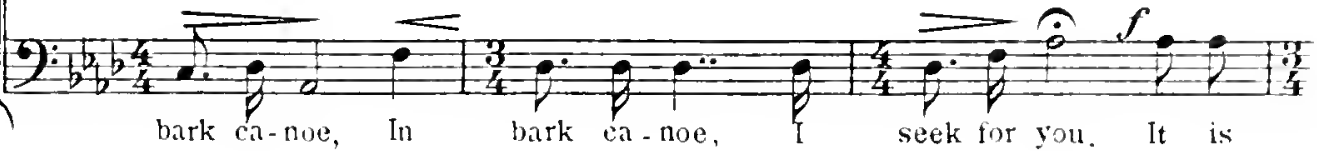
I, lixe, your

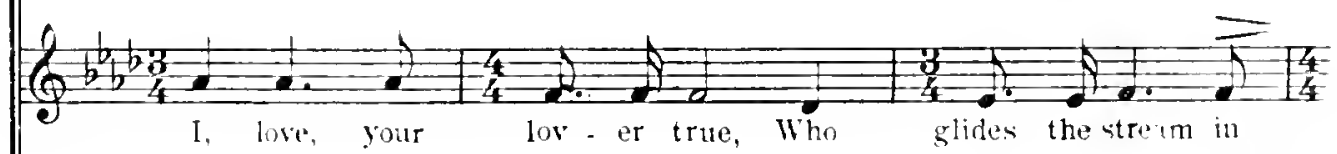
I, lov" your

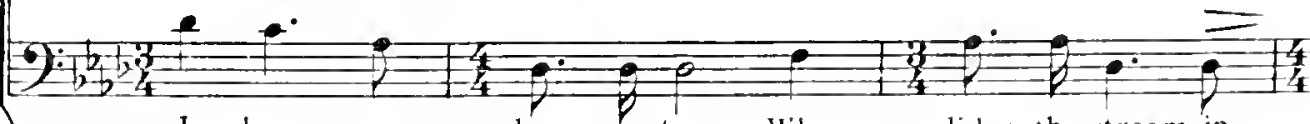
1, love, your lov-er true. Who glides the itream in

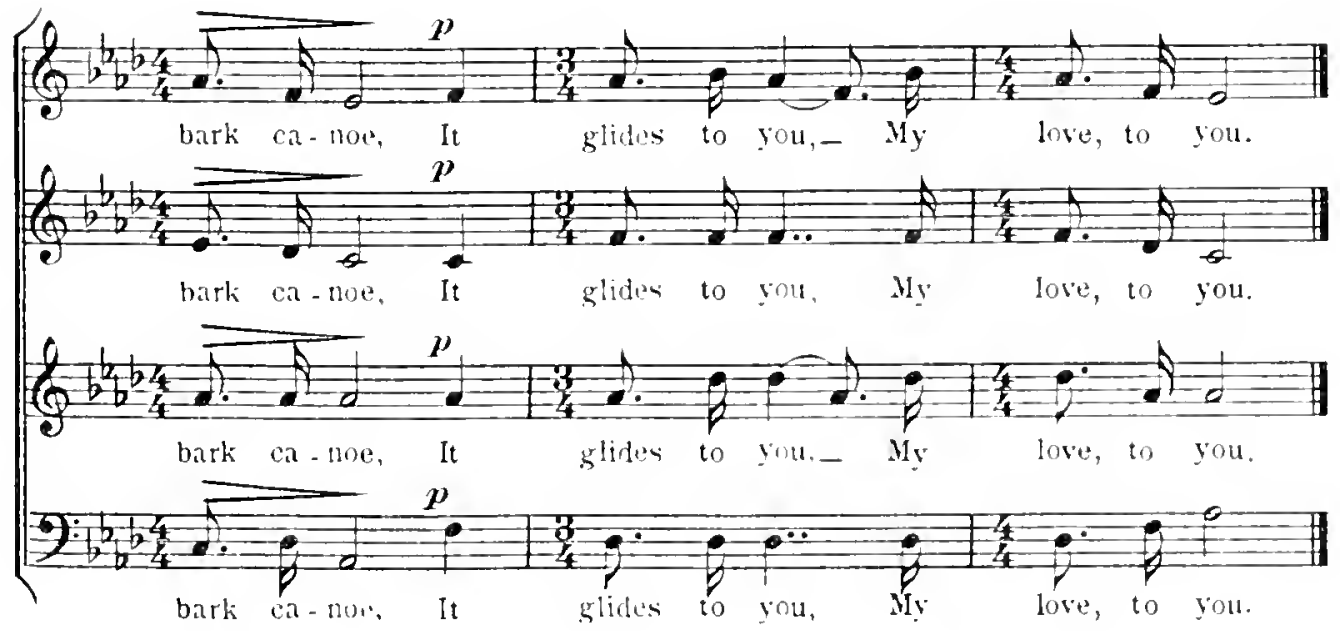




\section{A Song of Absence and Longing.}
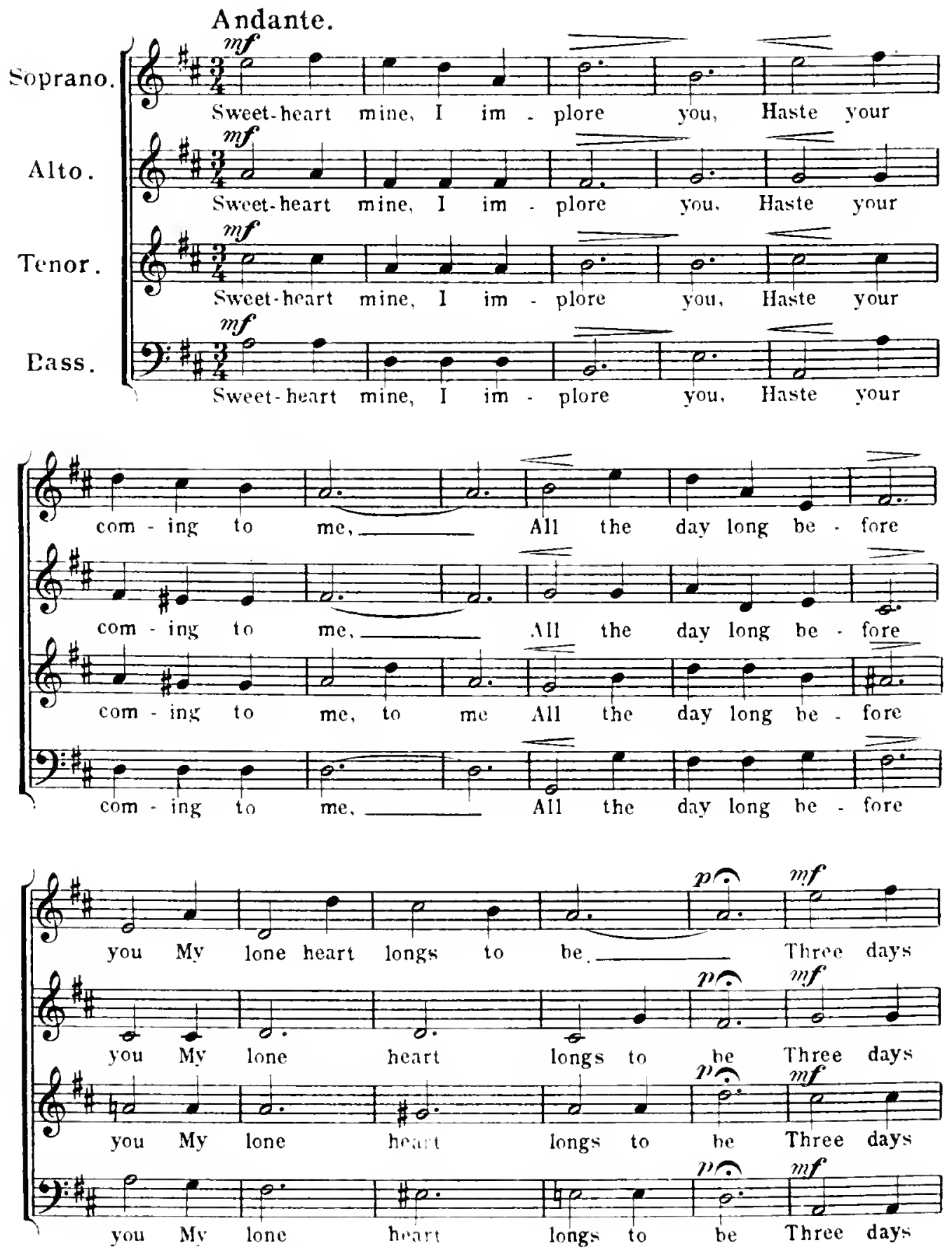

Copyright WCMLX by Freterick R. Burton. 


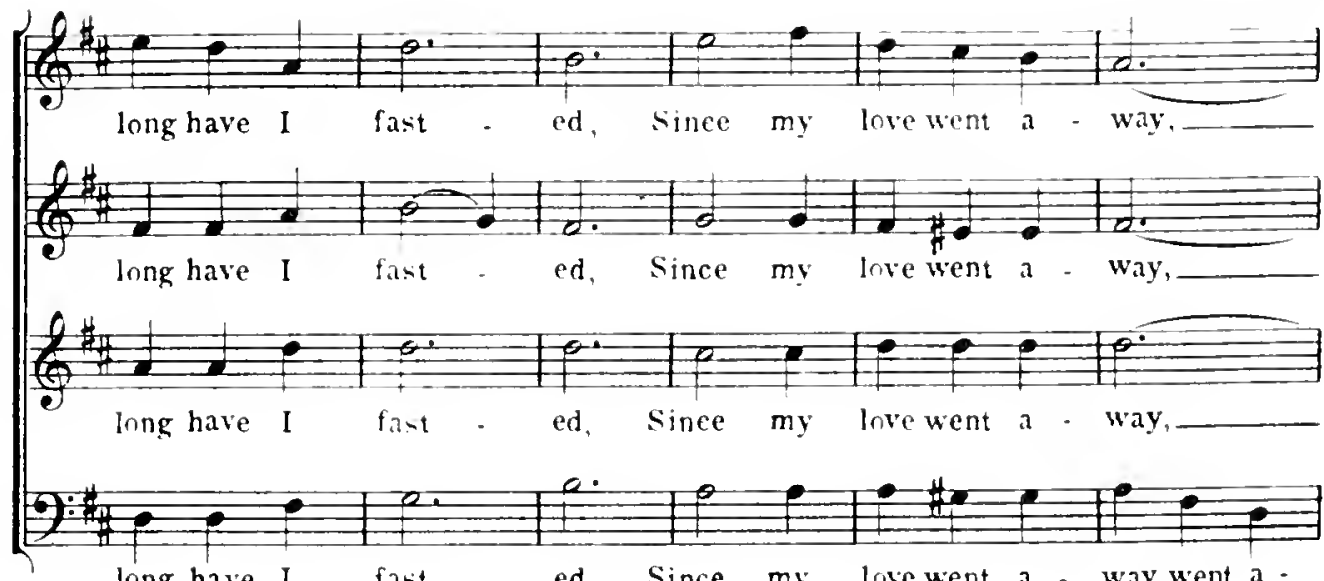

long have I fast - ed, since my losewent a way,went a -
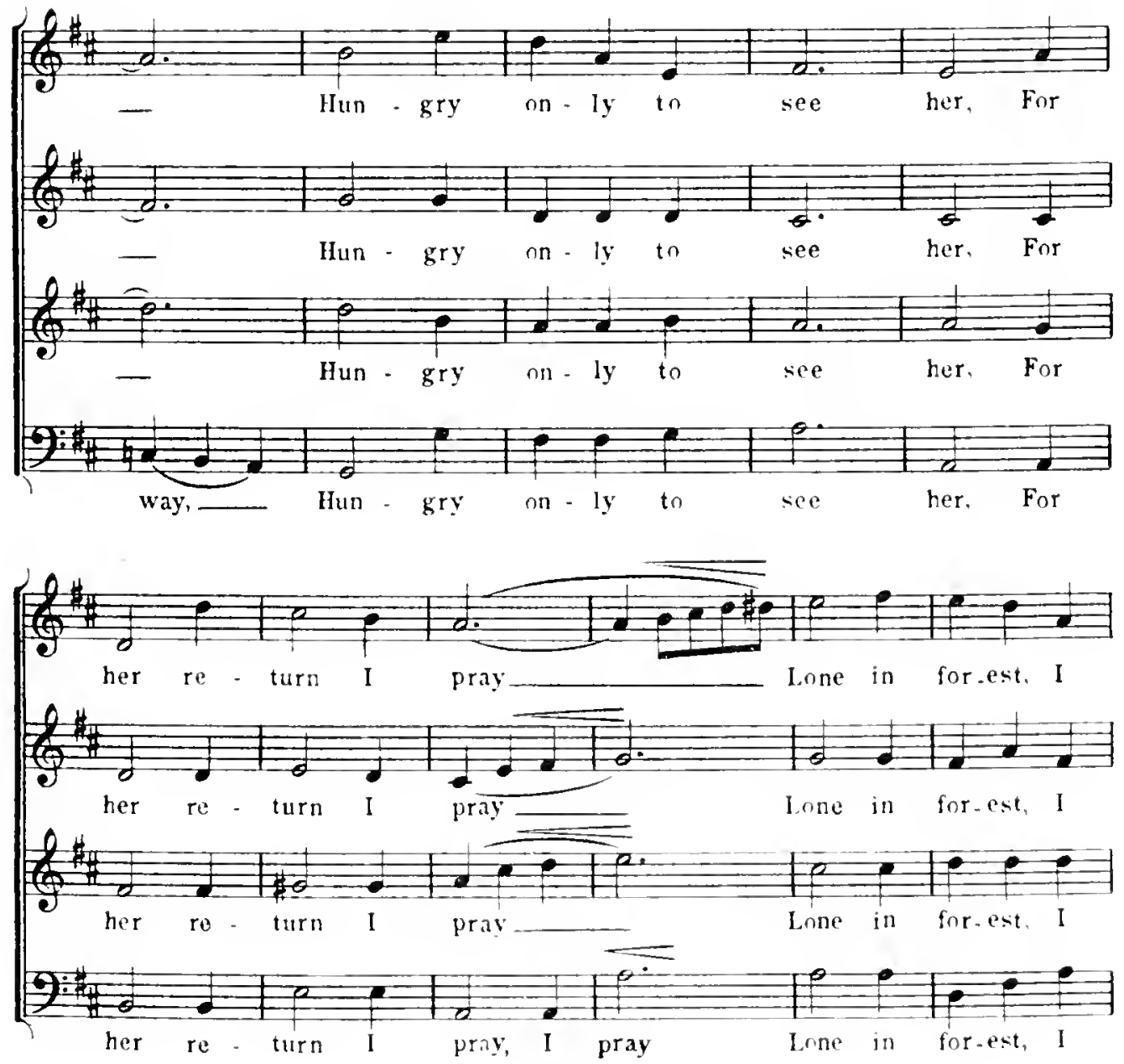

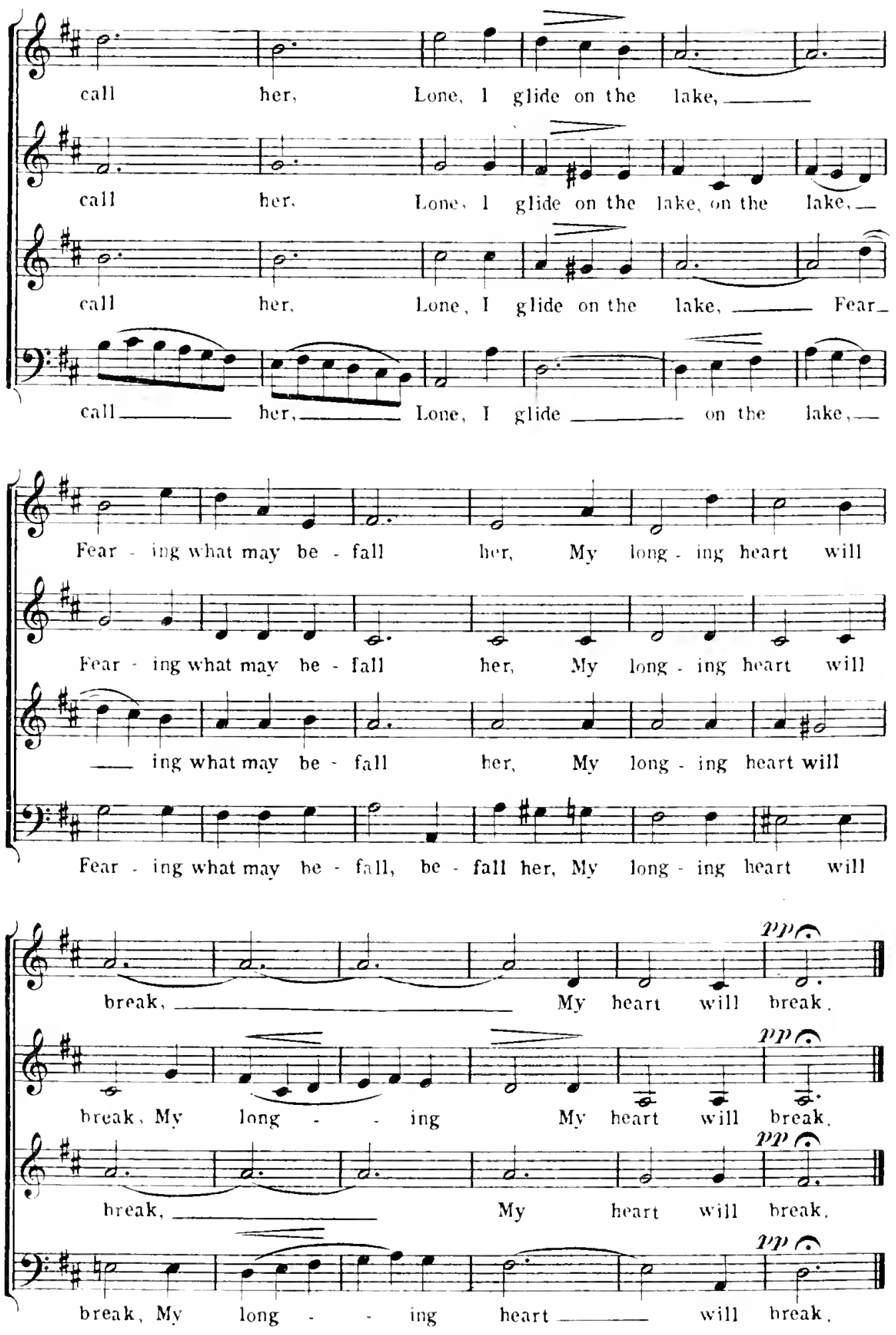
The Lake Sheen.

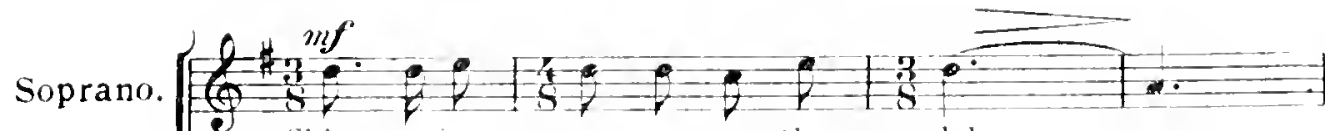
slim-mer-ing sun up. on the

lake.

Alto.

Tenor.

Bass. 2

$m f^{\circ}$
$8-2-1$

shim-mering sun lip-on lip

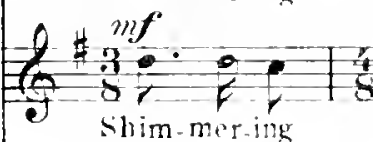
$\operatorname{sim}$

$(6): 3$ $m f$.

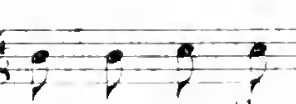
sin up - on the

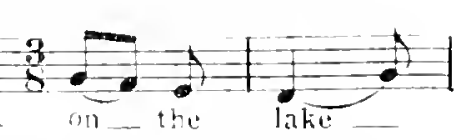

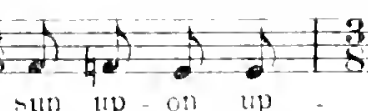

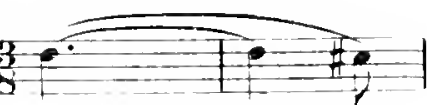

$+3$

lake
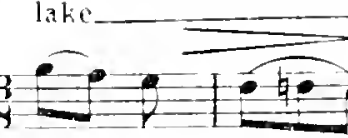

$2+1$

n- the lake.

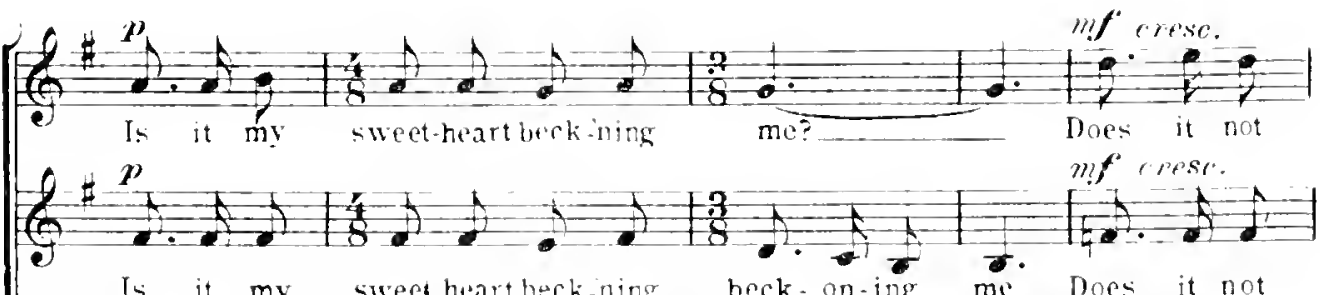

Is it my sweetheartbecking beck-on-ing mo Does it not $\left(\begin{array}{l}a \\ \text { (1) }\end{array}\right.$ Is it my swethertherking berk-on-ing me Does it not

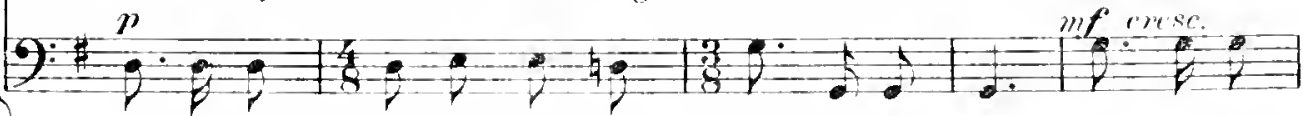
Is it my weetheartbeckining beck-on-ing me boes it not

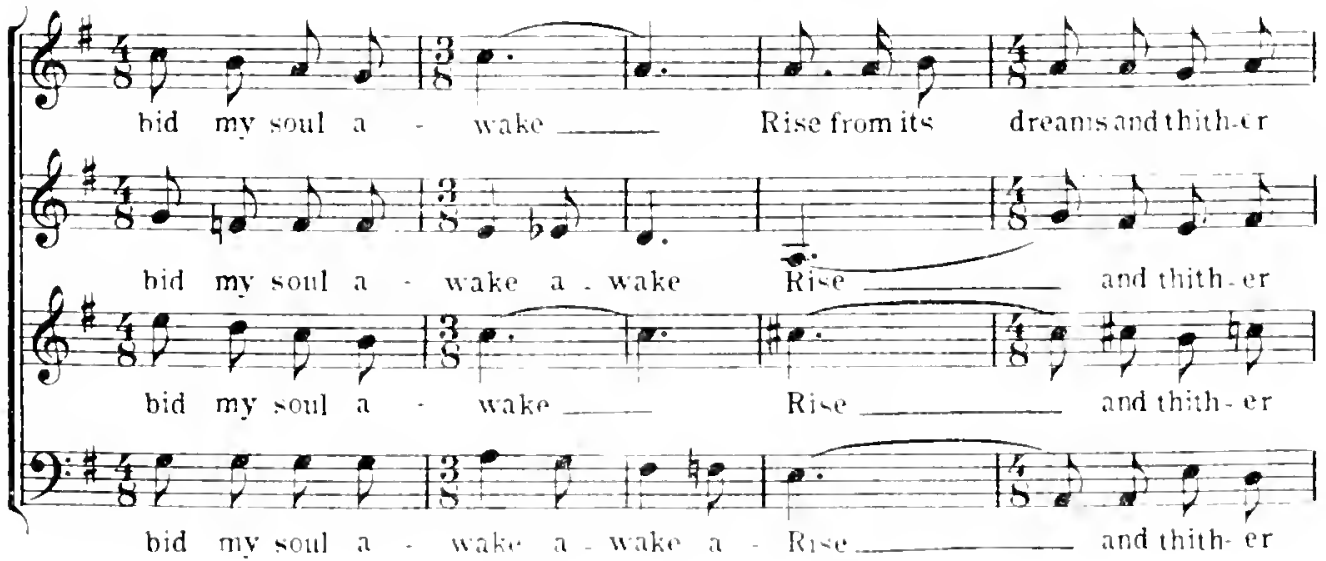

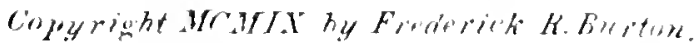




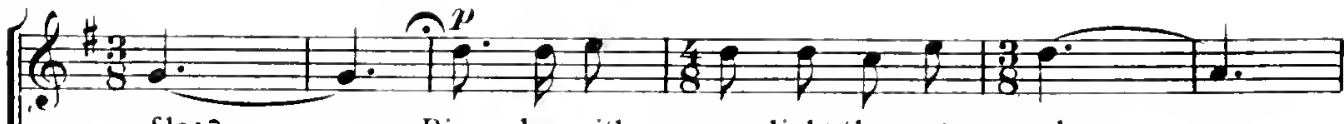

flee?

Rip-pleswith sun-light there at play

thith - er flee? Rip - pleswith sun-light there at play at play-

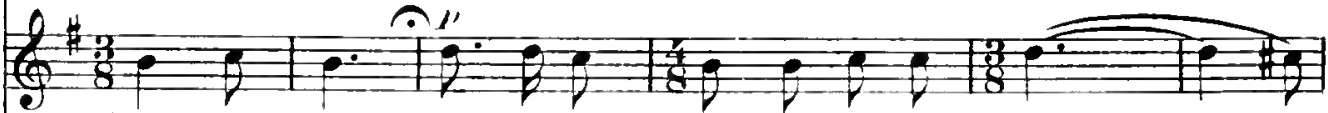

thith - er flee? Rip-pleswith sun-light thre at play

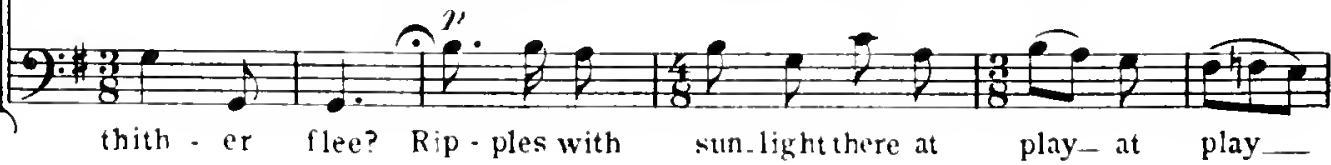

cresc.

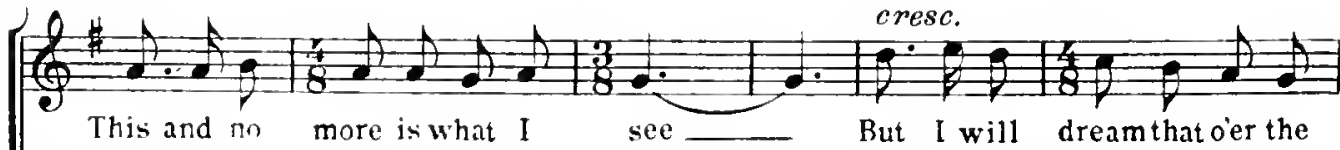

This and no more_- is what I see But I will dream_- that

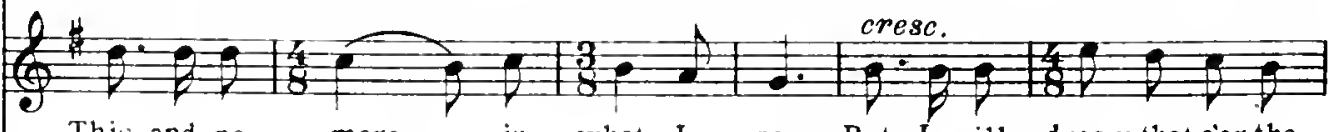

This and no more _ is what I see But I will dreamthatoerthe

cresc.

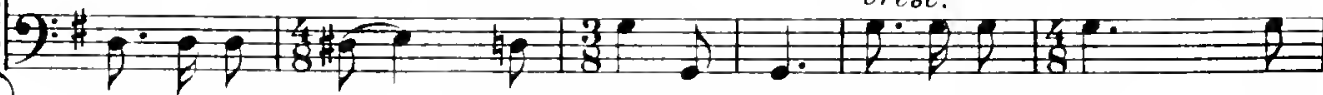

This and no more_ is what I see But I will dream that

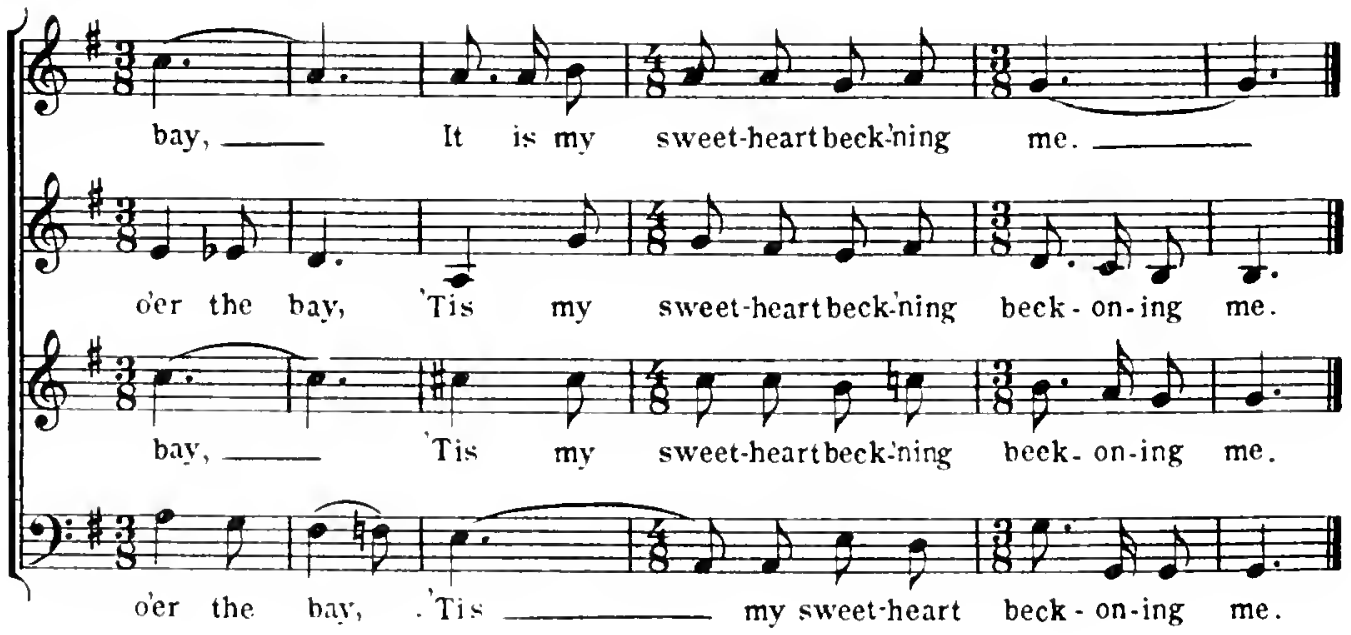


Hiawatha's I)eath Song.

Finale to Hiawatha, The Indian Play.

Andante matestoso.

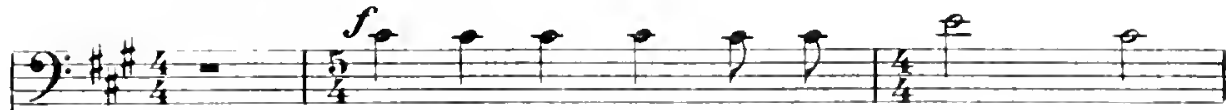

Mourn ye not o'er my de - part - ure,

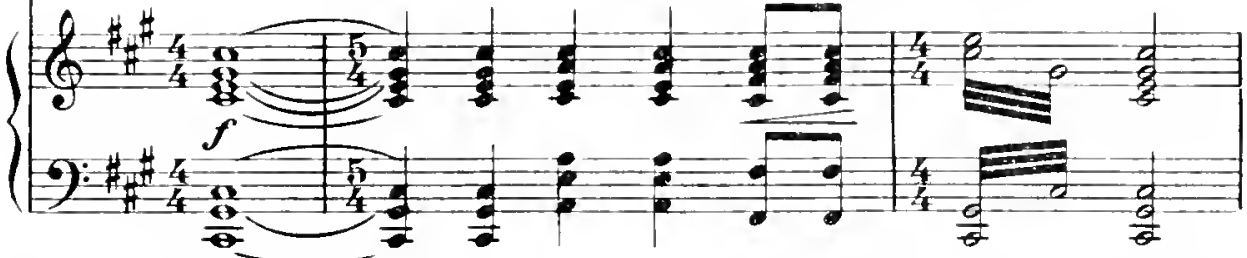

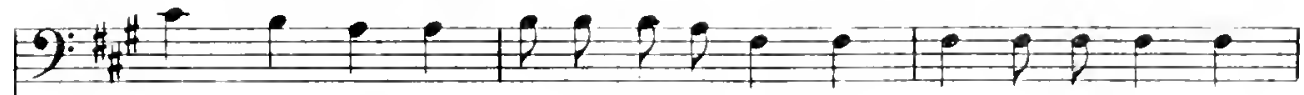
Mourn ye not; I go up - on a jour-ney, I, Hi - a - wa - tha,
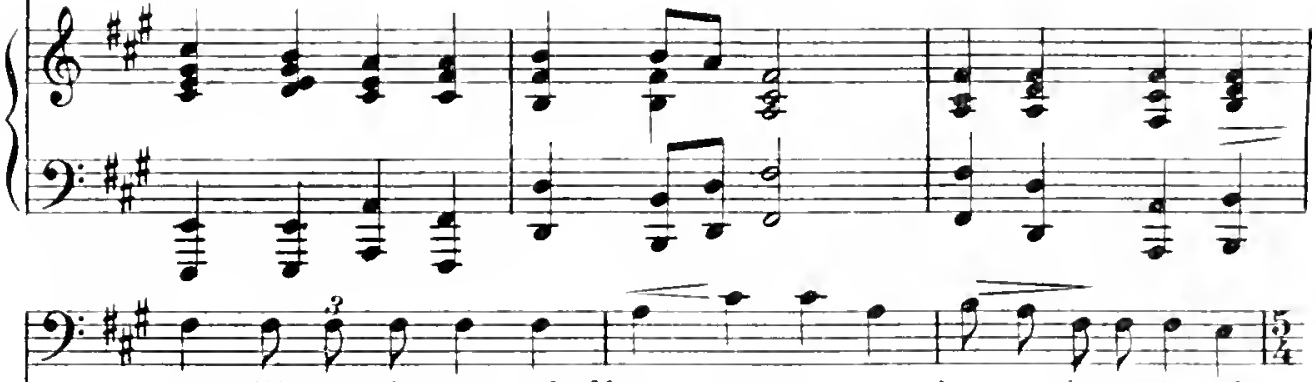
soon will have de part - ed. Nourn ye not; my jour-ney is e-ternal
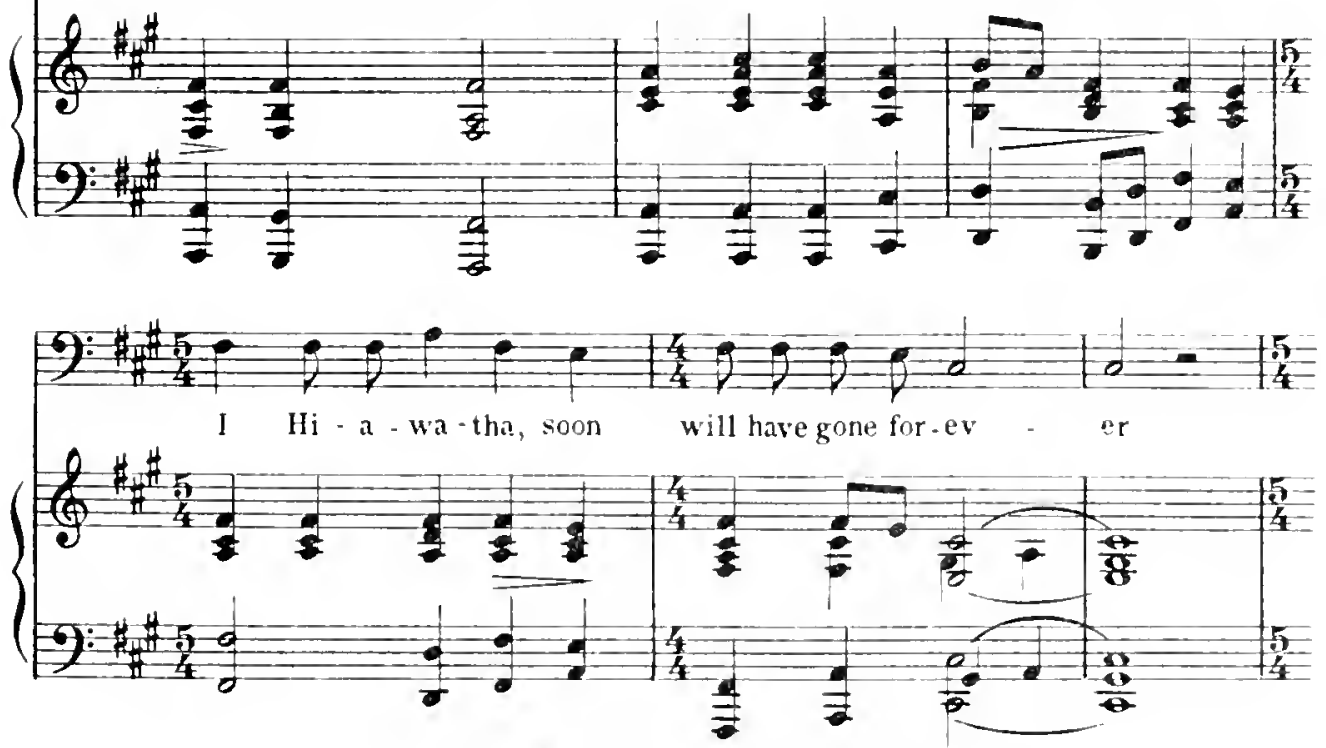

Copyright MCMIX by Frederick R. Burton. 

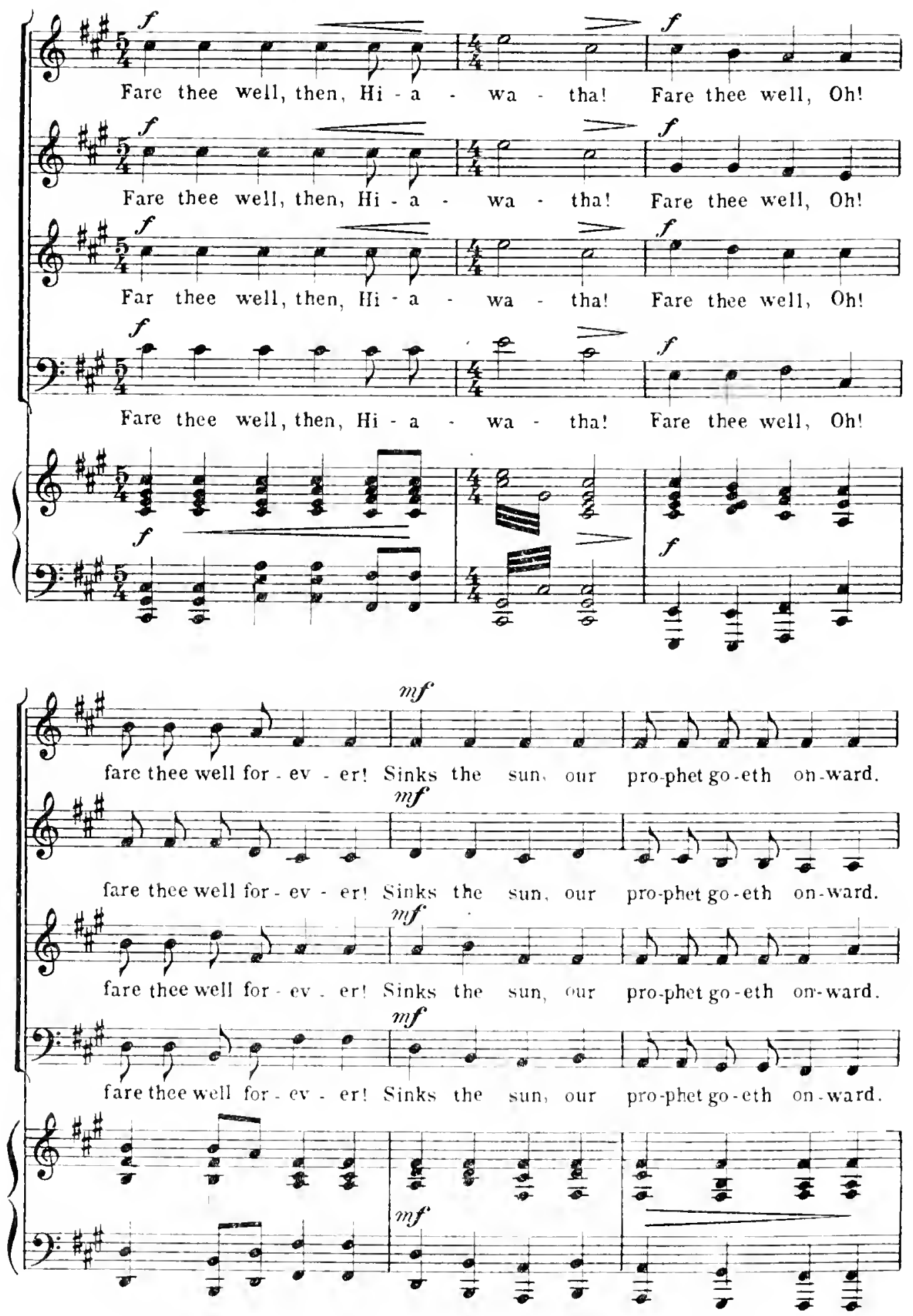

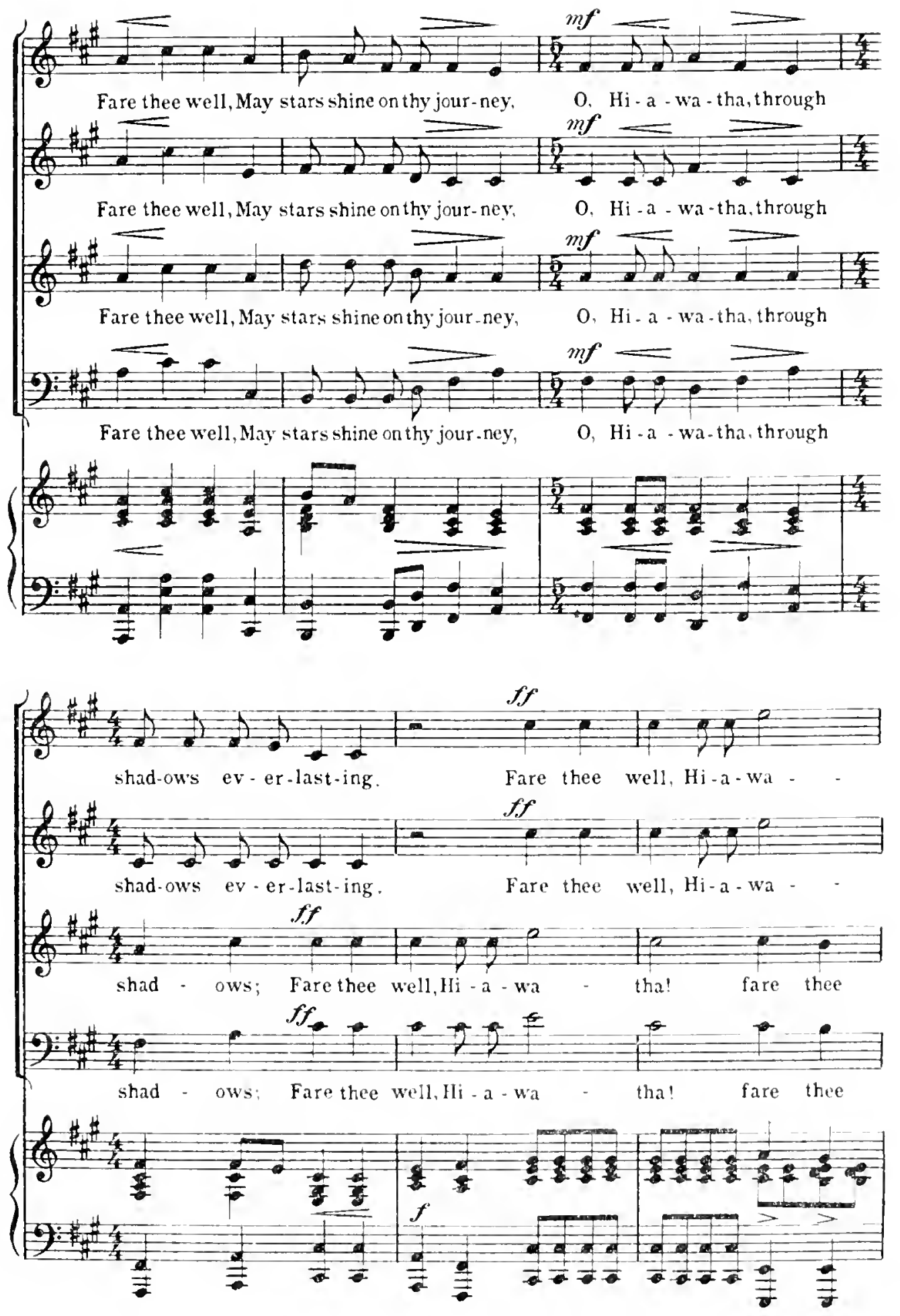

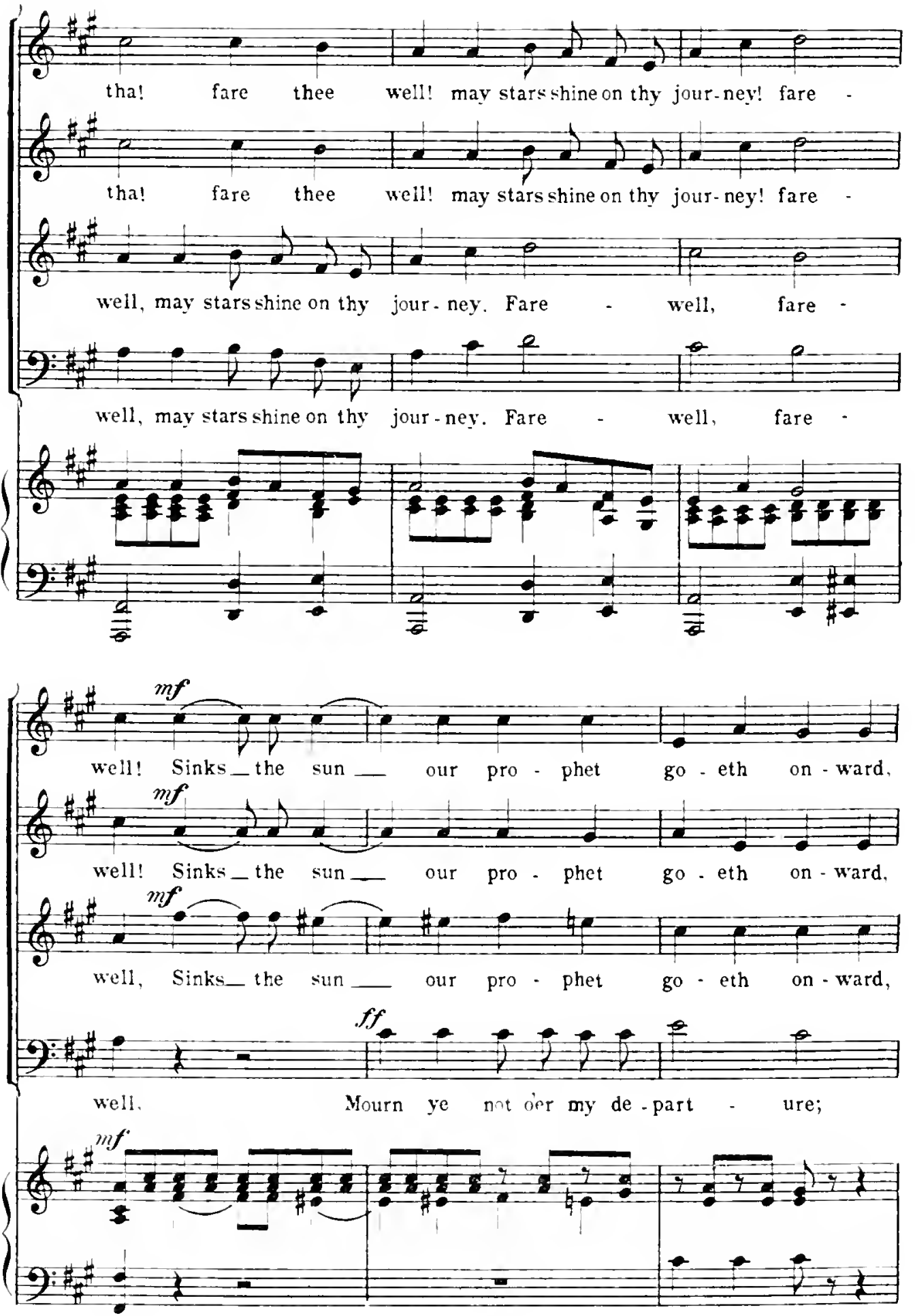

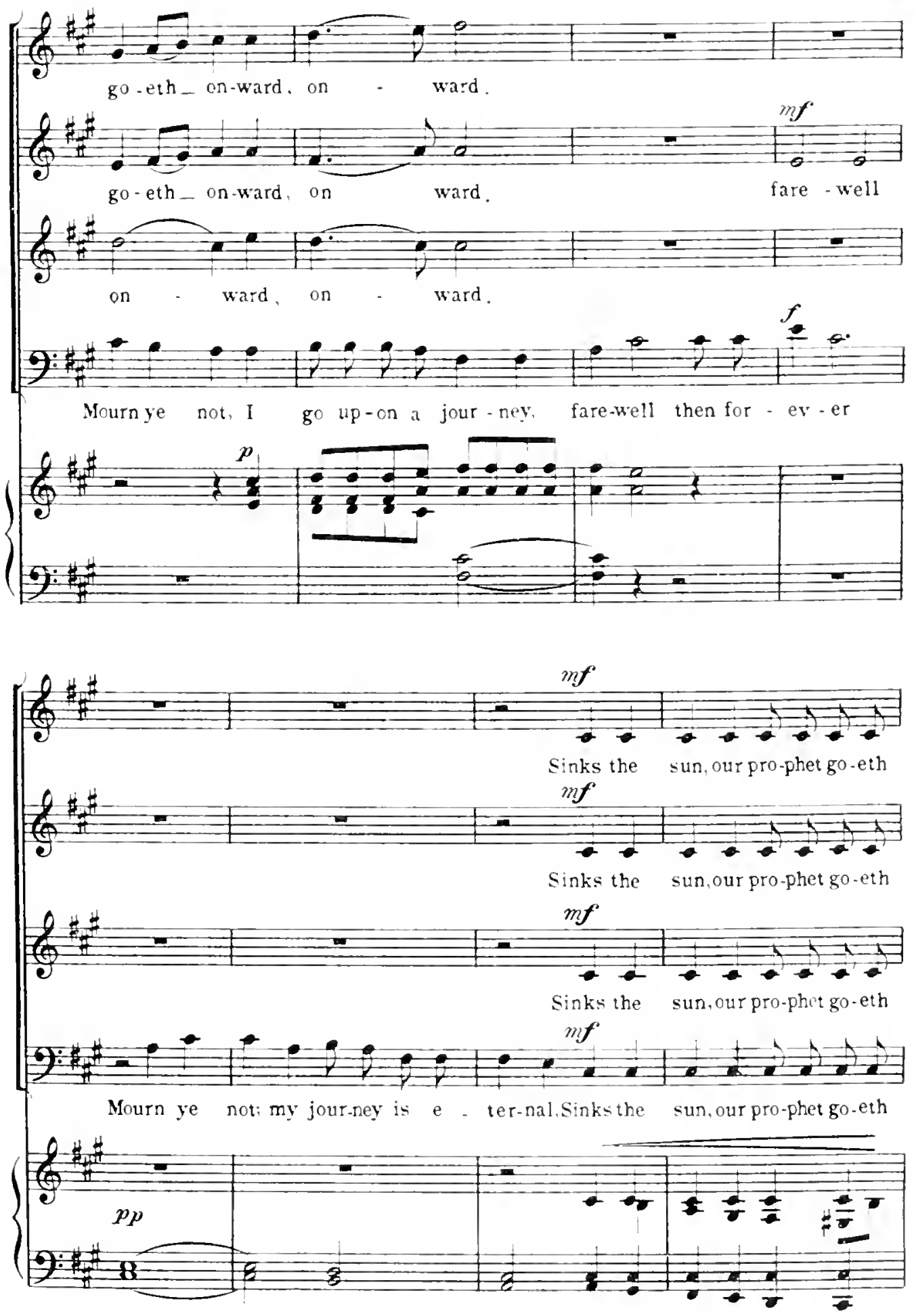

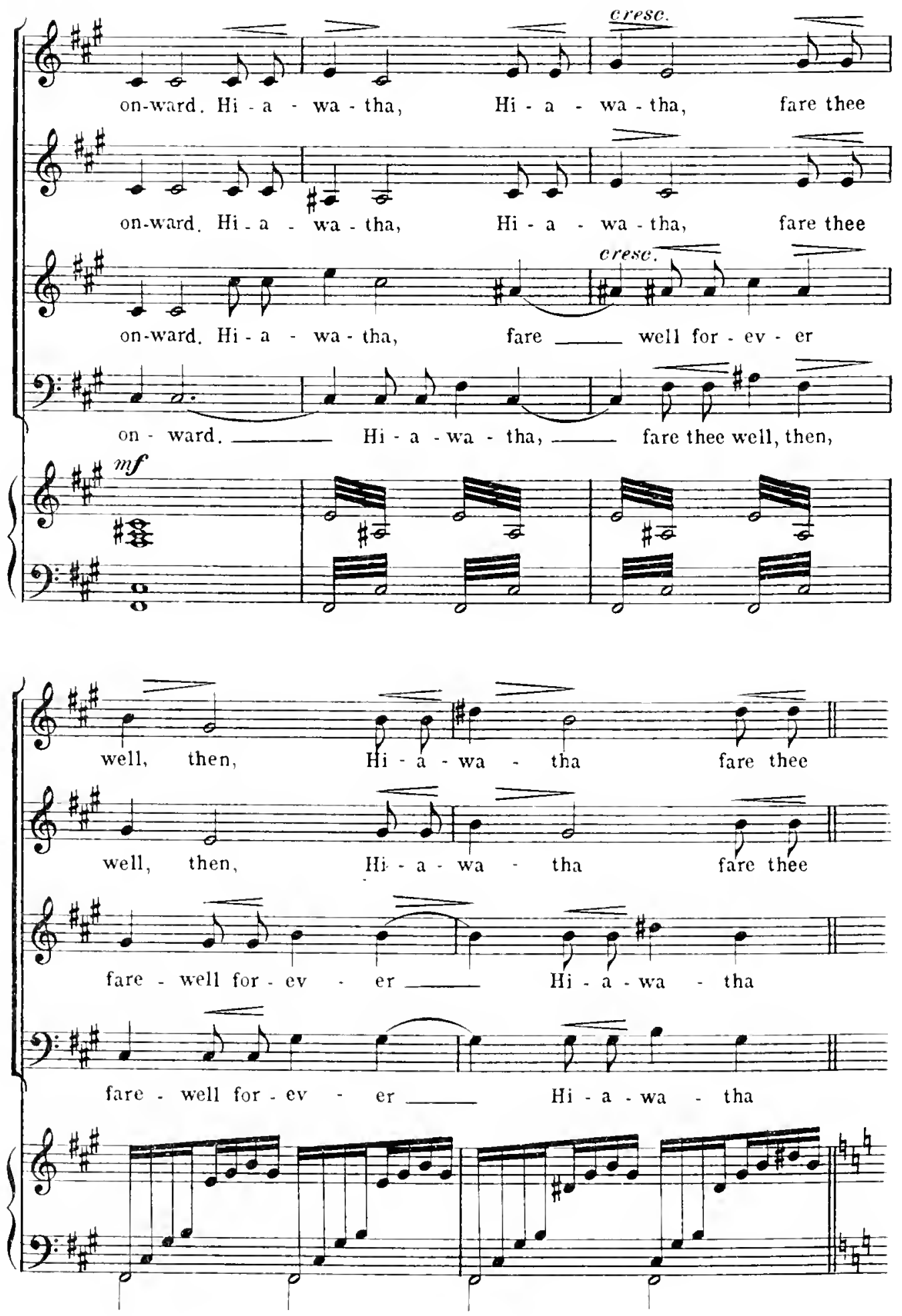

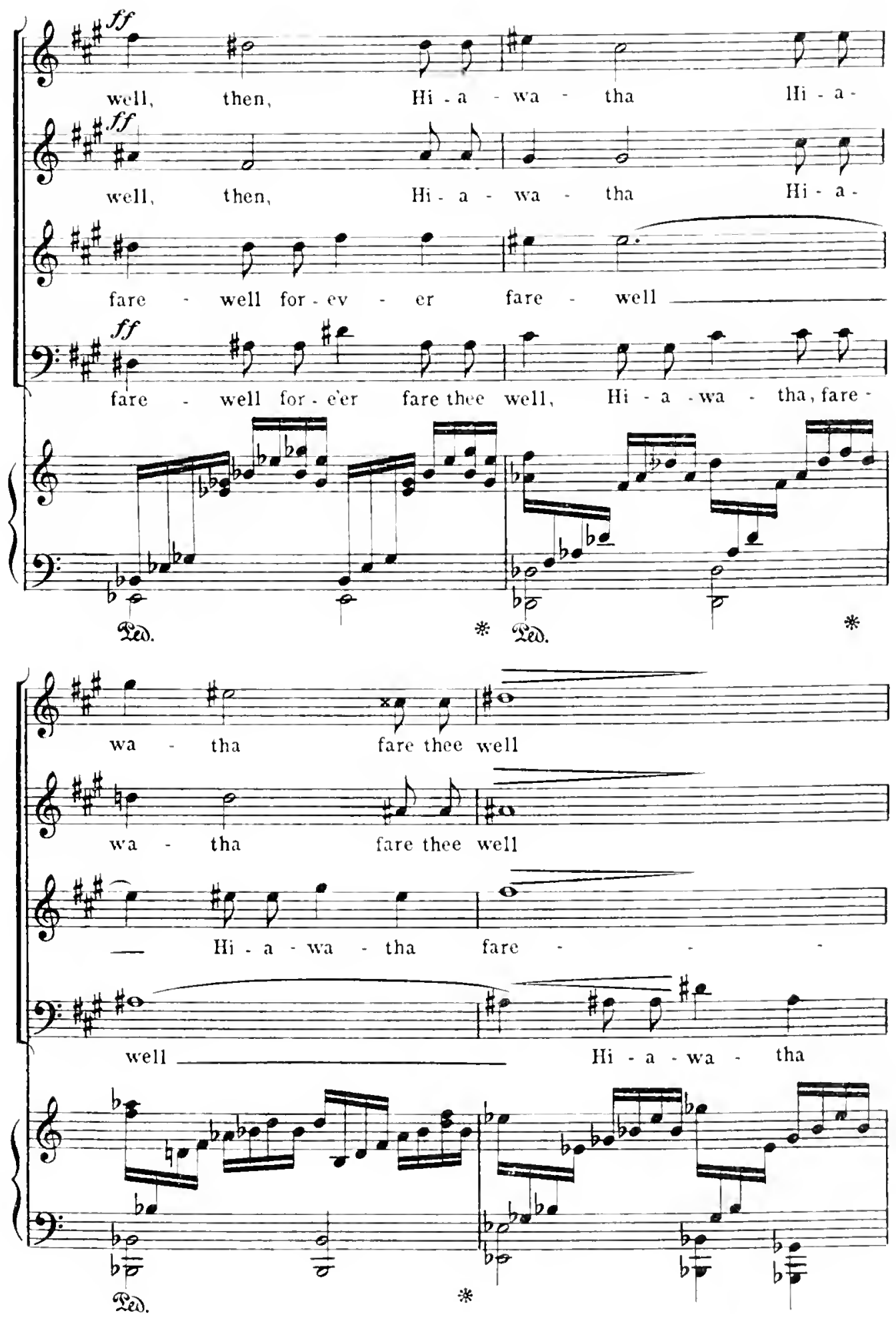

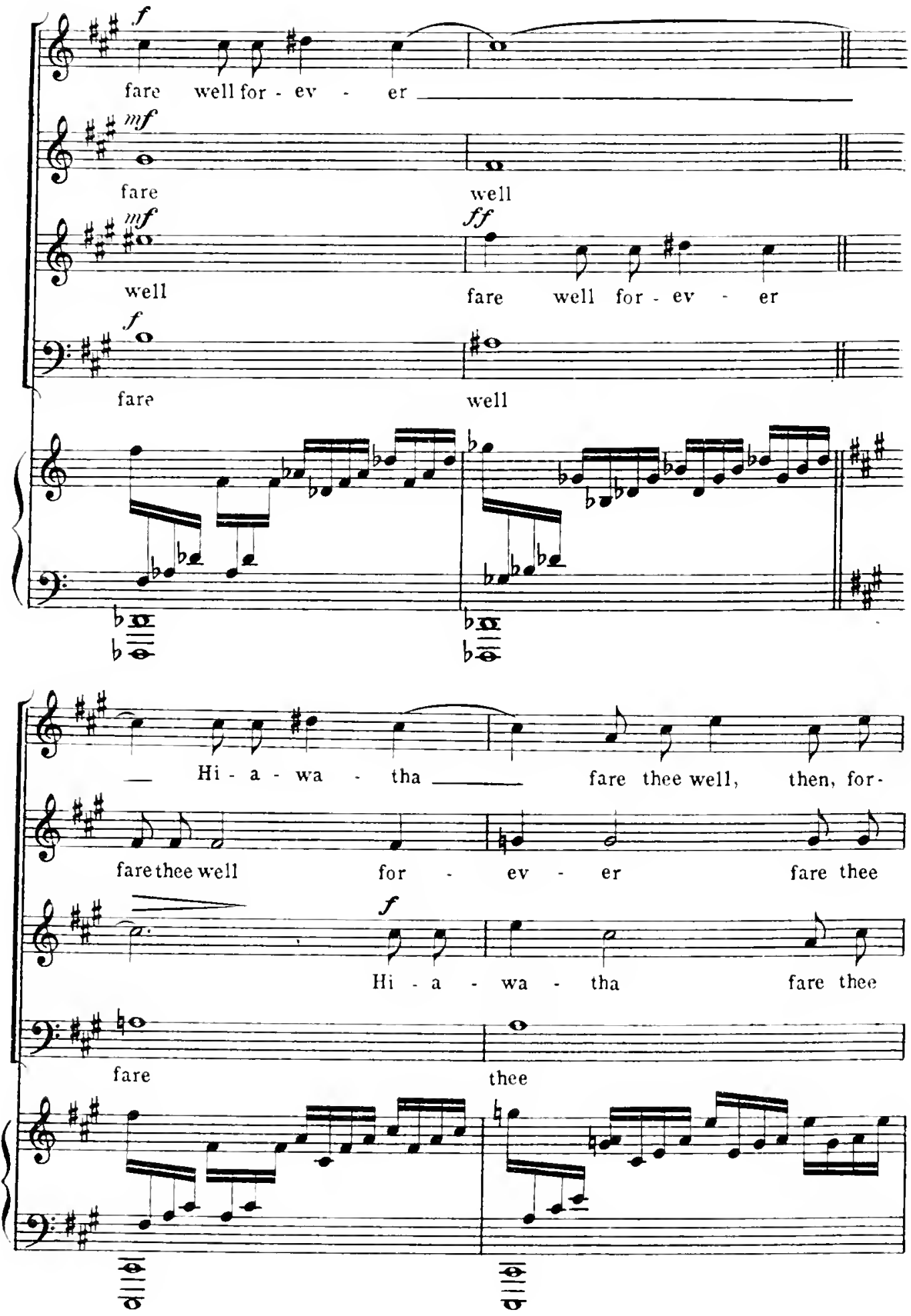

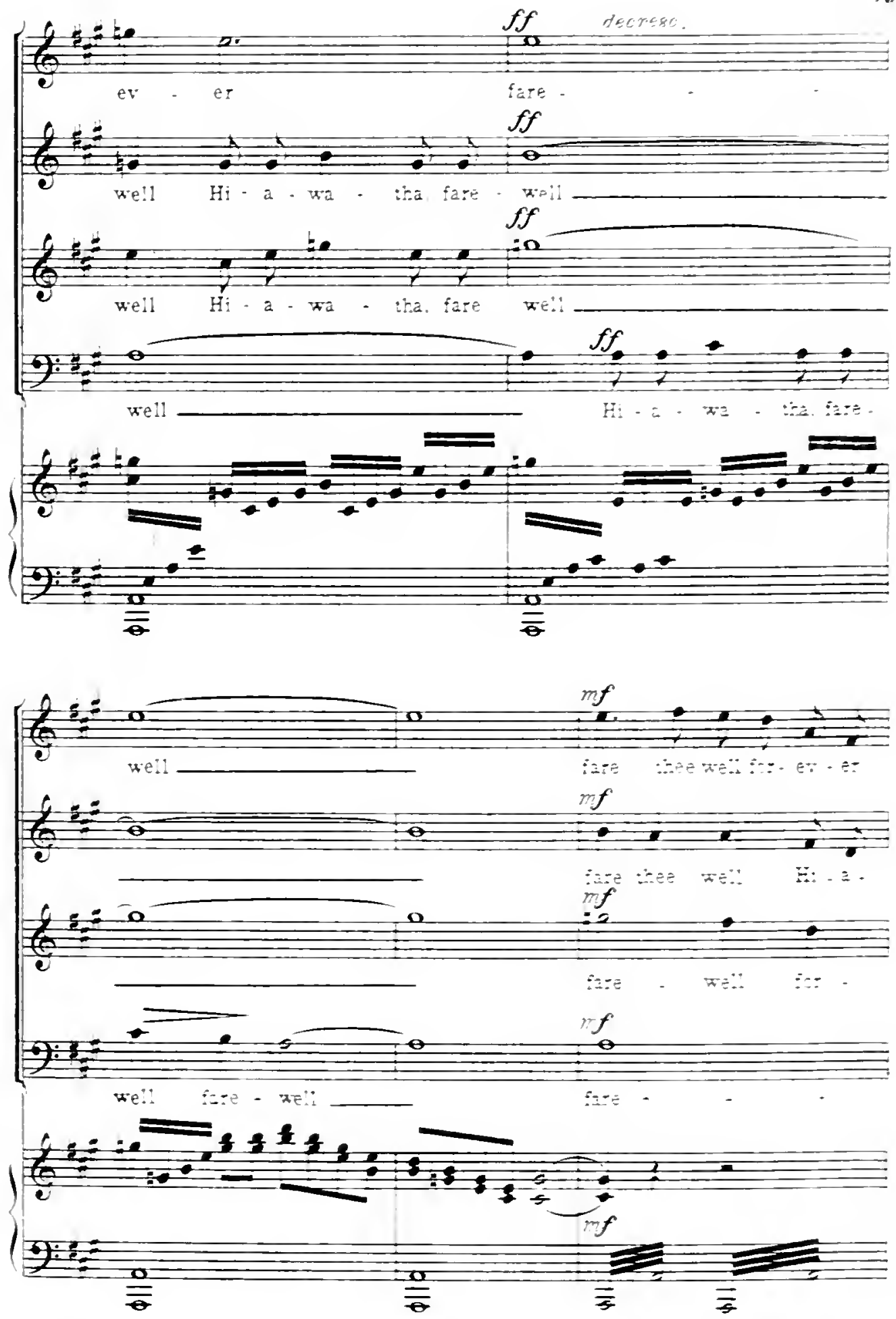


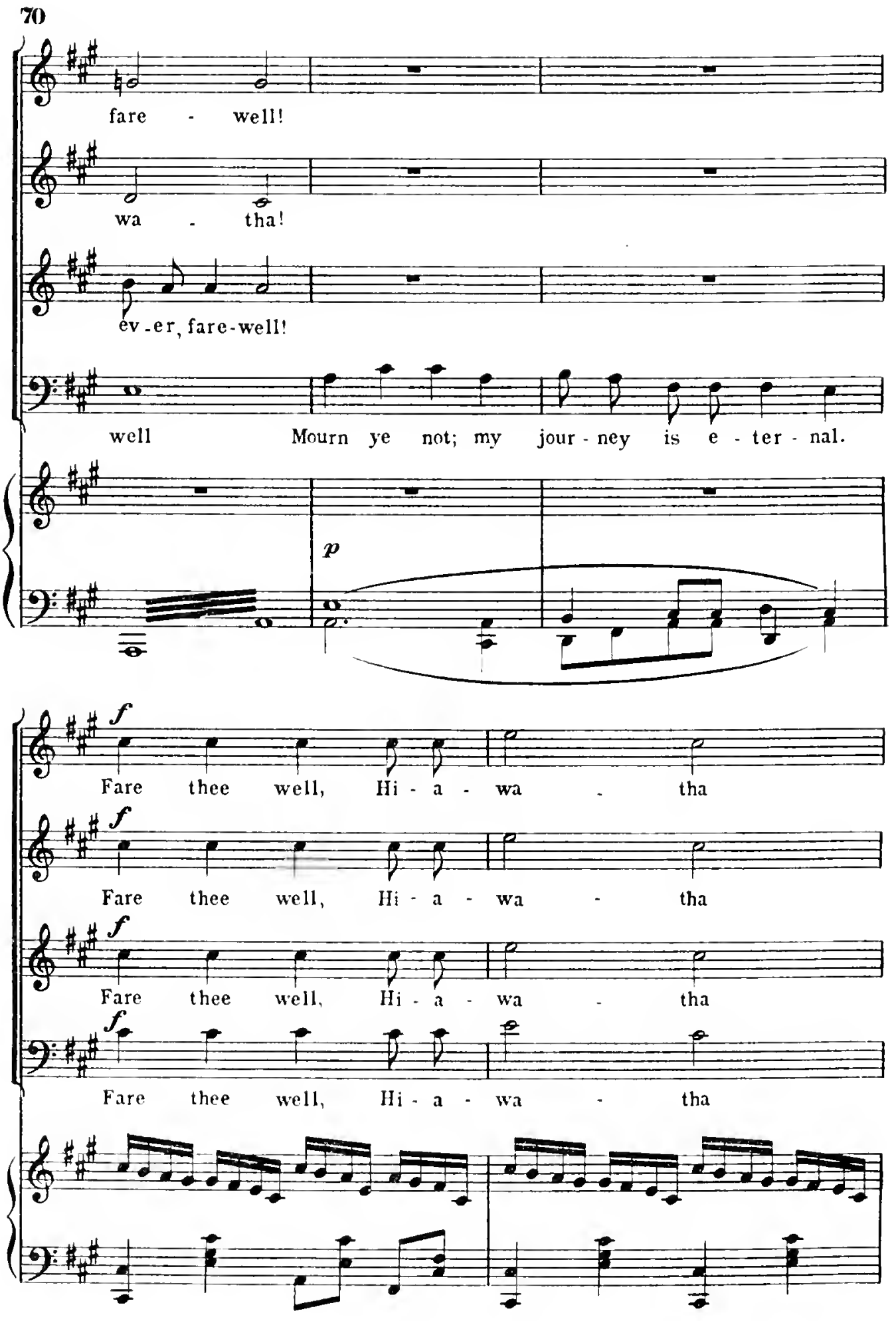



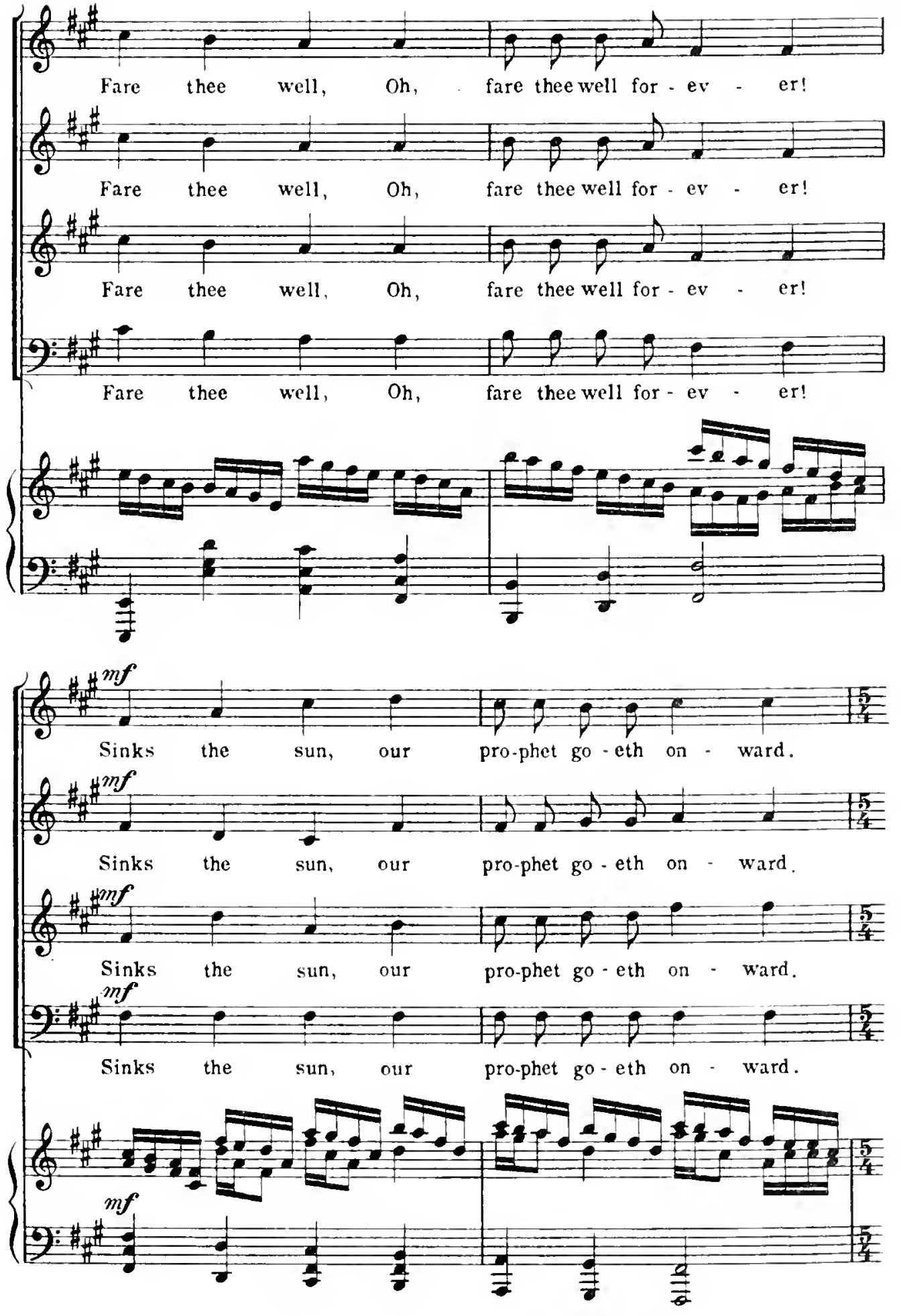


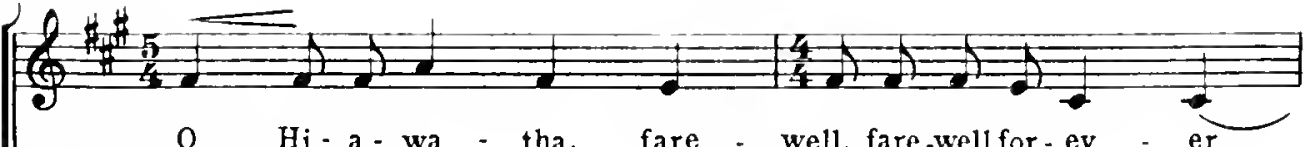
8 (2) (g)

o Hi-a - wa - tha, fare - well for - ev - er

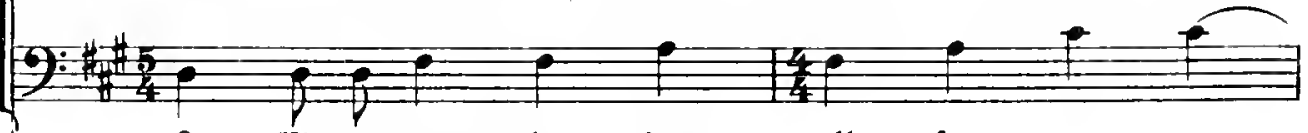

o Hi-a - wa - tha, fare - well for - ev - er
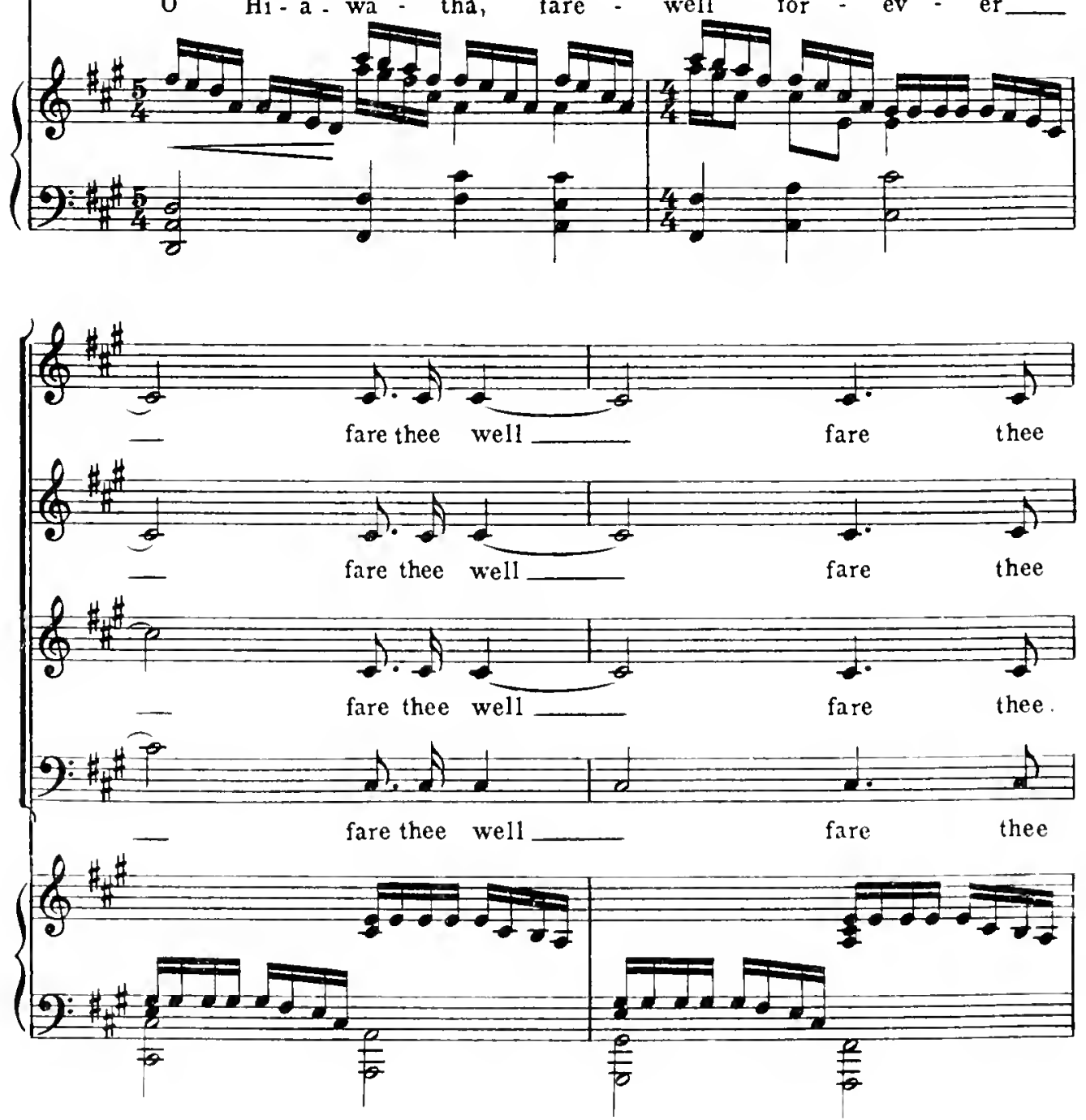

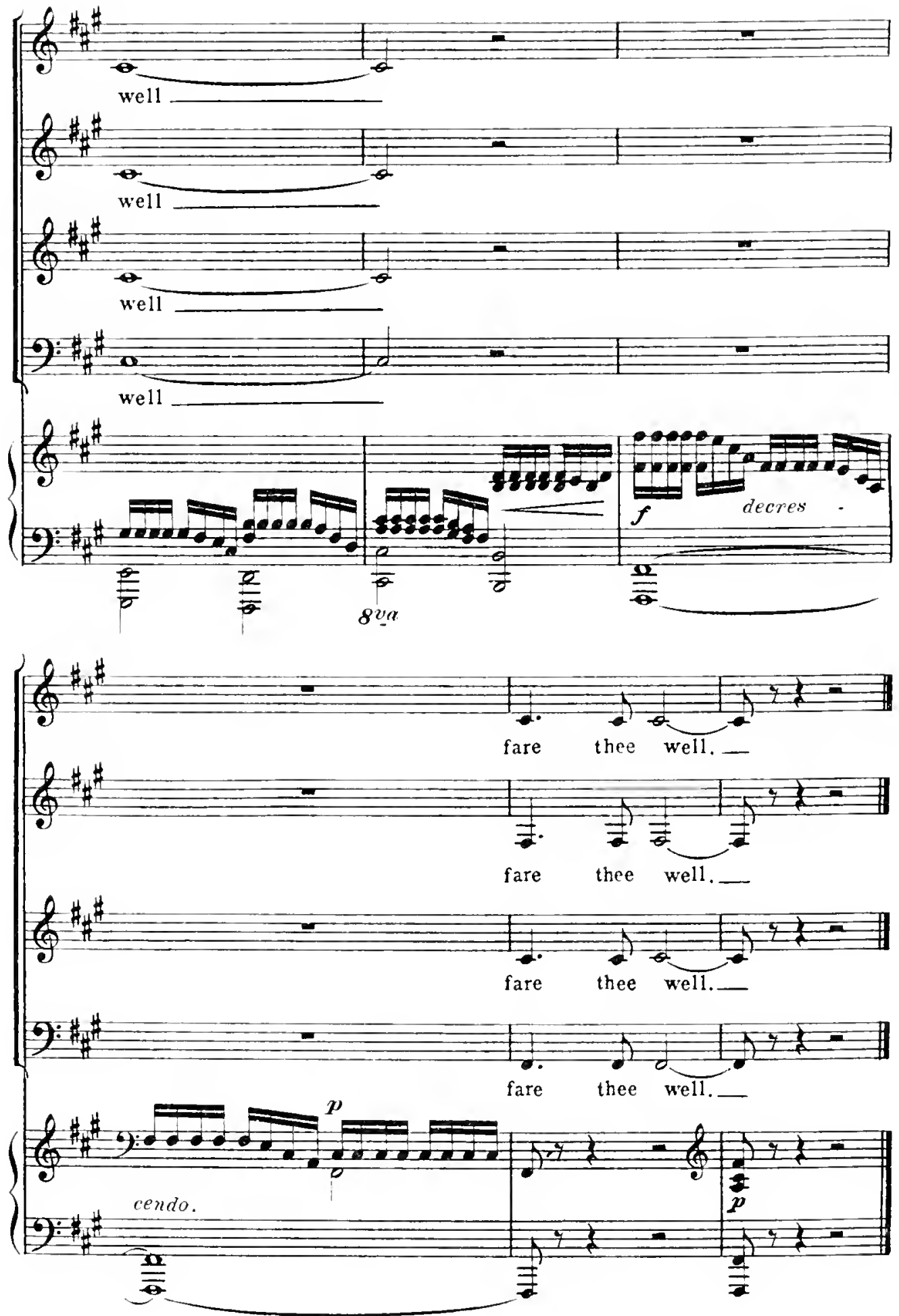



\section{GENERAL INDEX}

Abbreviations: ph., plonographlic record: H.v., harmonized version. The page references are to Parts I and II respectively.

Absence and Longing, a song of, Ojibway: I, 12; ph. 206; H.w., single voice, II, 26 , quartette, 57 .

Aкwexz, Jacob, Ojibway musician: I, 280-281.

All Biros Follow Me, Ojibway song: ph. I, 240-24.1.

Americin Museum of Niturie. Histom: $1.1,15,68$.

Apprenessiox, Ojibway song: ph. I, 260 .

Aristonenos: $1,33,36$.

Armstrong, L. O.: I, 110,267 .

Art Valce of Indix Songs: I, 2; 18, and Chapter IX, 178-200.

B.her, Dr. Theodone: I, 7-8; 36, 69, 298.

Bansined, Ojibway song: ph. I, 211-212; H.v. II, 45.

Bark (axoe, Mr: Ojibway song: I, 19, +2, 90, 96, 119, 121, 139, 1 H4; aecount of the translation, $149-159$; allusion to in argument for harmonization, 178-179. $26 \%$; pl. 208 ; H.x., single voice, II, 2; quartette, II, 55 .

Beater Songs, Ojibway: ph. I, 251-252.

Befone the Bßattle, Ojibway song: ph. I, 261-262.

Bind, Artiun: I, 182.

Bons, Dr. Fraxz: I, 15,37 .

Boy Terned to Exige. Tle': a Pawnee song used to illustrate the discussion of conflicting rlythms, I, 5 $2-5 \%, 61$.

Bhavest, The, Ojibway song: ph. I, $257-258$.

Buffalo Soxgs, Ojibway: jh. I, 219-250.

Buhwejunini, Tecunsen: I, 190.

Bireac of Etinologi: I, 13, 15, 2\$1.

Cadman, Cinhles Wakefield: I, 199.

Caribov, Ojibway dance songs: plu. I, 253-254-255. 


\section{GENERAL INDEX}

Carnegie Instite tion: I, 15, H. 70.

Carousal, Ojibway song: ph. I, 220; H.x. II, 4 .

Caruso: $1,17$.

Cary, Hexry: I, 148 .

CuCgindwat, Iroquois reservation: $I, 77$.

Cimminos: I, 199.

Confession, Ojibway song: pli. I, 230-231; H.r. II, 34.

Corder, Frederick: I, 49 .

Cownd, Song of a, Ojibway: 1, 42, 105 ; ph. 258-259; H.v. II, 16.

Chingan. A. 'T.: I, 7T.

Curtis, Miss Xitalie: $1,11,17,27,28,36,37$.

D.sкot.s: I, 37.

DANCE of PACPChKEEWIS: I, 19, 47.

D.1NeE: signiticance. I. 58-59.

Dentil Songs: I, 137-139. Sce also pp. 139-137, and “Hiawatha's Death Song," 263-270.

Desbarats, place where the Indian play was first giren: 1, 220, 267.

Detroit: 1,268 .

Donsey, Dr, George A.: 1, H, 53.

Dovbt, Ojibway song: ph. I, 265; H.r. II, 19.

Doxologx: use at Ojibway social githerings, I, 139-144.

Drinking Duette, Ojibway: pli. I, 221-295.

DRUM: I, 22, 16, 80, 109-110, 125-127, 130-131.

DroRAк: I. $11,183,195,196$.

Esquno: I, 15.

Faith, A song of, Ojibway: pl. I, 236 .

Farwell, Arther: $1,1 \%, 18 \%, 190$.

Fielo Colcabian Meseuat I, 1, th.

Field of Research: I, $3-6$.

Fillamole, John Comfort: I. 11, 36, 37.

FinefLr, Ojilwway song: from Dr. Balier's collection, I, 2Q9-230.

Flageolet: I. $83-86$.

Fletcilen, Miss Alice C.: I, 8-11, 17, 18, 36, 37, 116.189.

FLC'TE: I. 83-86. 


\section{GENERAI, INDEX}

Forest Chom, the, Ojibway song: ph. I. 231-932: H.x.. II, 36.

Fonest, In the, Ojibway song: I, 12; story of the originil words and attempt to substitute another text, 166-168; ph. 292: H.x. II, 20 .

Fons: see el. t. particularly Pp. 86-89, 90-91, 10t-105.

Foster, Stepliex C.: I, 197 .

Iriost, Rev. Frederick: I, $140,201$.

Ganbling: deseription of seene for "Hiawatha," the Indian play, I, 158161.

Ganblixg Soxg. Ojibway: ph. I. 989; H.x. II. 13.

Girdex Rrver. Ojibway reservation: I, 120, 128. 132, 140, $201,265$.

Gilmax. Bexjamin Ives: I, 15, 24-35.

Grefi Intenvals: I, $33,38$.

Grove's Dictionary of Music: I, 49.

IIADLEY, HENRY: I, 182.

Harmoxization of Indian songs: I, 177-181.

IInRoxy: I. S5; eonfidenee of the Ojibways won by it, 11\%-120; native attempts at. 121.

Henexway Sotthifestens Expedition: I, 15. 95.

Hexiy, Alexander: 1, 153, 293, 245.

Her Sindow. Ojilway song: I. 41 : ph. $906:$ H.r. II, 30.

IIswтия: eantata, I, 19. 48. 190.

How $267-268$.

Huwath's Deatu Soxg. Ojibway: I, 105, 191; ph. 270; its use in the Indian play, 267-270; H.v.. single voice, II, 53; quartette, II, 62.

Hoffus. W. J.: I, 21]-92.

Hopis: I, 15, 16, 24, 25, 27-29, 35.78.

Huntixg Songs: I, $114-115,125.215,2+9-252$.

Ixpestries and industrial songs, Ojibway: I, 12.1-127.

INigcanleng. Shawaxibexarse, pagan Ojibway singer: I, 111-11\%, 296. INstrumexts: I. S0-86.

Intenval: see Seales, P. I, Ch. 2. Ojibway interrals, 11-13.

Ix tile Fonest: see Forest.

Investigators: I. 6-16. 


\section{GENERAL INDEX}

IroQvols: 1, 1, 73-7\%.

Jones, Whulai: I, 70.

Kelley, Edger Stillmax: 1, 182.

Kw.nutu: I, $15,19,47,48$.

LAKe SHefe, The, Ojibway song: I, 96-100; ph. 208; H.v., single voiec,

II. 38 ; quartette, II, 60.

IANGOACE: fifty-eight ethinic familics of aboriginès, I, 4.

Lecture-Recituls :mong Ojibways: 1, 163.

LoNely, Ojibway song: I, fo: 170; ph. 201-805; H.v., II, I2.

LoNgFelow: scarch for origrinls mentioncel in his "Song of Hiawatha,"

I. 108 , 989-880; use of Ojihway traditions, 113; lis characterization

of persons and country. $198-199)$; $219,268$.

Looms, Harvey Wortmington: 1, 189 , 190.

Lucky Trapper, Ojibway song: ph. I. $951-255$; H.v., II, 21.

Macdowfle, Euward: I, 12, 182, 189, 189.

Megissun, Ojibway singer: I, 133-136.

Menomixee songs: ph. I, 974, 976 , 978.

Munight Tryst, Ojibwiy' song: ph. I, 2()9; H.x., IJ, 1 t.

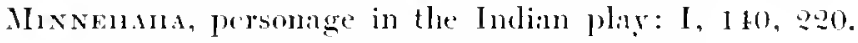

Missioniries: 270, 978-979. Sice nlso Irost.

Moxotoxy of Indian music: s!-!)?.

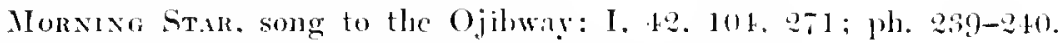

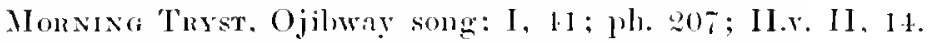

Mosplito. The, Iroquois song. I. 73-75, 7\%

My Bank Caxoe: see Barle Cinoe.

Mr Big Lover, Ojihway song: ph. I, 27.

N.uke Bear, The, Ojibway song: I, 12, 108, 217. 967: ph. 298: H.v. 11, ta.

Nindmozio, chief figure in Ojibwa mythology: I, 24:-246.

Nitonalism in Music: I, 11-12; 180-187.

New Wonlo Srmphosy: sec Drorik.

Nokomis, personage in the Indian pliy: I, 299. 266.

Nonsense Wonds in Indian verse: I, 147-118. 


\section{GENERAI, INDEX}

Nemerars, Ojibway, system of: 1, 61-66.

Oretossown, Clicet Charles: 1, 167.

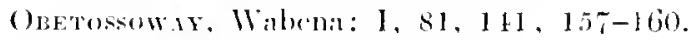

Opowarr songs: ph. 1. 212, 97

(O,d Itexmen: use at Ojilway social gatlerings, J, 139-14t.

OLD Silons. Ojibway song: I. S1: luw it wis found and incorrectly trans-

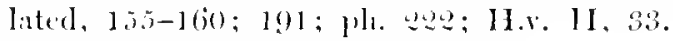

OMn11. $1,8,16,18,37,72,116$.

Onex, the, Ojibway song: ph. $237-238$.

PMNE, JOHN KNow Les: 1, 18 ?.

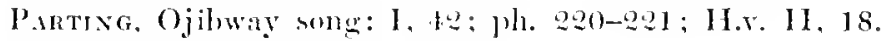

P.1WEes: $1,87,41,52-57,88$.

Pextatonie: 1, $11-13$.

Proverimipil, and phonographic records: 1, 10, 92.96, 68, 103, 191, 901275.

Piтcu: general discussion under Scales. P. 1, Cl. g.

Powell: $I, 4$.

Doret of VIEW: 1, 16-19. 33.31.

Puyfr Bo.nR: illustration, 1, 21.1; interpretation, 248-949.

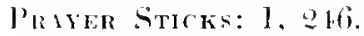

PRINe of Whies: visit to Canada. and the song composed for the oecasion, 1, $1019 ;$ ph. $26.5-266$.

prophet.hy Rights in somgs: l. 118.

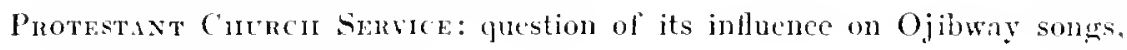
1. $975-980$.

Quarter-'Toxe: I, $20,26-10$.

R.ITTLES: $1,89$.

Rev 13ı.Axкет. Ojibway song: ph. I, 210; II.s. II, 3.

Rнттим: P. 1, Ch. ?, 11-66).

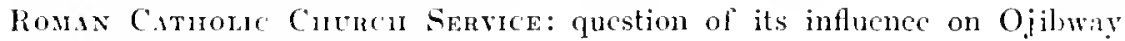
songs, 1,270 .

SAgranewose, Ojibway singer, I, 289. 


\section{GENERAL INDEX}

Sally in Our Alley: $1,148$.

SirNil: I, 265 .

Siult Ste. IIARE: I, 265. 268.

Scsles: I. 20-43; Ojibway scales, 40-13.

Sciloolcraft: I, 96, 97, 299-230.

Schubert : I, 181.

Sirexce of Music: its double nature. and its relation to ethnologs, 1, 3, 21.

Scotcu Sxip: I, 270.

Scour, Song of a, Ojibway: ph. I, 261 .

SHAwan, Jolin: I, 117 .

Shawaxo, J'ekumegzink, the "Hiawatha" of the Indian play: I, 110$149 ; 290$.

Silngwitk, Ojibway chief: I, $103,20 \% .265$.

SHINGWATk, Willim J.: I, 137, 161-162, 232, 271, 276, 277, 278.

Singing Contests: I, 109-111.

Sroux: 1, 72, 80, 108.

Skenk Soxk, Ojibway: ph. I. Q5t-2.5; H.v. II, 24.

Sleepy Thue. Ojilway song: low fomd, I, 217 ; ph. I. 228-299; H.v. II, 7.

Simll-Legs, Ojibway song: ph. I, $960-261$.

Smathonila Ixstitution: I, 21.

SNAKe DANCE, Iroquois song: 1, 75- $\%$.

Sole Survyor, Ojibway song: ph. I, 250.

Soxg Crezes, Ojibway: J, Q 11 (Wabeno), 219 (Buffalo), 251 (Beaver).

Sousa. JoHn Phille: $1,182,183$.

Siguagun, John: I, $10 \%$

STructere of Indian songs: I, 85-106.

Sirgar Canp. In the, Ojilway song: ph. I, 298-28t; H.v., 11, 82.

Tetenandundat, Ojibway singer: frontispieee; 1, 17, 39, 82, 128-131, 141, $143,15.156,167.933$.

Thaw, Mrs. Mhry Colley: I, 8.

Tonility: 1, 11, 7\%, 109.

T'manshation: I, 1+9-179, 208-203.

Travel, Ojilwaly songs of: I, 263-270.

Trover. Carlos: I, 197 .

T'nest, a song of, Ojibway: ph. 1, 298-2s9. 


\section{GENERAL INDEX}

Vaxity, Ojl'way song: ph. I, 27I.

Vanetr and lick of it in Ojibway songs: $1,5-6,171-173,202-203$.

Vense, Ojibway: I, 1 15-17\%; its compactuess, I $16-153$; subordination of verse to melody, $153-165$; rerse a mnemonic summary, 163 ; sentiment and incongruities, 166-1\%?; inversion of sentiment, 168-172; latek of variety, $171-173$ and $202-203$.

Visitixg Soxq, Ojibway: I, 95, I00-103. 116: ph. 927.

Voces, Indian: quality, compass, and so forth, I, 78, 79, 80.

Vulgarity in Ojibway songs: $1,166-17 \mathrm{I}$, 200.

Wabexos. Ojibway mystery men: I. 21-219. Song cycle, the same.

Watixg, Ojibway song: ph. I, 210-211.

War Soxg, Ojihway: 11, 16. Other Ojibway war songs, I, 257-26\%.

Warbesos's Loxgixg, Ojibway song: story, I, l6s; wh. 208: H.x. II, 6.

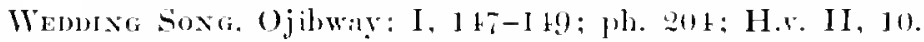

Wixter. Sollg of, Ojihwily: I, 12 ; story of the song, 161-162; versitication. 165; 171; ph. 221; H.r. I1, 21.

Witc1. the, Ojihway song: ph. 1, 256-257.

Wood, WiLlihM: 1, 79 .

Zixis: $1,15,25,32,35,10 \%$. 


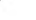


$-$ 
DATE DUE

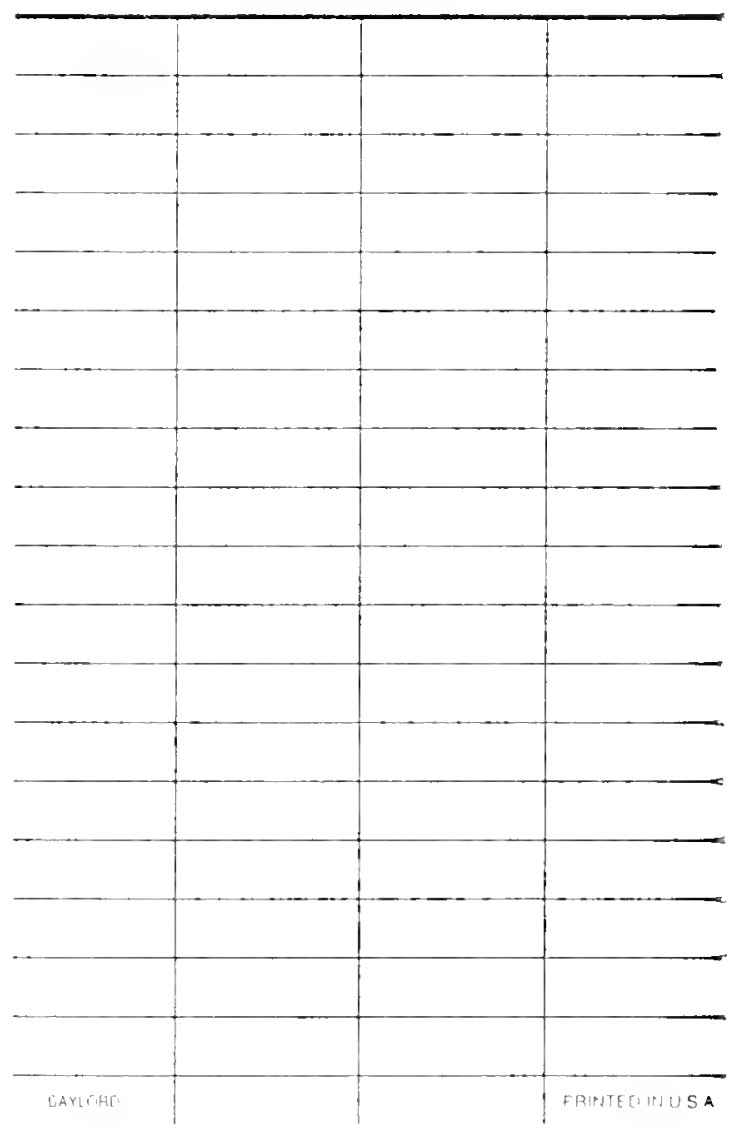




\section{3557 . BG}

Burtor, Frederlck Ruseell, $1861-1909$.

Americian frimitive mueic.

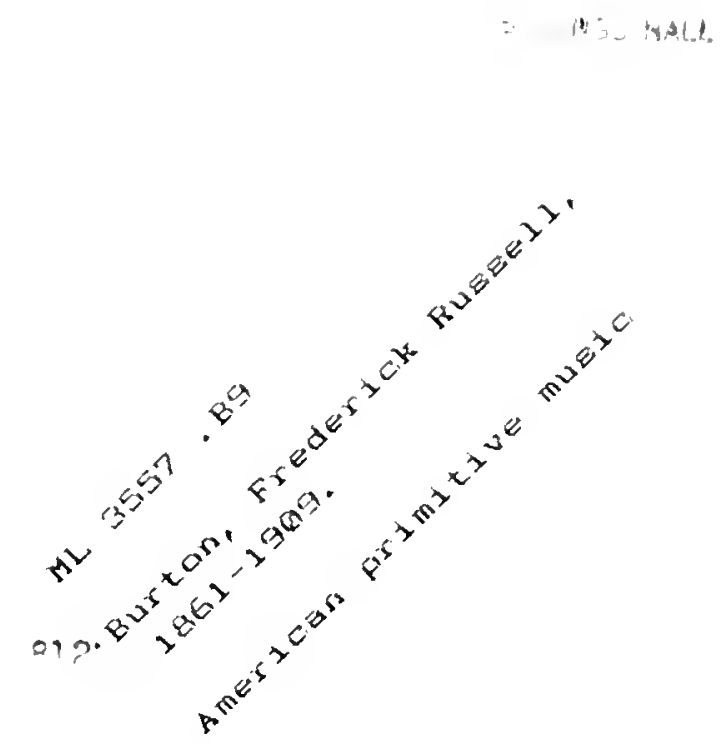


